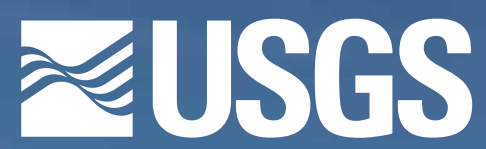

science for a changing world

Prepared in cooperation with the Bureau of Land Management

\title{
Overview with Methods and Procedures of the U.S. Geological Survey Mineral-Resource Assessment of the Sagebrush Focal Areas of Idaho, Montana, Nevada, Oregon, Utah, and Wyoming
}

Chapter A of

Mineral Resources of the Sagebrush Focal Areas of Idaho, Montana, Nevada, Oregon, Utah, and Wyoming

Scientific investigations Report $2016=5089-\mathrm{A}$ Version 2.0, October 2016

U.S. Department of the Interior U.S. Geological Survey
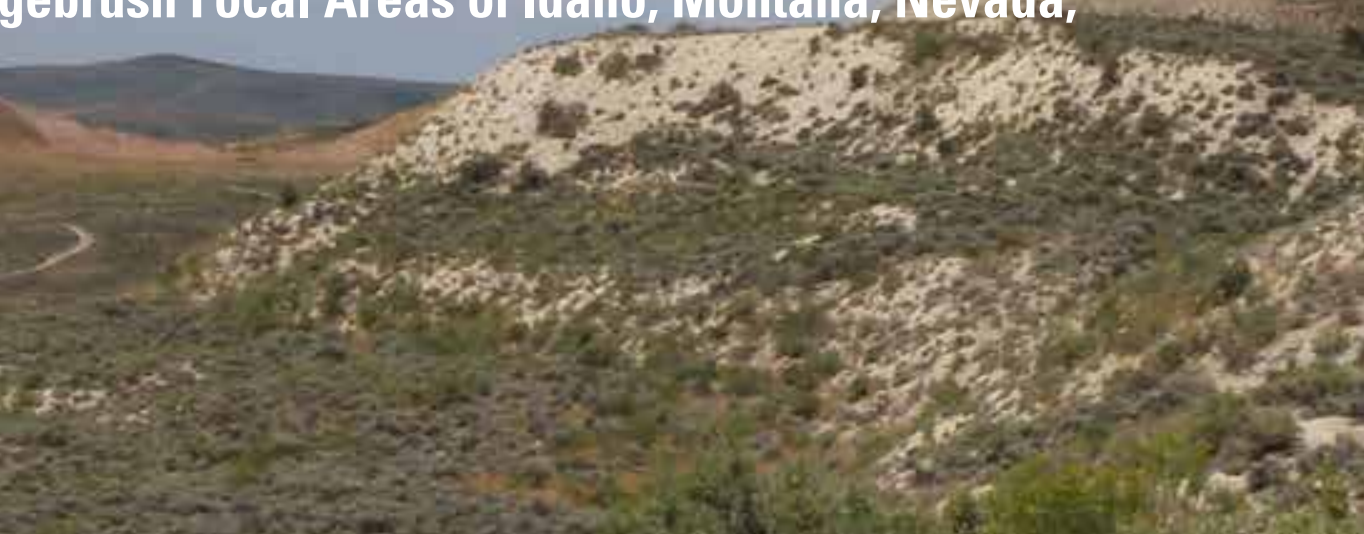

$4=5$ 
COVER. Photograph of sagebrush lands in southwestern Wyoming (U.S. Geological Survey photograph by Anna Wilson). 


\section{Overview with Methods and Procedures of the U.S. Geological Survey Mineral-Resource Assessment of the Sagebrush Focal Areas of Idaho, Montana, Nevada, Oregon, Utah, and Wyoming}

By Warren C. Day, Jane M. Hammarstrom, Michael L. Zientek, and Thomas P. Frost, editors

With additional sections by Eric D. Anderson, Donald I. Bleiwas, Ronald M. Drake II, Jacob DeAngelo, Connie L. Dicken, Gregory L. Fernette, Helen W. Folger, Stuart A. Giles, Jonathan M.G. Glen, Aimee E. Graeber, Matthew Granitto, Gregory L. Gunther, Jon E. Haacke, Cassandra K. Hennings, M. Christopher Jenkins, Karen D. Kelley, Duc M. Nguyen, Heather L. Parks, David A. Ponce, Barnaby Rockwell, Carma A. San Juan, Elizabeth S. Sangine, Peter N. Schweitzer, Steven M. Smith, John C. Wallis, Colin F. Williams, and Douglas B. Yager

Chapter A of

Mineral Resources of the Sagebrush Focal Areas of Idaho, Montana, Nevada, Oregon, Utah, and Wyoming

Edited by Warren C. Day, Thomas P. Frost, Jane M. Hammarstrom, and Michael L. Zientek

Prepared in cooperation with the Bureau of Land Management

Scientific Investigations Report 2016-5089-A

Version 2.0, October 2016 


\title{
U.S. Department of the Interior SALLY JEWELL, Secretary
}

\section{U.S. Geological Survey Suzette M. Kimball, Director}

\author{
U.S. Geological Survey, Reston, Virginia \\ First release: 2016 \\ Revised: October 2016 (ver. 2.0)
}

\begin{abstract}
For more information on the USGS - the Federal source for science about the Earth, its natural and living resources, natural hazards, and the environment-visit http://www.usgs.gov or call 1-888-ASK-USGS.

For an overview of USGS information products, including maps, imagery, and publications, visit http://store.usgs.gov.
\end{abstract}

\footnotetext{
Any use of trade, firm, or product names is for descriptive purposes only and does not imply endorsement by the U.S. Government.

Although this information product, for the most part, is in the public domain, it also may contain copyrighted materials as noted in the text. Permission to reproduce copyrighted items must be secured from the copyright owner.

Suggested citation:

Day, W.C., Hammarstrom, J.M., Zientek, M.L., and Frost, T.P., eds., 2016, Overview with methods and procedures of the U.S. Geological Survey mineral-resource assessment of the Sagebrush Focal Areas of Idaho, Montana, Nevada, Oregon, Utah, and Wyoming (ver. 2.0, October 2016): U.S. Geological Survey Scientific Investigations Report 2016-5089-A, 211 p., http://dx.doi.org/10.3133/sir20165089A.

ISSN 2328-0328 (online)
} 


\section{Foreword}

Scientific Investigations Report 2016-5089 and accompanying data releases are the products of the U.S. Geological Survey (USGS) Sagebrush Mineral-Resource Assessment (SaMiRA). The assessment was done at the request of the Bureau of Land Management (BLM) to evaluate the mineral-resource potential of some 10 million acres of Federal and adjacent lands in Idaho, Montana, Nevada, Oregon, Utah, and Wyoming. The need for this assessment arose from the decision by the Secretary of the Interior to pursue the protection of large tracts of contiguous habitat for the greater sage-grouse (Centrocercus urophasianus) in the Western United States. One component of the Department of the Interior plan to protect the habitat areas includes withdrawing selected lands from future exploration and development of mineral and energy resources, including copper, gold, silver, rare earth elements, and other commodities used in the U.S. economy. The assessment evaluates the potential for locatable minerals such as gold, copper, and lithium and describes the nature and occurrence of leaseable and salable minerals for seven Sagebrush Focal Areas and additional lands in Nevada ("Nevada additions") delineated by BLM. Supporting data are available in a series of USGS data releases describing mineral occurrences (the USGS Mineral Deposit Database or "USMIN"), oil and gas production and well status, previous mineral-resource assessments that covered parts of the areas studied, and a compilation of mineral-use cases based on data provided by BLM, as well as results of the locatable mineral-resource assessment in a geographic information system. The present assessment of mineralresource potential will contribute to a better understanding of the economic and environmental trade-offs that would result from closing approximately 10 million acres of Federal lands to mineral entry.

The initial request for USGS involvement in this resource assessment occurred in October 2015, with a need to provide a report to BLM by mid-July 2016 to inform the National Environmental Policy Act (NEPA) process and environmental impact statement (EIS) preparation. Such a short timeframe required mobilizing a large number of USGS Mineral Resources Program staff to focus on the SaMiRA project, which began in November 2015 with a series of programwide teleconferences to get the project rolling. All of the 61 staff members enlisted to work on the project, including three emeritus scientists who are experts in assessment and in the geology of the areas under consideration, put aside other research and dedicated themselves to this new effort. The first step was to assemble the many types of data needed, including geology, geophysics, geochemistry, location of known deposits, production history, current exploration results, and information from State geological surveys and industry.

By the end of January 2016, the assessment teams were working hard to evaluate the myriad data needed for the assessments. State geological surveys were invited to participate in the process, and meetings were held over a period of several weeks in February and March in Butte, Montana; Denver, Colorado; Menlo Park, California; Moscow, Idaho; and Reno, Nevada, to conduct the assessment workshops and present the results to the State geological surveys for their feedback. The immense task of report writing and figure preparation began during and following the assessment meetings, always mindful of the looming July deadline. The support of the USGS Science Publishing Network is gratefully acknowledged in getting these reports finished in time to meet the BLM's EIS and NEPA deadlines.

We are, as individuals and as an organization, proud of these reports and the dedication and hard work of all the scientists and specialists who worked to produce them. We hope these volumes serve to inform the decisions regarding the future of these Federal lands in the West, the protection of greater sage-grouse and their habitat, and the economies of the Western States. Although we sought information and advice from numerous outside contributors, the results of this study are solely those of the USGS.

\section{Larry Meinert, Program Coordinator, Mineral Resources Program, USGS}




\section{Preface}

Landscape-scale conservation efforts by the Bureau of Land Management (BLM), U.S. Fish and Wildlife Service (FWS), the U.S. Forest Service (USFS), State agencies, private landowners, and other partners are striving to conserve the breeding sagebrush habitat for the greater sage-grouse (Centrocercus urophasianus) across 11 Western States. In September 2015, the FWS decided that the greater sage-grouse did not warrant protection under the Endangered Species Act. Concurrent with this decision, the BLM and USFS finalized land-use plans for the Federal lands containing sagebrush habitat, consisting of more than 165 million acres, of which 10 million acres (15,625 square miles) of BLM and National Forest System lands have been proposed for withdrawal from mineral entry across Idaho, Montana, Nevada, Oregon, Utah, and Wyoming. An additional 394,289 acres (616 square miles) in Nevada (termed the "Nevada

additions") were also evaluated by the U.S. Geological Survey (USGS), at the request of the BLM, that were proposed by the State of Nevada for consideration. The land-use plans outline management practices aimed at conserving viable sagebrush habitats that support the greater sage-grouse across large areas termed Sagebrush Focal Areas (SFAs). The SFAs contain lands that have been proposed for withdrawal ("withdrawal areas") from location and entry under the U.S. mining laws, subject to valid existing rights.

The USGS Sagebrush Mineral-Resource Assessment (SaMiRA) project was initiated in November 2015 and supported by the BLM to (1) assess locatable mineral-resource potential and (2) to describe leasable and salable mineral resources for the seven SFAs and Nevada additions. Because of the limited duration of the SaMiRA project, the effort focused on publically available geoscience data. Additionally, the State geological surveys of Idaho, Montana, Nevada, Oregon, Utah, and Wyoming provided valuable mineral resource and geologic data, as well as scientific expertise. Information was solicited directly by the USGS from the mineral industry, as well as through BLM's public comment process, regarding any information the mineral industry wished to make public and have considered in the assessment. However, the conclusions presented herein are solely those of the USGS. 


\section{Acknowledgments}

This endeavor has been made possible through the combined efforts of numerous people throughout the Bureau of Land Management (BLM) and the U.S. Geological Survey (USGS). Rick Deery, Mitchell Leverette, Adam Merrill, and Thomas (Scott) Murrellwright (BLM Division of Solid Minerals, Washington, D.C.) have provided crucial guidance that set the overall direction of the project. John Varner and Anthony Titolo and their colleagues at the BLM's National Operations Center, Denver, Colorado, provided the claim and lease information from the BLM Legacy Rehost System, or LR2000, database and the geospatial portrayals of the various components of land status within the Sagebrush Focal Areas (SFAs) and proposed withdrawal area boundaries. From the BLM in Montana, we particularly thank Dave Williams, Craig Towery, Joan Gabelman, and Nate Arave.

State geological surveys and other State agencies provided valuable input for the area assessments. In Idaho, Ed Ratchford, State Geologist, and Renee Breedlovestrout, Dennis Feeney, Virginia Gillerman, Reed Lewis, William Phillips, and Christopher Tate provided feedback on the assessment results. For Montana, Dick Berg (emeritus) from the Montana Bureau of Mines and Geology provided information on industrial minerals, and John Metesh, Thomas Patton, Jay Gunderson, Peggy Delaney, Phyllis Hargrave, and Stan Korzeb also provided important feedback. Jay Gunderson of the Montana Board of Oil and Gas Conservation provided oil and gas field boundaries. From the Montana Department of Environmental Quality, we particularly thank Warren McCullough, Robert Cronholm, Herb Rolfes, Wayne Jepson, Ed Coleman, Chris Yde, and Chris Cronin. James E. Faulds, State Geologist for Nevada, made certain that the USGS assessment team covering areas in Nevada was aware of the recent report released by the State on mineral and energy resources in the Nevada part of the SFAs. From the Oregon Department of Geology and Mineral Industries, Robert Houston and lan Madin participated in the Nevada Borderlands assessment meetings. Ken Krahulec, Minerals Section Manager, from the Utah Geological Survey, participated in the Nevada Borderlands assessment meetings. In addition, Andrew Rupke, industrial minerals geologist from the Utah Geological Survey, participated in the Wyoming-Utah assessment meetings. This effort was also greatly improved through discussions in the Wyoming-Utah assessment meetings with Wyoming State Geological Survey staff, including Tom Drean, Director, and geologists Wayne Sutherland and Robert Gregory.

Acquisition, archiving, and analysis of multiple types of geospatial data were the backbone of the project. Numerous geographic information system (GIS) databases were developed from existing reports, data releases, company reports, and State sources, which in many instances had to be converted into digital geospatial format to allow for analysis. The USGS GIS group in Denver, Colorado, was led by Carma San Juan and included Paul Denning, Stuart Giles, and John Horton. Connie Dicken in Reston, Virginia, provided database, GIS, and land-status support. Pam Cossette, Heather Parks, and John Wallis from Spokane, Washington, provided GIS and graphics expertise.

Mineral-resource information compiled by USGS staff was key to the analysis. This included the Mineral Resource Data System (MRDS) and the new Mineral Deposit Database (USMIN) project, which is partly funded by the BLM and is being developed by Gregory Fernette and Peter Schweitzer. The geochemical database compilation was done by Karen Duttweiler-Kelly, 
Matthew Granitto, Douglas Yager, and Stephen Smith. The geophysical data were compiled and processed by Eric Anderson and David Ponce; Barnaby Rockwell provided data and guidance on interpretation of remote sensing data. A number of USGS energy experts contributed data and analysis for uranium, geothermal energy, oil and gas, and coal (see below). Donald Bleiwas, Beth Sangine, and the staff of the USGS National Minerals Information Center (NMIC) contributed commodity information and expertise.

Before writing began, the individual area preliminary assessment tracts were reviewed by an "Assessment Oversight Committee" (AOC) comprised of USGS project leads and scientists of the project to evaluate completeness and consistency from area to area. AOC leads include Thomas Frost, Jane Hammarstrom, and Michael Zientek. Panelists include Donald Bleiwas, Warren Day, Jeffrey Mauk, Mark Mihalasky, Gilpin Robinson, and Bradley Van Gosen.

The following provides an outline of the SaMiRA project structure and lists the names of contributors.

\section{SaMiRA Project Coordination}

Warren C. Day, co-lead

Thomas P. Frost, co-lead

\section{North-Central Montana SFA Team}

B. Carter Hearn, Jr. (Emeritus)

Jeffrey L. Mauk, lead

Heather L. Parks

Michael L. Zientek

\section{North-Central Idaho SFA Team}

Mary Ellen Benson

Stephen E. Box

Albert H. Hofstra

David A. John

Karen Lund, lead

Gilpin R. (Rob) Robinson

Bradley S. Van Gosen

Lukas Zürcher

\section{Southwestern and South-Central Wyoming and Bear River Watershed SFA Team}

Mary Ellen Benson

Timothy S. Hayes

Bradley S. Van Gosen

Anna B. Wilson, lead

Douglas B. Yager

\section{Nevada Borderland SFAs Team}

Mary Ellen Benson 
Joseph P. Colgan

Edward A. du Bray

Susan Hall

Albert H. Hofstra

David A. John

Steve Ludington (Emeritus)

Mark J. Mihalasky

James J. Rytuba (Emeritus)

Lisa L. Stillings

Peter G. Vikre, lead

Lukas Zürcher

\section{Mineral-Resource Assessment Team}

Jane M. Hammarstrom, co-lead

Mark J. Mihalasky

Gilpin R. (Rob) Robinson

Michael L. Zientek, co-lead

\section{Geospatial Information Systems (GIS) and Enterprise Network Team}

Pamela M. Cossette

Randall E. Dailey, Enterprise Network lead

Paul D. Denning

Connie L. Dicken

Stuart A. Giles

John D. Horton

Heather L. Parks

Carma A. San Juan, lead

John C. Wallis, contractor

\section{Geochemistry Team}

Helen W. Folger

Stuart A. Giles

Matthew Granitto

Karen D. Kelley, co-lead

Steven M. Smith, co-lead

Doug B. Yager

\section{Remote Sensing Team}

Barnaby W. Rockwell

\section{Geophysics Team}

Eric D. Anderson, lead

David A. Ponce 


\section{Energy Resources Team}

Jacob DeAngelo, geothermal resources

Ronald M. Drake, oil and gas resources

Jonathan M.G. Glen, geothermal resources

Gregory L. Gunther, energy resource GIS

Jon E. Haacke, coal resources

Susan M. Hall, uranium resources

Colin F. Williams, geothermal resources

\section{Mineral Deposit, Commodity, and Database Teams}

Donald I. Bleiwas, co-lead NMIC Team

Gregory L. Fernette, lead USMIN (see Fernette and others, this volume, for additional acknowledgments)

Peter N. Schweitzer, lead MRDS

Elizabeth S. Sangine, co-lead NMIC Team (see Sangine, appendix 5, for additional acknowledgments)

\section{Assessment Oversight Committee}

Thomas P. Frost, Jane M. Hammarstrom, Michael L. Zientek, leads

Donald I. Bleiwas

Warren C. Day

Jeffrey L. Mauk

Mark J. Mihalasky

Gilpin R. (Rob) Robinson

Bradley S. Van Gosen

\section{Scientific Peer and GIS Metadata Reviewers}

Arthur A. Bookstrom, chapter C

William F. Cannon, chapter E

Mark E. Gettings, chapter D

Christopher S. Holm-Denoma, chapter D

Michaela R. Johnson, metadata

Victoria E. Langenheim, chapter A

Keith R. Long, chapter A

Celestine N. Mercer, chapter C

Barry C. Moring, metadata

William I. Ridley, chapter A

Klaus J. Schulz, chapter E

Ryan D. Taylor, chapter B

Charles H. Thorman (emeritus), chapter B

Erin Todd, chapter C

Philip L. VerPlanck, chapter A

Kathryn E. Watts, chapter B 


\section{Mineral-Deposit Models}

Mary Ellen Benson

Susan Hall

Jane M. Hammarstrom

David A. John

Mark J. Mihalasky

Gilpin R. (Rob) Robinson

Lisa L. Stillings

Bradley S. Van Gosen

Michael L. Zientek 


\section{Contents}

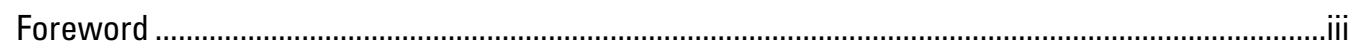

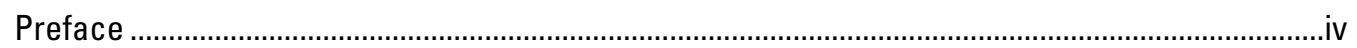

Acknowledgments ................................................................................................................

Section A. Overview of the U.S. Geological Survey Sagebrush Mineral-Resource Assessment

(SaMiRA) Project.

By Warren C. Day, Jane M. Hammarstrom, Michael L. Zientek, and Thomas P. Frost

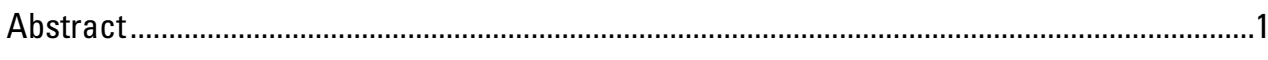

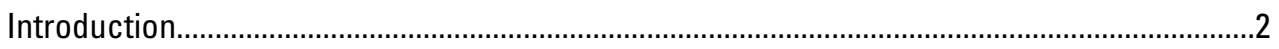

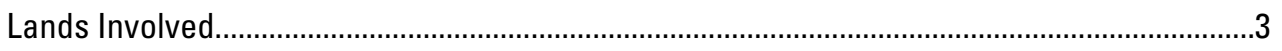

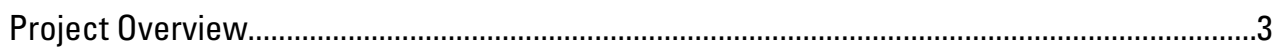

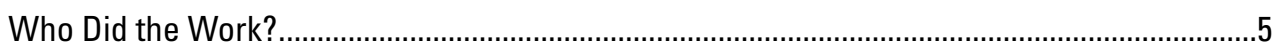

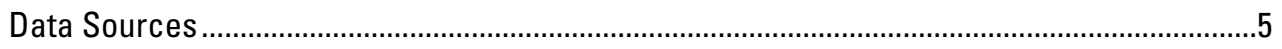

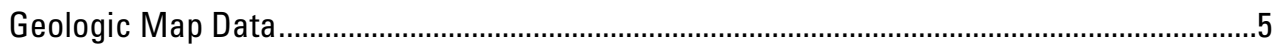

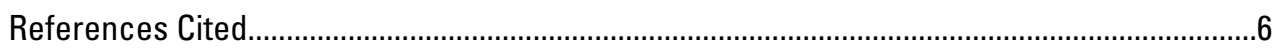

Section B. Mineral-Resource Information ................................................................................

By Gregory L. Fernette, Peter N. Schweitzer, and Elizabeth S. Sangine

USMIN Project Mineral-Resource Data for the USGS SaMiRA Project..................................11

By Gregory L. Fernette

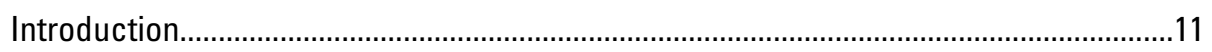

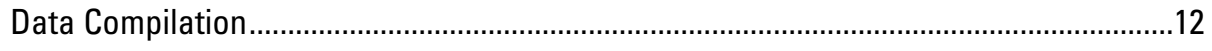

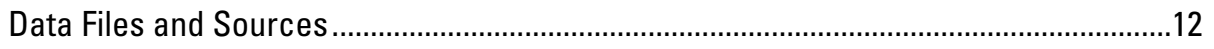

Prospect- and Mine-Related Features...................................................................12

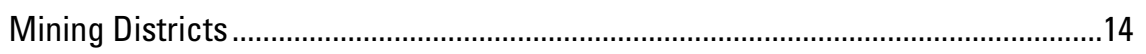

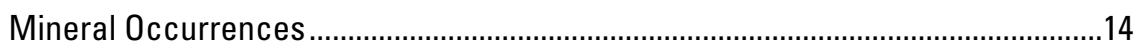

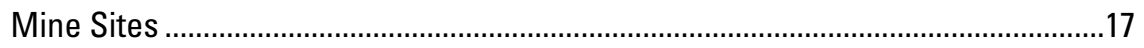

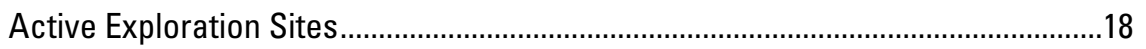

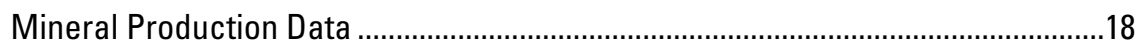

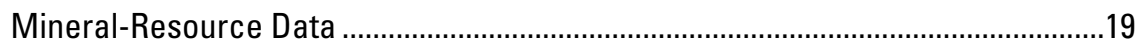

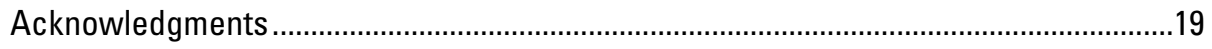

Mineral Resources Data System (MRDS) .......................................................................19

By Peter N. Schweitzer

Mineral-Resource Data from the USGS National Mineral Information Center......................20

By Elizabeth S. Sangine

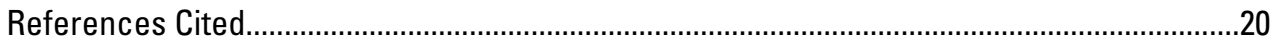

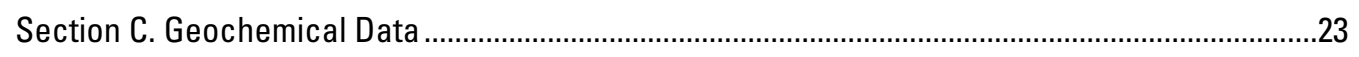

By Steven M. Smith, Karen D. Kelley, Helen W. Folger, Douglas B. Yager, Matthew Granitto, and Stuart A. Giles

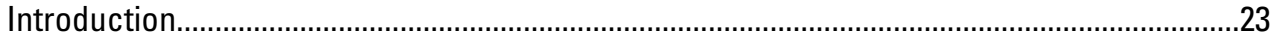

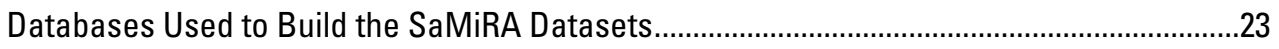

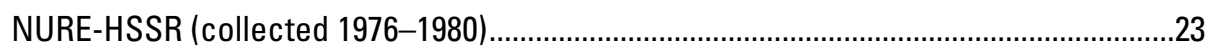

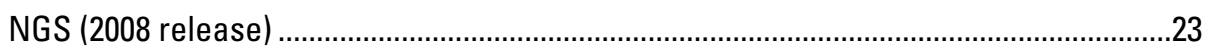

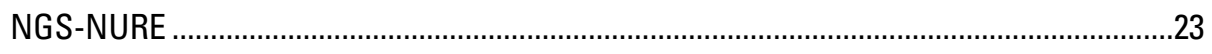

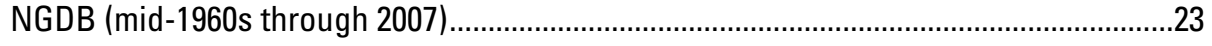




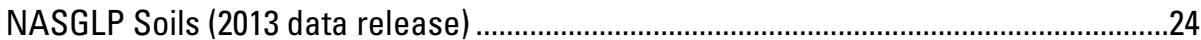

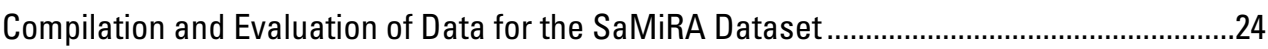

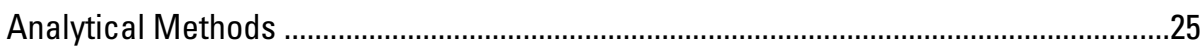

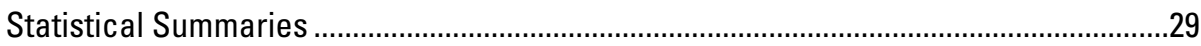

Determination of Threshold Values for SedsSoils and Rocks..........................................29

Determination of Threshold Values for Concentrates .........................................................31

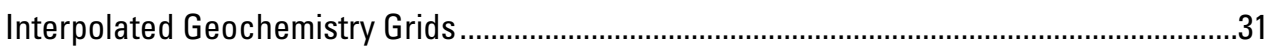

Geographic Information Systems and Symbolized Layers ......................................................32

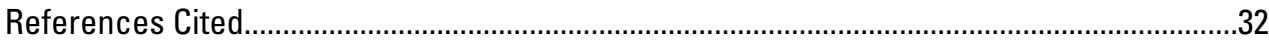

Section D. Geophysical Data and Methods Used in Mineral-Resource Assessments within the Sagebrush Focal Areas ...............................................................................................37

By Eric D. Anderson and David A. Ponce

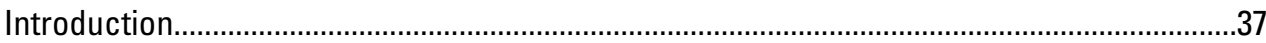

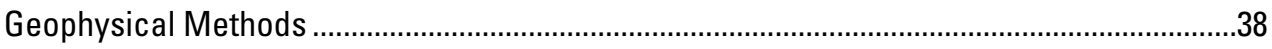

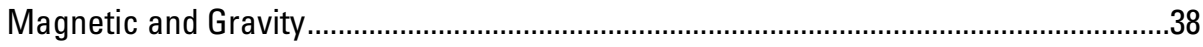

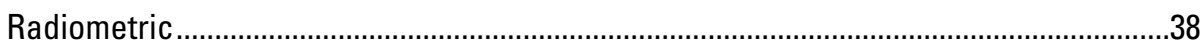

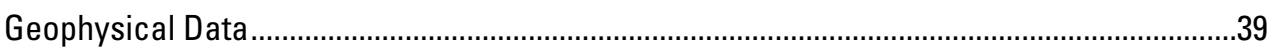

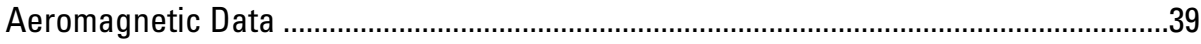

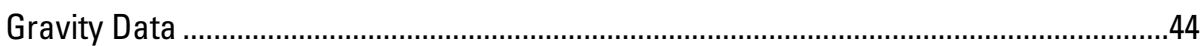

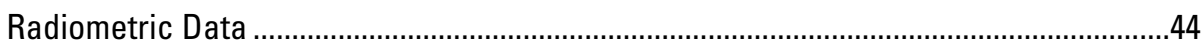

Derivative Geophysical Products........................................................................................

Reduction-to-the-Pole (RTP) of Magnetic Data ..........................................................

Total Horizontal Gradient of Magnetic and Gravity Data ...............................................47

First Vertical Derivative of Magnetic and Gravity Data .................................................4

Tilt Derivative of Magnetic and Gravity Data ..................................................................4

Analytic Signal of Magnetic and Gravity Data..............................................................48

Radioelement Element and Ratio Maps of Radiometric Data ..........................................48

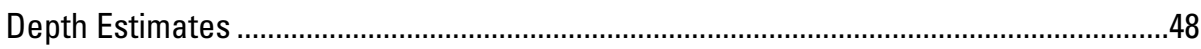

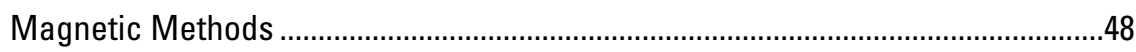

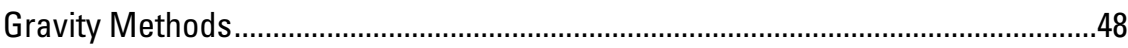

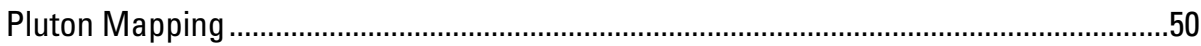

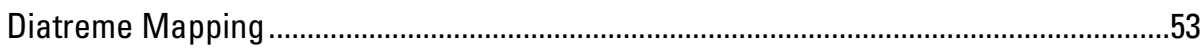

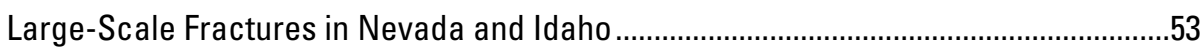

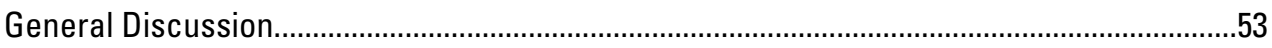

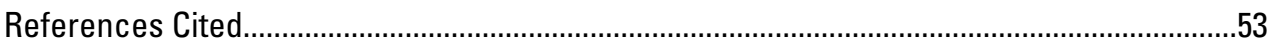

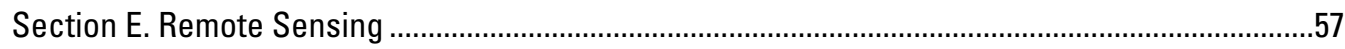

By Barnaby W. Rockwell

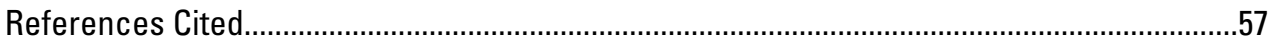

Section F. BLM Legacy Rehost System (LR2000) ......................................................................59

By Connie L. Dicken and Carma San Juan

Geothermal........................................................................................................................

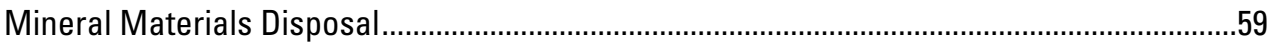

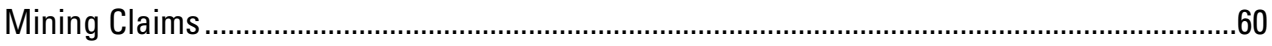

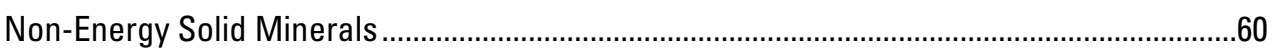

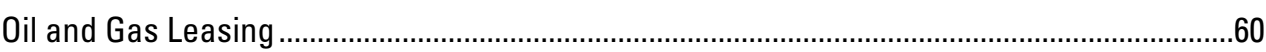


Notices and Plans (Surface Management) .........................................................................60

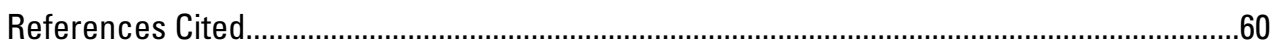

Section G. Previous Mineral-Resource Assessment Data Compilation..........................................61

By Heather L. Parks, Michael L. Zientek, M. Christopher Jenkins, Cassandra K. Hennings, John C. Wallis, and Duc M. Nguyen

References Cited. 62

Section H. Mineral-Resource Assessment for Locatable Minerals ...............................................65

By Jane M. Hammarstrom and Michael L. Zientek

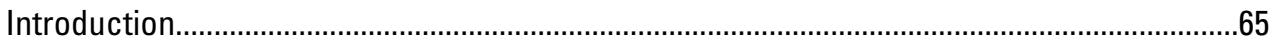

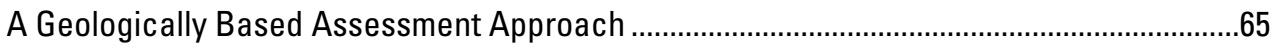

Mineral-Deposit Types and Models............................................................................65

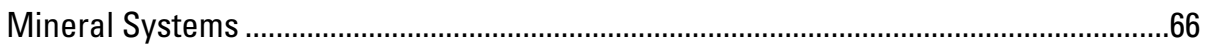

Map Scale and Resolution ................................................................................68

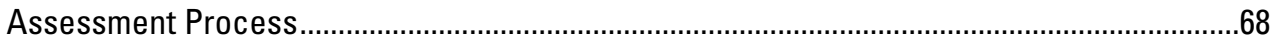

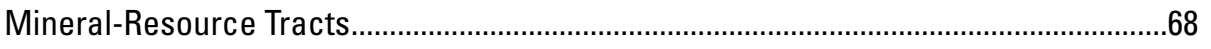

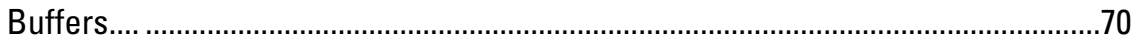

Using Near Distance and Density Mapping to Map Areas with Mineral

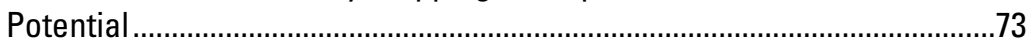

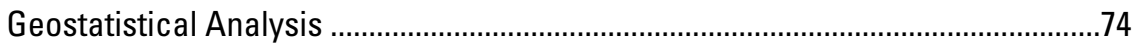

Mineral-Resource Potential and Certainty...................................................................

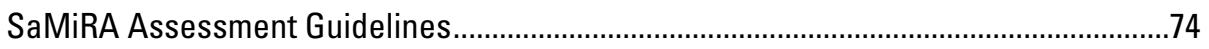

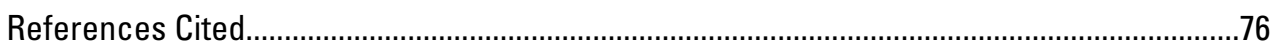

Section I. Locatable Mineral Market-Demand Analysis Commodity Profiles ..................................79

By Donald I. Bleiwas

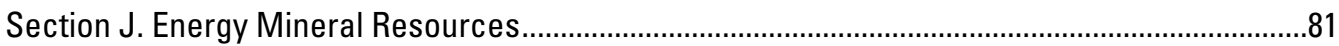

By Jonathan M.G. Glen, Jacob DeAngelo, Colin F. Williams, Jon E. Haacke, Ronald M. Drake II, Gregory L. Gunther, Stuart A. Giles, and Aimee E. Graeber

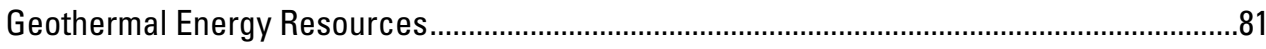

By Jonathan M.G. Glen, Jacob DeAngelo, and Colin F. Williams

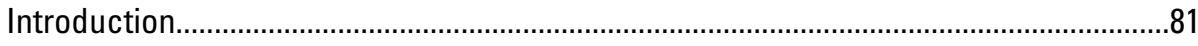

Overview of USGS Geothermal-Resource Assessments and Definitions......................81

Conventional Geothermal Resources............................................................................81

Unconventional Geothermal Resources ...............................................................82

2008 USGS National Resource Assessment ………...................................................82

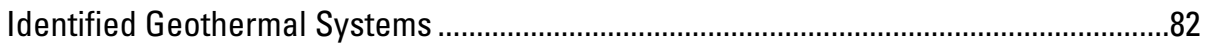

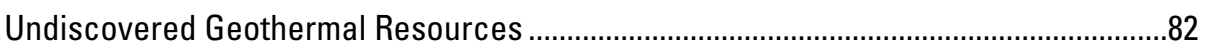

Enhanced Geothermal Systems (EGS) Resources ......................................................87

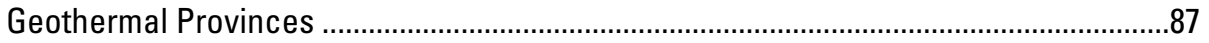

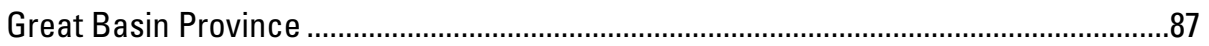

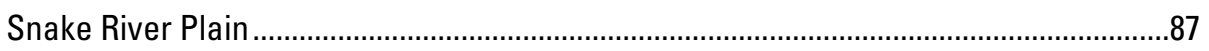

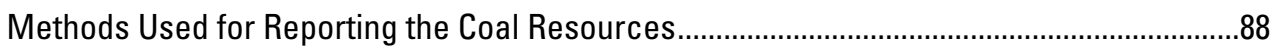

By Jon E. Hacke

Methods Used for Reporting the Oil and Gas Resources ........................................................88

By Ronald M. Drake II, Gregory L. Gunther, Stuart A. Giles, and Aimee E. Graeber

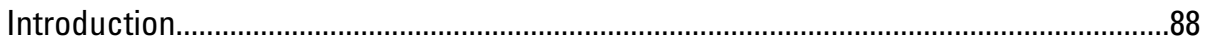

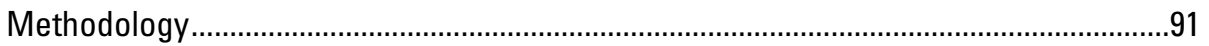




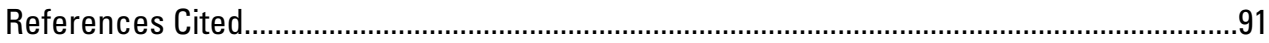

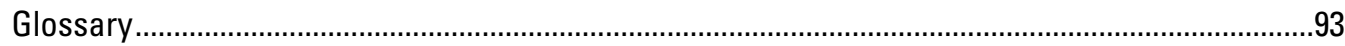

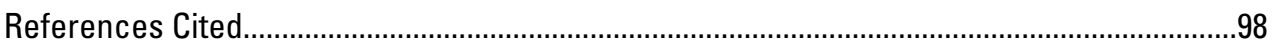

Appendix 1. List of Locatable, Leasable, and Salable Minerals .....................................................100

Appendix 2. Mineral-Potential Classification System .................................................................102

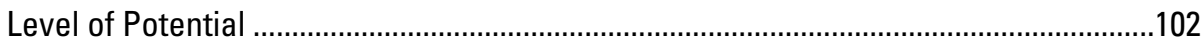

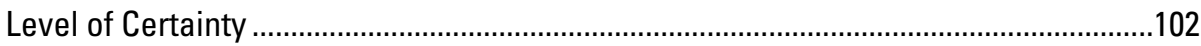

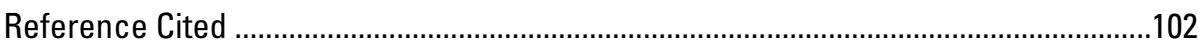

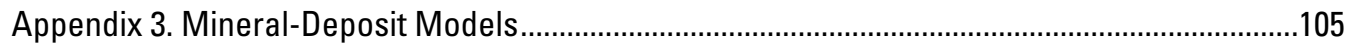

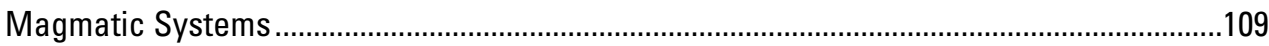

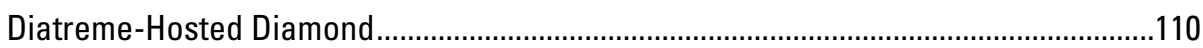

Basalt-Hosted Sunstone.......................................................................................112

Hydrothermal—Plutonic Rock Associated System .........................................................113

Porphyry Copper ...................................................................................................114

Arc-Related Porphyry Molybdenum (low fluorine) ....................................................115

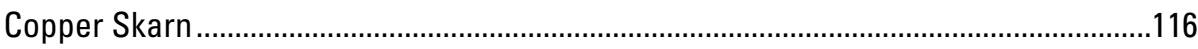

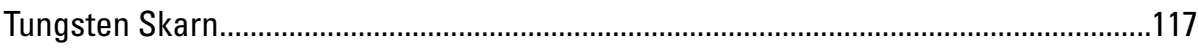

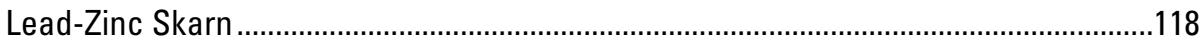

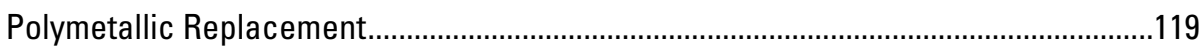

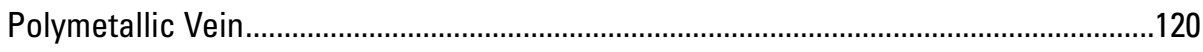

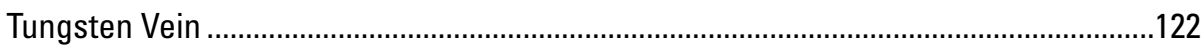

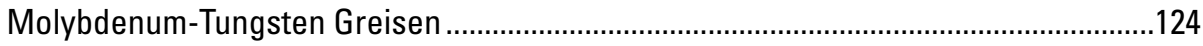

Distal Disseminated Silver-Gold ............................................................................125

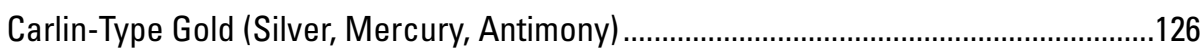

Hydrothermal—Volcanic Rock Associated System ........................................................128

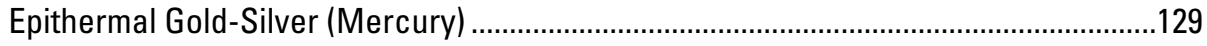

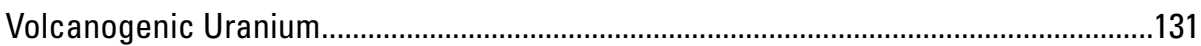

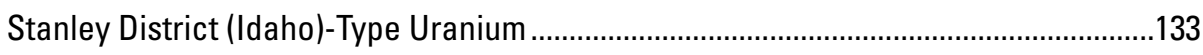

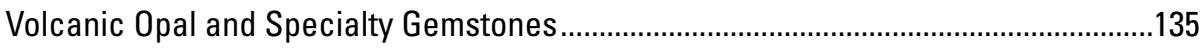

Hectorite (Lithium-Rich Clay) and Specialty Clay......................................................136

Hydrothermal—Exhalative-Magmatic Processes System .................................................137

Volcanogenic Massive Sulfide (Besshi-subtype VMS) _...............................................138

Hydrothermal—Exhalative-Sedimentary Processes System ..............................................140

Sedimentary-Exhalative (SEDEX) Lead-Zinc-Silver ……...............................................141

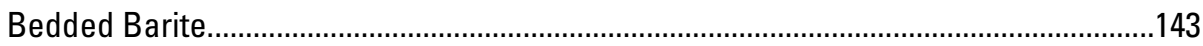

Hydrothermal—Metamorphic Rock Associated System....................................................145

Orogenic Low Sulfide Gold-Quartz Veins...................................................................146

Sedimentary System (formed during or after the conversion from sediment to

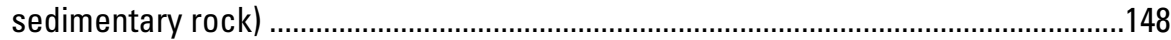

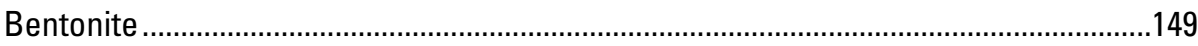

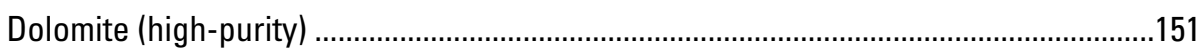

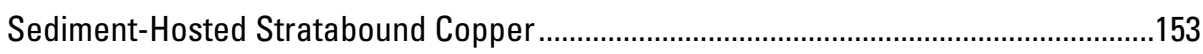

Sandstone Uranium (Roll Front) in Intermontane Basins..............................................155

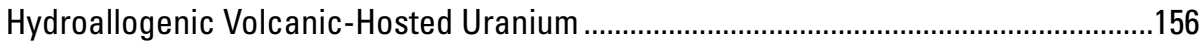

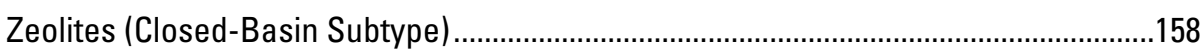

Zeolites (Open-Basin Subtype) ..................................................................................160 
Sedimentary System (formed during deposition of the sediment) .........................................162

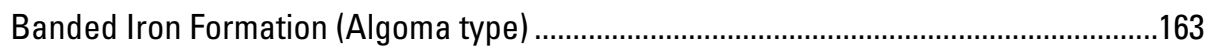

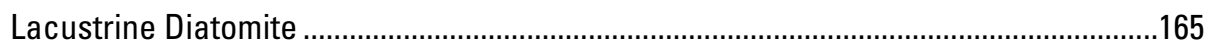

Surficial-Mechanical (Placer) Mineral System ........................................................................167

Heavy Mineral Placers ..................................................................................................... 168

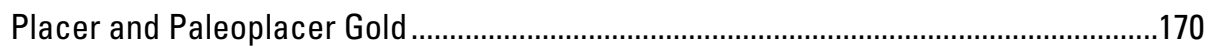

Other (Non-Locatable) Deposit Types .........................................................................................172

Dimension Stone (Sandstone and Quartzite) ................................................................173

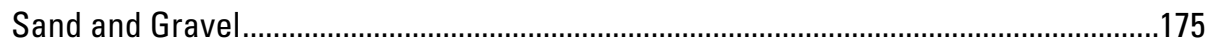

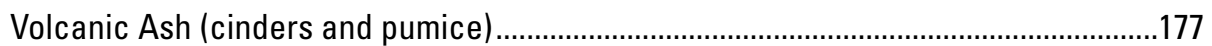

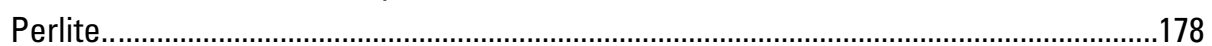

Appendix 4. Strategic and Critical Materials ..................................................................................179

References Cited................................................................................................................ 179

Appendix 5. Market-Demand Commodity Profiles .........................................................................181

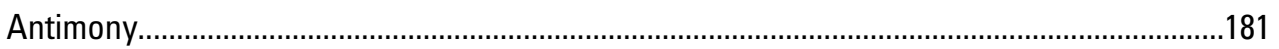

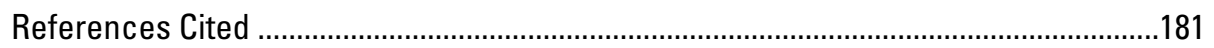

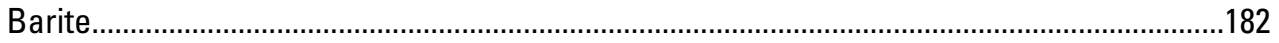

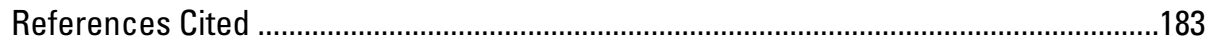

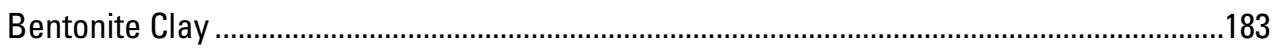

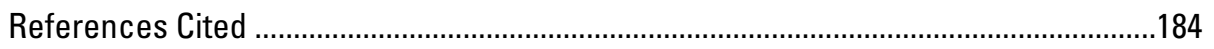

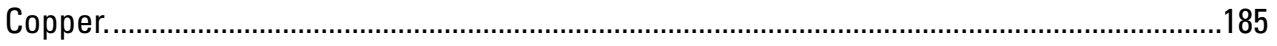

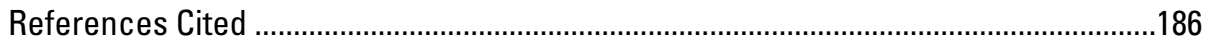

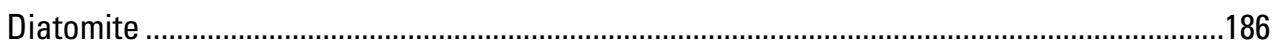

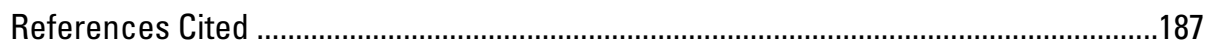

Dimension Stone - Quartzite ............................................................................................. 187

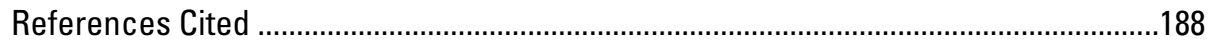

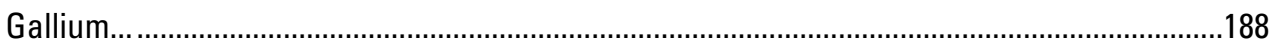

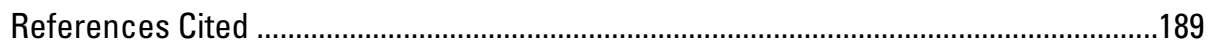

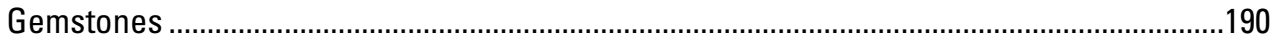

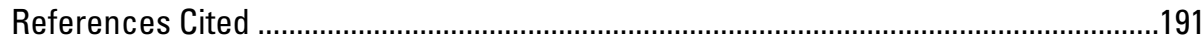

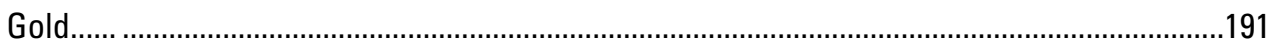

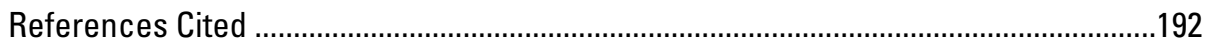

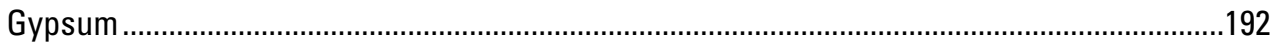

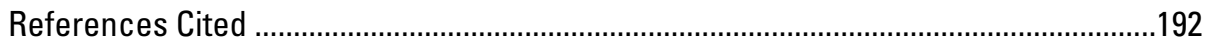

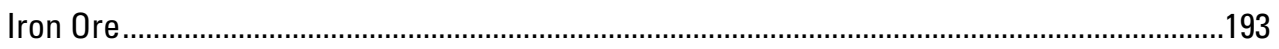

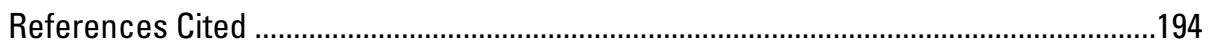

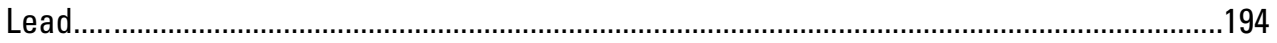

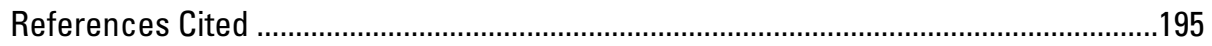

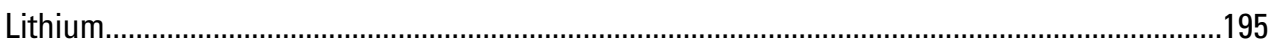

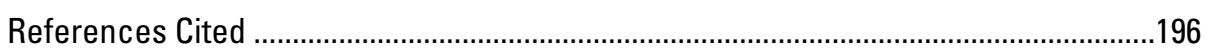

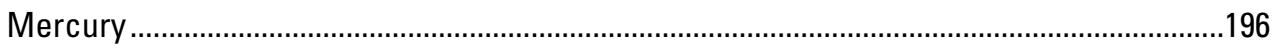

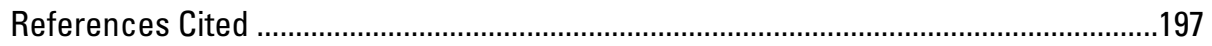

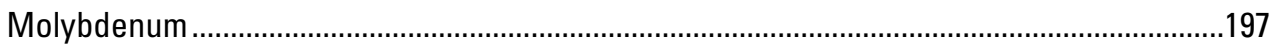

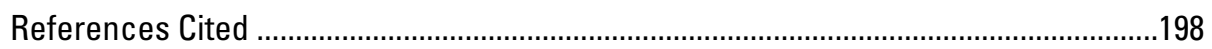

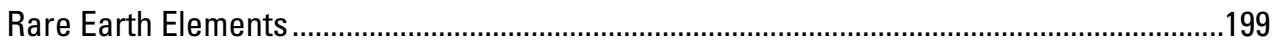

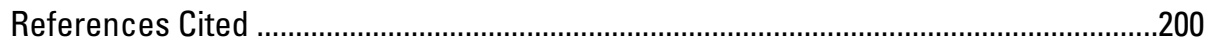


Silver. .201

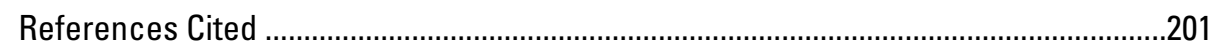

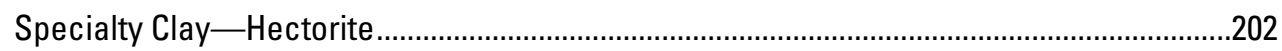

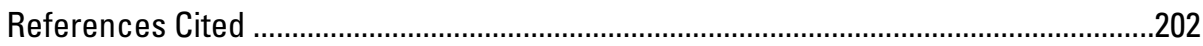

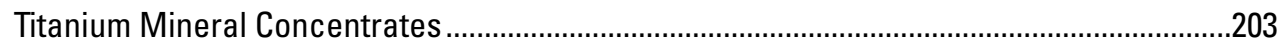

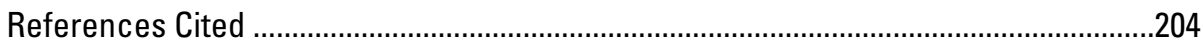

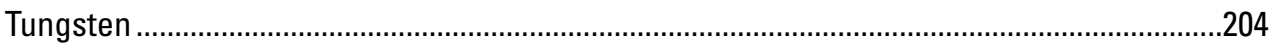

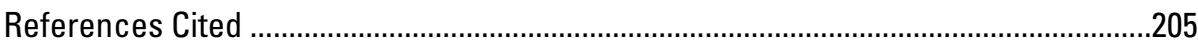

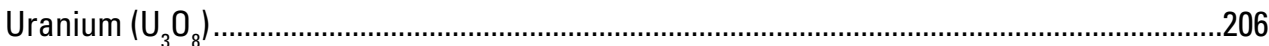

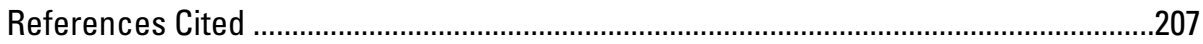

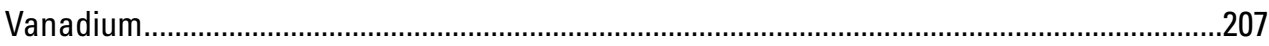

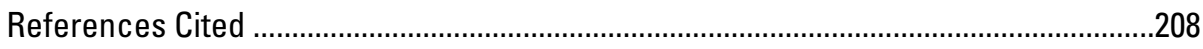

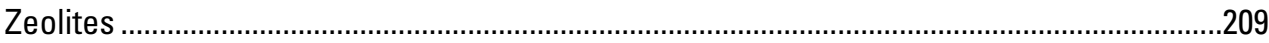

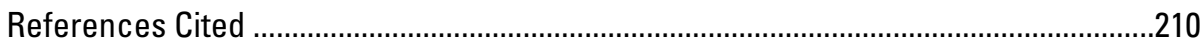

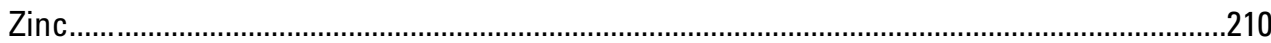

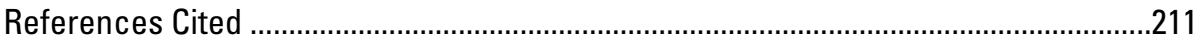

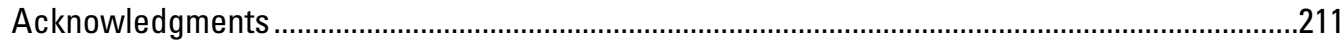

\section{Figures}

A1. Map showing U.S. Geological Survey (USGS) study areas and the extent of the Sagebrush Focal Areas (SFAs) for the Sagebrush Mineral-Resource Assessment (SaMiRA) project, Western United States.

B1. Map showing U.S. Geological Survey (USGS) study areas and the extent of the Sagebrush Focal Areas (SFAs) for the Sagebrush Mineral-Resource Assessment (SaMiRA) project, Western United States.

B2. Map of the mining districts in and near U.S. Geological Survey (USGS) study areas for the Sagebrush Mineral-Resource Assessment (SaMiRA) project, Western United States.

C1. Map showing the distribution of all geochemistry sample sites for the Sagebrush Focal Areas (SFA) studied in the Sagebrush Mineral-Resource Assessment (SaMiRA) project, Western United States.

C2. Example diagram showing copper concentrations in parts per million (ppm) in streamsediment and soil samples (SedsSoils) from the Sheldon-Hart Mountain National Wildlife Refuge, Southern Idaho and Northern Nevada, and Southeastern Oregon and NorthCentral Nevada Sagebrush Focal Areas.

C3. Diagram showing dimensions of inverse distance weighted (IDW) grid cell used for geochemical data in the Sagebrush Mineral-Resource Assessment (SaMiRA) project........ 32

D1. Map showing airborne magnetic surveys that intersect a rectangular region encompassing a 25-kilometer buffer surrounding Sagebrush Focal Areas (SFAs), Western United States.

D2. Map showing total magnetic intensity (TMI) in the Western United States............................. 41

D3. Complete Bouguer gravity anomaly map for four rectangular regions surrounding Sagebrush Focal Areas (SFAs) in the Western United States, which was created as part of the Sagebrush Mineral-Resource Assessment (SaMiRA) project............................................... 45

D4. Ternary radiometric map of the Western United States............................................................... 46

D5. Map of Euler depth estimates overlain on a reduced-to-pole (RTP) magnetic-anomaly map of the North-Central Montana Sagebrush Focal Area.. 
D6. Isostatic-anomaly map and basin-thickness estimates derived from gravity inversions over the North-Central Idaho Sagebrush Focal Area 51

D7. Map of residual magnetic anomalies used to help map plutons in North-Central Idaho Sagebrush Focal Area..

H1. Illustration of a schematic cross section of possible deposit types associated with a hydrothermal-plutonic rock associated system.

H2. Illustration showing an example of datasets used to develop a mineral-resource tract for porphyry copper and skarn deposits.

H3. Matrix of possible mineral potential and certainty designations and criteria used for the mineral-resource assessment for locatable minerals in the Sagebrush Mineral-Resource Assessment (SaMiRA) project

J1. Geothermal-favorability map showing the relative favorability of occurrence for conventional moderate- to high-temperature geothermal resources across the western contiguous United States

J2. Geothermal-temperature map showing temperature in degrees Celsius $\left({ }^{\circ} \mathrm{C}\right)$ at 6-kilometers $(\mathrm{km})$ depth across the western contiguous United States that provides a proxy for the favorability of occurrence for enhanced geothermal systems (EGS) resources.

J3. Geothermal-favorability map for the region of Sagebrush Focal Areas (SFAs), Western United States, showing logistic regression results for geothermal favorability spanning the areas proposed for withdrawal...

J4. Geothermal-temperature map for the region of Sagebrush Focal Areas (SFAs), Western United States, showing temperature in degrees Celsius $\left({ }^{\circ} \mathrm{C}\right)$ at 6-kilometers $(\mathrm{km})$ depth, which provides a proxy for enhanced geothermal systems (EGS) favorability spanning the areas proposed for withdrawal

J5. Map of known coal occurrences for the region of the Sagebrush Focal Areas (SFAs), Western United States

J6. Map showing the $1 / 4$ section-level cell summary oil and gas exploration and well-type information from the propriety IHS Energy Group (2016) database and from Gunther and others (2016b) used for the Sagebrush Mineral-Resource Assessment (SaMiRA) project.... 90

2-1 Matrix showing the classification system used for qualitative mineral-resource potential for locatable minerals in the Sagebrush Mineral-Resource Assessment.....103

\section{Tables}

B1. District data theme attribute fields used for the Sagebrush Mineral-Resource Assessment

(SaMiRA) project, Western United States

B2. Mineral-occurrence data theme attribute fields used for the Sagebrush Mineral-Resource Assessment (SaMiRA) project, Western United States.

B3. Mines data theme attribute fields used for the Sagebrush Mineral-Resource Assessment (SaMiRA) project, Western United States

B4. Exploration data theme attribute fields used for the Sagebrush Mineral-Resource Assessment (SaMiRA) project, Western United States.

C1. Number of samples listed by sample media type for Sagebrush Focal Areas (SFA) studied in the Sagebrush Mineral-Resource Assessment (SaMiRA) project, Western United States... 25 
C2. Analytical methods used for the Sagebrush Mineral-Resource Assessment (SaMiRA) project soil and stream-sediment samples (SedsSoils), concentrate samples, and rock samples

C3. Abundance values for stream-sediment and soil samples (SedsSoils) and rocks used in the Sagebrush Mineral-Resource Assessment (SaMiRA) project.

D1. List of filtered or transformed geophysical datasets generated for the Sagebrush Focal Areas as part of the Sagebrush Mineral-Resource Assessment (SaMiRA) project

D2. Aeromagnetic surveys used to generate new, higher resolution compilations for the Sagebrush Focal Areas (SFAs) as part of the Sagebrush Mineral-Resource Assessment (SaMiRA) project

D3. Specifications for State-compilation of magnetic data over the Sagebrush Focal Areas (SFAs) as part of the Sagebrush Mineral-Resource Assessment (SaMiRA) project ....44

D4. Reduction-to-the-pole (RTP) parameters used to transform magnetic-intensity anomaly data as part of the Sagebrush Mineral-Resource Assessment (SaMiRA) project

D5. Density-depth functions used to constrain final basin gravity fields as part of the Sagebrush Mineral-Resource Assessment (SaMiRA) project.

G1. Geodatabases containing mineral-resource assessment geographic information system (GIS) data that covered the Sagebrush Mineral-Resource Assessment (SaMiRA) study areas compiled from preexisting reports

H1. Relation between classes of mineral deposits, mineral systems, and mineral-deposit types with locatable commodities used in the Sagebrush Mineral-Resource Assessment (SaMiRA) project

H2. Guide to map scale, detectable size of a map feature, and resolution

H3. Example data table for a mineral-resource tract used in the Sagebrush MineralResource Assessment (SaMiRA) project.

H4. Example of mineral-resource tract criteria used in the Sagebrush Mineral-Resource Assessment (SaMiRA) project for Carlin-type gold deposits in the Southeastern Oregon and North-Central Nevada, Southern Idaho and Northern Nevada, and Sheldon-Hart Mountain National Wildlife Refuge Complex of Oregon Sagebrush Focal Areas

H5. Relations among mineral occurrences, deposits, prospects, and showings used in the Sagebrush Mineral-Resource Assessment (SaMiRA) project.

H6. Sources of information for classifying mineral occurrences as deposits or prospects used in the Sagebrush Mineral-Resource Assessment (SaMiRA) project

H7. Summary statistics for the areal extent of mineralized rock and alterations systems associated with various deposit types and suggested buffer radius for tract delineation used in the Sagebrush Mineral-Resource Assessment (SaMiRA) project.

H8. Examples of near distance calculations that were considered for kernel-density mapping used in the Sagebrush Mineral-Resource Assessment (SaMiRA) project...........................73

H9. Direct and indirect evidence indicators for assigning mineral potential used in the Sagebrush Mineral-Resource Assessment (SaMiRA) project.

3-1. Typical mining methods for mineral-deposit types assessed within the Sagebrush Mineral-Resource Assessment (SaMiRA) study areas .106

4-1. Elemental listing of materials stockpiled by the Defense Logistics Agency .179

4-2. Potential acquisitions of materials selected by the Defense Logistics Agency for fiscal year 2016 


\section{Conversion Factors}

[U.S. customary units to International System of Units]

\begin{tabular}{|c|c|c|}
\hline Multiply & By & To obtain \\
\hline \multicolumn{3}{|c|}{ Length } \\
\hline inch (in.) & 2.54 & centimeter $(\mathrm{cm})$ \\
\hline inch (in.) & 25.4 & millimeter (mm) \\
\hline foot $(\mathrm{ft})$ & 0.3048 & meter $(\mathrm{m})$ \\
\hline mile (mi) & 1.609 & kilometer $(\mathrm{km})$ \\
\hline yard (yd) & 0.9144 & meter $(\mathrm{m})$ \\
\hline \multicolumn{3}{|c|}{ Area } \\
\hline acre & 4,047 & square meter $\left(\mathrm{m}^{2}\right)$ \\
\hline acre & 0.4047 & hectare (ha) \\
\hline acre & 0.4047 & square hectometer $\left(\mathrm{hm}^{2}\right)$ \\
\hline acre & 0.004047 & square kilometer $\left(\mathrm{km}^{2}\right)$ \\
\hline square foot $\left(\mathrm{ft}^{2}\right)$ & 929.0 & square centimeter $\left(\mathrm{cm}^{2}\right)$ \\
\hline square foot $\left(\mathrm{ft}^{2}\right)$ & 0.09290 & square meter $\left(\mathrm{m}^{2}\right)$ \\
\hline square inch $\left(\mathrm{in}^{2}\right)$ & 6.452 & square centimeter $\left(\mathrm{cm}^{2}\right)$ \\
\hline square mile $\left(\mathrm{mi}^{2}\right)$ & 259.0 & hectare (ha) \\
\hline square mile $\left(\mathrm{mi}^{2}\right)$ & 2.590 & square kilometer $\left(\mathrm{km}^{2}\right)$ \\
\hline \multicolumn{3}{|c|}{ Volume } \\
\hline barrel (bbl; petroleum, 1 barrel=42 gal) & 0.1590 & cubic meter $\left(\mathrm{m}^{3}\right)$ \\
\hline \multicolumn{3}{|c|}{ Mass } \\
\hline ounce, troy $(\mathrm{oz})$ & 31.103 & $\operatorname{gram}(\mathrm{g})$ \\
\hline pound, avoirdupois (lb) & 0.4536 & kilogram (kg) \\
\hline ton, short $(2,000 \mathrm{lb})$ & 0.9072 & metric ton $(\mathrm{t})$ \\
\hline ton, long $(2,240 \mathrm{lb})$ & 1.016 & metric ton $(\mathrm{t})$ \\
\hline
\end{tabular}

[International System of Units to U.S. customary units]

\begin{tabular}{lcl}
\hline \multicolumn{1}{c}{ Multiply } & By & \multicolumn{1}{c}{ To obtain } \\
\hline centimeter $(\mathrm{cm})$ & Length & \\
millimeter $(\mathrm{mm})$ & 0.3937 & inch (in.) \\
meter $(\mathrm{m})$ & 0.03937 & inch (in.) \\
kilometer $(\mathrm{km})$ & 3.281 & foot $(\mathrm{ft})$ \\
kilometer $(\mathrm{km})$ & 0.6214 & mile (mi) \\
meter $(\mathrm{m})$ & 0.5400 & mile, nautical $(\mathrm{nmi})$ \\
& 1.094 & yard $(\mathrm{yd})$ \\
\hline square meter $\left(\mathrm{m}^{2}\right)$ & Area & \\
square kilometer $\left(\mathrm{km}^{2}\right)$ & 0.0002471 & acre \\
square centimeter $\left(\mathrm{cm}^{2}\right)$ & 247.1 & acre \\
square meter $\left(\mathrm{m}^{2}\right)$ & 0.001076 & square foot $\left(\mathrm{ft}^{2}\right)$ \\
square centimeter $\left(\mathrm{cm}^{2}\right)$ & 10.76 & square foot $\left(\mathrm{ft}^{2}\right)$ \\
square kilometer $\left(\mathrm{km}^{2}\right)$ & 0.1550 & square inch $\left(\mathrm{ft}^{2}\right)$ \\
& 0.3861 & square mile $\left(\mathrm{mi}^{2}\right)$ \\
\hline cubic meter $\left(\mathrm{m}^{3}\right)$ & Volume & \\
cubic meter $\left(\mathrm{m}^{3}\right)$ & 6.290 & barrel $\left(\right.$ petroleum, $\left.1 \mathrm{barrel}=42 \mathrm{gal}^{2}\right)$ \\
cubic meter $\left(\mathrm{m}^{3}\right)$ & 264.2 & gallon $(\mathrm{gal})$ \\
cubic centimeter $\left(\mathrm{cm}^{3}\right)$ & 0.0002642 & million gallons $(\mathrm{Mgal})$ \\
& 0.06102 & cubic inch $\left(\mathrm{in}^{3}\right)$ \\
\hline
\end{tabular}




\begin{tabular}{lcl}
\hline \multicolumn{1}{c}{ Multiply } & By & \multicolumn{1}{c}{ To obtain } \\
\hline cubic meter $\left(\mathrm{m}^{3}\right)$ & 35.31 & cubic foot $\left(\mathrm{ft}^{3}\right)$ \\
cubic meter $\left(\mathrm{m}^{3}\right)$ & 1.308 & cubic yard $\left(\mathrm{yd}^{3}\right)$ \\
cubic kilometer $\left(\mathrm{km}^{3}\right)$ & 0.2399 & cubic mile $\left(\mathrm{mi}^{3}\right)$ \\
cubic meter $\left(\mathrm{m}^{3}\right)$ & 0.0008107 & acre-foot $(\mathrm{acre}-\mathrm{ft})$ \\
\hline \multicolumn{3}{c}{ Mass } \\
\hline gram $(\mathrm{g})$ & 0.032 & ounce, troy $(\mathrm{oz})$ \\
gram $(\mathrm{g})$ & 0.03527 & ounce, avoirdupois $(\mathrm{oz})$ \\
kilogram $(\mathrm{kg})$ & 2.205 & pound avoirdupois $(\mathrm{lb})$ \\
metric ton $(\mathrm{t})$ & 1.102 & ton, short $[2,000 \mathrm{lb}]$ \\
metric ton $(\mathrm{t})$ & 0.9842 & ton, long [2,240 $\mathrm{lb}]$ \\
\hline & Density & \\
\hline kilogram per cubic meter $\left(\mathrm{kg} / \mathrm{m}^{3}\right)$ & 0.06242 & pound per cubic foot $\left(\mathrm{lb} / \mathrm{ft}^{3}\right)$ \\
gram per cubic centimeter $\left(\mathrm{g} / \mathrm{cm}^{3}\right)$ & 62.4220 & pound per cubic foot $\left(\mathrm{lb} / \mathrm{ft}^{3}\right)$ \\
\hline
\end{tabular}

\section{Supplemental Information}

Temperature in degrees Celsius $\left({ }^{\circ} \mathrm{C}\right)$ may be converted to degrees Fahrenheit $\left({ }^{\circ} \mathrm{F}\right)$ as ${ }^{\circ} \mathrm{F}=(1.8 \times$ $\left.{ }^{\circ} \mathrm{C}\right)+32$.

Temperature in degrees Fahrenheit $\left({ }^{\circ} \mathrm{F}\right)$ may be converted to degrees Celsius $\left({ }^{\circ} \mathrm{C}\right)$ as ${ }^{\circ} \mathrm{C}=\left({ }^{\circ} \mathrm{F}-\right.$ 32) / 1.8 .

\section{Datum}

Vertical coordinate information is referenced to the North American Datum of 1983 (NAD 83).

Horizontal coordinate information is referenced to the North American Datum of 1983 (NAD 83).

Altitude, as used in this report, refers to distance above the vertical datum. 


\section{Abbreviations}

\begin{tabular}{|c|c|}
\hline $\mathrm{Ad}$ & andradite (iron-rich garnet) \\
\hline AMIS & Automated Minerals Information System \\
\hline $\mathrm{AOC}$ & Assessment Oversight Committee \\
\hline API & American Petroleum Institute \\
\hline AR & "as received" \\
\hline ASTER & Advanced Spaceborne Thermal Emission and Reflection Radiometer \\
\hline ASTM & American Society for Testing and Materials \\
\hline AU & assessment unit (oil and gas) \\
\hline BCF, BCFG & billion cubic feet (of gas) \\
\hline BHT & bottom-hole temperature \\
\hline BLM & Bureau of Land Management \\
\hline BRW & Bear River Watershed (Sagebrush Focal Area) \\
\hline BV & "best value" \\
\hline CAGR & compound annual growth rate \\
\hline CAI & conodont alteration index \\
\hline CFR & Code of Federal Regulations \\
\hline CIGS & copper-indium-gallium selenide \\
\hline CSA & Canadian Standards Association \\
\hline CSM & clay-sulfate-mica \\
\hline CSAMT & controlled-source audiofrequency magnetotellurics \\
\hline DLA & Defense Logistics Agency \\
\hline DOD & U.S. Department of Defense \\
\hline $\mathrm{DOE}$ & U.S. Department of Energy \\
\hline DOI & U.S. Department of the Interior \\
\hline EGS & enhanced geothermal system \\
\hline EIS & Environmental Impact Statement \\
\hline ETM+ & Landsat 7 Enhanced Thematic Mapper Plus \\
\hline FLPMA & Federal Land Policy and Management Act of 1976 \\
\hline f.o.b. & free on board \\
\hline FWS & U.S. Fish and Wildlife Service \\
\hline$g / t$ & gram per metric ton \\
\hline $\mathrm{Ga}$ & giga-annum or billions of years ago \\
\hline GFTZ & Great Falls Tectonic Zone \\
\hline
\end{tabular}




\begin{tabular}{|c|c|}
\hline GHC & Geo-Heat Center \\
\hline GIS & geographic information system \\
\hline HSSR & Hydrogeochemical and Stream Sediment Reconnaissance \\
\hline IDW & inverse distance weighted \\
\hline LEDs & light-emitting diodes \\
\hline LLD & lower limit(s) of determination \\
\hline m.y. & millions of years \\
\hline $\mathrm{Ma}$ & mega-annum or millions of years ago \\
\hline MAS & Minerals Availability System \\
\hline MCF & thousand cubic feet of gas \\
\hline MILS & Mineral Industry Location System \\
\hline MMBO & million barrels of oil \\
\hline MMBNGL & million barrels of natural gas liquids \\
\hline MOP & muriate of potash \\
\hline Moz & million troy ounces \\
\hline MRDS & Mineral Resources Data System \\
\hline Mt & million metric tons \\
\hline MTU & metric ton unit \\
\hline MVT & Mississippi-Valley-type \\
\hline MW & megawatt \\
\hline MWe & megawatt electricity \\
\hline NASGLP & North American Soils Geochemical Landscape Project \\
\hline NBMG & Nevada Bureau of Mines and Geology \\
\hline NDS & National Defense Stockpile \\
\hline NEPA & National Environmental Policy Act of 1989 \\
\hline NGDB & National Geochemical Database \\
\hline NGL & natural gas liquids \\
\hline NGS & National Geochemical Survey \\
\hline NMIC & USGS National Minerals Information Center \\
\hline NOAA & National Oceanic and Atmospheric Administration \\
\hline NOGA & USGS National Oil and Gas Assessment \\
\hline NURE & National Uranium Resource Evaluation \\
\hline NWR & National Wildlife Refuge \\
\hline opt & troy ounce per short ton \\
\hline $0 z$ & troy ounce \\
\hline
\end{tabular}




$\begin{array}{ll}\text { PGE } & \text { platinum-group element } \\ \text { PGM } & \text { platinum-group metal } \\ \text { PLSS } & \text { Public Land Survey System } \\ \text { ppm } & \text { parts per million } \\ \text { REE } & \text { rare earth element } \\ \text { REOE } & \text { rare earth oxide equivalent(s) } \\ \text { RMOTC } & \text { Rocky Mountain Oilfield Testing Center } \\ \text { ROD } & \text { Record of Decision } \\ \text { RTP } & \text { reduction-to-the-pole or reduced-to-pole } \\ \text { SaMiRA } & \text { Sagebrush Mineral-Resource Assessment } \\ \text { SEDAR } & \text { Canadian System for Electronic Document Analysis and Retrieval } \\ \text { SEDEX } & \text { sedimentary exhalative } \\ \text { SFA } & \text { Sagebrush Focal Area } \\ \text { SG } & \text { specific gravity } \\ \text { SI } & \text { structural index } \\ \text { SOP } & \text { sulfate of potash } \\ \text { SWIR } & \text { shortwave-infrared (region of the electromagnetic spectrum) } \\ \text { t } & \text { metric ton } \\ \text { TCM } & \text { Tax Court Memorandum } \\ \text { Th/K } & \text { thorium/potassium ratio } \\ \text { TMI } & \text { total magnetic intensity } \\ \text { TOMS } & \text { Topographically Occurring Mine Symbols } \\ \text { TPS } & \text { total petroleum system } \\ \text { UMOS } & \text { Utah Mineral Occurrence System } \\ \text { USBM } & \text { former U.S. Bureau of Mines } \\ \text { USFS } & \text { U.S. Forest Service } \\ \text { USGS } & \text { U.S. Geological Survey } \\ \text { USMIN } & \text { USGS Mineral Deposit Database } \\ \text { WMS } & \text { volcanogenic massive sulfide } \\ \text { wt. } & \end{array}$




\section{Chemical Symbols and Formulas Used}

\begin{tabular}{|c|c|c|c|}
\hline $\mathrm{Ag}$ & silver & $\mathrm{Gd}$ & gadolinium \\
\hline Al & aluminum & $\mathrm{Ge}$ & germanium \\
\hline $\mathrm{Al}_{2} \mathrm{O}_{3}$ & aluminum oxide & $\mathrm{H}$ & hydrogen \\
\hline $\mathrm{Ar}$ & argon & $\mathrm{H}_{2} \mathrm{~S}$ & hydrogen sulfide \\
\hline As & arsenic & $\mathrm{Hf}$ & hafnium \\
\hline $\mathrm{Au}$ & gold & $\mathrm{Hg}$ & mercury \\
\hline B & boron & Ho & holmium \\
\hline $\mathrm{Ba}$ & barium & $\ln$ & indium \\
\hline $\mathrm{BaSO}_{4}$ & barium sulfate & Ir & iridium \\
\hline $\mathrm{Be}$ & beryllium & K & potassium \\
\hline $\mathrm{Bi}$ & bismuth & $\mathrm{K}_{2} \mathrm{O}$ & potassium oxide \\
\hline $\mathrm{Br}$ & bromine & $\mathrm{La}$ & lanthanum \\
\hline C & carbon & $\mathrm{Li}$ & lithium \\
\hline $\mathrm{C}_{\text {org }}$ & organic carbon & Lu & lutetium \\
\hline $\mathrm{CO}$ & carbon monoxide & $\mathrm{Mg}$ & magnesium \\
\hline $\mathrm{CO}_{2}$ & carbon dioxide & $\mathrm{MgO}$ & magnesium oxide \\
\hline $\mathrm{Ca}$ & calcium & $\mathrm{Mn}$ & manganese \\
\hline $\mathrm{CaO}$ & calcium oxide & Mo & molybdenum \\
\hline $\mathrm{Cd}$ & cadmium & $\mathrm{N}$ & nitrogen \\
\hline $\mathrm{Ce}$ & cerium & $\mathrm{NH}_{3}$ & ammonia \\
\hline $\mathrm{CH}_{4}$ & methane & $\mathrm{Na}$ & sodium \\
\hline $\mathrm{Cl}$ & chlorine & $\mathrm{NaCl}$ & sodium chloride \\
\hline Co & cobalt & $\mathrm{Na}_{2} \mathrm{O}$ & sodium oxide \\
\hline $\mathrm{Cr}$ & chromium & $\mathrm{Nb}$ & niobium \\
\hline Cs & cesium & $\mathrm{Nd}$ & neodymium \\
\hline $\mathrm{Cu}$ & copper & $\mathrm{Ni}$ & nickel \\
\hline Dy & dysprosium & 0 & oxygen \\
\hline Er & erbium & 0s & osmium \\
\hline Eu & europium & $P$ & phosphorous \\
\hline $\mathrm{F}$ & fluorine & $\mathrm{P}_{4}$ & elemental (white) phosphorus \\
\hline $\mathrm{Fe}$ & iron & $\mathrm{PO}_{4}$ & phosphate \\
\hline $\mathrm{Fe}_{2} \mathrm{O}_{3}$ & ferric iron oxide & $\mathrm{P}_{2} \mathrm{O}_{5}$ & phosphorous pentoxide \\
\hline $\mathrm{Ga}$ & gallium & $\mathrm{Pb}$ & lead \\
\hline GaAs & gallium arsenide & $\mathrm{Pd}$ & palladium \\
\hline GaN & gallium nitride & $\operatorname{Pr}$ & praseodymium \\
\hline
\end{tabular}




\begin{tabular}{llll}
$\mathrm{Pt}$ & platinum & $\mathrm{Te}$ & tellurium \\
$\mathrm{Rb}$ & rubidium & $\mathrm{Th}$ & thorium \\
$\mathrm{Re}$ & rhenium & $\mathrm{Ti}$ & titanium \\
$\mathrm{Rh}$ & rhodium & $\mathrm{TiO}_{2}$ & titanium dioxide \\
$\mathrm{Ru}$ & ruthenium & $\mathrm{Tm}$ & thulium \\
$\mathrm{S}$ & sulfur & $\mathrm{Tl}$ & thallium \\
$\mathrm{Sb}$ & antimony & $\mathrm{U}$ & uranium \\
$\mathrm{Sc}$ & scandium & $\mathrm{U}_{3} \mathrm{O}_{8}$ & triuranium octaoxide (yellowcake) \\
$\mathrm{Se}$ & selenium & $\mathrm{V}$ & vanadium \\
$\mathrm{Si}$ & silicon & $\mathrm{V}_{2} \mathrm{O}_{5}$ & vanadium pentoxide \\
$\mathrm{SiO}$ & silicon dioxide (silica) & $\mathrm{W}_{2}$ & tungsten \\
$\mathrm{Sm}$ & samarium & $\mathrm{WO}_{3}$ & tungsten trioxide \\
$\mathrm{Sn}$ & tin & $\mathrm{Y}$ & yttrium \\
$\mathrm{Sr}$ & strontium & $\mathrm{Yb}$ & ytterbium \\
$\mathrm{Ta}$ & tantalum & $\mathrm{Zn}$ & zinc \\
$\mathrm{Tb}$ & terbium & $\mathrm{Zr}$ & zirconium \\
\hline
\end{tabular}

\section{Mineral Formulas Used}

\begin{tabular}{|c|c|}
\hline adularia & $\mathrm{KAISi}_{3} \mathrm{O}_{8}$ \\
\hline alunite & $\mathrm{KAl}_{3}\left(\mathrm{SO}_{4}\right)_{2}(\mathrm{OH})_{6}$ \\
\hline andradite (garnet) & $\mathrm{Ca}_{3} \mathrm{Fe}_{2}^{3+}\left(\mathrm{SiO}_{4}\right)_{3}$ \\
\hline ankerite & $\mathrm{Ca}(\mathrm{Fe}, \mathrm{Mg}, \mathrm{Mn})\left(\mathrm{CO}_{3}\right)_{2}$ \\
\hline argentite & $\mathrm{Ag}_{2} \mathrm{~S}$ \\
\hline arsenopyrite & FeAsS \\
\hline barite & $\mathrm{BaSO}_{4}$ \\
\hline bornite & $\mathrm{Cu}_{5} \mathrm{FeS}_{4}$ \\
\hline cassiterite & $\mathrm{SnO}_{2}$ \\
\hline chalcocite & $\mathrm{Cu}_{2} \mathrm{~S}$ \\
\hline chalcopyrite & $\mathrm{CuFeS}_{2}$ \\
\hline cinnabar & $\mathrm{HgS}$ \\
\hline clinoptilolite (zeolite) & $(\mathrm{Ca}, \mathrm{Na}, \mathrm{K})_{2-3} \mathrm{Al}_{3}(\mathrm{Al}, \mathrm{Si})_{2} \mathrm{Si}_{13} \mathrm{O}_{36} \cdot 12\left(\mathrm{H}_{2} \mathrm{O}\right)$ \\
\hline coffinite & $\left.\mathrm{U}\left[\mathrm{SiO}_{4}, \mathrm{OH}\right)_{4}\right]$ \\
\hline
\end{tabular}




\begin{tabular}{|c|c|}
\hline corderoite & $\mathrm{Hg}_{3} \mathrm{~S}_{2} \mathrm{Cl}_{2}$ \\
\hline dolomite & $\mathrm{CaMg}\left(\mathrm{CO}_{3}\right)_{2}$ \\
\hline erionite (zeolite) & $(\mathrm{Ca}, \mathrm{Na}, \mathrm{K})_{10}\left[\mathrm{Al}_{10} \mathrm{Si}_{26} \mathrm{O}_{72}\right] \cdot \sim 30 \mathrm{H}_{2} \mathrm{O}$ \\
\hline fluorite & $\mathrm{CaF}_{2}$ \\
\hline galena & $\mathrm{PbS}$ \\
\hline hectorite (smectite clay) & $\mathrm{Na}_{3}(\mathrm{Mg}, \mathrm{Li})_{3} \mathrm{Si}_{4} \mathrm{O}_{10}(\mathrm{~F}, \mathrm{OH})_{2}$ \\
\hline hematite & $\mathrm{Fe}_{2} \mathrm{O}_{3}$ \\
\hline ilmenite & $\mathrm{FeTiO}_{3}$ \\
\hline kaolinite & $\mathrm{Al}_{2} \mathrm{Si}_{2} \mathrm{O}_{5}(\mathrm{OH})_{4}$ \\
\hline leucite & $\mathrm{K}\left(\mathrm{AlSi}_{2} \mathrm{O}_{6}\right)$ \\
\hline magnetite & $\mathrm{Fe}_{3} \mathrm{O}_{4}$ \\
\hline molybdenite & $\mathrm{MoS}_{2}$ \\
\hline molybdite & $\mathrm{MoO}_{3}$ \\
\hline monazite & $(\mathrm{Ce}, \mathrm{La}, \mathrm{Th}, \mathrm{Nd}) \mathrm{PO}_{4}$ \\
\hline montmorillonite & $(\mathrm{Na}, \mathrm{Ca})_{0.33}(\mathrm{Al}, \mathrm{Mg})_{2}\left(\mathrm{Si}_{4} \mathrm{O}_{10}\right)(\mathrm{OH})_{2} \cdot \mathrm{nH}_{2} \mathrm{O}$ \\
\hline nepheline & $\mathrm{Na}_{3} \mathrm{KAl}_{4} \mathrm{Si}_{4} \mathrm{O}_{16}$ \\
\hline opal & $\mathrm{SiO}_{2} \cdot \mathrm{nH}_{2} \mathrm{O}$ \\
\hline phillipsite (zeolite) & $(\mathrm{Ca}, \mathrm{Na}, \mathrm{K})_{4-7}\left[\mathrm{Al}_{4-7} \mathrm{Si}_{2-9} \mathrm{O}_{32}\right] \cdot 12 \mathrm{H}_{2} \mathrm{O}$ \\
\hline powellite & $\mathrm{CaMoO}_{4}$ \\
\hline pyrite & $\mathrm{FeS}_{2}$ \\
\hline quartz & $\mathrm{SiO}_{2}$ \\
\hline rutile & $\mathrm{TiO}_{2}$ \\
\hline scheelite & $\mathrm{CaWO}_{4}$ \\
\hline siderite & $\mathrm{FeCO}_{3}$ \\
\hline sillimanite & $\mathrm{Al}_{2} \mathrm{SiO}_{5}$ \\
\hline sylvite & $\mathrm{KCl}$ \\
\hline sylvinite & $\mathrm{KCl}+\mathrm{NaCl}$ \\
\hline sphalerite & $(\mathrm{Zn}, \mathrm{Fe}) \mathrm{S}$ \\
\hline staurolite & $\mathrm{Fe}_{2} \mathrm{Al}_{9} \mathrm{Si}_{4} \mathrm{O}_{23}(\mathrm{OH})$ \\
\hline stilpnomelane & $(\mathrm{K}, \mathrm{Ca}, \mathrm{Na})\left(\mathrm{Fe}^{2+}, \mathrm{Mg}, \mathrm{Fe}^{3+}\right)_{8}(\mathrm{Si}, \mathrm{Al})_{12}(\mathrm{O}, \mathrm{OH})_{27} \cdot \mathrm{nH}_{2} \mathrm{O}$ \\
\hline tetrahedrite & $(\mathrm{Cu}, \mathrm{Fe}, \mathrm{Ag}, \mathrm{Zn})_{12} \mathrm{Sb}_{4} \mathrm{~S}_{13}$ \\
\hline uraninite & $\mathrm{UO}_{2}$ \\
\hline xenotime & $\mathrm{YPO}_{4}$ \\
\hline zircon & $\mathrm{ZrSiO}_{4}$ \\
\hline
\end{tabular}





\title{
Overview with Methods and Procedures of the U.S. Geological Survey Mineral-Resource Assessment of the Sagebrush Focal Areas of Idaho, Montana, Nevada, Oregon, Utah, and Wyoming
}

\author{
By Warren C. Day, Jane M. Hammarstrom, Michael L. Zientek, and Thomas P. Frost, editors
}

With additional sections by Eric D. Anderson, Donald I. Bleiwas, Ronald M. Drake II, Jacob DeAngelo, Connie L. Dicken, Gregory L. Fernette, Helen W. Folger, Stuart A. Giles, Jonathan M.G. Glen, Aimee E. Graeber, Matthew Granitto, Gregory L. Gunther, Jon E. Haacke, Cassandra K. Hennings, M. Christopher Jenkins, Karen D. Kelley, Duc M. Nguyen, Heather L. Parks, David A. Ponce, Barnaby Rockwell, Carma A. San Juan, Elizabeth S. Sangine, Peter N. Schweitzer, Steven M. Smith, John C. Wallis, Colin F. Williams, and Douglas B. Yager

\section{Section A. Overview of the U.S. Geological Survey Sagebrush Mineral-Resource Assessment (SaMiRA) Project}

By Warren C. Day, Jane M. Hammarstrom, Michael L. Zientek, and Thomas P. Frost

\author{
Abstract \\ This report, chapter A of Scientific Investigations Report \\ 2016-5089, provides a project overview and a consolidated \\ resource for the methods, procedures, and voluminous \\ fundamental reference information used throughout the \\ Sagebrush Mineral-Resource Assessment (SaMiRA) \\ project. Mineral occurrence and deposit information is a key \\ component of assessments for non-energy minerals. Data were \\ used from several major databases. The new U.S. Geological \\ Survey (USGS) Mineral Deposit Database project (USMIN) \\ (Fernette, section B) provides a modern compilation that \\ captures all information publically available through historical \\ records, Federal and State databases, company reports, and \\ from the Bureau of Land Management's (BLM) public \\ comments on the proposed withdrawal action of greater sage- \\ grouse (Centrocercus urophasianus) habitat received by the \\ USGS on April 4, 2016. USMIN provides updated location
}

and mineral information on mine sites, mining districts, areas of active exploration, and production data. The USGS Mineral Resource Data System (MRDS) legacy database (Schweitzer, section B) contains mineral-resource information used in the SaMiRA project. The Automated Minerals Information System (AMIS) database operated by the USGS (see Sangine, section B) contains proprietary mineral data that, when aggregated to assure that the individual operators were not identified, provided a list of active facilities in the project area.

Geochemical data for approximately 26,300 stream sediment and soil samples, 3,700 heavy concentrate fractions, and 6,890 rock samples were compiled from USGS geochemical databases for the SaMiRA project. After statistical evaluation, selected elements indicative of a wide variety of mineral-deposit types were used to identify areas with mineral potential (Smith and others, section C). Geophysical methods are powerful tools to map geologic materials that have differing physical properties in areas 
that are both exposed on the land surface and concealed beneath thick sequences of overburden. Such information helps define mineral-potential tracts like those used in the SaMiRA project. Anderson and Ponce (section D) review the magnetic susceptibility, density, and radioactivity data sources and analytical methods used. Rockwell (section E) describes remote-sensing data used for the project.

The BLM's Legacy Rehost System, or LR2000, database provides a compendium of information on mineral-use authorizations for oil, gas, and geothermal leasing, rights-ofways, coal and other mineral development, land and mineral titles, mining claims, withdrawals, classifications, and more on Federal lands or on Federal mineral estates. The LR2000 data used in the SaMiRA reports as described by Dicken and San Juan (section F) are as of March 6, 2016. To expedite the locatable mineral-resource assessments and consolidate the LR2000 data for the leasable and salable minerals, Dicken and San Juan built a geographic information system (GIS) database that relates the attributes to allow for statistical analysis of claim- and lease-density information for numerous commodities (Dicken and San Juan, 2016).

The primary focus of the SaMiRA project was to provide qualitative mineral-resource assessments for the significant locatable mineral commodities. Mineral-deposit models provide powerful tools to integrate various geologic, geochemical, geophysical, and mineral-deposit data to develop the locatable mineral assessment tracts. Parks and others (section G) compiled data on previous mineral assessments that overlap the SaMiRA project area, which were published in Parks and others (2016). Hammarstrom and Zientek (section H) review the principal mineral-deposit types and mineral systems applicable to the vast landscape of the SaMiRA project area. They provide an overview of the assessment methods and procedures for creating the tracts for locatable mineral resources, evaluating the potential and level of certainty for the tracts, and the assessment guidelines used. The geospatial data for all of the locatable mineral resources assessed for the SaMiRA project are presented in San Juan and others (2016).

The BLM requested present and potential future market-demand analyses for the locatable minerals. Bleiwas (section I) provides a general description of domestic production and a qualitative assessment of inferred future market demands for the important locatable minerals identified to have a moderate or high potential for occurrence within the proposed withdrawal areas.

The SaMiRA project was tasked with describing the nature and occurrence of the leasable and salable minerals relevant for each Sagebrush Focal Area (SFA). Leasable minerals include energy-resource commodities and fertilizer minerals such as potash. The evaluation of energy minerals was based on previous USGS assessments and the information from the BLM's LR2000 database. Glen and others (section J) provide a review of the source information, an overview of previous USGS geothermal-assessment reports, discussion of the identified geothermal systems, and context for the geothermal-energy setting for the major geothermal provinces of the project area. Coal is a vital energy resource for the Nation; Haacke (section J) provides a brief overview on how coal resource information was incorporated into each of the assessment reports. Oil and gas development plays an important part in land-use planning for the BLM. Drake and others (section J) review the Total Petroleum System (TPS) methodology used in USGS oil and gas assessments. A TPS is a naturally occurring hydrocarbon-fluid system that presumes that migration pathways exist now or existed in the past and that they connect the provenance with the accumulations. Such concepts and data such as that in Gunther and others $(2016 a, b)$ led to the descriptions presented in the individual SFA reports.

The extensive appendixes that accompany this report are a major resource used throughout the SaMiRA project. They provide a comprehensive listing of the individual locatable, leasable, and salable minerals; mineral-potential classification system used; a general glossary of terms; a consolidation of the applicable mineral-deposit models; and market-demand commodity profiles for the locatable mineral commodities that have moderate to high potential of occurrence.

\section{Introduction}

In September 2015, the Bureau of Land Management (BLM) and U.S. Forest Service (USFS) finalized land-use plans for regions containing sagebrush habitat for more than 165 million acres of public and National Forest System lands across in Idaho, Montana, Nevada, Oregon, Utah, and Wyoming. The intent of the plans is to provide guidance on land-management practices to conserve viable sagebrush ecosystems that support the greater sage-grouse (Centrocercus urophasianus; hereafter sage-grouse). The plans, released as Records of Decision (RODs) for the Great Basin greater sagegrouse sub-regions (Bureau of Land Management, 2015a) and for the Rocky Mountain region (Bureau of Land Management, 2015b), identified Sagebrush Focal Areas (SFAs), which are landscape-scale unconsolidated and contiguous tracts of land that contain high breeding population densities of sage-grouse and high quality sagebrush ecosystems (see Bureau of Land Management, 2015c). Notification of the extent of the SFAs was initially given in September 2015 in the Federal Register (U.S. Department of the Interior, 2015a), with subsequent corrections to the legal land descriptions in October 2015 (U.S. Department of the Interior, 2015b).

The BLM and USFS RODs of September 2015 recommended withdrawal from location and entry under U.S. mining laws. To inform the decision on whether to withdraw the SFAs from mineral entry, the BLM requires a mineral-resource assessment be completed to identify mineral resources within the proposed area of withdrawal. Mineralpotential reports are required to satisfy the requirements of 43 CFR 2310.3-2, "Development and processing of casefile for submission to the Secretary." The analysis needs to provide information on the general geology, known mineral deposits, past and present mineral production, mining claims, and 
mineral leases, as well as an evaluation of future mineral potential and a review of mineral economics.

The USGS initiated the Sagebrush Mineral-Resource Assessment (SaMiRA) project in November 2015. There are seven SFAs discussed herein-(1) North-Central Idaho, (2) North-Central Montana, (3) Southeastern Oregon and North-Central Nevada, (4) Southern Idaho and Northern Nevada, (5) Sheldon-Hart Mountain National Wildlife Refuge Complex of Oregon, (6) Bear River Watershed of Utah, and (7) Southwestern and South-Central Wyoming. In February 2016, the BLM requested assessments of two additional areas in Nevada, termed the "Nevada additions," which lie to the south of the Southern Idaho and Northern Nevada SFA and the Southeastern Oregon and North-Central Nevada SFA (fig. A1). The Nevada additions were proposed by the Governor of Nevada in January 2016 (http://gov.nv.gov/uploadedFiles/ govnvgov/Content/News and Media/Press/2016 Images and_Files/Final Transmittal Letter 1.15.16 Signed-reducedcombined.pdf).

The data used throughout this report are based on publicly available sources. Very limited new field data and no new geochemical or geophysical data were collected because of the limited time available to provide preliminary information to the BLM by July 15, 2016. Because the proposed withdrawal only affects locatable minerals, these reports focus on the potential for and provide market analysis only on those mineral commodities that are classified as "locatable" minerals under the General Mining Act of 1872 (30 U.S.C. 22-42) that are important to the regional, national, and international economies (see appendix 1). The present and potential future market-demand analysis is focused on current use and U.S. domestic production to provide a qualitative assessment of inferred future market demands for the relevant locatable minerals. These reports also review the current situation, but not future potential, for leasable minerals (such as, oil, gas, coal, geothermal energy minerals, and phosphate deposits) and salable minerals (such as, sand and gravel resources). The USGS relied on the BLM's LR2000 database for information on mining claims, mineral leases, mineralmaterial sales contracts, and surface-management (43 CFR 3809) authorizations.

This report summarizes the approach taken to provide mineral-resource information to the BLM, with discussions on the sources of data incorporated, mineral-resource assessment methods, the mineral-deposit models employed, and an analysis of the market demand.

\section{Lands Involved}

The U.S. Department of the Interior (DOI) (2015a, b) defined the initial legal boundaries of the proposed lands for withdrawal from mineral entry within the SFAs. There are three important terms used in these reports that reference the lands under consideration by the BLM for conservation actions (fig. A1) - (1) Sagebrush Focal Areas (SFAs), (2) the part of the SFAs that are under consideration and proposed for withdrawal from mineral entry ("withdrawal areas"), and (3) Public Land Survey System (PLSS) boundaries, which are the boundaries of the townships that contain proposed withdrawal areas.

The SFAs are broad landscape-scale regions considered to have high breeding-population densities of sage-grouse and existing high-quality sagebrush habitat within the Western Association of Fish and Wildlife Agencies sagegrouse management zones. Only some parts of the SFAs are proposed for withdrawal from locatable mineral entry. Within the SFAs, some lands, such as BLM wilderness study areas, have already been excluded from mineral entry. There are also inholdings of State and private lands within the SFAs. Examples include the two sections set aside in every PLSS township to support State schools, mineral patents, and homesteads. With these exclusions, the proposed withdrawal areas have irregular and patchy shapes. To ensure complete coverage of the withdrawal areas, USGS used a study area that is made up of all the townships that include areas proposed for withdrawal. The townships include those first described by BLM (Bureau of Land Management, 2015c), as formally proposed by DOI (U.S. Department of the Interior, 2015a, b), plus amendments proposed by the State of Nevada on January 15, 2016 (http://gov.nv.gov/uploadedFiles/govnvgov/Content/ News_and_Media/Press/2016_Images_and_Files/Final Transmittal Letter 1.15.16 Signed-reduced-combined.pdf), and further amended by BLM through correspondence (Anthony Titolo, BLM, written commun., April 22, 2016). The adjacent PLSS township boundaries were dissolved to define the study area and then modified to exclude Native American lands, which are sovereign and exempt from withdrawal, that are inside the study area (fig. A1). Inclusion of lands in the USGS mineral assessment that are not part of the formally proposed withdrawal areas has no implications regarding land value, management alternatives, or recommendation for disposition. They were included only to assure continuity in evaluation of the regional geologic information to inform the assessment of the proposed withdrawal areas.

A 25-kilometer $(\mathrm{km})$ buffer zone beyond the outermost PLSS boundary was defined within which the USGS compiled the geologic, geochemical, geophysical, and mine and mineral-deposit data, to assure completeness, although the analysis does not include the buffer areas. This assured that the USGS effort captured the pertinent data adjacent to the PLSS townships and consequently, all data relevant to the proposed withdrawal areas.

\section{Project Overview}

The BLM uses legal definitions that group minerals into three categories - (1) locatable minerals (General Mining Act of 1872, 30 U.S.C. 22-42), including most metallic commodities and many high-unit value industrial commodities), (2) leasable minerals (Mineral Leasing Act of 


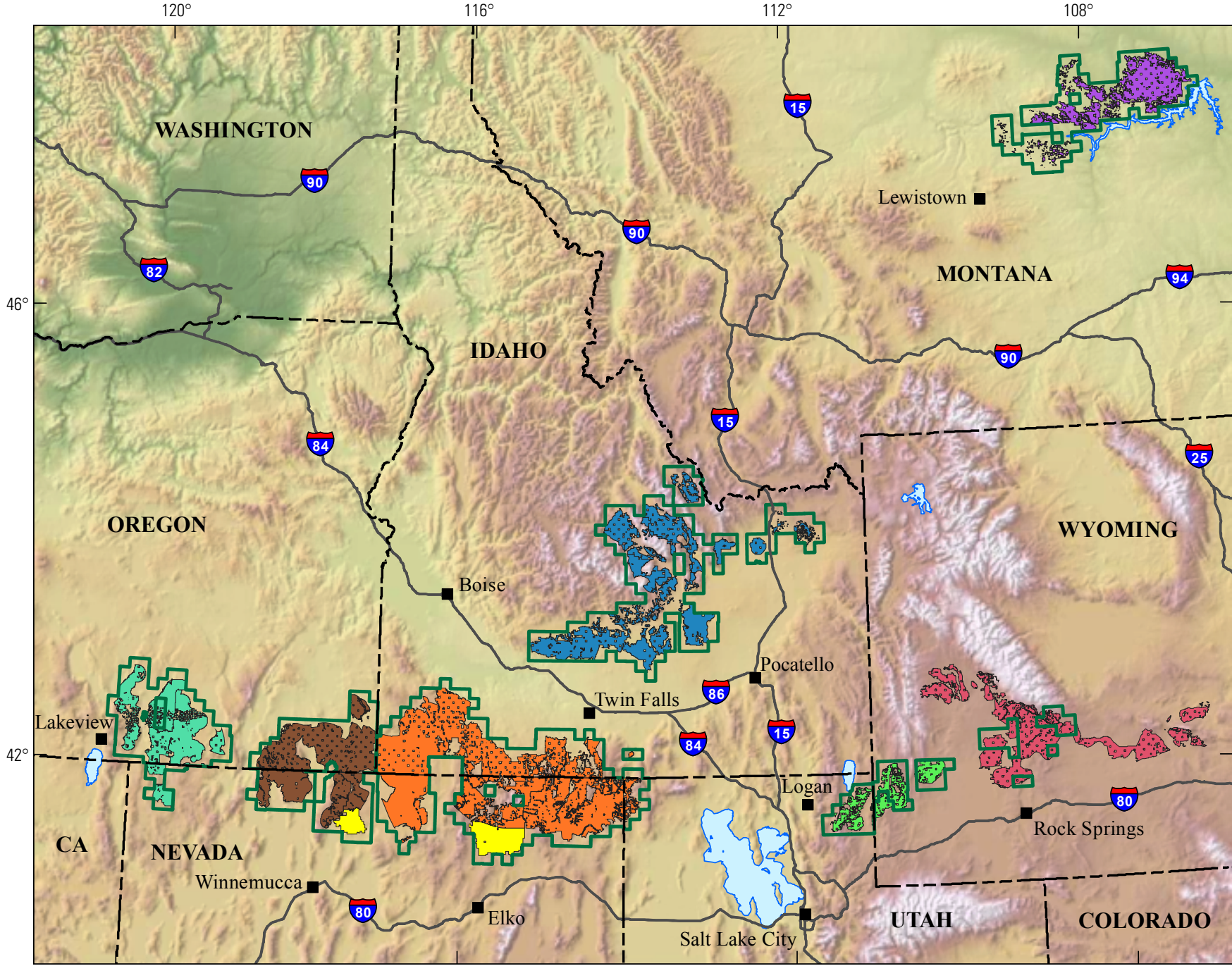

Base modified from U.S. Geological Survey DEM data, 2016. Roads and political data copyright (C) 2014 Esri and its licensors. Boundary data from San Juan and others (2016). USA Contiguous Albers Equal Area Conic Projection. Central meridian, $114^{\circ} \mathrm{W}$, latitude of origin, $37.5^{\circ} \mathrm{N}$. North American Datum of 1983.

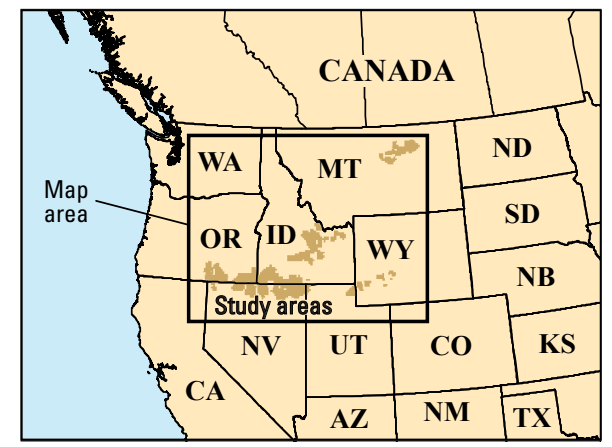

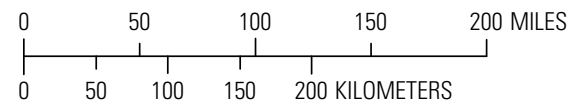

EXPLANATION

USGS study area boundary

Bear River Watershed SFA

North-Central Montana SFA

North-Central Idaho SFA

Southeast Oregon and North-Central Nevada SFA

Sheldon-Hart Mountain NWR Complex SFA

Southern Idaho and Northern Nevada SFA

Southwestern and South-Central Wyoming SFA

Proposed Nevada additions

Figure A1. Map showing U.S. Geological Survey (USGS) study areas (green outlines) and the extent of the Sagebrush Focal Areas (SFAs) (in color) for the Sagebrush Mineral-Resource Assessment (SaMiRA) project, Western United States. NWR, National Wildlife Refuge. 
1920, 30 U.S.C. 181 et seq.), including energy and fertilizer minerals), and (3) salable minerals (Mineral Materials Act of 1947, 30 U.S.C. 601 et seq.), which includes common varieties of sand, stone, gravel, pumice, pumicite, cinders, and clay. A listing of the mineral commodities and their classification is given in appendix 1.

For this study, the USGS integrated publically available regional-scale geoscience data to discuss the mineral potential (current condition and future potential) for locatable minerals in the seven SFAs and the Nevada additions and provide a summary of the current condition for the most important leasable and salable minerals. The mineral-assessment reports follow the general guidelines outlined in BLM Manual Sections 3031 (Bureau of Land Management, 1985) and 3060 (Bureau of Land Management, 1994) using the best data from the published literature and USGS and BLM databases. The BLM requested that the USGS mineral-resource assessments use the overall method summarized by Goudarzi (1984), which prescribes a qualitative approach to evaluating mineral-resource potential (none, low, moderate, or high) with levels of certainty dependent on the available evidence for the occurrence of a given mineral-deposit type (for example, least certain with insufficient evidence to most certain with abundant direct and indirect evidence). Appendix 2 provides a description of the criteria for determining the levels of mineral potential and certainty as requested by BLM. The geospatial data that outline the assessment tracts, potential for occurrence, and levels of certainty for the mineral deposit types that often contain the locatable minerals using the BLM guidelines discussed above are given in San Juan and others (2016).

\section{Who Did the Work?}

The assessment work was done by a multidisciplinary team of USGS geologists, economic geologists, geophysicists, geochemists, mineral commodity specialists, and GIS experts. These geoscientists reached out to the State geological surveys (or equivalent) for Idaho, Montana, Nevada, Oregon, Utah, and Wyoming to gather the most recent geologic and mineral information available. The State geological surveys provided invaluable data and expertise that informed the USGS effort.

Reports for this study include other chapters of Scientific Investigations Report 2016-5089 by Mauk and others (2016) for the North-Central Montana SFA assessment study and Lund and others (2016) for the North-Central Idaho SFA. Vikre and others (2016) combined three SFAs that occur along the northern Nevada border (Sheldon-Hart Mountain National Wildlife Refuge, Southeast Oregon and North-Central Nevada, and Southern Idaho and Northern Nevada SFAs) and the Nevada additions into one report. Vikre and others (2016) provides a coherent summary over a large region, yet presents mineral-potential results for the individual SFAs and Nevada additions. Similarly, the discussion of the geologic overview and potential mineral-deposit types for the Bear River Watershed, Utah, and the Southwestern and South-Central Wyoming SFAs was combined by Wilson and others (2016).

\section{Data Sources}

The USGS mineral-resource assessments for the locatable mineral commodities are based on integration of the available digital geospatial information that address the favorability criteria defined by the specific mineral-deposit models applicable to the SFA under consideration. The mineral-deposit models (see appendix 3 ) are extremely powerful tools that simplify the complex ore-forming processes into criteria that can be used to estimate the favorability of landscape-scale tracts such as the SFAs. The models are syntheses of key features of the mineral deposits that include succinct geologic descriptions, associated mineral commodities, key features of the geologic environment of formation, ore controls, and economic factors for each deposit type. Mineral-deposit models provide rigorous constructs that specify the geologic, geochemical, and geophysical features that lead to formation of a given mineraldeposit type. Mineral-deposit models can be highly detailed (for example, Hayes and others, 2015), the full application of which demands detailed datasets such as isotope geochemical studies, detailed geologic mapping, alteration mineralogical studies, multispectral remote-sensing studies, and high-precision geophysical data. Such detailed models are extremely powerful at the ore-deposit to district-scales and can lead to discovery of individual mineral deposits. In contrast, the generalized oredeposit models compiled by and used for the SaMiRA study (appendix 3), which rely on large, regional-scale geoscience datasets to delineate tracts of the locatable mineral commodities, result in landscape-scale qualitative mineral-resource assessments that meet the requirements of the regulations followed by the BLM. The following is a brief description of the major datasets that were combined with the mineral-deposit models that underpin delineation of the resource-potential tracts for the locatable minerals.

\section{Geologic Map Data}

Geologic maps provide a fundamental building block for mineral-resource assessments. The USGS relied on publically available geologic maps published at a variety of scales to conduct the resource analyses. Digital geologic map compilations for this project built on the approach taken by Ludington and others (2005), Stoeser and others (2005), and Zientek and others (2005) for geologic maps of the Western United States and included the maps from the California (Saucedo and others, 2000), Idaho (Bond and others, 1978; Lewis and others, 2012), Montana (Vuke and others, 2007), Nevada (Crafford, 2007), Oregon (Walker and others, 2002), Utah (Hintze and others, 2000), and Wyoming (Green and Drouillard, 1994) at their original scales. The digital geologic map compilations do not resolve map-unit discontinuities along the borders between the States nor the inherent differences in mapping styles and scales between the source maps. However, their compilation provided a useful first-order dataset where more detailed published digital geologic maps were not available. 
Several more-detailed geologic maps were used to refine the assessment-tract boundaries and identify key lithologic information to help delineate the assessment tracts for locatable mineral-resource potential. For Idaho, the 1:100,000-scale maps of Link and others (1995), Evans and Green (2003), Kuntz and others (2007), Skipp and others (2009), and Othberg and others (2012) were incorporated in the assessments along with the 1:250,000-scale maps of Worl and others (1991), Fisher and others (1992), Wilson and Skipp (1994), and Worl and Johnson (1995).

The digital geologic-map data used for Montana were a series of 1:100,000-scale, $30^{\prime} \times 60^{\prime}$ quadrangle maps developed by the Montana Bureau of Mines and Geology (http://www. mbmg.mtech.edu/gis/gis-datalinks.asp). The maps used include the Dodson (Bergantino, 2001), Fort Peck Lake East (Wilde and Bergantino, 2004a), Fort Peck Lake West (Wilde and Bergantino, 2004b), Glasgow (Bergantino, 1999a), Jordan (Wilde and Vuke, 2004a), Malta (Bergantino, 1999b), Winnett (Porter and Wilde, 1993), Sand Springs (Wilde and Vuke, 2004b), and Zortman (Porter and Wilde, 2001) quadrangles.

The digital geospatial information incorporated for assessments of the SFAs in Nevada included sources from several map scales. The 1:250,000-scale Crafford (2007) map formed the basic reference for the statewide data. This was augmented by data on intrusive rocks from du Bray and Crafford (2007). Reheis (1999) provided constraints on the extent of Pleistocene-aged lake deposits. In addition to the Oregon geologic map of Miller and others (2002), we incorporated data from the Oregon Department of Geology and Mineral Industries released in the GIS data compilation of Smith and Roe (2015).

For Utah, the Hinze and others (2000) State-scale geologic map was used. The primary source of digital geologic information used for the assessment of the Bear River Watershed was the 1:100,000-scale map of Dover (1995) for the Logan $30^{\prime} \times 60^{\prime}$ quadrangle.

The digital geologic map information used for the mineral-resource assessments for Wyoming included the digital geologic-map compilation of Green and Drouillard (1994), which was based on the 1:500,000-scale mapping of Love and Christiansen (1985). More detailed geologic data were captured from the 1:100,000-scale mapping of M'Gonigle and Dover (2004), Sutherland and Hausel (2006), Johnson and Sutherland (2009), Jones and Scott (2010), and Sutherland and Luhr (2011).

\section{References Cited}

Bergantino, R.N., 1999a, Geologic map of the Glasgow $30^{\prime} \times 60$ ' quadrangle, northeast Montana: Montana Bureau of Mines and Geology Open-File Report 390, 4 p., 2 sheets, scale 100,000, accessed March 15, 2016, at http://www. mbmg.mtech.edu/pdf_100k/glasgow.pdf.
Bergantino, R.N., 1999b, Geologic and structure contour maps of the Malta $30^{\prime} \times 60$ ' quadrangle, northeastern Montana: Montana Bureau of Mines and Geology Open-File Report 389, 4 p., 2 sheets, scale 100,000, accessed March 15, 2016, at http:/ www.mbmg.mtech.edu/pdf_100k/malta.pdf.

Bergantino, R.N., 2001, Geologic map of the Dodson 30' $\times 60^{\prime}$ quadrangle, north-central Montana: Montana Bureau of Mines and Geology Open-File Report 439, 9 p., 1 sheet, scale 100,000, accessed March 15, 2016, at http://www.mbmg.mtech.edu/ pdf_100k/Dodson.pdf.

Bond, J.G., Kauffman, J.D., Miller, D.A., and Venkatakrishnan, Ramesh, 1978, Geologic map of Idaho: Moscow, Idaho, Idaho Bureau of Mines and Geology, with contributions from U.S. Geological Survey, scale 1:500,000.

Bureau of Land Management, 1985, Energy and mineral resource assessment: Washington, D.C., U.S. Department of Interior, Bureau of Land Management, accessed March 15, 2016, at http://www.blm.gov/wo/st/en/info/regulations/Instruction Memos_and_Bulletins/blm_manual.html.

Bureau of Land Management, 1994, Mineral reports-preparation and review: Washington, D.C., U.S. Department of Interior, Bureau of Land Management, accessed March 15, 2016, at http://www.blm.gov/wo/st/en/info/regulations/Instruction Memos_and_Bulletins/blm_manual.html.

Bureau of Land Management, 2015a, Record of Decision and approved resource management plan amendments of the Great Basin region, including the greater sage-grouse subregions of Idaho and Southwestern Montana, Nevada and northeastern California: Washington, D.C., U.S. Department of Interior, Bureau of Land Management, September 2015, accessed March 15, 2016, at http://www.blm.gov/style/ medialib/blm/wo/Communications_Directorate/public affairs/sage-grouse_planning/documents.Par.44118.File.dat/ GB\%20ROD.pdf.

Bureau of Land Management, 2015b, Record of Decision and approved resource management plan amendments for the Rocky Mountain region, including the greater sage-grouse sub-regions of Lewiston, North Dakota, Northwest Colorado, Wyoming, and the approved resource management plans for Billings, Buffalo, Cody, HiLine, Miles City, Pompeys Pillar National Monument, South Dakota, Worland: Washington, D.C., U.S. Department of Interior, Bureau of Land Management, September, 2015, accessed March 15, 2016, at http://www.blm.gov/style/medialib/blm/wo/Communications Directorate/public_affairs/sage-grouse_planning/documents. Par.57493.File.dat/RM\%20ROD.pdf.

Bureau of Land Management, 2015c, Sage-grouse and sagebrush conservation: Bureau of Land Management Web page, accessed October 29, 2015, at http://www.blm.gov/ wo/st/en/prog/more/sagegrouse.html. 
Crafford, A.E.J., 2007, Geologic map of Nevada: U.S. Geological Survey Data Series 249, 1 CD-ROM, 46 p., 1 plate, scale 1:250,000, accessed March 15, 2016, at http://pubs.usgs.gov/ds/2007/249/.

Dicken, C.L., and San Juan, C.A., 2016, Bureau of Land Management's Land and Mineral Legacy Rehost System (LR2000) mineral use cases for the Sagebrush MineralResource Assessment, Idaho, Montana, Nevada, Oregon, Utah, and Wyoming: U.S. Geological Survey data release, http://dx.doi.org/10.5066/F7RX996K.

Dover, J.H., 1995, Geologic map of the Logan 30' $\times 60^{\prime}$ quadrangle, Cache and Rich Counties, Utah, and Lincoln and Uinta Counties, Wyoming: U.S. Geological Survey, Miscellaneous Investigations Series Map I-2210, scale 100,000, accessed March 15, 2016, at http://ngmdb.usgs. gov/Prodesc/proddesc_10189.htm.

du Bray, E.A., and Crafford, A.E.J., 2007, Modal composition and age of intrusions in north-central and northeast Nevada: U.S. Geological Survey Data Series 250, 1 CD-ROM, 16 p., 1 plate, scale 500,000 scale, accessed March 15, 2016, at http://pubs.usgs.gov/ ds $/ 2007 / 250 /$.

Evans, K.V., and Green, G.N., 2003, Geologic map of the Salmon National Forest and vicinity, east-central Idaho: U.S. Geological Survey Investigation Series I-2765, 19 p. plus 2 sheets, accessed March 15, 2016, at http://pubs. usgs.gov/imap/i-2765.

Fisher, F.S., McIntyre, D.H., and Johnson, K.M., 1992, Geologic map of the Challis $1^{\circ} \times 2^{\circ}$ quadrangle, Idaho: U.S. Geological Survey Geologic Investigations Series I-1819, scale 250,000, accessed March 15, 2016, at http:// pubs.usgs.gov/imap/i-1819/.

Goudarzi, G.H., compiler, 1984, Guide to preparation of mineral survey reports on public lands: U.S. Geological Survey Open-File Report 84-0787, https://pubs.usgs.gov/ of/1990/0331/report.pdf.

Green, G.N., and Drouillard, P.H., 1994, The digital geologic map of Wyoming in ARC/INFO format: U.S. Geological Survey Open-File Report 94-0425, scale 1:500,000, accessed March 15, 2016, at https://pubs.er.usgs.gov/ publication/ofr94425.

Gunther, G.L., Graeber, A.E., and Drake II, R.M., 2016a, Exploration and well status, quarter miles cells-SaMiRA: U.S. Geological Survey data release, http://dx.doi. org/10.5066/F7FB511V.

Gunther, G.L., Graeber, A.E., and Drake II, R.M., 2016b, Cumulative production per township-SaMiRA: USGS data release, http://dx.doi.org/10.5066/F7B85670.
Hayes, T.S., Cox, D.P., Piatak, N.M., and Seal, R.R., II, 2015, Sediment-hosted stratabound copper deposit model: U.S. Geological Survey Scientific Investigations Report 2010 5070-M, 147 p., accessed March 15, 2016, at http://dx.doi. org/10.3133/sir20105070M.

Hintze, L.F., Willis, G.C., Laes, D.Y.M., Sprinkel, D.A., and Brown, K.D., 2000, Digital geologic map of Utah: Utah Geological Survey, Map 179DM, scale 1:500,000, accessed March 15, 2016, at http://geology.utah.gov/maps/geomap/ statemap/index.htm.

Johnson, J.F., and Sutherland, W.M., 2009, Geologic map of the Lander $30^{\prime} \times 60^{\prime}$ quadrangle, Fremont County, Wyoming: Wyoming State Geological Survey MS-87, 1 sheet, scale $1: 100,000$.

Jones, R.W., and Scott, J.E., 2010, Geologic map of the Rock Springs $30^{\prime} \times 60^{\prime}$ quadrangle, Sweetwater County, Wyoming: Wyoming State Geological Survey Map Series 96, 1 sheet, scale $1: 100,000$.

Kuntz, M.A., Skipp, Betty, Champion, D.E., Gans, P.B., Van Sistine, D.P., and Snyders, S.R., 2007, Geologic map of the Craters of the Moon 30' $\times 60^{\prime}$ quadrangle, Idaho: U.S. Geological Survey Scientific Investigations Map 2969, 64 p. pamphlet, 1 plate, scale 1:100,000, accessed March 15, 2016, at http://pubs.usgs.gov/sim/2007/2969/.

Lewis, R.S., Link, P.K., Stanford, L. R., and Long, S.P., 2012, Geologic map of Idaho: Idaho Geological Survey, Geologic Map 9 (M-9), 18 p., 1 sheet, scale 1:750,000, accessed March 15, 2016, at http://www.idahogeology.org/Products/ reverselook.asp?switch=title\&value=Geologic_Map_of_ Idaho.

Link, P.K., Mahoney, J.B., Bruner, D.J., Batatian, L.D., Wilson, E., and Williams, F.J.C., 1995, Geologic map of outcrop areas of sedimentary units in the eastern part of the Hailey $1^{\circ} \times 2^{\circ}$ quadrangle and part of the southern part of the Challis $1^{\circ} \times 2^{\circ}$ quadrangle, south-central Idaho: U.S. Geological Survey Bulletin 2064-C, plate 1, scale 1:100,000, accessed March 15, 2016, at http://pubs.usgs.gov/bul/b2064-c/.

Love, J.D., and Christiansen, A.C., 1985, Geologic map of Wyoming: U.S. Geological Survey (Wyoming State Geological Survey release 2014), 3 pls., scale 1:500,000. [Also available at http://ngmdb.usgs.gov/Prodesc/proddesc_16366. htm.]

Ludington, Steve, Moring, B.C., Miller, R.J., Stone, P.A., Bookstrom, A.A., Bedford, D.R., Evans, J.G., Haxel, G.A., Nutt, C.J., Flyn, K.S., and Hopkins, M.J., 2005, Preliminary integrated geologic map databases for the United StatesWestern States: California, Nevada, Arizona, Washington, Oregon, Idaho and Utah: U.S. Geological Survey Open-File Report 2005-1305, ver. 1.3, accessed March 15, 2016, at http://pubs.usgs.gov/of/2005/1305. 
Lund, K., Zürcher, L., Hofstra, A.H., Van Gosen, B.S., Benson, M.E., Box, S.E., Anderson, E.D., Bleiwas, D.I., DeAngelo, J., Drake, R.M., II, Fernette, G.L., Giles, S.A., Glen, J.M.G., Haacke, J.E., Horton, J., John, D.M., Robinson, G.R., Jr., Rockwell, B.W., San Juan, C.A., Shaffer, B.N., Smith, S.M., and Williams, C.F., 2016, Geology and mineral resources of the North-Central Idaho Sagebrush Focal Area: U.S. Geological Survey Scientific Investigations Report 2016-5089-C, 147 p., http://dx.doi. org/10.3133/sir20165089C.

Mauk, J.L., Zientek, M.L., Hearn, B.C., Jr., Parks, H.L., Jenkins, M.C., Anderson, E.D., Benson, M.E., Bleiwas, D.I., DeAngelo, J., Denning, P.D., Dicken, C.L., Drake, R.M., II, Fernette, G.L., Folger, H.W., Giles, S.A., Glen, J.M.G., Granitto, M., Haacke, J.E., Horton, J.D., Kelley, K.D., Ober, J.A., Rockwell, B.W., San Juan, C.A., Sangine, E.S., Schweitzer, P.N., Shaffer, B.N., Smith, S.M., Williams, C.F., and Yager, D.B., 2016, Geology and mineral resources of the North-Central Montana Sagebrush Focal Area: U.S. Geological Survey Scientific Investigations Report 20165089-D, 104 p., http://dx.doi.org/10.3133/sir20165089D.

M'Gonigle, J.W., and Dover, J.H., 2004, Geologic map of the Kemmerer $30^{\prime} \times 60^{\prime}$ quadrangle, Lincoln, Uinta, and Sweetwater Counties, Wyoming: Wyoming State Geological Survey Open-File Report 7, 1 sheet, scale 1:100,000, accessed March 1, 2016, at http://ngmdb.usgs.gov/Prodesc/ proddesc_10112.htm.

Othberg, K.L., Kauffman, J.D., Gillerman, V.S., and Garwood, D.L., 2012, Geologic map of the Twin Falls 30' $\times 60$ ' quadrangle, Idaho: Idaho Geological Survey Geologic Map GM-49, 31 p., 1 sheet, scale 1:100,000, accessed March 15, 2016, at http://www.idahogeology.org/Products/reverselook. asp? switch=title\&value=Geologic_Map_of_the_Twin_ Falls_30_x_60_Minute_Quadrangle,_Idaho.

Parks, H.L., Zientek, M.L., Jenkins, M.C., Hennings, C.K., Wallis, J.C., Nguyen, D.M., and Cossette, P.M., 2016, Previous mineral-resource assessment data compilation for the U.S. Geological Survey Sagebrush Mineral-Resource Assessment project: U.S. Geological Survey data release, http://dx.doi.org/10.5066/F7736P0C.

Porter, K.W., and Wilde, E.M., 1993, Geologic map of the Winnett 30' $\times 60^{\prime}$ quadrangle, central Montana: Montana Bureau of Mines and Geology Open-File Report 307, 16 p., 2 sheets, scale 1:100,000, accessed March 15, 2016, at http://www.mbmg.mtech.edu/pdf_100k/winnett.pdf.

Porter, K.W., and Wilde, E.M., 2001, Geologic map of the Zortman $30^{\prime} \times 60^{\prime}$ quadrangle, central Montana: Montana Bureau of Mines and Geology Open-File Report 438, 16 p., 1 sheet, scale 1:100,000, accessed March 15, 2016, at http:// www.mbmg.mtech.edu/pdf_100k/zortman.pdf.
Reheis, Marith, 1999, Extent of Pleistocene lakes in the western Great Basin: U.S. Geological Survey, Miscellaneous Field Studies Map MF-2323, 1 sheet, scale 1:800,000, accessed March 15, 2016, at http://pubs.usgs.gov/mf/1999/ $\mathrm{mf}-2323 /$.

San Juan, C.A., Horton, J.D., Parks, H.L., Mihalasky, M.J., Anderson, E.D., Benson, M.E., Box, S.E., Cossette, P.M., Denning, P.D., Giles, S.A., Hall, S.M., Hayes, T.S., Hearn, B.C., Jr., Hofstra, A.H., John, D.A., Ludington, S., Lund, K., Mauk, J.L., Robinson, G.R., Jr., Rockwell, B.W., Rytuba, J.J., Smith, S.M., Stillings, L.L., Van Gosen, B.S., Vikre, P.G., Wallis, J.C., Wilson, A.B., Zientek, M.L., and Zürcher, L., 2016, Locatable mineral assessment tracts for the U.S. Geological Survey Sagebrush Mineral-Resource Assessment project: U.S. Geological Survey data release, http://dx.doi.org/10.5066/F7833Q4R.

Saucedo, G.J., Bedford, D.R., Raines, G.L., Miller, R.J., and Wentworth, C.M., 2000, GIS data for the geologic map of California: California Department of Conservation, Division of Mines and Geology, CD-ROM 2000-07, scale 1:750,000, accessed March 16, 2016, at http://www.consrv.ca.gov/ cgs/information/publications/pub_index/Pages/statewide_ references.aspx\#statewide.

Skipp, Betty, Snider, L.G., Janecke, S.U., and Kuntz, M.A., 2009, Geologic map of the Arco 30'×60' quadrangle, south-central Idaho, GM-47, GIS credit: Stanford, L.R., Freed, J.S., Bird, J.S., Taylor, T.A., and Studer, B.E., Idaho Geological Survey, 42 p., 1 sheet, scale 1:100,000, dataset, accessed January 4, 2016, at http://www.idahogeology.org/ Products/reverselook.asp?switch $=$ title \&value $=$ Geologic Map_of_the_Arco_30_x_60_Minute_Quadrangle, SouthCentral_Idaho.

Smith, R.L., and Roe, W.P., comps., 2015, Oregon geologic data compilation (OGDC)-release 6: Oregon Department of Geology and Industries, accessed March 15, 2016, at http:// www.oregongeology.org/pubs/dds/p-OGDC-6.htm.

Stoeser, D.B., Green, G.N., Morath, L.C., Heran, W.D., Wilson, A.B., Moore, D.W., and Van Gosen, B.S., 2005, Preliminary integrated geologic map databases for the United States - Central States: Montana, Wyoming, Colorado, New Mexico, North Dakota, South Dakota, Nebraska, Kansas, Oklahoma, Texas, Iowa, Missouri, Arkansas, and Louisiana: U.S. Geological Survey, OpenFile Report 2005-1351, ver. 1.2, accessed March 15, 2016, at http://pubs.usgs.gov/of/2005/1351.

Sutherland, W.M., and Hausel, W.D., 2006, Geologic map of the South Pass $30^{\prime} \times 60^{\prime}$ quadrangle, Fremont and Sweetwater Counties, Wyoming: Wyoming State Geological Survey Map Series 70, 1 sheet, scale 1:100,000. 
Sutherland, W.M., and Luhr, S.C., 2011, Preliminary bedrock geologic map of the Farson $30^{\prime} \times 60^{\prime}$ Quadrangle, Sweetwater, Sublette and Fremont Counties, Wyoming: Wyoming State Geological Survey, Open-File Report 11-6, 1 sheet, scale 1:100,000.

U.S. Department of the Interior, 2015a, Notice of proposed withdrawal; Sagebrush Focal Areas; Idaho, Montana, Nevada, Oregon, Utah, and Wyoming and Notice Of Intent to prepare an Environmental Impact Statement: Federal Register, v. 80 , no. 185 , p. $57635-57637$, accessed March 31, 2016, at https://www.gpo.gov/fdsys/pkg/FR-2015-0924/pdf/2015-24212.pdf.

U.S. Department of the Interior, 2015b, Notice of proposed withdrawal; Sagebrush Focal Areas; Idaho, Montana, Nevada, Oregon, Utah, and Wyoming and Notice of Intent to prepare an Environmental Impact Statement-Correction: Federal Register, v. 80, no. 202, p. 63583, accessed March 15, 2016, at https://www.gpo.gov/fdsys/pkg/FR-2015-1020/pdf/2015-26633.pdf.

Vikre, P.G., Benson, M.E., Bleiwas, D.I., Colgan, J.P., Cossette, P.M., DeAngelo, J., Dicken, C.L., Drake, R.M., II, du Bray, E.A., Fernette, G.L., Glen, J.M.G., Haacke, J.E., Hall, S.M., Hofstra, A.H., John, D.A., Ludington, S., Mihalasky, M.J., Rytuba, J.J., Shaffer, B.N., Stillings, L.L., Wallis, J.C., Williams, C.F., Yager, D.B., and Zürcher, L., 2016, Geology and mineral resources of the Sheldon-Hart Mountain National Wildlife Refuge Complex (Oregon and Nevada), the Southeastern Oregon and North-Central Nevada, and the Southern Idaho and Northern Nevada (and Utah) Sagebrush Focal Areas: U.S. Geological Survey Scientific Investigations Report 2016-5089-B, 220 p., http://dx.doi.org/10.3133/sir20165089B.

Vuke, S.M., Porter, K.W., Lonn, J.D., and Lopez, D.A., 2007, Geologic map of Montana-Compact Disc: Montana Bureau of Mines and Geology: Geologic Map 62-C, 73 p., 2 sheets, scale 1:500,000, accessed March 15, 2016, at http://www.mbmg.mtech.edu/mbmgcat/public/ListCitation. asp?pub_id $=30080 \&$.

Walker, G.W, MacLeod, N.S., Miller, R.J., Raines, G.L., and Connors, K.A., 2002, Spatial digital database for the geologic map of Oregon: U.S. Geological Survey Open-File Report 03-67, accessed March 15, 2016, at http://pubs.usgs. gov/of/2003/of03-067/.

Wilde, E.M., and Bergantino, R.N., 2004a, Geologic and structure contour map of the Fort Peck Lake East 30' $\times 60$ ' quadrangle, eastern Montana: Montana Bureau of Mines and Geology Open-File Report 498, 10 p., 1 sheet, scale 1:100,000, accessed March 15, 2016, at http://www.mbmg. mtech.edu/pdf_100k/ftPeckLakeEast.pdf.
Wilde, E.M., and Bergantino, R.N., 2004b, Geologic and structure contour map of the Fort Peck Lake West 30'×60' quadrangle, eastern Montana: Montana Bureau of Mines and Geology Open-File Report 499, 8 p., 1 sheet, scale 1:100,000, accessed March 15, 2016, at http://www.mbmg.mtech.edu/pdf_100k/ ftPeckLakeWest.pdf.

Wilde, E.M., and Vuke, S.M., 2004, Geologic map of the Jordan 30 ' $\times 60$ ' quadrangle, eastern Montana: Montana Bureau of Mines and Geology Open-File Report 514, 8 p., 1 sheet, scale 1:100,000, accessed March 15, 2016, at http://www.mbmg. mtech.edu/pdf_100k/jordan.pdf.

Wilde, E.M., and Vuke, S.M., 2004, Geologic map of the Sand Springs 30' $\times 60$ ' quadrangle, eastern Montana: Montana Bureau of Mines and Geology Open-File Report 515, 8 p., 1 sheet, scale 100,000, accessed March 15, 2016, at http://www.mbmg.mtech. edu/pdf_100k/sandSprings.pdf.

Wilson, A.B., Hayes, T.S., Benson, M.E., Yager, D.B., Anderson, E.D., Bleiwas, D.I., DeAngelo, J., Dicken, C.L., Drake, R.M., II, Fernette, G.L., Giles, S.A., Glen, J.M.G., Haacke, J.E., Horton, J.D., Parks, H.L., Rockwell, B.W., and Williams, C.F., 2016, Geology and mineral resources of the Southwestern and SouthCentral Wyoming Sagebrush Focal Area, Wyoming, and the Bear River Watershed Sagebrush Focal Area, Wyoming and Utah: U.S. Geological Survey Scientific Investigations Report 2016-5089E, 128 p., http://dx.doi.org/10.3133/sir20165089E.

Wilson, A.B., and Skipp, Betty, 1994, Geologic map of the eastern part of the Challis National Forest and vicinity, Idaho: U.S. Geological Survey Geologic Investigations Series I-2395, 1 sheet, scale 1:250,000, accessed March 15, 2016, at http://pubs. usgs.gov/imap/i-2395/.

Worl, R.G., and Johnson, K.M., 1995, Map showing geologic terranes of the Hailey $1^{\circ} \times 2^{\circ}$ quadrangle and the western part of the Idaho Falls $1^{\circ} \times 2^{\circ}$ quadrangle, South-Central Idaho: U.S. Geological Survey Bulletin 2064-A, plate 1, scale 1:250,000, accessed March 15, 2016, at http://pubs.usgs.gov/bul/b2064-a/.

Worl, R.G., Kiilsgaard, T.H., Bennett, E.H., Link, P.K., Lewis, R.S., Mitchell, V.E., Johnson, K.M., and Snyder, L.D., 1991, Geologic map of the Hailey $1^{\circ} \times 2^{\circ}$ quadrangle, Idaho: U.S. Geological Survey Open-File Report 91-340, 1 sheet, scale 1:250,000, accessed March 15, 2016, at http://ngmdb.usgs.gov/Prodesc/ proddesc_18123.htm.

Zientek, M.L., Derkey, P.D., Miller, R.J., Causey, J.D., Bookstrom, A.A., Carlson, M.H., Green, G.N., Frost, T.P., Boleneus, D.E., Evans, K.V., Van Gosen, B.S., Wilson, A.B., Larsen, J.C., Kayser, H.Z., Kelley, W.N., and Assmus, K.C., 2005, Spatial databases for the geology of the Northern Rocky Mountains-Idaho, Montana, and Washington: U.S. Geological Survey Open-File Report 2005-1235, 201 p., scale 1:100,000 and 1:250,000, accessed March 15, 2016, at http://pubs.usgs.gov/of/2005/1235/. 



\title{
Section B. Mineral-Resource Information
}

\author{
By Gregory L. Fernette, Peter N. Schweitzer, and Elizabeth S. Sangine
}

This discussion on mineral-resource information used in the SaMiRA project consists of three sections. The first section describes the U.S. Geological Survey (USGS) Mineral Deposit Database (USMIN) data compilation developed for the Bureau of Land Management. The second section describes the USGS Mineral Resources Data System (MRDS). The third section describes the data contributed by the USGS National Minerals Information Center (NMIC).

\section{USMIN Project Mineral-Resource Data for the USGS SaMiRA Project}

\author{
By Gregory L. Fernette
}

\section{Introduction}

Mineral-occurrence, mining, and mineral-exploration information is one of the foundations for developing mineralresource assessments such as the U.S. Geological Survey (USGS) Sagebrush Mineral-Resource Assessment (SaMiRA) project done for the Bureau of Land Management (BLM). The BLM mineralresource assessment guidelines outlined in BLM Manual Sections 3031 (Bureau of Land Management, 1985) and 3060 (Bureau of Land Management, 1994) require that mineral-assessment reports contain information on current and past mining, exploration activity, and known mineral occurrences. The USGS has an ongoing project, the USGS Mineral Deposit Database (USMIN), whose objective is to develop a new geospatial database of the mineral resources of the United States. Personnel working on this project were temporarily retasked to work exclusively on the SaMiRA Project.

This report describes the type, source, and nature of the mineral-resource data compiled for the assessment by the USMIN project, which was used along with other data throughout the USGS SaMiRA project. The data compiled for the SaMiRA assessment differs somewhat in structure from that being compiled for USMIN. The mineral-resource data for SaMiRA were compiled as a series of GIS data "themes" designed to meet the requirements of BLM assessments. Previously compiled USMIN GIS data showing mine- and prospect-related features from USGS topographic maps were also made available to the SaMiRA project.

A core part of the USGS Mineral Resources Program's mission is to inventory the mineral resources of the United States. Consequently, the USGS has a long history of publishing maps and reports on domestic mineral resources. The first USGS digital mineral-resource database began to be built in late 1960s and was released in 1972 as the Computerized Resources Information Bank (CRIB) (Calkins and others, 1973). The name was changed in the early 1980s to the Mineral Resource Data System (MRDS). The MRDS database was used to manage descriptive data about mines, prospects, and mineral occurrences (Arndt, 1990). Much of the data in MRDS were entered during the 1970s and 1980s, when USGS conducted numerous mineral-resource assessments for the U.S. Forest Service (USFS) and the BLM.

The U.S. Bureau of Mines (USBM) concurrently developed two digital databases - the Minerals Availability System (MAS) and the Mineral Industry Location System (MILS) (Berg and Carrillo, 1980; Babitzke and others, 1982). The primary purpose of the MAS/MILS databases was to support the minerals-supply analysis function of the USBM (Davidoff, 1980). After closure of the USBM in 1996, the MAS/MILS databases were transferred to the USGS (McFaul and others, 2000).

The MAS/MILS and MRDS databases were merged into a single Oracle database, which was available on the USGS Mineral Resources Data Web site (http://mrdata.usgs.gov). The database now has a total of about 303,000 records, of which some 270,000 are for sites in the United States (U.S. Geological Survey, 2016). Work thereafter concentrated on improving the Oracle database interface with little updating of data. In 2012, the USMIN project began with the objective of providing an up-to-date, comprehensive, site-specific, geospatial database of the mines, mineral regions, and mineral occurrences of the United States. The following year an interagency agreement covering the USMIN project was implemented with the BLM Solid Minerals Program, whereby BLM provided additional funding for the project.

The reasons for the development of the new USMIN database include the following:

- Advances in Geographic Information Systems (GIS) software and data delivery mechanisms via the Internet allow for the use and analysis of large landscape-scale datasets of which mineral resources are a part.

- New technology for data capture, such as "heads up" digitizing from georeferenced raster images of paper 
maps, allows the rapid capture of accurate locations and other digital data.

- New sources of data, such as digital air photos and high-resolution satellite imagery, allow for the rapid and efficient capture of spatial data.

- New laws that require permitting of mine sites at both the State and Federal level provide new sources of timely data on the nature and location of mine sites, which can be incorporated into a national database.

An underlying concept of USMIN is to transition USGS mineral-resource information from the traditional "point with attributes" style of database into the geospatial realm where the data also include the spatial elements of mineral resources, such as the footprints of the mineral deposits and the spatial extent of mine features and mineral regions.

The USMIN database has three feature groups-(1) mineral occurrences, (2) mineral regions, and (3) mine features. Each feature group contains spatial data in the form of points and polygons, but all features are tied to point locations. Feature locations are captured primarily by "heads up" digitizing from georeferenced maps and (or) imagery. Point locations are captured for all features and, where available, the polygons that outline the footprint of a given feature. In USMIN, a mineral occurrence is considered "a concentration of a mineral (usually, but not necessarily, considered in terms of some commodity, such as copper, barite, or gold) that is considered valuable by someone somewhere, or that is of scientific or technical interest" (Cox and Singer, 1986). Mineral occurrences are classified as deposits, prospects, or showings. A mineral deposit is a mineral occurrence that has a defined size and grade as shown by past production and (or) a resource estimate. A mineral prospect is a mineral occurrence where there is sufficient data to describe at least two dimensions of the occurrence and its commodity. A mineral showing is a site where a potentially valuable mineral is present. Mineral regions are geographic features, such as mining districts, mineral belts, and mineral provinces that are associated with mineral-resource data. Mine features are those features created as part of the process of mining mineral deposits, such as mine shafts, adits, open pits, and waste piles. As noted above, the structure of the data compiled for SaMiRA, where the data was organized into "themes," differs from that in USMIN and includes a data theme for Active Exploration Sites. This data is not a part of USMIN but was added to the SaMiRA data specifically to meet the requirements of BLM assessment reports.

\section{Data Compilation}

Work on the USMIN project started in 2012 with an emphasis on augmenting and complementing existing USGS data and laying the foundation for the eventual geospatial database. An early focus of the project was on compiling data on active mineral exploration sites and active mines in the United States, as most of the data in MRDS had not been updated since the 1980s. For the SaMiRA project, the data compilation effort focused on those lands proposed for withdrawal including a 25-kilometer $(\mathrm{km})$ buffer that enclosed the Public Land Survey System (PLSS) township boundaries that include the proposed withdrawal areas in the seven Sagebrush Focal Areas (SFA) and two additions in Nevada (fig. B1).

The data were compiled from all publicly available sources including USGS publications, data from other Federal agencies, State geological surveys, other State agencies, geological societies, and mineral-industry data. A considerable amount of additional data came from sources such as industry Web sites, press releases, presentations, annual reports, and technical reports filed with regulatory agencies. An important example is the technical reports prepared in accordance with Canadian National Instrument 43-101, referred to as "NI 43-101 Reports." Completed preliminary maps of active mines and exploration sites were sent to the State geological surveys of Montana, Wyoming, Idaho, Utah, Nevada and Oregon for review and comment. Data were also sent to BLM and U.S. Forest Service geologists in the affected regions. Maps of active mine and exploration sites were also displayed at the annual meeting of the American Exploration and Mining Association (AEMA) in December 2015. Industry and government agency personnel at the meeting were invited to review the maps and the site listings and identify missing sites. In April 2016, BLM provided the USGS with copies of public comments received on the proposed land withdrawals. Comments specific to mineral resources were reviewed to insure that any specific mineral occurrences, mines, and (or) exploration sites mentioned were in the data being used by the assessment teams.

\section{Data Files and Sources}

USMIN project data used in the SaMiRA project are presented as six data themes, described below. One of these themes for prospect- and mine-related sites, is a subset of a larger database that was published separately (Fernette and others, 2016b). The data described here are being published as a USGS data release (Fernette and others, 2016a).

\section{Prospect- and Mine-Related Features}

Locations of historical or past mining sites were compiled by capturing prospect- and mine-related symbols from USGS 7.5- and 15-minute topographic maps. In the SaMiRA region, mine symbols are shown on USGS topographic maps published between 1935 to 2006 . Early in the USMIN project, it was decided to capture these data as a first step in developing a GIS of mines in the United States. The process and rationale were based on the Abandoned Mine Lands programs of the Nevada Division of Minerals (Hess, 2001) and the California Department of Conservation's Abandoned Mine Lands Unit (California Department of Conservation, 2013). 


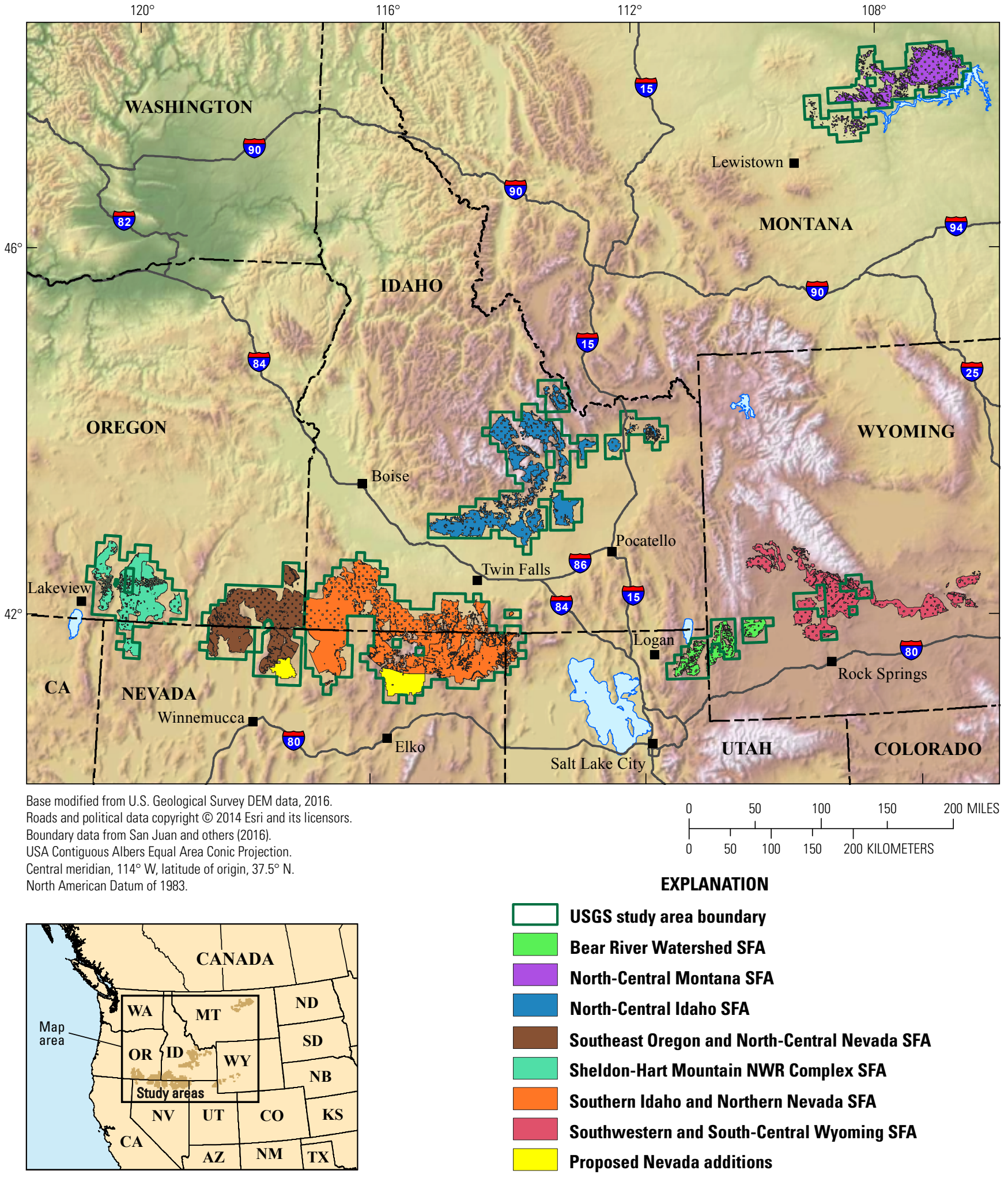

Figure B1. Map showing U.S. Geological Survey (USGS) study areas (green outlines) and the extent of the Sagebrush Focal Areas (SFAs) (in color) for the Sagebrush Mineral-Resource Assessment (SaMiRA) project, Western United States. NWR, National Wildlife Refuge. 
The historical mine site data were captured by digitizing from georeferenced raster images of historic topographic maps of the United States obtained from the USGS Historical Topographic Map Collection (see http://ngmdb.usgs.gov/maps/TopoView/). Mine sites were digitized and attributed with the source map name and date and the feature type. Locational accuracy for data derived from 7.5-minute quadrangle (1:24,000-scale) topographic maps is estimated to be about 100 feet. The most common features captured were mineshafts, adits, open pit mines, and prospect pits. In the mineral-resource assessment process, these data can be used to highlight areas of past mining activity, which is one of the requirements of the BLM mineral-assessment reports.

\section{Mining Districts}

Mining districts are historical administrative areas organized by miners under the mining laws of the United States. They typically comprise an area covering a group of mines that often exploit the same or similar commodity such as gold or silver. Considerable mineral-resource information, including production data, is tied to mining districts, and they have been the focus of many USGS studies (Hill, 1912; Koschmann and Bergendahl, 1968).

Mining districts were being compiled as a part of the Mineral Regions USMIN feature group, and data in progress was extracted for the SaMiRA Project. Most district locations were obtained from compilations by the State geological surveys of Nevada (Tingley, 1998), Utah (Doelling and Tooker, 1983; Utah Geological Survey, 2012), Idaho (Ross, 1941; Gustafson, 1987), Montana (Chavez, 1994), and Wyoming (Gregory and others, 2010; Harris and others, 1985). For Oregon, district locations were compiled primarily from Bradley (1982) and Gilluly and others (1933).
Mining district locations are areas represented as polygons. In the GIS data, all districts also have a point location, which is typically the centroid of the polygon. Mining-district data attributes are shown in table B1. The distribution of mining districts in the SaMiRA region is shown on figure B2.

All commodities associated with mineral occurrences located within a district are recorded whether they have been mined or not, contingent on the available data. Commodity groups for districts include metallic minerals (excluding uranium), industrial minerals, gemstones, and uranium. The USGS mineral-deposit models for mineral deposits present in a district were extracted from the Mineral Occurrence data theme. Geoenvironmental deposit models were derived from the equivalency relationship in du Bray (1995).

Mining districts can be used as a part of the mineralresource assessment process, as they highlight areas of past mining activity, groupings of mineral occurrences, and provide a focus for the discussion of other data such as production.

\section{Mineral Occurrences}

The locations of mineral occurrences were compiled from a variety of sources. Early in the USMIN project a review of the literature with the objective of identifying existing mineral-resource databases that could be incorporated into USMIN eliminated the need for a completely new data compilation. The State geological surveys of Oregon, Idaho, and Utah have published mineral occurrence databases that include the SaMiRA assessment areas. For the SaMiRA project, data were compiled on a state-by-state basis with USGS, USBM, and other data being added to State data. A large number of mineral occurrences were found through the USMIN compilation of active exploration projects.

Table B1. District data theme attribute fields used for the Sagebrush Mineral-Resource Assessment (SaMiRA) project, Western United States.

\begin{tabular}{|c|c|}
\hline Field name & Description \\
\hline Name & Primary name of the district. \\
\hline Other name & Other names for the district. \\
\hline State & State in which the district is located. \\
\hline Commodity(s) & Commodities present in mineral deposits in the district. \\
\hline Commodity group & $\begin{array}{l}\text { Group to which the commodities belong: metallic minerals, nonmetallic and industrial minerals, gemstones, } \\
\text { and uranium. }\end{array}$ \\
\hline Geoenvironmental model(s) & Names of the USGS geoenvironmental deposit models for mineral deposits present in the district. \\
\hline Remarks & Additional data or comments on the data. \\
\hline References & Source of the location and other data for the district. \\
\hline Associated polygon & Whether or not there is a shape associated with the point (yes/no). \\
\hline Polygon definition & Description of the nature of the polygon. \\
\hline
\end{tabular}




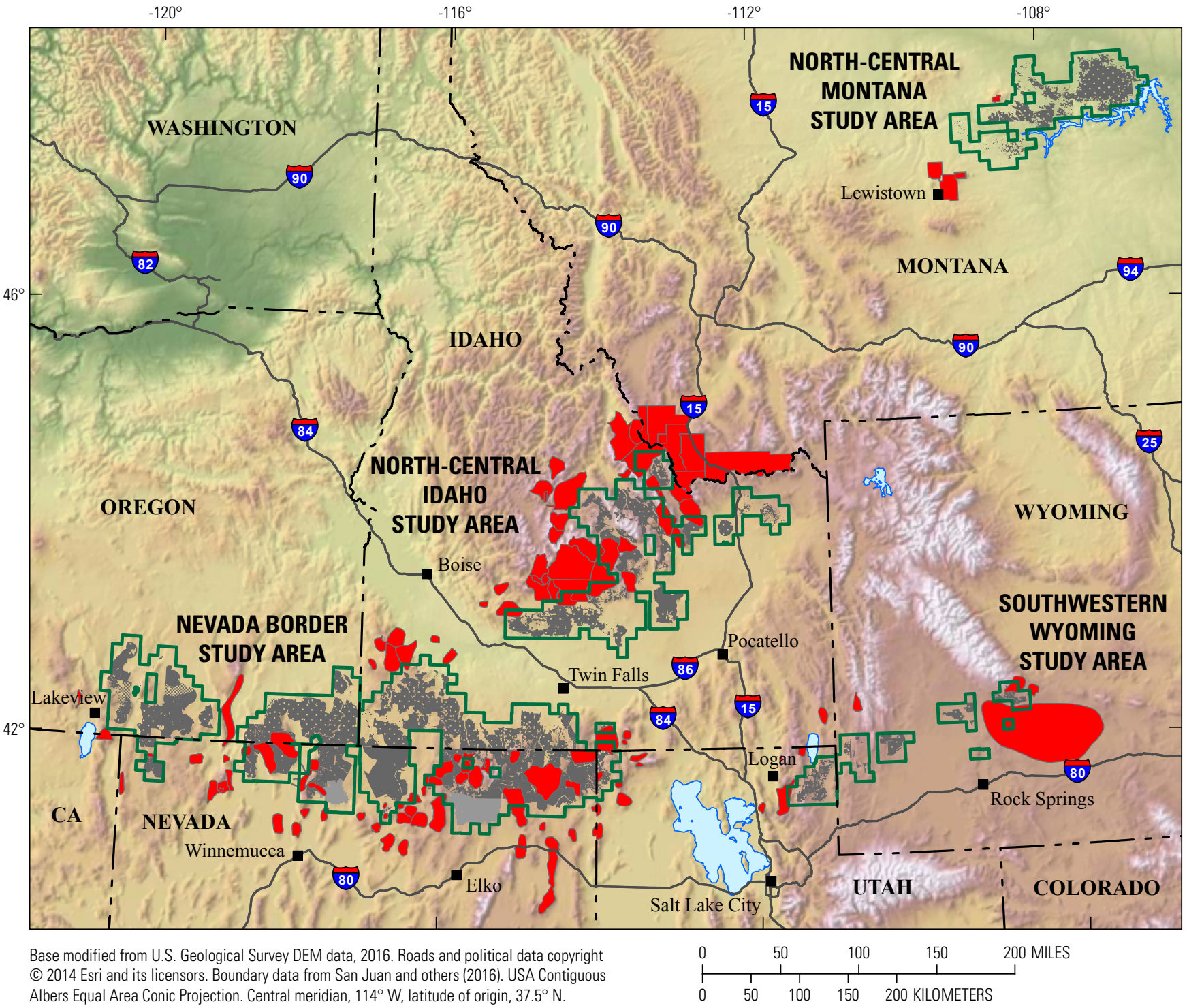

Albers Equal Area Conic Projection. Central meridian, $114^{\circ} \mathrm{W}$, latitude of origin, $37.5^{\circ} \mathrm{N}$. North American Datum of 1983.

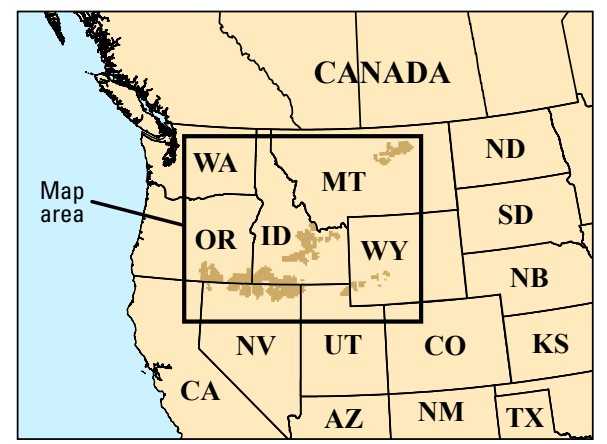

\section{EXPLANATION}

U.S. Mineral Database mining districts USGS study area boundaries Proposed withdrawal areas Proposed Nevada additions

Figure B2. Map of the mining districts in and near U.S. Geological Survey (USGS) study areas for the Sagebrush Mineral-Resource Assessment (SaMiRA) project, Western United States. BLM, Bureau of Land Management. 
For the State of Nevada, the primary sources of data were commodity reports produced by the Nevada Bureau of Mines and Geology (NBMG); for example, Stager and Tingley (1988), Papke and Castor (2003), Davis and others (2006), and the county reports on Elko, Humboldt and Washoe Counties (Willden, 1964; Bonham, 1969; Lapointe and others, 1991). Active mines and exploration sites were compiled from annual reports by the Nevada Division of Minerals and the NBMG and through a search of company activities in mining publications on the Web. Locations of material sites and gravel pits were obtained from the Nevada Department of Transportation. Active mine and exploration sites were identified from permits of the Nevada Department of Environmental Protection, the BLM, and USFS. Significant data were also collected from publications of the Geological Society of Nevada. Data from these sources were captured and then reconciled into single data layers.

For Oregon, data were extracted from the Oregon Department of Geology and Mineral Industries Mineral Information Layer MILO-2 (Oregon Department of Geology and Mineral Industries, 2010). This was augmented with data from other sources, including BLM Plans of Operations, company data, and USGS and USBM reports.

For Utah, the Utah Mineral Occurrence System (Utah Geological Survey, 2015) was the primary data source. This was augmented by data from the Utah Geological Association, company data, and USGS and USBM reports.

The primary sources of mineral occurrence data in Idaho were the Idaho Geological Survey's Database of Mines and Prospects and the Database of Select Aggregate Material Sources (Idaho Geological Survey, 2015; Tate and others, 2015). These data were augmented by reports of the USGS and USBM.
For Wyoming, the primary data sources were Wilson and others (2001), Wilson (2014), and Wyoming Geological Survey maps and publications (Harris and others, 1985; Hausel, 1986, 1989; Harris, 2004; Gregory and others, 2010). These data were augmented by company data collected by the USMIN project.

For Montana, the primary data sources were MRDS (U.S. Geological Survey, 2016) and the Montana Abandoned and Inactive Mines Database (Montana Bureau of Mines and Geology, 2006). Additional data were added from other USGS databases, including Klein (2004), and Spanski (2001, 2004), as well as from company data.

Attributes assigned to mineral occurrences in the GIS data were limited to those judged most critical for assessment purposes (table B2). The key geological attributes were commodity and mineral-deposit model. The mineral-deposit model ascribed to each occurrence was derived from the source data inasmuch as no mineral deposit classification was done by USMIN project personnel. Geoenvironmental models were assigned by using the equivalency relation in du Bray (1995).

A primary objective of the compilation of mineral occurrences was to develop accurate locations, commodity data, deposit models, source references, and where available production and resource (grade-tonnage) data. Industry data were one of the most important sources for accurate locations, deposit outlines (or footprints), and resource data. Whenever a deposit footprint was available, it was captured as a polygon that is associated with the point location. The meaning of the deposit footprint is variable. In some deposits that were at the resource estimation stage at the time of the data compilation, there were often maps showing the extent of the estimated resource. In other cases, a grade limit or gradethickness map might be available. Older reports tended to show the limit of mineralization.

Table B2. Mineral-occurrence data theme attribute fields used for the Sagebrush Mineral-Resource Assessment (SaMiRA) project, Western United States.

\begin{tabular}{ll}
\hline \multicolumn{1}{c}{ Field name } & Description \\
\hline Name & Primary name of the occurrence. \\
Other name & Other names for the occurrence. \\
State & State in which the occurrence is located. \\
Feature type & Classification of occurrence as deposit, prospect, or showing. \\
$\begin{array}{l}\text { Exploration project } \\
\text { Commodity(s) }\end{array}$ & Name of exploration project associated with the mineral occurrence. \\
Commodity group & Commodities present in mineral occurrence. \\
& $\begin{array}{l}\text { Group to which the commodities belong: metallic minerals, nonmetallic and industrial minerals, stone, sand and } \\
\text { gravel, gemstones, and uranium. }\end{array}$ \\
$\begin{array}{l}\text { Deposit model number(s) } \\
\text { Deposit model name(s) }\end{array}$ & ID numbers for the USGS deposit models of mineral deposits present in the district. \\
Deposit model source & Names of the USGS deposit models of mineral deposits present in the district. \\
Geoenvironmental model(s) & Source of the deposit model(s). \\
Remarks & Names of the USGS geoenvironmental deposit models for mineral deposits present in the district. \\
References & Additional data or comments on the data. \\
$\begin{array}{l}\text { Associated polygon } \\
\text { Polygon definition }\end{array}$ & Reference for the primary source of the location and other data for the occurrence. \\
\hline
\end{tabular}




\section{Mine Sites}

A discussion of current and past mining activity is a required part of the BLM mineral-assessment reports. Data on mines, both active and closed, in the assessment areas were compiled from a number of sources to form the Mines data theme. The USGS National Mineral Information Center (NMIC) publishes data on active mines and mineral processing plants in the United States (U.S. Geological Survey, 2005) and provided the 2011 version of these data to the SaMiRA project. These data include only mines that voluntarily report data to NMIC. In the USMIN project these data are augmented by data collected from other sources such as the Mine Safety and Health Administration (MSHA) and other Federal and State agencies so that as complete an inventory of mines as possible could be compiled. Amongst valuable sources of data on active mines in the SaMiRA region are State agency data for mine permits and BLM and USFS Plans of Operations.

In the State of Nevada, locations of active mines are published annually by the Nevada Division of Minerals and the Nevada Bureau of Mines and Geology (NBMG) in their Major Mines of Nevada Special Publication series. This series provides location and production data for most mines in Nevada. Additional sources of data were the NBMG maps of mines and energy resources (for example, Hess and Davis, 2010). The Nevada Department of Environmental Protection provides the locations of mining permits on its Web site (http://ndep.nv.gov). The Nevada Department of Transportation Material Site Atlas contains the locations of gravel and borrow pits (Nevada Department of Transportation, 2013).

For Utah, a GIS database of mine permit locations was obtained from the Utah Division of Oil Gas and Mining (Utah Division of Oil Gas and Mining, 2016). Mine locations are also published by the Utah Geological Survey (Bon and Heuscher, 2008; Bon and Wakefield, 2008).

Mine locations and current status of mine sites in Oregon were obtained from permit data from the Oregon Department of Geology and Mineral Industries (Oregon Department of Geology and Mineral Industries, 2015).

Data on active mines in Wyoming were provided by the Land Quality Division of the Wyoming Department of Environmental Quality (Wyoming Department of Environmental Quality, 2015). Additional information was obtained from the Annual Reports of the Wyoming State Inspector of Mines (Wyoming Department of Workforce Services, 2013, 2014).

Locations of open-cut mines in Montana were obtained from the Montana Department of Environmental Quality, Open Cut Mining Program (Montana Department of Environmental Quality, 2015). Further data were obtained from the annual presentations of the Montana Bureau of Mines and Geology (for example, McCullogh, 2014) and BLM Plans of Operations.

In Idaho, locations of active mines were obtained from the annual mineral industry reports of the Idaho Geological Survey (for example, Gillerman, 2014), the Idaho Geologic Survey aggregate site database (Tate and others, 2015), and from BLM and USFS field office personnel.

The attributes for the mines data theme are listed in table B3. The data-capture process for mines emphasized accurate locations and status data that were as timely as possible. Permit data were checked using digital air photos, and locations were corrected to the actual site of the mining activity. Where applicable, notes on the current level of activity, as visible on air photos, were made.

Table B3. Mines data theme attribute fields used for the Sagebrush Mineral-Resource Assessment (SaMiRA) project, Western United States.

\begin{tabular}{|c|c|}
\hline Field name & Description \\
\hline Name & Primary name of the mine. \\
\hline Other name & Other names for the mine. \\
\hline Operator & Name of the operator of the mine based on the source data. \\
\hline Commodity(s) & Commodities being mined. \\
\hline Current status & Activity status of the mine-active, inactive (closed), unknown. \\
\hline Status date & Year of the status data. \\
\hline Remarks & Additional data or comments on the data. \\
\hline References & Source(s) of the location and other data for the mine. \\
\hline
\end{tabular}




\section{Active Exploration Sites}

BLM mineral-resource assessment guidelines require a discussion of current and past exploration activity in the assessment areas. The collection of information on the location and nature of active mineral-exploration projects in the United States was one of the principal components of the USMIN data compilation effort before the SaMiRA project. Previously collected and newly compiled data for exploration projects within the SaMiRA areas were compiled into the Exploration Sites data theme. Exploration projects were classed as "active" if data on exploration activity within the past 10 years could be found. Key sources for the SaMiRA project area were the annual exploration reports and other reports of the NBMG, Idaho Geological Survey, Utah Geological Survey, Wyoming Geological Survey, Oregon Department of Mineral Industries, and Montana Bureau of Mines and Geology. Other data were collected from mining trade publications, such as the Canadian and American Mines Handbook, the Northern Miner, and Mining News.

Additional important sources of information were the individual mining company Web sites and technical reports filed in the Canadian System for Electronic Document Analysis and Retrieval (SEDAR) on-line database (http://www.sedar.com/). An extensive review of the Web sites of mining and exploration companies had been started in 2013, and this data was used in the SaMiRA project. Where Web sites contained information on exploration projects, the data were captured by printing to a .pdf file. For Canadian companies, National Instrument 43-101 technical reports (NI 43-101 Reports) were searched for using the SEDAR on-line database and company Web sites. These reports are a significant source of data on project history, mine production, the resources of mineral deposits, and typically also contain a description of the property history. Exploration sites were located as points and, where available, polygons showing the aerial extent of the project or property. "Properties" can be blocks of mining claims or exploration target areas. The sites were attributed with data on ownership, exploration status, and commodity (table B4).

\section{Mineral Production Data}

BLM mineral-assessment reports are required to present data on current and past mine production within the assessment areas. Production data for mines within the buffer zone surrounding the SFAs were compiled from a variety of sources. Reported production data were then converted to standard units and formatted for presentation in the production data theme. This data theme contains a summary of available production data, including ore tonnage, value, and (or) amounts of commodities produced.

For Nevada, the annual Major Mines of Nevada reports published by the Nevada Division of Minerals and NBMG contain production data and locations for major mines. Production data for past-producing mines were compiled from other NBMG reports and company reports. Important sources of information included Couch and Carpenter (1943), Lapointe and others (1991), Bailey and Phoenix (1944), and Stager and Tingley (1988). Production data for past producing mines in Idaho was found in Staff Reports of the Idaho Geological Survey and in the Idaho Mines and Prospects Database (Idaho Geological Survey, 2015). The data in the Mines and Prospect database are presented as ranges. For the Production data theme, the minimum values in each range were used. Significant additional mine production data for Idaho were found in Spanski (2004).

Table B4. Exploration data theme attribute fields used for the Sagebrush Mineral-Resource Assessment (SaMiRA) project, Western United States.

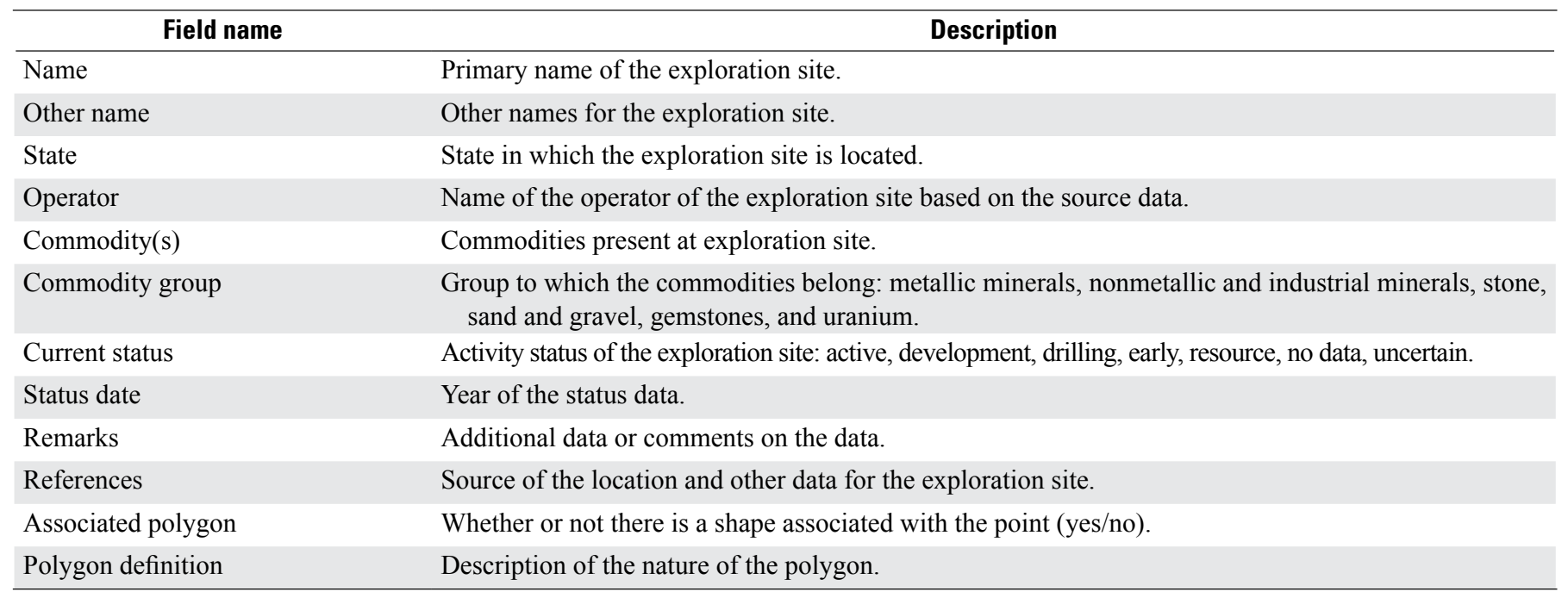


The principal sources of mine production data in Wyoming were Gregory and others (2010), Hausel (1986), and the Wyoming Mines Inspector annual reports (Wyoming Department of Workforce Services, Office of Mine Inspector, 2014).

NI 43-101 reports are also valuable sources of data for both currently active and formerly active mines. For active mines, the Web sites and annual reports of the operators were consulted.

\section{Mineral-Resource Data}

The BLM mineral-assessment reports are also required to contain information on the resources contained in known mineral deposits in the assessment area. Data on the resources (tonnage and grade) of mineral deposits located in the $25-\mathrm{km}$ buffer zone around the SFAs were compiled to develop the Resource data theme. This data theme includes summaries of the tonnage and grade of mineral deposits for which data were available. For many deposits, these data were discovered during the compilation of data on active exploration projects. Projects at the resource stage frequently present resource data in NI 43-101 reports, which were the major source of recent resource estimates. Other sources of data included USGS and USBM reports, such as Wilderness Study reports and USGS mineral-resource assessment data (for example, Spanski, 2004). For the Resource data theme, all categories of resources such as "reserves" and "resources" were combined into a total tonnage and average grade for each deposit.

\section{Acknowledgments}

Many people contributed to the USMIN data compilation process. USGS contractors Jesse Bellora, Marie Bartels, Stephanie Gallegos, Jeremy Jordan, Kathleen Tureck, and Adam Chapman worked on the SaMiRA data compilation. Lauren Foiles, Meredith Burger, Ryan Finley, Shauna Bladt, Brandon Gill, Chris Karns, Nicole Demontigny, Josef Bourgeois, Saige Sanchez, and Sara Hartman worked on the USMIN project in prior years and laid the foundation for the SaMiRA data. Carma San Juan, Peter Schweitzer, John Horton, Stu Giles, Paul Denning, Damon Bickerstaff, and E.G. Boyce of the USGS provided abundant technical assistance and advice.

Our colleagues in the BLM and USFS kindly reviewed our data and shared their on-the-ground knowledge. From the BLM, we would like to thank Jeff Clauson, Joe Larsen, Ken Gardner, Adam Merril, Rick Deery, Larry Garahana, Deb MacFarland, Micheal Jackson, Marilyn Wegweiser, Chris Rye, Jeff Clawson, Tim Barnes, and Ricky Wells. From the USFS, we thank Greg Graham, Susan Elliott, and Amanda Kriwox. Our colleagues and friends with the State geological surveys of Montana, Idaho, Wyoming, Utah, Nevada, and Oregon kindly reviewed the USMIN data and gave of their unparalleled local knowledge. In particular, we thank Clark Niewendorp, Oregon Department of
Geology and Mineral Industries; Ken Krahulec, Utah Geological Survey; John Muntean, Nevada Bureau of Mines and Geology; Richard Perry, Nevada Division of Minerals; Wayne Sutherland, Wyoming State Geological Survey; and Virginia Gillerman and Chris Tate, Idaho Geological Survey. Personnel at numerous other State agencies asked only that their agencies and departments be acknowledged. These agencies include the Nevada Department of Transportation, the Nevada Department of Environmental Protection, the Montana Division of Environmental Quality, the Utah Division of Lands, and the Wyoming Land Quality Division.

Finally, we would like to thank Mitch Leverette, Rick Deery, and Mike Nedd of the Solid Minerals Program of the BLM for their leadership in developing the cooperative agreement between USGS and BLM.

\section{Mineral Resources Data System (MRDS)}

\section{By Peter N. Schweitzer}

Several sources of mineral deposit information were used for the U.S. Geological Survey (USGS) Sagebrush MineralResource Assessment (SaMiRA) reports. One such data source for mine and mineral-district information is available through the Mineral Resources Data System (MRDS) (U.S. Geological Survey, 2016). MRDS contains global mineral-resource occurrence data, most thoroughly within the United States. The database contains the records previously provided in the Mineral Resource Data System (MRDS) of the USGS and the Mineral Availability System/Mineral Industry Locator System (MAS/MILS) of the U.S. Bureau of Mines.

MRDS is a large and complex relational database developed over several decades by hundreds of researchers and collaborators. The content of MRDS records was drawn from reports previously published or made available to USGS researchers, some of which are no longer available.

The information contained in MRDS reflects the limitations of the material used as sources, and its recency is that of the date of the source reports. Mining operations are continually evolving and global mineral economies represent a dynamic flow of information. Consequently, MRDS does not reflect up-to-date changes to the operating status of mines, ownership, land status, production figures, and estimates of reserves and resources or the nature, size, and extent of workings. However, the geological characteristics of the mineral resource are likely to remain correct and are very useful for understanding the deposit type and mineral commodities present for the major and many of the smaller mines, occurrences, and prospects. 


\section{Mineral-Resource Data from the USGS National Mineral Information Center}

\author{
By Elizabeth S. Sangine
}

The Automated Minerals Information System (AMIS) database operated by the U.S. Geological Survey (USGS) National Minerals Information Center (NMIC) is a large and complex database developed over several decades based on surveys conducted annually on mineral commodities. More than 140 surveys are conducted annually on mineral commodities from domestic producers. More than 18,000 domestic producer and consumer establishments voluntarily complete about 40,000 survey forms annually. In developing lists of companies to canvass for each of the commodities, NMIC specialists monitor the published literature, review company reports, review commodityspecific reports prepared by industry, and gather information from conferences, field trips, and industry and Government contacts.

The NMIC AMIS database has comprehensive mineralcommodity data from the 1980 s to the present. Mining operations are continually evolving, and AMIS houses both historical and current production figures and estimates of production. The USGS canvass forms contain a proprietary data banner that describes the treatment of the company data collected. The proprietary information is considered sensitive and usually contains commercially valuable business data, such as production figures and consumption projections. Before specific statistics can be published, a determination must be made as to whether the publication would result in the disclosure of proprietary data. In order to publish production data, the policy is that there must be three or more companies contributing to an aggregated statistic; however, if the minerals statistic under consideration does have three or more companies but one company contributes more than 75 percent of the total, or two companies contribute more than 90 percent, then the figure cannot be published because the preponderance of the data released is considered proprietary.

For the Sagebrush Mineral-Resource Assessment (SaMiRA) project, NMIC staff queried the AMIS database for active facilities using States and counties with assessment areas contained within. A listing of the facility names and physical locations, latitudes and longitudes, was then provided for mapping against the specific proposed withdrawal areas. Specific production figures were not provided for these facilities, as that would violate business proprietary rules.

\section{References Cited}

Arndt, R.E., 1990, U.S. Geological Survey's Mineral Resources Data System, in Sweet, P.C., ed., Proceedings of the 26th Forum on the Geology of Industrial Minerals, May 14-18, 1990: Virginia Division of Mineral Resources Publication 119, p. 86.
Babitzke, H.R, Barsotti, A.F, Coffman, J.S., Thompson, J.G., and Bennett, H.J., 1982, The Bureau of Mines Mineral Availability System-An update of Information Circular 8654: U.S. Bureau of Mines Information Circular 8887, $54 \mathrm{p}$.

Bailey, E.H., and Phoenix, D.A., 1944, Quicksilver deposits in Nevada: Nevada Bureau of Mines and Geology Bulletin 41, 206 p.

Berg, A.W., and Carrillo, F.V., 1980, MILS-The Mineral Industry Location System of the Federal Bureau of Mines: U.S. Bureau of Mines Information Circular 8815, $24 \mathrm{p}$.

Bon, R.L., and Heuscher, Sonja, 2008, Small mines in Utah 2008: Utah Geological Survey Circular 108, 6 p., map scale 1:700,000.

Bon, R.L., and Wakefield, Sharon, 2008, Large mines in Utah 2008: Utah Geological Survey Map Open-File Report-515, scale 1:700,000.

Bonham, H.F., 1969, Geology and mineral deposits of Washoe and Storey Counties, Nevada: Nevada Bureau of Mines and Geology Bulletin 70, $140 \mathrm{p}$.

Bradley, Robin, 1982, Mining districts and mineral deposits of the Basin and Range Province of Oregon: U.S. Geological Survey Open-File Report 82-58, 15 p.

Bureau of Land Management, 1985, Energy and mineral resource assessment: Washington, D.C., U.S. Department of Interior, Bureau of Land Management, accessed March 15, 2016, at http://www.blm. gov/wo/st/en/info/regulations/Instruction_Memos_and Bulletins/ blm_manual.html.

Bureau of Land Management, 1994, Mineral reports-preparation and review: Washington, D.C., U.S. Department of Interior, Bureau of Land Management, accessed March 15, 2016, at http:/www.blm. gov/wo/st/en/info/regulations/Instruction_Memos_and_Bulletins/ blm_manual.html.

California Department of Conservation, 2013, TOMS Mine Reclamation-Topographically Occurring Mine Symbols (data): California Department of Conservation, Office of Mine Reclamation, Abandoned Mine Lands Unit, digital dataset, accessed August 28, 2015, at http://www.conservation.ca.gov/omr/abandoned_mine lands/toms.

Calkins, J.A., Kays, Olaf, and Keefer, E.K., 1973, CRIB - The Mineral Resources Data Bank of the U.S. Geological Survey: U.S. Geological Survey Circular 681, 39 p., accessed May 1, 2016, at https://pubs. er.usgs.gov/publication/cir681.

Chavez, Joel, 1994, Mining districts of Montana: Montana Department of State Lands, Montana State Library, Natural Resource Information System (NRIS), Map 94-NRIS-230, 1 sheet, scale 1:1,000,000, accessed May 1, 2016, at http://eds.a.ebscohost.com/eds/detail/ detail?vid=1\&sid=c81ef35a-e302-462e-a622-5848fa93197f\%40sessi onmgr4004\&hid=4105\&bdata=JnNpdGU9ZWRzLWxpdmU\%3d\#A $\mathrm{N}=$ mont. $1807618 \& \mathrm{db}=\mathrm{cat} 00648 \mathrm{a}$.

Couch, B.F., and Carpenter, J.A., 1943, Nevada's metal and mineral production: Nevada Bureau of Mines and Geology Bulletin 38, $159 \mathrm{p}$. 
Cox, D.P., and Singer, D.A., eds., 1986, Mineral deposit models: U.S. Geological Survey Bulletin 1693, 379 p.

Davidoff, R.L., 1980, Supply Analysis Model (SAM)—A Minerals Availability System methodology: U.S. Bureau of Mines Information Circular 8820, 45 p.

Davis, D.A., Tingley, J.V., and Muntean, J.L., 2006, Gold and silver resources in Nevada: Nevada Bureau of Mines and Geology Map 149, scale 1:1,000,000.

Doelling, H.H., and Tooker, E.W., 1983, Utah mining district areas and principal metal occurrences: Utah Geological and Mineral Survey Map M-70, scale 1:750,000.

du Bray, E.A., ed., 1995, Preliminary compilation of descriptive geoenvironmental mineral deposit models (ver. 1.1): U.S. Geological Survey Open-File Report 95-831, 272 p. [Also available at http://pubs.usgs.gov/of/1995/ofr-95-0831/.]

Fernette, G.L., Bellora, J.D., Bartels, M.P., Gallegos, S.M., Jordan, J.K., Tureck, K.R. and Chapman, A.L., 2016a, USMIN mineral-resource data compiled for the USGS Sagebrush Mineral-Resource Assessment (SaMiRA) project: U.S. Geological Survey data release, http://dx.doi.org/10.5066/ F7J964GW.

Fernette, G.L., Horton, J.H., King, Z.R., San Juan, C.A., and Schweitzer, P.N, 2016b, Prospect- and mine-related features from U.S. Geological Survey 7.5- and 15-minute topographic quadrangle maps of the Western United States: U.S. Geological Survey data release, http://dx.doi.org/10.5066/F7JD4TWT.

Gillerman, V.S., 2014, Idaho mining and exploration 2014: Presentation at the Annual Meeting of the American Mining and Exploration Association, Reno, Nevada, December 3, 2014, 61 p.

Gilluly, James, Reed, J.C., and Park, C.F., 1933, Some mining districts in eastern Oregon: U.S. Geological Survey Bulletin 846-A, 140 p.

Gregory, R.W., Jones, R.W., and Cottingham, K.D., 2010, Uranium map of Wyoming: Wyoming State Geologic Survey Map Series 94, scale 1:500,000.

Gustafson, Jon, 1987, Mining districts of the State of Idaho: Idaho Geological Survey Map 6, scale 1:1,000,000.

Harris, R.E., 2004, Industrial minerals and construction materials map of Wyoming: Wyoming State Geological Survey Map Series 47, scale 1:500,000.

Harris, R.E., Hausel, W.D., and Meyer, J.E., 1985, Metallic and industrial minerals map of Wyoming: Geological Survey of Wyoming Map Series 14, scale 1:500,000.

Hausel, W.D., 1986, Gold districts of Wyoming: Geological Survey of Wyoming Report of Investigations No. 23, 71 p.
Hausel, W.D., 1989, The geology of Wyoming's precious metal lode and placer deposits: Geological Survey of Wyoming Bulletin 68, 248 p.

Hess, R.H., 2001, Nevada abandoned mines database compilation update: Nevada Bureau of Mines and Geology Open-File Report 2001-3.

Hess, R.H., and Davis, D.A., 2010, Nevada active mines and energy producers: Nevada Bureau of Mines and Geology and the Nevada Division of Mineral Resources Map 170, Scale 1:1,000,000.

Hill, J.M., 1912, The mining districts of the Western United States: U.S. Geological Survey Bulletin 507, 309 p., accessed May 1, 2016, at https://pubs.er.usgs.gov/publication/b507.

Idaho Geological Survey, 2015, Database of the mines and prospects of Idaho (ver. 1.2015.1): Idaho Geological Survey Database, accessed December 11, 2015, at http://www.idahogeology.org/Products/reverselook. asp? switch $=$ title\&value $=$ Database_of_the_Mines_and Prospects_of_Idaho.

Klein, T.L., 2004, Mineral deposit data for epigenetic base-and precious-metal and uranium-thorium deposits in southcentral and southwestern Montana and southern and central Idaho: U.S. Geological Survey Open-File Report 2004 1005, 16 p., http://pubs.usgs.gov/of/2004/1005/.

Koschmann, A.H., and Bergendahl, M.H., 1968, Principal gold-producing districts of the United States: U.S. Geological Survey Professional Paper 610, 283 p., accessed May 1, 2016, at http://pubs.usgs.gov/pp/0610/report.pdf.

Lapointe, D.D., Tingley, J. V., and Jones, R.B., 1991, Mineral Resources of Elko County, Nevada: Nevada Bureau of Mines and Geology, Bulletin 106, 236 p.

McCullogh, Warren, 2014, Mining, Permitting, and Exploration in Montana 2013-2014: Presentation at the American Exploration and Mining Association 2014 Annual Meeting, Reno, Nevada, December 3, 2014, 16 p.

McFaul, E.J., Mason, G.T., Jr., Ferguson, W.B., and Lipin, B.R., 2000, U.S. Geological Survey mineral databasesMRDS and MAS/MILS: U.S. Geological Survey Digital Data Series 52, two CD-ROMs.

Montana Bureau of Mines and Geology, 2006, Montana abandoned and inactive mines database: Montana Bureau of Mines and Geology database, accessed May 18, 2016, at ftp://ftp.geoinfo.msl.mt.gov/Data/Spatial/NonMSDI/Shapefiles/Mine_MBMG2006.zip.

Montana Department of Environmental Quality, 2015, Mapping DEQ's data, opencut permits: Montana Department of Environmental Quality Web site, accessed December 29, 2015, at http://svc.mt.gov/deq/wmadst/. 
Nevada Department of Transportation, 2013, NDOT material site map atlas: Nevada Department of Transportation Web site, accessed December 13, 2015, at http://www.nevadadot. com/uploadedFiles/NDOT/About_NDOT/NDOT_Divisions/ Operations/Materials/quad0201.pdf.

Oregon Department of Geology and Mineral Industries, 2010, Mineral information layer for Oregon, release 2 (MILORelease 2): Oregon Department of Geology and Mineral Industries, accessed December 11, 2015, at http://www. oregongeology.org/sub/milo/.

Oregon Department of Geology and Mineral Industries, 2015, Surface mining permits and production information, mining permits spreadsheet: Oregon Department of Geology and Mineral Industries, accessed October 22, 2015, at http://www. oregongeology.org/mlrr/surfacemining-report.html.

Papke, K.G., and Castor, S.B., 2003, Industrial mineral deposits in Nevada: Nevada Bureau of Mines and Geology Map 142, 22 p., 1 pl., scale 1:1,000,000.

Ross, C.P., 1941, The metal and coal mining districts of Idaho, with notes on the nonmetallic mineral resources of the State: Idaho Bureau of Mines and Geology Pamphlet No. 57, 263, p.

San Juan, C.A., Horton, J.D., Parks, H.L., Mihalasky, M.J., Anderson, E.D., Benson, M.E., Box, S.E., Cossette, P.M., Denning, P.D., Giles, S.A., Hall, S.M., Hayes, T.S., Hearn, B.C., Jr., Hofstra, A.H., John, D.A., Ludington, S., Lund, K., Mauk, J.L., Robinson, G.R., Jr., Rockwell, B.W., Rytuba, J.J., Smith, S.M., Stillings, L.L., Van Gosen, B.S., Vikre, P.G., Wallis, J.C., Wilson, A.B., Zientek, M.L., and Zürcher, L., 2016, Locatable mineral assessment tracts for the U.S. Geological Survey Sagebrush Mineral-Resource Assessment project: U.S. Geological Survey data release, http://dx.doi. org/10.5066/F7833Q4R.

Spanski, G.T., 2001, Inventory of mines and mining-related facilities in Idaho and western Montana active from 1997 through 2000: U.S. Geological Survey Open-File Report 01-129, $14 \mathrm{p}$.

Spanski, G.T., 2004, Inventory of significant mineral deposit occurrences in the Headwaters project area in Idaho, western Montana and extreme eastern Oregon and Washington: U.S. Geological Survey Open-File Report 04-1038, 13 p., http:// pubs.usgs.gov/of/2004/1038/.

Stager, H.K., and Tingley, J.V., 1988, Tungsten deposits in Nevada: Nevada Bureau of Mines and Geology Bulletin 105, $256 \mathrm{p}$.

Tate, C.A., Gillerman, V.S., and Stanford, L.R., 2015, Database of select aggregate material sources for Idaho (ver. 1.2015.1): Idaho Geological Survey Digital Database DD-9, accessed December 11, 2015, at http://www.idahogeology.org/ Products/reverselook.asp?switch=title\&value=Database_of Select_Aggregate_Material_Sources_for_Idaho.
Tingley, J.V., 1998, Mining districts of Nevada (second edition): Nevada Bureau of Mines and Geology Report 47, 128 p., scale $1: 1,000,000$.

U.S. Geological Survey, 2005, Active mines and mineral processing plants in the United States in 2003: U.S. Geological Survey Web site, accessed May 18, 2016, at http://mrdata.usgs.gov/mineplant.

U.S. Geological Survey, 2016, Mineral Resource Data System: U.S. Geological Survey Web site, accessed March 15, 2016, at http:// mrdata.usgs.gov/mrds/.

Utah Division of Oil, Gas and Mining, 2016, Utah minerals program permit database: Utah Division of Oil, Gas and Mining Database, accessed January 11, 2016, at http://inux3.ogm.utah.gov/ WebStuff/wwwroot/minerals/mineralstaskinfo.php.

Utah Geological Survey, 2012, Utah mining districts: Utah Geological Survey GIS database, updated through 2012, accessed December 11, 2015, at http://geology.utah.gov/resources/datadatabases/utah-mining-districts/.

Utah Geological Survey, 2015, Utah mineral occurrence system: Utah Geological Survey database, accessed December 11, 2015, at http://geology.utah.gov/resources/data-databases/utah-mineraloccurrence-system/.

Willden, Ronald, 1964, Geology and mineral deposits of Humboldt County Nevada: Nevada Bureau Mines and Geology Bulletin 59, $154 \mathrm{p}$.

Wilson, A.B., 2014, Uranium in the Wyoming Landscape Conservation Initiative Study Area, southwestern Wyoming: U.S. Geological Survey Open-File Report 2014-1123, 33 p., 1 plate, accessed May 1, 2016, at http://dx.doi.org/10.3133/ofr20141123.

Wilson, A.B., Klein, T.L., and Heran, W.D., 2001, Databases and simplified geology for mineralized areas, claims, mines and prospects in Wyoming: U.S. Geological Survey Open-File Report 2001-0497, 17 p., accessed May 1, 2016, at https://pubs.usgs.gov/ of/2001/ofr-01-0497/.

Wyoming Department of Environmental Quality, 2015, A viewer of land quality active permits: Wyoming Department of Environmental Quality online viewer and database, accessed December 23, 2015, at https://gis.deq.wyoming.gov/maps/lqd permit_public/index.html.

Wyoming Department of Workforce Services, Office of Mine Inspector, 2013, Annual report of the State Inspector of Mines for the year 2013: Wyoming Department of Workforce Services, 115 p., accessed May 18, 2016, at http://wyomingworkforce. org/_docs/mines/ar/2013.pdf.

Wyoming Department of Workforce Services, Office of Mine Inspector, 2014, Annual Report of the State Inspector of Mines for the year ending December 31, 2014: Wyoming Department of Workforce Services, Office of Mine Inspector, 115 p., accessed May 18, 2016, at http://wyomingworkforce.org/_docs/ mines/ar/2014.pdf. 


\title{
Section C. Geochemical Data
}

\author{
By Steven M. Smith, Karen D. Kelley, Helen W. Folger, Douglas B. Yager, Matthew Granitto, and Stuart A. Giles
}

\section{Introduction}

The geochemical datasets used for the assessments of the Bureau of Land Management (BLM) Sagebrush Focal Areas (SFA) were compiled from U.S. Geological Survey (USGS) geochemical databases and include soil and stream-sediment (primarily, but not exclusively, $<80$ and $<100$ mesh) samples (hereafter referred to as SedsSoils), concentrate fractions from sediment and soil samples (hereafter referred to as concentrates), and rock samples. The samples were collected and analyzed over a period of 50 years from the mid-1960s through 2013. After statistical evaluation, selected elements (silver, gold, and others) indicative of a wide variety of mineral-deposit types were plotted, either as point plots (rock, concentrates, and SedsSoils) or interpolated grids (SedsSoils only). A summary of the data sources, methods for statistical evaluation and determination of threshold values, replacement of lower limits of determination (LLD) required for gridding, and GIS methods are provided below.

\section{Databases Used to Build the SaMiRA Datasets}

Multiple USGS databases were evaluated for inclusion in the Sagebrush Mineral-Resource Assessment (SaMiRA) geochemical datasets. These are listed below with brief descriptions.

\section{NURE-HSSR (collected 1976-1980)}

The National Uranium Resource Evaluation (NURE) program included a Hydrogeochemical and Stream Sediment Reconnaissance (HSSR) task that collected and analyzed more than 300,000 sediment and soil samples from Alaska and the conterminous United States between 1976 and 1980. These data were compiled, reformatted, and released online by Smith (1997) and are available from the USGS Mineral Resources On-Line Spatial Data Web site (http://mrdata.usgs.gov/nure/sediment). The NURE-HSSR samples in the SaMiRA area were collected or analyzed under the auspices of three U.S. Department of Energy National Laboratories - Oak Ridge Gaseous Diffusion Plant (OR), Los Alamos National Laboratory (LA), and Savannah River National Laboratory (SR). Because multiple analytical methods in different laboratories were used, the NURE-HSSR database contains analytical bias between areas covered by each laboratory.
The NURE-HSSR program was terminated before collection and analyses of samples from the entire United States were completed.

\section{NGS (2008 release)}

The National Geochemical Survey (NGS) was a USGS project tasked with creating complete geochemical coverage of the United States at a scale of one sample per 289 square kilometers $\left(\mathrm{km}^{2}\right)$. The project (1) reanalyzed selected NURE-HSSR samples, (2) assembled other similar reanalyzed NURE-HSSR sample datasets, and (3) collected and analyzed additional samples where the NURE program was incomplete. This database was published (U.S. Geological Survey, 2004), and the data (as of the 2008 release) are available from the USGS Mineral Resources On-Line Spatial Data Web site (http://mrdata.usgs.gov/geochem).

\section{NGS-NURE}

Analytical bias displayed by many elements, due to the use of multiple analytical methods and labs, was characteristic of the original NURE-HSSR data. The NGS project described above was designed to reanalyze approximately 13 percent of the available NURE-HSSR samples using a 40-element inductively coupled plasma atomic emission spectrometry (ICP-AES) (Briggs, 2002) or ICP-MS (Briggs and Meier, 2002) method. The availability of new analyses by consistent methodology creates the possibility to mathematically level the NURE-HSSR data and remove most of the analytical bias. A review of overlapping analyses revealed that leveling was possible for 29 elements (Al, $\mathrm{As}, \mathrm{Au}, \mathrm{Be}, \mathrm{Ca}, \mathrm{Ce}, \mathrm{Co}, \mathrm{Cu}, \mathrm{Eu}$, $\mathrm{Fe}, \mathrm{K}, \mathrm{La}, \mathrm{Li}, \mathrm{Lu}, \mathrm{Mg}, \mathrm{Mn}, \mathrm{Mo}, \mathrm{Na}, \mathrm{Ni}, \mathrm{P}, \mathrm{Pb}, \mathrm{Sc}, \mathrm{Sm}, \mathrm{Ti}, \mathrm{U}$, $\mathrm{V}, \mathrm{Y}, \mathrm{Yb}$, and $\mathrm{Zn}$; chemical symbols are defined in the front matter of this report). A revised NGS-NURE database was created by combining the NGS and the leveled NURE-HSSR datasets. This process and database is described by Smith and others (2015) and the database is currently being prepared for release on the USGS Mineral Resources On-Line Spatial Data Web site (http://mrdata.usgs.gov/).

\section{NGDB (mid-1960s through 2007)}

The National Geochemical Database (NGDB) is a compilation of geochemical records from samples collected for various USGS projects and analyzed by USGS laboratories from the mid-1960s until the present, although currently only data 
through 2007 have been released. Because samples in the NGDB were originally collected and analyzed for multiple purposes, there is a large variety of geologic materials (for example, rocks, sediments, soils, concentrates), sampling densities, requested analytical procedures, and number of elements analyzed. Many of these samples came from mineral-resource assessment studies of $1^{\circ} \times 2^{\circ}$ quadrangles or BLM Wilderness Study Areas. The NGDB also contains reanalyzed NURE-HSSR samples from the NGS and other USGS projects. The NGDB rock, soil, sediment, and concentrate data (through 2007) are available from the USGS Mineral Resources On-Line Spatial Data Web site (http://mrdata. usgs.gov/ngdb).

\section{NASGLP Soils (2013 data release)}

The North American Soils Geochemical Landscape Project (NASGLP) collected and analyzed topsoil and C-horizon soil from the conterminous United States at a density of one sample per $1,600 \mathrm{~km}^{2}$. These samples were collected in conjunction with similar projects in Canada and Mexico. The use of randomly selected sites within a grid that covered the entire conterminous United States makes this an ideal dataset to use for the determination of elemental baseline or regional background concentrations for U.S. soils. These data were published (Smith and others, 2013) and are available from the USGS Mineral Resources On-Line Spatial Data Web site (http:// mrdata.usgs.gov/ds-801).

\section{Compilation and Evaluation of Data for the SaMiRA Dataset}

Data for concentrates, rocks, sediment, and soils were extracted exclusively from the NGDB (U.S. Geological Survey, 2016a-d). The combined dataset for SedsSoils was derived from all of the available USGS databases described above. However, most records for SedsSoils within the SaMiRA areas were pulled from the NGS-NURE database. Additional records were added from the NGDB and the NASGLP databases (A-horizon soils only because they were more likely to be consistent with the variety of other soil samples from other databases). Many samples were represented by duplicate records in the NGDB and NGS-NURE databases. Considerable effort was made to remove duplication and preserve the best information for each of the overlapping records. Every record in the SedsSoils database is identified by its data source:

1. NASGLPA-Horizon Soils-A-horizon soil records with chemistry and sample description information derived from the NASGLP database.

2. NGDB SedsSoils-with NGDB BV chemistry-Sample records pulled exclusively from the NGDB database with "best value" (BV) chemistry (Granitto and others, 2013) as described below.
3. NGSNURE-Leveled NURE plus NURE-Records for samples collected during the NURE program, analyzed only by NURE laboratories. The sample descriptive information comes from the NURE-HSSR database (Smith, 1997), and the chemistry for 29 leveled elements was obtained from the NGS-NURE database of Smith and others (2015). Additional chemistry for Ag, B, Ba, Cd, Cr, Cs, Dy, Hf, Nb, $\mathrm{Rb}, \mathrm{Sb}, \mathrm{Se}, \mathrm{Sn}, \mathrm{Sr}, \mathrm{Th}, \mathrm{W}$, and $\mathrm{Zr}$ was added directly from the original NURE-HSSR database.

4. NGS-NURE-with NGS chemistry-Sample records from the NGS database that were not found in the NGDB. Most of these were NURE-HSSR samples reanalyzed by USGS projects using non-USGS commercial or university laboratories. The sample descriptive information and the chemistry were combined from the NGS-NURE and NGS databases.

5. NGSNURE-with NGDB BV chemistry-Sample records from the NGS database that were duplicated in the NGDB. The sample descriptive information was obtained from the NGS-NURE database and the more complete "best value" chemistry (Granitto and others, 2013) was added from the NGDB.

When compilation of the datasets was complete, records were examined to remove samples that were not appropriate for the purpose of assessing the mineral potential of the BLM SFAs. Examples of samples removed include (1) those that were collected at depths greater than 1 meter below the surface (primarily drill cores), (2) those identified as mill products (for example, tailings, slag), and (3) those with no relevant chemical data. Surface samples collected at mine sites were not removed.

The NGDB contains many records with poor coordinate precision or accuracy. In the past, it was common to report sample coordinates that were less precise than the nearest second of latitude or longitude. Although the actual accuracy of a coordinate location is dependent on the care given by the submitter and cannot be assessed without other information, it is possible to assess the apparent coordinate precision, defined as the precision level to which a coordinate was reported (for example, nearest second, minute, degree, and fraction thereof). The apparent reported coordinate precision was determined for every latitude and longitude value. Because it is possible that a few coordinates in a batch (job) of samples actually did plot on what appears to be a less precise coordinate, each sample job was assessed based on the best apparent coordinate precision of samples within the batch. If coordinates in a job were not provided to the nearest 15 seconds or better ( \pm 760 feet or \pm 0.14 miles), samples were removed. After jobs with imprecise coordinates were removed, individual samples with poor apparent precision were assessed and, where it was evident that precision within a job was not maintained, those samples were also removed.

The duplication of samples at single sites was also assessed (after removal of samples with poor coordinate precision). Some additional jobs or batches of samples were removed when it became evident that the submitter had used only a 
single coordinate instead of accurate coordinates for a study. For example, samples were removed for a couple of soil surveys, known to have been collected on a traverse or grid, when all samples had the same single-site coordinates. Several rock samples with similar problems were also removed. However, within the existing database, a large number of rocks plotting at single sites more likely represent multiple sample collections from a single locality.

Finally, the analytical values were examined, and a few samples were checked against the original laboratory paperwork to correct or remove bad values that had been mistakenly entered. Another common issue was the use of two or more analytical methods on a sample or batch of samples, resulting in multiple values for the same element. This situation occurred most commonly when more than one multielement analytical package was used (typically with the second one containing some of the same elements but with better LLDs). To ensure that the most appropriate single value for each element was preserved in the database, we used the "best value" (BV) method as described by Granitto and others (2013). Because of the multitude of analytical methods used on these samples, there was also a large variation of LLDs for many elements - sometimes greatly exceeding the average crustal abundance of that element. For example, the median value for tellurium (Te) in the A-horizon soils throughout the conterminous United States (Smith and others, 2013) is 0.03 milligrams per kilogram $(\mathrm{mg} / \mathrm{kg}$ ) or parts per million (ppm), but the LLDs for Te in the SedsSoils database were $<0.02,<0.05,<0.1,<0.2,<0.5,<50$, and $<2,000 \mathrm{ppm}$, whereas the maximum detected value is $1.6 \mathrm{ppm}$ Te. It was determined that, in the case of Te, the values of $<50$ and $<2,000$ ppm were not useful for a mineral-resource assessment, and so these two LLD values were removed from the data. In summary, two rules were applied when determining which of multiple LLDs were not useful for the assessment:

1. For elements that were less than 40 percent censored ("censored" indicates values that are less than the LLD, for example, $<0.5 \mathrm{ppm}$, which is the LLD in this case), high
LLDs were removed when they exceeded 2 times the crustal abundance or median topsoil value in the United States, as determined by Smith and others (2013).

2. For elements that were 40 percent or more censored, two additional conservative criteria were applied - (1) the LLD of the method or methods with the majority of detected values was kept, even if it exceeded two times the estimated crustal abundance of the element in that media; and (2) high LLDs were not removed if they significantly changed the median and upper quartile statistics of the population.

Because heavy-mineral concentrates have undergone a concentration factor of 1,000 to 10,000 times the original source material (method for obtaining heavy-mineral concentrates is described in later section), even seemingly high LLDs can be meaningful. No LLD values were removed from the concentrate database.

The resulting database for the SaMiRA project is summarized in table $\mathrm{C} 1$ and distinguished based on sample media type within each of the four SFAs. Analyses from a total of 26,343 SedsSoils, 6,890 rock samples, and 3,717 concentrates were used in this evaluation. Data within the Public Land Survey System (PLSS) areas were included, as well as within a 25-kilometer $(\mathrm{km})$ buffer zone around each SFA in order to incorporate geochemical trends that could fall near the edge of the SFAs. The distribution of samples is shown in figure $\mathrm{C} 1$.

\section{Analytical Methods}

The SaMiRA database contains reported values obtained by analytical methods provided by multiple laboratories. In general, samples were collected and analyzed from the mid-1960s to the mid-2000s, and there were significant developments in analytical methods during that timeframe. Table $\mathrm{C} 2$ lists the analytical methods used. The method codes are included as a column in the sediment, soil, rock, and concentrate databases.

Table C1. Number of samples listed by sample media type for Sagebrush Focal Areas (SFA) studied in the Sagebrush MineralResource Assessment (SaMiRA) project, Western United States.

[SedsSoils, soil and stream-sediment samples]

\begin{tabular}{lccr}
\hline \multicolumn{1}{c}{ SFA } & SedsSoils & Concentrates & Rocks \\
\hline Nevada border $^{1}$ & 13,103 & 1,458 & 2,552 \\
North-Central Idaho & 8,624 & 1,905 & 3,765 \\
Wyoming/Utah & \\
Montana & 2,293 & 354 & 496 \\
Total & 2,323 & 0 & 77 \\
\hline
\end{tabular}

${ }^{1}$ Includes Sheldon-Hart Mountain National Wildlife Refuge, Southeast Oregon and North-Central Nevada, and Southern Idaho and Northern Nevada SFAs.

${ }^{2}$ Includes Bear River Watershed of Utah and Southwestern and South-Central Wyoming. 


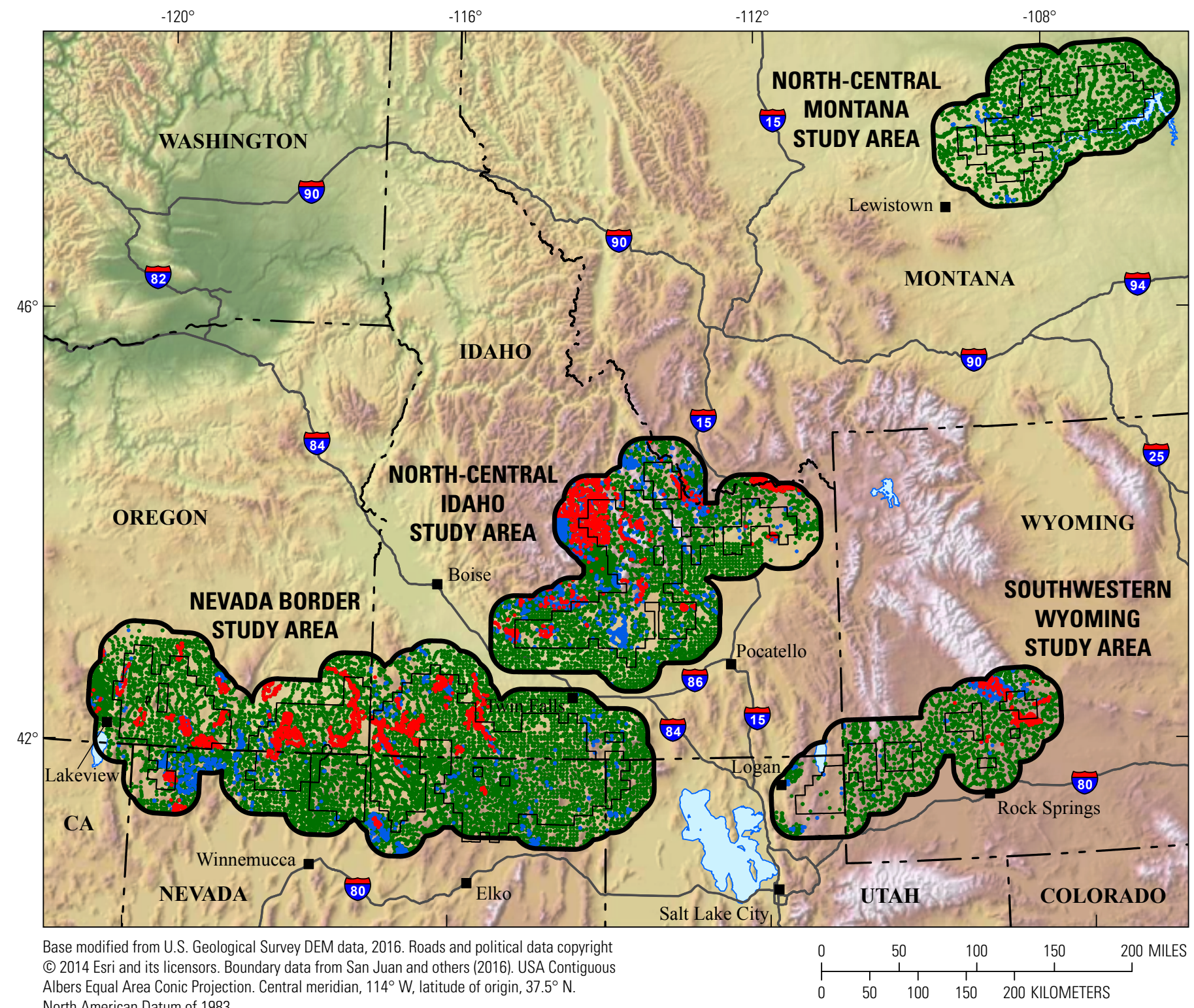

North American Datum of 1983.

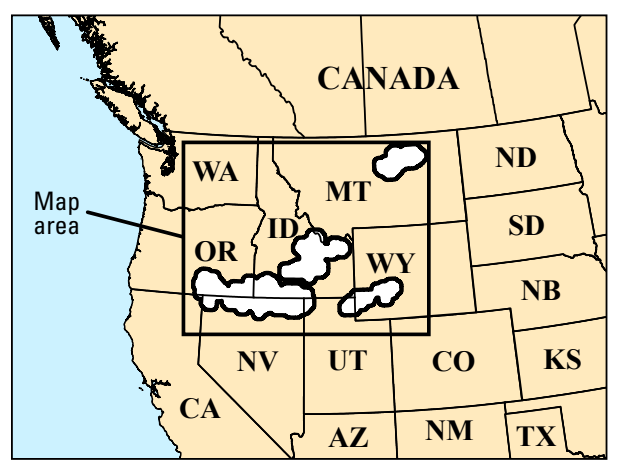

EXPLANATION

Geochemistry sample sites

CodSoil sample sites
25-kilometer sample selection buffer
$\square$ USGS study area boundaries

Figure C1. Map showing the distribution of all geochemistry sample sites for the Sagebrush Focal Areas (SFA) studied in the Sagebrush Mineral-Resource Assessment (SaMiRA) project, Western United States. See figure A1 for SFA boundaries and names. SedSoil, soil and stream-sediment. 
Table C2. Analytical methods used for the Sagebrush Mineral-Resource Assessment (SaMiRA) project soil and stream-sediment samples (SedsSoils), concentrate samples, and rock samples.

[NURE, National Uranium Resource Evaluation; DIBK, diisobuytl ketone, an extraction solvent sometimes written as di iso butyl; MIBK, methyl isobutyl ketone, an organic solvent; Aliquat 336, trioctylmethylammonium chloride; HF, hydrofluoric acid; other chemical symbols are defined in the front matter of this report]

\section{Analytical}

method code

\section{Analytical method description}

Mercury by cold-vapor atomic absorption spectrometry after multi-acid digestion and solution.

Mercury by cold-vapor atomic absorption spectrometry after wet oxidation from multi-acid digestion and solution.

AA_F_Fuse Major and minor elements by flame atomic absorption spectrometry after $\mathrm{LiBO}_{2} / \mathrm{Li}_{2} \mathrm{~B}_{4} \mathrm{O}_{7}$ fusion Shapiro, 1975 digestion.

AA_F_HBr Gold and tellurium by flame atomic absorption spectrometry after $\mathrm{HBr}_{-} \mathrm{Br}_{2}$ digestion and selective O’Leary and Meier, 1996 organic extraction with Aliquat 336-MIBK.

AA_F_HF Major and minor elements by flame atomic absorption spectrometry after multi-acid digestion with HF.

AA_FE Sodium and potassium by flame emission spectrometry (flame photometry) after $\mathrm{HF}_{-} \mathrm{HClO}_{4}$ dissolution or $\mathrm{LiBO}_{2}$ fusion.

AA_GF_HBr Gold and tellurium by graphite furnace atomic absorption spectrometry after $\mathrm{HBr}-\mathrm{Br}_{2}$ digestion and selective organic extraction with Aliquat 336-MIBK.

AA_GF_HF Arsenic, gold, bismuth, indium, antimony, tellurium and thallium by graphite furnace atomic absorption spectrometry after multi-acid digestion with $\mathrm{HF}$ and selective organic extraction with Aliquat 336-MIBK.

AA_GF_ST Thallium by graphite furnace atomic absorption spectrometry after $\mathrm{Na}_{2} \mathrm{O}_{2}$ sinter, $\mathrm{HCl}-\mathrm{HNO}_{3}$ dissolution, and selective organic extraction with DIBK.

AA_HG_Acid Selenium by flow injection or continuous flow hydride generation-atomic absorption spectrometry after digestion with $\mathrm{HNO}_{3}-\mathrm{HCl}-\mathrm{H}_{2} \mathrm{SO}_{4}-\mathrm{KMnO}_{4}$.

AA_HG_HF Arsenic, antimony, selenium and tellurium by flow injection or continuous flow hydride generation-atomic absorption spectrometry after multi-acid digestion with HF.

AA_HG_ST Arsenic and antimony by flow injection or continuous flow hydride generation-atomic absorption spectrometry after $\mathrm{Na}_{2} \mathrm{O}_{2}$ sinter digestion.

AA_TR

Mercury by thermal release and atomic absorption spectrometry after heating (Vaughn-McCarthy method). AES_Fuse Major and minor elements by inductively coupled plasma-atomic emission spectrometry after
$\mathrm{Li}_{2} \mathrm{~B}_{4} \mathrm{O}_{7}$ fusion digestion.

AES_HF Major and minor elements by inductively coupled plasma-atomic emission spectrometry after digestion with $\mathrm{HF}-\mathrm{HCl}-\mathrm{HNO}_{3}-\mathrm{HClO}_{4}$.

AES_HF_REE $\begin{aligned} & \text { Rare earth elements by ion exchange and inductively coupled plasma-atomic emission } \\ & \text { quantitative spectrometry after } \mathrm{HF}-\mathrm{HCl}-\mathrm{HNO}_{3}-\mathrm{HClO}_{4} \text { digestion. }\end{aligned}$
AES_IE
$\begin{aligned} & \text { Molybdenum, niobium and tungsten by inductively coupled plasma-atomic emission quantitative } \\ & \text { spectrometry after } \mathrm{HF}-\mathrm{HCl}-\mathrm{HNO}_{3}-\mathrm{HClO}_{4} \text { digestion and ion exchange separation. }\end{aligned}$

\begin{tabular}{ll} 
CB_IRC & Carbon and sulfur by infrared detection after combustion. \\
CB_TC & Total carbon and organic carbon by thermal conductivity detection after combustion. \\
CB_TT & Sulfur by iodometric titration after combustion. \\
CM_Acid & Arsenic by colorimetry after $\mathrm{Na}_{2} \mathrm{O}_{2}$ sinter digestion. \\
CM_Fuse & Major and minor elements by colorimetric spectrophotometry after fusion digestion. \\
\hline CM_HF & Vanadium and tungsten by colorimetric spectrophotometry after multi-acid digestion with $\mathrm{HF}$. \\
$\mathrm{CM}$ _HSF & Fluorine by colorimetric spectrophotometry after $\mathrm{H}_{2} \mathrm{SiF}_{6}$ digestion and chemical separation. \\
$\mathrm{CM}$ _ST & Chloride by colorimetric spectrophotometry after $\mathrm{Na}_{2} \mathrm{CO}_{3}$ and $\mathrm{ZnO}$ sinter digestion. \\
$\mathrm{CP}$ & Organic carbon, carbonate carbon and totals by computation. \\
DN & Uranium and thorium by delayed neutron activation counting.
\end{tabular}

CB_IRC Carbon and sulfur by infrared detection after combustion.

CB_TC

Total carbon and organic carbon by thermal conductivity detection after combustion

Arsenic by colorimetry after $\mathrm{Na}_{2} \mathrm{O}_{2}$ sinter digestion.

Major and minor elements by colorimetric spectrophotometry after fusion digestion.

Uranium and thorium by delayed neutron activation counting.

\section{Reference}

Brown and others, 2002

Huffman and others, 1972

Doughten and Grossman, 1993; Aruscavage and Crock, 1987

Fries and others, 1996; Jackson and others, 1987

O’Leary and Meier, 1996

Doughten and Grossman, 1993

Modified from Doughten and Grossman, 1993

Modified from Doughten and Grossman, 1993

Hageman and others, 2002

Modified from Hageman and Welsch, 1996

Ward and others, 1969

Doughten and Grossman, 1993

Briggs, 2002

Lichte and others, 1987

Doughten and Aruscavage, 1996

Brown and Curry, 2002a; Brown and Curry, 2002b

Jackson and others, 1987

O’Leary, 1990

Brown and others, 1975

Shapiro, 1975

Wilson and others, 1987

Shapiro, 1975

Jackson and others, 1987

Jackson and others, 1987

Knight and McKown, 2002 
Table C2.-Continued

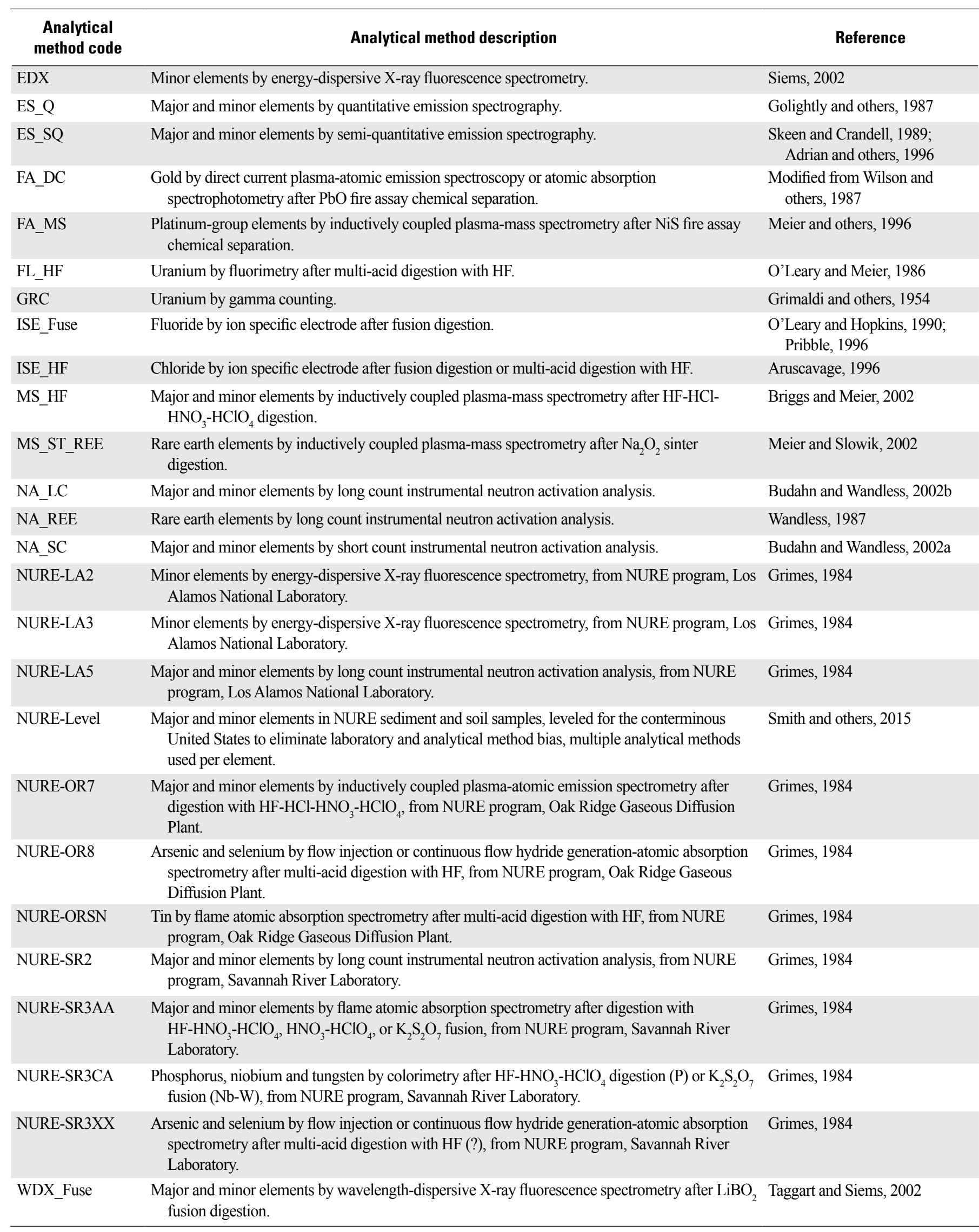




\section{Statistical Summaries}

Elements of most interest for the mineral assessment include $\mathrm{Ag}$, As, $\mathrm{Au}, \mathrm{Be}, \mathrm{Bi}, \mathrm{Ce}, \mathrm{Co}, \mathrm{Cr}, \mathrm{Cu}, \mathrm{Dy}, \mathrm{Ga}, \mathrm{Ge}, \mathrm{Hg}, \mathrm{La}$, $\mathrm{Li}, \mathrm{Mn}, \mathrm{Mo}, \mathrm{Nb}, \mathrm{Ni}, \mathrm{Pb}$, Re, platinum-group elements (Ir, Os, $\mathrm{Pd}, \mathrm{Pt}, \mathrm{Rh}$, and Ru), Sb, Sn, Te, Th, Tl, U, V, W, Y, Yb, and Zn, many of which are pathfinder elements for a variety of deposit types known to occur within or near one or more of the SFAs. Summary statistics were calculated for these elements in each of the three media types (SedsSoils, concentrates, and rocks). Distribution diagrams (histograms and boxplots) were constructed (for example, fig. C2) based only on the samples with values greater than the LLD, that is, uncensored values). This interval was selected to identify and evaluate the range of values that can reflect enrichment in these particular pathfinder elements. For the SedsSoils and rock databases, we also calculated minimum, maximum, and median values (for uncensored data). The four upper threshold values (determined by methods described below) are shown on each boxplot/histogram diagram, and are consistent with those used to create the point plots and grid maps.

\section{Determination of Threshold Values for SedsSoils and Rocks}

The purpose of geochemistry in mineral-resource assessments is to determine concentrations of elements that are relatively high compared to a threshold value (and thus, could potentially record proximity to mineral deposits containing those elements). Methods for determination of threshold values for a given dataset are varied, and it is critical to use one that is best suited for the goal of assessing mineral potential. Calculation of percentile values is a common method, and doing so will always produce element classes that are "anomalous" (for example, $>90$ th percentile) with respect to the dataset as a whole; however, the absolute concentrations of an element in samples represented by these $>90$ th percentile classes may not always be high (and thus, potentially not reflective of mineral deposits). Such false anomalies are not always meaningful for mineral-resource assessments. Hence, we chose a method that is consistent across all of the SFAs and would not elevate any element to anomalous status without justification. To do this, we used estimates of natural element abundance (described below) as the basis for classifying element concentrations. For SedsSoils, we primarily used the median value for A-horizon soils determined from samples collected throughout the entire conterminous United States (Smith and others, 2013). For rocks, we primarily used the crustal abundance estimates, also known as the Clarke Index, compiled by Fortescue (1992). For a few elements, it was necessary to obtain abundance values from other sources. Table C3 lists the abundance values (expressed in parts per million unless mentioned otherwise) used for SedsSoils and rocks.

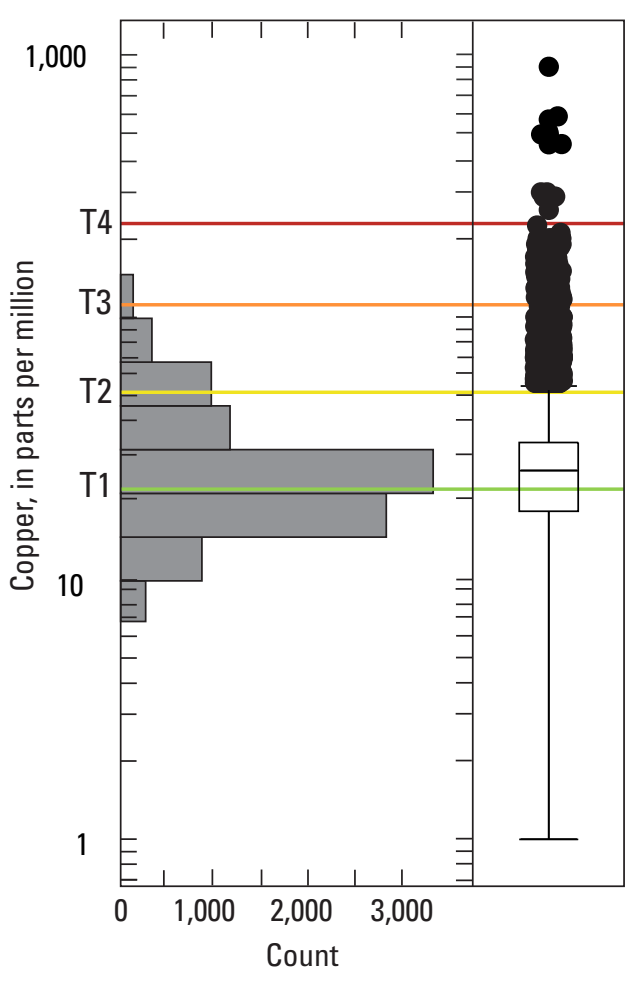

\begin{tabular}{|l|r|}
\hline Number of samples & 10,051 \\
\hline Minimum & 1 \\
\hline Maximum & 907 \\
\hline Median & 26 \\
\hline No. censored & 26 \\
\hline No. uncensored & 10,051 \\
\hline Total analysed & 10,077 \\
\hline $\begin{array}{l}\text { Percentage of censored } \\
\text { values (of total analyzed) }\end{array}$ & 0.3 \\
\hline
\end{tabular}

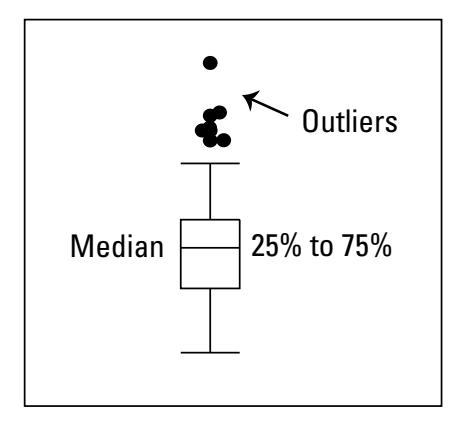

Figure C2. Example diagram showing copper concentrations in parts per million (ppm) in stream-sediment and soil samples (SedsSoils) from the Sheldon-Hart Mountain National Wildlife Refuge, Southern Idaho and Northern Nevada, and Southeastern Oregon and North-Central Nevada Sagebrush Focal Areas (see section A, fig. A1). The histograms and boxplot diagrams and median are based on uncensored (above lower limits of determination, LLD) data only, but the percentage of censored data is shown in statistics table in the diagram (N, number). T1, T2, T3, and $\mathrm{T} 4$ are the threshold values (see text for description). T1 = 2-3x background (green line), T2 = 4-7 $\times$ background (yellow line), T3 = 8-15 $\times$ background (orange line), and T4 = >16 $\times$ background (red line). \%, percent. 
Table C3. Abundance values for stream-sediment and soil samples (SedsSoils) and rocks used in the Sagebrush Mineral-Resource Assessment (SaMiRA) project.

[All values in parts per million (ppm) unless otherwise noted; wt.\%, elements reported in weight percent; chemical symbols are defined in the front matter of this report]

\begin{tabular}{|c|c|c|c|c|c|c|c|}
\hline \multicolumn{4}{|c|}{ Sediments and Soils ${ }^{1}$} & \multicolumn{4}{|c|}{ Rocks $^{2}$} \\
\hline Element & Abundance & Element & Abundance & Element & Abundance & Element & Abundance \\
\hline$\overline{\mathrm{Ag}^{3}}$ & 0.27 & Sc & 6.1 & $\mathrm{Ag}$ & 0.08 & Mo & 1.2 \\
\hline $\mathrm{Al}$ wt.\% & 4.71 & $\mathrm{Se}$ & 0.2 & $\mathrm{Al}$ wt.\% & 8.36 & Na wt.\% & 2.27 \\
\hline As & 5.2 & $\mathrm{Sm}^{3}$ & 3.96 & As & 1.8 & $\mathrm{Nb}$ & 20 \\
\hline $\mathrm{Au}^{4}$ & 0.004 & Sn & 1.3 & $\mathrm{Au}$ & 0.004 & $\mathrm{Nd}$ & 39.6 \\
\hline $\mathrm{B}^{5}$ & 26 & $\mathrm{Sr}$ & 122 & B & 9 & $\mathrm{Ni}^{6}$ & 75 \\
\hline $\mathrm{Ba}$ & 512 & $\mathrm{Ta}^{3}$ & 0.68 & $\mathrm{Ba}$ & 390 & P wt.\% & 0.112 \\
\hline $\mathrm{Be}$ & 1.3 & $\mathrm{Te}^{3}$ & 0.03 & $\mathrm{Be}$ & 2 & $\mathrm{~Pb}$ & 13 \\
\hline $\mathrm{Bi}$ & 0.16 & $\mathrm{Th}$ & 7.7 & $\mathrm{Bi}^{6}$ & 0.17 & $\mathrm{Pd}$ & 0.015 \\
\hline Ca wt.\% & 0.74 & Ti wt.\% & 0.24 & $\mathrm{Br}$ & 2.5 & $\operatorname{Pr}$ & 9.1 \\
\hline $\mathrm{Cd}$ & 0.2 & $\mathrm{Tl}$ & 0.4 & Ca wt.\% & 4.66 & $\mathrm{Pt}$ & 0.0005 \\
\hline $\mathrm{Ce}$ & 51.7 & $\mathrm{U}$ & 2 & $\mathrm{Cd}$ & 0.16 & $\mathrm{Rb}$ & 78 \\
\hline Co & 7.8 & $\mathrm{~V}$ & 54 & $\mathrm{Ce}$ & 66.4 & $\operatorname{Re}$ & 0.0007 \\
\hline $\mathrm{Cr}$ & 31 & W & 0.8 & $\mathrm{Cl}$ & 126 & $\mathrm{Rh}$ & 0.0002 \\
\hline $\mathrm{Cs}^{3}$ & 3.71 & $Y$ & 14.5 & Co & 29 & $\mathrm{Ru}$ & 0.001 \\
\hline $\mathrm{Cu}$ & 14.8 & $\mathrm{Yb}^{3}$ & 1.99 & $\mathrm{Cr}$ & 122 & S wt.\% & 0.034 \\
\hline$D y^{3}$ & 3.42 & $\mathrm{Zn}$ & 59 & $\mathrm{Cs}$ & 2.6 & $\mathrm{Sb}$ & 0.2 \\
\hline $\mathrm{Eu}^{3}$ & 0.77 & $\mathrm{Zr}^{5}$ & 180 & $\mathrm{Cu}$ & 68 & $\mathrm{Sc}$ & 25 \\
\hline Fe wt.\% & 1.99 & & & Dy & 5 & $\mathrm{Se}^{7}$ & 0.15 \\
\hline $\mathrm{Ga}$ & 11.2 & $\mid$ & & Er & 3.46 & $\mathrm{Sm}$ & 7.02 \\
\hline $\mathrm{Hf}^{3}$ & 5.55 & $\mid$ & & $\mathrm{Eu}$ & 2.14 & Sn & 2.1 \\
\hline $\mathrm{Hg}$ & 0.02 & $\mid$ & & F wt.\% & 0.0544 & $\mathrm{Sr}$ & 384 \\
\hline K wt.\% & 1.5 & I & & Fe wt.\% & 6.22 & $\mathrm{Ta}$ & 1.7 \\
\hline $\mathrm{La}$ & 25.7 & $\mid$ & & $\mathrm{Ga}$ & 19 & $\mathrm{~Tb}$ & 1.18 \\
\hline $\mathrm{Li}$ & 20 & $\mid$ & & $\mathrm{Gd}$ & 6.14 & $\mathrm{Te}$ & 0.004 \\
\hline $\mathrm{Lu}^{3}$ & 0.3 & I & & $\mathrm{Ge}$ & 1.5 & Th & 8.1 \\
\hline Mg wt.\% & 0.46 & 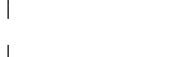 & & Hf & 2.8 & Ti wt.\% & 0.632 \\
\hline Mn wt.\% & 0.05 & $\mid$ & & $\mathrm{Hg}$ & 0.086 & $\mathrm{Tl}$ & 0.72 \\
\hline Mo & 0.78 & 1 & & Ho & 1.26 & $\mathrm{Tm}$ & 0.5 \\
\hline Na wt.\% & 0.69 & 1 & & In & 0.24 & $\mathrm{U}$ & 2.3 \\
\hline $\mathrm{Nb}$ & 8.6 & 1 & & Ir & 0.000002 & V & 136 \\
\hline $\mathrm{Nd}^{3}$ & 20.8 & 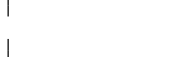 & & K wt.\% & 1.84 & W & 1.2 \\
\hline $\mathrm{Ni}$ & 13.8 & 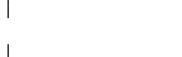 & & $\mathrm{La}$ & 34.6 & $Y$ & 31 \\
\hline P wt.\% & 0.055 & | & & $\mathrm{Li}$ & 18 & $\mathrm{Yb}$ & 3.1 \\
\hline $\mathrm{Pb}$ & 17.8 & $\mid$ & & $\mathrm{Lu}$ & 0.54 & $\mathrm{Zn}$ & 76 \\
\hline $\mathrm{Rb}$ & 65.8 & $\mid$ & & Mg wt.\% & 2.764 & $\mathrm{Zr}$ & 162 \\
\hline $\mathrm{Sb}$ & 0.57 & & & Mn wt.\% & 0.106 & & \\
\hline
\end{tabular}

${ }^{1}$ Sediment and soil abundance values from A-horizon median values of Smith and others (2013) unless otherwise noted.

${ }^{5}$ Shacklette and Boerngen (1984).

${ }^{2}$ Rock crustal abundance values from Fortescue (1992) Clarke Index unless otherwise noted.

${ }^{6}$ Taylor (1964).

${ }^{3}$ Salminen and others (2005) topsoil median.

${ }^{7}$ Gao and others (1998).

${ }^{4}$ Fortescue (1992) Clarke index. 
To map abundances in terms of classified ranges, the following scheme was used: background range was determined to be between $0.5 \times$ and $1.5 \times$ the abundance value; $2 \times$ background is the range from $1.5 \times$ to $2.5 \times$ abundance; $3 \times$ background is the range from $2.5 \times$ to $3.5 \times$ abundance, and so on. Classification ranges or multiples of background for each element were grouped in a pseudo-logarithmic scale of $<$ background, background, 2-3× background, $4-7 \times$ background, $8-15 \times$ background, and $>16 \times$ background. The thresholds (T1, T2, T3, and T4) between the upper four classification ranges were then assigned the values of $1.5 \times, 3.5 \times, 7.5 \times$, and $15.5 \times$ abundance, respectively. These thresholds are indicated by colored lines on histograms and boxplots (fig. C2).

\section{Determination of Threshold Values for Concentrates}

Many USGS mineral-resource assessment projects used concentrate samples that were derived from samples of stream sediment, soil, and less commonly, rock. These concentrates were processed by a variety of methods to concentrate the heavymineral fraction. These techniques commonly enhanced the concentration of selected minerals from 1,000 to more than 10,000 times their concentration in the original material and permitted the determination of elements in some samples that could not otherwise be detected.

Almost all concentrates were initially processed by panning the sample with a gold pan to remove clay, organic material, and the majority of lighter density minerals (primarily quartz and feldspar). A sample prepared to this point is known as a panned concentrate. Some of these panned concentrate samples were not processed further before geochemical analysis. Alternately, a panned concentrate might have had magnetite removed with a hand magnet before submittal. A larger proportion of panned concentrate samples were taken to the laboratory and processed by a heavy liquid, usually bromoform, which concentrated minerals with specific gravities of greater than about 2.8 . This was usually followed by an electromagnetic separation (Frantz Isodynamic Separator) to create three magnetic splits of the heavy-mineral sample - (1) strongly magnetic minerals ( $\mathrm{C} 1$ fraction), primarily magnetite and ilmenite; (2) weakly magnetic minerals (C2 fraction), including most of the iron and manganese oxides and ferromagnesian silicates; and (3) very weakly to nonmagnetic minerals ( $\mathrm{C} 3$ fraction), primarily consisting of zircon, apatite, and titanite but also including many ore-related oxide and sulfide minerals. The $\mathrm{C} 3$ fraction, commonly referred to as a nonmagnetic heavy-mineral concentrate, was commonly analyzed. The $\mathrm{C} 1$ and $\mathrm{C} 2$ fractions were occasionally analyzed.

Unfortunately, much of this concentrate processing information was not stored in the USGS geochemical databases. These older databases have now been combined into the NGDB, and a large, but still incomplete, effort has been made to distinguish various types of concentrates in the data. Therefore, the SaMiRA concentrate database contains a mixture of all of these types of concentrates. Thus, the data cannot be treated as a consistent sample medium but must be interpreted as a secondary source of information in areas that contain enhanced concentrations of elements of interest.

Unlike sediments, soils, or rocks, there are no relevant databases or crustal abundance estimates for concentrates that can be used to create classes of values by element. Using the SaMiRA concentrate data alone, we classified the data based on percentiles for the entire population (including values below lower detection limits) for each element. The chosen percentile classes for plotting concentrate data were as follows: not detected; $<25$ th percentile; $25-50$ th percentile; 50-75th percentile; 75-90th percentile; 90-97.5th percentile; and $>97.5$ th percentile. These seven classes allowed us to use the same colored dot symbols that we used for the Sediment/Soil and Rock geochemistry layers. Some highly censored elements, like Ag only had three classes - not detected, 90-97.5th percentile, and $>97.5$ th percentile. Four elements (As, $\mathrm{Au}, \mathrm{Cd}$, and $\mathrm{Sb}$ ) were so extremely censored that we had to modify these classes slightly to Not Detected, 97.5-99th percentile, and $>99$ th percentile. Two elements ( $\mathrm{Ti}$ and $\mathrm{Zr}$ ) had so many "greater than" values that we could not distinguish the upper end of the spectrum and had to make the last class as $>75$ th percentile.

\section{Interpolated Geochemistry Grids}

Before gridding, samples with elemental concentrations below the LLD were replaced with an arbitrary value of $1 / 2$ the lowest measured concentration. For some samples the LLDs were too high to be meaningful and those samples values were replaced with null values.

Geochemical data were gridded using an inverse distance weighted (IDW) algorithm and Geosoft Montaj ${ }^{\mathrm{TM}}$ software. The data were projected to the Albers equal-area conic with the datum of NAD 83 and a central meridian of $-114^{\circ}$ before gridding. The parameters used for IDW are (1) grid cell size: 1 $\mathrm{km}$; (2) weighting power: 2; (3) weighting slope: 1; (4) search radius: $4 \mathrm{~km}$; (5) blanking distance: $4 \mathrm{~km}$; (6) cells to extend beyond data: 0 ; (7) log option: linear; and (8) log minimum: 1. The grids were converted from Geosoft file (.grd) formats to Arc View Binary Grid (.flt) formats before being imported into an ArcGIS version 10.3.1 geodatabase. A typical sample would be located in the center of a $1-\mathrm{km}^{2}$ cell, and the gridding algorithm searched $4 \mathrm{~km}$ around this unit cell for neighboring samples (fig. C3). The value of neighboring samples influenced the values in the surrounding cells according to the distances from each unit cells. When more than one sample was located within a single cell, the algorithm took the average of the values for the unit cell value.

In ArcGIS, the grids were classified into six intervals based on elemental abundance concentrations of soils (tables $\mathrm{C} 3$ and $\mathrm{C} 4$ ). These intervals were ranked and colored in order of increasing concentration from blue to red. A buffer area extending $25 \mathrm{~km}$ outside of the study area was included to capture any trends that could exist near the PLSS boundaries. 


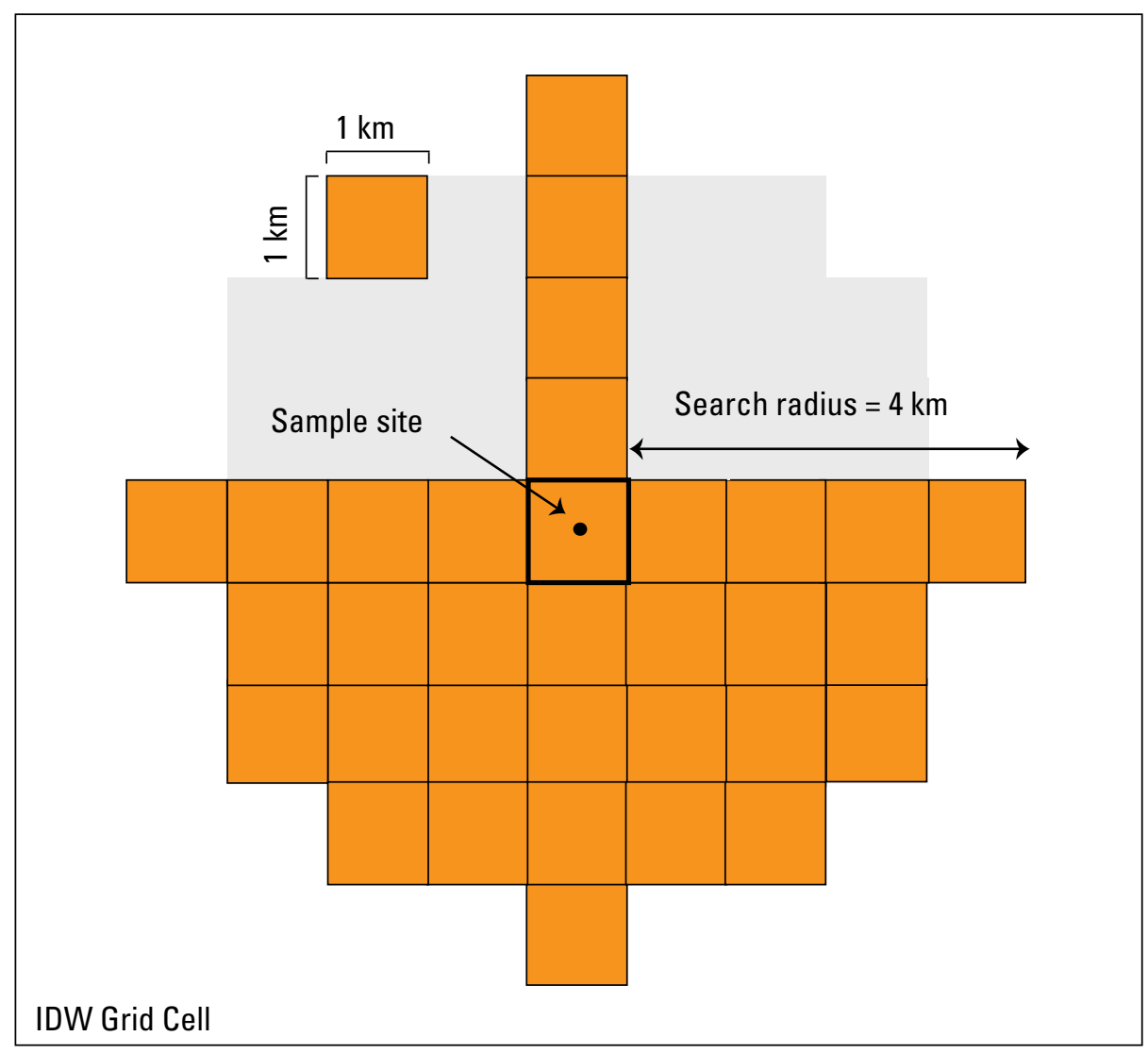

Figure C3. Diagram showing dimensions of inverse distance weighted (IDW) grid cell used for geochemical data in the Sagebrush Mineral-Resource Assessment (SaMiRA) project. km, kilometer.

The IDW grids, when combined with dot plots, yield a stable backdrop for comparing the different focal areas and for assessing areas that appear anomalous.

\section{Geographic Information Systems and Symbolized Layers}

To calculate spatially accurate sample locations and grids, all sample-site coordinates must be in a single geographic coordinate system. Sample sites with coordinates that were not already in the World Geodetic System of 1984 (WGS84) were selected by existing projection and exported into a working geographic information system (GIS) (Esri ArcGIS 10.3.1) as feature classes. The data in a particular projection were loaded into an ArcGIS map document with a WGS84 coordinate system and then had WGS84 coordinates calculated and appended to the data using the Xtools Pro for ArcGIS 11.1 extension. The new WGS84 coordinates were then extracted from the various sub-datasets and merged back into the Microsoft Access data tables. When all WGS84 coordinates were added, and the data collection, selection, and geochemistry preparation were complete, the data were assembled into final Access database tables for conversion into the project GIS.

After the geochemistry geodatabases were constructed and the feature classes, tables, and prediction grids were generated, the elements for each sample media type were classified (binned into ranges) and symbolized according to class divisions determined for each element. See previous discussions on determination of threshold values for details on class divisions.

\section{References Cited}

Adrian, B.M., Arbogast, B.F., Detra, D.E., and Mays, R.E., 1996, Direct-current arc emission spectrographic method for the semiquantitative analysis of geologic materials, in Arbogast, B.F., ed., Analytical methods manual for the Mineral Resource Surveys Program, U.S. Geological Survey: U.S. Geological Survey Open-File Report 96-525, p. 130-143, accessed March 15, 2016, at http://pubs.er.usgs. gov/publication/ofr96525. 
Aruscavage, P.J., 1996, Chloride by ion-selective electrode following $\mathrm{KMnO}_{4}-\mathrm{H}_{2} \mathrm{SO}_{4}$-HF dissolution, in Arbogast, B.F., ed., Analytical methods manual for the Mineral Resource Surveys Program, U.S. Geological Survey: U.S. Geological Survey Open-File Report 96-525, p. 191-194, accessed March 15, 2016, at http://pubs.er.usgs.gov/publication/ofr96525.

Aruscavage, P.J., and Crock, J.G., 1987, Atomic absorption methods, chapter $\mathrm{C}$ in Baedecker, P.A., ed., Methods for geochemical analysis: U.S. Geological Survey Bulletin 1770, p. C1-C6, accessed March 15, 2016, at http://pubs.er.usgs.gov/ publication/b1770.

Briggs, P.H., 2002, The determination of forty elements in geological and botanical samples by inductively coupled plasma-atomic emission spectrometry, in Taggart, J.E., Jr., ed., Analytical methods for chemical analysis of geologic and other materials, U.S. Geological Survey: U.S. Geological Survey Open-File Report 02-223-G, p. G1-G18, accessed March 15, 2016, at http://pubs.usgs.gov/of/2002/ofr-02-0223/ G01fortyelementICP-AESsolid_M.pdf.

Briggs, P.H., and Meier, A.L., 2002, The determination of fortytwo elements in geological materials by inductively coupled plasma-mass spectrometry, in Taggart, J.E., Jr., ed., Analytical methods for chemical analysis of geologic and other materials, U.S. Geological Survey: U.S. Geological Survey Open-File Report 02-223-I, p. I1-I14, accessed March 15, 2016, at http:// pubs.usgs.gov/of/2002/ofr-02-0223/I20NAWQAPlus_M.pdf.

Brown, F.M., Simon, F.O., and Greenland, L.P., 1975, Spectrophotometric-isotope dilution determination of arsenic in soils and rocks: U.S. Geological Survey Journal of Research, v. 3, no 2, p. 187-190, accessed March 15, 2016, at http://pubs. er.usgs.gov/publication/70007407.

Brown, Zoe Ann, and Curry, K.J., 2002a, Total carbon by combustion, in Taggart, J.E., Jr., ed., Analytical methods for chemical analysis of geologic and other materials, U.S. Geological Survey: U.S. Geological Survey Open-File Report 02-223-R, p. R1-R4, accessed March 15, 2016, at http://pubs. usgs.gov/of/2002/ofr-02-0223/R10TotalCarbon_M.pdf.

Brown, Zoe Ann, and Curry, K.J., 2002b, Total sulfur by combustion, in Taggart, J.E., Jr., ed., Analytical methods for chemical analysis of geologic and other materials, U.S. Geological Survey: U.S. Geological Survey Open-File Report 02-223-Q, p. Q1-Q4, accessed March 15, 2016, at http://pubs. usgs.gov/of/2002/ofr-02-0223/Q25TotS_M.pdf.

Brown, Zoe Ann, O’Leary, R.M., Hageman, P.L., and Crock, J.G., 2002, Mercury in water, geologic, and plant materials by continuous flow-cold vapor-atomic absorption spectrometry, in Taggart, J.E., Jr., ed., Analytical methods for chemical analysis of geologic and other materials, U.S. Geological Survey: U.S. Geological Survey Open-File Report 02-223-M, p. M1-M9, accessed March, 15, 2016, at http://pubs.usgs.gov/of/2002/ofr02-0223/M12HgCV_M.pdf.
Budahn, J.R., and Wandless, G.A., 2002a, Instrumental neutron activation by abbreviated count, in Taggart, J.E., Jr., ed., Analytical methods for chemical analysis of geologic and other materials, U.S. Geological Survey: U.S. Geological Survey OpenFile Report 02-223-Y, p. Y1-Y9, accessed March 15, 2016, at http://pubs.usgs.gov/of/2002/ofr-02-0223/Y15INAA-SHORT_M. pdf.

Budahn, J.R., and Wandless, G.A., 2002b, Instrumental neutron activation by long count, in Taggart, J.E., Jr., ed., Analytical methods for chemical analysis of geologic and other materials, U.S. Geological Survey: U.S. Geological Survey Open-File Report 02-223-X, p. X1-X13, accessed March 15, 2016, at http://pubs.usgs.gov/of/2002/ofr-02-0223/X14INAALong_M.pdf.

Doughten, M.W., and Aruscavage, P.J., 1996, Niobium, tungsten, and molybdenum by ion exchange/inductively coupled plasmaatomic emission spectrometry, in Arbogast, B.F., ed., Analytical methods manual for the Mineral Resource Surveys Program, U.S. Geological Survey: U.S. Geological Survey Open-File Report 96-525, p. 126-129, accessed March 15, 2016, at http://pubs. er.usgs.gov/publication/ofr96525.

Doughten, M.W., and Grossman, J.N., 1993, Method descriptions and bibliography of routine work performed by the Branch of Geochemistry analytical laboratories, U.S. Geological Survey: U.S. Geological Survey Open-File Report 93-1-B, 16 p., accessed March 15, 2016, at https://pubs.er.usgs.gov/publication/ ofr931B.

Fortescue, J.A.C., 1992, Landscape geochemistry; Retrospect and prospect-1990: Applied Geochemistry, v. 7, no. 1, p. 1-53.

Fries, T.L., Christie, J.H., and Pribble, S.T., 1996, Flame photometric determination of $\mathrm{K}_{2} \mathrm{O}$ and $\mathrm{Na}_{2} \mathrm{O}$, in Arbogast, B.F., ed., Analytical methods manual for the Mineral Resource Surveys Program, U.S. Geological Survey: U.S. Geological Survey Open-File Report 96-525, p. 144-148, accessed March 15, 2016, at http://pubs. er.usgs.gov/publication/ofr96525.

Gao, Shan, Luo, T.-C., Zhang, B.R., Zhang, H.F., Han, Y.W., Zhao, Z.D., and Hu, Y.K., 1998, Chemical composition of the continental crust as revealed by studies in East China: Geochimica et Cosmochimica Acta, v. 62, p. 1959-1975.

Golightly, D.W., Dorrzapf, A.F., Jr., Mays, R.E., Fries, T.L., and Conklin, N.M., 1987, Analysis of geologic materials by directcurrent arc emission spectrography and spectrometry, chapter A in Baedecker, P.A., ed., Methods for geochemical analysis: U.S. Geological Survey Bulletin 1770, p. A1-A13, accessed March 15, 2016, at http://pubs.er.usgs.gov/publication/b1770.

Granitto, Matthew, Schmidt, J.M., Shew, N.B., Gamble, B.M., and Labay, K.A., 2013, Alaska geochemical database, version 2.0 (AGDB2) - Including "best value" data compilations for rock, sediment, soil, mineral, and concentrate sample media: U.S. Geological Survey Data Series 759, 20 p., 1 DVD, accessed March 15, 2016, at http://pubs.usgs.gov/ds/759. 
Grimaldi, F.S., May, I., Fletcher, M.H., and Titcomb, Jane, 1954, Collected papers on methods of analysis for uranium and thorium: U.S. Geological Survey Bulletin 1006, 184 p., accessed March 15, 2016, at http://pubs.er.usgs.gov/ publication/b1006.

Grimes, J.G., 1984, NURE HSSR geochemical sample archives transfer report—Part 3, Geochemical Analysis: Oak Ridge, Tenn., Union Carbide Corporation, Nuclear Division, Oak Ridge Gaseous Diffusion Plant K/UR-500, Part 3, 154 p., accessed March 15, 2016, at http://pubs.usgs.gov/of/1997/ofr97-0492/pubs/kur-500.pdf.

Hageman, P.L., Brown, Zoe Ann, and Welsch, E.P., 2002, Arsenic and selenium by flow injection or continuous flowhydride generation-atomic absorption spectrophotometry, in Taggart, J.E., Jr., ed., Analytical methods for chemical analysis of geologic and other materials, U.S. Geological Survey: U.S. Geological Survey Open-File Report 02-223-L, p. L1-L7, accessed March 15, 2016, at http://pubs.usgs.gov/ of/2002/ofr-02-0223/L06AS24Se_M.pdf.

Hageman, P.L., and Welsch, E.P., 1996, Arsenic, antimony, and selenium by flow injection or continuous flow-hydride generation-atomic absorption spectrometry, in Arbogast, B.F., ed., Analytical methods manual for the Mineral Resource Surveys Program, U.S. Geological Survey: U.S. Geological Survey Open-File Report 96-525, p. 24-30, accessed March 15, 2016, at http://pubs.er.usgs.gov/publication/ofr96525.

Huffman, Claude, Jr., Rahill, R.L., Shaw, V.E., and Norton, D.R., 1972, Determination of mercury in geologic materials by flameless atomic absorption spectrometry, in Geological Survey research, 1972: U.S. Geological Survey Professional Paper 800-C, p. C203-C207, accessed March 15, 2016, at https://pubs.er.usgs.gov/publication/pp800C.

Jackson, L.L., Brown, F.W., and Neil, S.T., 1987, Major and minor elements requiring individual determination, classical whole rock analysis, and rapid rock analysis, chapter $\mathrm{G}$ in Baedecker, P.A., ed., Methods for geochemical analysis: U.S. Geological Survey Bulletin 1770, p. G1-G23, accessed March 15, 2016, at http://pubs.er.usgs.gov/publication/b1770.

Knight, R.J., and McKown, D.M., 2002, Uranium and thorium by delayed neutron counting, in Taggart, J.E., Jr., ed., Analytical methods for chemical analysis of geologic and other materials, U.S. Geological Survey: U.S. Geological Survey Open-File Report 02-223-Z, p. Z1-Z5, accessed March 15, 2016, at http://pubs.usgs.gov/of/2002/ofr-02-0223/ Z26UThDN_M.pdf.

Lichte, F.E., Golightly, D.W., and Lamothe, P.J., 1987, Inductively coupled plasma-atomic emission spectrometry, chapter B in Baedecker, P.A., ed., Methods for geochemical analysis: U.S. Geological Survey Bulletin 1770, p. B1B10, accessed March 15, 2016, at http://pubs.er.usgs.gov/ publication/b1770.
Meier, A.L., Carlson, R.R., Lichte, F.E., and Bullock, J.H., Jr., 1996, Platinum group elements by nickel sulfide fire assay separation and inductively coupled plasma-mass spectrometry, in Arbogast, B.F., ed., Analytical methods manual for the Mineral Resource Surveys Program, U.S. Geological Survey: U.S. Geological Survey Open-File Report 96-525, p. 158-165, accessed March 15, 2016, at http://pubs. er.usgs.gov/publication/ofr96525.

Meier, A.L., and Slowik, Tara, 2002, Rare earth elements by inductively coupled plasma-mass spectrometry, in Taggart, J.E., Jr., ed., Analytical methods for chemical analysis of geologic and other materials, U.S. Geological Survey: U.S. Geological Survey OpenFile Report 02-223-K, p. K1-K8, accessed March 15, 2016, at http://pubs.usgs.gov/of/2002/ofr-02-0223/ K19NewREE_M.pdf.

O’Leary, R.M., 1990, Determination of sulfur in geologic materials by iodometric titration, in Arbogast, B.F., ed., Quality assurance manual for the Branch of Geochemistry: U.S. Geological Survey Open-File Report 90-668, p. 136-138, accessed March 15, 2016, at http://pubs.er.usgs.gov/publication/ofr90668.

O'Leary, R.M., and Hopkins, D.M., 1990, Determination of fluoride in rock, soil, and stream-sediment samples by ion-selective electrode following $\mathrm{Na}_{2} \mathrm{CO}_{3}-\mathrm{K}_{2} \mathrm{CO}_{3}$ $\mathrm{KNO}_{3}$ fusion and dissolution with citric acid, in Arbogast, B.F., ed., Analytical methods manual for the Mineral Resource Surveys Program, U.S. Geological Survey: U.S. Geological Survey Open-File Report 96-525, p. 127-130, accessed March 15, 2016, at http://pubs.er.usgs.gov/publication/ofr90668.

O’Leary, R.M., and Meier, A.L., 1986, Analytical methods used in geochemical exploration, 1984: U.S. Geological Survey Circular 948, p. 42-45, accessed March 15, 2016, at http://pubs.er.usgs.gov/publication/ cir948.

O’Leary, R.M., and Meier, A.L., 1996, Gold by flame or graphite furnace atomic absorption spectrometry, in Arbogast, B.F., ed., Analytical methods manual for the Mineral Resource Surveys Program, U.S. Geological Survey: U.S. Geological Survey Open-File Report 96-525, p. 31-36, accessed March 15, 2016, at http:// pubs.er.usgs.gov/publication/ofr90668.

Pribble, S.T., 1996, Fluoride in silicates by ionselective electrode following $\mathrm{LiBO}_{2}$ fusion and $\mathrm{HNO}_{3}$ dissolution, in Arbogast, B.F., ed., Analytical methods manual for the Mineral Resource Surveys Program, U.S. Geological Survey: U.S. Geological Survey OpenFile Report 96-525, p. 195-199, accessed March 15, 2016, at http://pubs.er.usgs.gov/publication/ofr90668. 
Salminen, R. (chief-editor), Batista, M.J., Bidovec, M., Demetriades, A., De Vivo, B., De Vos, W., Duris, M., Gilucis, A., Gregorauskiene, V., Halamic, J., Heitzmann, P., Lima, A., Jordan, G., Klaver, G., Klein, P., Lis, J., Locutura, J., Marsina, K., Mazreku, A., O'Connor, P.J., Olsson, S.Å., Ottesen, R.T., Petersell, V., Plant, J.A., Reeder, S., Salpeteur, I., Sandström, H., Siewers, U., Steenfelt, A., Tarvainen, T., 2005, Geochemical atlas of Europe-Part 1, Background information, methodology and maps: Espoo, Geological Survey of Finland, 526 p.

San Juan, C.A., Horton, J.D., Parks, H.L., Mihalasky, M.J., Anderson, E.D., Benson, M.E., Box, S.E., Cossette, P.M., Denning, P.D., Giles, S.A., Hall, S.M., Hayes, T.S., Hearn, B.C., Jr., Hofstra, A.H., John, D.A., Ludington, S., Lund, K., Mauk, J.L., Robinson, G.R., Jr., Rockwell, B.W., Rytuba, J.J., Smith, S.M., Stillings, L.L., Van Gosen, B.S., Vikre, P.G., Wallis, J.C., Wilson, A.B., Zientek, M.L., and Zürcher, L., 2016, Locatable mineral assessment tracts for the U.S. Geological Survey Sagebrush Mineral-Resource Assessment project: U.S. Geological Survey data release, http://dx.doi.org/10.5066/F7833Q4R.

Shacklette, H.T., and Boerngen, J.G., 1984, Element concentrations in soils and other surficial materials of the conterminous United States: U.S. Geological Survey Professional Paper 1270, 105 p, accessed March 15, 2016, at https://pubs.er.usgs.gov/publication/ pp1270.

Shapiro, Leonard, 1975, Rapid analysis of silicate, carbonate, and phosphate rocks - Revised edition: U.S. Geological Survey Bulletin 1401, 76 p., accessed March 15, 2016, at http://pubs. er.usgs.gov/publication/b1401.

Siems, D.F., 2002, The determination of 30 elements in geological materials by energy-dispersive X-ray fluorescence spectrometry, in Taggart, J.E., Jr., ed., Analytical methods for chemical analysis of geologic and other materials, U.S. Geological Survey: U.S. Geological Survey Open-File Report 02-223-U, p. U1-U11, accessed March 15, 2016, at http://pubs.usgs.gov/of/2002/ofr-020223/U27edsfinal_U.pdf.

Skeen, C.J., and Crandell, W.B., 1989, Computerized spectrographic data for two new USGS rocks, AMH-1 and DTS-2: U.S. Geological Survey Open-File Report 89-183, 15 p., accessed March 15, 2016, at http://pubs.er.usgs.gov/publication/ofr89183.

Smith, D.B., Cannon, W.F., Woodruff, L.G., Solano, Federico, Kilburn, J.E., and Fey, D.L., 2013, Geochemical and mineralogical data for soils of the conterminous United States: U.S. Geological Survey Data Series 801, 19 p., accessed March 15, 2016, at http://pubs.usgs.gov/ds/801.

Smith, S.M., 1997, National Geochemical DatabaseReformatted data from the National Uranium Resource Evaluation (NURE) Hydrogeochemical and Stream Sediment Reconnaissance (HSSR) Program, version 1.40 (2006): U.S. Geological Survey Open-File Report 97-492, accessed March 15, 2016, at http://pubs.usgs.gov/of/1997/ofr-97-0492/ index.html.
Smith, S.M., Neilson, R.T., and Giles, S.A., 2015, Leveling and merging of two discrete national-scale geochemical databases-A case study showing the surficial expression of metalliferous black shales: 27th International Applied Geochemistry Symposium Abstracts, April 20-24, 2015, Tucson, Arizona.

Taggart, J.E., Jr., and Siems, D.F., 2002, Major element analysis by wavelength dispersive $\mathrm{X}$-ray fluorescence spectrometry, in Taggart, J.E., Jr., ed., Analytical methods for chemical analysis of geologic and other materials, U.S. Geological Survey: U.S. Geological Survey Open-File Report 02-223-T, p. T1-T9, accessed March 15, 2016, at http://pubs.usgs.gov/of/2002/ofr-020223/T16WDXRF_M.pdf.

Taylor, S.R., 1964, The abundance of chemical elements in the continental crust-A new table: Geochimica et Cosmochimica Acta, v. 28, no. 8, p. 1273-1285.

U.S. Geological Survey, 2004, The National Geochemical Survey; database and documentation, version 5.0 (2008): U.S. Geological Survey Open-File Report 2004-001, accessed March 15, 2016, at http://mrdata.usgs.gov/geochem/doc/home.htm.

U.S. Geological Survey, 2016a, National Geochemical DatabaseConcentrate: U.S. Geological Survey Web site, accessed July 14, 2016, at http://mrdata.usgs.gov/ngdb/concentrate.

U.S. Geological Survey, 2016b, National Geochemical DatabaseRock: U.S. Geological Survey Web site, accessed July 14, 2016, at http://mrdata.usgs.gov/ngdb/rock.

U.S. Geological Survey, 2016c, National Geochemical DatabaseSediment: U.S. Geological Survey Web site, accessed July 14, 2016, at http://mrdata.usgs.gov/ngdb/sediment.

U.S. Geological Survey, 2016d, National Geochemical DatabaseSoil: U.S. Geological Survey Web site, accessed July 14, 2016, at http://mrdata.usgs.gov/ngdb/soil.

Wandless, G.A., 1987, Radiochemical neutron activation analysis of geologic materials, in Baedecker, P.A., ed., Methods for geochemical analysis: U.S. Geological Survey Bulletin 1770, p. J1-J8, accessed March 15, 2016, at http://pubs.er.usgs.gov/ publication/b1770.

Ward, F.N., Nakagawa, H.N., Harms, T.F., and VanSickle, G.H., 1969, Atomic-absorption methods of analysis useful in geochemical exploration: U.S. Geological Survey Bulletin 1289, p. 41-42, accessed March 15, 2016, at http://pubs.er.usgs.gov/ publication/b1289.

Wilson, S.A., Kane, J.S., Crock, J.G., and Hatfield, D.B., 1987, Chemical methods of separation for optical emission, atomic absorption spectrometry, and colorimetry, in Baedecker, P.A., ed., Methods for geochemical analysis: U.S. Geological Survey Bulletin 1770, p. D1-D14, accessed March 15, 2016, at http:// pubs.er.usgs.gov/publication/b1770. 



\title{
Section D. Geophysical Data and Methods Used in Mineral- Resource Assessments within the Sagebrush Focal Areas
}

\author{
By Eric D. Anderson and David A. Ponce
}

\section{Introduction}

Geophysical investigations help assess the mineralresource potential of the Sagebrush Focal Areas (SFAs) in parts of Idaho, Montana, Nevada, Oregon, Utah, and Wyoming. Magnetic, gravimetric, and radiometric methods help map variation in the physical and geochemical properties of rocks both at and near the Earth's surface. Thus, publically available datasets have been described, processed, and interpreted to help provide a better understanding of the mineral-resource potential of the SFAs. Magnetic and gravity data transforms, including reduction-to-the-pole, total horizontal gradient, first vertical derivative, tilt derivative, and analytic signal were applied to facilitate interpretation. Similarly, radiometric data were ratioed to help further discriminate the radiogenic variations/ compositions of surface material.

Magnetic data sources include existing compilations, both at the national- and State-scale, as well as individual survey datasets. The data provide information on the lateral distribution of magnetic material within the Earth's crust, and in all SFAs these data were most effective for mapping plutonic rocks that could be associated with mineral systems. Magnetic data were also used to provide depth estimates to magnetic sources and showed that in Montana magnetic sources are likely too deep to be of interest for mineral extraction.

Gravity data from national-scale compilations are relatively coarse over the SFAs, thereby making them less useful for mapping lateral changes in rock types. These data are more effective for understanding basin thickness within the Basin and Range Province. Gravity inversions provide an estimate of the thickness of low-density basin fill, thereby helping to map depth to bedrock that could host mineral resources beneath basin fill.

Radiometric data provide information on the distribution of potassium, thorium, and uranium at the Earth's surface. Changes in the relative abundances of these elements can reflect rock types or hydrothermal alteration that could be associated with mineral deposits. In the SFAs, the radiometric data complemented geologic maps and helped differentiate subtle changes in rock compositions. Geophysical investigations of the Sagebrush Mineral-Resource Assessment (SaMiRA) focal areas are part of an interagency effort by the U.S. Geological Survey (USGS) and Bureau of Land
Management (BLM) to help characterize the mineral resources of parts of Idaho, Montana, Nevada, Oregon, Utah, and Wyoming. The seven Sagebrush Focal Areas (SFAs) are Bear River Watershed, North-Central Idaho, North-Central Montana, Southeastern Oregon and North-Central Nevada, Sheldon-Hart Mountain National Wildlife Refuge Complex, Southern Idaho and Northern Nevada, and Southwestern and South-Central Wyoming. For the purpose of geophysical data interpretation, the seven SFAs have been grouped into four areas based on proximity to each other. The areas and contained SFAs include (1) Area A: Sheldon-Hart Mountain National Wildlife Refuge Complex, Southeastern Oregon and North-Central Nevada, and Southern Idaho and Northern Nevada; (2) Area B: North-Central Idaho; (3) Area C: Bear River Watershed and Southwestern and South-Central Wyoming; and (4) Area D: North-Central Montana. This report section describes the geophysical methods, datasets, and analyses used to aid in the mineral-resource assessment of the SFAs.

Geophysical methods map geologic materials that have differing physical and (or) geochemical properties. In this study, the geophysical methods used magnetic, gravity, and radiometric data, which reflect variations in magnetization, density, and radioactivity, respectively. The geophysical methods are most effective where the rock properties vary considerably. Physical property variation can occur along and across geologic structures, across rock type contacts, or within a mineral deposit. For example, (1) structures that juxtapose differing rock types can show changes in physical properties; (2) structures can provide pathways for reactive hydrothermal fluids that can alter the physical properties of rocks; (3) the distribution of igneous rocks, both intrusive and extrusive, can lead to abrupt physical property changes; (4) sedimentary-rock layers within basins can have differing physical properties as a function of lithology; (5) the physical properties of a sedimentary-rock cover as a whole can differ from the underlying basement; (6) metamorphic rocks can have different physical properties; (7) hydrothermal fluids within, and surrounding, a mineral deposit can alter the host rock physical properties; and (8) mineral deposits themselves can have physical properties that contrast with the surrounding host rocks. Geophysical methods take advantage of these changes in the rock properties and can help identify the structures, host rocks, and hydrothermal systems that may be associated with ore deposit formation. 
Qualitative interpretation of magnetic and gravity anomalies helps produce a geology map based on anomaly patterns. The resultant maps can assist with identifying nearsurface favorable lithology or structures that host mineral deposits. Digital enhancements of these data can further facilitate interpretations. Enhancements include mathematical filters, or transforms, which can highlight areas of contrasting physical properties at both shallow and deep crustal levels. A gradient, or derivative, filter is commonly employed to emphasize changes in the dataset that may represent a geologic contact between bodies of contrasting physical properties. Filters can highlight anomalies of certain frequencies, or wavelengths, within the data that may represent a particular lithology or source depth. High-pass filters enhance the higher frequency, or short-wavelength, component of the dataset that generally corresponds to shallow sources. In contrast, a low-pass filter will highlight the lower frequency, or longwavelength, component of the dataset that may correspond to deeper sources.

Quantitative interpretation of magnetic and gravity anomalies, such as forward and inverse mathematical models, seeks to better understand the distribution of physical properties at depth. Depth to magnetic and gravity sources can be estimated to help develop a three-dimensional framework for subsurface geology. Such interpretations help to assess for mineral resources that are under cover.

\section{Geophysical Methods}

\section{Magnetic and Gravity}

Magnetic and gravity methods, commonly referred to as potential-field methods, have been used for geologic mapping and mineral-resource assessments (Grant, 1985; Hinze, 1985; Blakely, 1995; Clark, 1997; 1999; Nabighian and others, 2005a, b). They can provide a nearly continuous set of observations over large areas. Magnetic and gravity data are collected and processed in such a way that they reflect lateral changes in subsurface magnetization and density, respectively. Because the known spectrum of rock types can have several orders of magnitude variation in magnetic properties and can vary in density by about a factor of two, magnetic and gravity data provide powerful subsurface mapping tools. Gravity data are typically more difficult to process because effects not related to geology have to be removed. Such effects include the tidal attraction of the Moon and Sun, instrument drift, changes in gravity with elevation, changes in gravity with latitude, the Earth's curvature, and the surrounding topographic terrain. Magnetic data are simply corrected for diurnal variations in the Earth's magnetic field, magnetic effects of the aircraft (if applicable), and a regional geomagnetic model of the Earth.

Magnetic data provide information on the distribution of magnetic minerals, mainly magnetite, within the crust. These data can be used to map areas of magnetite variability within a hydrothermal system or more commonly to map magnetic patterns and trends that may reflect differing rock types and structures proximal to mineral deposits. Magnetic anomalies are caused by two different kinds of magnetism - induced and remanent. The induced component is mostly determined by magnetic susceptibility of the rock and is proportional to the magnetic field in which it is measured. The remanent component depends on the thermal, mechanical, and magnetic history of the rock and is independent of the field in which it is measured. In general, but not exclusively, the induced component is predominant, especially for Cenozoic volcanic rocks. Magnetic anomalies measured on rocks that carry significant remanent magnetization not aligned with the inducing field can be difficult to interpret.

Gravity data provide information on variations in subsurface rock density. In general, igneous and metamorphic rocks have higher densities than sedimentary rocks. For igneous rocks, increasing density tends to be negatively correlated with silica content. Thus, felsic rocks have low densities, intermediate rocks have moderate densities, and mafic and ultramafic rocks have highest densities. For sedimentary rocks, evaporites generally have low densities, siliciclastics have moderate densities, carbonates have high densities, and iron formations tend to be most dense. Gravity anomalies are centered over the source body and, similar to magnetic anomalies, will broaden with increasing distance from the source body.

\section{Radiometric}

The radiometric method measures gamma radiation intensities from the radioactive decay of potassium $(\mathrm{K})$, thorium (Th), and uranium (U) within the upper few centimeters of the Earth's surface (Dickson and Scott, 1997). Intensities can then be converted into elemental concentrations. These elements are the three most abundant radioactive elements present in various proportions in all rocks and soils. A measured intensity value from airborne data is an average element concentration over a surface area, the areal extent of which is determined by the altitude of the aircraft. Radiometric data are calibrated and corrected for instrument spikes, cosmic background, and height-related scattering. Airborne radiometric data are interpreted in terms of surface chemistry and presented as individual element maps or the ratio of two elements that aid the recognition of lithologic units. Linear features within the data may indicate 
the presence of faults, or structures, which can be favorable for mineral-deposit types. In general, felsic igneous rocks have higher radioelement concentrations than mafic rocks; whereas the radioelement concentration in sedimentary rocks reflects the parent source rocks (Dickson and Scott, 1997).

\section{Geophysical Data}

The magnetic, gravity, and radiometric data assembled for the mineral-resource assessments within the SFAs are derived from publically available databases. For each compiled dataset, several basic data-processing steps were conducted. Each dataset was projected into a common map projection (Albers equal-area conic with central meridian of $-114.0^{\circ}$ longitude). The final processed datasets were subset to remove all data outside of regions that encompass a 25-kilometer $(\mathrm{km})$ buffer surrounding the SFAs.

The U.S. Department of Energy as part of the National Uranium Resource Evaluation (NURE) program systematically collected airborne radiometric and magnetic data across the United States. The primary goal for the program was to identify uranium resources, and thus the airborne surveys were optimized for radiometric data collection. The airborne NURE datasets provide the most comprehensive radiometric and magnetic data coverage over the SFAs (Duval, 1999; Hill and others, 2009) and are the framework for the magnetic and radiometric compilations described below.

\section{Aeromagnetic Data}

Aeromagnetic data available as individual surveys and existing compilations were used to help understand the geologic setting and associated mineral deposits within the SFAs. The existing compilation that covers the United States, Canada, and Mexico has relatively low resolution of 1,000-meter (m) grid cells (Bankey and others, 2002), whereas the individual State compilations have higher resolution of 500-m grid cells (for example, Montana: McCafferty and others, 1998; Nevada: Kucks and others, 2006; Oregon: Roberts and others, 2008; and Wyoming: Kucks and Hill, 2000). The individual aeromagnetic survey datasets, available from the USGS Mineral Resources On-Line Spatial Data Web site (http://mrdata.usgs.gov/), exist in two forms - (1) digital, where original flight-line data are digitally preserved or (2) digitized, where analog contour maps have been digitized (no flight-line data are available). The individual surveys were designed for many purposes; as such their coverage varies considerably in both areal extent and anomaly resolution (fig. D1). In the focal areas, the flight-line spacing ranges from less than about $800 \mathrm{~m}$ to about $8,000 \mathrm{~m}$. The flight-line height ranges from about $120 \mathrm{~m}$ above ground to $3,960 \mathrm{~m}$ barometric elevation. Thus, most of the focal areas have low spatial and anomaly resolution. Because of low resolution, shallow magnetic sources of limited areal extent may not be well resolved in some parts of the aeromagnetic maps. Thus, these datasets are not adequate to map individual mineral deposits that have limited areal extent; instead these data are more useful for imaging the regional geologic framework within which the mineral resources occur.

The national-scale magnetic compilation data covering the study area were obtained from the magnetic anomaly map of North America (Bankey and others, 2002). In this compilation, all survey data were reduced using industry standard techniques (Luyendyk, 1997). The data were corrected for the Earth's magnetic field and diurnal variations, upward or downward continued to a common datum of $305 \mathrm{~m}$ above the topography, and merged to produce a uniform anomaly map with grid spacing of $1,000 \mathrm{~m}$. The resultant total magnetic intensity anomaly data (fig. D2) were the initial dataset from which subsequent data transforms, described below, were derived (table D1).

In addition, the individual surveys that encompass the focal areas were used to generate relatively high-resolution compilations with grid cell spacing of $500 \mathrm{~m}$ for the SFAs. The surveys within and surrounding the SFAs were assessed for quality, and the best available datasets were used to generate new, higher resolution compilations (table D2). The survey specifications varied considerably with flight-line spacing between 800 and $8,000 \mathrm{~m}$ and a range in flight-line altitude from $120 \mathrm{~m}$ above ground to $3,960 \mathrm{~m}$ barometric elevation. The NURE data were collected at low altitudes along relatively widely spaced flight lines. Such a survey geometry can cause problems when gridding flight-line data over magnetic sources. Artifacts can be introduced into the data in the form of lineations perpendicular to flight lines. To reduce these artifacts, the NURE flight-line data were continued to $305 \mathrm{~m}$ height before gridding. Where necessary, data gaps between individual surveys were filled using the existing State compilations (table D3). All survey data were corrected for the Earth's magnetic field and diurnal variations, upward or downward continued to a constant elevation of $305 \mathrm{~m}$ above the ground, gridded using a minimum curvature algorithm, and merged to produce a uniform map with a grid spacing of $500 \mathrm{~m}$. These data have a grid resolution four times higher than that of the national scale. The new compilations, although initially composed of surveys acquired with different specifications, allow seamless interpretation of magnetic anomalies across survey boundaries within the SFAs and provide the initial dataset from which subsequent data transforms described below were derived (table D1). 


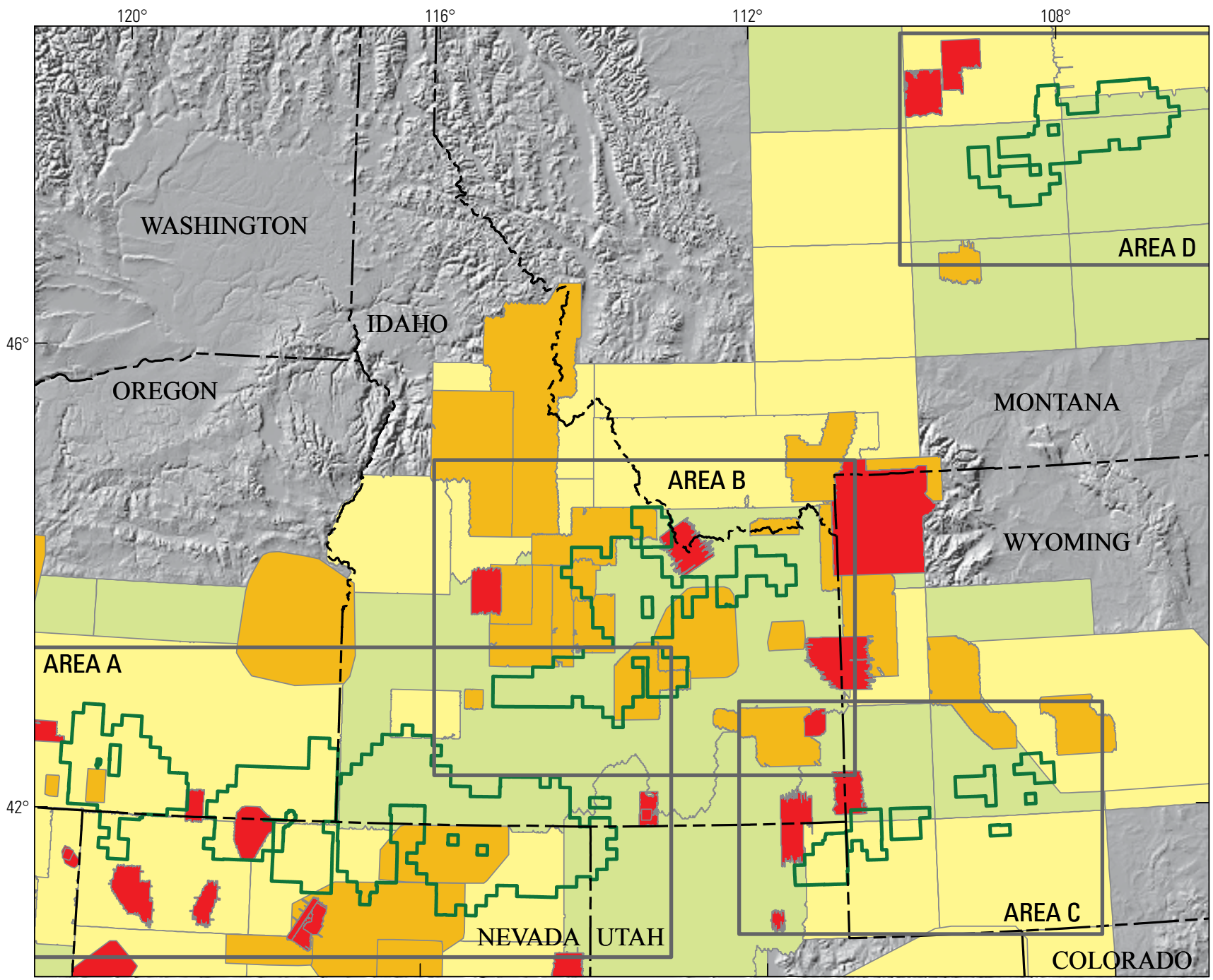

Base modified from U.S. Geological Survey DEM data, 2016 Roads and political data copyright (C) 2014 Esri and its licensors. Boundary data from San Juan and others (2016).

USA Contiguous Albers Equal Area Conic Projection. Central meridian, $114^{\circ} \mathrm{W}$., latitude of origin, $37.5^{\circ} \mathrm{N}$.

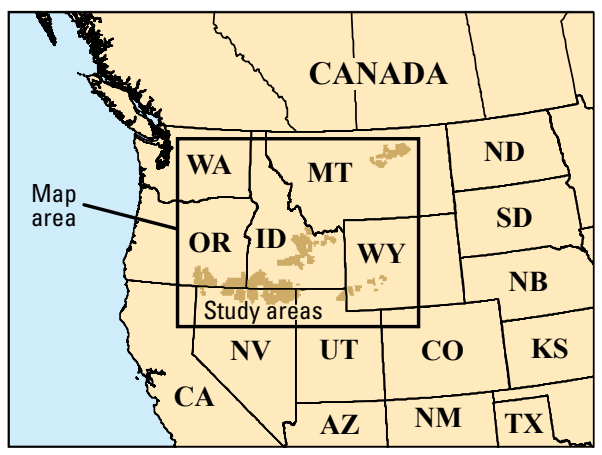

\section{EXPLANATION}

Flight-line spacing (meters)

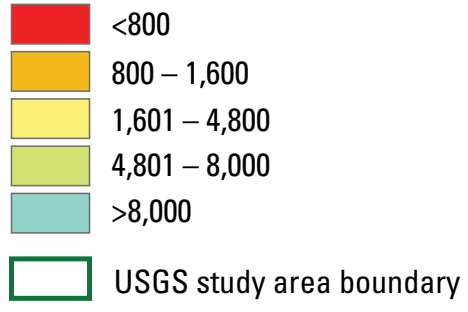

Figure D1. Map showing airborne magnetic surveys that intersect a rectangular region encompassing a 25-kilometer buffer surrounding Sagebrush Focal Areas (SFAs), Western United States. Data available through the U.S. Geological Survey (USGS) Mineral Resource Program on-line spatial data Web site (http://mrdata.usgs.gov/). 


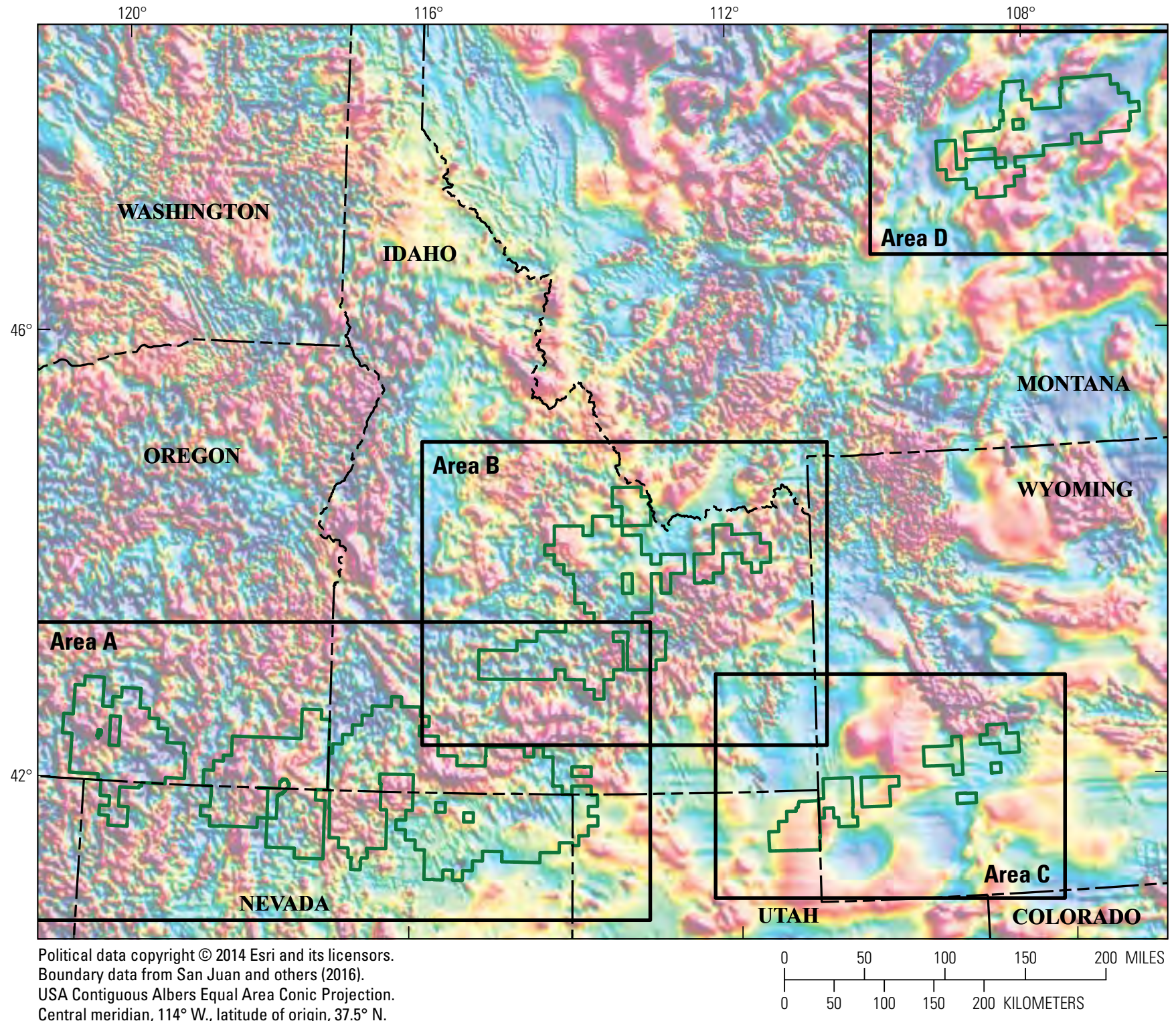

Central meridian $114^{\circ} \mathrm{W}$, latitude of origin, $375^{\circ} \mathrm{N}$

\section{EXPLANATION}

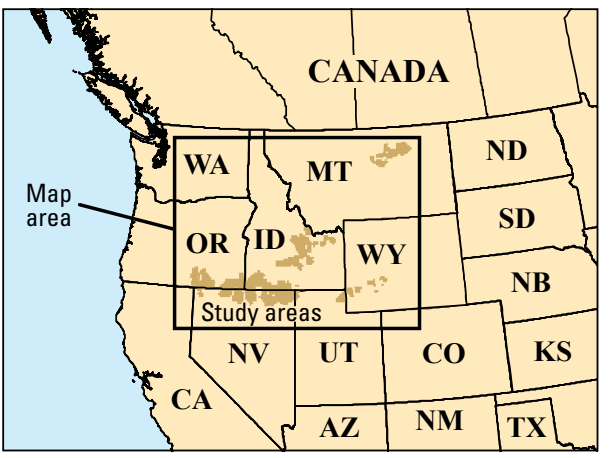

USGS study area boundary

\begin{tabular}{llllll}
-300 & -100 & -50 & 0 & 100 & 450 \\
\hline
\end{tabular}

Total Magnetic Intensity (nT)

Figure D2. Map showing total magnetic intensity (TMI) in the Western United States (Bankey and others, 2002). These data were subset to the four rectangular regions (black boxes) surrounding Sagebrush Focal Areas (SFAs; see section A, fig. A1) and provided the basis for subsequent data transforms (table D1). USGS, U.S. Geological Survey. nT, nanotesla. 
Table D1. List of filtered or transformed geophysical datasets generated for the Sagebrush Focal Areas (SFAs; see section A, fig. A1) as part of the Sagebrush Mineral-Resource Assessment (SaMiRA) project.

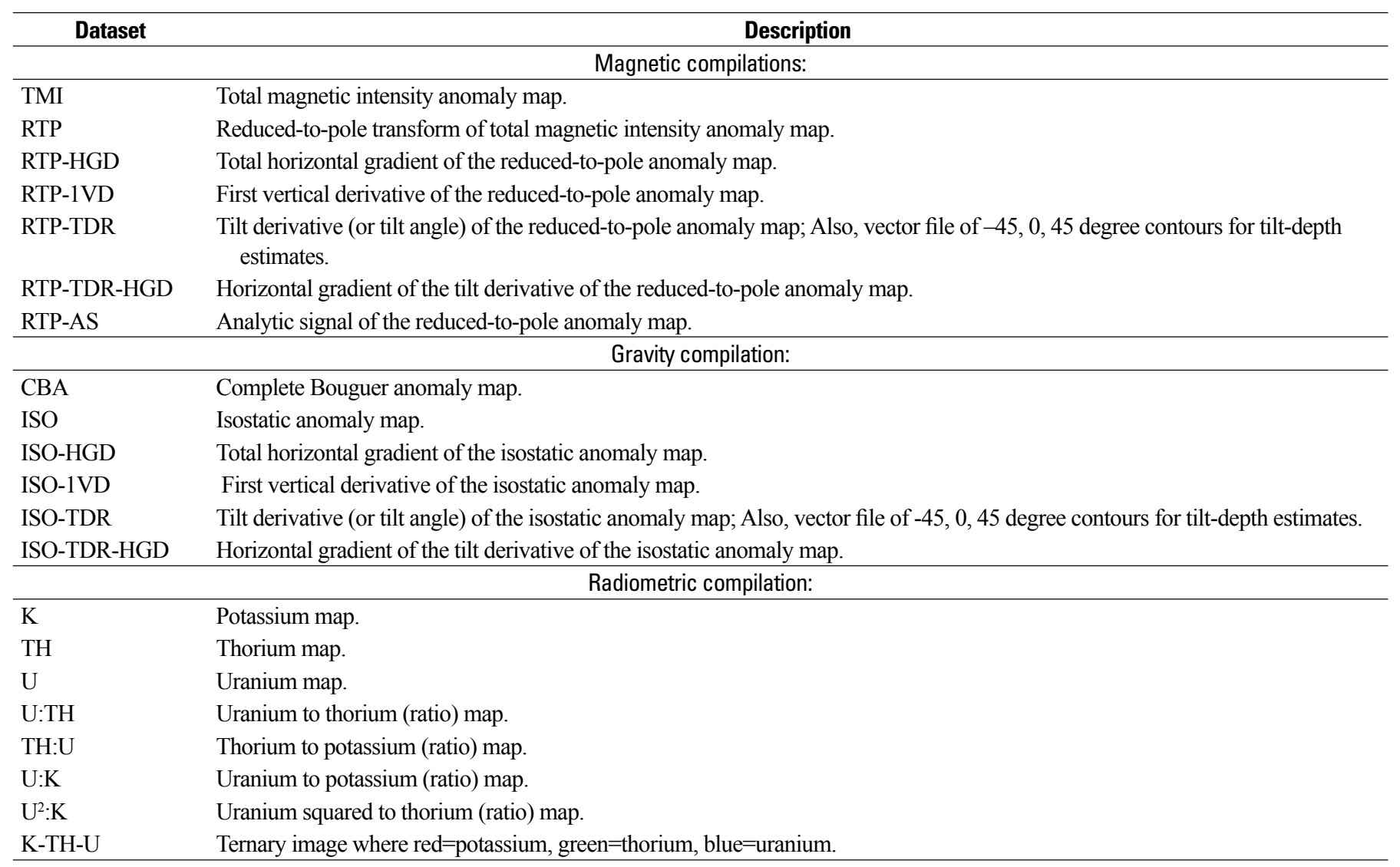

Table D2. Aeromagnetic surveys used to generate new, higher resolution compilations for the Sagebrush Focal Areas (SFAs) as part of the Sagebrush Mineral-Resource Assessment (SaMiRA) project.

[NURE, National Uranium Resource Evaluation; Focal areas: A, Sheldon-Hart Mountain National Wildlife Refuge Complex, Southeastern Oregon and North-Central Nevada, and Southern Idaho and Northern Nevada; B, North-Central Idaho; and C, Bear River Watershed and Southwestern and South-Central Wyoming]

\begin{tabular}{|c|c|c|c|c|c|c|}
\hline Survey name & Type & $\begin{array}{c}\text { Focal } \\
\text { area(s) }\end{array}$ & $\begin{array}{l}\text { Year } \\
\text { flown }\end{array}$ & $\begin{array}{l}\text { Line spacing } \\
\text { (m) }\end{array}$ & $\begin{array}{c}\text { Survey } \\
\text { height }(\mathrm{m})\end{array}$ & URL \\
\hline Modoc North-central & Digitized & A & 1957 & 3,200 & $2,100^{1}$ & $\begin{array}{l}\text { http://mrdata.usgs.gov/magnetic/show- } \\
\text { survey.php?id=CA03c }\end{array}$ \\
\hline Modoc South-central & Digitized & A & 1957 & 3,200 & $2,450^{1}$ & $\begin{array}{l}\text { http://mrdata.usgs.gov/magnetic/show- } \\
\text { survey.php?id=CA03d }\end{array}$ \\
\hline Modoc East & Digitized & A & 1957 & 3,200 & $2,900^{1}$ & $\begin{array}{l}\text { http://mrdata.usgs.gov/magnetic/show- } \\
\text { survey.php?id=CA03e }\end{array}$ \\
\hline Idaho Regional '69 & Digitized & A, B & 1969 & 8,000 & $3,650^{1}$ & $\begin{array}{l}\text { http://mrdata.usgs.gov/magnetic/show- } \\
\text { survey.php?id=0667 }\end{array}$ \\
\hline Susanville & NURE & A & 1965 & 8,000 & 120 & $\begin{array}{l}\text { http://mrdata.usgs.gov/magnetic/show- } \\
\text { survey.php?id=NURE-295 }\end{array}$ \\
\hline Boise & NURE & A & 1976 & 4,800 & 120 & $\begin{array}{l}\text { http://mrdata.usgs.gov/magnetic/show- } \\
\text { survey.php?id=NURE-227 }\end{array}$ \\
\hline
\end{tabular}


Table D2. Aeromagnetic surveys used to generate new, higher resolution compilations for the Sagebrush Focal Areas (SFAs) as part of the Sagebrush Mineral-Resource Assessment (SaMiRA) project.-Continued

\begin{tabular}{|c|c|c|c|c|c|c|}
\hline Survey name & Type & $\begin{array}{l}\text { Focal } \\
\text { area(s) }\end{array}$ & $\begin{array}{l}\text { Year } \\
\text { flown }\end{array}$ & $\begin{array}{l}\text { Line spacing } \\
\text { (m) }\end{array}$ & $\begin{array}{c}\text { Survey } \\
\text { height }(\mathrm{m})\end{array}$ & URL \\
\hline Brigham City & NURE & A, C & 1962 & 8,000 & 120 & $\begin{array}{l}\text { http://mrdata.usgs.gov/magnetic/show- } \\
\text { survey.php?id=NURE-270 }\end{array}$ \\
\hline Toole & NURE & A & 1970 & 8,000 & 120 & $\begin{array}{l}\text { http://mrdata.usgs.gov/magnetic/show- } \\
\text { survey.php?id=NURE-296 }\end{array}$ \\
\hline Challis & NURE & B & 1963 & 4,800 & 120 & $\begin{array}{l}\text { http://mrdata.usgs.gov/magnetic/show- } \\
\text { survey.php?id=NURE-210 }\end{array}$ \\
\hline Elk City & NURE & B & 1982 & 4,800 & 120 & $\begin{array}{l}\text { http://mrdata.usgs.gov/magnetic/show- } \\
\text { survey.php?id=NURE-186 }\end{array}$ \\
\hline Dubois & NURE & B & 1976 & 4,800 & 120 & $\begin{array}{l}\text { http://mrdata.usgs.gov/magnetic/show- } \\
\text { survey.php?id=NURE-194 }\end{array}$ \\
\hline Dillon & NURE & B & 1962 & 4,800 & 120 & $\begin{array}{l}\text { http://mrdata.usgs.gov/magnetic/show- } \\
\text { survey.php?id=NURE-171 }\end{array}$ \\
\hline Ashton & NURE & B & 1972 & 8,000 & 120 & $\begin{array}{l}\text { http://mrdata.usgs.gov/magnetic/show- } \\
\text { survey.php?id=NURE-207 }\end{array}$ \\
\hline Bozeman & NURE & B & 1972 & 4,800 & 120 & $\begin{array}{l}\text { http://mrdata.usgs.gov/magnetic/show- } \\
\text { survey.php?id=NURE-178 }\end{array}$ \\
\hline Driggs & NURE & B & 1972 & 4,800 & 120 & $\begin{array}{l}\text { http://mrdata.usgs.gov/magnetic/show- } \\
\text { survey.php?id=NURE-229 }\end{array}$ \\
\hline Preston & NURE & $\mathrm{B}, \mathrm{C}$ & 1978 & 8,000 & 120 & $\begin{array}{l}\text { http://mrdata.usgs.gov/magnetic/show- } \\
\text { survey.php?id=NURE- } 252\end{array}$ \\
\hline Pocatello & NURE & $\mathrm{C}$ & 1976 & 8,000 & 120 & $\begin{array}{l}\text { http://mrdata.usgs.gov/magnetic/show- } \\
\text { survey.php?id=NURE-243 }\end{array}$ \\
\hline Ogden & NURE & $\mathrm{C}$ & 1978 & 4,800 & 120 & $\begin{array}{l}\text { http://mrdata.usgs.gov/magnetic/show- } \\
\text { survey.php?id=NURE-283 }\end{array}$ \\
\hline Rock Springs & NURE & $\mathrm{C}$ & 1962 & 4,800 & 120 & $\begin{array}{l}\text { http://mrdata.usgs.gov/magnetic/show- } \\
\text { survey.php?id=NURE-287 }\end{array}$ \\
\hline Lander & NURE & C & 1978 & 8,000 & 120 & $\begin{array}{l}\text { http://mrdata.usgs.gov/magnetic/show- } \\
\text { survey.php?id=NURE-260 }\end{array}$ \\
\hline Wind River & Digitized & $\mathrm{C}$ & 1969 & 1,600 & $3,950^{1}$ & $\begin{array}{l}\text { http://mrdata.usgs.gov/magnetic/show- } \\
\text { survey.php?id=0669 }\end{array}$ \\
\hline Wind River Basin & Digital & $\mathrm{C}$ & 1974 & 3,200 & 120 & $\begin{array}{l}\text { http://mrdata.usgs.gov/magnetic/show- } \\
\text { survey.php?id=6001 }\end{array}$ \\
\hline Bonneville & Digitized & $\mathrm{C}$ & 1969 & 8,000 & $3,650^{1}$ & $\begin{array}{l}\text { http://mrdata.usgs.gov/magnetic/show- } \\
\text { survey.php?id=0664 }\end{array}$ \\
\hline Idaho Thrust Belt & Digitized & $\mathrm{C}$ & 1963 & 1,600 & $2,750^{1}$ & $\begin{array}{l}\text { http://mrdata.usgs.gov/magnetic/show- } \\
\text { survey.php?id=0523 }\end{array}$ \\
\hline Mt. Naomi & Digital & $\mathrm{C}$ & 1981 & 800 & 305 & $\begin{array}{l}\text { http://mrdata.usgs.gov/magnetic/show- } \\
\text { survey.php?id=3188 }\end{array}$ \\
\hline
\end{tabular}

${ }^{1}$ Barometric survey. 
Table D3. Specifications for State-compilation of magnetic data over the Sagebrush Focal Areas (SFAs) as part of the Sagebrush Mineral-Resource Assessment (SaMiRA) project.

\begin{tabular}{lccl}
\hline \multicolumn{1}{c}{ State } & Grid interval, in meters & Datum, in meters & \multicolumn{1}{c}{ Reference } \\
\hline California & 1,000 & 305 & Roberts and Jachens, 1999 \\
Idaho & 1,000 & 305 & McCafferty and others, 1999 \\
Montana & 500 & 305 & McCafferty and others, 1998 \\
Nevada & 500 & 305 & Kucks and others, 2006 \\
Oregon & 500 & 305 & Roberts and others, 2008 \\
Utah & 1,000 & $3,810^{1}$ & Bankey and others, 1998 \\
Wyoming & 500 & 305 & Kucks and Hill, 2000 \\
\hline
\end{tabular}

${ }^{1}$ Barometric altitude.

\section{Gravity Data}

Gravity stations were compiled from the Pan-American Center for Earth and Environmental Studies (PACES) U.S. Gravity Database accessed January 5, 2016, at http:// irpsrvgis08.utep.edu/viewers/Flex/GravityMagnetic/ GravityMagnetic_CyberShare/ (Hildenbrand and others, 2002; Aldouri and Keller, 2011). The gravity-station spacing is irregular and coarse, having approximately 0.1 stations per square kilometer. Gravity-station data were processed using standard data reduction techniques (Hinze and others, 2005) and include the following corrections: (1) an Earth-tide correction, which corrects for tidal effects of the Moon and Sun; (2) an instrument-drift correction, which compensates for drift in the instrument's spring; (3) a latitude correction, which accounts for variation in the Earth's gravity with latitude; (4) free-air correction, which accounts for the variation in gravity due to elevation relative to sea level; (5) a Bouguer correction, which corrects for the attraction of material between the station and sea level; (6) a curvature correction, which corrects the Bouguer correction for the effect of the Earth's curvature; and (7) a terrain correction, which removes the effect of topography to a radial distance of $167 \mathrm{~km}$ from the station. Gravity-station data were gridded using a minimum curvature algorithm at an interval of $500 \mathrm{~m}$ to produce complete Bouguer anomaly datasets over the four areas (fig. D3). The Bouguer anomaly data were the initial starting point from which the gravity data transforms described below were derived (table D1). For each area, an isostatic correction was applied to remove the long-wavelength variations in the gravity field related to the compensation of topographic loads. For this reduction, the digital elevation model (Lukas and others, 2015) was resampled to $500 \mathrm{~m}$. A 2.67-gram per cubic centimeter $\left(\mathrm{g} / \mathrm{cm}^{3}\right)$ Bouguer density and a $0.35-\mathrm{g} / \mathrm{cm}^{3}$ Moho density contrast were assumed.

\section{Radiometric Data}

Radiometric data over the SFAs were derived from previously released map compilations across the United States (Duval and others, 2005). The original data were acquired as part of the National Uranium Resource Evaluation (NURE) program in the 1970s. The NURE flight-line spacing over the SFAs varied from $3,200 \mathrm{~m}$ to $8,000 \mathrm{~m}$ and had a nominal terrain clearance of $120 \mathrm{~m}$. The flight-line data were previously processed to produce internally consistent data (Duval, 1999; Duval and Riggle, 1999). Data corrections included compensation for aircraft and cosmic radiation background, altitude variations, Compton scattering, and airborne bismuth-214. The data were subsequently converted from counts per second to concentration values. The compiled radiometric data provide a uniform suite of maps showing potassium, thorium, and uranium concentrations within the upper few centimeters of surface material at a grid spacing of $2,000 \mathrm{~m}$. These data can be combined in single display by producing a ternary image where potassium, thorium, and uranium concentrations are displayed as red, green, and blue, respectively (fig. D4). The concentration maps form the basis for additional data transforms (table D1) described below. 


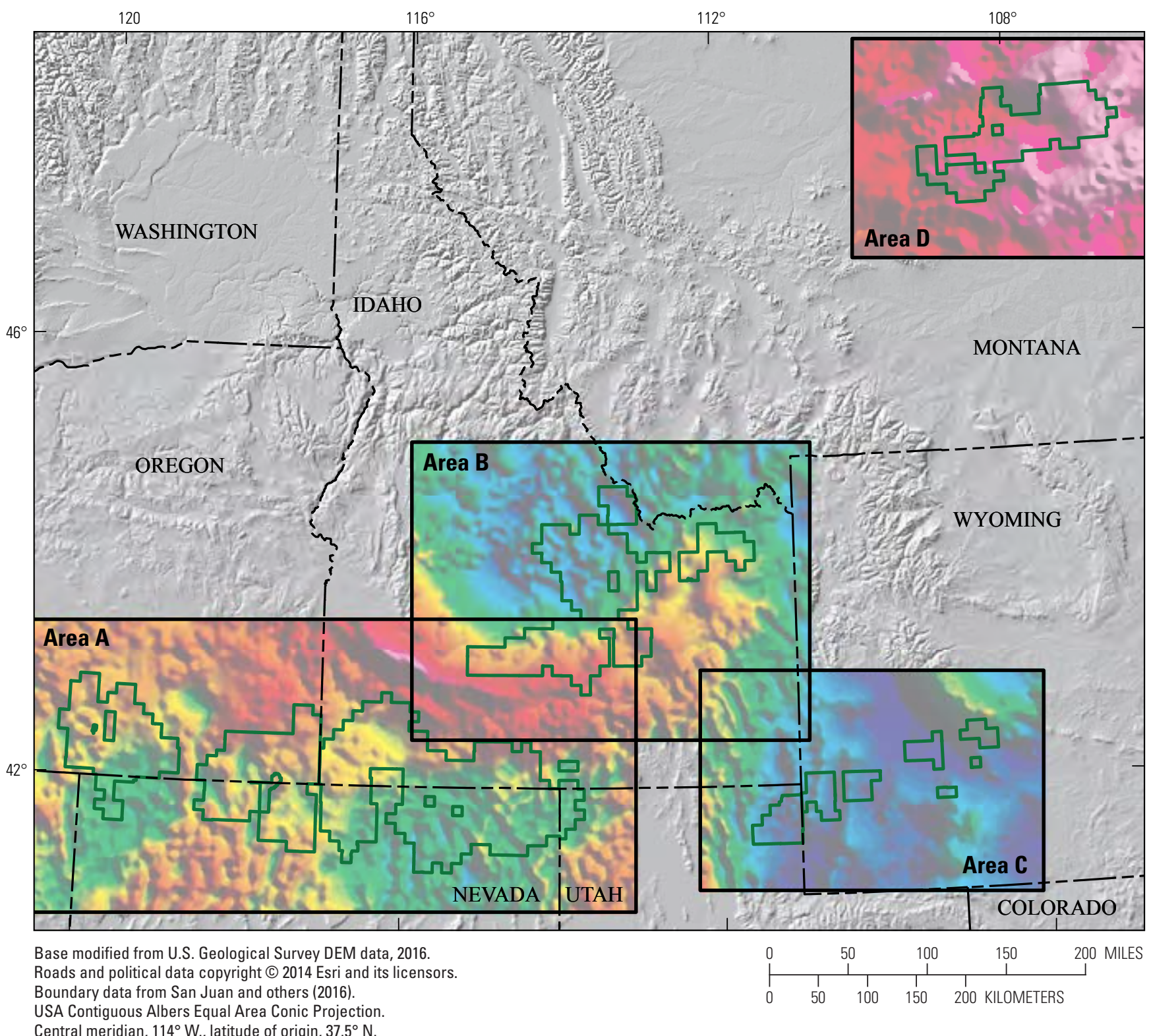

USA Contiguous Albers Equal Area Conic Projection.

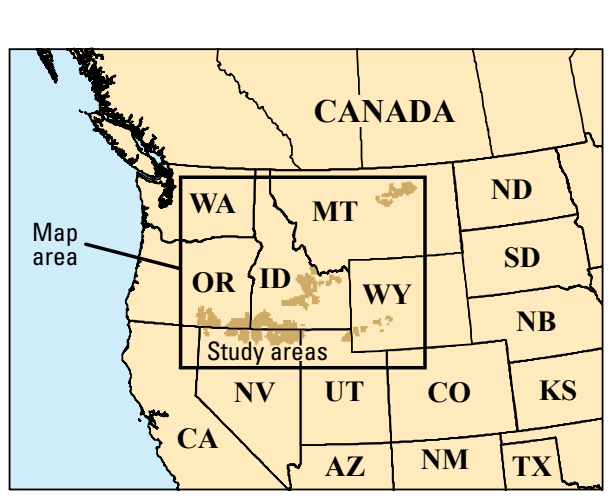

EXPLANATION

USGS study area boundaries

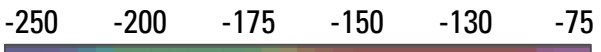

Complete Bouguer anomaly (mGal)

Figure D3. Complete Bouguer gravity anomaly map for four rectangular regions surrounding Sagebrush Focal Areas (SFAs; see section A, fig. A1) in the Western United States, which was created as part of the Sagebrush Mineral-Resource Assessment (SaMiRA) project. USGS, U.S. Geological Survey. mGal, milligal. 
120

$116^{\circ}$

$112^{\circ}$

$108^{\circ}$

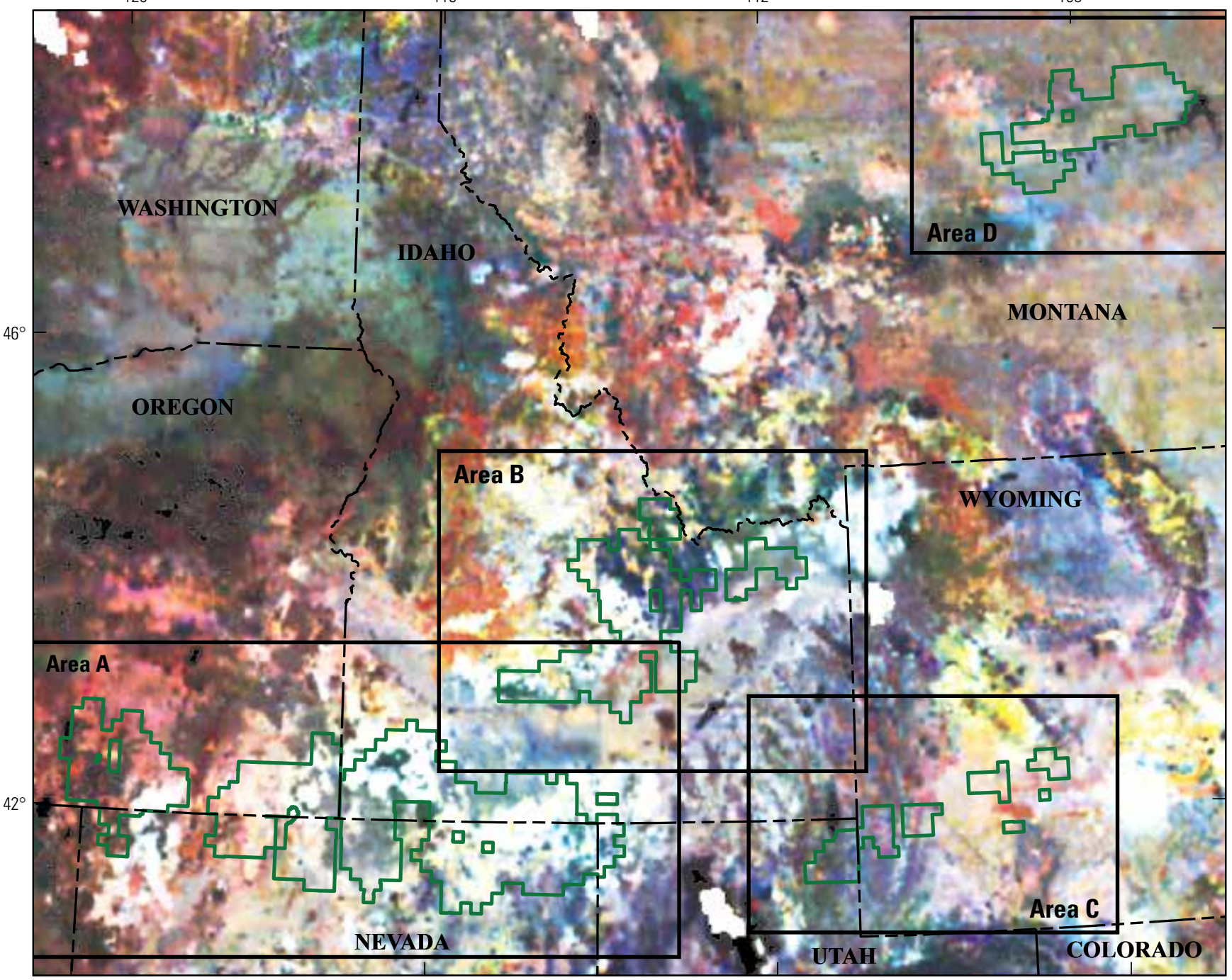

Political data copyright (C) 2014 Esri and its licensors

Boundary data from San Juan and others (2016).

USA Contiguous Albers Equal Area Conic Projection.

Central meridian, $114^{\circ} \mathrm{W}$., latitude of origin, $37.5^{\circ} \mathrm{N}$.
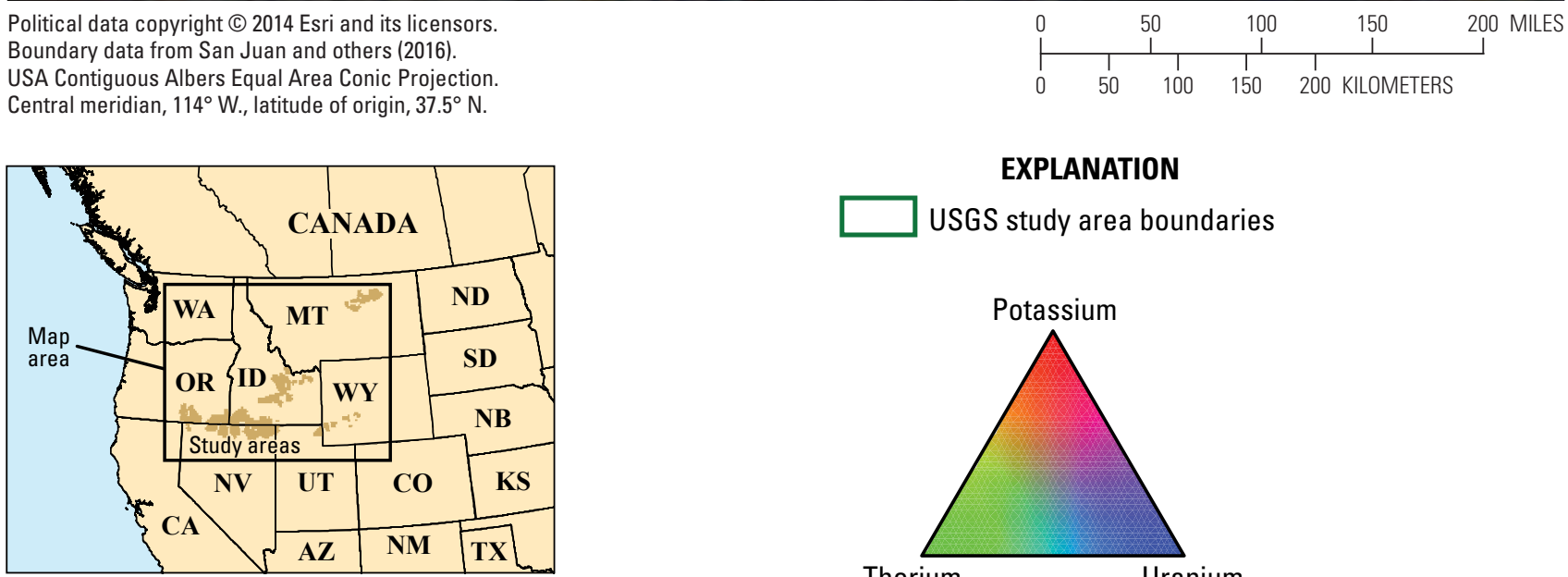

\section{EXPLANATION}

USGS study area boundaries

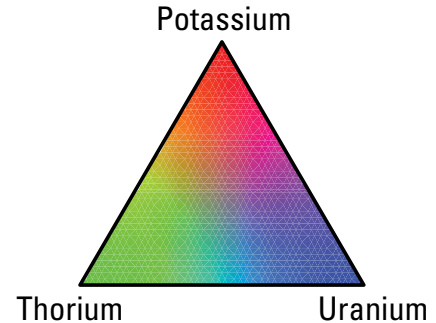

Figure D4. Ternary radiometric map of the Western United States (Duval and others, 2005). These data were subset to four rectangular regions (black boxes) surrounding the Sagebrush Focal Areas (SFAs; see section A, fig. A1) and provided the basis for subsequent data transforms (table D1) used as part of the Sagebrush Mineral-Resource Assessment (SaMiRA) project. USGS, U.S. Geological Survey. 


\section{Derivative Geophysical Products}

\section{Reduction-to-the-Pole (RTP) of Magnetic Data}

The reduction-to-pole (RTP) transform better aligns magnetic anomalies with causative sources (Baranov and Naudy, 1964; Blakely, 1995). The transform removes the effect of the direction of the Earth's magnetic field and the direction of magnetization by transforming the data to their expression at a vertical field and magnetization as if measured at the north magnetic pole. This transformation approximately centers magnetic anomalies over their sources and will produce a symmetrical anomaly over a symmetrical source. Remanent magnetization is assumed to be either negligible or in the same direction as the Earth's magnetic field. The total magnetic-intensity anomaly data were transformed to RTP data using parameters described in table D4.

\section{Total Horizontal Gradient of Magnetic and Gravity Data}

The total horizontal gradient of potential-field data maps the edges of anomaly sources (Cordell and Grauch, 1985; Grauch and Cordell, 1987). The transform, which assumes a vertical contact and vertical magnetization for the case of magnetic sources, produces maxima coincident with the contact. If a body is dipping or the source is narrow, the total horizontal gradient response will be displaced; however, displacement is only normally significant in high-resolution data (Grauch and Cordell, 1987). To help map geologic contacts and structures, the total horizontal gradient method was applied to the RTP, isostatic anomaly, and tilt derivatives (see below) of the RTP and isostatic anomaly data (table D1).

\section{First Vertical Derivative of Magnetic and Gravity Data}

The first vertical derivative (for example, Evjen, 1936; Blakely, 1995) amplifies short-wavelength anomalies and typically highlights steep gradients along edges of shallow sources. Thus, local features are sharpened at the expense of broad or regional features that can often mask shallow anomalies. Although horizontal gradients mentioned above enhance edges of causative features, vertical derivatives narrow the width of the anomaly and help to better constrain the location of the causative feature. Because first vertical derivative maps reflect shallow sources, they are also useful for correlating geophysical anomalies with exposed surface geology. In addition, the first vertical derivative of gravity anomalies is equivalent to a pseudomagnetic transformation and thus can be used to compare gravity anomalies with observed magnetic anomalies (for example, Simpson and others, 1986).

\section{Tilt Derivative of Magnetic and Gravity Data}

The tilt derivative and its total horizontal gradient are useful tools for enhancing causative sources and can be less sensitive to noise than other higher order derivatives (Miller and Singh, 1994; Verduzco and others, 2004). The tilt derivative is defined as the arctangent of the ratio of the first vertical derivative of the potential field to the horizontal gradient of the field. The ratio of the derivatives helps to overcome the large dynamic range in the size of the gradients, whereas the arctangent places the ratio in the range of $-90^{\circ}$ and $90^{\circ}$. The result is a map sensitive to both shallow and deep sources, where positive values occur over the source, zero values occur along the edge of vertical contacts, and negative values occur outside the source region. The total horizontal gradient method can be applied to the tilt derivative to indicate the anomaly edge in shallow basement targets (Verduzco and others, 2004). The tilt-depth method provides a rapid way to estimate source depths (Salem and others, 2007; Fairhead and

Table D4. Reduction-to-the-pole (RTP) parameters used to transform magnetic-intensity anomaly data as part of the Sagebrush Mineral-Resource Assessment (SaMiRA) project.

[Focal areas: A, Sheldon-Hart Mountain National Wildlife Refuge Complex, Southeastern Oregon and North-Central Nevada, and Southern Idaho and Northern Nevada; B, North-Central Idaho; C, Bear River Watershed and Southwestern and South-Central Wyoming; and D, North-Central Montana; nT, nanotesla]

\begin{tabular}{clcccc}
\hline Focal area & Longitude & Latitude & Field strength, in nT & Inclination & Declination \\
\hline A & -117.011 & 42.1205 & 53,190 & 66.3 & 15.3 \\
B & -113.39 & 43.7846 & 54,683 & 68.4 & 14.6 \\
C & -110.17 & 42.0032 & 54,264 & 67.6 & 12.9 \\
D & -107.952 & 47.73 & 57,207 & 72.6 & 13.0 \\
\hline
\end{tabular}


others, 2011). This method estimates the depth to a vertical contact by calculating half the distance between the $-45^{\circ}$ and $45^{\circ}$ tilt angle.

\section{Analytic Signal of Magnetic and Gravity Data}

The analytic signal can be computed from the horizontal and vertical gradients of potential-field data in both two and three dimensions (Nabighian, 1972; Roest and others, 1992). The result depends on the geometry of the source body, not its magnetization, such that all bodies with the same geometry have the same analytic signal. The analytic signal can be used to determine location and estimate the depth of causative bodies (Nabighian, 1972; Roest and others, 1992). Because the analytic signal is independent of the direction of magnetization, it can also be used to estimate the magnetization of source bodies (for example, Blakely, 1995). The analytic signal peaks are symmetrical and occur directly over the edges of wide bodies and directly over the centers of narrow bodies. Thus, the analytic signal maps can be used to map source contacts and geometries.

\section{Radioelement Element and Ratio Maps of Radiometric Data}

Radiometric data map major variations in the radioelement concentrations in soil and exposed rock. Minor variations in radioelement concentration within rock units can be due to lithological changes, weathering, or mineralizing events (Dickson and Scott, 1997). These minor variations can be enhanced using ratios of the radiometric data. Ratio maps have the added advantage of being able to discriminate areas where relative concentrations of elements have increased or decreased possibly as a result of hydrothermal alteration within an ore system. For example, potassium enrichment associated with formation of potassium-rich bearing minerals formed during hydrothermal event(s) can be imaged using the potassium/ thorium ratio. Potassium and thorium generally covary with changing silica content in unaltered rocks. Because thorium is relatively immobile during hydrothermal alteration, the potassium/thorium ratio map may better show potassically altered rocks than potassium concentrations alone (Dickson and Scott, 1997; Shives and others, 2000).

\section{Depth Estimates}

\section{Magnetic Methods}

Euler deconvolution is a semiautomated way to estimate source position and depths (Reid and others, 1990; Phillips, 2002). The calculated depths are dependent on the source geometry. For this reason, a structural index (SI) term is used as a measure of the rate of change of a field with distance. The SI changes with source geometry such that geologic contacts, vertical dikes, vertical pipes, and spheres (or point sources) have a SI of $0,1,2$, and 3, respectively. A SI that is too low gives depths that are too shallow, whereas one that is too high gives estimates that are too deep. A data window size is chosen such that it incorporates substantial variation of the magnetic field, but is small enough to minimize significant contributions from multiple sources.

The Euler deconvolution method was used in the NorthCentral Montana SFA to better understand the source depth of the northeast-trending RTP magnetic anomalies (fig. D5). The anomalies have been previously interpreted as reflecting Paleoproterozoic oceanic-arc rocks that accreted to the Archean Wyoming craton margin (Sims and others, 2004). Near the NorthCentral Montana SFA, Precambrian rocks are exposed as roof pendants in the Tertiary plutonic rocks within the Little Rocky Mountains. Recently digitized high-resolution aeromagnetic data (Anderson and others, 2016) indicate that the Tertiary plutonic rocks also appear to contribute to the northeast-trending anomalies.

The depth estimates presented here are for source geometries that represent the contact of plutonic bodies. Structural indices of $0.0,0.5$, and 1.0 were chosen and estimates were generated for window sizes that ranged from 2,500 to $8,500 \mathrm{~m}$. The solutions were subset to a 1,000-m buffer along the maximum total horizontal gradient associated with the northeasttrending magnetic anomalies. The results were compared to a structure contour map to top of Precambrian crystalline rock based on geology and drill-hole information that indicates the top of Precambrian rocks deepens from about 1,500 m east of the Little Rocky Mountains to more than 2,500 m just east of the eastern extent of the North-Central Montana SFA (Bergantino and Clark, 1985).

The preferred results were calculated from the RTP data using an SI of 0.5 and a window size of $8,500 \mathrm{~m}$ (fig. D5). The results show good clustering of solutions along the total horizontal gradients of the RTP data. The northeast-trending anomalies appear to have sources typically greater than $2,000 \mathrm{~m}$ depth. This agrees generally with the reported depths to the top of Precambrian basement, which range from 1,500 to 2,500 m depth (Bergantino and Clark, 1985). Shallow sources occur over the Little Rocky Mountains that likely reflect the outcropping Tertiary plutonic rocks. Two areas within the north-central Montana Sagebrush Focal Area indicate relatively shallow magnetic sources - (1) approximately $50 \mathrm{~km}$ southeast of the Little Rocky Mountains are clusters of shallow solutions ranging from 500 to $2,000 \mathrm{~m}$, and (2) approximately $35 \mathrm{~km}$ east-southeast of Malta, Montana, is another cluster of depth solutions that range mostly from 500 to $2,000 \mathrm{~m}$. Both areas may represent Mesozoic to Cenozoic igneous rocks.

\section{Gravity Methods}

Previously, an iterative gravity inversion method was used to determine the thickness of Cenozoic basin deposits in Nevada and Utah (Jachens and Moring, 1990; Saltus and Jachens, 1995). The depth-to-basement method separates the gravity field into two components - (1) the field caused by preCenozoic basement rocks and (2) the field caused by overlying younger basin deposits. An initial basement gravity field is determined by using just those gravity measurements located 


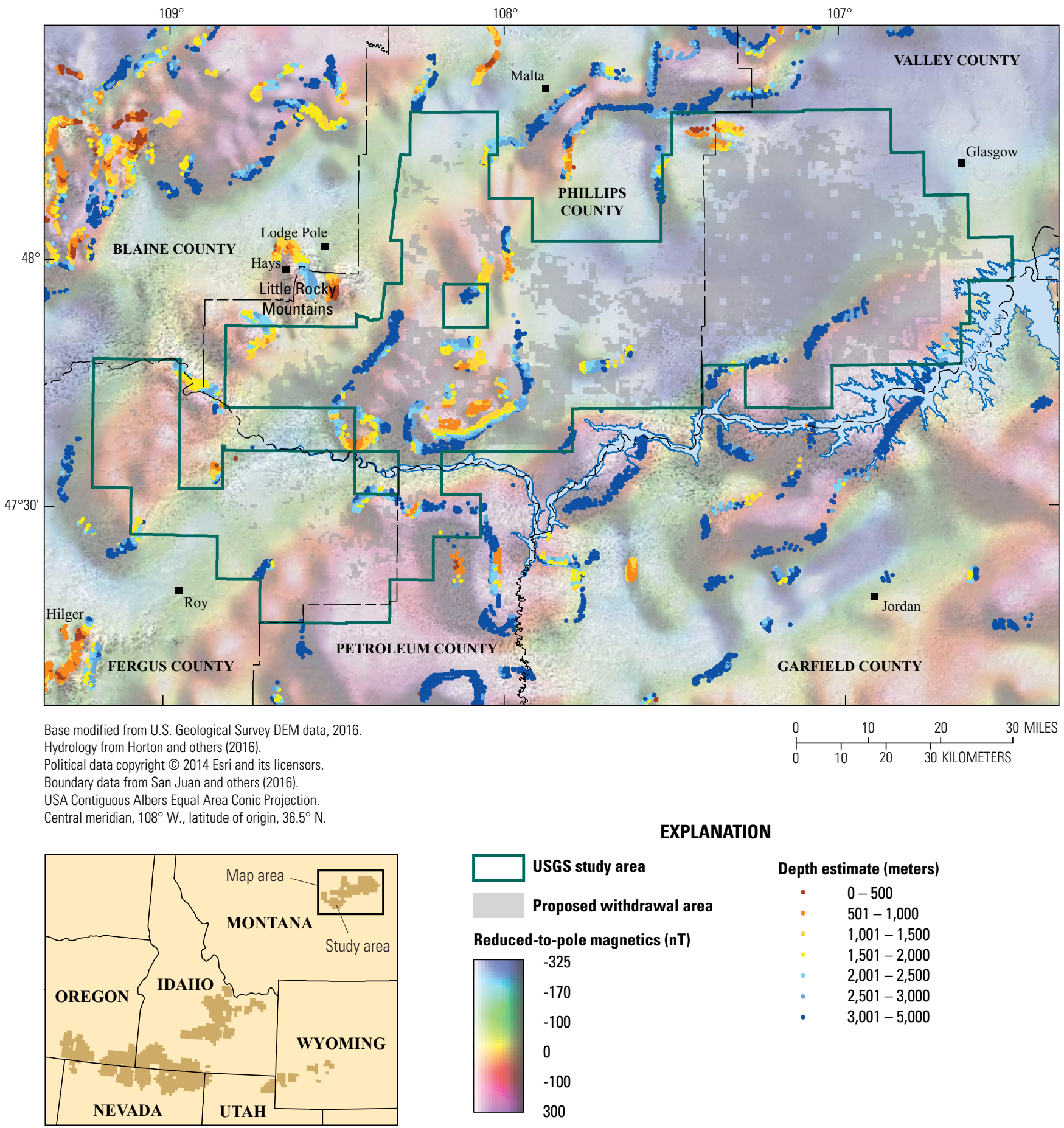

Figure D5. Map of Euler depth estimates overlain on a reduced-to-pole (RTP) magnetic-anomaly map of the North-Central Montana Sagebrush Focal Area (SFA; see section A, fig. A1). Map was generated as part of the Sagebrush Mineral-Resource Assessment (SaMiRA) project. nT, nanotesla. 
on pre-Cenozoic basement outcrops. The initial basement gravity field is only approximate, because measurements located on basement are influenced by the gravity effect of low-density deposits in nearby basins, especially for those measurements near the edge of the basins. The difference between the isostatic gravity and basement gravity fields provides the first estimate of the basin gravity field, which is inverted to provide the first estimate of the basin depth and shape. The gravitational effects of the basins are subtracted from each measurement located on basement, and a new and improved basement gravity field is determined. This process is repeated until successive iterations converge. Inversion of the final basin gravity field constrained with a density-depth function (table D5) and geology yields an estimate of the depth to pre-Cenozoic basement. The density of basement rocks is allowed to vary horizontally, whereas the density of basin-filling deposits increases with depth according to the density-depth relations shown in table D5. The density-depth function is based on density information from rock samples, geophysical well logs, and borehole gravity data. A densitydepth profile representative for the state of Nevada (Jachens and Moring, 1990) was used for sedimentary and volcanic deposits.

A number of limitations are inherent in the gravity data themselves, as well as in the inversion process. Uncertainties are related to the distribution of gravity data, especially for measurements on basement outcrops, the assumed densitydepth function, accuracy or scale of the geologic mapping, simplifying assumptions regarding concealed geology, and the distribution of basement outcrops. The depth-to-basement process itself is regional in scope, and caution should be exercised when using these results at a scale greater than about 1:250,000. A more detailed discussion of the limitations and accuracy of the method are provided by Jachens and Moring (1990).

In the North-Central Idaho SFA, three-dimensional (3-D) gravity inversions were used to map areas in the Pahsimeroi and Lemhi Valleys where the thickness of Cenozoic basins exceeds $1,000 \mathrm{~m}$, a depth that is nonpermissive for economic extraction of hard rock mineral resources. The gravity inversion

Table D5. Density-depth functions used to constrain final basin gravity fields as part of the Sagebrush Mineral-Resource Assessment (SaMiRA) project.

[g/cm³ ${ }^{3}$ gram per cubic centimeter]

\begin{tabular}{ccc}
\hline $\begin{array}{c}\text { Depth range, in } \\
\text { kilometers }\end{array}$ & $\begin{array}{c}\text { Sedimentary density } \\
\text { contrast, in } \mathbf{~} / \mathbf{c m}^{\mathbf{3}}\end{array}$ & $\begin{array}{c}\text { Volcanic density } \\
\text { contrast, in } \mathbf{~} / \mathbf{c m}^{\mathbf{3}}\end{array}$ \\
\hline $0-0.2$ & -0.65 & -0.45 \\
$0.2-0.6$ & -0.55 & -0.40 \\
$0.6-1.2$ & -0.35 & -0.35 \\
$>1.2$ & -0.25 & -0.25 \\
\hline
\end{tabular}

method assumed a two-layer model with $0.3-\mathrm{g} / \mathrm{cm}^{3}$ density contrast (Liberty and others, 2006) that consisted of low-density basins underlain and surrounded by higher density material representing pre-Cenozoic bedrock. Three datasets were used to constrain the inversion - isostatic anomaly, topography, and mapped geology. The isostatic anomaly map (described above) characterized the observed anomalous gravity field. The topography was defined by a digital elevation model (DEM) generated as part of the USGS 3D Elevation Program (Lukas and others, 2015). Mapped surface lithologies were used to define lateral extent of basin and bedrock materials (Lewis and others, 2012). The basin thickness was initially set at 1,000 m below topography. The inversion process iteratively adjusted the basin thickness until the predicted gravity field adequately matched that of the observed gravity field. The inversions over the Pahsimeroi and Lemhi Valleys were run separately. The Pahsimeroi Valley inversion was first run and parameters were adjusted until areas within the basin agreed well with seismicreflection data (Liberty and others, 2006). The inversions over the Lemhi Valley were then run using similar parameters and areas of overlap were inspected for consistency. The results were then contoured and the 1,000 m-depth contour helped define tract boundaries by indicating depths too deep for mineral resource extraction (fig. D6).

\section{Pluton Mapping}

Isostatic gravity, aeromagnetic, and the horizontal gradient of gravity and magnetic anomalies were used to infer the lateral extent of known and unknown granitoid plutons in Nevada (Grauch and others, 1988; Grauch, 1996). Although aeromagnetic data (Hildenbrand and Kucks, 1988) and their correlation to mapped granitic rocks (Stewart and Carlson, 1978) was primarily used, isostatic- and basement-gravity maps of Nevada (Jachens and Moring, 1990; Saltus and Jachens, 1995) were also used to supplement the aeromagnetic interpretations. Because mineral-resource deposits are often spatially or temporally associated with granitic plutons, their inferred horizontal extent plays a major role in mineralresource assessments.

In the North-Central Idaho SFA, plutons were also mapped using transformed RTP data. The upward continuation transformation calculates the magnetic field at an elevation higher than that at which it was originally measured. This transform attenuates near-surface effects and accentuates the anomalies from deeper magnetic sources (Blakely, 1995). A common technique to enhance near-surface sources, such as shallow plutons, is to upward continue magnetic data a short distance to generate a regional field and then subtract this regional field from the original dataset. The resulting map is a high-frequency-passed magnetic field associated with shallow sources. Using a 1,000-m upward-continuation distance and the RTP field, the resultant anomalies helped map near-surface plutons in North-central Idaho SFA (fig. D7). 

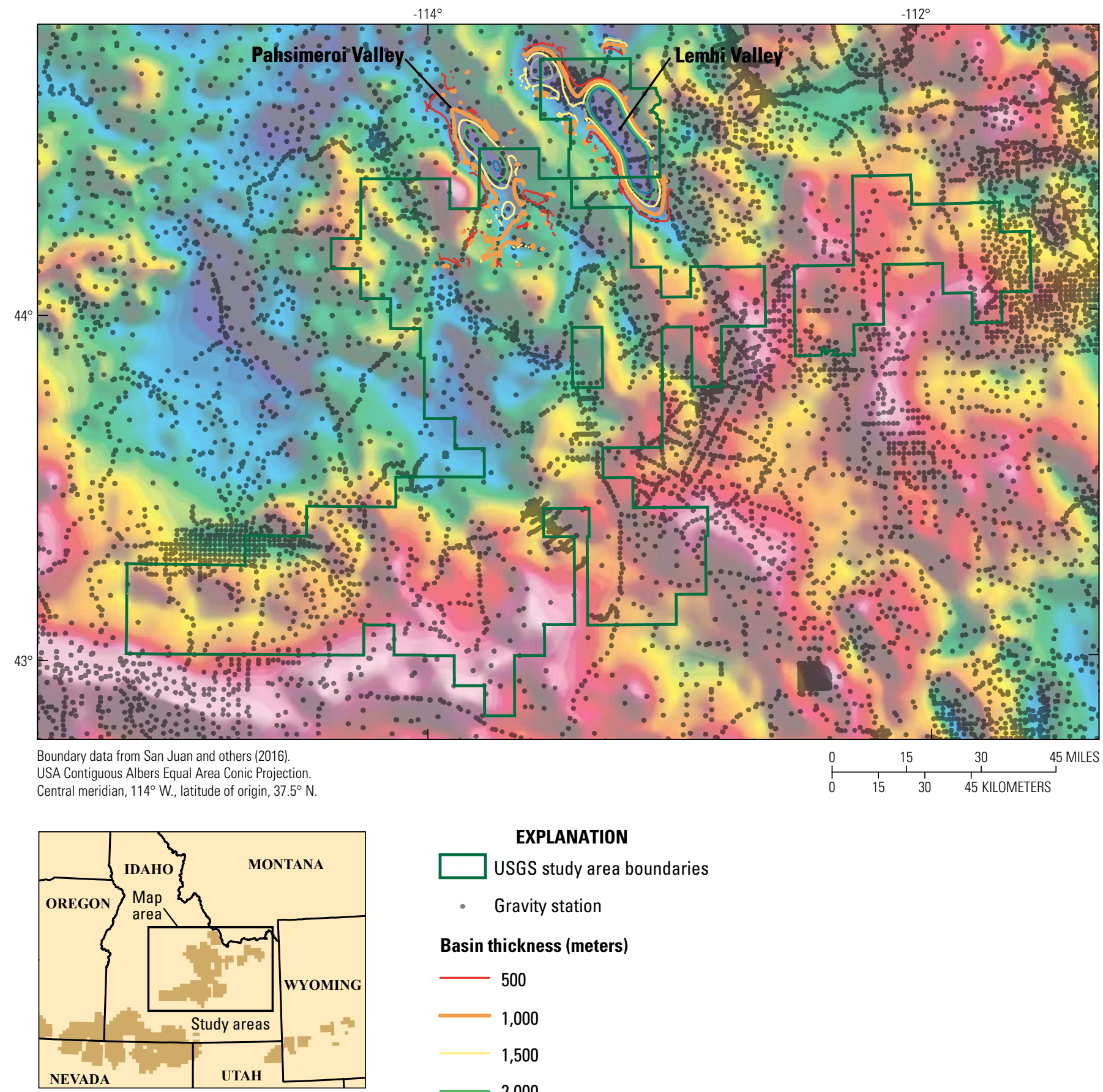

\section{EXPLANATION}

SGS study area boundaries

- Gravity station

Basin thickness (meters)
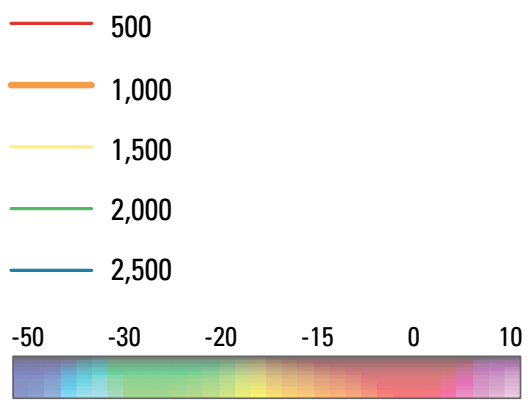

Isostatic anomaly (mGal)

Figure D6. Isostatic-anomaly map and basin-thickness estimates derived from gravity inversions over the North-Central Idaho Sagebrush Focal Area (SFA; see section A, fig. A1). Map was generated as part of the Sagebrush Mineral-Resource Assessment (SaMiRA) project. USGS, U.S. Geological Survey. 

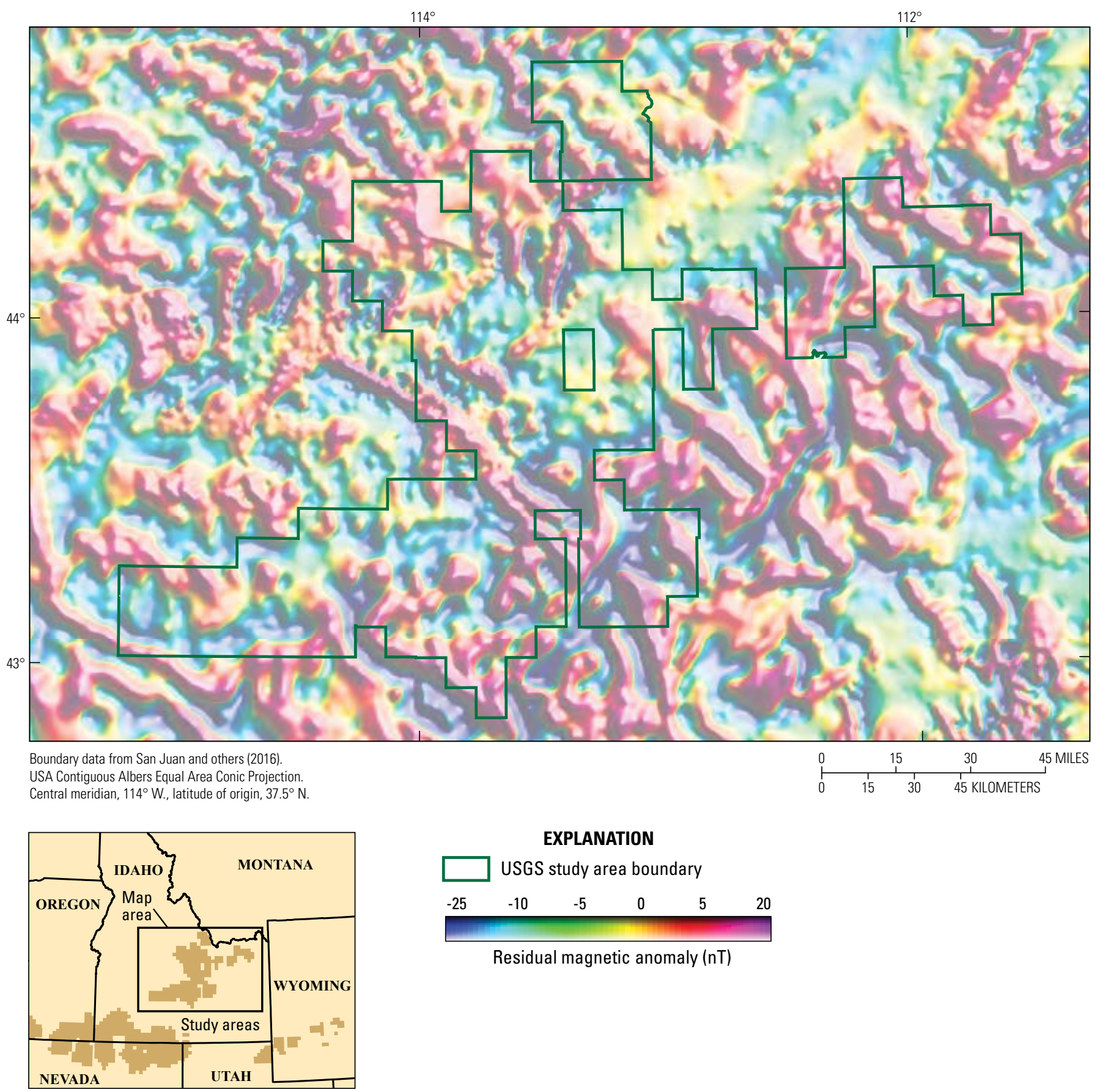

EXPLANATION

$\square$ USGS study area boundary

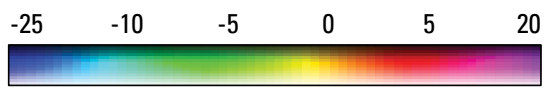

Residual magnetic anomaly (nT)

Figure D7. Map of residual magnetic anomalies used to help map plutons in North-Central Idaho Sagebrush Focal Area (SFA). Map was generated as part of the Sagebrush Mineral-Resource Assessment (SaMiRA) project. USGS, U.S. Geological Survey. 


\section{Diatreme Mapping}

In 1981, Anaconda Minerals Company collected highresolution aeromagnetic data over the Missouri Breaks diatremes in Montana. The survey was flown along north-south flight lines spaced $200 \mathrm{~m}$ at a nominal terrain clearance of $130 \mathrm{~m}$. The analog contour maps of these data were digitized (Anderson and others, 2016) and digitally enhanced. The RTP anomaly map shows discrete magnetic highs over mapped diatremes. The analytic signal also images these rocks and suggests the location of additional diatremes in the shallow subsurface.

\section{Large-Scale Fractures in Nevada and Idaho}

On the basis of gravity and aeromagnetic data, Ponce and Glen (2002) interpreted large-scale fractures across northern Nevada and extending into Idaho that are probably related to the inception of the Yellowstone Hotspot. These features are particularly evident in aeromagnetic data as linear positive anomalies, but some are also prominently expressed in gravity data. These geophysical lineaments represent major crustal discontinuities within the Earth that are interpreted to have formed as a result of mid-Miocene rift-related magmatism.

These large-scale features may have served as conduits for ore-forming hydrothermal solutions and are both spatially and temporally associated with mid-Miocene epithermal gold-silver deposits (Ponce and Glen, 2002). The statistical proximity of these arcuate features to mid-Miocene and younger epithermal gold-silver deposits suggests that they may serve as a guide to future epithermal mineral-resource potential in Nevada, Oregon, and Idaho.

\section{General Discussion}

Gravity and magnetic anomalies can be used to infer the subsurface structure of known or unknown geologic features, where a physical-property contrast occurs across the geologic boundaries. Typically, gravity anomalies reflect lateral (horizontal) density variations in the middle to upper crust. Thus, isostaticgravity anomalies can be used to infer the subsurface structure of known or unknown geologic features. In general, gravity anomalies reflect carbonate rocks, calderas, deep sedimentary basins, plutons, and linear geologic features such as faults. Many of these features play an important role in assessing the mineralresource potential across the SFAs.

Magnetic anomalies typically reflect lateral changes in rock magnetic properties and can be analyzed to gain insights into the three-dimensional nature of the causative source. In general, short-wavelength, high-amplitude magnetic anomalies are caused by moderately to strongly magnetic volcanic rocks, whereas broad circular long-wavelength magnetic anomalies reflect magnetic granitoid intrusions or other mafic basement rocks. Many of these features play an important role in ore formation, and their distribution is important to the understanding of the mineral-resource potential of the area.
The diverse physical properties of rock units that underlie this region are well suited to geophysical investigations. The contrast in magnetic properties between pre-Cenozoic rocks, volcanic rocks, and alluvium produces a distinctive pattern of anomalies that can be used to determine the sources of the anomalies and their subsurface extent.

Radiometric data map the surficial variation in potassium, thorium, and uranium concentrations. These data map lateral changes in geologic material and complement geologic maps. Ore deposits can have preferential host or source rocks, which may be imaged by the data. In addition, the hydrothermal systems associated with ore deposits can alter the concentrations of potassium, thorium, and uranium, thereby making them an effective dataset for mineral-resource assessment. However, because of the relatively low spatial resolution of the data over the SFAs, these data are most useful for lithologic mapping. The contrast in radioactivity between Paleozoic sedimentary rocks, volcanic rocks, and plutonic rocks made these data effective for understanding their surficial distribution throughout the SFAs.

Most Paleozoic rocks are relatively nonmagnetic within the study area, whereas intrusive rocks are, in general, moderately magnetic and are associated with magnetic highs. Tertiary volcanic rocks are strongly magnetic with variable magnetic properties, and they play significant roles in assessing the mineral-resource potential and extensional history of the area. Thick accumulations of these volcanic rocks are present throughout the study area. Alluvial deposits within the study area are essentially nonmagnetic and most basins have subdued magnetic anomalies with the exception of those basins that may contain volcanic centers, buried volcanic rocks, or buried granitic rocks.

\section{References Cited}

Aldouri, R., and Keller, G.R., 2011, Development of robust data system for gravity and magnetic anomaly data-A case study of a community-based effort for point data, in Keller, G.R., and Baru, C., eds., Geoinformatics cyber infrastructure for the solid Earth sciences: Cambridge England, Cambridge University Press, p. 224-236, accessed March 15, 2016, at http://dx.doi.org/10.1017/ CBO9780511976308.015.

Anderson, E.D., Parks, H.L., Jenkins, M.C., Nguyen, D.M., Hearn, B.C., Jr., and Zientek, M.L., 2016, Missouri Breaks project, Montana - Digitized aeromagnetic data: U.S. Geological Survey data release, accessed March 15, 2016, at http://dx.doi.org/10.5066/F7TH8JTN.

Bankey, V., Grauch, V.J.S., and Kucks, R.P., 1998, Utah aeromagnetic and gravity maps and data-A website for distribution of data: U.S. Geological Survey Open-File Report 98-761, accessed March 15, 2016, at http://pubs. usgs.gov/of/1998/ofr-98-0761/. 
Bankey, V., Cuevas, A., Daniels, D.L., Finn, C.A., Hernandez, I., Hill, P.L., Kucks, R.P., Miles, W.F., Pilkington, M., Roberts, C.W., Roest, W.R., Rystrom, V.L., Shearer, S.E., Snyder, S.L., Sweeney, R.E., Velez, J., Phillips, J.D., and Ravat, D.K.A., 2002, Digital data grids for the magnetic anomaly map of North America: U.S. Geological Survey Open-File Report 2002-0414, accessed March 15, 2016, at http://pubs.usgs.gov/ of/2002/ofr-02-414/.

Baranov, V., and Naudy, H., 1964, Numerical calculation of the formula of reduction to the magnetic pole: Geophysics, v. 29, p. $67-79$.

Bergantino, R.N., and Clark, M., 1985, Structure contour map on the top of the Precambrian crystalline rocks, Montana: Montana Bureau of Mines and Geology Open-File Report 158, 1 sheet, scale $1: 1,000,000$.

Blakely, R.J., 1995, Potential theory in gravity and applications: New York, Cambridge University Press, 441 p.

Clark, D.A., 1997, Magnetic petrophysics and magnetic petrology - Aids to geological interpretation of magnetic surveys: Journal of Australian Geology and Geophysics, v. 17, p. $83-103$.

Clark, D.A., 1999, Magnetic petrology of igneous intrusionsImplications for exploration and magnetic interpretation: Exploration Geophysics, v. 30, p. 5-26.

Cordell, L., and Grauch, V.J.S., 1985, Mapping basement magnetization zones from aeromagnetic data in the San Juan Basin, New Mexico, in Hinze, W.J., ed., The utility of regional gravity and magnetic anomaly maps: Tulsa, Oklahoma, Society of Exploration Geophysicists, p. 181-197.

Dickson, B.L., and Scott, K.M., 1997, Interpretation of aerial gamma-ray surveys-adding the geochemical factors: Journal of Australian Geology and Geophysics, v. 17, p. 187-200.

Duval, J.S., 1999, Aerial gamma-ray surveys of the conterminous United States and Alaska: U.S. Geological Survey Open-File Report 99-562-K, accessed March 15, 2016, at https://pubs. er.usgs.gov/publication/ofr99562K.

Duval, J.S., and Riggle, F.E., 1999, Profiles of gamma-ray and magnetic data from aerial surveys over the conterminous United States: U.S. Geological Survey Digital Data Series 31.

Duval, J.S., Carson, J.M., Holman, P.B., and Darnley, A.G., 2005, Terrestrial radioactivity and gamma-ray exposure in the United States and Canada: U.S. Geological Survey Open-File Report 2005-1413, accessed March 15, 2016, at http://pubs.usgs.gov/ of/2005/1413/.

Evjen, H.J., 1936, The place of the vertical gradient in gravitational interpretations: Geophysics, v. 1, p. 127-136.
Fairhead, J.D., Salem, A., Cascone, L., Hammill, M., Masterton, S., and Samson, E., 2011, New developments of the magnetic tilt-depth method to improve structural mapping of sedimentary basins: Geophysical Prospecting, v. 59, p. 1072-1086.

Grant, F.S., 1985, Aeromagnetics, geology and ore environments - I. Magnetite in igneous, sedimentary and metamorphic rocks-An overview: Geoexploration, v. 23, p. 303-333.

Grauch, V.J.S., 1996, Magnetically interpreted, granitoid plutonic bodies in Nevada, in Singer, D.A., ed., An analysis of Nevada's metal-bearing mineral resources: Nevada Bureau of Mines and Geology Open-File Report 96-2, chapter 7, 16 p., 1 plate.

Grauch, V.J.S., and Cordell, L., 1987, Limitations of determining density or magnetic boundaries from the horizontal gradient of gravity or pseudogravity data: Geophysics, v. 52, p. 118-121.

Grauch, V.J.S., Blakely, R.J., Blank, H.R., Oliver, H.W., Plouff, Donald, and Ponce, D.A., 1988, Geophysical delineation of granitic plutons in Nevada: U.S. Geological Survey Open-File Report 88-11, 7 p., 2 plates, scale 1:1,000,000.

Hildenbrand, T.G., and Kucks, R.P., 1988, Total intensity magnetic anomaly map of Nevada: Nevada Bureau of Mines and Geology Map 93A, 1 sheet, scale 1:750,000.

Hildenbrand, T.G., Briesacher, A., Flanagan, G., Hinze, W.J., Hittelman, A.M., Keller, G.R., Kucks, R.P., Plouff, D., Roest, W.R., Seeley, J., Smith, D.A., and Webring, M.W., 2002, Rationale and operational plan to upgrade the U.S. Gravity Database: U.S. Geological Survey Open-File Report 02-463, 12 p., accessed March 15, 2016, at http://pubs.usgs.gov/ of/2002/0463/.

Hill, P.L., Kucks, R.P., and Ravat, D.K.A., 2009, Aeromagnetic and aeroradiometric data for the conterminous United States and Alaska from the National Uranium Resources Evaluation (NURE) Program of the U.S. Department of Energy: U.S. Geological Survey Open-File Report 2009-1129, accessed March 15, 2016, at http://pubs.usgs.gov/of/2009/1129/.

Hinze, W.J., 1985, The utility of regional gravity and magnetic anomaly maps: Society of Exploration Geophysicists, 469 p., doi:10.1190/1.0931830346.

Hinze, W.J., Aiken, C., Brozena, J., Coakley, B., Dater, D., Flanagan, G., Forsberg, R., Hildenbrand, T.G., Keller, G.R., Kellogg, J., Kucks, R.P., Li, X., Mainville, A., Morin, R., Pilkington, M., Plouff, D., Ravat, D.K.A., Roman, D., UrrutiaFucugauchi, J., Véronneau, M., Webring, M.W., and Winester, D., 2005, New standards for reducing gravity data - The North American gravity database: Geophysics, v. 70, p. J25J32, doi:10.1190/1.1988183. 
Jachens, R.C., and Moring, B.C., 1990, Maps of the thickness of Cenozoic deposits and the isostatic residual gravity over basement for Nevada: U.S. Geological Survey Open-File Report 90-404, accessed March 15, 2016, at https://pubs. er.usgs.gov/publication/ofr90404.

Kucks, R.P., and Hill, P.L., 2000, Wyoming aeromagnetic and gravity maps and data- $\mathrm{A}$ website for distribution of data: U.S. Geological Survey Open-File Report 00-0198, accessed March 15, 2016, at http://pubs.usgs.gov/of/2000/ ofr-00-0198/.

Kucks, R.P., Hill, P.L., and Ponce, D.A., 2006, Nevada magnetic and gravity maps and data-A website for the distribution of data: U.S. Geological Survey Data Series 234, accessed March 15, 2016, at http://pubs.usgs.gov/ ds/2006/234.

Lewis, R.S., Link, P.K., Stanford, L.R., and Long, S.P., 2012, Geologic map of Idaho: Idaho Geological Survey, Geologic Map 9, scale 1:750,000.

Liberty, L.M., Hess, S., and Beukelmann, G., 2006, Stratigraphic and structural controls of ground water flow in the Pahsimeroi Basin, Idaho-Insights from geophysical data: Boise State University, Boise, Idaho, Center for Geophysical Investigation of Shallow Subsurface (CGISS), Technical Report BSU CGISS 06-01 prepared for the Bureau of Land Management, $15 \mathrm{p}$.

Lukas, V., Eldridge, D.F., Jason, A.L., Saghy, D.L., Steigerwald, P.R., Stoker, J.M., Sugarbaker, L.J., and Thunen, D.R., 2015, Status report for the 3D Elevation Program, 2013-2014: U.S. Geological Survey Open-File Report 2015-1161, 17 p., accessed March 15, 2016, at http://dx.doi.org/10.3133/ofr20151161.

Luyendyk, A.P.J., 1997, Processing of airborne magnetic data: Journal of Australian Geology and Geophysics, v. 17, p. 31-38.

McCafferty, A.E., Bankey, V., and Brenner, K.C., 1998, Montana Aeromagnetic and Gravity Maps and Data: U.S. Geological Survey Open-File Report 98-333, accessed March 15, 2016, at http://pubs.usgs.gov/of/1998/ofr-980333/.

McCafferty, A.E., Kucks, R.P., Hill, P.L., and Racey, S.D., 1999, Aeromagnetic map for the State of Idaho-A website for distribution of data: U.S. Geological Survey Open-File Report 99-371, accessed March 15, 2016, at http://pubs. usgs.gov/of/1999/ofr-99-0371/.

Miller, H.G., and Singh, V.J., 1994, Potential field tilt-A new concept for location of potential field sources: Applied Geophysics, v. 32, p. 213-217.
Nabighian, M.N., 1972, The analytic signal of two-dimensional magnetic bodies with polygonal cross section-Its properties and use for automated anomaly interpretation: Geophysics, v. 37 , p. 507-517.

Nabighian, M.N., Ander, M.E., Grauch, V.J.S., Hansen, R.O., LaFehr, T.R., Li, Y., Pearson, W.C., Peirce, J.W., Phillips, J.D., and Ruder, M.E., 2005a, Historical development of the gravity method in exploration: Geophysics, v. 70, p. 63ND-89ND.

Nabighian, M.N., Grauch, V.J.S., Hansen, R.O., LaFehr, T.R., Li, Y., Peirce, J.W., Phillips, J.D., and Ruder, M.E., 2005b, The historical development of the magnetic method in exploration: Geophysics, v. 70, p. 33ND-61ND.

Phillips, J.D., 2002, Two-step processing for 3D magnetic source locations and structural indices using extended Euler or analytic signal methods: Society of Exploration Geophysicists 72nd Annual Meeting, Salt Lake City, Utah, United States of America, 2002, Technical Program Expanded Abstracts, p. 727-730, doi:10.1190/1.1817359.

Ponce, D.A., and Glen, J.M.G, 2002, Relationship of epithermal gold deposits to large-scale fractures in northern Nevada: Economic Geology, v. 97, no. 1, p. 3-9.

Ponce, D.A., and Moring, B.C., 1998, Drill-hole lithology map of the Winnemucca 1:250,000-scale quadrangle, Nevada: U.S. Geological Survey Open-File Report 98-220, 1 sheet, scale 1:250,000, accessed March 15, 2016, at https://pubs. er.usgs.gov/publication/ofr98220.

Reid, A.B., Allsop, J.M., Granser, H., Millett, A.J., and Somerton, I.W., 1990, Magnetic interpretation in three dimensions using Euler deconvolution: Geophysics, v. 55, p. $80-91$.

Roberts, C.W., and Jachens, R.C., 1999, Preliminary aeromagnetic anomaly map of California: U.S. Geological Survey Open-File Report 99-440, 14 p., accessed March 15, 2016, at http://pubs.usgs.gov/of/1999/0440/.

Roberts, C.W., Kucks, R.P., and Hill, P.L., 2008, Oregon magnetic and gravity maps and data-A website for distribution of data: U.S. Geological Survey Data Series 355, accessed March 15, 2016, at http://pubs.usgs.gov/ ds $/ 355 /$.

Roest, W.R., Verhoef, J., and Pilkington, M., 1992, Magnetic interpretation using the 3-D analytic signal: Geophysics, v. 57 , p. $116-125$.

Salem, A., Williams, S., Fairhead, J.D., Ravat, D.J., and Smith, R., 2007, Tilt-depth method-A simple depth estimation method using first-order magnetic derivatives: The Leading Edge, p. 1502-1505. 
Saltus, R.W., and Jachens, R.C., 1995, Gravity and basin-depth maps of the Basin and Range Province, Western United States: U.S. Geological Survey Geophysical Investigation Map 1012, 1 pl., scale 1:2,500,000, accessed March 15, 2016, at http://pubs.er.usgs. gov/publication/gp1012/.

San Juan, C.A., Horton, J.D., Parks, H.L., Mihalasky, M.J., Anderson, E.D., Benson, M.E., Box, S.E., Cossette, P.M., Denning, P.D., Giles, S.A., Hall, S.M., Hayes, T.S., Hearn, B.C., Jr., Hofstra, A.H., John, D.A., Ludington, S., Lund, K., Mauk, J.L., Robinson, G.R., Jr., Rockwell, B.W., Rytuba, J.J., Smith, S.M., Stillings, L.L., Van Gosen, B.S., Vikre, P.G., Wallis, J.C., Wilson, A.B., Zientek, M.L., and Zürcher, L., 2016, Locatable mineral assessment tracts for the U.S. Geological Survey Sagebrush Mineral-Resource Assessment project: U.S. Geological Survey data release, http://dx.doi. org/10.5066/F7833Q4R.

Shives, R.B., Charbonneau, B.W., and Ford, K.L., 2000, The detection of potassic alteration by gamma-ray spectrometryrecognition of alteration related to mineralization: Geophysics, v. 65 , p. 2001-2011.
Simpson, R.W., Jachens, R.C., Saltus, R.W., and Blakely, R.J., 1986, Isostatic residual gravity, topographic, and first-verticalderivative gravity maps of the conterminous United States: U.S. Geological Survey Geophysical Map GP-975, 2 pl., scale $1: 1,750,000$.

Sims, P.K., O’Neill, J.M., Bankey, V., and Anderson, E.D., 2004, Precambrian basement geologic map of Montana-An interpretation of aeromagnetic anomalies: U.S. Geological Survey Scientific Investigations Map 2829, 1 sheet, scale 1:1,000,000, accessed March 15, 2016, at http://pubs.usgs. gov/sim/2004/2829/.

Stewart, J.H., and Carlson, J.E., 1978, Geologic map of Nevada: U.S. Geological Survey in cooperation with Nevada Bureau of Mines and Geology, 2 pl., scale $1: 500,000$.

Verduzco, B., Fairhead, J.D., Green, C.M., and MacKenzie, C., 2004, New insights into magnetic derivatives for structural mapping: The Leading Edge, v. 23, p. 116-119. 


\title{
Section E. Remote Sensing
}

\author{
By Barnaby W. Rockwell
}

The occurrence and mineralogy of exposed, hydrothermally altered rocks related to locatable mineralresource potential in the U.S. Geological Survey (USGS) Sagebrush Mineral-Resource Assessment (SaMiRA) project study areas were assessed using digital geospatial data derived from spectral analysis of satellite remote sensing data. Maps of alteration types and key mineral groups derived from automated analysis of Advanced Spaceborne Thermal Emission and Reflection Radiometer (ASTER) data were the most important source of surface mineralogical information (Rockwell, 2012). Maps of mineral groups derived from automated analysis of Landsat 7 Enhanced Thematic Mapper Plus $(\mathrm{ETM}+)$ data were used to verify occurrences of anomalous mineral concentrations observed using the ASTERderived maps, especially in areas with abundant dry vegetation that can complicate remote sensing-based mineral mapping, such as the northern Great Basin (Rockwell, 2013). In northern Nevada, maps of quartz and carbonate abundance derived from analysis of ASTER thermal infrared data were used to identify jasperoids associated with Carlin-type gold deposits and hydrothermal quartz in areas of potential epithermal gold-silver mineralization (Rockwell and Hofstra, 2008). The mineral maps used for the mineral-resource assessment are available through an online viewer and associated data services (Rockwell and others, 2015).

The maps of surficial mineralogy were not used as the sole criteria for defining permissive tracts in the mineralresource assessment but locally were used to refine the boundaries of tracts for epithermal gold-silver and intrusionrelated deposits for which hydrothermal alteration is an important characteristic of the deposit type. The areas defined by mapped occurrences of the "sericite and (or) smectite" mineral group from the ASTER-derived data exhibited high correlation with known bentonite claims, mines, and exposures of thin, light-colored, bentonite-bearing beds interpreted using aerial imagery within widespread shales of the Bearpaw Formation in the North-Central Montana Sagebrush Focal Area. As a result, the ASTER-derived data were used as an important criterion for the delineation of permissive tracts for bentonite in that study area. Strong hematitic alteration associated with sediment-hosted "roll front" uranium deposits, such as that mapped using both the ASTER and ETM+ data in sandstones on Red Rim, 21 kilometers southwest of Rawlins, Wyoming, is another example of an alterationrelated mineralogical signature used as an assessment criterion for a specific deposit type. Integration of various data types, including data of known mineral deposits, claims, permissive lithologic map units, airborne geophysics, regional geochemistry, and remote sensing typically yields higher confidence levels when defining permissive tracts, and the mineral maps derived from remote sensing play a key role in that process for certain deposit types.

\section{References Cited}

Rockwell, B.W., 2012, Description and validation of an automated methodology for mapping mineralogy, vegetation, and hydrothermal alteration type from ASTER satellite imagery with examples from the San Juan Mountains, Colorado: U.S. Geological Survey Scientific Investigations Map 3190, 35 p. pamphlet, 5 map sheets, scale 100,000, accessed March 15, 2016, at http://pubs.usgs. gov/sim $/ 3190 /$.

Rockwell, B.W., 2013, Automated mapping of mineral groups and green vegetation from Landsat Thematic Mapper imagery with an example from the San Juan Mountains, Colorado: U.S. Geological Survey Scientific Investigations Map 3252, 25 p. pamphlet, 1 map sheet, scale 325,000, accessed March 15, 2016, at http://pubs.usgs.gov/sim/3252/.

Rockwell, B.W., Bonham, L.C., and Giles, S.A., 2015, USGS national map of surficial mineralogy: U.S. Geological Survey Web site, accessed March 15, 2016, at http:// cmerwebmap.cr.usgs.gov/usminmap.html.

Rockwell, B.W., and Hofstra, A.H., 2008, Identification of quartz and carbonate minerals across northern Nevada using ASTER thermal infrared emissivity data-Implications for geologic mapping and mineral resource investigations in well-studied and frontier areas: Geosphere, v. 4, no. 1, p. 218-246, doi:10.1130/GES00126.1, accessed March 15, 2016, at http://geosphere.gsapubs.org/content/4/1/218. 



\title{
Section F. BLM Legacy Rehost System (LR2000)
}

\author{
By Connie L. Dicken and Carma San Juan
}

The Bureau of Land Management's (BLM) Legacy Rehost System, or LR2000, contains legal descriptions of BLM lands. LR2000 provides reports on BLM land- and mineral-use authorizations for oil, gas, and geothermal leasing, rights-of-ways, coal and other mineral development, land and mineral title, mining claims, withdrawals, classifications, and more on Federal lands or on Federal mineral estates (Bureau of Land Management, 2016).

The LR2000 database was queried for relevant data for the seven focal areas in the Western United States included in the Sagebrush Mineral-Resource Assessment (SaMiRA) project. The BLM compiled tabular queries and reports to generate data spreadsheets that were processed and delivered to U.S. Geological Survey (USGS) as spatial information; BLM reported an expected accuracy of 90 percent for the data provided (John Varner, BLM, written commun., 2016).

Spatial data were compiled by BLM and delivered to USGS on March 6, 2016, using the data extracted from LR2000 for the study area. The data included polygon feature classes and nonspatial tables in an Esri file geodatabase format to be used in a geographic information system (GIS). The database contained seven feature classes - coal, geothermal, mineral materials, mining claims, non-energy solid minerals, oil and gas, and notices and plans. Each feature class was comprised of a polygon file of Public Land Survey System (PLSS) sections and a nonspatial related table. The PLSS is used to describe and subdivide land in the United States. The PLSS is typically divided into 6-mile-square townships and those townships are then subdivided into 36 one-mile-square sections (U.S. Geological Survey, 2016).

To work with the data in a more simplified way, the related tables were merged with the spatial sections and processed so that the data could be easily queried. The processing required the creation of frequency tables for each feature class and removing duplicate entries. After the frequency tables were complete, those tables were joined with corresponding feature class based on a unique attribute. This process allowed the nonspatial tables to be connected with polygon sections in a one-to-one relation. The next step was to combine sections that contained the same unique case number, which was done by dissolving polygon section boundaries. This allowed users to visualize the data in a GIS, as well as define queries to show spatial distribution of the data. Status and number of mining claims, mineral leases, mineralmaterial sales sites, and surface-management (43 CFR 3809) authorizations were provided as summary tables for each focal area based on the processed LR2000 data. The processed LR2000 data for the SaMiRA project are available in a data release (Dicken and San Juan, 2016).

Each of the seven feature classes was used for the mineral-resource assessment. The following descriptions were provided by BLM for each dataset.

\section{Coal}

Nonrenewable energy.-The Mineral Leasing Act of 1920, as amended, and the Mineral Leasing Act for Acquired Lands of 1947, as amended, gives the BLM responsibility for coal leasing on approximately 570 million acres where the coal mineral estate is owned by the Federal Government. The surface estate of these lands could be controlled by BLM, the U.S. Forest Service, private landowners, State landowners, or other Federal agencies. Not all public lands are available for coal exploration or leasing. The purpose of the coal-screening part of the land-use planning process (43 CFR 3420.1-4) is to identify those Federal lands that are acceptable for further consideration for coal leasing and development.

\section{Geothermal}

Renewable energy.-Geothermal energy is the use of steam and hot water generated by heat from the Earth to perform work. Geothermal resources include (1) all products of geothermal processes, including indigenous steam, hot water, and hot brines; (2) steam and other gases, hot water, and hot brines resulting from water, gas, or other fluids artificially introduced into geothermal formations, heat or other associated energy found in geothermal formations, and any byproducts.

\section{Mineral Materials Disposal}

43 CFR 3600.-This law applies to disposal of sand, gravel, and other mineral and vegetative materials that are not subject to mineral leasing or location under the mining laws. Mineral materials means, but is not limited to, petrified wood and common varieties of sand, stone, gravel, pumice, pumicite, cinders, and clay. Mineral materials are some of our 
most basic natural resources, such as sand, gravel, dirt, and rock, used in every day building and other construction uses. These materials generally are bulky and have a low unit price.

\section{Mining Claims}

A mining claim on Federal land gives exclusive rights to develop the minerals under the claim beginning on the date the mining claim was located. Within a mining claim, the surface lands remain open to the public for other multiple uses. A mining claim is located in order to acquire the right to develop the mineral values in a specified area. Locating a mining claim requires a discovery of a valuable mineral.

\section{Non-Energy Solid Minerals}

The BLM leases certain solid minerals, such as phosphate, sodium, potassium, sulfur, gilsonite, or a hardrock mineral, on public and other Federal lands. The BLM can also lease these minerals on certain private lands, provided the mineral rights are owned by the Federal Government. Prospecting permits are issued under 43 CFR 3505 in areas where it is not known a mineral deposit exists. A prospecting permit provides the exclusive right to prospect and explore for leasable mineral deposits.

\section{Oil and Gas Leasing}

Leasable minerals include energy resources of coal, phosphate, oil, oil shale, and gas on the public domain as designated by the Mineral Leasing Act of 1920, as amended. An oil and gas lease grants the lessee the right to explore and drill for, extract, remove, and dispose of oil and gas deposits, except helium, that may be found in the leased lands.

\section{Notices and Plans (Surface Management)}

Surface-management notices and plans refers to all surface disturbing activity conducted under the General Mining Act of 1872 (30 U.S.C. 22-42), as amended, and the Federal Land Policy and Federal Land Policy and Management Act of 1976 (FLPMA; Pub. L. 94-579; 90 Stat. 2743), as well other laws. Notices and plans facilitate the administration of exploration, mining, and milling activities on the public lands, or interests in such lands, in order to prevent unnecessary or undue degradation of the lands.

\section{References Cited}

Bureau of Land Management, 2016, Bureau of Land Management's Land and Mineral Legacy Rehost 2000 System-LR2000: Bureau of Land Management Web site, accessed March 7, 2016, at http://www.blm.gov/lr2000/.

Dicken, C.L., and San Juan, Carma, 2016, Bureau of Land Management's Land and Mineral Legacy Rehost System (LR2000) mineral use cases for the Sagebrush MineralResource Assessment, Idaho, Montana, Nevada, Oregon, Utah, and Wyoming: U.S. Geological Survey data release, http://dx.doi.org/10.5066/F7RX996K.

U.S. Geological Survey, 2016, The National Map_The Public Land Survey System (PLSS): U.S. Geological Survey Web site, accessed April 28, 2016, at http://nationalmap.gov/ small_scale/a_plss.html. 


\title{
Section G. Previous Mineral-Resource Assessment Data Compilation
}

\author{
By Heather L. Parks, Michael L. Zientek, M. Christopher Jenkins, Cassandra K. Hennings, John C. Wallis, and \\ Duc M. Nguyen
}

For the Sagebrush Mineral-Resource Assessment (SaMiRA) project, mineral-potential maps from previous mineral-resource assessments that covered the project area were compiled into raster or vector geographic information system (GIS) databases. Georeferenced tract-map images from Bureau of Land Management (BLM) and U.S. Forest Service (USFS) wilderness study summary reports were used, along with multiple other mineral-potential reports that were done under the U.S. Geological Survey (USGS) Conterminous United States Mineral Assessment Program (CUSMAP) program and for USGS assessments of U.S. National Forests. In the previous studies, assessment results were described using different schemes. The BLM used "qualitative categorical," and others used the USGS "three-part form" (Singer and Menzie, 2010). For this compilation, we captured the information as presented but also standardized nomenclature when we could in Parks and others (2016).

We reviewed BLM and USFS wilderness study summary reports along with BLM Surface Management Agency GIS data to help locate the reports that covered the SaMiRA project areas. The USFS wilderness studies were summarized in USGS Professional Paper 1300 (Marsh and others, 1984). The BLM wilderness studies were summarized in unpublished reports for Montana and Wyoming and published reports for Idaho, Oregon, and Nevada (Diggles, 1991; U.S. Geological Survey Central Mineral Resources and U.S. Bureau of Mines Western Field Operations Center, 1989; Conrad, 1990). We did not locate a summary report for Utah but consulted the BLM Surface Management Agency's Special Public Purpose Withdrawal Areas GIS data to double check that there were no assessments covering the SaMiRA Utah areas (DOI-BLM, National Operations CenterDivision of Information Resource Management, 2016). Fifty-nine mineral potential reports covering the SaMiRA project areas were located, and 134 mineral potential maps shown in these reports were either extracted from report .pdf files or scanned and then georeferenced using ArcGIS. The georeferenced images were imported into four ArcGIS raster mosaic datasets, one for each of the four report areasMT.gdb, NC_IDAHO.gdb, NV_ID_OR.gdb, and WY.gdb. The $M T . g d b$ raster mosaic dataset contained 7 georeferenced images, $N V$ ID_OR.gdb contained 66 georeferenced images, $N C \_I D A H O . g d b$ contained 60 georeferenced images, and the $W Y . g d b$ contained 1 georeferenced image.

When viewed in ArcMap, the raster mosaic dataset appears as a group of three layers under the mosaic dataset. The first item in the group is the "Boundary," which contains a single polygon representing the extent of all images in the dataset. The second item is the "Footprint," which contains a polygon representing the extent of each individual image in the dataset. The "Footprint" layer also contains the attribute-table data associated with each of the images. The third item is the "Image" layer and contains the images in the dataset. The images are overlapping and must be selected and locked or queried in order to be viewed one at a time. To select and lock an image, rightclick on the "Footprint" layer in the table of contents window and hover over "Selection," then click "Lock To Selected Rasters." Another way to view a single image is to run a definition query on the image. This is done by right clicking on the raster mosaic in the table of contents and opening the layer properties box. Then click on the "Definition Query" tab and create a query for the desired image.

The images were clipped to the extent of the map and all explanatory text gathered from map explanations or report text was imported into the raster mosaic dataset database as attributes. The data compiled into the attribute tables contained the figure caption from the original map. In addition, the images were catalogued according the legal definition of mineral resources - metallic, nonmetallic, leasable non-fuel, leasable fuel, geothermal, paleontological, and salable. This allows users to view the image along with information about the images without the need for referring back to the source report.

Some previous mineral-resource assessments were available in vector GIS format. We searched for reports covering the SaMiRA project area and compiled the GIS vector data. The original data was both in ArcInfo coverage and shapefile format. The coverages were converted to shapefiles, and then these and the other shapefiles were imported into ArcGIS geodatabases. Table G1 lists the geodatabases and reports used in the compilation. 
Table G1. Geodatabases containing mineral-resource assessment geographic information system (GIS) data that covered the Sagebrush Mineral-Resource Assessment (SaMiRA) study areas compiled from preexisting reports.

[USGS, U.S. Geological Survey]

\begin{tabular}{|c|c|c|}
\hline Geodatabase name & Source report number and title & Reference \\
\hline IdOr_USGSar2016_MJA_Asmt.gdb & USGS unpublished data, Oregon and Idaho & James Evans, USGS, written commun., 1999 \\
\hline Nv_USGSofr2004-1245_2004_Asmt.gdb & $\begin{array}{l}\text { USGS Open-File Report 04-1245: Spatial databases } \\
\text { of the Humboldt Basin mineral-resource } \\
\text { assessment, northern Nevada }\end{array}$ & Mihalasky and Moyer, 2004 \\
\hline $\begin{array}{l}\text { US_USGSc1178_2000_and_PacNW_ } \\
\text { USGSofr682_1996_Asmt.gdb }\end{array}$ & $\begin{array}{l}\text { USGS Open-File Report 95-682: Assessment of } \\
\text { undiscovered mineral resources in the Pacific } \\
\text { Northwest-A contribution to the Interior } \\
\text { Columbia Basin Ecosystem Management Project }\end{array}$ & Box and others, 1996 \\
\hline
\end{tabular}

The original GIS data had varying data structures, and therefore, we reformatted the data so that all of the GIS files had a consistent attribute-table structure. We referred to the report text in some instances to fill in missing data into the attribute tables. We used two basic attributetable structures - one for reports that had quantitative data and one for reports with qualitative data. We set up a general attribute table structure, which contained fields for information on the deposit type assessed, assessment rank, type of assessment, and tract name and identifier. For the attribute table of the quantitatively assessed reports that used the USGS three-part form of assessment, we added additional fields for the deposit model name and number, probabilistic assessment results data, and estimators.

These results were crucial in defining what deposit types needed to be assessed for this project. The deposit types assessed were compiled and distributed to all assessment teams as part of the evaluation of what expertise and data would be needed. This compilation helped to determine what deposit models needed to be developed (appendix 3). Assessment teams used the results to guide mineral-potential assessment. Assessment Oversight Committee (AOC) members used the compilation to assess the work done by the assessment teams.

\section{References Cited}

Box, S.E., Bookstrom, A.A., Zientek, M.L., Derkey, P.D., Ashley, R.P., Elliott, J.E., and Peters, S.G., 1996, Assessment of undiscovered mineral resources in the Pacific Northwest-A contribution to the Interior Columbia Basin Ecosystem Management Project: U.S. Geological Survey Open-File Report 95-682, 432 p., and GIS data, also available at http://pubs.usgs. gov/of/1995/of95-682/.

Carlson, M.H., Zientek, M.L., Causey, J.D., Kayser, H.Z., Spanski, G.T., Wilson, A.B., Van Gosen, B.S., and Trautwein, C.M., 2007, A compilation of spatial digital databases for selected U.S. Geological Survey nonfuel mineral resource assessments for parts of Idaho and Montana: U.S. Geological Survey Open-File Report 2007-1101, v. 1.0, 34 p., and GIS data, also available at $h t t p: / / p u b s . u s g s . g o v / o f / 2007 / 1101 /$.

Conrad, J.E., ed., 1990, Mineral summaries for Nevada — U.S. Bureau of Land Management wilderness study areas: U.S. Geological Survey Open-File Report 90-638, 373 p.

Diggles, M.F., ed., 1991, Mineral summaries for Oregon-U.S. Bureau of Land Management wilderness study areas: U.S. Geological Survey Open-File Report 91-139, 298 p. 
DOI-BLM, National Operations Center-Division of Information Resource Management, 2016, Surface Management Agency (Special Public PurposeWithdrawal Areas): Bureau of Land Management Geocommunicator Web page, accessed May 11, 2016, at http://www.geocommunicator.gov/ArcGIS/rest/services/ SurfaceManagementAgency/MapServer.

Marsh, S.P., Kropschot, S.J., and Dickinson, R.G., eds., 1984, Wilderness mineral potential-Assessment of mineralresource potential in U.S. Forest Service lands studied 1964-1984: U.S. Geological Survey Professional Paper 1300, v. 2, p. 552-1183.

Mihalasky, M.J., and Moyer, L.A., 2004, Spatial databases of the Humboldt Basin mineral resource assessment, northern Nevada: U.S. Geological Survey Open-File Report 20041245, 17 p., and GIS data, also available at http://pubs.usgs. gov/of/2004/1245/.

Parks, H.L., Zientek, M.L., Jenkins, M.C., Hennings, C.K., Wallis, J.C., Nguyen, D.M., and Cossette, P.M., 2016, Previous mineral-resource assessment data compilation for the U.S. Geological Survey Sagebrush Mineral-Resource Assessment project: U.S. Geological Survey data release, http://dx.doi.org/10.5066/F7736P0C.
Peters, S.G., Nash, J.T., John, D.A., Spanski, G.T., King, H.D., Connors, K.A., Moring, B.C., Doebrich, J.L., McGuire, D.J., Albino, G.V., Dunn, V.C., Theodore, T.G., and Ludington, S.D., 1996, Metallic mineral resources in the U.S. Bureau of Land Management's Winnemucca District and Surprise Resource Area, northwest Nevada and northeast California: U.S. Geological Survey OpenFile Report 96-712, 146 p., and 11 plates, also available at http://pubs.er.usgs.gov/publication/ofr96712.

Singer, D.A., and Menzie, W.D., 2010, Quantitative mineral resource assessments-An integrated approach: New York, Oxford University Press, 219 p.

U.S. Geological Survey Central Mineral Resources and U.S. Bureau of Mines Western Field Operations Center, 1989, Mineral summaries, Bureau of Land Management wilderness study areas, Idaho: Bureau of Land Management, Idaho Briefing Book, 187 p.

U.S. Geological Survey National Mineral Resource Assessment Team, 1998, Assessment of undiscovered deposits of gold, silver, copper, lead, and zinc in the United States: U.S. Geological Survey Circular 1178, 22 p., and GIS data. [Also available at http://pubs.usgs.gov/circ/ c1178/.] 



\title{
Section H. Mineral-Resource Assessment for Locatable Minerals
}

\author{
By Jane M. Hammarstrom and Michael L. Zientek
}

\section{Introduction}

The objective of this project is to provide a description of mineral potential of the Sagebrush Focal Areas (SFAs) evaluated in the Sagebrush Mineral-Resource Assessment (SaMiRA) project in narrative form and on maps that can be used by others to evaluate reasonably foreseeable development in the study area. For this study, the assessment of mineral potential is required only for locatable minerals. Leasable and salable minerals are discussed in the reports prepared for the focal areas, but their potential was not evaluated.

Bureau of Land Management (BLM) focal areas in Montana, Wyoming and Utah, central Idaho, and the Oregon-Nevada-Idaho area were assessed by four different teams, each of whom produced an assessment report for their region. Each team (1) identified the possible mineral-deposit types for locatable commodities that could be present within the focal areas identified by the BLM for possible withdrawal from future mineral activity, (2) outlined those areas that could contain different types of mineral deposits on the basis of geology and other publically available data, and (3) evaluated the level of mineral-resource potential and level of certainty associated with the outlined areas using BLM assessment categories. In this study, areas that have potential for one or more types of mineral deposits are called mineral-resource tracts.

\section{A Geologically Based Assessment Approach}

The potential for mineral resources is a prediction of the likelihood of the occurrence of these resources. The specific form of the assessment qualitatively classifies mineral potential into categories based on the level of potential and the level of certainty as specified in BLM Manual Sections 3031 and 3060. The level of potential is based on favorable geologic environment, inferred geological processes, mineral occurrences, and other evidential data such as geochemistry and geophysics. The level of certainty is based on the amount of direct and indirect evidence to support the interpretation of the level of potential. For this study, a geologically based assessment method used the interrelated concepts of mineraldeposit types and mineral systems to evaluate mineral-resource potential. Models based on these concepts provide a predictive capability largely based on analogy with well-characterized mineral deposits and research on geologic processes of ore formation.

In this study, we report mineral potential by deposit type, rather than commodity, to facilitate the evaluation of reasonably foreseeable development. We use our understanding of geologic processes to define favorable geologic environments and elevated mineral potential. This assessment addresses the potential for deposits that may occur within the upper 1 kilometer $(\mathrm{km})$ of the Earth's surface. Exploration and development of deeper-seated deposits is technically feasible but extremely costly.

\section{Mineral-Deposit Types and Models}

A mineral deposit is a mineral concentration of sufficient size and quality that it might, under the most favorable of circumstances, be considered to have potential for economic development. Most mineral commodities occur in a variety of different types of mineral deposits. Gold, for example, occurs in surficial concentrations as placer deposits, in some volcanic environments as epithermal vein deposits, in metamorphic terrains as orogenic gold deposits, and as a coproduct in porphyry copper deposits that form in shallowly emplaced igneous intrusions.

Mineral deposits that share characteristics, in terms of how they form, their inherent value (tonnage and grade), the mining and beneficiation methods that can be used to develop them, and the remediation that must be done to minimize environmental impacts of mining are grouped into types. Mineral-deposit models are descriptive summaries of mineral-deposit types, used primarily for classifying occurrences into types but also for providing descriptive information on the favorable geologic setting.

Mineral-deposit models describe the essential attributes of each types of mineral deposit (Cox and others, 1986). The function of the model is to provide the geologist with information that they can interpret and use to discriminate (1) possible mineralized environments from barren environments and (2) types of known deposits from each other. Within the Bureau of Land Management (BLM), mineral-deposit models are used for resource assessment to classify land as to its potential for mineral and energy resources (Fisher and Juilland, 1986).

Descriptive mineral-deposit models such as the U.S. Geological Survey (USGS) models of Cox and Singer (1986) and the BLM models compiled by Fisher and Juilland (1986) list characteristics of the geologic environments in which the deposits are found and identifying characteristics of deposits. The deposit description includes information on host rocks, mineralogy, alteration, and geochemical and geophysical anomalies that are used by the assessment geologists to recognize the deposit type and to discriminate one deposit type from another. Mineral-deposit models compiled for the SFAs are included as appendix 3 . 


\section{Mineral Systems}

Individual mineral deposits can be small parts of much larger mineralizing systems. For example, porphyry copper deposits, associated skarns, polymetallic veins, and epithermal precious-metal veins can all be reflections of a hydrothermal system associated with plutonic rocks (fig. H1). Similarly, sediment-hosted copper deposits and Mississippi-Valley-type zinc-lead-silver deposits are associated with regional fluid flow involving basinal brines in areas that lack active magmatism.

Knowledge of processes that control where mineral deposits form at regional and local scales is used to describe favorable geologic environments and can be expressed by mineral systems models. These models differ from simply descriptive models of mineral-deposit types, because they explicitly integrate research on geologic process. Commonly, mineral system models use "source-transport-trap" as a way to summarize information (Magoon and Dow, 1994; Wyborn and others, 1994; Magoon and Schmoker, 2000), but any model that summarizes a processbased understanding could be used. Mineral system models were developed for exploration targeting and mineral potential mapping.

Mineral-system models use components and processes to organize ideas about how different mineral-deposit types form. For example, hydrothermal mineral deposits can be understood by

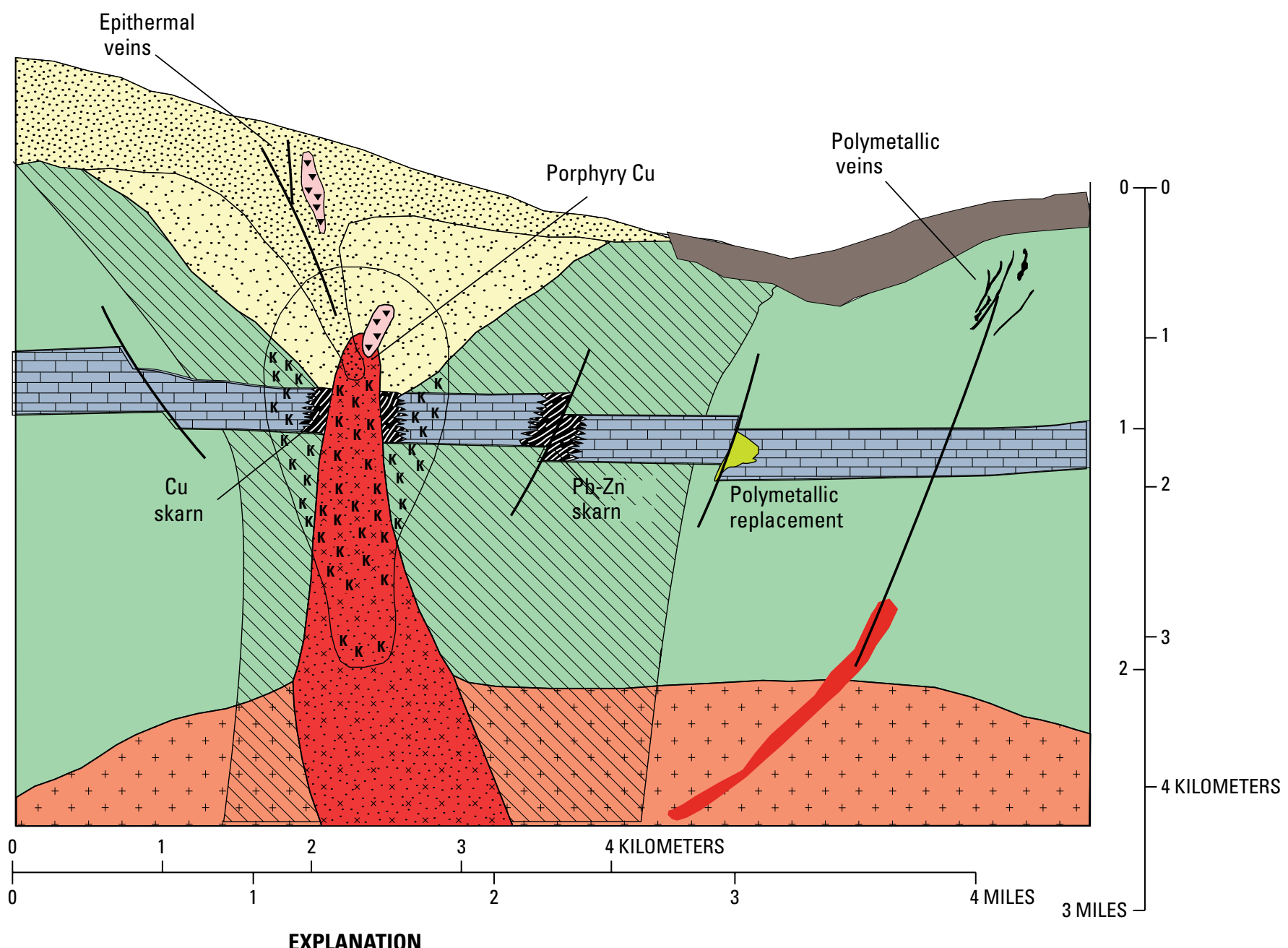

EXPLANATION

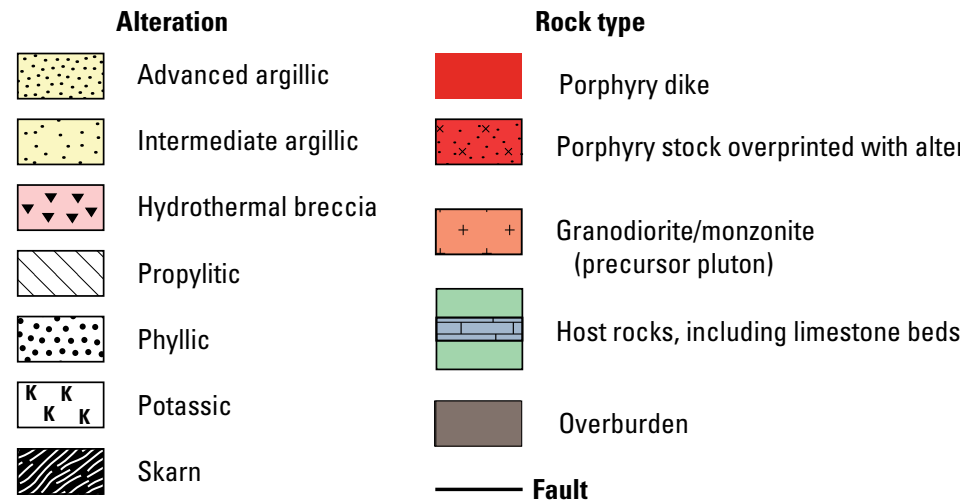

Figure H1. Illustration of a schematic cross section of possible deposit types associated with a hydrothermal-plutonic rock associated system. 
considering the source of the ore-forming fluid, its physical and chemical character, the mechanisms for dissolving and transporting ore-forming components, and the causes of precipitation from it (Skinner and Barton, 1973). Sites where appropriate combinations of structural, chemical, and physical conditions that force oremineral precipitation reactions are called ore traps (Reed, 1997). The deposition of ore minerals will not occur unless all the essential components are present and processes occur in the correct sequence and location (Magoon and Dow, 1994; Kreuzer and others, 2008; McCuaig and others, 2010).

Mineral systems models serve two functions in mineralresource assessments. All components and processes that relate to mineral-deposit type can be systematically evaluated to identify areas where a mineral-forming system could be present. Another function of these models is to use the components and processes of the mineral-system model to define the assessment unit in areas where the existence of a mineral-forming system is known from the presence of deposits and prospects.

The types of mineral deposits that may occur within the focal areas are grouped in mineral systems associated with magmatic, hydrothermal, sedimentary, or surficial geologic processes (table H1). Within a given mineral system, a variety of different types of deposits can form. The occurrence of porphyry copper deposits for example, suggests that the hydrothermal-plutonic mineral system may have also formed skarns or replacement deposits or other deposit types where metals are transported in magmatic fluids interacting with meteoric water in a plutonic setting. The mineral-system concept provides a framework for considering what could occur in a given setting.

Table H1. Relation between classes of mineral deposits, mineral systems, and mineral-deposit types with locatable commodities used in the Sagebrush Mineral-Resource Assessment (SaMiRA) project.

[Systems represent a subjective classification of deposit types adopted for SaMiRA to group deposit types that share some broad genetic characteristics or processes of formation. Note that some of the models listed in appendix 3 cover multiple deposit types, such as hectorite and specialty clay. In addition, some mineral-resource tracts were developed for multiple deposit types, such as both porphyry copper and copper skarn. SEDEX, sedimentary exhalative deposits]

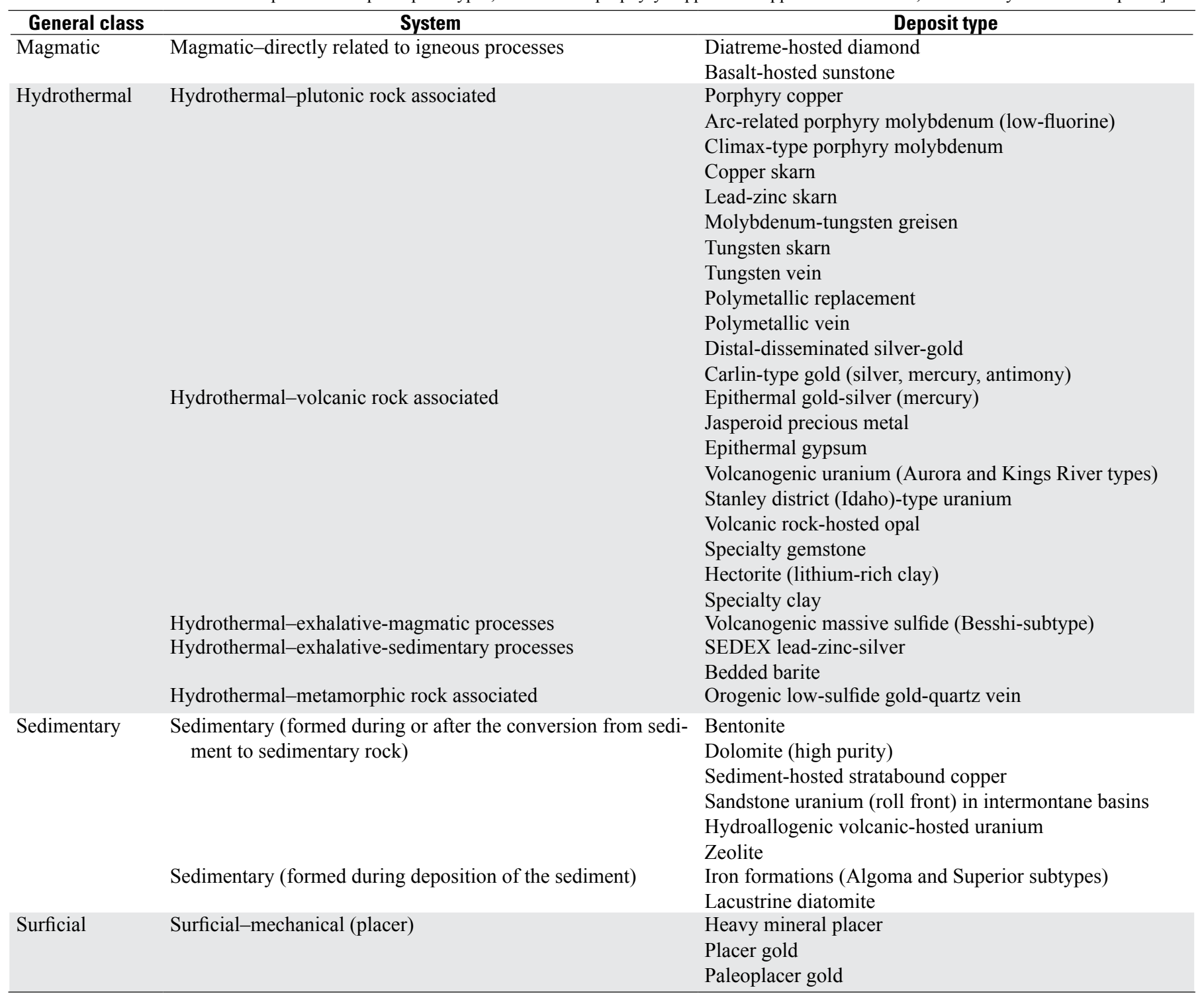




\section{Map Scale and Resolution}

We assume that the scale at which the data are needed is about $1: 100,000$ to $1: 250,000$. For a given scale, the minimum map unit is the size in map units below which a narrow feature can be reasonably represented by a line and an area by a point. USGS map standards state that the minimum polygon size on maps is about 1 square millimeter $\left(\mathrm{mm}^{2}\right)$ (GDS-FGDC, 2006). For 1:100,000-scale maps, $1 \mathrm{~mm}^{2}$ corresponds to 0.01 square kilometer $\left(\mathrm{km}^{2}\right)\left(10,000\right.$ square meters, $\left.\mathrm{m}^{2}\right)$. For 1:250,000scale maps, $1 \mathrm{~mm}^{2}$ corresponds to $0.063 \mathrm{~km}^{2}\left(62,500 \mathrm{~m}^{2}\right)$. The acceptable error for USGS maps is about 1/50th of an inch (U.S. Geological Survey, 1999), which corresponds to 50 meters (m) for 1:100,000-scale maps and $100 \mathrm{~m}$ for 1:250,000-scale maps.

In 1987, Waldo Tobler, analytical cartographer (now emeritus from University of California-Santa Barbara) wrote, "The rule is: divide the denominator of the map scale by 1,000 to get the detectable size in meters. The resolution is one half of this amount" (Nagi, 2010). This rule is a useful guide to keep in mind when applying geographic information system (GIS) tools in assessment (table $\mathrm{H} 2$ ).

Table H2. Guide to map scale, detectable size of a map feature, and resolution.

\begin{tabular}{ccc}
\hline $\begin{array}{c}\text { Map } \\
\text { scale }\end{array}$ & $\begin{array}{c}\text { Detectable size, in } \\
\text { meters }\end{array}$ & $\begin{array}{c}\text { Raster resolution, in } \\
\text { meters }\end{array}$ \\
\hline $1: 100,000$ & 100 & 50 \\
$1: 250,000$ & 250 & 125 \\
\hline
\end{tabular}

\section{Assessment Process}

The focal area assessment teams followed a number of steps or procedures to conduct the assessment of mineral potential. In general, the steps were:

1. Work with project managers to understand the scope of work and the anticipated end use of the assessment. This started with a project meeting in December 2015 and continued throughout the course of the assessment work.

2. Determine which mineral-deposit types and commodities need to be assessed and make sure appropriate models are available. This was done by using the expertise of USGS scientists who have worked in the study areas and by reviewing results of previous mineral-resource investigations and assessments in the study area.

3. Gather and compile data such as geology, mineral occurrences, mineral exploration, rock alteration inferred from satellite imagery, soil and stream-sediment geochemistry, and potential-field geophysics. Many of the datasets used for these assessments are described in other sections of this report.
4. Enhance existing datasets as needed from larger scale geologic maps and geological literature.

5. Construct preliminary maps showing areas with mineral potential

6. Conduct a workshop to revise the preliminary maps and assign levels of mineral potential and certainty. In most cases, representatives from State geological surveys were observers or participants at the workshops.

7. Present results of the assessment to an evaluation panel.

8. Prepare report for technical review.

Before each workshop, the assessment teams developed a list of possible mineral-deposit types and commodities to consider, classified known deposits and prospects in terms of deposit type, and identified mineral-deposit models needed to conduct the assessment. The assessment teams evaluated available data and developed preliminary mineral-resource tracts.

At the workshops, the teams refined the tracts and assigned a mineral potential and level of certainty to each tract. The tracts were compared to compilations that summarized the level of mineral activity as indicated by authorized and closed mining claims, surface-management notices and plans, and a compilation of active exploration areas from literature. The rationale for tract delineation and the classification potential and certainty were recorded and summarized in a tabular format (table H3).

Following each workshop, the mineral-potential tracts were refined, and any unresolved issues identified during the assessment workshops were addressed. Each focal area team prepared a presentation for an evaluation panel composed of five scientists who were not directly involved in the assessment of the focal area. The selection of mineral-deposit models, rationale for mineral-resource tracts, and classification of mineral potential for locatable commodities were evaluated by the panel and comments were communicated to the assessment team prior to final report preparation. The panel also evaluated the information presented for leasable and salable commodities. This evaluation process provided a check on consistency in applying the assessment criteria throughout the focal areas.

\section{Mineral-Resource Tracts}

According to BLM guidelines, when known geologic conditions in an area fit a model, they define a "favorable geologic environment." Mineral-resource specialists determine favorable geologic environments by integrating and assessing different lines of evidence (Bureau of Land Management, 1985):

A. Favorable rocks (lithostratigraphic suitability).

B. Favorable geologic structure (faults, folds, and other structural features). 
Table H3. Example data table for a mineral-resource tract used in the Sagebrush Mineral-Resource Assessment (SaMiRA) project.

[BLM, Bureau of Land Management; MRDS, Mineral Resources Data System; USMIN, U.S. Geological Survey Mineral Deposit Database project; PLSS, Public Land Survey System; ASTER, Advanced Spaceborne Thermal Emission and Reflection Radiometer]

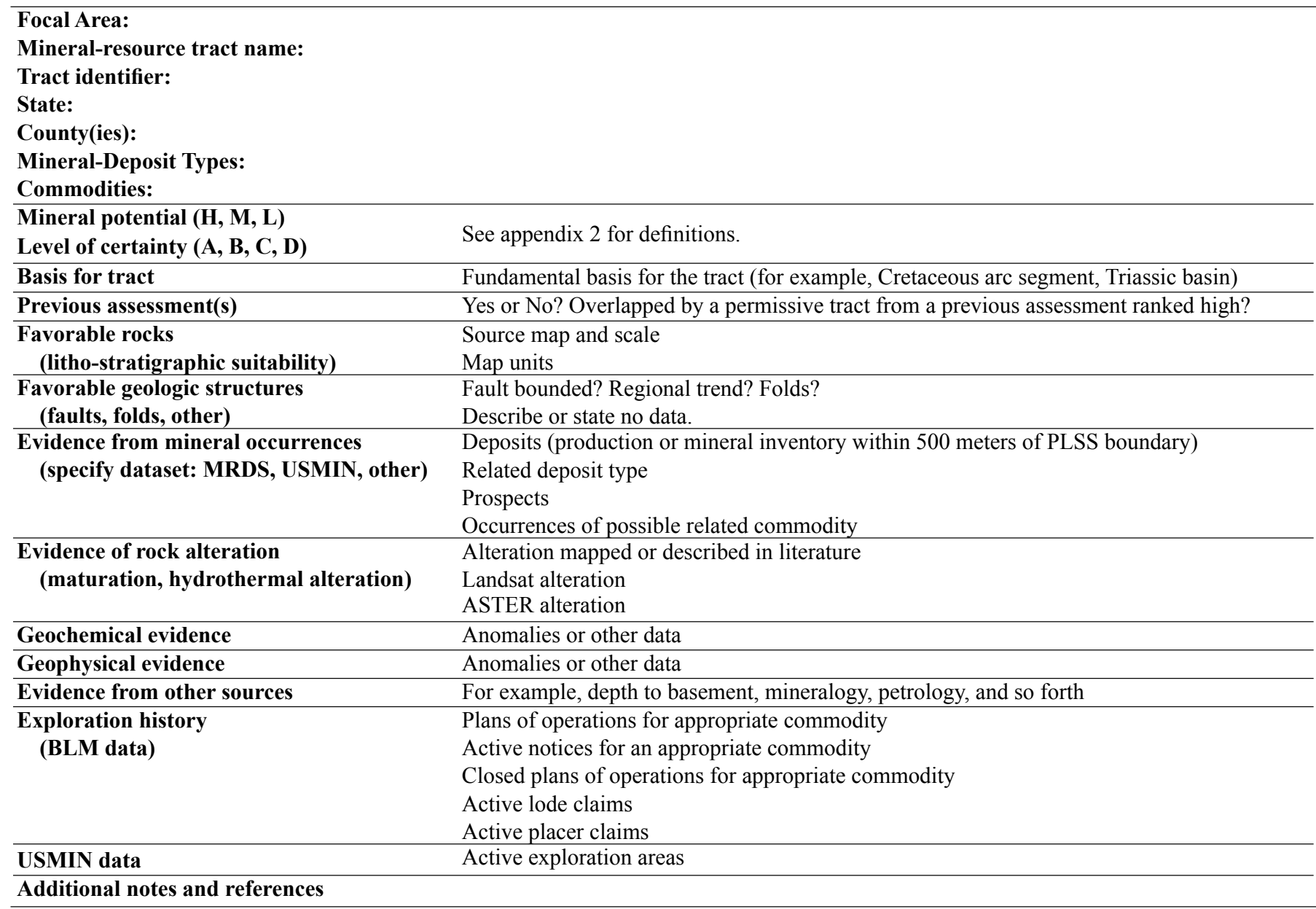

C. Evidence of rock alteration (maturation, hydrothermal alteration).

D. Geochemical evidence (anomalies).

E. Geophysical evidence (anomalies).

F. Evidence from mineral occurrences.

G. Evidence from other sources (depth to basement, mineralogy, and so forth).

Mineral-resource tracts were constructed by identifying the appropriate geological environments and the deposit types likely to occur in each focal area (see table $\mathrm{H} 4$ for an example). When data and time permit, computational techniques can be used to map mineral potential by combining digital files for the different types of evidence as listed above. For this study, a single computational approach was not possible, given the quality of the data and the diversity of deposit types and mineral systems that were present. The areal extent of a particular mineralresource tract varies by mineral system and by deposit type. Experts determined what data and approach was best suited to map areas with mineral potential. In the following sections, we give some examples of how mineral potential was mapped. Specific descriptions are included with each focal area report.

A mineral-resource tract for a hydrothermal mineral system associated with plutonic rocks, for example, could contain porphyry deposits, as well as associated deposit types such as skarn and replacement deposits in carbonate rocks, polymetallic veins, and distal disseminated deposits. In some cases, mineralresource tracts for one deposit type are coincident with tracts for other deposit types. However, the mineral potential and uncertainty are assigned by deposit type. Shallow-level magmatic rocks formed at convergent tectonic-plate margins are indicative of the favorable environment for porphyry copper deposits. For some deposit types, criteria were established by defining very specific lithologies. Skarns, for example, typically form at the contact of limestone with a calcalkaline pluton. For polymetallic 
Table H4. Example of mineral-resource tract criteria used in the Sagebrush Mineral-Resource Assessment (SaMiRA) project for Carlin-type gold deposits in the Southeastern Oregon and North-Central Nevada, Southern Idaho and Northern Nevada, and SheldonHart Mountain National Wildlife Refuge Complex of Oregon Sagebrush Focal Areas (SFAs; see section A, fig. A1).

$[\mathrm{km}$, kilometer $]$

Necessary criteria for a mineral-resource tract

1. Areas underlain by continental crust and subcontinental lithospheric mantle (for example, east of the initial strontium 0.706 crustal discontinuity).

2. Areas within the limits of the southward sweeping Eocene calcalkaline magmatic arc.

3. Cambrian to Permian marine calcareous or dolomitic sedimentary rocks deposited along the western margin of the United States in slope, shelf, foreland basin, and overlap settings, as well as rocks of the Havallah Basin. The largest deposits are in Ordovician, Silurian, and Devonian slope facies near the platform margin below the Roberts Mountains allochthon. Nevada border map units: PzMzs, Pzrm, Pzh. State of Nevada map units include Nolan, Basin, Slope, Shelf, Foreland, Overlap, and Golconda.

4. Aforementioned sedimentary host rocks are within $1 \mathrm{~km}$ of present surface. In other words less than $1 \mathrm{~km}$ of sedimentary, volcanic, or alluvial cover.

veins to form, structural controls such as faults are more important than host rock because the structures provide hydrothermal fluid transport pathways through a variety of rock types.

In addition to permissive geology for the deposit type, the tract is drawn to include any direct evidence of mineral occurrences, such as deposits that have a defined resource, active exploration projects for the deposit type, and (or) BLM permits, as well as indirect evidence, such as geochemical anomalies, mineral showings of a commodity that could be related to the deposit type, and (or) alteration (fig. H2). Mineral occurrences include mineral deposits, mineral prospects, and mineral showings. Table H5 lists the criteria used to assign mineraloccurrence data to one of these three categories. The essential distinction between a deposit and a prospect is that a deposit has a formal mineral inventory (table H6). The nature and density of mineral occurrences, the nature and density of alteration appropriate for the deposit type, and the level of exploration and mining activity indicated by BLM permits and claims were also considered in delineating the extent, potential, and level of certainty associated with each tract. A mineral-resource tract may or may not contain known deposits or prospects.

In some cases, a geologic structure such as a fault provided a tract boundary. Geophysical data (chapter $\mathrm{C}$ ) provided guidance on areas where shallow buried plutons might exist or areas of thick basin cover ( $>1 \mathrm{~km})$ are present. Although deposits can occur at greater depth, this assessment only considered the mineral potential within the upper $1 \mathrm{~km}$ of the surface.

A number of tools are available for processing data to facilitate making mineral-resource tracts. These include the application of buffer distances around known deposits or particular map units and using geospatial tools to examine the density of mineral occurrences. These tools, used in conjunction with the other available data, aid the delineation of the spatial extent of mineral-resource tracts, as described in the focal area reports. The mineral-resource tracts for locatable minerals for the SaMiRA project are provided in a data release of spatial data (San Juan and others, 2016). Mineral potential and level of certainty are included in the tract attributes.

\section{Buffers}

The geoprocessing buffer tool in ArcGIS can be used to simplify complex shapes, address cartographic uncertainty, approximate the size of a feature that is not mapped, and (or) determine an appropriate search radius for adjacent deposits. Buffering was used by most of the assessment teams. Most of the geologic-map databases used in the assessment combine geologic bedrock and surficial geologic units. If a favorable geologic unit is selected from the database, the polygon commonly has a complex shape because of intersecting surficial geologic units. Buffering can be used to fill in areas underlain by alluvium to make a polygon that more closely represents the bedrock extent of the permissive unit.

Buffering was also used to approximate the extent of hydrothermal alterations systems that are associated with hydrothermal deposit types. Hydrothermal mineral deposits are the most common mineral-deposit types, but direct evidence of the areal extent of hydrothermal alteration is almost never shown on regional-scale (1:100,000-1:250,000) geologic maps. For some hydrothermal mineral deposits, the sizes of areas underlain by mineralized or altered rock have been compiled and summary statistics can be calculated. For example, these data have been compiled for porphyry copper deposits (Singer and others, 2008), polymetallic veins (Bliss, 1994), and sediment-hosted gold deposits (Berger and others, 2014). Using the information compiled for these systems, a buffer radius was selected and applied to data points that provided direct evidence for the presence of a hydrothermal mineral occurrence (of a given type).

Depending on the scale of available geologic maps, deposit type, and the occurrence of unexposed mineral deposits, the presence of a mineral system may not always be readily inferred from a geologic map. In such cases, the mapped mineral occurrences can serve as the primary sampling method for delineating the extent of a mineral-resource tract. The approximate diameter of well-exposed pluton-related hydrothermal systems ranges from just a few hundred meters to tens of kilometers 

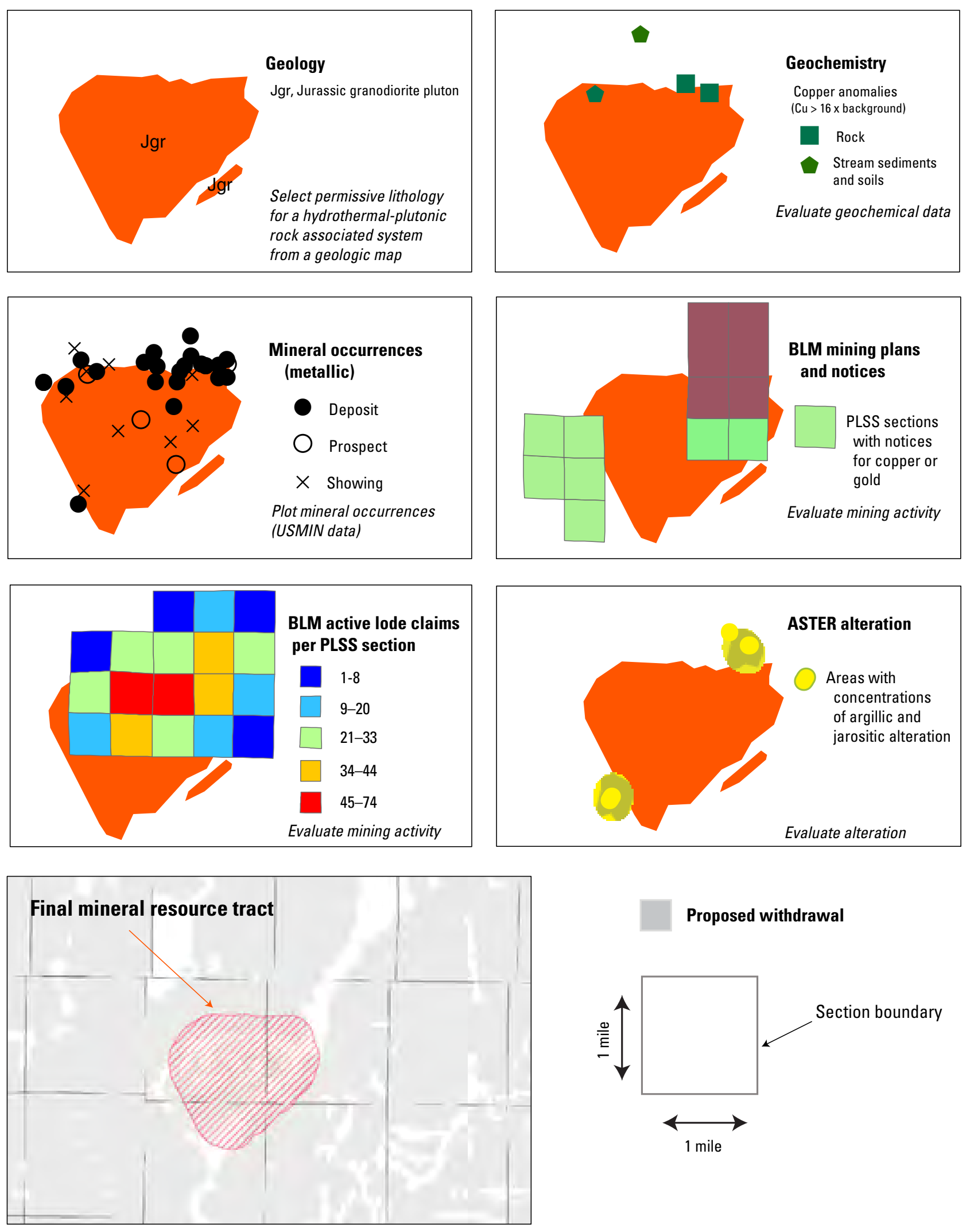

\section{Proposed withdrawal}

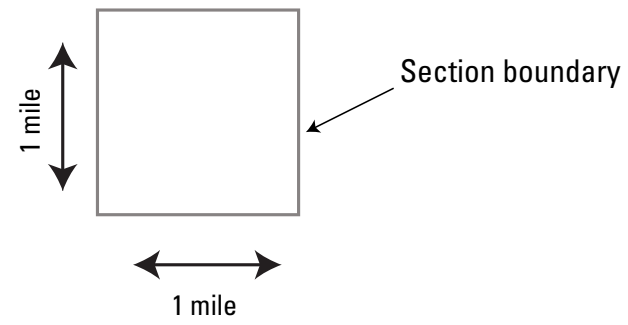

Figure H2. Illustration showing an example of datasets used to develop a mineral-resource tract for porphyry copper and skarn deposits. The final tract outline encompasses the permissive map unit, the mineral occurrences, alteration, and areas of exploration interest based on Bureau of Land Management (BLM) records. PLSS, Public Land Survey System; ASTER, Advanced Spaceborne Thermal Emission and Reflection Radiometer; USMIN, U.S. Geological Survey Mineral Deposit Database. 
Table H5. Relations among mineral occurrences, deposits, prospects, and showings used in the Sagebrush Mineral-Resource Assessment (SaMiRA) project.

\begin{tabular}{|c|c|c|c|}
\hline Name & Name & Criteria & Notes \\
\hline \multirow[t]{3}{*}{$\begin{array}{l}\text { Mineral } \\
\text { occurrence }\end{array}$} & $\begin{array}{l}\text { Mineral } \\
\text { deposit }\end{array}$ & $\begin{array}{l}\text { Has a formally defined (drill-indicated) mineral-resource estimate; does not } \\
\text { need to be economic (include sites with resources, as well as reserves) }\end{array}$ & $\begin{array}{l}\text { May be able to categorize by } \\
\text { deposit type }\end{array}$ \\
\hline & $\begin{array}{l}\text { Mineral } \\
\text { prospect }\end{array}$ & Significant exploration site; drilling; plan-of-operation & $\begin{array}{l}\text { May be able to categorize by } \\
\text { deposit type }\end{array}$ \\
\hline & $\begin{array}{l}\text { Mineral } \\
\text { showing }\end{array}$ & Exploration target; minor occurrence & $\begin{array}{l}\text { May only know commodities } \\
\text { present }\end{array}$ \\
\hline
\end{tabular}

Table H6. Sources of information for classifying mineral occurrences as deposits or prospects used in the Sagebrush MineralResource Assessment (SaMiRA) project.

[BLM, Bureau of Land Management; USFS, U.S. Forest Service; NI, National Instrument]

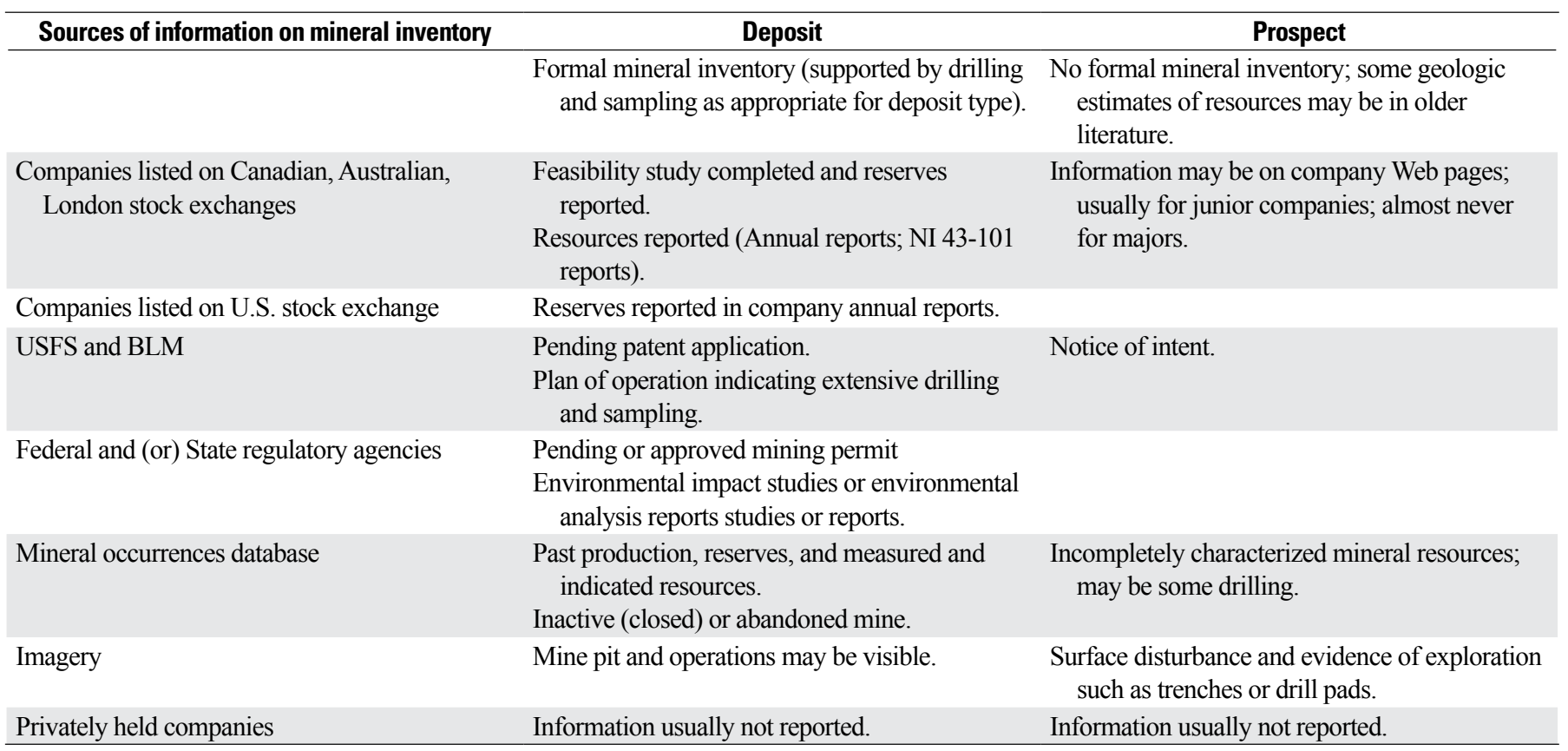

(Sillitoe, 2010). The maximum radius that would be appropriate to depict the uncertainty in the location of a hidden or unmapped part of a mineral system related to a sampling point (mineral occurrence) that encounters the system would be half that distance (probably less than $10 \mathrm{~km}$ ). The footprint of porphyry copper systems, the archetype of pluton-related systems, for example, was documented by Berger and others (2008). The median radius for those systems is about $5 \mathrm{~km}$, and the 90th percentile is about $2.6 \mathrm{~km}$ (table H7). These data represent minimum sizes, because parts of many porphyry systems are covered. Thus, about $3 \mathrm{~km}$ may serve as an appropriate buffer radius around a porphyry-type mineral occurrence as a tool for developing mineral-resource tracts for porphyry copper deposits.

The polygons created by buffering the mineral occurrence points formed the basis for many of the mineral-potential tracts in some reports. What buffer radius should be used to approximate the size of a hydrothermal system for a known mineral-occurrence point? Histograms of available data show that alteration areas are right skewed for a given deposit type (similar to tonnage values). Some assessors wanted to use a buffer radius that would approximate the maximum size of an alteration area; others argued that the buffer radius should be closer to the mean or median value. The recommended radius is based on the 90th percentile (table H7).

Users of the mineral-resource tracts should consult the tract descriptions in the SaMiRA reports for each SFA to understand the rationale for the buffer radius, the value that was used (maximum, mean, or other), and how it was applied (to data points corresponding to a mineral occurrence of a given deposit type). 
Table H7. Summary statistics for the areal extent of mineralized rock and alterations systems associated with various deposit types and suggested buffer radius for tract delineation used in the Sagebrush Mineral-Resource Assessment (SaMiRA) project.

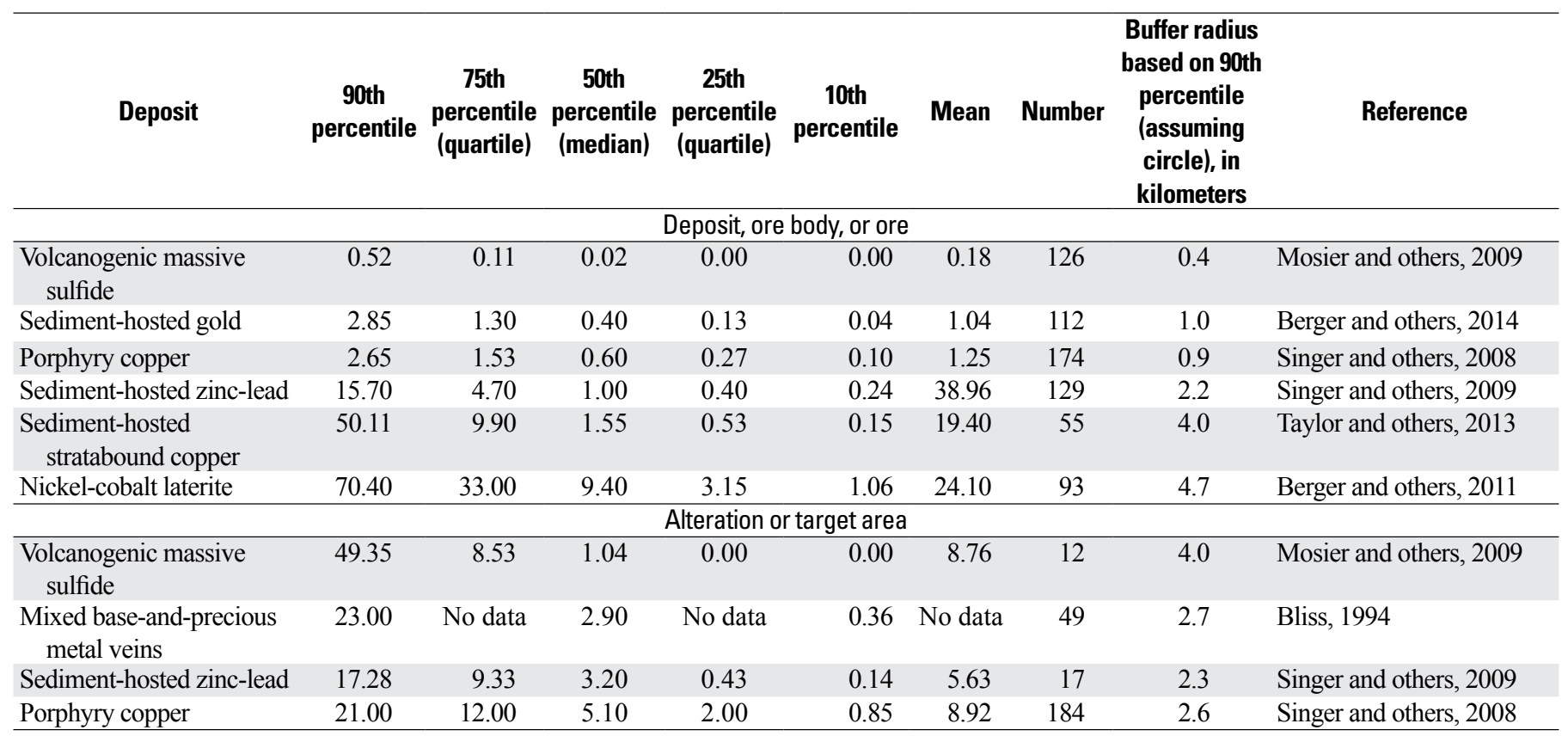

\section{Using Near Distance and Density Mapping to Map Areas with Mineral Potential}

Other geoprocessing tools were used to examine the distance relations between one site and another as a guide to delineating mineral-resource tracts. In applying these tools, the spatial relation of, for example, metallic-mineral sites relative to each other can be determined using a proximity tool to compute the distance that one would have to search from a given site to reach other sites. The results of generating a "near distance table" provide a guide to the distance beyond which it would be highly unlikely that another site would be found

Mineral occurrences tend to be spatially clustered. Statistics that summarize the nearest distance between spatially clustered points were used in the development of some mineral-potential tracts when the distribution of mineral occurrences could not be related to features on geologic maps. In the absence of other information, the maximum near distance between clustered points for a given type of mineral occurrence was used as the buffer distance to establish the farthest search area for that deposit type. In some cases, this was used to define the lowest ranked mineral tracts in this study (low levels of potential and confidence).

To define areas of higher confidence, density of mineraloccurrence points was calculated using the kernel-density tool in ArcGIS. This tool calculates a magnitude-per-area from the point features to illustrate the spatial density of sites. Tobler's first law of geography (http://support.esri.com/other-resources/ gis-dictionary/term/Tobler's\%20First $\% 20$ Law $\% 20$ of $\% 20$

Geography) was used when generating kernel-density maps for SaMiRA (table H8). ArcGIS usually asks for cell size of output raster, and the information in table $\mathrm{H} 2$ was used to determine an appropriate value. The 90th-percentile value near distance was used as the search radius when performing this calculation. This value was chosen because a search distance of this radius

Table H8. Examples of near distance calculations that were considered for kernel-density mapping used in the Sagebrush MineralResource Assessment (SaMiRA) project.

[MRDS, U.S. Geological Survey Mineral Resource Database; USMIN, U.S. Geological Survey Mineral Deposit Database project]

\begin{tabular}{lccc}
\hline \multicolumn{1}{c}{ Data } & $\begin{array}{c}\text { Number of } \\
\text { points }\end{array}$ & $\begin{array}{c}\text { Near-distance, 90th } \\
\text { percentile, in meters }\end{array}$ & $\begin{array}{c}\text { Near-distance, 95th } \\
\text { percentile, in meters }\end{array}$ \\
\hline Missouri River Breaks diatremes & 86 & 3,923 & 11,220 \\
Leucite Hills diatremes & 25 & 7,123 & 7,643 \\
Bedded barite in MRDS and USMIN in Sagebrush Focal Areas in Nevada & & 2,700 & 3,300 \\
Carlin-type gold deposits in Nevada & & 4,200 & 12,000 \\
\hline
\end{tabular}


should find most ( 90 percent) of the mineral occurrences used in the calculations. The resulting density maps were classified into groups and used to map level of certainty. This approach was used for assessing diamond potential associated with diatremes and related intrusions in Montana (Missouri River Breaks field) and Wyoming (Leucite Hills).

\section{Geostatistical Analysis}

Geostatistical models were used to model where bentonite should crop out in the assessment for bentonite in the Montana focal area. The models were also used to create surfaces that represent the bentonite layers or the interval containing the bentonite layers. Those modeled surfaces were then intersected with a digital elevation model to create a map showing where bentonite layers should crop out.

\section{Mineral-Resource Potential and Certainty}

The assessment methodology used in this report follows the BLM assessment guidelines and relies on subjective assessment. For locatable minerals, areas are assigned high, moderate, low, or no mineral-resource potential according to the degree of likelihood that geologic processes operated in an area in such a way as to permit accumulation of resources (appendix 2). If no useful data are available, the designation ND (not determined) is used. In addition to the level of mineral-resource potential, a level of certainty is applied to document the quality and quantity of data available to support the assigned level of potential (appendix 2). These levels range from A (least certain) to D (most certain), depending on the evidence to support the possible existence of mineral resources on the mineral-resource tract. Known deposits, for example, provide direct evidence of mineral resources, whereas a geochemical anomaly or a mineral showing might represent indirect evidence of mineral resources.

The definitions of these levels of resource potential were developed by Goudarzi (1984) and adopted by BLM (1985). The range of possible mineral-potential classifications for a given mineral-resource tract is illustrated in figure H3. The assessment of mineral potential and level of certainty assigned to mineral-resource tracts depends on consideration of BLM evidence factors. For example, a mineral-resource tract assigned an H/D classification has a high potential for mineral resources and a high level of certainty. By definition, mineral-resource tracts have at least a low potential because the tract is based on some geologic evidence that indicates that the area is permissive for the occurrence of the deposit type. Additional types of evidence are necessary to warrant a designation of moderate or high mineral potential.

A practical way to interpret the different subjective levels might be that most mining companies would be willing to risk exploration dollars in an area with high potential, whereas areas with moderate potential might be attractive to some optimistic investors but not to more conservative ones (Ludington, 2006). The level of certainty of the assigned resource potential reflects the amount and quality of useful data available at the time of the assessment. As new or more detailed information becomes available, the resource potential and level of certainty in an area can change. The designation of an area as having high potential does not necessarily imply that deposits that might be discovered there could be developed and operated successfully. When information is available about resource quality that might bear on the economic viability of deposits, it is presented separately from the potential designation.

\section{SaMiRA Assessment Guidelines}

The guidelines adopted for assigning mineral potential and level of certainty for locatable minerals in SaMiRA are summarized in figure H3. Specific rationales for each permissive tract are cited in the focal area reports. The tract example shown in figure $\mathrm{H} 2$ would be classified as $\mathrm{H} / \mathrm{D}$ because of the abundant direct evidence illustrated by the occurrence of deposits with production, prospects, and exploration activity, and the indirect evidence from geochemistry and alteration. Examples of datasets that provided direct and indirect evidence to support the interpretation of the level of potential and certainty are listed in table H9. Direct evidence indicates that the mineral occurrence can be assigned to a deposit type or that mineralized rock is present. These guidelines, in combination with the subject matter expertise of the assessment teams, determined the final designation of each mineral-resource tract.

Table H9. Direct and indirect evidence indicators for assigning mineral potential used in the Sagebrush Mineral-Resource Assessment (SaMiRA) project.

[ASTER, Advanced Spaceborne Thermal Emission and Reflection Radiometer]

\begin{tabular}{|c|c|c|c|c|c|c|c|}
\hline \multirow[b]{2}{*}{ Criteria } & \multicolumn{2}{|c|}{ Mineral occurence databases } & \multirow[b]{2}{*}{$\begin{array}{c}\text { Geochemistry } \\
\text { of soils, stream } \\
\text { sediments, and } \\
\text { rocks }\end{array}$} & \multirow[b]{2}{*}{$\begin{array}{c}\text { ASTER } \\
\text { anomalies }\end{array}$} & \multirow[b]{2}{*}{$\begin{array}{l}\text { Regional- } \\
\text { scale } \\
\text { geophysics }\end{array}$} & \multirow[b]{2}{*}{$\begin{array}{c}43 \text { CFR } \\
3809 \\
\text { permits }\end{array}$} & \multirow[b]{2}{*}{$\begin{array}{l}\text { Mining } \\
\text { claims }\end{array}$} \\
\hline & $\begin{array}{l}\text { Current or historical } \\
\text { deposit with } \\
\text { identified resources, } \\
\text { past production, or } \\
\text { active exploration }\end{array}$ & $\begin{array}{l}\text { Prospect or } \\
\text { showing }\end{array}$ & & & & & \\
\hline $\begin{array}{l}\text { Direct evidence of a } \\
\text { particular deposit type }\end{array}$ & $\mathrm{X}$ & & & & & & \\
\hline Indirect only & & & & $\mathrm{X}$ & $\mathrm{X}$ & $\mathrm{X}$ & $\mathrm{X}$ \\
\hline
\end{tabular}




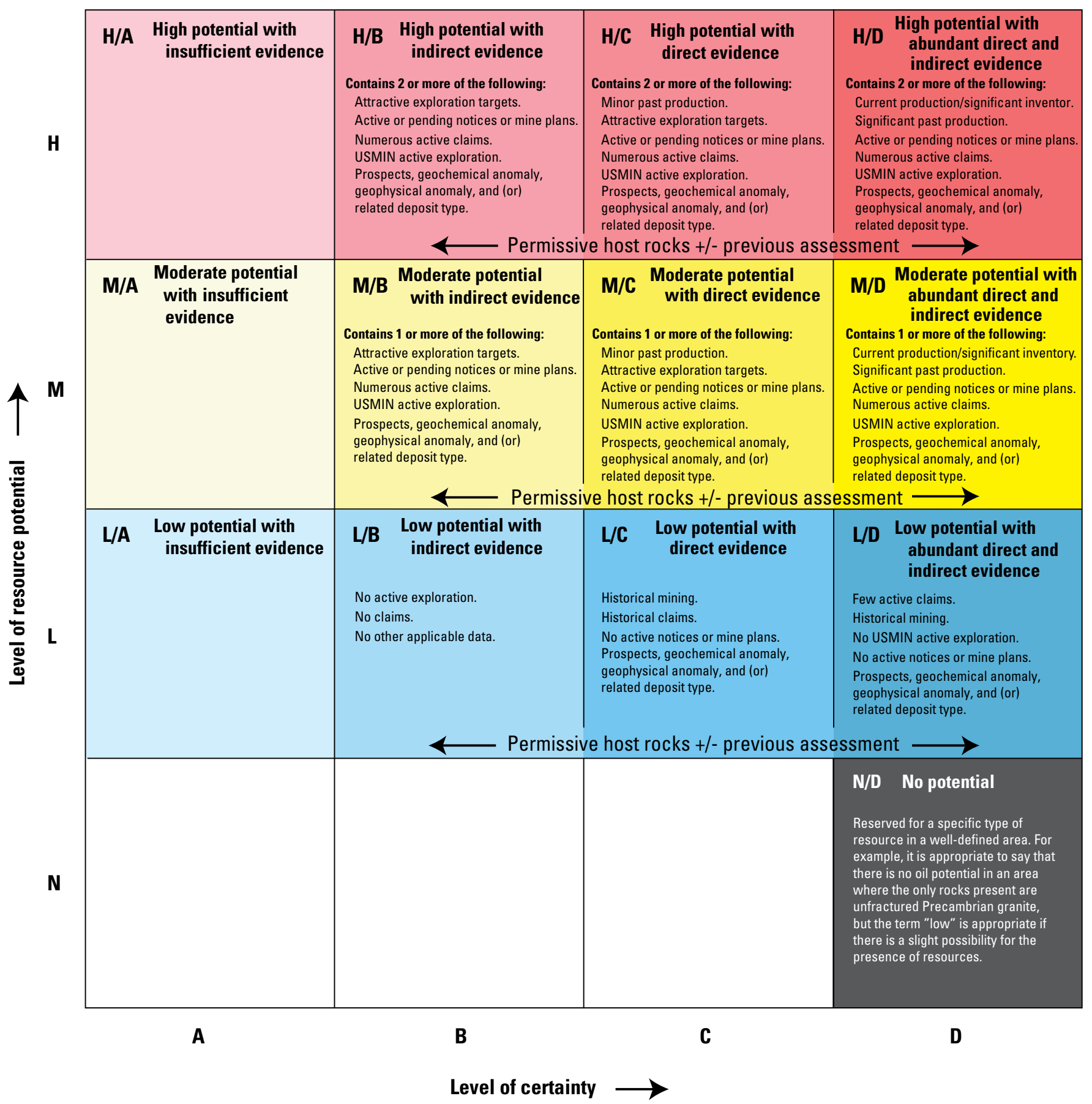

Figure H3. Matrix of possible mineral potential and certainty designations and criteria used for the mineral-resource assessment for locatable minerals in the Sagebrush Mineral-Resource Assessment (SaMiRA) project. Levels of resource potential: $N$, none; L, low; $M$, moderate; $H$, high. Levels of certainty: $A$, insufficient evidence; $B$, indirect evidence; $C$, direct evidence; D, abundant evidence. USMIN, U.S. Geological Survey Mineral Deposit Database. 


\section{References Cited}

Berger, B.R., Ayuso, R.A., Wynn, J.C., and Seal, R.R., 2008, Preliminary model of porphyry copper deposits: U.S. Geological Survey Open-File Report 2008-1321, 55 p., accessed May 15, 2009, at http://pubs.usgs.gov/ of/2008/1321.

Berger, V.I., Mosier, D.L., Bliss, J.D., and Moring, B.C., 2014, Sediment-hosted gold deposits of the world-Database and grade and tonnage models (ver. 1.1, June 2014): U.S. Geological Survey Open-File Report 2014-1074, 46 p., accessed March 10, 2016, at http://dx.doi.org/10.3133/ ofr20141074.

Berger, V.I., Singer, D.A., Bliss, J.D., and Moring, B.C., 2011, Ni-Co laterite deposits of the world-Database and grade and tonnage models: U.S. Geological Survey Open-File Report 2011-1058, accessed March 10, 2016, at http://pubs. usgs.gov/of/2011/1058/.

Bliss, J.D., 1994, Mineral deposit modeling using components for complex mineral deposits-Mixed base- and preciousmetal veins of the Idaho Batholith, Idaho: U.S. Geological Survey Open-File Report 94-690, 53 p.

Bureau of Land Management, 1985, MS-3031-Energy and mineral resource assessment: Bureau of Land Management, BLM Manual, Release 3-115, 29 p., accessed May 1, 2016, at http://www.blm.gov/style/medialib/blm/wo/Information Resources_Management/policy/blm_manual.Par.36483.File. dat $/ 3031 \% 20-\% 20$ ENERGY\%20AND\%20MINERAL $\% 20$ RESOURCE\%20ASSESSMENT.pdf.

Bureau of Land Management, 1994, MS-3060-Mineral reports-Preparation and review: Bureau of Land Management, BLM Manual, Release 3-324, 49 p., accessed December 9, 2015, at http://www.blm.gov/style/medialib/ blm/wo/Information_Resources_Management/policy/blm_ manual.Par.18421.File.dat/3060.pdf.

Cox, D.L., and Singer, D.A., 1986, Mineral deposit models: U.S. Geological Survey Bulletin 1693, 379 p., accessed May 18, 2016, at https://pubs.usgs.gov/bul/b1693/.

Fisher, D.G., and Juilland, J.D., 1986, Mineral deposit types and their characteristics: Bureau of Land Management Technical Reference 3031-1, 158 p.

GDS-FGDC, 2006, Digital cartographic standard for geologic map symbolization: Federal Geographic Data Committee [FGDC] Document Number FGDC-STD-013-2006, 307 p., accessed June 19, 2016, at http://www.fgdc.gov/standards/ projects/FGDC-standards-projects/geo-symbol/FGDCGeolSymFinalDraft.pdf.
Goudarzi, G.H., compiler, 1984, Guide to preparation of mineral survey reports on public lands: U.S. Geological Survey OpenFile Report 84-0787, 41 p., accessed December 9, 2015, at https://pubs.er.usgs.gov/publication/ofr84787.

Kreuzer, O.P., Etheridge, M.A., Guj, P., McMahon, M.E., and Holden, D., 2008, Linking mineral deposit models to quantitative risk analysis and decision-making in exploration: Economic Geology, v. 103, p. 829-850.

Ludington, Steve, ed., 2006, Mineral resource assessment of selected areas in Clark and Nye Counties, Nevada: U.S. Geological Survey Scientific Investigations Report 2006-5197, 244 p, accessed March 18, 2016, at http://pubs.usgs.gov/ sir/2006/5197/.

Magoon, L.B., and Dow, W.G., 1994, The petroleum system, in L. B. Magoon, L.B., and Dow, W.G., eds., The petroleum system - From source to trap: American Association of Petroleum Geologists Memoir 60, p. 3-24.

Magoon, L.B., and Schmoker, J.W., 2000, The total petroleum system-The natural fluid network that constrains the assessment unit, in USGS World Energy Assessment Team, U.S. Geological Survey World petroleum assessment 2000Description and results: U.S. Geological Survey Digital Data Series 60, chapter PS, 31 p., https://pubs.usgs.gov/dds/dds-060/.

McCuaig, T.C., Beresford, Steve, and Hronsky, Jon, 2010, Translating the mineral systems approach into an effective exploration targeting system: Ore Geology Reviews, v. 38, p. 128-138.

Mosier, D.L., Berger, V.I., and Singer, D.A., 2009, Volcanogenic massive sulfide deposits of the world; database and grade and tonnage models: U.S. Geological Survey Open-File Report 2009-1034, 46 p., accessed May 15, 2016, at http://pubs.usgs. gov/of/2009/1034/.

Nagi, Rajinder, 2010, On map scale and raster resolution: ArcGIS Blog, accessed May 18, 2016, at https://blogs.esri.com/esri/ arcgis/2010/12/12/on-map-scale-and-raster-resolution/.

San Juan, C.A., Horton, J.D., Parks, H.L., Mihalasky, M.J., Anderson, E.D., Benson, M.E., Box, S.E., Cossette, P.M., Denning, P.D., Giles, S.A., Hall, S.M., Hayes, T.S., Hearn, B.C., Jr., Hofstra, A.H., John, D.A., Ludington, S., Lund, K., Mauk, J.L., Robinson, G.R., Jr., Rockwell, B.W., Rytuba, J.J., Smith, S.M., Stillings, L.L., Van Gosen, B.S., Vikre, P.G., Wallis, J.C., Wilson, A.B., Zientek, M.L., and Zürcher, L., 2016, Locatable mineral assessment tracts for the U.S. Geological Survey Sagebrush Mineral-Resource Assessment project: U.S. Geological Survey data release, http://dx.doi.org/10.5066/ F7833Q4R.

Sillitoe, R.H., 2010, Porphyry copper systems: Economic Geology, v. 105, p. 3-42. 
Singer, D.A., Berger, V.I., and Moring, B.C., 2008, Porphyry copper deposits of the World-Database and grade and tonnage models, 2008: U.S. Geological Survey Open-File Report 2008-1155, http://pubs.usgs.gov/of/2008/1155/.

Singer, D.A., Berger, V.I., and Moring, B.C., 2009, Sedimenthosted zinc-lead deposits of the world-Database and grade and tonnage models: U.S. Geological Survey Open-File Report 2009-1252, http://pubs.usgs.gov/of/2009/1252/.

Skinner, B.J., and Barton, P.B., Jr., 1973, Genesis of mineral deposits: Annual Review Earth Planetary Sciences, v. 1, p. 183-211.

Taylor, C.D., Causey, J.D., Denning, P.D., Hammarstrom, J.M., Hayes, T.S., Horton, J.D., Kirschbaum, M.J., Parks, H.L., Wilson, A.B., Wintzer, N.E., and Zientek, M.L., 2013, Descriptive models, grade-tonnage relations, and databases for the assessment of sediment-hosted copper deposits-With emphasis on deposits in the Central Africa Copperbelt, Democratic Republic of the Congo and Zambia: U.S. Geological Survey Scientific Investigations Report 2010-5090-J, 154 p. and data files, accessed May 20, 2016, at http://pubs.usgs.gov/sir/2010/5090/j/.
U.S. Geological Survey, 1999, Map accuracy standards: U.S. Geological Survey Fact Sheet 171-99, 2 p.

Wyborn, L.A.I., Heinrich, C.A, and Jaques, A.L., 1994, Australian Proterozoic mineral systems essential ingredients and mappable criteria: Proceedings of the Australasian Institute of Mining and Metallurgy Annual Conference, Darwin, Australia, p. 109-116, accessed May 24, 2012, at http:/www.ga.gov.au/image_cache/ GA5228.pdf.

Zientek, M.L., Hayes, T.S., and Taylor, C.D., 2013, Grade and tonnage relations for sediment-hosted stratabound copper deposits, chap. 2 of Taylor, C.D., Causey, J.D., Denning, P.D., Hammarstrom, J.M., Hayes, T.S., Horton, J.D., Kirschbaum, M.J., Parks, H.L., Wilson, A.B., Wintzer, N.E., and Zientek, M.L., Descriptive models, grade-tonnage relations, and databases for the assessment of sediment-hosted copper deposits - With emphasis on deposits in the Central African Copperbelt, Democratic Republic of the Congo and Zambia: U.S. Geological Survey Scientific Investigations Report 2010-5090-J, p. 17-59, accessed May 15, 2016, at http://pubs. usgs.gov/sir/2010/5090/j/. 



\title{
Section I. Locatable Mineral Market-Demand Analysis Commodity Profiles
}

\author{
By Donald I. Bleiwas
}

The present and potential future market-demand analyses were developed to provide a general description of domestic production and a qualitative assessment of inferred future market demands for the important locatable minerals identified to have a moderate and high potential for occurrence within the proposed withdrawal areas in the Bureau of land Management (BLM) Sagebrush Focal Areas (SFAs; see section A, fig. A1). A table of strategic and critical materials is provided in appendix 4. A complete listing of the market-demand commodity profiles are provided in appendix 5 .

Individual mineral-commodity profiles contained in the market-demand analysis section were developed by U.S. Geological Survey (USGS) minerals and materials specialists in the National Minerals Information Center (NMIC). The NMIC's primary mission is to collect, monitor, and analyze data on domestic and foreign nonfuel mining and mineral-processing industries and markets for more than 90 mineral commodities essential to the U.S. economy and national security.

The sources of information used for developing the mineral-commodity profiles include academia, Federal, State and local agencies, industry contacts, international and domestic organizations, publications, questionnaires and surveys, and site visits.

Each mineral-commodity profile contains descriptive and statistical information that address domestic and global production, domestic consumption, historical and recent prices, major uses, recycling, stocks, shipments, the strategic and critical nature of the commodity, and trade. In some cases, recent mine production in or proximal to the proposed withdrawal area is discussed in each commodity profile. 



\title{
Section J. Energy Mineral Resources
}

\author{
By Jonathan M.G. Glen, Jacob DeAngelo, Colin F. Williams, Jon E. Haacke, Ronald M. Drake II, Gregory L. \\ Gunther, Stuart A. Giles, and Aimee E. Graeber
}

This section on energy mineral resources data compiled for the Sagebrush Mineral-Resource Assessment (SaMiRA) project consists of three subsections. The first section describes geothermal energy resources. The second section provides an overview of methods used for reporting coal resources. The third section describes the methods used in reporting oil and gas data.

\section{Geothermal Energy Resources}

\author{
By Jonathan M.G. Glen, Jacob DeAngelo, and Colin \\ F. Williams
}

\section{Introduction}

Geothermal energy constitutes one of the Nation's largest sources of renewable electric power. Its potential is an important consideration given that current projections indicate the United States will need to increase its electrical power generating capacity by approximately 25 percent over the next 25 years (Energy Information Administration, 2015). Although the installed capacity of geothermal (approximately 3,000 megawatts-electric or MWe) falls short of meeting the Nation's entire power needs, it constitutes a potentially significant part of the estimated available resources based on recent assessments. With potential advances in exploration and development technologies, these resources could provide a substantial source of baseload electric power. Owing to government mandates and incentives for renewable energy, it is expected that the demand for geothermal energy will continue to grow, and, given the concentration of geothermal resources in the Western United States, a substantial part of this growth could occur on public lands. This section, which provides a review of the geothermal resource potential of the proposed Sagebrush Focal Areas, is based on the results of the USGS 2008 assessment of the Nation's moderate- and high-temperature geothermal resources (Williams and others, $2008 \mathrm{~b}$ ) that includes a provisional assessment of Enhanced Geothermal Systems (EGS), as well as earlier USGS and State-level inventories and assessments.

\section{Overview of USGS Geothermal-Resource Assessments and Definitions}

Comprehensive efforts to assess the geothermal resources of the United States began after passage of the Geothermal Energy Research, Development, and Demonstration Act of 1974, which assigned responsibility for the evaluation and assessment of geothermal resources to the USGS through the U.S. Department of the Interior. The USGS produced three national geothermalresource assessments in the following 8 years, USGS Circular 726, Assessment of Geothermal Resources of the United States-1975 (White and Williams, 1975), USGS Circular 790, Assessment of Geothermal Resources of the United States-1978 (Muffler, 1979), and USGS Circular 892, Assessment of Low-temperature Geothermal Resources of the United States-1982 (Reed, 1983). After the passage of the Energy Policy Act of 2005, the USGS produced an updated assessment of the moderate-temperature (90 to 150 degrees Celsius, ${ }^{\circ} \mathrm{C}$ ) and high-temperature $\left(>150{ }^{\circ} \mathrm{C}\right.$ ) geothermal resources of the United States (Williams and others, 2008a, b). In the 2008 assessment, the USGS provided estimates of the geothermal electrical power generation potential from identified and undiscovered resources and included a provisional estimate of the power-production potential of Enhanced Geothermal Systems (EGS) techniques, which involve the creation of producing geothermal reservoirs in low-permeability rock units.

All four of these national geothermal assessments consider both identified and undiscovered resources and use the following definitions established for the USGS by Muffler and Cataldi (1978). The geothermal-resource base is all of the thermal energy in the Earth's crust beneath a specific area, measured from the local mean annual temperature. The geothermal resource is that part of the resource base at depths shallow enough to be tapped by drilling in the foreseeable future that can be recovered as useful heat economically and legally at some reasonable future time. Similarly, the geothermal reserve is the identified part of the resource that can be recovered economically and legally at the present time using existing technology.

\section{Conventional Geothermal Resources}

In the context of this report, geothermal resources are divided into two categories - conventional and unconventional. Conventional resources are those associated with geothermal systems defined by Muffler (1979) as “any regionally localized 
geological setting where naturally occurring parts of the Earth's thermal energy are transported close enough to the Earth's surface by circulating steam or hot water to be readily harnessed for use." These geothermal (or alternatively, hydrothermal) systems involve the natural vertical movement of water through either free or forced convection (for example, Duffield and Sass, 2003). All of the geothermal systems developed for commercial electric power generation in the United States fall in this category. Within this framework, identified hydrothermal systems are divided into three temperature classes - low temperature $\left(<90^{\circ} \mathrm{C}\right)$, moderate temperature $\left(90\right.$ to $\left.150{ }^{\circ} \mathrm{C}\right)$, and high temperature $\left(>150^{\circ} \mathrm{C}\right)$. High-temperature systems include both liquid- and vapor-dominated resources. Moderatetemperature systems are principally liquid dominated, and all low-temperature systems are liquid dominated. All three temperature classes are suitable for direct-use applications, but in general only moderate- and high-temperature systems are economically viable for electric power generation. The heat source of a hydrothermal system can be characterized as either magmatic or amagmatic. Magmatic geothermal reservoirs, which derive their heat from shallow-crustal magma bodies, are typically larger and higher in temperature than amagmatic systems that owe their heat to deep circulating fluids within the background geothermal gradient of the upper crust (Coolbaugh and others, 2006).

\section{Unconventional Geothermal Resources}

In addition to conventional hydrothermal resources, there are several geothermal-resource types that have the technical potential either for electric power generation, reductions in demand for other nonrenewable sources of energy, or directuse applications but have not yet been adopted commercially. These resources include deep high-temperature sedimentary basins; especially geothermal resources colocated with oil and gas accumulations or zones of geopressured fluids, and EGS. Enhanced geothermal systems are the part of a geothermal resource for which a measureable increase in production over its natural state is or can be attained through mechanical, thermal, and (or) chemical stimulation of the reservoir rock (Williams and others, 2011).

This section, dealing with the geothermal-resource potential of Sagebrush Focal Areas, is primarily based on results from the 2008 assessment that addresses moderatetemperature $\left(90\right.$ to $\left.150{ }^{\circ} \mathrm{C}\right)$ and high-temperature (greater than $150^{\circ} \mathrm{C}$ ) conventional and EGS systems capable of electric power generation. In addition, low-temperature systems that may offer important direct-use applications are briefly discussed. Also considered are sedimentary-basin resources that may hold substantial future potential when technologies have improved to allow commercial exploitation of those resources for electric power generation and other applications, such as in Utah and Wyoming.

\section{USGS National Resource Assessment}

The USGS 2008 national resource assessment (Williams and others, 2008b) assessed the electric power generation potential of geothermal resources in the United States. These resources are concentrated in 13 States that include all 6 of the States (Idaho, Montana, Nevada, Oregon, Utah, and Wyoming) spanned by the Sagebrush Focal Areas (SFAs). The assessment considered conventional moderate-temperature $\left(90\right.$ to $\left.150^{\circ} \mathrm{C}\right)$ and hightemperature (greater than $150^{\circ} \mathrm{C}$ ) geothermal systems located on private or accessible public lands and included a provisional estimate of the power-generation potential from the application of unconventional, EGS technology.

The assessment of conventional resources addresses those that can be accessed and exploited in the foreseeable future with existing methods and technology (Williams and others, 2011). In contrast, the provisional EGS assessment addresses EGS resources that are within depths accessible with existing technology but that will require methods and technology presently being developed, which have not yet been established as commercially viable (Department of Energy, 2008), for stimulation of the reservoir.

\section{Identified Geothermal Systems}

The majority of identified moderate- and high-temperature geothermal systems across the Western United States occur within the Great Basin Province and Snake River Plain (fig. J1). These are resources that are known and characterized by in-situ measurements through drilling or other lines of evidence such as geochemical, geophysical, and geological surveys. There are numerous low- and moderate- to high-temperature identified geothermal systems that occur within and around the proposed withdrawal areas (figs. J1-J4). Although there are currently no installed geothermal power plants located with the proposed withdrawal areas, there are four producing sites that lie within 100 kilometers $(\mathrm{km})$ of the withdrawal boundaries in Oregon, Idaho, and Nevada, as well as sites under development (according to the National Renewable Energy Laboratory; http://www.nrel.gov/gis/geothermal.html) in those States and Utah (figs. J3 and J4; see individual SFA reports for further information).

\section{Undiscovered Geothermal Resources}

Undiscovered geothermal resources were assessed for the Western States that contain identified moderateand high-temperature geothermal systems in the 2008 assessment. The assessment was based in part on a series of Geographic Information Systems (GIS) weights-of-evidence and logistic regression analyses through which geothermal potential was modeled using a weighted combination of evidence layers derived from mappable geologic and tectonic 


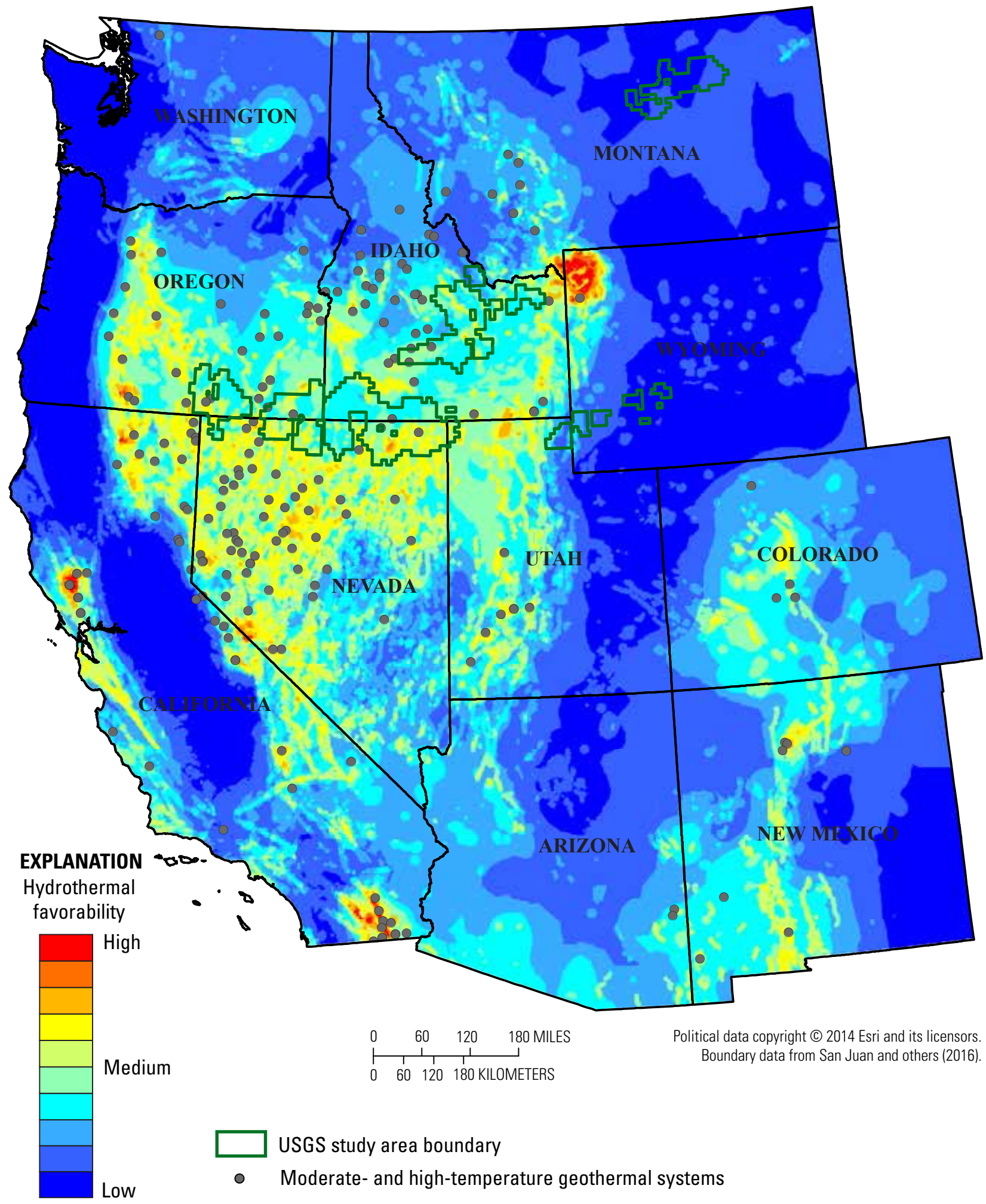

Figure J1. Geothermal-favorability map showing the relative favorability of occurrence for conventional moderate- to high-temperature geothermal resources across the western contiguous United States (after Williams and others, 2008b). Warmer colors equate with higher favorability. Identified geothermal systems are represented by black dots. USGS, U.S. Geological Survey. 


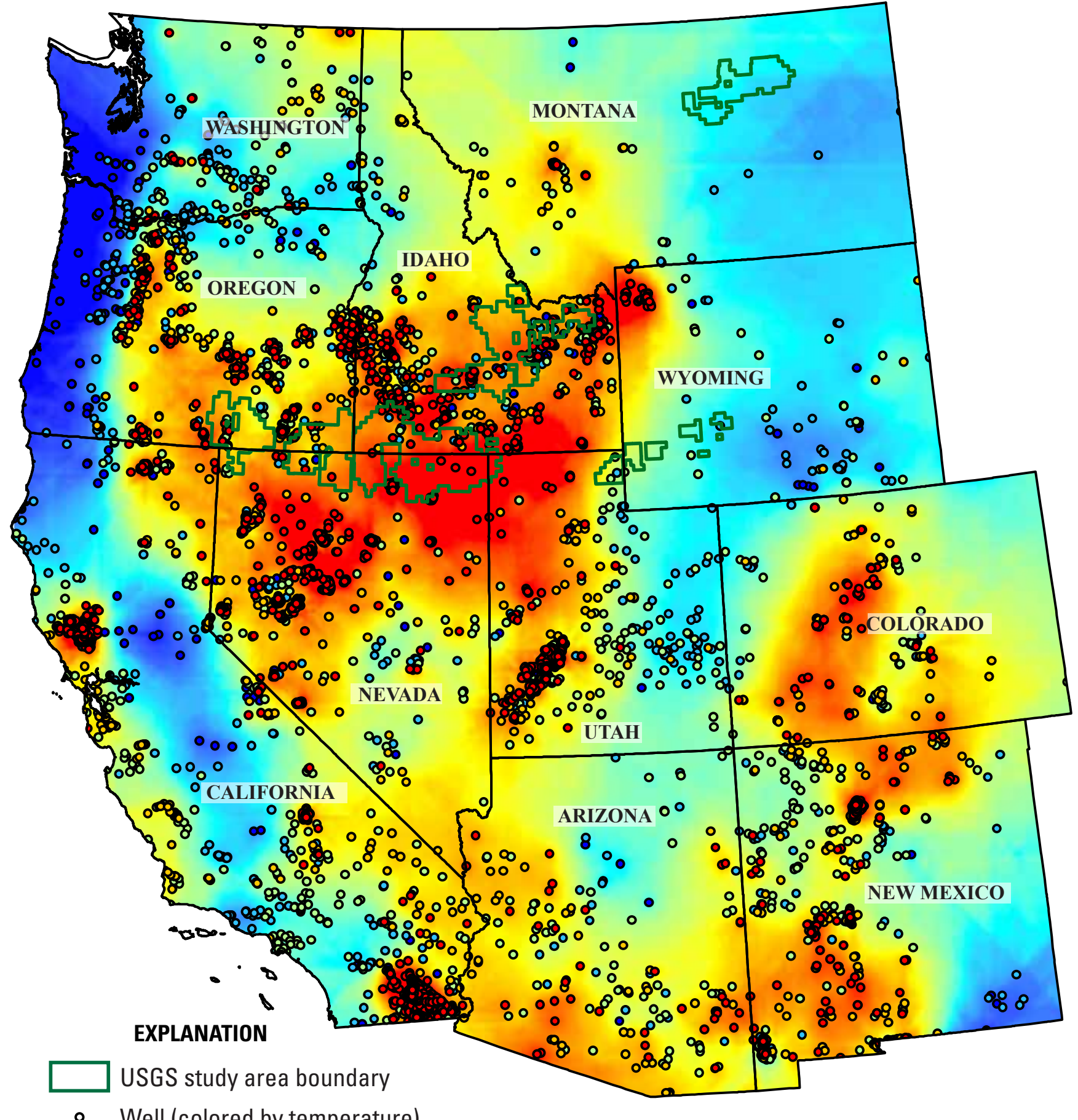

- Well (colored by temperature)

Temperature at 6-km $\left(\mathrm{C}^{\circ}\right)$

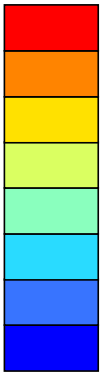

$>250$

$225.1-250$

$200.1-225$

$175.1-200$

$150.1-175$

$125.1-150$

$100.1-125$

$<100$
$0 \quad 60 \quad 120 \quad 180$ MILES Political data copyright (C) 2014 Esri and its licensors Boundary data from San Juan and others (2016).

$0 \quad 60 \quad 120 \quad 180$ KILOMETERS

Figure J2. Geothermal-temperature map showing temperature in degrees Celsius $\left({ }^{\circ} \mathrm{C}\right)$ at 6 -kilometers $(\mathrm{km})$ depth across the western contiguous United States that provides a proxy for the favorability of occurrence for enhanced geothermal systems (EGS) resources. Warmer colors equate with higher temperatures (and higher EGS favorability). Dots indicate temperature-gradient wells colored according to their estimated heat-flow values. USGS, U.S. Geological Survey. 


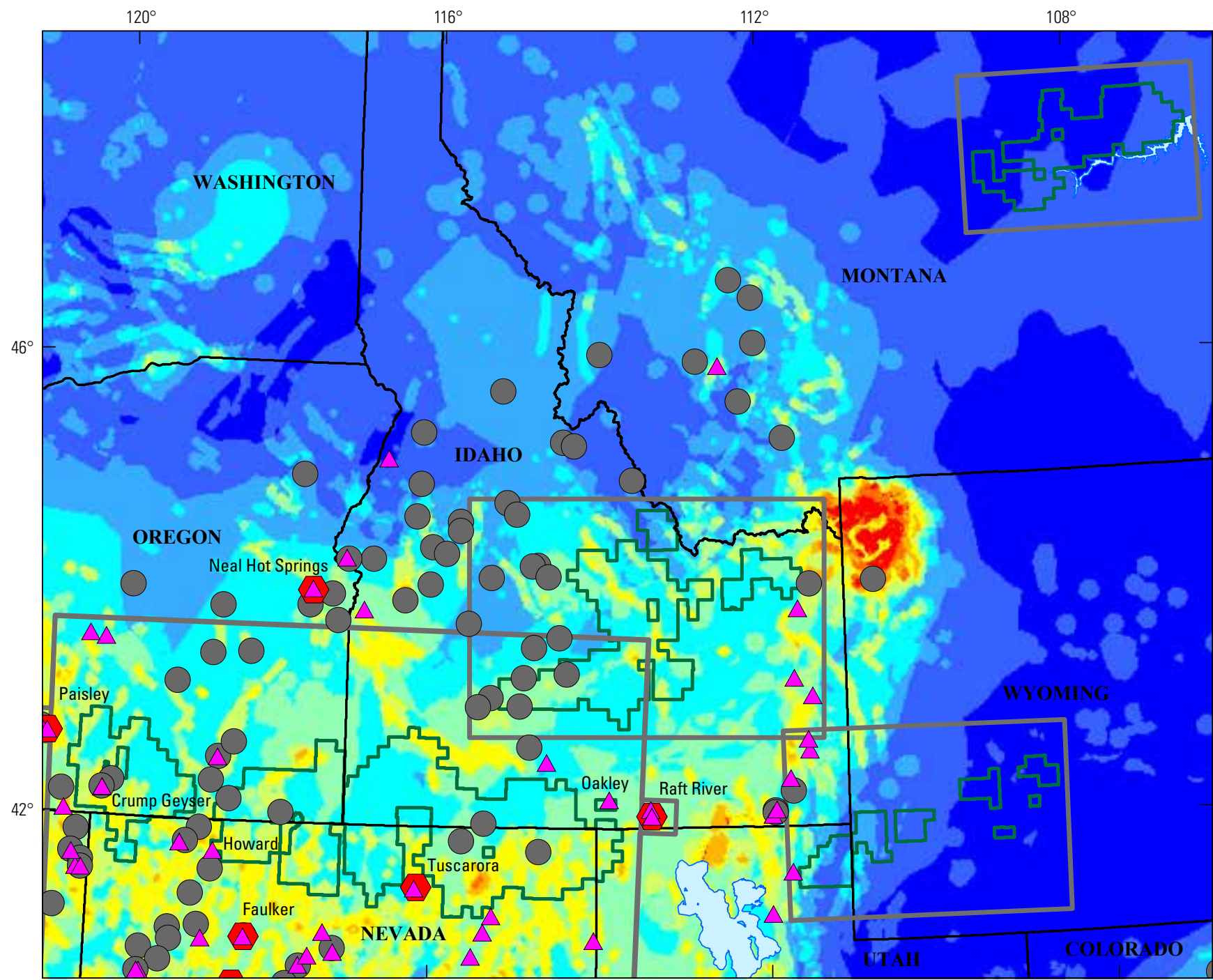

Base modified from U.S. Geological Survey DEM data, 2016. Roads and political data copyright (C) 2014 Esri and its licensors. Boundary data from San Juan and others (2016). USA Contiguous Albers Equal Area Conic Projection. Central meridian, $114^{\circ} \mathrm{W}$., latitude of origin, $37.5^{\circ} \mathrm{N}$.

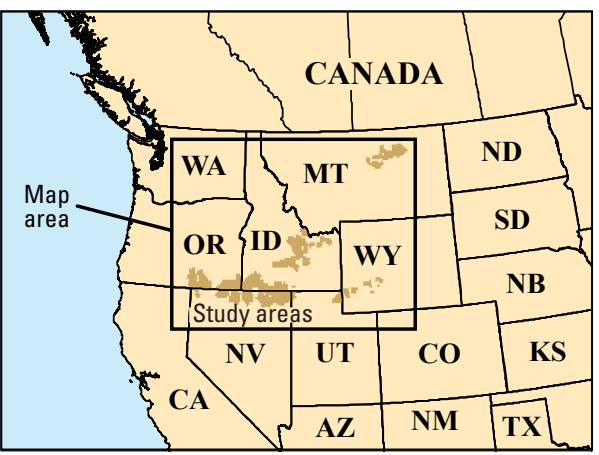

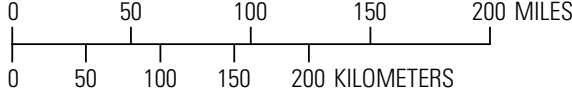

EXPLANATION

$\triangle$ Geothermal developing sites (as of September 2, 2014)

Geothermal operating sites (as of October 26, 2015)

Moderate- and high-temperature geothermal systems

USGS SaMiRA project report areas USGS study area boundary
Hydrothermal favorability

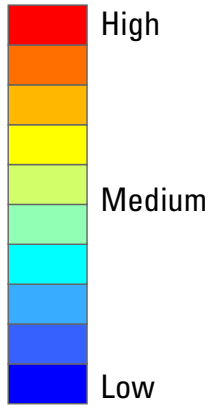

Figure J3. Geothermal-favorability map for the region of Sagebrush Focal Areas (SFAs; see section A, fig. A1), Western United States, showing logistic regression results for geothermal favorability (after Williams and others, 2008b) spanning the areas proposed for withdrawal. Warmer colors equate with higher favorability. USGS, U.S. Geological Survey; SaMiRA, Sagebrush Mineral-Resource Assessment. 


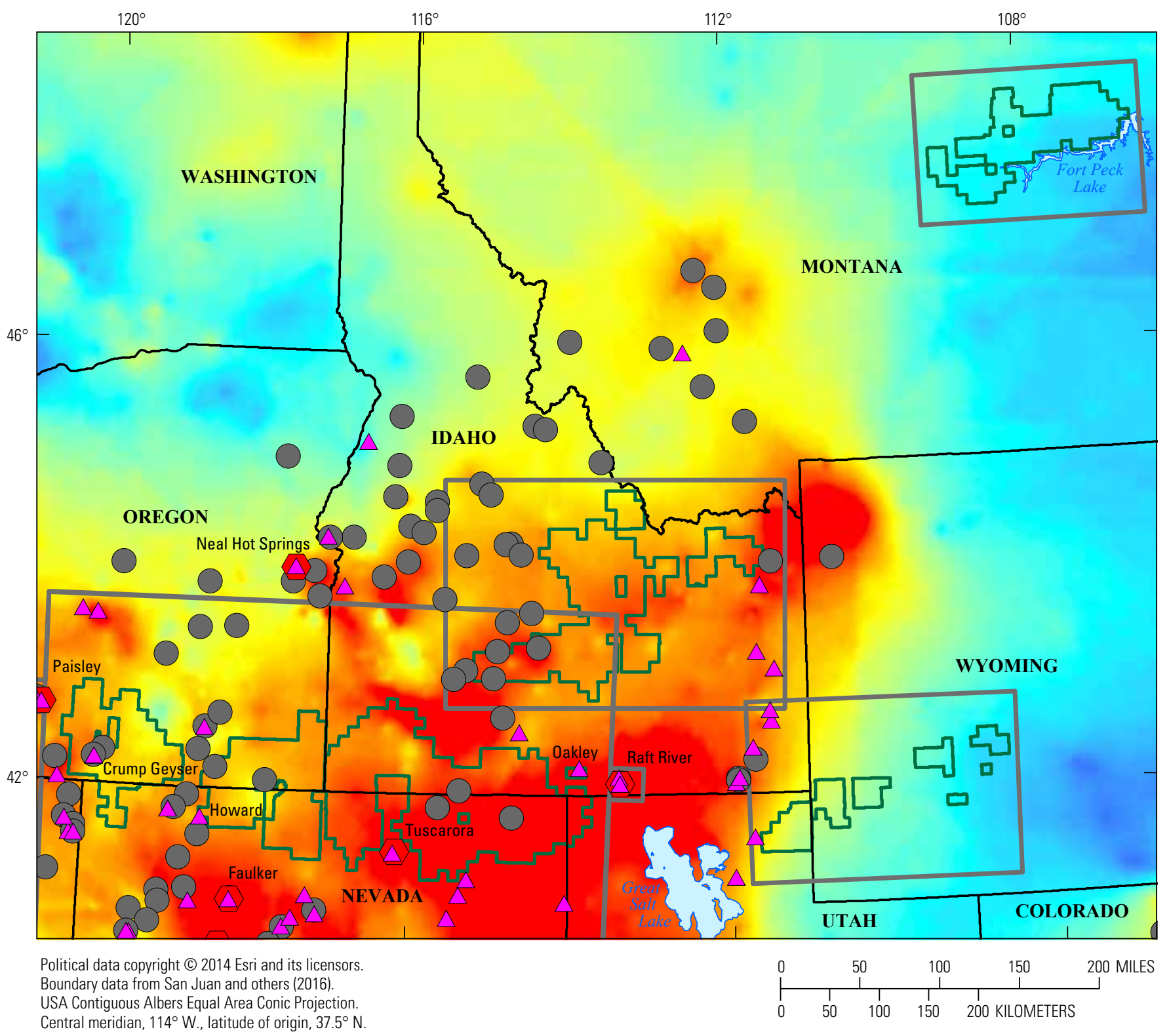

USA Contiguous Albers Equal Area Conic Projection.
Central meridian, $114^{\circ} \mathrm{W}$., latitude of origin, $37.5^{\circ} \mathrm{N}$.

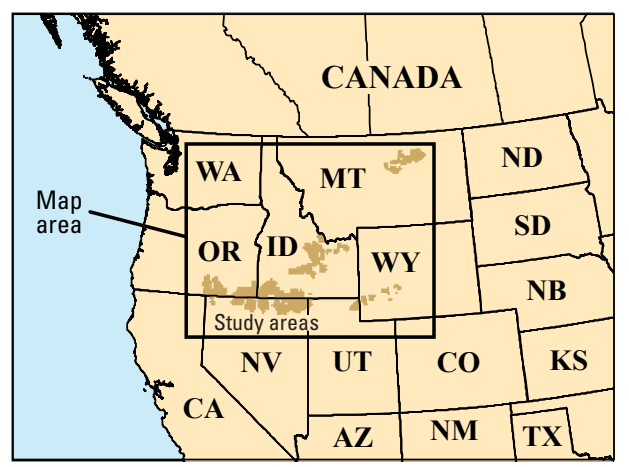

EXPLANATION

Temperature at 6-km depth $\left({ }^{\circ} \mathrm{C}\right) \quad \Delta \quad$ Geothermal developing sites (as of

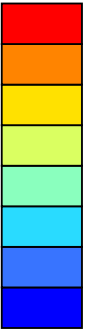
greater than 250
$225.1-250$
$200.1-225$
$175.1-200$
$150.1-175$
$125.1-150$
$100.1-125$
less than 100 September 2, 2014)
Geothermal operating sites (as of October 26, 2015)
Moderate- and high-temperature geothermal systems
USGS SaMiRA project report areas USGS study area boundary

Figure J4. Geothermal-temperature map for the region of Sagebrush Focal Areas (SFAs; see section A, fig. A1), Western United States, showing temperature in degrees Celsius $\left({ }^{\circ} \mathrm{C}\right)$ at 6-kilometers $(\mathrm{km})$ depth, which provides a proxy for enhanced geothermal systems (EGS) favorability spanning the areas proposed for withdrawal. Warmer colors equate with higher temperatures (and higher EGS favorability). USGS, U.S. Geological Survey; SaMiRA, Sagebrush Mineral-Resource Assessment. 
features available in digital databases (Coolbaugh and others, 2005; Williams and DeAngelo, 2008; Williams and others, 2009). The spatial variations in probability for the presence of a geothermal system were determined by mapping the presence or absence of various indicators comprising evidence layers that were weighted for their influence on the feature of interest.

Based on the 2008 assessment, the mean estimated power production potential from undiscovered geothermal resources is more than three times that from identified geothermal systems (more than 30,000 MWe versus approximately 9,000 MWe, respectively). These results indicate that additional exploration for undiscovered systems could substantially augment the potential exploitable resources. A plot of relative geothermal-resource favorability of both identified and undiscovered systems is given in figures $\mathrm{J} 1$ and J3. As indicated by the geothermal-favorability maps, regions with significant geothermal potential but few identified geothermal systems include parts of the proposed SFAs. The favorability scale in these maps is set relative to the average favorability for the occurrence of moderate- and high-temperature geothermal systems in the Western United States, which has significantly greater geothermal resource potential than east of the Rocky Mountains. Consequently, low values of favorability should be evaluated in this context and not considered an absolute measure of resource absence.

\section{Enhanced Geothermal Systems (EGS) Resources}

Enhanced Geothermal Systems involve efforts to engineer geothermal reservoirs where they did not previously exist by stimulating the host rock to generate permeable pathways for the circulation of hot water or steam necessary for electrical power generation. Although this has yet to be demonstrated on a commercial basis in the United States, EGS are the focus of substantial research and development worldwide due to their vast resource potential. For the 2008 provisional estimates of EGS potential (Williams and others, 2008b), the dominant factor determining the favorability of occurrence for EGS resources is the presence of elevated temperatures at viable drilling depths (Williams and DeAngelo, 2011). As a simple proxy for the detailed assessment analyses EGS potential is represented in figures $\mathrm{J} 2$ and $\mathrm{J} 3$, as well as subsequently in the regional sections, by the estimated temperature at a depth of $6 \mathrm{~km}$. The provisional estimate of EGS resources indicates that the EGS electric power production potential is significantly larger than from conventional geothermal resources $(\sim 500,000$ megawatts, MW, versus $\sim 30,000 \mathrm{MW}$ ) and represents approximately half of the current installed electric power generating capacity in the United States (Williams and others, 2008b). In comparison to the geothermal-favorability map (fig. J1), the high crustal heat flow favorable for EGS development (fig. J2) is much more uniformly distributed across the Western United States.

\section{Geothermal Provinces}

The Western United States is a region characterized by active tectonics and magmatism that has resulted in an elevated conductive thermal gradient capable of driving hydrothermal convection of water along permeable pathways in the crust. Hydrothermal systems driven by magmatic sources are typically concentrated along the western margin of the actively extending tectonic zones within the Great Basin and along the Snake River Plain, whereas those that result from amagmatic sources tend to be associated with basin and range settings. Extensive geothermal resources relevant to the present study occur principally in the northern Great Basin, Snake River Plain, and their surroundings (including the basin and range north of the plain, Oregon-Idaho Graben, and the High Lava Plains).

\section{Great Basin Province}

The Great Basin Province is a broad, highly extended basin and range province characterized by significantly elevated heat flow relative to the rest of the continental craton (Sass and others, 2005). It represents one of the largest geothermal provinces in the world and hosts more than 20 operating power plants that support roughly $550 \mathrm{MW}$ of installed capacity. Estimates based on the 2008 National assessment (Williams and others, 2008b) suggest that the province has the potential of producing 30,000 MW. Most of the geothermal systems within the Great Basin Province are believed to be primarily faultcontrolled and not related to magmatic heat sources residing in the upper crust. Furthermore, many of these systems have little or no surface manifestation (Faulds and Hinz, 2015; Coolbaugh and others, 2006). Given the presence of such "blind" systems, assessments may underestimate the region's full geothermal potential. The high geothermal potential of the province is attributed to significant crustal thinning from high extensional strain rates (Blewitt and others, 2005; Faulds and others, 2012) that have led to elevated geothermal gradients.

\section{Snake River Plain}

The Snake River Plain is a major physiographic feature of the Western United States that forms a continuous arcuate topographic depression extending from the Oregon-Idaho border, across southern Idaho, to northwest Wyoming. The western plain represents a rift graben that developed 11-12 million years ago (Ma) with the eruption of silicic volcanic rocks, and it is filled with thick sequences (several kilometers) of late Cenozoic lacustrine sediments. In contrast, the eastern plain forms a topographic depression thought to represent an expression of a mantle plume that heats the base of the continental crust in response to the northeast migration of the Yellowstone hotspot from the south-central Snake River Plain to its present location at Yellowstone as the North American Plate passed over the 
plume. The eastern plain is filled with a thick sequence of basalts that blanket a series of caldera complexes and associated silicic volcanic rocks that were all emplaced during passage of the hotspot.

The Snake River Plain and its surroundings represent one of the highest heat flow provinces in North America. The thermal anomaly associated with the plain originates from a thinned lithosphere, voluminous silicic volcanism, and extensive intrusions emplaced into the middle and lower crust. Very high heat-flow values are expected for the youngest part of the plain that have experienced recent (in the past 2,000 years) basaltic volcanism (Brott and others, 1978, 1981). Although the Snake River Plain and surroundings likely represents an important geothermal resource area (Fleischmann, 2006; Shervais and others, 2016; Welhan, 2016), much of the eastern plain's expected high heat flow is masked by shallow groundwater flow (Brott and others, 1981). This leads to relatively low heatflow values observed along the axis of the plain (with the exception of a few deep boreholes that penetrate below the base of the aquifer). Although the most recent volcanism occurs in the eastern Snake River Plain, relatively young $(\sim 200,000$ years ago) basaltic volcanism has also occurred in the west. Elevated heat-flow values mark the margins of the western Snake River Plain, where it is believed that the heatflow pattern is influenced by crustal-scale thermal refraction imposed by the thick sequence of sediments infilling the western graben.

\section{Methods Used for Reporting the Coal Resources}

\section{By Jon E. Haacke}

Coal is a major energy source in the United States. Although its contribution has diminished significantly in recent years, as of 2014 some 39 percent of U.S. electricity generation came from coal (U.S. Energy Information Administration, 2015). More than half of U.S. coal production comes from the Western States. Because so much is on lands with Federal mineral ownership, coal resources in the Western United States have been extensively evaluated by the U.S. Geological Survey (USGS).

The USGS divides the United States into coal regions that are known to contain coal and (or) lignite (East, 2013). The regions are further subdivided into coal fields, which are those areas that are or have been actively mined or that have significant potential to be mined.

Coal assessments by the USGS can be unofficially divided into four levels of detail:

1. Presence of coal.- At the simplest level is a geologic study to identify those areas that have any coal deposits.
2. Estimation.-An estimate of coal resources based on general knowledge of the geology.

3. Zonal.-A more detailed study of coal resources to add up all the coal at a given thickness and at some maximum depth, such as coal greater than 30 -inches thick and at a depth no greater than 1,000 feet.

4. Resources and Reserves.-The most detailed approach involves bed-by-bed correlation, calculation of available coal resources, and evaluation of the economically minable reserves.

For the coal assessment of the Sagebrush Focal Areas (SFAs; see section A, fig. A1), the first step was to determine those areas that were within any of the coal regions. For those focal areas in known coal areas, publications of the USGS and other sources were referenced.

The majority of the SFAs are not within regions of known coal occurrences (fig. J5). In the late 1990s, the National Coal Resource Assessment (Fort Union Coal Assessment Team, 1999) studied much of the Western United States; however, none of the focal areas were assessed. For those focal areas within coalbearing regions, there is low economic potential. None of the focal areas are within the higher (zonal or resource and reserves) assessment levels. The only area with estimated coal resources is a small part of the Bear River Watershed SFA.

\section{Methods Used for Reporting the Oil and Gas Resources}

\author{
By Ronald M. Drake II, Gregory L. Gunther, Stuart A. \\ Giles, and Aimee E. Graeber
}

\section{Introduction}

The U.S. Geological Survey (USGS) was tasked with providing a summary of published oil and gas assessments that overlie the land tracts for the Sagebrush Focal Areas (SFAs; see section A, fig. A1). The USGS oil and gas assessments were conducted at a basin scale using the Total Petroleum System (TPS) concept. As defined by Magoon and Schmoker (2000), the TPS approach considers the source rock, reservoir rock, seal rock, and overburden rock and processes of generation, migration, accumulation, and trap formation for discovered and undiscovered accumulations. A TPS is a naturally occurring hydrocarbon-fluid system that presumes that migration pathways exist now or in the past, and they connect the provenance with the accumulations. Therefore, the goal of the previous assessments was to map this natural fluid system, or TPS, in three-dimensional space through time to locate, define, and evaluate those areas for undiscovered hydrocarbons (Magoon and Schmoker, 2000). 


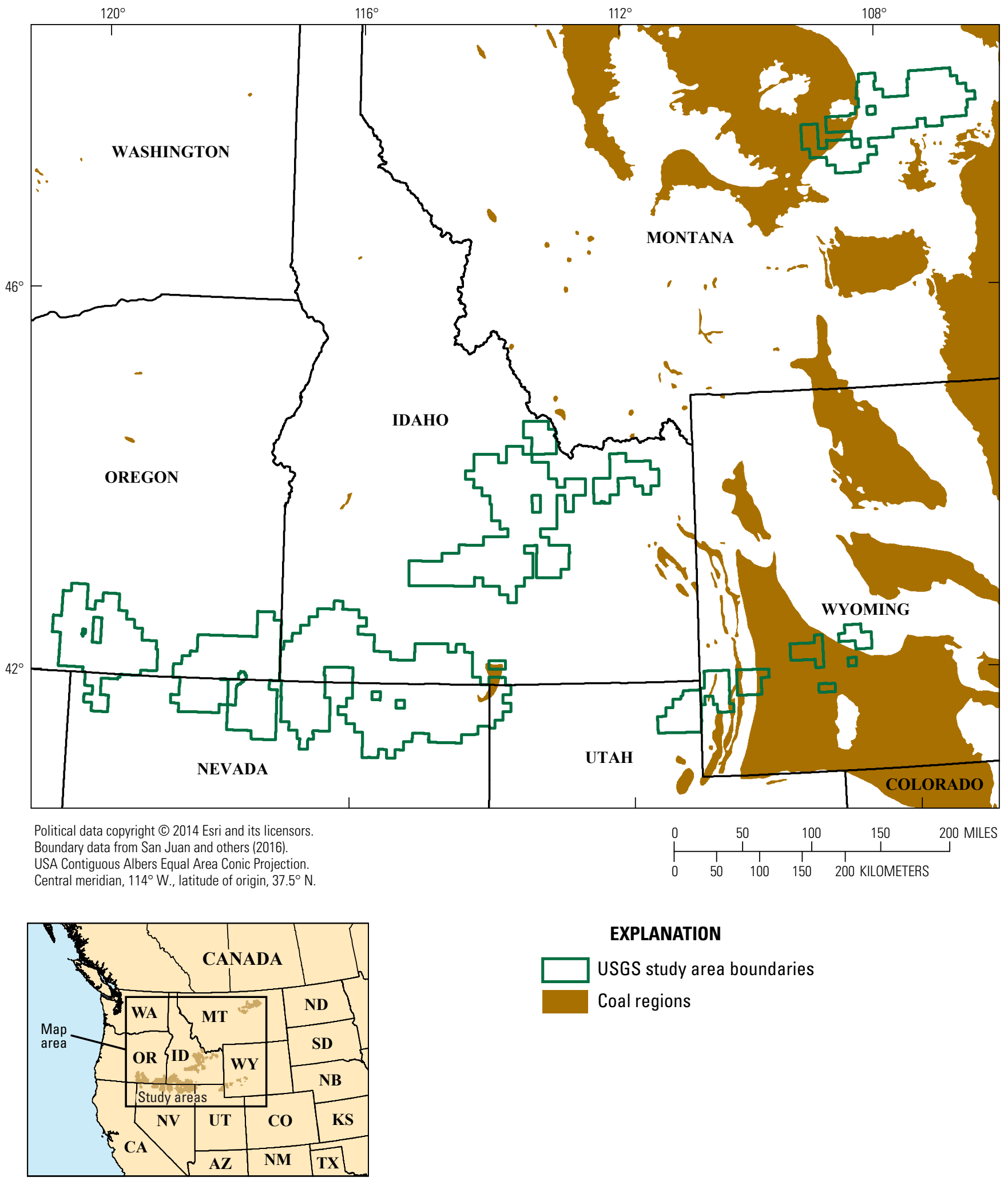

Figure J5. Map of known coal occurrences for the region of the Sagebrush Focal Areas (SFAs; see section A, fig. A1), Western United States. Coal regions from East (2013). USGS, U.S. Geological Survey. 

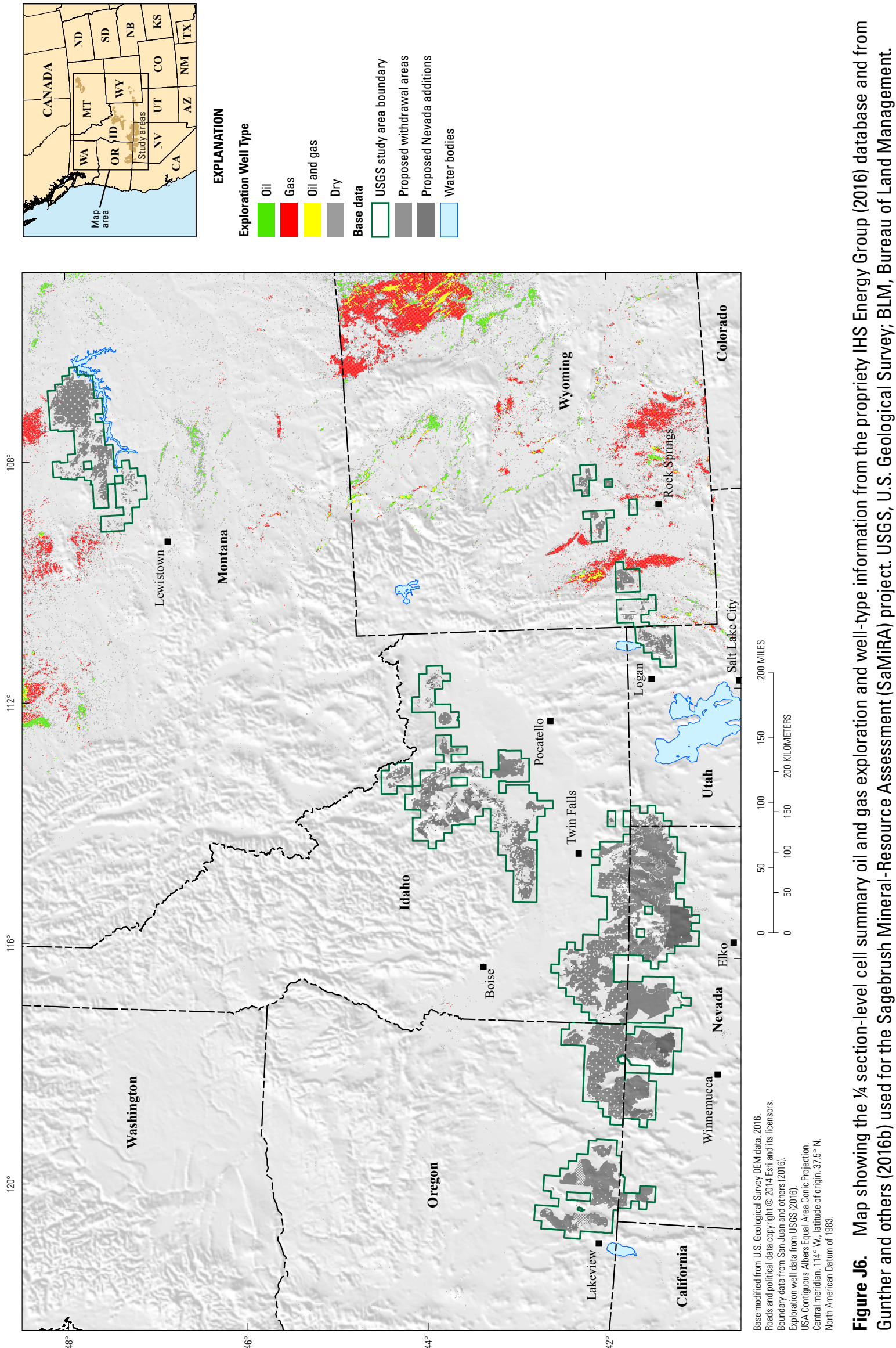


\section{Methodology}

A geographic information system (GIS) dataset was created that combined the Sagebrush Mineral-Resource Assessment (SaMiRA) township areas (as defined by the BLM) and USGS oil and gas assessment boundaries. A query was run within the GIS for intersecting assessment units within the Public Land Survey System (PLSS) townships containing SFAs. The resulting table related each PLSS Township with any correlating USGS oil and gas assessment unit or play. If an assessment was done in 1995, then the terminology used was "Play," and, after 1995, the terminology became "Assessment Unit" (AU). In many cases, more than one play or assessment unit (AU) was present within a PLSS Township. The table created lists each PLSS Township and the associated play or AU, the name of the AU or play, the publication title, and a URL link to the published USGS geologic assessment report. The published USGS assessment reports include many details regarding the source rocks, reservoir rocks, type of trap, reservoir properties, and resource potential. In some cases, many AUs or plays overlie a township. A table of oil and gas plays and AUs for each SFA is given in the corresponding SaMiRA report chapter as an appendix.

Using the list of AUs and plays that overlap the SFA townships, we were able to report the assessed potential oil and gas resources for those AUs and plays. The assessed resources are for areas larger than the SFA's PLSS township boundary. The assessment units and plays are usually basin size in scale.

Map figures provided in each individual SFA report incorporate borehole data from the IHS Energy Group (2016) and from Gunther and others (2016a, b) for well type and oil and gas production data. Although these data are proprietary, we were able to summarize the data by showing the majority type of wells at the $1 / 4$ section scale (fig. J6). These maps have been added to the reports for each SFA if there was production within a PLSS township containing a given proposed withdrawal area.

Nearly all oil and gas production occurred outside of the proposed withdrawal areas. For example, only one inactive well in Sweetwater County, Wyoming, produced a minor amount of oil and gas within the proposed withdrawal areas (IHS Energy Group, 2016). Although there are many assessed potential oil and gas resources near the proposed withdrawal areas, there has not been any significant hydrocarbon production within them.

\section{References Cited}

Blewitt, G., Hammond, W.C., and Kreemer, C., 2005, Relating geothermal resources to Great Basin tectonics using GPS: Geothermal Resources Council Transactions, v. 29, p. 331-336.

Brott, C.A., Blackwell, D.D., and Mitchell, J.C., 1978, Tectonic implications of the heat flow of the western Snake River plain: Geological Society of America Bulletin, v. 89, p. 1697-1707.
Brott, C.A., Blackwell, D.D., and Ziagos, J.P., 1981, Thermal and tectonic implications of heat flow in the Eastern Snake River Plain, Idaho: Journal of Geophysical Research, v. 86, B12, p. 11709-11734.

Coolbaugh, M.F., Raines, G.L., Zehner, R.E., Shevenell, L., and Williams, C.F., 2006, Prediction and discovery of new geothermal resources in the Great Basin - Multiple evidence of a large undiscovered resource base: Geothermal Resources Council Transactions, v. 30, p. 867-873.

Coolbaugh, M.F., Zehner, R.E., Kreemer, Corné, Blackwell, David, Oppliger, Gary, Sawatzky, Don, Blewitt, Geoff, Pancha, Aasha, Richards, Maria, Helm-Clark, Catherine, Shevenell, Lisa, Raines, G.L., Johnson, Gary, Minor, Tim, and Boyd, Tonya, 2005, Geothermal potential map of the Great Basin, Western United States: Nevada Bureau of Mines and Geology Map 151, 1 sheet, scale 1:1,000,000, accessed March 10, 2016, at http://pubs.nbmg. unr.edu/Geoth-potential-map-Great-Basin-p/m151.htm.

Department of Energy Geothermal Technologies Program, 2008, An evaluation of enhanced geothermal systems technology, 37 p., accessed March 10, 2016, at http://www1.eere.energy.gov/ geothermal/pdfs/evaluation_egs_tech_2008.pdf.

Duffield, W.A., and Sass, J.H., 2003, Geothermal energy — Clean power from the Earth's heat: U.S. Geological Survey Circular 1249, 35 p., accessed March 10, 2016, at http://pubs.usgs.gov/ circ/2004/c1249/.

East, J.A., 2013, Coal fields of the conterminous United StatesNational Coal Resource Assessment updated version: U.S. Geological Survey Open-File Report 2012-1205, 1 pl., 1:5,000,000, accessed March 10, 2016, at http://pubs.usgs.gov/ of $/ 2012 / 1205 /$.

Faulds, J.E., and Hinz, N.H., 2015, Favorable tectonic and structural settings of geothermal systems in the Great Basin region, Western USA - Proxies for Discovering Blind Geothermal Systems: Proceedings World Geothermal Congress 2015 Melbourne, Australia, April 19-25, 2015, 6 p.

Faulds, J.E., Hinz, N.H., Kreemer, C., and Coolbaugh, M.F., 2012, Regional patterns of geothermal activity in the Great Basin region, Western USA - Correlation with strain rates: Geothermal Resources Council Transactions, v. 36, p. 897-902.

Fleischmann, D.J., 2006, Geothermal development needs in Idaho: Geothermal Energy Association for the U.S. Department of Energy, 51 p., accessed March 10, 2016, at http://geo-energy.org/ reports/Idaho\%20Geothermal\%20Report.pdf.

Fort Union Coal Assessment Team, 1999, 1999 resource assessment of selected Tertiary coal beds and zones in the northern Rocky Mountains and Great Plains Region: U.S. Geological Survey Professional Paper 1625-A, 2 CD-ROMs, accessed March 10, 2016, at http://pubs.usgs. gov/pp/p1625a/. 
Gunther, G.L., Graeber, A.E., and Drake II, R.M., 2016a, Exploration and well status, quarter miles cells-SaMiRA: U.S. Geological Survey data release, http://dx.doi.org/10.5066/F7FB511V.

Gunther, G.L., Graeber, A.E., and Drake II, R.M., 2016b, Cumulative production per township—SaMiRA: USGS data release, http:// dx.doi.org/10.5066/F7B85670.

IHS Energy Group, 2016, ENERDEQ U.S. well data: IHS Energy Group, online database available from IHS Energy Group, 15 Inverness Way East, D205, Englewood, CO 80112, accessed January 11, 2016, at https://www.ihs.com/industry/oil-gas.html.

Magoon, L.B., and Schmoker, J.W., 2000, The total petroleum system-The natural fluid network that constrains the assessment unit, chapter PS, in U.S. Geological Survey World Energy Assessment Team, U.S. Geological Survey World Petroleum Assessment 2000-Description and results: U.S. Geological Survey Digital Data Series 60, ver. 1.0, CD-ROM, disk one, 31 p., accessed March 10, 2016, at http://energy.cr.usgs.gov/WEcont/ chaps/PS.pdf.

Muffler, L.P.J., 1979, Assessment of geothermal resources of the United States-1978: U.S. Geological Survey Circular 790, 163 p., accessed March 10, 2016, at https:/pubs.er.usgs.gov/ publication/cir790.

Muffler, L.P.J., and Cataldi, R., 1978, Methods for regional assessment of geothermal resources: Geothermics, v. 7, p. 53-89.

Reed, M.J., ed., 1983, Assessment of low-temperature geothermal resources of the United States-1982: U.S. Geological Survey Circular 892, 73 p., accessed March 10, 2016, at http://pubs.usgs. gov/circ/1983/0892/report.pdf.

San Juan, C.A., Horton, J.D., Parks, H.L., Mihalasky, M.J., Anderson, E.D., Benson, M.E., Box, S.E., Cossette, P.M., Denning, P.D., Giles, S.A., Hall, S.M., Hayes, T.S., Hearn, B.C., Jr., Hofstra, A.H., John, D.A., Ludington, S., Lund, K., Mauk, J.L., Robinson, G.R., Jr., Rockwell, B.W., Rytuba, J.J., Smith, S.M., Stillings, L.L., Van Gosen, B.S., Vikre, P.G., Wallis, J.C., Wilson, A.B., Zientek, M.L., and Zürcher, L., 2016, Locatable mineral assessment tracts for the U.S. Geological Survey Sagebrush Mineral-Resource Assessment project: U.S. Geological Survey data release, http://dx.doi. org/10.5066/F7833Q4R.

Sass, J.H., Priest, S.S., Lachenbruch, A.H., Galanis, S.P., Moses, T.H., Jr., Kennelly, J.P., Jr., Munroe, R.J., Smith, E.P., Grubb, F.V., Husk, R.H., Jr., and Mase, C.W., 2005, Summary of supporting data for USGS regional heat-flow studies of the Great Basin, 1970-1990: U.S. Geological Survey Open-File Report 2005-1207, accessed March 10, 2016, at http://pubs.usgs.gov/of/2005/1207/.

Shervais, J.W., Glen, J.M., Nielson, D., Garg, S., Dobson, P., Gasperikova, E., Sonnenthal, E., Visser, C., Liberty, L.M., Deangelo, J., Siler, D., and Evans, J.P., 2016, Geothermal play fairway analysis of the Snake River Plain-Phase 1: Proceedings, 41st Workshop on Geothermal Reservoir Engineering Stanford University, Stanford, California, February 22-24, 2016, SGP-TR-209.
U.S. Energy Information Administration, 2015, Annual energy outlook: U.S. Energy Information Administration, 154 p., accessed March 10, 2016, at https://www.eia.gov/forecasts/ aeo/.

U.S. Energy Information Administration, 2016, Annual coal report: U.S. Energy Information Administration, accessed March 23, 2016, at http://www.eia.gov/coal/annual/index. cfm.

Welhan, J.A., 2016, Gigawatt-scale power potential of a magma-supported geothermal system in the fold and thrust belt of southeast Idaho: Proceedings, 41st Workshop on Geothermal Reservoir Engineering, Stanford, California, February 2016, SGP-TR-209, 13 p., accessed March 10, 2016, at https://pangea.stanford.edu/ERE/db/GeoConf/ papers/SGW/2016/Welhan.pdf.

White, D.E., and Williams, D.L., 1975, Assessment of geothermal resources of the United States-1975: U.S. Geological Survey Circular 726, 155 p., accessed March 10, 2016, at http://pubs.usgs.gov/circ/1975/0726/report.pdf.

Williams, C.F., and DeAngelo, J., 2008, Mapping geothermal potential in the Western United States: Transactions of the Geothermal Resources Council, v. 32, p. 181-187.

Williams, C.F., and DeAngelo, J., 2011, Evaluation of approaches and associated uncertainties in the estimation of temperatures in the upper crust of the Western United States: Transactions of the Geothermal Resources Council, v. 35, p. 1599-1606.

Williams, C.F., Reed, M.J., and Anderson, A.F., 2011, Updating the classification of geothermal resources: Proceedings of the 36th Workshop on Geothermal Reservoir Engineering, Stanford University, Stanford, California, 7 p., accessed March 10, 2016, at https://pangea.stanford.edu/ ERE/pdf/IGAstandard/SGW/2011/williams.pdf.

Williams, C.F., Reed, M.J, DeAngelo, J., and Galanis, S.P., Jr., 2009, Quantifying the undiscovered geothermal resources of the United States: Transactions of the Geothermal Resources Council, v. 33, p. 995-1003, accessed March 10, 2016, at https://pubs.er.usgs.gov/publication/70158979.

Williams, C.F., Reed, M.J., and Mariner, R.H., 2008a, A review of methods applied by the U.S. Geological Survey in the assessment of identified geothermal resources: U.S. Geological Survey Open-File Report 2008-1296, 27 p., accessed March 10, 2016, at http://pubs.usgs.gov/ of $/ 2008 / 1296 /$.

Williams, C.F., Reed, M.J., Mariner, R.H., DeAngelo, J., and Galanis, S.P., Jr., 2008b, Assessment of moderate- and hightemperature geothermal resources of the United States: U.S. Geological Survey Fact Sheet 2008-3082, 4 p., accessed March 10, 2016, at http://pubs.usgs.gov/fs/2008/3082/. 


\section{Glossary}

B

base metal A metal inferior in value to gold and silver, a term generally applied to the commercial metals such as copper and lead (Bureau of Land Management, 2000).

base metals Those metals usually considered to be of lesser value and of greater chemical reactivity compared to the noble or precious) metals, most commonly copper, lead, zinc, and tin (NRC, 1999).

beneficiation Improvement of the grade of ores by milling, flotation, sintering, gravity concentration, or other processes. Also termed "concentration" (National Research Council, 1999). The dressing or processing of ores to (1) regulate the size of a desired product, (2) remove unwanted constituents, and (3) improve the quality, purity, or assay grade of a desired product. Beneficiation includes concentration or other preparation of ore for smelting by drying, flotation, or magnetic separation (Bureau of Land Management, 2000).

bentonite A rock consisting of clay minerals formed from the decomposing of volcanic ash. Commonly bentonite can readily absorb or adsorb water and swell accordingly (Bureau of Land Management, 2000).

BLM Bureau of Land Management.

\section{C}

casual use Mining activities that only negligibly disturb Federal lands and resources. Casual use generally includes the collecting of geochemical, rock, soil, or mineral specimens using hand tools, hand panning, and nonmotorized sluicing. It also generally includes use of metal detectors, gold spears, and other batteryoperated devices for sensing the presence of minerals, and hand and battery-operated drywashers. Operators may use motorized vehicles for casual-use activities if the use conforms to the regulations governing such use, off-road vehicle use designations in BLM land-use plans, and temporary closures. Casual use does not include use of mechanized earth-moving equipment, truckmounted drilling equipment, suction dredges, motorized vehicles in areas designated as closed to off-road vehicles, chemicals, or explosives. It also does not include occupancy or operations where the cumulative effects of the activities result in more than negligible disturbance. Under casual use, operators do not have to notify BLM, and operations do not need to be approved. But operations are subject to monitoring by BLM to ensure that Federal lands do not undergo unnecessary or undue degradation. Casual use operations must be reclaimed (Bureau of Land Management, 2000). claim See mining claim (Bureau of Land Management, 2000).

common variety minerals Mineral materials that do not have a special quality, quantity, character, or location that makes them of unique commercial value. On public lands such minerals are considered salable and are disposed of by sales or by special permits to local governments (National Research Council, 1999). Stone, gravel, pumice, pumicite, and cinders that, though possibly having value for trade, manufacture, the sciences, or the mechanical or ornamental arts, do not have a distinct, special value for such use beyond normal uses. On Federal lands such minerals are considered salable and are disposed of by sales or by special permits to local governments. (National Research Council, 1999). See salable minerals, mineral materials, and uncommon variety minerals.

critical minerals Minerals essential to the national defense, the procurement of which in war, although difficult, is less serious than those of strategic minerals because they can be either domestically produced or obtained in more adequate amounts or are less essential, and for which some degree of conservation and distribution control is needed (Bureau of Land Management, 2000). See strategic minerals.

D

development (mineral) The preparation of a proven deposit for mining (Bureau of Land Management, 2000).

discovery As used in this report, initial recognition and demonstration of the presence of valuable mineral within a claim (National Research Council, 1999). The knowledge of the presence of valuable minerals within or close enough to a location to justify a reasonable belief in their existence. Discovery is an extremely important to public-lands mining because the General Mining Act of 1872 (30 U.S.C. 22-42) provides that mining claims can be located only after a discovery is made. Discovery was first legally defined in a landmark Department of the Interior 1894 land decision - Castle versus Womble. The definition, now known as the "Prudent Person Test, 'described a discovery as'... where minerals have been found and the evidence is of such a character that a person of ordinary prudence would be justified in the further expenditure of his labor and means, with a reasonable prospect of success in developing a valuable mine ...." (Bureau of Land Management, 2000).

E

entry An application to acquire title to public lands (Bureau of Land Management, 2000). 
environmental assessment (EA) A concise public document for which a Federal agency is responsible that does the following: (1) briefly gives enough evidence and analysis for determining whether to prepare an environmental impact statement (EIS) or a finding of no significant impact (FONSI), (2) aids an agency's compliance with the National Environmental Act when no EIS is needed, and (or) (3) facilitates preparing an EIS when one is needed (Bureau of Land Management, 2000).

environmental impact statement (EIS) A document required by the National Environmental Policy Act (NEPA) for certain actions "significantly affecting the quality of the human environment."

evaporite Sedimentary rock formed by the evaporation of a saline solution. Examples include rock salt, gypsum, and chemically precipitated limestone (Bureau of Land Management, 2000).

exploration The work of investigating a mineral deposit to determine by geological surveys, geophysical surveys, geochemical surveys, boreholes, pits, and underground workings if it is feasible to mine. Exploration is undertaken to gain knowledge of the size, shape, position, characteristics, and value of the deposit. For 43 CFR 3809 regulations, exploration means creating surface disturbance that is greater than casual use and that includes sampling, drilling, or developing surface or underground workings to evaluate the type, extent, quantity, or quality of mineral values present. Exploration does not include activities where material is extracted for commercial use or sale (Bureau of Land Management, 2000).

\section{$\mathbf{F}$}

Federal Land Policy and Management Act (FLPMA) The act that (1) set out for the Bureau of Land Management standards for managing the public lands, including land-use planning, sales, withdrawals, acquisitions, and exchanges; (2) authorized the setting up of local advisory councils representing major citizens groups interested in land-use planning and management; (3) established criteria for review of proposed wilderness areas; and (4) provided guidelines for other aspects of public land management such as grazing (Bureau of Land Management, 2000).

ferrous metals Metals commonly occurring in alloys with iron, such as chromium, nickel, manganese, vanadium, molybdenum, cobalt, silicon, tantalum, and columbium (niobium) (National Resource Council, 1999).

FWS U.S. Fish and Wildlife Service.
G

General Mining Act of 1872 (30 U.S.C. 22-42) The Federal act of May 10, 1872, that, with its amendments, formed the framework for the mining of locatable minerals on the public lands. This law declared that "valuable" mineral deposits rather than simply "mineral deposits" were to be free and open to exploration and purchase, limited individual claims to 20 acres, required $\$ 100$ worth of assessment work yearly, and allowed milling or processing claims of 5 acres or less to be entered on nonmineral lands (Bureau of Land Management, 2000).

geophysical exploration The use of geophysical instruments and methods to determine subsurface conditions by analyzing such properties as specific gravity, electrical conductivity, or magnetic susceptibility (Bureau of Land Management, 2000).

\section{H}

hardrock Locatable minerals that are neither leasable minerals (oil, gas, coal, oil shale, phosphate, sodium, potassium, sulfur, asphalt, or gilsonite) nor salable mineral materials (for example, common variety sand and gravel). Hardrock minerals include, but are not limited to, copper, lead, zinc, magnesium, nickel, tungsten, gold, silver, bentonite, barite, feldspar, fluorspar, and uranium. (Bureau of Land Management, 2000b) Usually refers to rock types or mining environments where the rocks are hard and strong and where blasting is needed to break them for effective mining. As used in this report, the term hardrock minerals are defined synonymous with "locatable minerals."

heavy metal Any of the metals that react readily with dithizone, including zinc, copper, cobalt, lead, bismuth, gold, cadmium, iron, manganese, nickel, tantalum, tellurium, platinum, and silver (Bureau of Land Management, 2000).

\section{I}

industrial minerals Rock and minerals that are not produced as sources of metals and are not mineral fuels. Examples include salt, gravels, building materials, talc, and sands (Bureau of Land Management, 2000).

$\mathbf{L}$

leasable minerals A legal term that identifies a mineral or mineral commodity that is leasable by the Federal Government under the Mineral Leasing Act of 1920 and similar legislation. Leasable minerals include oil, gas, sodium, potash, phosphate, 
coal, and all minerals on acquired lands (NRC, 1999) (examples are given in appendix 1). Minerals whose extraction from Federal land requires a lease and the payment of royalties. Leasable minerals include coal, oil and gas, oil shale and tar sands, potash, phosphate, sodium, and geothermal steam (Bureau of Land Management, 2000).

locatable minerals A legal term that identifies minerals acquired through the General Mining Act of 1872 (30 U.S.C. 22-42), as amended (examples are given in appendix 1). Locatable minerals are distinguished from federally owned minerals that are disposed of by leasing (see leasable minerals). In some situations, the term "hardrock minerals" is applied to locatable minerals (National Research Council, 1999). Minerals that may be acquired under the General Mining Act of 1872, as amended (Bureau of Land Management, 2000).

location The act of taking or appropriating a parcel of mineral land, including the posting of notices, the recording thereof when required, and marking the boundaries so they can be readily traced; also the claim acquired by an act of location. See mining claim (Bureau of Land Management, 2000).

lode claim A public lands mining claim that contains valuable minerals occurring in a vein or lode (Bureau of Land Management, 2000).

lode A mineral deposit in solid rock (Bureau of Land Management, 2000).

\section{M}

millsite A site located on nonmineral land and used for erecting a mill or reduction works, or for other uses reasonably incident to support of a mine. Millsites are limited to 5 acres and may be located either by metes and bounds or by legal subdivision. See location and mining claim (Bureau of Land Management, 2000).

mine An opening or excavation in the earth for extracting minerals (Bureau of Land Management, 2000).

mineral activity Mining and mineral exploration (Bureau of Land Management, 2000).

mineral assessment The determination of mineral potential, including the process for making that determination. Assessment usually does not include calculations of value or quantity, although these data may be part of an assessment where they are already known (Bureau of Land Management, 1985).

mineral claimant A person, association, corporation, or government that claims minerals rights or title in the public lands (Bureau of Land Management, 2000). mineral entry The filing of a claim on public land to obtain the right to any minerals it may contain (Bureau of Land Management, 2000).

mineral materials Materials such as common varieties of sand, stone, gravel, pumice, pumicite, and clay, that are not obtainable under the mining or leasing laws but that can be acquired under the Mineral Materials Act of 1947, as amended. See common variety minerals (Bureau of Land Management, 2000).

mineral occurrence A concentration of mineral that is considered to be valuable or that is of technical or scientific interest (National Research Council, 1999).

mineral prospect A mineral property whose value has not been proved by exploration (Bureau of Land Management, 2000).

mineral resource "A concentration of naturally occurring solid, liquid, or gaseous materials in or on the Earth's crust in such form that economic extraction of a mineral resource is currently or potentially feasible (after USGS Circular 831, p.1)" (Bureau of Land Management, 1985).

mineral rights Ownership of all minerals, including all rights needed for access, exploration, development, mining, ore dressing, and transportation (Bureau of Land Management, 2000).

mineral Several other common meanings, but the following are used in this report: Any natural resource extracted from the earth for human use; for example, ores, salts, coal, or petroleum (National Research Council, 1999). Any solid or fluid inorganic substance that can be extracted from the earth for profit (Bureau of Land Management, 2000).

mineral species Term used in this report to distinguish specific mineralogical species from the unmodified term "mineral" as defined above (National Research Council, 1999).

mineralization The processes taking place in the Earth's crust resulting in the formation of valuable minerals or ore bodies (Bureau of Land Management, 2000).

mineralogy The study of minerals - their formation, occurrence, properties, composition, and classification (Bureau of Land Management, 2000).

mining claim A parcel of land that a miner takes and holds for mining purposes, having acquired the right of possession by complying with the General Mining Act of $\mathbf{1 8 7 2}$ and local laws and rules. A single mining claim may contain as many adjoining locations as the locator may make or buy. There are four categories of mining claims: lode, placer, millsite, and tunnel site. For 43 CFR 3809 regulations, mining claim means any unpatented mining claim, millsite, or tunnel site 
located under the mining laws. The term also applies to mining claims and millsites that were located in the California Desert Conservation Area and patented after the enactment of the Federal Land Policy and Management Act of 1976 (Bureau of Land Management, 2000). See location, lode claim, placer claim, millsite, and tunnel site claim.

mining district An area, usually designated by name, with described or understood boundaries, where minerals are found and mined under rules prescribed by the miners, consistent with the General Mining Act of 1872 (Bureau of Land Management, 2000).

mining laws The Lode Law of July 26, 1866, as amended (14 Stat. 251); the Placer Law of July 9, 1870, as amended (16 Stat. 217); and the General Mining Act of May 10, 1872, as amended (17 Stat. 91); as well as all laws supplementing and amending those laws, including the Building Stone Act of August 4, 1892, as amended (27 Stat. 348); the Saline Placer Act of January 31, 1901 (31 Stat. 745); the Surface Resources Act of 1955 (30 U.S.C. 611-614); and the Federal Land Policy and Management Act of 1976 (43 U.S.C. 1701 et seq.) (Bureau of Land Management, 2000).

mining location A mining claim on the public lands (Bureau of Land Management, 2000).

\section{$\mathbf{N}$}

National Environmental Policy Act (NEPA) The Federal law, going into effect on January 1, 1970, that established a national policy for the environment and requires Federal agencies (1) to become aware of the environmental ramifications of their proposed actions, (2) to fully disclose to the public proposed Federal actions and provide a mechanism for public input to Federal decision-making, and (3) to prepare environmental impact statements for every major action that would significantly affect the quality of the human environment (Bureau of Land Management, 2000).

notice level operation A mining or exploration operation on BLM land involving more than casual use but requiring that the operator submit only a notice rather than a plan of operations. It is limited to an area of disturbance of 5 or fewer acres (National Research Council, 1999).

\section{0}

open-pit mining A surface mining method in which overlying rock and soil are removed to expose an ore body, which is then drilled, blasted, and hauled from the pit (Bureau of Land Management, 2000).

operations All functions, work, facilities, and activities on public lands in connection with prospecting, exploration, discovery, and assessment work, development, extraction, and processing of mineral deposits locatable under the mining laws; reclamation of disturbed areas; and all other reasonably incident uses, whether on a mining claim or not, including the building of roads, transmission lines, pipelines, and other means of access across public lands for support facilities.

operator Any person who manages, directs, or conducts mining operations at a project area, including a parent entity or an affiliate who materially participates in such management, direction, or conduct. An operator on a particular mining claim may also be the mining claimant (Bureau of Land Management, 2000).

ore The naturally occurring material from which a mineral or minerals of economic value can be extracted profitably or to satisfy social or political objectives (National Research Council, 1999).

ore body A mineralized mass whose characteristics have been determined and deemed commercially viable. The term ore body is used once the economic limits of the mineralized mass and its grade have been examined (Bureau of Land Management, 2000).

ore reserves The part of a mineral deposit that can be profitably mined. Use of this term implies detailed knowledge of all the geological, engineering, economic, and environmental parameters that might affect the profitability of an operation. For a new mining project or for the mining of new zones in an existing mine, a formal feasibility study is conducted to evaluate all the project's parameters (Bureau of Land Management, 2000).

ore deposit A mineral deposit of high enough quality to be mined at a profit (Bureau of Land Management, 2000).

$\mathbf{P}$

patent The instrument by which the Federal Government conveys title to public lands (Bureau of Land Management, 2000).

placer claim A mining claim located on gravel or ground whose mineral contents are extracted by the use of water (Bureau of Land Management, 2000).

placer deposit A mass of gravel, sand, or similar material resulting from the crumbling and erosion of solid rocks containing particles of gold or other valuable minerals that have been derived from rocks or veins (Bureau of Land Management, 2000).

placer mining A method of mining in which the overburden is removed to expose gold-bearing gravel deposits beneath. The gravel is then sluiced to separate the gold (Bureau of Land Management, 2000).

placer An alluvial deposit of sand and gravel containing valuable minerals such as gold (Bureau of Land Management, 2000). 
plans of operations Plans for mining exploration or development on BLM land involving more than 5 acres or a plan for mining where the operator with preexisting, valid claims intends to mine in an area of critical environmental concern or a wilderness area. Also a plan required for mining or exploration on U.S. Forest Service lands whenever the U.S. Forest Service determines that the operation will result in "significant" disturbance of the land surface (National Research Council, 1999).

precious metal A general term for gold, silver, or any of the metals of the platinum group (Bureau of Land Management, 2000). Any of several relatively scarce and valuable metals, such as gold, silver, and the platinum-group metals (National Research Council, 1999).

priority habitat management area (PHMA) BLM-administered lands as having the highest habitat value for maintaining sustainable sage-grouse populations. These areas are larger than the SFAs.

project area The area of land on which an operator conducts mining operations, including the area needed for building or maintaining of roads, transmission lines, pipelines, or other means of access (Bureau of Land Management, 2000).

public lands Any land and interest in land owned by the United States and administered by the Secretary of the Interior through the Bureau of Land Management, without regard to how the United States acquired ownership, except for (1) land located on the Outer Continental Shelf and (2) land held for the benefit of Indians, Aleuts, and Eskimos (Bureau of Land Management, 2000).

\section{Public Lands Survey System (PLSS) boundary or "study area"} The aggregate of all townships shown at various times since October 2015 on BLM Web sites, the Records of Decision (Bureau of Land Management, 2015a, b), or in written communication from BLM (Anthony Titolo, April 20, 2016) as those that include the "withdrawal areas."

\section{$\mathbf{R}$}

rare earth metals A group of widely distributed metals consisting of the elements scandium, yttrium, and 15 elements of atomic numbers 57 to 71 , inclusive. These metals have the same arrangement of the two external shells of electrons in their atoms and resemble one another closely in chemical and physical properties, being thus most difficult to separate from each other. It is for this property, rather than their actual rarity in nature, that they are so described (Bureau of Land Management, 2000).

record of decision (ROD) A document signed by a responsible official recording a decision that was preceded by the preparing of an environmental impact statement (Bureau of Land Management, 2000). reserve "That portion of a mineral resource from which a mineral commodity can be economically and legally extracted at the time of determination (after USGS Circular 831, p. 2)" (Bureau of Land Management, 1985).

resource management plan (RMP) A BLM planning document, prepared in accordance with Section 202 of the Federal Land Policy and Management Act that presents systematic guidelines for making resource management decisions for a resource area. An RMP is based on an analysis of an areas' resources, their existing management, and their capability for alternative uses. RMPs are issue oriented and developed by an interdisciplinary team with public participation (Bureau of Land Management, 2000).

\section{S}

sagebrush focal area or "SFA" FWS has identified as important landscape blocks with high breeding-population densities of greater sage-grouse (Centrocercus urophasianus), existing high quality sagebrush habitat, and a preponderance of Federal ownership or protected area that serves to anchor the conservation value of the landscape. "The BLM and USFS plans will focus the highest protections in the SFAs." (http://www.blm.gov/wo/st/en/ prog/more/sagegrouse/documents_and_resources.html)

salable minerals A legal term that defines mineral commodities that are sold by contract from the Federal Government. These are generally construction materials and aggregates. (National Research Council, 1999). See appendix 1.

segregation Any act such as a withdrawal or exchange that suspends the operation of the public land laws. See withdrawal (Bureau of Land Management, 2000).

SFA Sagebrush Focal Area

strategic minerals Minerals essential to the national defense for the supply of which during war we are wholly or partly dependent on sources outside the continental limits of the United States, and for which strict measures are needed to control conservation and distribution. See critical minerals (Bureau of Land Management, 2000).

study area See Public Lands Survey System (PLSS) boundary

$\mathbf{T}$

trace metals Metals that are present in small concentrations (Bureau of Land Management, 2000).

troy ounce A unit of measure based on troy weight (12 ounces to a pound) and equal to 1.09714 avoirdupois ounces. (An avoirdupois ounce is the conventional U.S. weight measure in which 16 ounces equal 1 pound.) 
tunnel site claim A mining claim located to secure an area for a tunnel. A tunnel site claim may be located on land where a tunnel is run to develop a vein or lode, or for intersecting unknown veins or lodes. See location and mining claim (Bureau of Land Management, 2000).

\section{U}

uncommon variety minerals On the Federal lands stone, gravel, pumice, pumicite, and cinder deposits that have distinct and special properties making them commercially valuable for use in a manufacturing, industrial, or processing operation. Such minerals are locatable under the General Mining Act of 1872, as amended. In determining a deposit's commercial value, the following factors may be considered: quality and quantity of the deposit, geographic location, accessibility to transportation, and proximity to market or point of use (National Research Council, 1999).

USFS U.S. Forest Service.

USGS U.S. Geological Survey.

wilderness area A congressionally designated area of undeveloped Federal land retaining its primeval character and influence, without permanent improvements or human habitation, that is protected and managed to preserve its natural conditions and that (1) generally appears to have been affected mainly by the forces of nature, with human imprints substantially unnoticeable; (2) has outstanding opportunities for solitude or a primitive and unconfined type of recreation; (3) has at least 5,000 acres or is large enough to make practical its preservation and use in an unimpaired condition; and (4) may also contain ecological, geological, or other features of scientific, educational, scenic, or historic value (Bureau of Land Management, 2000).

wilderness study area On BLM-managed lands, a roadless area that has been inventoried (but not designated by Congress) and found to have wilderness characteristics as described in Section 603 of the Federal Land Policy and Management Act of 1976 (FLPMA; Pub. L. 94-579; 90 Stat. 2743) and section (c) of the Wilderness Act of 1964 (PUB. L. 88-577). BLM manages wilderness study areas to protect their wilderness characteristics until Congress decides whether to designate them as wilderness (Bureau of Land Management, 2000). withdrawal areas, or "withdrawals" Informal term used within these reports to identify those Federal lands within the Sagebrush Focal Areas (SFAs) that are proposed for closure to locatable mineral entry subject to valid existing rights. The proposed withdrawal areas are a subset of lands within the larger SFAs.

\section{References Cited}

Bureau of Land Management, 1985, Energy and mineral resource assessment: Washington, D.C., U.S. Department of Interior, Bureau of Land Management, accessed March 15, 2016, at http:// www.blm.gov/wo/st/en/info/regulations/Instruction_Memos_ and_Bulletins/blm_manual.html.

Bureau of Land Management, 2000, Surface management regulations for locatable mineral operations: Bureau of Land Management, Final Environmental Impact Statement, v. 1, 664 p., accessed May 25, 2016, at https://archive.org/details/ surfacemanagemen $01 /$.

Bureau of Land Management, 2015a, Record of Decision and approved resource management plan amendments of the Great Basin region, including the greater sage-grouse sub-regions of Idaho and Southwestern Montana, Nevada and northeastern California: Washington, D.C., U.S. Department of Interior, Bureau of Land Management, September 2015, accessed March 15, 2016, at http://www.blm.gov/style/medialib/blm/ wo/Communications_Directorate/public_affairs/sage-grouse_ planning/documents.Par.44118.File.dat/GB\%20ROD.pdf.

Bureau of Land Management, 2015b, Record of Decision and approved resource management plan amendments for the Rocky Mountain region, including the greater sage-grouse sub-regions of Lewiston, North Dakota, Northwest Colorado, Wyoming, and the approved resource management plans for Billings, Buffalo, Cody, HiLine, Miles City, Pompeys Pillar National Monument, South Dakota, Worland: Washington, D.C., U.S. Department of Interior, Bureau of Land Management, September, 2015, accessed March 15, 2016, at http://www.blm.gov/style/medialib/blm/ wo/Communications_Directorate/public_affairs/sage-grouse_ planning/documents.Par.57493.File.dat/RM\%20ROD.pdf.

National Research Council, 1999, Hardrock mining on Federal Lands: Washington, D.C., National Academy Press, 260 p., accessed May 25, 2016, at http://www.nap.edu/catalog/9682/ hardrock-mining-on-federal-lands. 
Appendixes 1-5 


\section{Appendix 1. List of Locatable, Leasable, and Salable Minerals}

[BLM, Bureau of Land Management]

\begin{tabular}{|c|c|c|}
\hline Mineral commodity & BLM designation & Comment \\
\hline \multicolumn{3}{|r|}{ Primarily locatable minerals } \\
\hline Aluminum & Locatable & None \\
\hline Antimony & Locatable & None \\
\hline Barite & Locatable & None \\
\hline Bentonite & Locatable & None \\
\hline Beryllium & Locatable & None \\
\hline Calcium borates & Locatable & Calcium borates are locatable minerals. Sodium borates are leasable minerals. \\
\hline Carbon & Locatable & $\begin{array}{l}\text { Carbon is not usually a metal in the Mendeleev Periodic Chart of the Elements. It is } \\
\text { included in this list as a metal because of its metallic properties, such as being a } \\
\text { conductor of electricity, which is useful in certain green energy batteries. Carbon is } \\
\text { also locatable as an industrial mineral, and as diamond. }\end{array}$ \\
\hline Decorative stone & Locatable or salable & $\begin{array}{l}\text { Most decorative stone requires a mineral material sales contract. Only uncommon } \\
\text { varieties of decorative stone may be acquired using mining claims. }\end{array}$ \\
\hline Diamond & Locatable & None \\
\hline Diatomite & Locatable & None \\
\hline Fluorspar & Locatable & Also known as fluorite. \\
\hline Gallium & Locatable & None \\
\hline Garnet & Locatable & None \\
\hline Gemstones & Locatable or salable & $\begin{array}{l}\text { Most nonprecious and semiprecious gemstones require a mineral material sale } \\
\text { contract. But most production comes from hobby collection on mining claims. }\end{array}$ \\
\hline Geodes & Primarily salable & Geodes are seldom locatable. Only uncommon varieties of geodes are. \\
\hline Gypsum & Locatable & None \\
\hline Mica & Locatable & None \\
\hline Mineral Specimens & Rarely locatable & $\begin{array}{l}\text { Mineral specimens are seldom locatable. Only uncommon varieties of geodes are } \\
\text { considered locatable. }\end{array}$ \\
\hline Niobium & Locatable & Also called columbium. \\
\hline Perlite & Locatable & None \\
\hline Platinum-group metals & Locatable & $\begin{array}{l}\text { Platinum-group metals (PGMs) commonly occur together and include platinum, } \\
\text { palladium, rhodium, ruthenium, osmium, and iridium. }\end{array}$ \\
\hline Pozzolan & Locatable & $\begin{array}{l}\text { Pozzolan is a naturally occurring additive to concrete. When pozzolan meets } \\
\text { specifications, it increases the strength of the resulting structure. Pozzolan can } \\
\text { generally replace portland cement in the concrete by about one-to-one. Doing so } \\
\text { reduces the emission of carbon dioxide }\left(\mathrm{CO}_{2}\right) \text { during the production of the portland } \\
\text { cement. Not a specific mineral; can be from volcanic ash, pumice, or diatomaceous } \\
\text { earth. }\end{array}$ \\
\hline $\begin{array}{l}\text { Pumice (greater than } 2 \\
\text { inches diameter) }\end{array}$ & Locatable & $\begin{array}{l}\text { By Act of Congress, to be locatable, pumice must have at least one dimension that is } 2 \\
\text { inches or larger. }\end{array}$ \\
\hline
\end{tabular}




\begin{tabular}{|c|c|c|}
\hline Mineral commodity & BLM designation & Comment \\
\hline \multicolumn{3}{|r|}{ Primarily locatable minerals-Continued } \\
\hline Rare Earth Elements & Locatable & $\begin{array}{l}\text { Elements commonly referred to as rare earths include yttrium, scandium, lanthanum, } \\
\text { cerium, praseodymium, neodymium, promethium, samarium, europium, gadolinium, } \\
\text { terbium, dysprosium, holmium, erbium, thulium, ytterbium, and lutetium. }\end{array}$ \\
\hline $\begin{array}{l}\text { Silica and Silica Sand (high } \\
\text { purity or uncommon } \\
\text { variety) }\end{array}$ & Locatable & $\begin{array}{l}\text { Silica must be high purity, suitable for an uncommon use. Silica sand must be an } \\
\text { uncommon variety, such as proppant sand for hydrofracking. }\end{array}$ \\
\hline Sulfur & Locatable or leasable & None \\
\hline Tantalum & Locatable & None \\
\hline Tellurium & Locatable & None \\
\hline Thorium & Locatable & None \\
\hline Tin & Locatable & None \\
\hline Vanadium & Locatable & None \\
\hline Vermiculite & Locatable & None \\
\hline Zeolite & Locatable & None \\
\hline Zinc & Locatable & None \\
\hline Zirconium & Locatable & None \\
\hline \multicolumn{3}{|r|}{ Leasable minerals } \\
\hline Bituminous rock & Leasable & None \\
\hline Coal & Leasable & None \\
\hline Geothermal energy & Leasable & None \\
\hline Native asphalt & Leasable & None \\
\hline Helium & Leasable & None \\
\hline Magnesium evaporites & Leasable & Or "bitterns" \\
\hline \multicolumn{3}{|r|}{ Primarily salable minerals } \\
\hline Sand & Salable & None \\
\hline Stone & Salable & None \\
\hline Gravel & Salable & None \\
\hline Pumice & Salable & None \\
\hline Pumicite & Salable & None \\
\hline Cinders & Salable & None \\
\hline Clay (common) & Salable & None \\
\hline Decorative stone & Salable & None \\
\hline Building stone (common) & Locatable or salable & None \\
\hline Gemstones & Locatable or salable & None \\
\hline Limestone & Locatable or salable & None \\
\hline
\end{tabular}




\section{Appendix 2. Mineral-Potential Classification System}

The approach to classification of the qualitative mineralresource potential for locatable minerals followed that prescribed in Bureau of Land Management (BLM) Manual Sections 3031 and 3060 defined originally by Goudarzi (1984) (fig. 2-1).

\section{Level of Potential}

N. The geologic environment, the inferred geologic processes, and the lack of mineral occurrences do not indicate potential for accumulation of mineral resources.

L. The geologic environment and the inferred geologic processes indicate low potential for accumulation of mineral resources.

M. The geologic environment, the inferred geologic processes, and the reported mineral occurrences or valid geochemical/ geophysical anomaly indicate moderate potential for accumulation of mineral resources.

H. The geologic environment, the inferred geologic processes, the reported mineral occurrences and (or) valid geochemical/geophysical anomaly, and the known mines or deposits indicate high potential for accumulation of mineral resources. The "known mines and deposits" do not have to be within the area that is being classified but have to be within the same type of geologic environment.

ND. Minerals potential not determined due to lack of useful data. This does not require a level of certainty qualifier.

\section{Level of Certainty}

A. The available data are insufficient and (or) cannot be considered as direct or indirect evidence to support or refute the possible existence of mineral resources within the respective area.

B. The available data provide indirect evidence to support or refute the possible existence of mineral resources.

C. The available data provide direct but quantitatively minimal evidence to support or refute the possible existence of mineral resources.

D. The available data provide abundant direct and indirect evidence to support or refute the possible existence of mineral resources.

For the determination of "no potential" use N/D. This class shall be seldom used, and when used it should be for a specific commodity only. For example, if the available data show that the surface and subsurface types of rock in the respective area are batholithic (igneous intrusive), one can conclude, with reasonable certainty, that the area does not have potential for coal.

As used in this classification, potential refers to potential for the presence (occurrence) of a concentration of one or more energy and (or) mineral resources. It does not refer to or imply potential for development and (or) extraction of the mineral resource(s). It does not imply that the potential concentration is or may be economic, that is, could be extracted profitably.

\section{Reference Cited}

Goudarzi, G.H., compiler, 1984, Guide to preparation of mineral survey reports on public lands: U.S. Geological Survey Open-File Report 84-787, 41 p., accessed December 9, 2015, at https://pubs.er.usgs.gov/publication/ofr84787. 


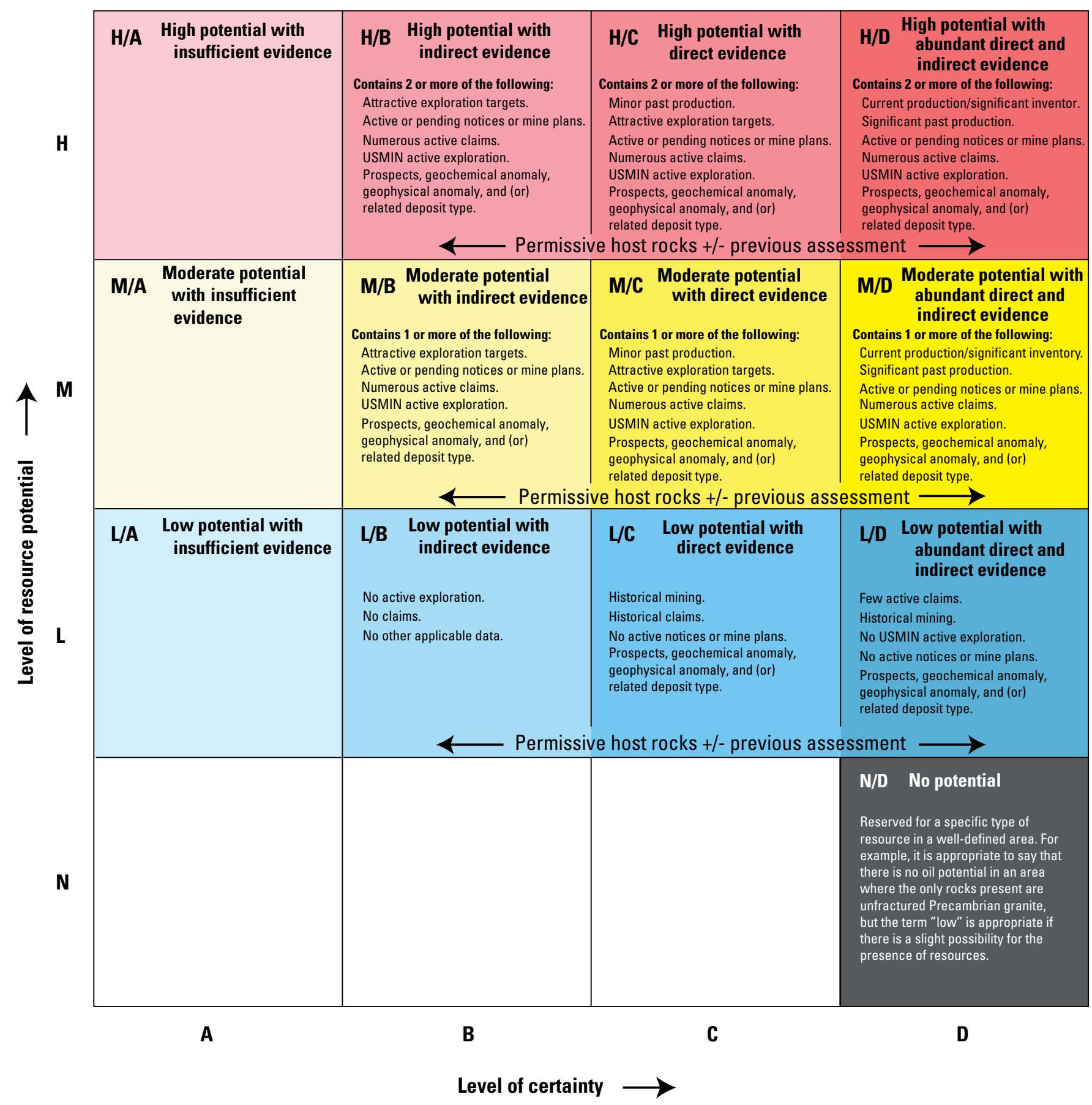

Figure 2-1. Matrix showing the classification system used for qualitative mineral-resource potential for locatable minerals in the Sagebrush Mineral-Resource Assessment (see text for abbreviations). USMIN, U.S. Geological Survey Mineral Deposit Database. 



\section{Appendix 3. Mineral-Deposit Models}

Concise mineral-deposit models for the mineral-deposit types that were considered for the Sagebrush Mineral-Resource Assessment (SaMiRA) study are included in this appendix, grouped by the mineral systems adopted for this study. See section $\mathrm{H}$ for a discussion of mineral systems and mineral deposits. These mineral-deposit models are based on the references cited for each model. See the complete reference for additional information on the deposit type. The table that accompanies this appendix contains additional information about these deposit types such as an association of the deposit type with metallic or nonmetallic commodities and strategic or critical minerals (table 3-1). In addition, the most common mining methods associated with each deposit type are listed using Bureau of land management (BLM) mining method classifications (A. Merrill, written commun., May 2016). The last two columns of the table list median tonnages and references for the deposit types that have published tonnage models. The populations of deposits used to construct the cited tonnage models may or may not be appropriate for the study area; these are simply provided as a general guide to the order of magnitude of tonnages typically associated with the deposit type throughout the world. (Note that chemical symbols used in the tables below are defined in the front matter of this report.) 


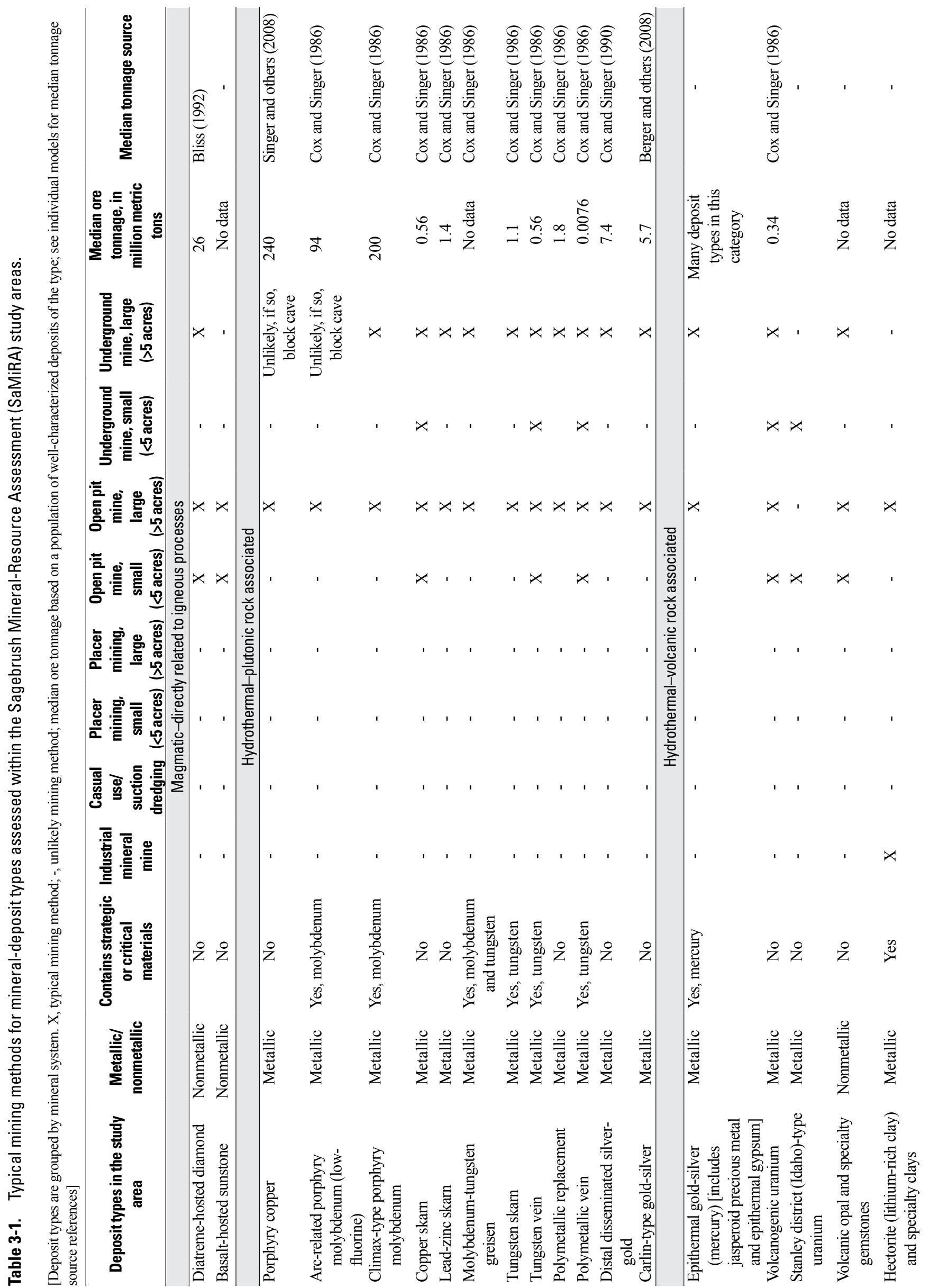




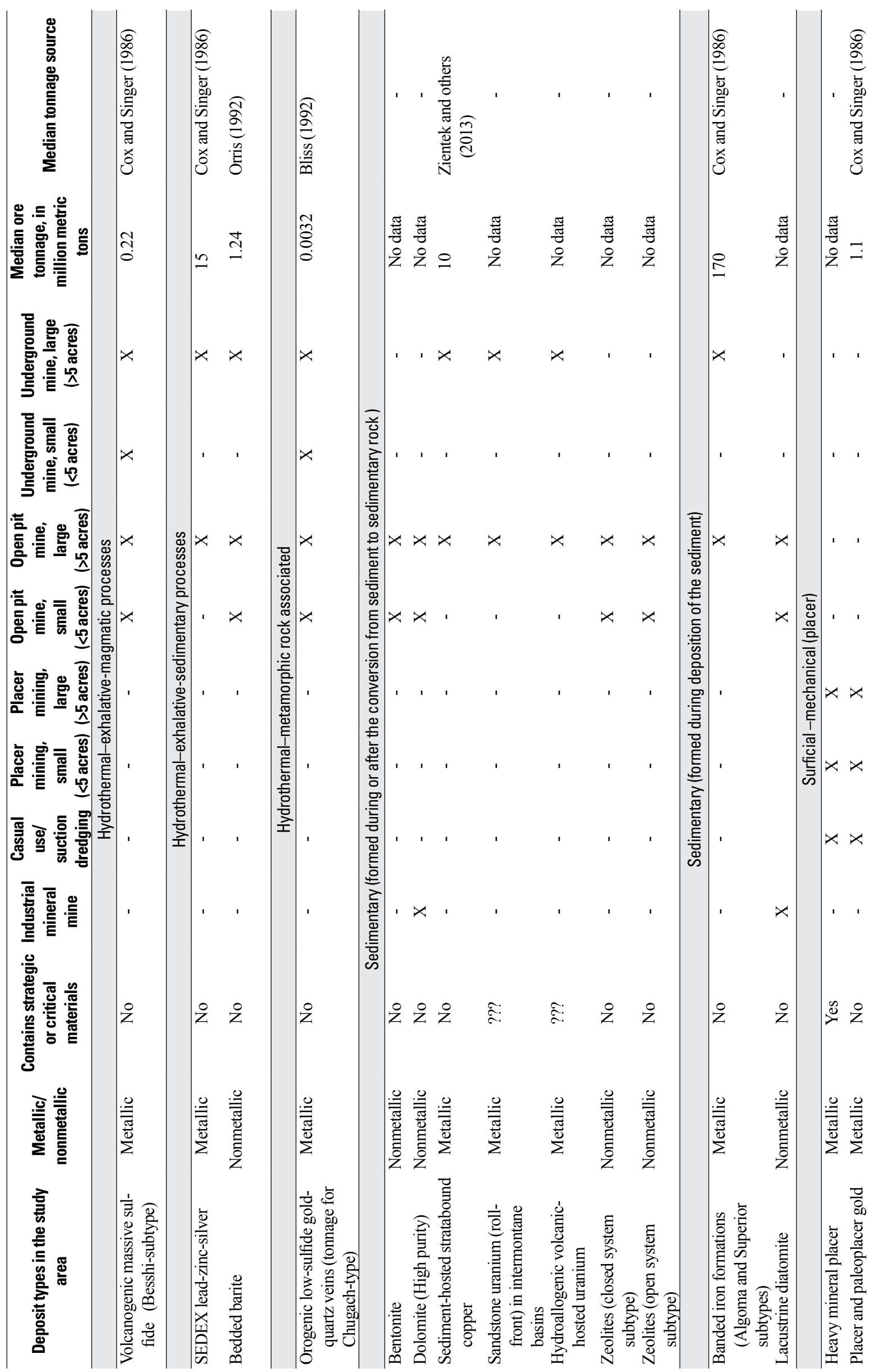




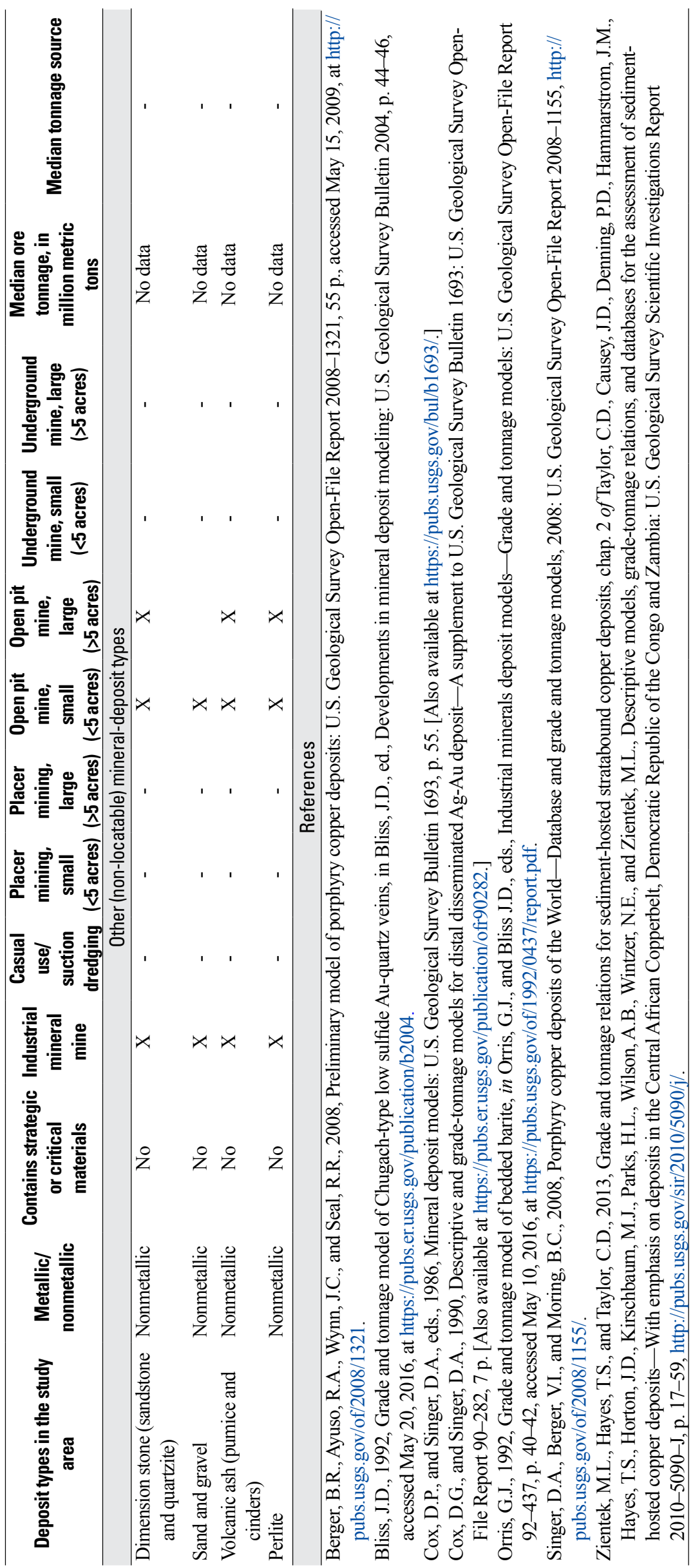




\section{Magmatic Systems}

Deposit types in the study area

Diatreme-hosted diamond

Basalt-hosted sunstone 


\section{Diatreme-Hosted Diamond}

[km, kilometer; t, metric ton; $\mathrm{g} / \mathrm{t}$, grams per metric ton; ppm, parts per million; Ma, mega-annum or millions of years ago]

\begin{tabular}{ll}
\hline Synonyms & Diamond-bearing kimberlite pipes, diamond pipes, group-1 kimberlites. \\
Commodities & Diamond. \\
Description & $\begin{array}{c}\text { Diamonds in kimberlite diatremes and other alkaline mafic rocks. Kimberlites are volatile-rich, potassic ultrabasic rocks } \\
\text { with macrocrysts (and sometimes megacrysts and xenoliths) set in a fine-grained matrix. }\end{array}$ \\
\hline
\end{tabular}

Geological environment

Rock types

Depositional environment

Tectonic setting(s)

Associated deposit types

Small hypabyssal intrusions that grade upwards into diatreme breccias near surface and pyroclastic rocks in the crater facies at surface. Kimberlites are volatile-rich, potassic ultrabasic rocks that commonly exhibit a distinctive inequigranular texture resulting from the presence of macrocrysts (and sometimes megacrysts and xenoliths) set in a fine-grained matrix. The megacryst and macrocryst assemblage in kimberlites includes anhedral crystals of olivine, magnesian ilmenite, pyrope garnet, phlogopite, Ti-poor chromite, diopside, and enstatite. Some of these phases may be xenocrystic in origin. Matrix minerals include microphenocrysts of olivine and one or more of monticellite, perovskite, spinel, phlogopite, apatite, and primary carbonate and serpentine.

Kimberlites crosscut all types of rocks.

Any age except Archean for host intrusions. Economic deposits occur in kimberlites from Proterozoic to Tertiary in age. The diamond ages vary from early Archean to as young as $990 \mathrm{Ma}$.

Kimberlites rise quickly from the mantle and are emplaced as multistage, high-level diatremes, tuff-cones and rings, and hypabyssal dikes and sills.

Ancient stable cratons, alkalic rock provinces, regions of crustal tension with deep-seated fractures, broad anticlines and synclines with deep-seated fractures, and regions of low geothermal gradient.

Diamonds can be concentrated, by weathering to produce residual concentrations, or within placer deposits. Lamproitehosted diamond deposits form in a similar manner, but the magmas may be of different origin.

\section{Deposit description}

Ore mineralogy

Alteration

Ore controls

Geochemical signatures

Geophysical signature

\section{Diamond}

Serpentinization in many deposits; silicification or bleaching along contacts. Secondary calcite, quartz, and zeolites can occur on fractures. Diamonds can undergo graphitization or resorption.

Kimberlites typically occur in fields comprising as much as 100 individual intrusions, often grouped in clusters. Each field can exhibit considerable diversity with respect to the petrology, mineralogy, mantle xenolith and diamond content of individual kimberlites. Economically diamondiferous and barren kimberlites can occur in close proximity. Controls on the differences in diamond content between kimberlites are not completely understood. They may be due to depths of origin of the kimberlite magmas (above or below the diamond stability field); differences in the diamond content of the mantle sampled by the kimberlitic magma; degree of resorption of diamonds during transport; flow differentiation; batch mixing; or some combination of these factors.

Elevated $\mathrm{Ti}, \mathrm{Cr}, \mathrm{Ni}, \mathrm{Mg}, \mathrm{Ba}$ and $\mathrm{Nb}$ in overlying residual soils. However, caution must be exercised as other alkaline rocks can give similar geochemical signatures.

Geophysical techniques are used to locate kimberlites but give no indication as to their diamond content. Ground and airborne magnetometer surveys are commonly used; kimberlites can show as either magnetic highs or lows. In equatorial regions, the anomalies are characterized by a magnetic dipolar signature in contrast to the "bulls-eye" pattern in higher latitudes. Some kimberlites, however, have no magnetic contrast with surrounding rocks. Some pipes can be detected using electrical methods (for example, electromagnetic and very low frequency, resistivity) in airborne or ground surveys. These techniques are particularly useful where the weathered, clay-rich, upper parts of pipes are preserved because they are conductive and may contrast sufficiently with the host rocks to be detected. Ground-based gravity surveys can be useful in detecting kimberlites that have no other geophysical signature and in delineating pipes. Deeply weathered kimberlites or those with a thick sequence of crater sediments generally give negative responses and where fresh kimberlite is found at surface, a positive gravity anomaly may be obtained.

Economic factors

Grade and tonnage

The amount of diamond contained within diamond bearing pipes is extremely small, with commercially mineable concentrations ranging from $.01 \mathrm{ppm}$ to $0.80 \mathrm{ppm}$ ( 0.04 to 4.0 carats per ton). The clarity, size, shape, color, and volume of diamonds within a pipe need to be carefully determined before the true economic potential of a diamond-bearing pipe can be determined. 


\begin{tabular}{|c|c|}
\hline \multicolumn{2}{|r|}{ Other assessment and exploration guides } \\
\hline \multicolumn{2}{|c|}{$\begin{array}{l}\text { Mineral chemistry is used extensively to help determine whether the kimberlite source is diamondiferous or barren. Diamond-bearing kimberlites can } \\
\text { contain high-Cr, low-Ca pyrope garnets (G10 garnets), sodium-enriched eclogitic garnets, high-Cr chromites with moderate to high Mg contents, and } \\
\text { magnesian ilmenites. }\end{array}$} \\
\hline In/near focal areas & Kimberlites occur in north-central Montana; however, only one microdiamond has been reported. \\
\hline Elsewhere & Koala, Panda, Sable, Fox and Misery (Northwest Territories, Canada); Kimberly, Premier and Venetia (South Africa) \\
\hline \multicolumn{2}{|r|}{ References } \\
\hline \multirow{2}{*}{\multicolumn{2}{|c|}{$\begin{array}{l}\text { Hearn, Jr., B.C., 1968, Diatremes with kimberlite affinities in north-central Montana: Science, v. 159, p. 622-625. } \\
\text { Michalski, T.C., and Modreski, P.J., 1991, Descriptive model of diamond-bearing kimberlite pipes, in Orris, G.J., and Bliss, J.D., eds., Some industrial } \\
\text { mineral deposit models: U.S. Geological Survey Open-File Report 91-11-A, p. 1- 5, accessed April 15, 2016, at http://pubs.usgs.gov/of/1991/ofr-91- } \\
\text { 0011-a/ofr-91-0011a.pdf. }\end{array}$}} \\
\hline & \\
\hline \multicolumn{2}{|c|}{$\begin{array}{l}\text { Pell, J., 1998, Kimberlite-hosted diamonds, in Geological Fieldwork 1997, British Columbia Ministry of Employment and Investment, Paper 1998-1, p. } \\
\text { 24L-1 to 24L-4. }\end{array}$} \\
\hline \multicolumn{2}{|c|}{$\begin{array}{l}\text { Kjarsgaard, B.A., 2007, Kimberlite diamond deposits, in Goodfellow, W.D., ed., Mineral deposits of Canada—A synthesis of major deposit types, district } \\
\text { metallogeny, the evolution of geological provinces, and exploration methods: Geological Association of Canada, Mineral Deposits Divisions, Special } \\
\text { Publication No. 5, p. 245-272. }\end{array}$} \\
\hline
\end{tabular}




\section{Basalt-Hosted Sunstone}

[t, metric ton; N/A, not applicable]

\begin{tabular}{|c|c|}
\hline Synonyms & Gem labradorite feldspar. \\
\hline Commodities & Sunstone. \\
\hline Description & $\begin{array}{l}\text { Gem-quality labradorite in weathered basalt flows that exhibit adventurescence, a light reflectance phenomenon } \\
\text { caused by inclusions of copper (in Oregon) or hematite (other localities). }\end{array}$ \\
\hline \multicolumn{2}{|r|}{ Geological environment } \\
\hline Rock types & $\begin{array}{l}\text { In Oregon, sunstone occurs locally in a weathered basalt flow that is part of a classic volcanic highland typified } \\
\text { by shield volcanoes, cinder cones, large bodies of ashfall tuffs, regionally extensive basalt flows of varying } \\
\text { thicknesses, and locally extensive red cinder beds. }\end{array}$ \\
\hline \multicolumn{2}{|r|}{ Deposit description } \\
\hline Ore mineralogy & Labradorite \\
\hline Alteration & $\begin{array}{l}\text { Groundmass of gem-bearing zones at the Ponderosa Mine is highly weathered to unconsolidated reddish-brown } \\
\text { material. }\end{array}$ \\
\hline Ore controls & $\begin{array}{l}\text { Sunstone occurs as phenocrysts in a moderately to heavily weathered scoriaceous porphyritic basalt of } \\
\text { calcalkaline affinity composed of labradorite feldspar and basaltic glass, with minor olivine and magnetite/ } \\
\text { ilmenite present as accessory phases. The vesicles are filled to varying amounts with nonspecific clay and } \\
\text { feldspar alteration products. }\end{array}$ \\
\hline Geochemical signatures & $\mathrm{N} / \mathrm{A}$ \\
\hline Geophysical signature & $\mathrm{N} / \mathrm{A}$ \\
\hline
\end{tabular}

\begin{tabular}{|c|c|}
\hline \multicolumn{2}{|r|}{ Economic factors } \\
\hline Importance & $\begin{array}{l}\text { The premier U.S. gem-quality feldspar is the red labradorite, known as sunstone, mined in Oregon. Large } \\
\text { quantities of gem-quality labradorite from deposits in southeastern Oregon for many years. The common } \\
\text { color of Oregon sunstone is straw-yellow, it also can be pink, peach, red, salmon red-orange, red-green, and } \\
\text { blue-green. It also can be bicolored and tricolored in combinations of yellow, red, and green, and a small } \\
\text { percentage is dichroic and trichroic. } \\
\text { In 1988, the availability and quality of sunstone, other than the standard yellow Oregon variety, drastically } \\
\text { increased with the discovery of the Ponderosa Mine. The vivid-red faceted stones and cabochons from this } \\
\text { mine set a new world standard sunstone. The opening of the mine also increased the supply of peach, salmon } \\
\text { red-orange, red-green, green, blue-green, and bicolored and tricolored in combinations of yellow, red, and } \\
\text { green. For the first time ever, there was a continuous U.S. supply of the more desirable colors in sizes needed } \\
\text { by the jewelry industry. The largest faceted high-quality red sunstone is more than } 10 \text { carats. The supply from } \\
\text { this and other developed deposits will continue to be adequate for many years into the future. }\end{array}$ \\
\hline
\end{tabular}

Other assessment and exploration guides

\section{N/A}

\section{Examples}

In/near focal areas $\quad$ Ponderosa Mine, Oregon; Dust Devil Mine, Oregon; Sunstone Butte Mine, Oregon.

\section{References}

Brown, D.E., McLean, G.D., and Black, G.L., 1981, Preliminary geology and geothermal potential of the southern Harney Basin: Oregon Department of Geology and Mineral Industries, Open File Report 0-80-07.

Johnston, C.L., Gunter, M.E., and Knowles, C.R., 1991, Sunstone labradorite from the Ponderosa mine, Oregon: Gems and Gemology, v. 27, no. 4, p. 220-233.

Pay, Duncan, Weldon, Robert, McClure, Shane, and Schumacher, Kevin, 2013, Three occurrences of Oregon sunstone: Gems and Gemology, v. 49, no. 3, 162-171, accessed April 28, 2016, at http:/www.gia.edu/gems-gemology/FA13-oregon-sunstone-pay.

U.S. Bureau of Mines, 1995, An overview of production of specific U.S. gemstones: U.S. Bureau of Mines Special Publication 14-95, accessed April 21, 2016, at http://minerals.usgs.gov/minerals/pubs/commodity/gemstones/sp14-95/index.html. 


\section{Hydrothermal—Plutonic Rock Associated System}

Deposit types in the study area

Porphyry copper
Arc-related porphyry molybdenum (low-fluorine)
Copper skarn
Tungsten skarn
Lead-zinc skarn
Polymetallic replacement
Polymetallic vein
Tungsten vein
Molybdenum-tungsten greisen
Distal disseminated silver-gold
Carlin-type gold-silver




\section{Porphyry Copper}

[wt.\%, weight percent; g/t, grams per metric ton; Mt, million metric tons; avg, average; km, kilometer]

\begin{tabular}{|c|c|}
\hline Synonyms & Calcalkaline porphyry. \\
\hline Commodities & $\mathrm{Cu}, \mathrm{Mo}, \mathrm{Au}, \mathrm{Ag}$. \\
\hline Description & $\begin{array}{l}\text { Porphyry copper deposits consist of disseminated copper minerals and copper minerals in veins and breccias that are } \\
\text { relatively evenly distributed in large volumes of rock, forming high tonnage ( }>100 \mathrm{Mt}) \text {, low to moderate grade } \\
(0.3-2.0 \mathrm{wt} . \% \mathrm{Cu}) \text { ores. Host rocks are altered and genetically related granitoid porphyry intrusions and adjacent wall } \\
\text { rocks. }\end{array}$ \\
\hline
\end{tabular}

\begin{tabular}{lc}
\hline Geological environment \\
\hline Rock types $\quad$ Tonalite to monzogranite or syenitic porphyry intruding granitic, volcanic, calcareous sedimentary, and other rocks.
\end{tabular}

Rock types

Textures

Age range

Depositional environment

Tectonic setting(s)

Associated deposit types

Ore mineralogy

Alteration

Ore controls

Geochemical signatures

Geophysical signature
Porphyry has closely spaced phenocrysts and microaplitic quartz-feldspar groundmass.

Mainly Mesozoic and Cenozoic, but may be any age.

High-level intrusive complexes that commonly include stocks, dikes, and breccia pipes. Many deposits are focused in swarms of porphyry dikes that may radiate from larger intrusions or batholiths. The deposits form at shallow (mostly $6 \mathrm{~km}$ or less) depth by fluids exsolved from underlying crystallizing magmas emplaced at greater than $3-10-\mathrm{km}$ depth in the upper crust and by external waters heated by those magmas.

Localized in time and space within magmatic arcs along convergent plate margins where subduction of oceanic crust and arc-type magmatism generates hydrous, oxidized upper crustal granitoids genetically related to ores. Arc crust is relatively thick, and there is evidence for broadly coeval compressional or transpressional tectonism.

Skarns $(\mathrm{Cu}, \mathrm{Fe}, \mathrm{Au}, \mathrm{Zn})$, polymetallic replacement, polymetallic veins, distal-disseminated $\mathrm{Au}-\mathrm{Ag}$, epithermal veins.
Deposit description

Hypogene: Chalcopyrite+pyrite \pm molybdenite; chalcopyrite + magnetite \pm bornite $\pm \mathrm{Au}$; assemblages may be superposed. Quartz+K-feldspar+biotite \pm anhydrite; quartz+sericite+clay minerals. Late veins of enargite, tetrahedrite, galena, sphalerite, and barite in some deposits. Supergene: brochantite, copper pitch, cuprite, native copper, tenorite, chrysocolla, neotocite, malachite, and atacamite.

Major alteration types are (1) potassic, (2) sericitic, (3) advanced argillic, (4) intermediate argillic, (5) propylitic, (6) sodiccalcic and sodic, (7) greisen, and (8) skarn. Weathering can form an enriched oxide zone above sulfide ore.

Stockwork veins in porphyry, along porphyry contact, and in favorable country rocks such as carbonate rocks, mafic igneous rocks, and older granitic plutons.

$\mathrm{Cu}+\mathrm{Mo} \pm \mathrm{Au}+\mathrm{Ag}+\mathrm{W}+\mathrm{B}+\mathrm{Sr}$ center, $\mathrm{Pb}, \mathrm{Zn}, \mathrm{Au}, \mathrm{As}, \mathrm{Sb}, \mathrm{Se}, \mathrm{Te}, \mathrm{Mn}, \mathrm{Co}, \mathrm{Ba}$, and Rb outer. Locally Hg and Sn form most distal anomalies. High $\mathrm{S}$ in all zones. Some deposits have weak $\mathrm{U}$ anomalies.

Ore zones can be associated with magnetite-rich rocks and are indicated by magnetic surveys. Intensely hydrothermally altered rocks, with quartz-pyrite-sericite (phyllic) alteration produce magnetic and resistivity lows. Pyritic haloes surrounding ore respond well to induced polarization (IP) surveys but in sulfide-poor systems the ore itself provides the only significant IP response.

Remote sensing: In areas of good exposure with limited vegetation, airborne and spaceborne multispectral and hyperspectral imaging systems can be used to map alteration mineral associations and their spatial relations in porphyry copper systems. Hydrothermal minerals characteristic of sericitic, intermediate and advanced argillic, and propylitic alteration, iron oxides and hydroxides, and silica can be remotely mapped using their distinctive absorption features in the visible near-infrared through short-wave infrared and thermal-infrared wavelengths.

\section{Economic factors}

Grade and tonnage

$\mathrm{Cu}$ grades vary from 0.03 to $2 \mathrm{wt} . \%$; avg $0.44 \mathrm{wt} . \%$. Mo grades vary from < 0.001 to $0.1 \mathrm{wt.} \%$; avg $0.019 \mathrm{wt} . \%$. Au varies from 0.001 to $6.6 \mathrm{~g} / \mathrm{t}$; avg $0.31 \mathrm{~g} / \mathrm{t}$. Ag varies from 0.08 to $65 \mathrm{~g} / \mathrm{t}$; avg $3.2 \mathrm{~g} / \mathrm{t}$. Tonnages range from 2 to 21,000 Mt.

Importance Porphyry copper deposits supply about 60 percent of the world's copper.

\section{Examples}

\begin{tabular}{ll}
\hline In/near focal area & Contact, Nevada. \\
Elsewhere & Bingham, Utah; Yerington and Ann Mason, Nevada; Butte, Montana.
\end{tabular}

References

John, D.A., Ayuso, R.A., Barton, M.D., Blakely, R.J., Bodnar, R.J., Dilles, J.H., Gray, Floyd, Graybeal, F.T., Mars, J.C., McPhee, D.K., Seal, R.R., Taylor, R.D., and Vikre, P.G., 2010, Porphyry copper deposit model, chap. B of Mineral deposit models for resource assessment: U.S. Geological Survey Scientific Investigations Report 2010-5070-B, 169 p., accessed April 15, 2016, at http://pubs.usgs.gov/sir/2010/5070/b/. 


\section{Copper Skarn}

[wt.\%, weight percent; Mt, million metric tons]

\begin{tabular}{ll}
\hline Synonyms & Pyrometasomatic and contact metasomatic copper deposits. \\
Commodities & $\mathrm{Cu}, \mathrm{Au}, \mathrm{Ag}, \mathrm{Mo}, \mathrm{W}$, magnetite. \\
Description & $\begin{array}{c}\mathrm{Cu}-\text { dominant mineralization (generally chalcopyrite) genetically associated with a skarn gangue (includes calcic and } \\
\text { magnesian Cu skarns). }\end{array}$ \\
\hline
\end{tabular}

\begin{tabular}{|c|c|}
\hline \multicolumn{2}{|r|}{ Geological environment } \\
\hline Rock types & Tonalite to monzogranite intruding carbonate rocks or calcareous clastic rocks. \\
\hline Age range & Mainly Mesozoic, but may be any age. \\
\hline Tectonic setting(s) & $\begin{array}{l}\text { Most common where Andean-type plutons intrude older continental-margin carbonate sequences. Can be associated with } \\
\text { oceanic island arc plutonism. Commonly associated with porphyry copper deposits intrusive into carbonate rocks. }\end{array}$ \\
\hline Associated deposit types & Porphyry $\mathrm{Cu}$ deposits, other skarns ( $\mathrm{Au}, \mathrm{Fe}, \mathrm{Zn}-\mathrm{Pb}$ ), and replacement $\mathrm{Pb}-\mathrm{Zn}-\mathrm{Ag}$ deposits. \\
\hline Ore mineralogy & $\begin{array}{l}\text { Moderate to high sulfide content. Chalcopyrite } \pm \text { pyrite } \pm \text { magnetite in inner garnet-pyroxene zone. Bornite } \pm \text { chalcopyrite } \\
\pm \text { sphalerite } \pm \text { tennantite in outer wollastonite zone. Hematite, pyrrhotite, or magnetite may predominate (depending on } \\
\text { oxidation state). Scheelite and traces of molybdenite, bismuthinite, galena, cosalite, arsenopyrite, enargite, tennantite, } \\
\text { loellingite, cobaltite, and tetrahedrite may be present. }\end{array}$ \\
\hline Alteration & $\begin{array}{l}\text { Diopside+andradite center; wollastonite+tremolite outer zone; marble peripheral zone. Igneous rocks may be altered to } \\
\text { epidote+pyroxene+garnet (endoskarn). Retrograde alteration to actinolite, chlorite, and clays may be present. }\end{array}$ \\
\hline Geochemical signatures & $\begin{array}{l}\text { Rock analyses may show } \mathrm{Cu}-\mathrm{Au}-\mathrm{Ag} \text {-rich inner zones grading outward through } \mathrm{Au}-\mathrm{Ag} \text { zones with high } \mathrm{Au}: \mathrm{Ag} \text { ratios to an } \\
\text { outer } \mathrm{Pb}-\mathrm{Zn} \text {-Ag zone. } \mathrm{Co}-\mathrm{As}-\mathrm{Sb}-\mathrm{Bi}-\mathrm{Mo}-\mathrm{W} \text { geochemical anomalies are present in the more reduced } \mathrm{Cu} \text { skarn deposits. }\end{array}$ \\
\hline Geophysical signature & $\begin{array}{l}\text { Magnetics: plutons, batholiths, and regional geology/structure can be imaged. Oxidized plutons generally produce mag } \\
\text { highs, whereas reduced plutons produce mag lows. Highs/lows also depend on contrast with host rocks. More oxidized } \\
\text { in island-arc versus continental arc. Thick sedimentary pile of host rocks may reduce magmas during assimilation, } \\
\text { thereby reducing magnetic response. Magnetite may be produced (sodic-calcic, K-feldspar, propylitic zones) or } \\
\text { destroyed (phyllic and argillic, advanced argillic zones) during hydrothermal alteration processes, but regional } \\
\text { geophysical surveys are unlikely to see hydrothermal system because of low resolution. Gravity: regional geology/ } \\
\text { structure. Radiometrics: lithology and hydrothermal alteration potassium enrichment (Th/K). }\end{array}$ \\
\hline
\end{tabular}

Economic factors

\begin{tabular}{l} 
Grade and tonnage \\
$\begin{array}{l}\text { Average } 1 \text { to } 2 \mathrm{wt} . \% \text { copper. Worldwide, they generally range from } 1 \text { to } 100 \mathrm{Mt} \text {, although some exceptional deposits } \\
\text { exceed } 300 \mathrm{Mt} .\end{array}$ \\
$\begin{array}{l}\text { Historically, these deposits were a major source of copper, although porphyry deposits have become much more important. } \\
\text { However, major } \mathrm{Cu} \text { skarns are still worked throughout the world, including in China and the United States. }\end{array}$ \\
\hline Other assessment and exploration guides
\end{tabular}

Limestone/carbonate rocks proximal to calcalkaline intrusive complexes.

Limestone converted to marble.

Porphyry copper deposits; many skarns are porphyry-copper related.

Endoskarn alteration in intrusions; hornfels around intrusions.

Close proximity to stock contacts with oxidized skarn mineralogy dominated by andraditic garnet.

Zoning from garnet near the pluton to pyroxene to vesuvianite or wollastonite at the marble contact.

\begin{tabular}{ll}
\hline \multicolumn{1}{c}{ Examples } \\
\hline $\begin{array}{l}\text { In/near focal areas } \\
\text { Elsewhere }\end{array}$ & Contact, Nevada; Empire Mine, Idaho. \\
\hline & Carr Fork, Utah; Mason Valley, Copper Canyon, and Victoria, Nevada. \\
\hline
\end{tabular}

Einaudi, M.T., 1981, Skarns associated with porphyry plutons. I—Description of deposits, southwestern North America, II—General features and origin, in Titley, S. R., ed., Advances in geology of the porphyry copper deposits of southwestern North America: Tucson, University of Arizona Press, p. 139-183.

Meinert, L.D., 2005, World skarn deposits, in Hedenquist, J.W., Thompson, J.F.H., Goldfarb, R.J., and Richards, J.P., eds., Economic Geology—One hundredth anniversary volume 1905-2005: Littleton, Colorado, Society of Economic Geologists, Inc., p. 299-336. 


\section{Tungsten Skarn}

[wt.\%, weight percent; Mt, million metric tons]

\begin{tabular}{|c|c|}
\hline Synonyms & Pyrometasomatic or contact metasomatic tungsten deposits. \\
\hline Commodities & $\mathrm{W}, \mathrm{Mo}, \mathrm{Cu}, \mathrm{Sn}, \mathrm{Zn}$. \\
\hline Description & Scheelite-dominant mineralization genetically associated with a skarn gangue. \\
\hline \multicolumn{2}{|r|}{ Geological environment } \\
\hline Rock types & $\begin{array}{l}\text { Pure and impure limestones, calcareous to carbonaceous pelites. Associated with tonalite, granodiorite, quartz } \\
\text { monzonite and granite of both I- and S-types. W skarn-related granitoids, compared to Cu skarn- related plutonic } \\
\text { rocks, tend to be more differentiated, more contaminated with sedimentary material, and have crystallized at a } \\
\text { deeper structural level. }\end{array}$ \\
\hline Age range & Mainly Mesozoic, but may be any age. \\
\hline Depositional environment & Contacts and roof pendants of batholith and thermal aureoles of apical zones of stocks that intrude carbonate rocks. \\
\hline Tectonic setting(s) & $\begin{array}{l}\text { Continental margin, synorogenic plutonism intruding deeply buried sequences of eugeoclinal carbonate-shale } \\
\text { sedimentary rocks. Can develop in tectonically thickened packages in back-arc thrust settings. }\end{array}$ \\
\hline Associated deposit types & Other skarn types ( $\mathrm{Sn}, \mathrm{Mo}, \mathrm{Zn}-\mathrm{Pb}, \mathrm{W})$. \\
\hline \multicolumn{2}{|r|}{ Deposit description } \\
\hline Ore mineralogy & $\begin{array}{l}\text { Scheelite } \pm \text { molybdenite } \pm \text { chalcopyrite } \pm \text { pyrrhotite } \pm \text { sphalerite } \pm \text { arsenopyrite } \pm \text { pyrite } \pm \text { powellite. May contain } \\
\text { trace wolframite, fluorite, cassiterite, galena, marcasite and bornite. Reduced types are characterized by pyrrhotite, } \\
\text { magnetite, bismuthinite, native bismuth and high pyrrhotite:pyrite ratios. Variable amounts of quartz-vein stockwork } \\
\text { (with local molybdenite) can cut both the exoskarn and endoskarn. }\end{array}$ \\
\hline Alteration & $\begin{array}{l}\text { Exoskarn alteration: Inner zone of diopside-hedenbergite } \pm \text { grossular-andradite } \pm \text { biotite } \pm \text { vesuvianite, with outer barren } \\
\text { wollastonite-bearing zone. An innermost zone of massive quartz may be present. Late stage spessartine } \pm \text { almandin } \\
\text { e } \pm \text { biotite } \pm \text { amphibole } \pm \text { plagioclase } \pm \text { phlogopite } \pm \text { epidote } \pm \text { fluorite } \pm \text { sphene. Exoskarn envelope can be associated with } \\
\text { extensive areas of biotite hornfels. Endoskarn alteration: Pyroxene } \pm \text { garnet } \pm \text { biotite } \pm \text { epidote } \pm \text { amphibole } \pm \text { muscovite } \pm \\
\text { plagioclase } \pm \text { pyrite } \pm \text { pyrrhotite } \pm \text { trace tourmaline and scapolite; local greisen developed. }\end{array}$ \\
\hline Ore controls & $\begin{array}{l}\text { Carbonate rocks in extensive thermal aureoles of intrusions; gently inclined bedding and intrusive contacts; structural } \\
\text { and (or) stratigraphic traps in sedimentary rocks and irregular parts of the pluton/country rock contacts. }\end{array}$ \\
\hline Geochemical signatures & $\mathrm{W}, \mathrm{Cu}, \mathrm{Mo}, \mathrm{As}, \mathrm{Bi}$, and B. Less commonly $\mathrm{Zn}, \mathrm{Pb}, \mathrm{Sn}, \mathrm{Be}$, and F. \\
\hline Geophysical signature & $\begin{array}{l}\text { Magnetic and induced polarization surveys can be used to outline the surface projection of ore bodies because } \\
\text { magnetite, pyrrhotite, and other sulfide minerals are common in these deposits. Although skarns typically have a } \\
\text { positive density contrast relative to adjacent intrusions and carbonate rocks, gravity surveys are not commonly used } \\
\text { due to high cost and nonspecificity for ore. Remote-sensing techniques can effectively identify carbonate terranes } \\
\text { and iron enrichment in skarns if skarn is exposed. In some cases, contacts between intrusions and sedimentary rocks } \\
\text { can be mapped and carbonate rocks can be distinguished from noncarbonate rocks. }\end{array}$ \\
\hline \multicolumn{2}{|r|}{ Economic factors } \\
\hline Grade and tonnage & Grades range between 0.4 and 2 wt. $\% \mathrm{WO}_{3}$ (typically $0.7 \mathrm{wt} . \%$ ). Deposits vary from 0.1 to $>30 \mathrm{Mt}$. \\
\hline Importance & Historically, skarn deposits have accounted for nearly 60 percent of the Western world's tungsten production. \\
\hline
\end{tabular}

Reduced W skarns form in carbonaceous rocks and (or) at greater depth.

Oxidized W skarns form in hematitic or noncarbonaceous rocks, and (or) at shallower depths.

Late retrograde alteration is an important factor in many W skarns because, during retrogression, the early low-grade mineralization is often scavenged and redeposited into economic high-grade ore zones.

Dolomitic rocks tend to inhibit the development of W skarns; consequently, magnesian W skarns are uncommon.

\begin{tabular}{|c|c|}
\hline \multicolumn{2}{|r|}{ Examples } \\
\hline In/near focal areas & None. \\
\hline Elsewhere & Osgood Range, Nevada; Pine Creek, California. \\
\hline \multicolumn{2}{|r|}{ References } \\
\hline \multicolumn{2}{|c|}{$\begin{array}{l}\text { Cox, D.P., 1986, Descriptive model of W skarn deposits, in Cox, D.P. and Singer, D.A., eds., Mineral deposit models: U.S. Geological Survey, Bulletin } \\
\text { 1693, p. 55. [Also available at https://pubs.usgs.gov/bul/b1693/.] }\end{array}$} \\
\hline \multicolumn{2}{|c|}{$\begin{array}{l}\text { Meinert, L.D., 2005, World skarn deposits, in Hedenquist, J.W., Thompson, J.F.H., Goldfarb, R.J., and Richards, J.P., eds., Economic Geology-One } \\
\text { hundredth anniversary volume 1905-2005: Littleton, Colorado, Society of Economic Geologists, Inc., p. 299-336. }\end{array}$} \\
\hline $\begin{array}{l}\text { Ray, G.E., 1995, W } \\
\text { British Columbia } \\
\text { gov.bc.ca/Mining }\end{array}$ & $\begin{array}{l}\text { Lefebure, D.V. and Ray, G.E., eds., Selected British Columbia mineral deposit profiles, volume 1-Metallics and coal: } \\
\text { of Energy of Employment and Investment, Open File 1995-20, p. 71-74, accessed April 25, 2016, at http://www.empr. } \\
\text { nce/PublicationsCatalogue/OpenFiles/1995/Pages/1995-20.aspx. }\end{array}$ \\
\hline
\end{tabular}




\section{Lead-Zinc Skarn}

[wt.\%, weight percent; Hd, hedenbergite; Jo, johannsenite; Mt, million metric tons; m, meter; CSAMT, controlled-source audiofrequency magnetotellurics]

\begin{tabular}{|c|c|}
\hline Synonyms & Pyrometasomatic or contact metasomatic $\mathrm{Pb}-\mathrm{Zn}$ deposits. \\
\hline Commodities & $\mathrm{Pb}, \mathrm{Zn}, \mathrm{Ag},(\mathrm{Cu}, \mathrm{Cd}, \mathrm{W}, \mathrm{Au})$ \\
\hline Description & Galena and (or) sphalerite-dominant mineralization genetically associated with a skarn gangue. \\
\hline & Geological environment \\
\hline Rock types & $\begin{array}{l}\text { Host rocks vary from high-level skarns in thick limestones, calcareous tuffs and sediment to deeper level skarns in marbles } \\
\text { and calcsilicate-bearing migmatites. Associated intrusive rocks are granodiorite to leucogranite, diorite to syenite (mostly } \\
\text { quartz monzonite). Pb-Zn skarns tend to be associated with small stocks, sills and dikes and less commonly with larger } \\
\text { plutons. The composition of the intrusions responsible for many distal Pb-Zn skarns is uncertain. }\end{array}$ \\
\hline
\end{tabular}

Age range

Mainly Mesozoic.

Depositional environment Commonly occur along igneous or stratigraphic contacts, as subvertical chimneys or veins along faults and fissures, and as subhorizontal blankets. $\mathrm{Pb}-\mathrm{Zn}$ skarn deposits formed either at higher structural levels or distal to the intrusions tend to be larger and more $\mathrm{Mn}$ - rich compared to those formed at greater depths or more proximal.

Tectonic setting(s) Plutonism. Pb-Zn skarns occur at a wide range of depths, being associated with subvolcanic aphanitic dikes and high-level breccia pipes, as well as deep-level batholiths.

Associated deposit types Porphyry $\mathrm{Cu}$ deposits, other skarns ( $\mathrm{Au}, \mathrm{Fe}, \mathrm{Zn}-\mathrm{Pb}$ ), and replacement $\mathrm{Pb}-\mathrm{Zn}$ - $\mathrm{Ag}$ deposits

\begin{tabular}{|c|c|}
\hline & Deposit description \\
\hline Ore mineralogy & $\begin{array}{l}\text { Sphalerite } \pm \text { galena } \pm \text { pyrrhotite } \pm \text { pyrite } \pm \text { magnetite } \pm \text { arsenopyrite } \pm \text { chalcopyrite } \pm \text { bornite. Other trace minerals reported include } \\
\text { scheelite, bismuthinite, stannite, cassiterite, tetrahedrite, molybdenite, fluorite, and native gold. } \\
\text { Proximal skarns tend to be richer in } \mathrm{Cu} \text { and } \mathrm{W} \text {, whereas distal skarns contain higher amounts of } \mathrm{Pb}, \mathrm{Ag} \text {, and } \mathrm{Mn} \text {. }\end{array}$ \\
\hline Alteration & $\begin{array}{l}\text { Exoskarn alteration: Mn-rich hedenbergite }\left(\mathrm{Hd}_{30-90}, \mathrm{Jo}_{10-50}\right) \text {, andraditic garnet }\left(\mathrm{Ad}_{20-100}, \mathrm{Spess}_{2-10}\right) \pm \text { wollastonite } \pm \text { bustamite } \pm \mathrm{r} \\
\text { hodonite. Late-stage Mn-rich actinolite } \pm \text { epidote } \pm \text { ilvaite } \pm \text { chlorite } \pm \text { dannermorite } \pm \text { rhodochrosite } \pm \text { axinite. } \\
\text { Endoskarn alteration: Highly variable in extent of development, and in many of the distal } \mathrm{Pb}-\mathrm{Zn} \text { skarns the nature of the } \\
\text { endoskarn is unknown. However, Zn-rich skarns formed near stocks are often associated with abundant endoskarn that } \\
\text { may equal or exceed the exoskarn. Endoskarn mineralogy is dominated by epidote } \pm \text { amphibole } \pm \text { chlorite } \pm \text { sericite with } \\
\text { lesser rhodonite } \pm \text { garnet } \pm \text { vesuvianite } \pm \text { pyroxene } \pm \mathrm{K} \text {-feldspar } \pm \text { biotite and rare topaz. Marginal phases may contain greisen } \\
\text { and (or) tourmaline. }\end{array}$ \\
\hline
\end{tabular}

Ore controls

Carbonate rocks, particularly along structural and (or) lithologic contacts (shale-limestone contacts or pre-ore dikes). Deposits may occur considerable distances $(100-1,000 \mathrm{~m})$ from the source intrusions.

Geochemical signatures

$\mathrm{Pb}, \mathrm{Zn}, \mathrm{Ag}, \mathrm{Cu}, \mathrm{Mn}, \mathrm{As}, \mathrm{Bi}, \mathrm{W}, \mathrm{F}, \mathrm{Sn}, \mathrm{Mo}, \mathrm{Co}, \mathrm{Sb}, \mathrm{Cd}$, and $\mathrm{Au}$

Geophysical signature

Generally good induced polarization response. Galena-rich ore bodies may be marked by gravity anomalies whereas pyrrhotite-rich mineralization may be detected by magnetic surveys. CSAMT may also be a useful exploration system.

\section{Economic factors}

\begin{tabular}{|c|c|}
\hline Grade and tonnage & $\begin{array}{l}\mathrm{Pb}-\mathrm{Zn} \text { skarns tend to be small }(<3 \mathrm{Mt}) \text { but can reach } 45 \mathrm{Mt} \text {, grading as much as } 15 \mathrm{wt} . \% \mathrm{Zn}, 10 \mathrm{wt} \% \mathrm{~Pb} \text { and }>150 \mathrm{~g} / \mathrm{t} \mathrm{Ag} \\
\text { with substantial } \mathrm{Cd} \text {. } \mathrm{Cu} \text { grades are generally }<2 \mathrm{wt} . \% \text {. Some deposits contain } \mathrm{Au} \text {. }\end{array}$ \\
\hline Importance & Important past and current producers exist in Mexico, China, United States (New Mexico and California), and Argentina. \\
\hline
\end{tabular}

Thick limestones distal to small granitoid stocks.

Structural traps and lithological contacts.

Exoskarns with low garnet/pyroxene ratios.

Mn-rich pyroxenes.

\begin{tabular}{|c|c|}
\hline \multicolumn{2}{|r|}{ Examples } \\
\hline In/near study area & White Knob Mine and Champion Group, Idaho. \\
\hline Elsewhere & Hanover-Fierro district, New Mexico. \\
\hline \multicolumn{2}{|c|}{$\begin{array}{l}\text { Cox, D.P., 1986, Descriptive model of Zn-Pb skarn deposits, in Cox, D.P. and Singer, D.A., eds., Mineral deposit models: U.S. Geological Survey, Bulletir } \\
\text { 1693, p. 90. [Also available at https://pubs.usgs.gov/bul/b1693/.] }\end{array}$} \\
\hline \multicolumn{2}{|c|}{$\begin{array}{l}\text { Meinert, L.D., 2005, World skarn deposits, in Hedenquist, J.W., Thompson, J.F.H., Goldfarb, R.J., and Richards, J.P., eds., Economic Geology-One } \\
\text { hundredth anniversary volume 1905-2005: Littleton, Colorado, Society of Economic Geologists, Inc., p. 299-336. }\end{array}$} \\
\hline \multicolumn{2}{|c|}{$\begin{array}{l}\text { Mosier, D.L., 1986, Grade and tonnage model of Zn-Pb skarn deposits, in Cox, D.P. and Singer, D.A., eds., Mineral deposit models: U.S. Geological } \\
\text { Survey, Bulletin 1693, p. 90-93. [Also available at https://pubs.usgs.gov/bul/b1693/.] }\end{array}$} \\
\hline \multicolumn{2}{|c|}{$\begin{array}{l}\text { Ray, G.E., 1995, Pb-Zn skarns, in Lefebure, D.V., and Ray, G.E., eds., Selected British Columbia mineral deposit profiles, volume 1-Metallics and coal: } \\
\text { British Columbia Ministry of Energy of Employment and Investment, Open File 1995-20, p. 61-62, accessed April 15, 2016, at http://www.empr.gov. } \\
\text { bc.ca/Mining/Geoscience/PublicationsCatalogue/OpenFiles/1995/Pages/1995-20.aspx. }\end{array}$} \\
\hline
\end{tabular}




\section{Polymetallic Replacement}

[wt.\%, weight percent; Mt, million metric tons; SEDEX, sedimentary exhalative deposits]

\begin{tabular}{ll}
$\begin{array}{l}\text { Synonyms } \\
\text { Commodities } \\
\text { Description }\end{array}$ & $\begin{array}{l}\text { Manto. } \\
\mathrm{Ag}, \mathrm{Pb}, \mathrm{Zn}, \mathrm{Cu} \text { (byproduct } \mathrm{Au}, \mathrm{Sn}, \mathrm{Bi}) . \\
\text { Hydrothermal, epigenetic, } \mathrm{Ag}, \mathrm{Pb}, \mathrm{Zn}, \mathrm{Cu} \text { minerals in massive lenses, pipes in limestone, dolomite, or other soluble rock near } \\
\text { igneous. Most massive ore contains more than 50 percent sulfide minerals. }\end{array}$ \\
\hline Rock types & \multicolumn{1}{c}{ Geological environment } \\
Hosted by limestone and dolostone. The carbonates are typically within a thick sediment package with siliciclastic rocks \\
that is cut by granite, quartz monzonite, and other intermediate to felsic hypabyssal, porphyritic lithologies. There may be \\
volcanic rocks in the sequence, or more commonly above, which are related to the intrusive rocks. \\
Depositional environment \\
$\begin{array}{l}\text { Many are late Mesozoic to early Cenozoic; age is not important. } \\
\text { Carbonate host rocks that commonly occur in broad sedimentary basins, such as epicratonic shelf. Replacement by solutions } \\
\text { emanating from volcanic centers and epizonal plutons. Calderas may be favorable. Can be distal to skarns and intrusions. }\end{array}$ \\
$\begin{array}{l}\text { Intrusions emplaced into miogeoclinal to platformal, continental settings. Most deposits occur in mobile belts that have } \\
\text { undergone moderate deformation and have been intruded by small plutons. }\end{array}$
\end{tabular}

Associated deposit types Base-metal skarns, porphyry $\mathrm{Cu}$.

Ore mineralogy Sphalerite, galena, pyrite, chalcopyrite, marcasite; arsenopyrite, pyrargyrite/proustite, enargite, tetrahedrite, geocronite, electrum, digenite, jamesonite, jordanite, bournonite, stephanite, polybasite, rhodochrosite, sylvanite, calaverite. Chimneys may be more $\mathrm{Zn}$-rich, Pb-poor than manto deposits.

Alteration

Limestone wallrocks are commonly dolomitized and (or) silicified, whereas shale and igneous rocks are argillized and chloritized. Jasperoid occurs in some U.S. examples.

Ore controls The irregular shapes of these deposits and their occurrence in carbonate hosts emphasize the importance of ground preparation in controlling fluid channels and depositional sites. Controls include faults, fault intersections, fractures, anticlinal culminations, bedding channelways (lithologic contrasts), karst features and pre-existing permeable zones. In several districts karst development associated with unconformities is believed to have led to development of open spaces subsequently filled by ore. Some deposits are spatially associated with dikes.

Geochemical signatures Elevated $\mathrm{Pb}-\mathrm{Zn} \pm \mathrm{Cu} \pm \mathrm{Au} \pm \mathrm{Ag} \pm \mathrm{Mo} \pm \mathrm{As} \pm \mathrm{Bi} \pm \mathrm{Sb}$. In some districts, ore proximal to igneous intrusions is $\mathrm{Cu}$ - and $\mathrm{Au}$ rich, and grades laterally (and sometimes vertically) into $\mathrm{Pb}-\mathrm{Zn}-\mathrm{Ag}$ ore. A distal, Mn-enriched zone is present in some districts. Elevated $\mathrm{Ba}$ and $\mathrm{Ag}$ in jasperoid.

Geophysical signature Magnetics: Igneous intrusions at depth may be imaged. Felsic character suggests a low magnetic response. Also, intrusions commonly emplaced into miogeoclinal to platformal, continental settings so should consider potential for sedimentary rocks to reduce oxygen fugacity of magma.

Gravity: Igneous intrusions at depth may be imaged.

Radiometrics: Lithology and alteration patterns may be evident.

\begin{tabular}{|c|c|}
\hline \multicolumn{2}{|r|}{ Economic factors } \\
\hline Grade and tonnage & $\begin{array}{l}\text { Deposits are small }(10,000 \mathrm{t} \text { ) to very large (as much as } 30-40 \mathrm{Mt} \text { ). Individual deposits average about a million metric tons } \\
\text { grading tens to hundreds of } \mathrm{g} / \mathrm{t} \mathrm{Ag} \text { and approximately } 5 \text { to } 20 \mathrm{wt} . \% \text { combined } \mathrm{Pb}-\mathrm{Zn} \text {. }\end{array}$ \\
\hline Importance & $\begin{array}{l}\text { As sources of base metals, manto deposits are overshadowed on a world scale by the giant syngenetic classes such as SEDEX } \\
\text { and volcanogenic massive sulfide deposits. However, because of their high precious metal contents, they provide exciting } \\
\text { targets for small producers. }\end{array}$ \\
\hline
\end{tabular}
Other assessment and exploration guides

Concentration of $\mathrm{Ag}-\mathrm{Pb}-\mathrm{Zn}$ vein deposits in or near carbonates.

Structural controls include regional faults, folds, fractures, fissures, and caverns.

Mantos and chimneys are usually carbonate-hosted and remote from intrusions (relative to skarns).

\begin{tabular}{ll}
\hline & \multicolumn{1}{c}{ Examples } \\
\hline In/near focal areas & Copper Mountain Mine, Idaho. \\
Elsewhere & Park City, Utah; Leadville, Colorado; Northern Mexico. \\
\hline & \\
\hline
\end{tabular}

Megaw, P.K.M., Ruiz, Joaquin, and Titley, S.R., 1988, High-temperature, carbonate-hosted Ag-Pb-Zn(Cu) deposit of northern Mexico: Economic Geology, v. 83, p. 1856-1885.

Nelson, J.L., 1996, Polymetallic mantos Ag-Pb-Zn, in Lefebure, D.V. and Hõy, T., eds., Selected British Columbia mineral deposit profiles, volume 2 Metallic deposits: British Columbia Ministry of Employment and Investment, Open File 1996-13, p. 101-104, accessed April 25, 2016, at http://www. empr.gov.bc.ca/MINING/GEOSCIENCE/MINERALDEPOSITPROFILES/LISTBYDEPOSITGROUP/Pages/JManto.aspx.

Vikre, P.G., 1998, Intrusion-related polymetallic carbonate replacement deposits in the Eureka District, Eureka County, Nevada: Nevada Bureau of Mines and Geology Bulletin 110, 52 p. 


\section{Polymetallic Vein}

[wt.\%, weight percent; km, kilometer; t, metric ton; g/t, grams per metric ton; m, meter]

\begin{tabular}{ll}
\hline Synonyms & Felsic-intrusion-associated $\mathrm{Ag}-\mathrm{Pb}-\mathrm{Zn}$ veins, clastic metasediment-hosted silver-lead-zinc veins. \\
Commodities & $\mathrm{Ag}, \mathrm{Pb}, \mathrm{Zn}(\mathrm{Cu}, \mathrm{Au}, \mathrm{Mn})$. \\
Description & Quartz-carbonate veins with $\mathrm{Au}$ and $\mathrm{Ag}$ associated with base-metal sulfides related to hypabyssal intrusions in
\end{tabular}
sedimentary and metamorphic terranes.

\begin{tabular}{|c|c|}
\hline \multicolumn{2}{|r|}{ Geological environment } \\
\hline Rock types & $\begin{array}{l}\text { These deposits are principally hosted by sedimentary rocks (dolomite, limestone, sandstone, and shale) that } \\
\text { have been intruded by intermediate- to felsic-composition igneous stocks, dikes, and sills. Many veins are } \\
\text { associated with dikes following the same structures. }\end{array}$ \\
\hline Age range & Proterozoic or younger. Most are Mesozoic and Cenozoic, but may be any age. \\
\hline Depositional environment & $\begin{array}{l}\text { Metasediment host: Veins are emplaced along faults and fractures in sedimentary basins dominated by clastic } \\
\text { rocks that have been deformed, metamorphosed and intruded by igneous rocks. Veins postdate deformatior } \\
\text { and metamorphism. } \\
\text { Igneous host: Veins typically occur in country rock marginal to an intrusive stock. Typically veins crosscut } \\
\text { volcanic sequences and follow volcano- tectonic structures, such as caldera ring-faults or radial faults. In } \\
\text { some cases the veins cut older intrusions. }\end{array}$ \\
\hline Tectonic setting(s) & $\begin{array}{l}\text { These veins occur in virtually all tectonic settings except oceanic, including continental margins, island arcs, } \\
\text { continental volcanic and cratonic sequences. }\end{array}$ \\
\hline ociate & olymetallic replacement, porphyry, skarn, placer Au. \\
\hline
\end{tabular}

\section{Deposit description}

Ore mineralogy Galena, sphalerite, tetrahedrite-tennantite, sulfosalts including pyrargyrite, stephanite, bournonite and acanthite, native silver, chalcopyrite, pyrite, arsenopyrite, stibnite.

Silver minerals often occur as inclusions in galena; native gold and electrum in some deposits. Au grades are normally low for the amount of sulfides present.

Rhythmic compositional banding sometimes present in sphalerite.

Some veins contain more chalcopyrite and gold at depth.

\section{Alteration}

Ore controls

Geochemical signatures

Geophysical signature
Generally wide propylitic zones and narrow sericitic and argillic zones.

Silicification of carbonate rocks to form jasperoid.

Regional faults, fault sets, and fractures are an important ore control; however, veins are typically associated with second order structures. In igneous rocks the faults may relate to volcanic centers. Significant deposits are restricted to competent lithologies. Dikes are often emplaced along the same faults and may be roughly contemporaneous with mineralization. Polymetallic veins are typically steeply dipping, narrow tabular or splayed veins and commonly occur as sets of parallel and offset veins. Individual veins vary from $\mathrm{cm}$ as much as more than 3-m wide and can be followed from a few hundred to more than 1,000 $\mathrm{m}$ in length and depth. Veins may widen to tens of meters in stockwork zones.

Areas of high permeability: intrusive contacts, fault intersections, and breccia veins and pipes. Replacement ore bodies may form where structures intersect carbonate rocks

$\mathrm{Zn}, \mathrm{Cu}, \mathrm{Pb}, \mathrm{As}, \mathrm{Au}, \mathrm{Ag}, \mathrm{Mn}, \mathrm{Ba}, \mathrm{Cd}$. Anomalies zoned outward from $\mathrm{Cu}-\mathrm{Au}$ to $\mathrm{Zn}-\mathrm{Pb}-\mathrm{Ag}$ to $\mathrm{Mn}$ at periphery.

Magnetics: Veins are unlikely to be evident, but plutons below may be imaged depending on tectonic setting in which they formed (continental margins, island arcs, continental volcanic and cratonic sequences). More oxidized magmas will result in plutons with stronger magnetic response. Gravity: Regional geology/structure can be imaged. Relatively large underlying plutons or batholiths can be imaged.

Radiometrics: Lithology and alteration can be imaged.

\section{Economic factors}

Grade and tonnage

Median size 7,600 t at 9 wt.\% Pb, 2.1 wt.\% Zn, 820 g/t Ag, and $13 \mathrm{~g} / \mathrm{t}$ Au. Polymetallic veins of two types appear to exist - a base-metal polymetallic vein worked primarily for a base metal or metals and silver and a gold-silver polymetallic vein with copper, lead, and zinc production 
Ubiquitous in many setting. These veins were a significant source of $\mathrm{Ag}, \mathrm{Pb}$, and $\mathrm{Zn}$ until the 1960s. They have declined in importance as industry focused more on syngenetic massive sulfide deposits. Larger polymetallic vein deposits are still attractive because of their high grades and relatively easy beneficiation. They are potential sources of cadmium and germanium.

Other assessment and exploration guides

Presence of vein deposits.

Presence of base or precious metals in rock or stream-sediment samples.

Presence of faults, breccias, shear zones, fault intersections, or intrusive contacts. Strong structural control on veins and common occurrence of deposits in clusters can be used to locate new veins.

Presence of Mesozoic or Tertiary plutons or hypabyssal igneous bodies.

Near-surface fractures and breccias within thermal aureole of clusters of small intrusions.

Some polymetallic veins are found surrounding intrusions with porphyry deposits or prospects.

\begin{tabular}{ll}
\hline & \multicolumn{1}{c}{ Examples } \\
\hline In/near focal areas & Valley View Mine, Idaho. \\
Elsewhere & Wallapi district, Arizona; Marysville district, Montana. \\
\hline
\end{tabular}

\section{References}

Bliss, J.D., and Cox, D.P., 1986, Grade and tonnage model of polymetallic veins, in Cox, D.P. and Singer, D.A., eds., Mineral deposit models: Geological Survey Bulletin 1693, p. 125-129. [Also available at http://pubs.usgs.gov/bul/b1693/.]

Cox, D.P., 1986, Descriptive model of polymetallic veins, in Cox, D.P. and Singer, D.A., eds., Mineral deposit models: Geological Survey Bulletin 1693, p. 125-129. [Also available at http://pubs.usgs.gov/bul/b1693/.]

Lefebure, D.V., and Church, B.N., 1996, Polymetallic veins Ag-Pb-Zn \pm Au, in Lefebure, D.V. and Hõy, eds., Selected British Columbia mineral deposit profiles, volume 2-Metallic deposits: British Columbia Ministry of Energy of Employment and Investment, Open File 1996-13, p. 67-70, accessed April 25, 2016, at http://www.empr.gov.bc.ca/Mining/Geoscience/MineralDepositProfiles/Pages/default.aspx. 


\section{Tungsten Vein}

[wt.\%, weight percent; km, kilometer; t, metric ton; g/t, grams per metric ton; REE, rare earth elements]

\begin{tabular}{ll} 
Synonyms & Quartz-wolframite veins. \\
Commodities & W, Mo, Sn. \\
Synoptic statement & $\begin{array}{l}\text { Magmatic hydrothermal veins associated with granitic rocks and pegmatites. } \\
\text { Description }\end{array}$ \\
$\begin{array}{c}\text { Simple to complex fissure filling or replacement quartz veins, including discrete single veins, swarms or systems of veins, or } \\
\text { vein stockworks, that contain mainly wolframite series minerals (huebnerite-ferberite). }\end{array}$ \\
\hline
\end{tabular}

\section{Geological environment}

Rock types
Age range
Depositional environment
Tectonic setting(s)

Granitic plutonic rocks, especially late-stage, highly evolved, specialized biotite and (or) muscovite (S-type or A-type) ilmenite series granites and leucogranites.

Paleozoic to late Tertiary.

Tensional fractures in epizonal granitic plutons and their wallrocks.

Belts of granitic plutons derived from remelting of continental crust.

Country rocks are metamorphosed to greenschist facies.

Associated deposit types Sn skarn, W skarn, Sn replacement, complex Sn-Ag-sulfide veins, Climax-type Mo deposits, and Mo vein and greisen deposits.

\section{Deposit description}

Ore mineralogy

In general, the most common minerals in tungsten vein deposits in addition to quartz are: wolframite series minerals (huebnerite-ferberite), molybdenite, bismuthinite, pyrite, pyrrhotite, arsenopyrite, bornite, chalcopyrite, scheelite, cassiterite, beryl, mica, and fluorite.

Alteration

Alteration directly associated with ore includes greisenization, albitization, and (or) tourmalinization. Deepest zones, pervasive albitization; higher pervasive to vein-selvage pink K-feldspar replacement with minor disseminated REE minerals; upper zones, vein selvages or zinnwaldite (greisen). Chloritization. Widespread tourmaline alteration at Isla de Pines deposit, Cuba.

Ore controls

Swarms of parallel veins cutting granitic rocks or sedimentary rocks near igneous contacts.

Geochemical signatures

$\mathrm{W}, \mathrm{Mo}, \mathrm{Sn}, \mathrm{Bi}, \mathrm{As}, \mathrm{Cu}, \mathrm{Pb}, \mathrm{Zn}, \mathrm{Be}, \mathrm{F}$. Soil and stream sediment may have elevated tin and tungsten contents (tens to hundreds of ppm) and may contain anomalous abundances of elements characteristic of specialized granites $(\mathrm{F}, \mathrm{Rb}, \mathrm{Be}$, $\mathrm{Nb}, \mathrm{Ta}, \mathrm{Mo}, \mathrm{U}, \mathrm{Th}, \mathrm{Li}$, and REE). Other possible pathfinder elements are $\mathrm{As}, \mathrm{Bi}, \mathrm{B}, \mathrm{Cu}, \mathrm{Pb}$, and $\mathrm{Zn}$.

Geophysical signature Magnetics: Plutons generated from remelting of continental crust. I-type granites can produce relatively high magnetic anomalies, whereas S-type granites are likely to be reduced, having low magnetic response. Regional geology/structure can be imaged.

Gravity: Orogenic granites can have low gravity response. Radiometrics: Host rock lithology and alteration patterns can be imaged.

\section{Economic factors}

Grade and tonnage

The most common tungsten vein deposits are quartz-wolframite veins. These range from less than 0.1 to about 10 million Mt of ore containing 0.4 to $1.6 \mathrm{wt} . \% \mathrm{WO}_{3}$; median size and grade is $680,000 \mathrm{Mt}$ and $0.81 \mathrm{wt} \% \mathrm{WO}_{3}$.

Importance Relative to W skarn deposits, W vein systems typically have smaller tonnages and comparable grades.

\section{Other assessment and exploration guides}

Veins and greisen deposits are found within or near highly evolved, rare-metal enriched plutonic rocks, especially near contacts with surrounding country rock; settings in or adjacent to cupolas of subsurface granitic batholiths are particularly favorable.

Deposits may be endocontact or exocontact. Exocontact deposits usually are in pelitic and arenaceous sedimentary or metamorphic rocks and within the contact metamorphic aureole of a pluton. Most endocontact deposits, are in or near cupolas and ridges developed on the roof or along margins of granitoids.

Wolframite persists in soils and stream sediments; stolzite and tungstite may occur as weathering products.

Zoned alteration has been identified in some tungsten vein systems, upper parts of veins have well developed greisen zones; middle parts have quartz-rich greisen and silicification; and lower parts have K-feldspar-rich greisen. Higher tungsten grades are found in the upper and middle parts of veins.

\begin{tabular}{ll}
\hline & \\
\hline In/near focal areas & Round Mountain, Nevada. \\
Elsewhere & Hamme district, North Carolina; Isla de Pines, Cuba.
\end{tabular}


References

Cox, D.P., and Bagby, W.C., 1986, Descriptive model of W veins, in Cox, D.P. and Singer, D.A., eds., Mineral deposit models: U.S. Geological Survey Bulletin 1693, p. 64. [Also available at http://pubs.usgs.gov/bul/b1693/.]

Elliott, J.E., Kamilli, R.J., Miller, W.R., and Livo, K.E., 1995, Vein and greisen Sn and W deposits, in du Bray, E.A., ed., Preliminary compilation of descriptive geoenvironmental mineral deposit models: U.S. Geological Survey Open-File Report 95-0831, p. 62-69. [Also available at http://pubs.usgs. gov/of/1995/ofr-95-0831/.]

Jones, G.M., and Menzie, W.D., 1986, Grade and tonnage model of W veins, in Cox, D.P. and Singer, D.A., eds., Mineral deposit models: Geological Survey Bulletin 1693, p. 65-66. [Also available at http://pubs.usgs.gov/bul/b1693/.]

Menzie, W.D., Jones, G.M., and Elliott, J.E., 1992, Tungsten — Grades and tonnages of some deposits, in DeYoung, J.H., Jr., and Hammarstrom, J.M., eds., Contributions to commodity geology research: U.S. Geological Survey Bulletin 1877, p. J1-J7, accessed May 25, 2016, at https://pubs.usgs.gov/ bul/1877/report.pdf.

Shawe, D.R., Foord, E.E., and Conklin, N.M., 1984, Huebnerite veins near Round Mountain, Nye County, Nevada: U.S. Geological Survey Professional Paper 1287, $48 \mathrm{p}$. 


\section{Molybdenum-Tungsten Greisen}

[wt.\%, weight percent; ppm, parts per million; km, kilometer; Mt, million metric tons;*, based on 10 well-described deposits, including 5 in Nevada]

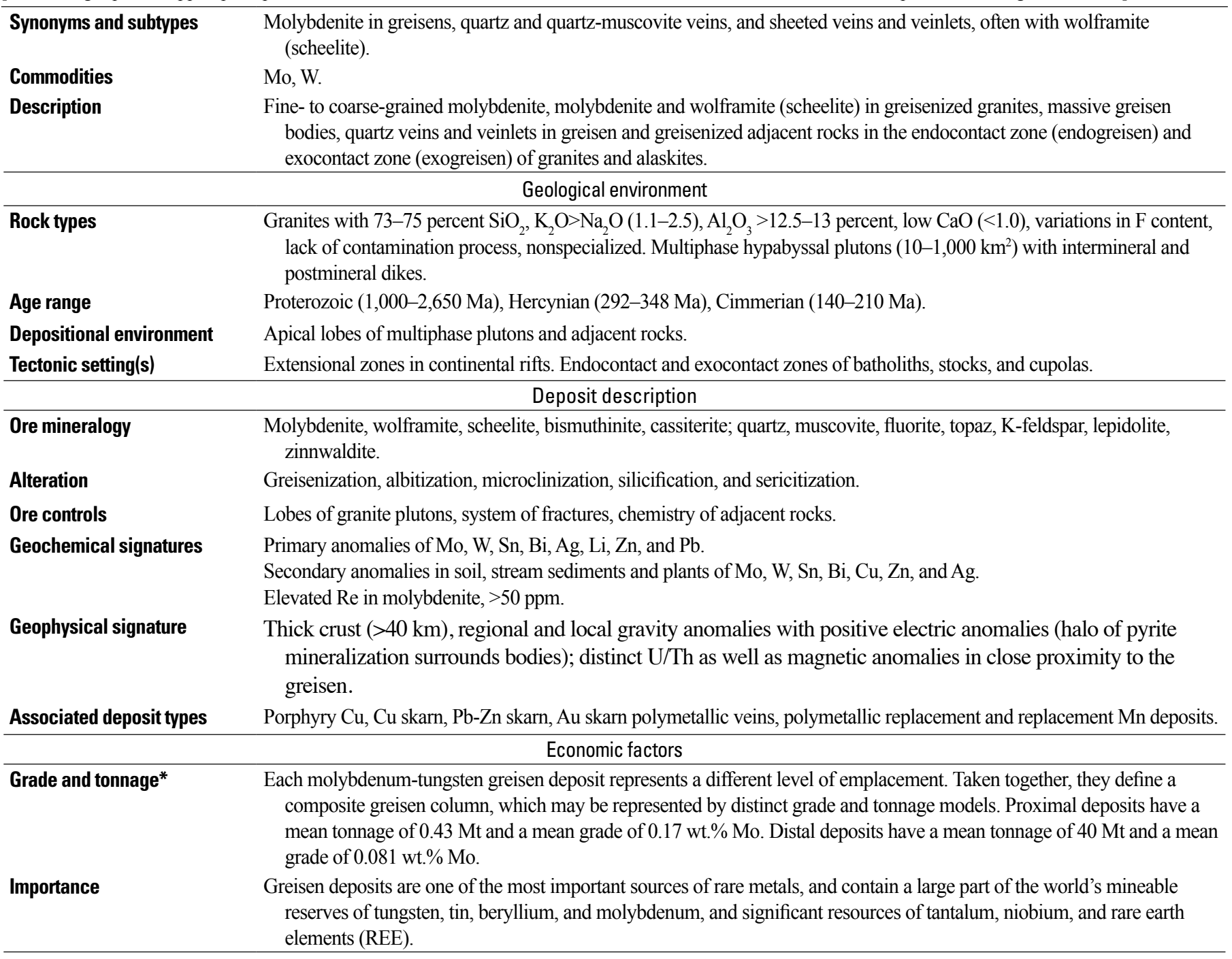

Assessment and Exploration Guides

Molybdenum-tungsten greisen is a distinct type of mineral deposit, apparently confined to granitic plutons in extensional rift zones in Proterozoic, Hercynian and Cimmerian continental plates, and primarily found in areas with thick crust in Asia.

General prospecting guides include extensional zones where crustal thickness is more than $40-45 \mathrm{~km}$. Regional negative gravity anomalies, that may represent felsic plutons are also indicative. General analysis of geologic (petrologic and petrochemical) data, combined with the results of regional geophysical surveys, can lead to the delineation of potential targets.

Experience in exploration for this type of deposit in different countries shows that subsequent fieldwork must include geochemical surveys (rock, soil, or stream sediments), detailed gravimetric measurements, and aeromagnetic surveys. These methods usually detect the ore-bearing granites, particularly hidden plutons or their cupolas. Local negative gravity and positive magnetic anomalies may outline unexposed plutons, the specific characteristics of roof morphology (lobes), and variations in the thickness of granites (roots). Zonal dispersion of lead, zinc and copper from one side and molybdenum, tungsten, tin and bismuth from the other indicates the polarity, or symmetry of the metallized system. Separation of tungsten and molybdenum within a district, with tungsten dominant, might be the sign of an unexposed, compound mineral deposit

Although molybdenum-tungsten greisen deposits have many similarities with Climax-type deposits, they seem to form at greater depths, in a mostly plutonic environment.

\section{Examples}

\begin{tabular}{ll}
\hline In/near focal areas & Springs W deposit, Nevada. \\
Elsewhere & Mount Pleasant, Canada; Koktenkol, Akchatau, Bainazar, Kazakhstan; Yugodzir, Mongolia.
\end{tabular}

\section{References}

Kotlyar, B.B., Ludington, Steve, and Mosie, D.L., 1996, Descriptive, grade, and tonnage models for molybdenum-tungsten greisen deposits: U.S. Geological Survey Open-File Report 95-584, 16 p. [Also available at https://pubs.er.usgs.gov/publication/ofr95584.] 


\section{Distal Disseminated Silver-Gold}

[g/t, grams per metric ton; Mt, million metric tons; ${ }^{*}$, based on 10 well-described deposits, including 5 in Nevada]

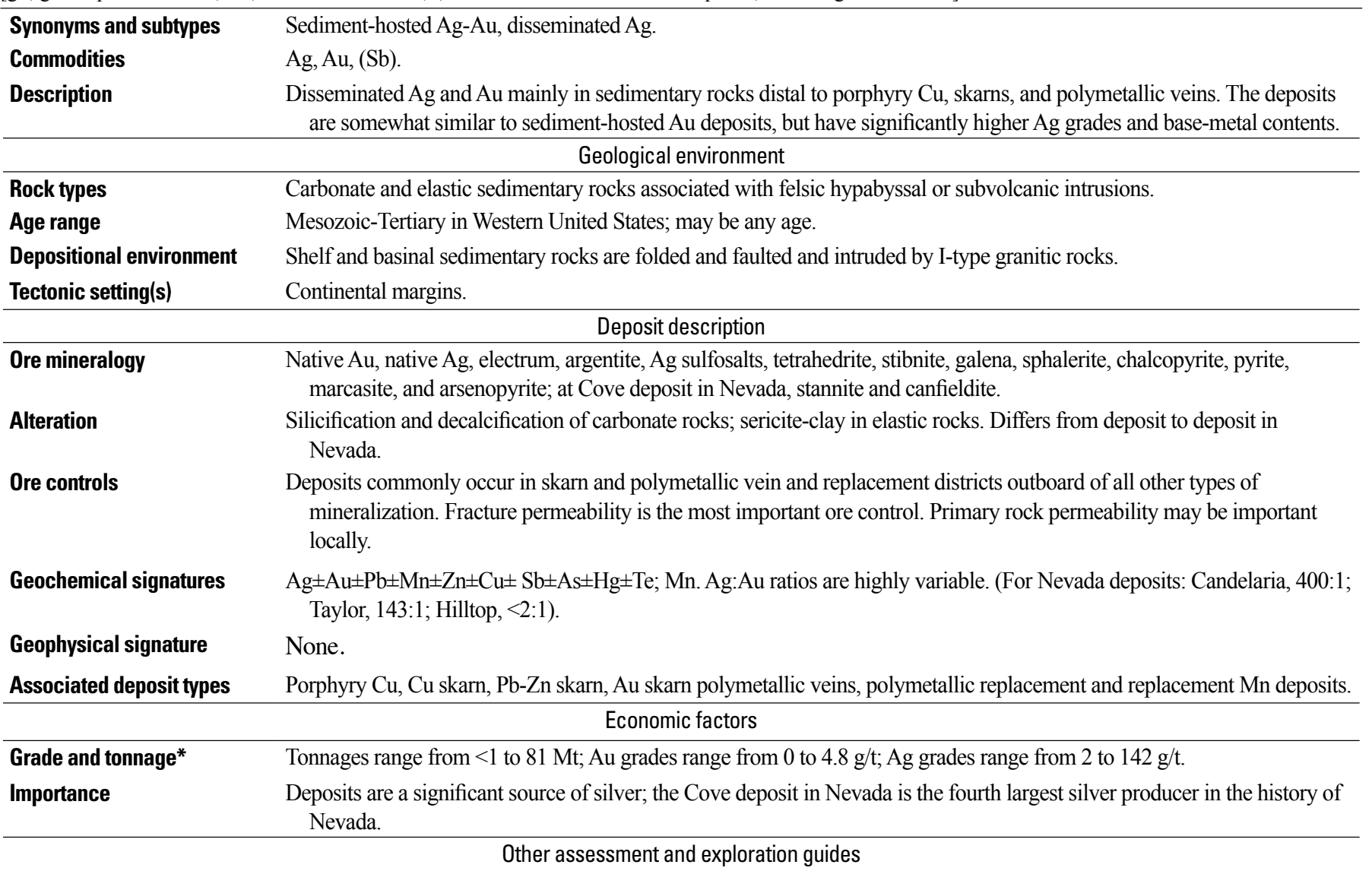

Structural setting: Shear zones, axial plane fractures in folded rocks.

Ore deposit geometry: Irregular bodies, locally conformable to bedding.

Weathering: Leaching and redeposition of Ag as cerargyrite forms bonanza deposits (White Pine district, Nevada; Vekol, Arizona).

Gangue minerals: Quartz, rhodochrosite, Ag-rich manganocalcite.

Depth: Typically form at higher crustal levels than porphyry copper deposits.

\begin{tabular}{|c|c|}
\hline \multicolumn{2}{|r|}{ Examples } \\
\hline In/near focal areas & Vipont, Nevada. \\
\hline Elsewhere & $\begin{array}{l}\text { Taylor, Candelaria, Star Pointer, Cove deposits, White Pine district, Nevada; Tecoma, Utah; Vekol, Tombstone, and } \\
\text { Hardshell, Arizona. }\end{array}$ \\
\hline \multicolumn{2}{|r|}{ References } \\
\hline \multicolumn{2}{|c|}{$\begin{array}{l}\text { Cox, D.P., 1992, Descriptive model of distal disseminated Ag-Au, in Bliss, J.D., Developments in mineral deposit modeling: U.S. Geological Survey } \\
\text { Bulletin 2004, p. 19, accessed April 25, 2016, at http://pubs.usgs.gov/bul/b2004/model19c.pdf. }\end{array}$} \\
\hline \multicolumn{2}{|c|}{$\begin{array}{l}\text { Theodore, T.G., 1998, Large distal-disseminated precious-metal deposits, Battle Mountain mining district, Nevada, in Tosdal, R.M., ed., Contributions to } \\
\text { the gold metallogeny of northern Nevada: U.S. Geological Survey Open-File Report 98-338-B, p. 253-258, accessed April 25, 2016, at http://pubs. } \\
\text { usgs.gov/of/1998/of98-338/of98_338.pdf. }\end{array}$} \\
\hline
\end{tabular}




\section{Carlin-Type Gold (Silver, Mercury, Antimony)}

$\left[\%\right.$, percent; wt.\%, weight percent; g/t, grams per metric ton; Mt, million metric tons; ${ }^{\circ} \mathrm{C}$, degrees Celsius; m, meter; ASTER, Advanced Spaceborne Thermal Emission Radiometer]

\begin{tabular}{|c|c|}
\hline Synonyms and subtypes & Sediment-hosted gold, Micro-disseminated gold, Micron gold. \\
\hline Commodities & Au. Byproducts: Ag, Hg, Sb. \\
\hline Description & $\begin{array}{l}\text { Epigenetic, replacement, disseminated, auriferous pyrite deposits at intersections of high angle faults and permeable } \\
\text { reactive sedimentary rocks. }\end{array}$ \\
\hline Rock types & $\begin{array}{l}\text { Most deposits are hosted in Paleozoic, marine, carbonaceous, pyritic, and calcareous and (or) dolomitic sedimentary rocks } \\
\text { deposited on the slope near the carbonate platform margin. Some deposits are hosted in marginal basin, shelf, foreland } \\
\text { basin, and overlap sequences. Others occur in dolomitize limestones, contact metamorphic aureoles of Mesozoic } \\
\text { intrusions, and Jurassic lamprophyre dikes. }\end{array}$ \\
\hline Age range & Mostly Eocene. \\
\hline Depositional environment & $\begin{array}{l}\text { Epizone, subvolcanic, a few } 100 \text { to } 5,000 \mathrm{~m} \text { below the paleosurface. } \\
\text { Temperature } 100-240{ }^{\circ} \mathrm{C}, 0-9 \text { wt. } \% \mathrm{NaCl}, \mathrm{pH}<5, \mathrm{CO}_{2}<4 \mathrm{~mole} \%, \mathrm{CH}_{4}<0.4 \text { mole } \%, \mathrm{H}_{2} \mathrm{~S} 10^{-1}-10^{-2} \text { molar. } \\
\text { Gold-bearing disseminated pyrite precipitates where } \mathrm{H}_{2} \mathrm{~S} \text {-bearing hydrothermal fluids react with iron-bearing minerals or } \\
\text { external fluids in sedimentary rocks. }\end{array}$ \\
\hline
\end{tabular}
Deposit description

Ore mineralogy

Most of the gold and trace elements reside in micron-sized disseminated pyrite that often forms rims on diagenetic pyrite. Common open-space filling minerals include drusy quartz, calcite, barite, stibnite, orpiment, and realgar. Rare minerals include native gold, cinnabar, lorandite, getchellite, and galkhaite. Micron-sized native gold occurs in jasperoid and in supergene goethite pseudomorphs of pyrite.

Alteration

Ore controls

Geochemical signatures

Geophysical signature
Ore pyrite was produced by sulfidation of iron-bearing minerals, silicification to form jasperoid, dissolution of carbonate minerals, argillization of silicate minerals, and mobilization of preexisting organic carbon. Ammonium phyllosilicates are present locally.

Intersections of faults and permeable reactive strata, sedimentary breccias, karsted unconformities, dolomitized limestones, calcsilicate hornfels, lamprophyre dikes, and hydrothermal dissolution collapse breccias.

Common pathfinder elements in rock, soil, and stream sediment: Au, As, Sb, Tl, Hg. Au/Ag generally more than three and often much higher. Base metals and Ag generally are not anomalous.

Aeromagnetics: Map the distribution of plutons and dikes.

Radiometrics: Detect shaley cap rocks (K high) and Valmy quartzites (K, Th, U low).

Gravity: Map regional structures associated with deposits and underlying intrusive rocks.

Remote sensing: ASTER data permit recognition of carbonate host rocks, quartzites, argillaceous cap rocks, jasperoid, ferric iron (oxidized pyrite), and clay minerals.

Electrical methods: Delineating low-resistivity zones associated with organic carbon, clay, or sulfide-rich zones at shallow levels. Magnetotelluric methods can detect crustal scale features.

Seismic methods: Detect the thickness of alluvial or volcanic cover. 


\section{Other assesment and exploration guides}

Subcontinental lithospheric mantle may have been hydrated and enriched in Au by Mesozoic subduction- and rift-related magmatism.

Metalliferous black shales may be a potential source for $\mathrm{Au}$ and trace elements in the deposits.

Sedimentary facies and sequence stratigraphy.

Regional and local structural features. For example, extensional step-over faults within strike-slip fault zones and dilatant fracture systems on margins of Mesozoic plutons.

In areas with low ground water tables, supergene oxidation of pyrite allows Au recovery by low-cost cyanide heap leach methods.

Information on depth of post-mineralization cover and depth of erosion.

Exploration and drilling history.

\begin{tabular}{ll}
\hline & \multicolumn{1}{c}{ Examples } \\
\hline In/near focal areas & Doby George, Nevada. \\
Nevada gold trends & Independence, Getchell, Carlin, Battle Mountain-Eureka, Alligator Ridge, Long Canyon. \\
\hline
\end{tabular}

References

Berger, V.I., Mosier, D.L., Bliss, J.D., and Moring, B.C., 2014, Sediment-hosted gold deposits of the world—Database and grade and tonnage models (ver. 1.1, June 2014): U.S. Geological Survey Open-File Report 2014-1074, 46 p., accessed April 25, 2016, at http://dx.doi.org/10.3133/ofr20141074.

Cook, H.E., 2015, The evolution and relationship of the western North American Paleozoic carbonate platform and basin depositional environments to Carlin-type gold deposits in the context of sequence stratigraphy, in Pennell, W.M., and Garside, L.J., eds., New concepts and discoveries: Geological Society of Nevada Symposium 2015, p. 1-80.

Cline, J.S. Hofstra, A.H., Muntean, J.L, Tosdal, R.M. and Hickey, K.A., 2005, Carlin-type gold deposits in Nevada—Critical geologic characteristics and viable models: Economic Geology, 100th Anniversary Volume, p. 451-484.

Emsbo, Poul, Groves, D.I., Hofstra, A.H., and Bierlein, F.P., 2006, The giant Carlin gold province-A protracted interplay of orogenic, basinal, and hydrothermal processes above a lithospheric boundary: Mineralium Deposita, v. 41, p. 517-525.

Hofstra, A.H., and Cline, J.S., 2000, Characteristics and models for Carlin-type gold deposits, chapter 5, in Hagemann, S.G., and Brown, P.E., eds., Gold in 2000: Reviews in Economic Geology, v. 13, p. 163-220.

Large, R.R., Bull, S.W., and Maslennikov, V.V., 2011, A carbonaceous sedimentary source-rock model for Carlin-type and orogenic gold deposits: Economic Geology v.106, p. 331-358.

Muntean, J.L., Cline, J.S., Simon, A.C., and Longo, A.A., 2011, Magmatic-hydrothermal origin of Nevada's Carlin-type gold deposits: Nature Geoscience v. 4, p. $122-127$. 


\section{Hydrothermal_-Volcanic Rock Associated System}

Deposit types in the study area

Epithermal gold-silver (mercury)

Volcanogenic uranium

Stanley district (Idaho)-type uranium

Volcanic opal and specialty gemstones

Hectorite (lithium-rich clay) and specialty clays 


\section{Epithermal Gold-Silver (Mercury)}

[g/t, grams per metric ton; Mt, million metric tons; ${ }^{*}$, based on 90 well-described deposits; CSMAT, controlled-source audio magnetotelluric surveys] Synonyms and subtypes Quartz-alunite (high-sulfidation), quartz-adularia (low sulfidation), hot spring deposits. Quartz-adularia subtypes include layered vein and polymetallic variants. Alkaline igneous rock-related epithermal gold deposits. Bonanza ores $(>1$ troy ounce gold per ton $(34.3 \mathrm{~g} / \mathrm{t})$.

Commodities

Description
$\mathrm{Au}, \mathrm{Ag}$. Byproducts: $\mathrm{Pb}, \mathrm{Zn}, \mathrm{Cu}$, and (or) $\mathrm{Hg}$ (quartz-adularia); $\mathrm{Cu}$ (quartz-alunite), gypsum.

Epithermal gold-silver deposits are shallowly formed vein, stockwork, disseminated, and replacement deposits that are mined primarily for their gold and silver contents. Hot-spring-type mercury deposits are commonly the near-surface expression of hot-spring type gold-silver deposits that occur at deeper levels below mercury-enriched sinter. Epithermal gypsum forms where carbonate host rocks are altered by sulfur-bearing hydrothermal fluids.

\section{Geological environment}

Rock types

Most commonly hosted by alkaline to calcalkaline volcanic rocks and hypabyssal intrusions that range in composition from mafic to felsic, but generally fall into suites of andesite-dacite \pm rhyolite compositions or bimodal basalt-rhyolite compositions. Rocks of the andesite-dacite \pm rhyolite suite mostly have calcalkaline compositions, whereas some bimodal basalt-rhyolite suites have tholeiitic compositions, notably rocks associated with quartz-adularia deposits of the northern Nevada rift that are related to extension and hot spot or mantle plume magmatism in a back arc setting. Hosts for some deposits are silica-undersaturated, highly alkali-rich $\left(\mathrm{Na}_{2} \mathrm{O}+\mathrm{K}_{2} \mathrm{O}\right)$ rocks ranging from felsic phonolites to ultramafic lamprophyres. Other igneous, sedimentary, and metamorphic rock types also can host deposits.

Age range

Mostly of Cenozoic age, which reflects preferential preservation of these shallowly formed deposits in tectonically active regions. Deposits as old as 1.9 billion years are preserved within some cratons.

Depositional environment Quartz-alunite deposits: Lava domes and flows, diatremes, tuff rings, maars, and intrusive breccias associated with diatremes; uplands and basins with pyroclastic and volcaniclastic rocks.

Quartz-adularia, layered vein, and hot springs deposits: Lava domes and flows; uplands and basins with pyroclastic and volcaniclastic rocks; dikes.

Quartz-adularia, polymetallic deposits: Lava domes and flows, diatremes, tuff rings, maars, and intrusive breccias associated with diatremes; uplands and basins with pyroclastic and volcaniclastic rocks.

Tectonic setting(s) Form from subaerial hydrothermal systems in volcanic arcs at convergent plate margins in continental and oceanic settings, in continental-margin back arcs, in rifts, and in intraplate environments.

Deposit description

Ore mineralogy

Quartz-alunite: Gold, electrum, $\mathrm{Au}-\mathrm{Ag}$ tellurides, Ag-bearing tennantite-tetrahedrite, enargite, luzonite, chalcopyrite, numerous Au-Ag-Cu-As-Sb-Bi-Sn-Te-Se-S minerals.

Quartz-adularia, layered veins: Electrum, Ag sulfides, selenides and sulfosalts; low Ag/Au; generally no other metals recovered.

Quartz-adularia, polymetallic: Electrum, Ag sulfides and sulfosalts; Ag-bearing tetrahedrite-tennantite; high Ag/Au; chalcopyrite, galena, sphalerite.

Alkaline igneous rock-related epithermal gold deposits: native $\mathrm{Au}$, numerous telluride minerals, auriferous pyrite.

Hot springs deposits: cinnabar, metacinnabar, tiemannite, HgSeS minerals, sulfur.

Alteration

Quartz-alunite: Zoned. Inner residual (vuggy) quartz grading progressively outward to quartz-alunite; kaolinite (dickite) or pyrophyllite; illite; montmorillonite; distal chlorite-calcite \pm epidote. All + pyrite.

Quartz-adularia: Zoned: inner quartz/chalcedony \pm adularia, carbonate, grading progressively outward to sericite/illite \pm adularia; mixed layer clay \pm chlorite; distal chlorite-calcite \pm epidote. All + pyrite.

Epithermal deposits may be overlain by zones of steam-heated opal, kaolinite, alunite, and (or) montmorillonite. Silica sinter overlies some quartz-adularia deposits. Gypsum replacement bodies occur in some systems.

Hot-spring Hg deposits: Volcanic host rocks and associated clastic sedimentary rocks are altered to an assemblage of adularia, quartz, and sericite at depth, and in the near surface, to an advanced argillic alteration assemblage of kaolinite, alunite, and cristobalite that commonly contains elemental sulfur. Some of these deposits are hosted in hot-spring sinter that was deposited at the surface and that consists of banded silica phases and beds of hydrothermal eruption breccia.

Ore controls

Geochemical signatures
Breccias (magmatic, tectonic, hydrothermal, diatreme); faults, fractures, voids; fault intersections.

$\mathrm{Au}, \mathrm{Ag}, \mathrm{As}, \mathrm{Sb}, \mathrm{Hg} \pm \mathrm{Tl}, \mathrm{F}, \mathrm{Mo}$, Se, Te, and $\mathrm{W}$ are generally enriched in and near epithermal deposits; combinations of $\mathrm{Ba}$, $\mathrm{Cu}, \mathrm{Zn}, \mathrm{Pb}, \mathrm{Sn}$, and Bi may or may not be present. Hot-spring $\mathrm{Hg}$ deposits: $\mathrm{Hg}$, Li, B, As, Sb, Au, Ag, Th, and W. 
Geophysical signature

Importance

Aeromagnetics: Hydrothermal fluids can destroy magnetite; therefore, pervasively altered volcanic rock appears as areas of subdued magnetic anomalies (magnetic quiet zones) relative to high-amplitude, short-wavelength anomalies of surrounding unaltered volcanic rock.

Radiometrics: Central zone of K metasomatism in quartz-adularia deposits characterized by enriched K/Th values, which may be particularly pronounced in alkaline igneous rock-related epithermal gold deposits.

Gravity: Useful in mapping and characterizing regional structures associated with deposits, such as concealed basins, calderas, and underlying intrusive rocks. High-resolution gravity measurements may directly characterize hydrothermal alteration, which may reduce porosity, thereby increasing density.

Remote sensing: Host rocks are commonly enriched in hydrothermal minerals that have diagnostic absorption features in the visible (VIS), near-infrared (NIR), shortwave-infrared (SWIR), and thermal infrared (TIR) regions of the electromagnetic spectrum. ASTER data permit mineralogical differentiation of various alteration types (argillic, phyllic, alunitic), carbonate minerals, and high concentrations of quartz.

Electrical methods: Hydrothermal alteration associated with gold mineralization commonly involves the replacement of host rocks by clay and sulfide minerals, which can decrease electrical resistivity by several orders of magnitude, and silicification or quartz veining, which increases resistivity. Methods focused on shallow parts of the crust are useful in delineating low-resistivity zones associated with clay or sulfide-rich alteration or highly resistive zones dominated by quartz veins or silicification. CSAMT now widely used.

\begin{tabular}{lll}
\hline & \multicolumn{1}{c}{ Economic factors } \\
\hline Grade and tonnage* $^{*}$ & Quartz-alunite & Quartz-adularia \\
& Au grade $3.8 \mathrm{~g} / \mathrm{t}(\mathrm{avg}), 0.45-17 \mathrm{~g} / \mathrm{t}(\mathrm{range})$ & $9.9 \mathrm{~g} / \mathrm{t}(\mathrm{avg}), 0.26-68 \mathrm{~g} / \mathrm{t}(\mathrm{range})$ \\
& Ag grade $53 \mathrm{~g} / \mathrm{t}(\mathrm{avg}), 2.4-600 \mathrm{~g} / \mathrm{t}(\mathrm{range})$ & $164 \mathrm{~g} / \mathrm{t}(\mathrm{avg}), 1.6-1,100 \mathrm{~g} / \mathrm{t}(\mathrm{range})$ \\
& Tonnage $170 \mathrm{Mt}(\mathrm{avg}), 1.2-1,700 \mathrm{Mt}(\mathrm{range})$ & $142 \mathrm{Mt}(\mathrm{avg}), 0.1-2,300 \mathrm{Mt}(\mathrm{range})$ \\
Importance & $\begin{array}{l}\text { These deposits are attractive because of their relatively rich gold and silver grades, their wide range of tonnage-grade charac- } \\
\text { teristics, including bonanza grades, which are amenable to both underground and bulk tonnage mining, and in some cases, } \\
\text { recovery of byproducts. }\end{array}$ \\
\hline \multicolumn{2}{c}{ Other assessment and exploration guides } \\
\hline
\end{tabular}

Known epithermal deposits and prospects.

Volcanic and volcaniclastic rocks coeval with similar rocks known to host deposits.

Hydrothermal alteration known to accompany epithermal deposits.

Regional and local structural features (for example, extensional stepover zones within strike-slip fault zones).

Some hot-spring $\mathrm{Hg}$ deposits occur in hot-spring sinter that consists of layered or bedded silica phases and hydrothermal eruption breccia.

Shallow hydrothermal features, such as sinters, stratiform alteration zones, and hydrothermal eruption breccias.

Information on depth of post-mineralization cover and depth of erosion.

Exploration and drilling history.

Examples

In/near focal areas $\quad$ Buckskin Mountain, Nevada (quartz-adularia, layered vein).

Zortman-Landusky, Montana (alkaline igneous rock-related).

Clear Creek gypsum mine, Idaho.

Elsewhere

Quartz-alunite: Goldfield, Nevada; Summitville, Colorado.

Quartz-adularia, layered veins: Midas, Round Mountain, and Sleeper, Nevada.

Quartz-adularia, polymetallic: Comstock Lode and Tonopah, Nevada.

Alkaline igneous rock-related: Cripple Creek, Colorado; Golden Sunlight, Montana; Ladolam and Porgera, Papua New

Guinea.

References

John, D.A., USGS, written commun., 2016.

Kelley, K.D., and Spry, P.G., 2015, Critical elements in alkaline igneous rock-related epithermal gold deposits: Reviews in Economic Geology, v. 18, p. $195-216$.

Rytuba, J.J., 2002, Mercury geoenvironmental models, in Seal, R.R., II, and Foley, N.K., eds., Progress on geoenvironmental models for selected mineral deposit types: U.S. Geological Survey Open-File Report 02-195-J, p. 161-175, accessed February 9, 2016, at http://pubs.usgs.gov/of/2002/of02-195/ OF02-195J.pdf.

Skipp, Betty, Hassemer, Jerry R., Kulik, D.M., Sawatzky, Leszcykowski, A.M., and Winters, R.A., 1988, Mineral resources of the Eighteenmile Wilderness Study Area, Lemhi County, Idaho: U.S. Geological Survey Bulletin 1718-B, 22 p. [Also available at http://pubs.usgs.gov/bul/1718b/report.pdf.] 


\section{Volcanogenic Uranium}

[wt.\%, weight percent; $\mathrm{ft}$, feet; $\mathrm{mi}^{2}$, square miles]

\begin{tabular}{|c|c|}
\hline Synonyms & None. \\
\hline Commodities & Uranium (sometimes associated mineable fluorite, molybdenum, mercury). \\
\hline Description & Uranium minerals associated with felsic volcanic in caldera systems. \\
\hline \multicolumn{2}{|r|}{ Geological environment } \\
\hline Rock types & $\begin{array}{l}\text { Felsic volcanic rocks and associated volcanoclastic sediments and tuffs. Uranium enrichment increases with differentiation to } \\
\text { more felsic composition, and deposits are most common in rocks with aluminous and alkaline affinities and high fluorine } \\
\text { content (Cuney and Kyser, 2009). }\end{array}$ \\
\hline Age range & Proterozoic through Tertiary \\
\hline Depositional environment & $\begin{array}{l}\text { Felsic volcanic centers: Both fracture zones and volcanoclastic sediments, tuffs and permeable lava flows associated that } \\
\text { make up felsic volcanic complexes. }\end{array}$ \\
\hline Tectonic setting(s) & $\begin{array}{l}\text { Diverse tectonic settings, including rifts, hot spots (McDermitt caldera, Nevada), back arcs, and subduction zones where the } \\
\text { stress field has shifted from compressional to extensional. }\end{array}$ \\
\hline Associated deposit types & Mercury, fluorite, and molybdenum. \\
\hline
\end{tabular}

\begin{tabular}{|c|c|}
\hline \multicolumn{2}{|r|}{ Deposit description } \\
\hline Ore mineralogy & $\begin{array}{l}\text { Uraninite, pitchblende and coffinite with brannerite and uranothorite in more alkaline volcanic rocks. Associated fluorite and } \\
\text { molybdenite in most volcanogenic uranium deposits; rare earth elements, thorium and zirconium in peralkaline volcanic } \\
\text { systems. Polymetallic deposits (with copper, lead, silver, and zinc) in Europe and Asia are the result of a multistage } \\
\text { hydrothermal history. }\end{array}$ \\
\hline Alteration & $\begin{array}{l}\text { Pre-ore alteration: alkali metasomatism with quartz, sericite, pyrite and carbonate mineral veining. Ore-stage alteration: } \\
\text { uranium minerals associated with argillic alteration and fluorite. Post-ore alteration: redistribution of uranium and late- } \\
\text { stage carbonate minerals, sulfates and additional argillic alteration. }\end{array}$ \\
\hline Geochemical signatures & $\begin{array}{l}\text { Elevated uranium, fluoride, and molybdenum in rock, water, soil, and stream sediments. Concealed deposits may be } \\
\text { identified by elevated radon in soil gas samples and uranium and indicator elements (U, F, Mo) in groundwater. }\end{array}$ \\
\hline
\end{tabular}

\begin{tabular}{lc}
\hline Economic factors \\
\hline Grade and tonnage & Vein and stockwork deposits extend for tens to several hundreds of meters along strike and tens to hundreds of meters in dip. \\
Stratabound deposits can extend for hundreds of meters laterally and range from less than one to tens of meters in thick- \\
ness. These deposits have low to moderate grades of 0.05 to $0.23 \mathrm{wt} \% \mathrm{U}_{3} \mathrm{O}_{8}$. Known deposits range from relatively small \\
deposits of a few thousand pounds. $\mathrm{U}_{3} \mathrm{O}_{8}$ to the Stretsovskoye district, which contains over 250 million pounds $\mathrm{U}_{3} \mathrm{O}_{8}$. \\
Within the U.S., known deposits in Idaho, Nevada, Oregon and Utah produced an estimated 2 million pounds $\mathrm{U}_{3} \mathrm{O}_{8}$ during \\
mining from the 1950s to 1970s. \\
Worldwide volcanogenic uranium deposits contain about 1.2 billion pounds of $\mathrm{U}_{3} \mathrm{O}_{8}$, which is about 6 percent of the world's \\
known global resources (International Atomic Energy Agency, 2009). Within the U.S. potential resources within volcanic \\
rocks are estimated to be 232 million pounds of $\mathrm{U}_{3} \mathrm{O}_{8}$ (Department of Energy, 1980).
\end{tabular}
Other assessment and exploration guides

Areas favorable to these deposits typically have basement rocks that are enriched in uranium. Crustal thinning accompanied by partial melting and hydrothermal fluid interaction with this enriched crust is thought to contribute uranium to the felsic volcanic rocks that host the deposits.

Multiple overprinting volcanic episodes may help concentrate uranium in later stage melts and hydrothermal fluids.

The identification of regions with progressive concentration of uranium by successive magmatic episodes may help identify favorable terrain.

\section{Examples}

In/near focal areas $\quad$ McDermitt Caldera District (Aurora, Bretz, Moonlight deposits), Nevada-Oregon.


Elsewhere Streltsovskoye, Russia.

References

Breit, G.N., and Hall, S.M., 2011, Deposit model for volcanogenic uranium deposits: U.S. Geological Survey Open-File Report 2011-1255, 5 p., accessed May 10, 2016, at http://pubs.usgs.gov/2011/1255/.

Cuney, M., and Kyser, K., 2009, Recent and not-so-recent developments in uranium deposits and implications for exploration: Mineralogical Association of Canada, Short Course Series, v. 39, 257 p.

Cunningham, C.G., Rasmussen, J.E., Steven, T.A., Rye, R.O., Rowley, P.D., Romberger, S.B. and Selverstone, J., 1998, Hydrothermal uranium deposits containing molybdenum and fluorite in the Marysvale volcanic field, west-central Utah: Mineralium Deposits, v. 33, p. $477-494$.

Department of Energy, 1980, An assessment report on uranium in the United States of America: U.S. Department of Energy Report, GJO-111 (80), 157 p. International Atomic Energy Agency, 2009, International Atomic Energy Agency world distribution of uranium deposits (UDEPO) with uranium deposit classification: Vienna, Austria, International Atomic Energy Agency, IAEA-TECHDOC-1629, 117 p.

Nash, J.T., 2010, Volcanogenic uranium deposits: geology and geochemical processes, and criteria for resource assessment: U.S. Geological Survey OpenFile Report 2010-1001, 98 p. [Also available at http://pubs.usgs.gov/of/2010/1001/.] 


\section{Stanley District (Idaho)-Type Uranium}

[Mt, million metric tons]

\begin{tabular}{ll}
\hline Synonyms & Unconformity sandstone-conglomerate-hosted uranium; vein-hosted uranium. \\
Commodities & Uranium. \\
Description & $\begin{array}{c}\text { In the Stanley district, the uranium deposits occur in two geologic settings: (1) as disseminated uranium minerals } \\
\text { within fluvial-channel arkosic sandstones and conglomerates that rest on the eroded surface of the Cretaceous Idaho } \\
\text { batholith and immediately beneath the Eocene Challis Volcanic Group and (2) as thin pockets of uranium minerals } \\
\text { in silicified fractures that cut through the granitoid rocks of the batholith (Kern, 1959; Johnson and others, 1995a, } \\
\text { 1995b; Van Gosen and others, 2006). }\end{array}$ \\
\hline
\end{tabular}
Geological environment

\begin{tabular}{ll}
\hline Rock types & Arkosic sandstones and conglomerates and thin siliceous veins in granitic rocks. \\
Age range & Uranium deposition is likely to be Eocene, perhaps younger. \\
Depositional environment & $\begin{array}{l}\text { Microscopic textures in the uranium minerals suggest that the uranium mineralization in the strata-bound deposits is } \\
\text { genetically linked to the widespread hydrothermal alteration in the area that was associated with igneous intrusions } \\
\text { related to the eruption of the Eocene Challis Volcanic Group (Van Gosen and others, 2006). }\end{array}$
\end{tabular}

Tectonic setting(s) Mid-cratonic setting in volcanic terranes.

\begin{tabular}{ll}
\hline Ore mineralogy & Deposit description \\
& Uraninite; meta-autunite; uranophane; a calcium uranium phosphate mineral (autunite? phosphuranylite?); kasolite, a \\
member of the phosphuranylite-renardite series; beta-uranophane; clarkeite; schoepite; and vandendriesscheite (see & Choate, 1962, p. 31; Van Gosen and others, 2006). \\
Microscopic alteration of minerals in the U-mineralized intervals. \\
Ore controls & Uranium mineralization is confined to fluvial-channel arkosic sandstones and conglomerates that rest upon the eroded \\
surface of the Cretaceous Idaho batholith and immediately beneath the Eocene Challis Volcanic Group and (2) as thin \\
pockets of uranium minerals in silicified fractures that cut through the granitoid rocks of the Idaho batholith. Organic \\
matter and sulfide minerals in the sedimentary hot rocks provided reductant materials for the precipitation of the \\
uranium minerals. \\
Ueochemical signature
\end{tabular}

\section{Economic factors}

Grade and tonnage

The average grade (about 0.18 weight percent $\mathrm{U}_{3} \mathrm{O}_{8}$ ) of the uranium deposits mined in the Stanley district was comparable to other U.S. producers during the late 1950s and early 1960s, but the district's output (no more than 8,000 metric tons of uranium ore per year) and its mines were relatively small.

Importance

Small production of uranium ore came from mines in the Stanley district from 1957 to 1962, making it the first commercial uranium district in Idaho. This district comprised at least 27 uranium mines and prospect claim groups, scattered across an area of about 10 square miles.

Other assessment and exploration guides

Identify Tertiary sandstones and conglomerates that rest of the surface of granitoid plutonic rocks of the Idaho Batholith and occur immediately below volcanic and volcaniclastic rocks of the Eocene Challis Volcanics.

Survey the appropriate sedimentary units and stratigraphic horizons for radioactivity using airborne radiometric surveys, followed up by on-the-ground radiometric surveys (scintillometer or Geiger counter).

Economic deposits of this type typically are exploited only if they lie at or within a few tens of meters of the surface due to their modest uranium concentrations and tonnage.

\begin{tabular}{lc}
\hline & Examples \\
\hline In/near focal areas & Central Idaho where Challis Volcanics lie in contact with the Idaho batholith.
\end{tabular}


Elsewhere

The uranium deposits of the Marysvale volcanic field in west-central Utah comprise another uranium district with geologic characteristics generally similar to those of the Stanley district. Uranium in the Marysvale volcanic field occurs in a variety of geologic settings, including hydrothermal vein deposits and sedimentary-trap deposits in basin-fill sediments (Steven and others, 1981).

\section{References}

Choate, Raoul, 1962, Geology and ore deposits of the Stanley area: Idaho Bureau of Mines and Geology Pamphlet No. 126, 122 p.

Johnson, K.M., and Cookro, T.M., 1995a, Stratiform uranium deposits in sedimentary rocks, in Fisher, F.S., and Johnson, K.M., eds., Geology and mineral resource assessment of the Challis $1^{\circ} \times 2^{\circ}$ quadrangle, Idaho: U.S. Geological Survey Professional Paper 1525, p. $167-168$.

Johnson, K.M., and Cookro, T.M., 1995b, Uranium veins, in Fisher, F.S., and Johnson, K.M., eds., Geology and mineral resource assessment of the Challis $1^{\circ} \times 2^{\circ}$ quadrangle, Idaho: U.S. Geological Survey Professional Paper 1525, p. 119-121.

Kern, B.F., 1959, Geology of the uranium deposits near Stanley, Custer County, Idaho: Idaho Bureau of Mines and Geology Pamphlet 117, 40 p.

Steven, T.A., Cunningham, C.G., and Machette, M.N., 1981, Integrated uranium systems in the Marysvale volcanic field, west-central Utah, in Goodell, P.C., and Waters, A.C., eds., Uranium in volcanic and volcaniclastic rocks: American Association of Petroleum Geologists Studies in Geology No. 13, p. 111-122.

Van Gosen, B.S., Hammarstrom, J.M., Eppinger, R.G., Briggs, P.H., Crock, J.G., Meier, A.L., Sutley, S.J., Theodorakos, P.M., and Hageman, P.L., 2006, A reconnaissance geochemical and mineralogical study of the Stanley uranium district, Custer County, central Idaho: U.S. Geological Survey Scientific Investigations Report 2005-5264, 54 p., accessed May 10, 2016, at http://pubs.usgs.gov/sir/2005/5264/. 


\section{Volcanic Opal and Specialty Gemstones}

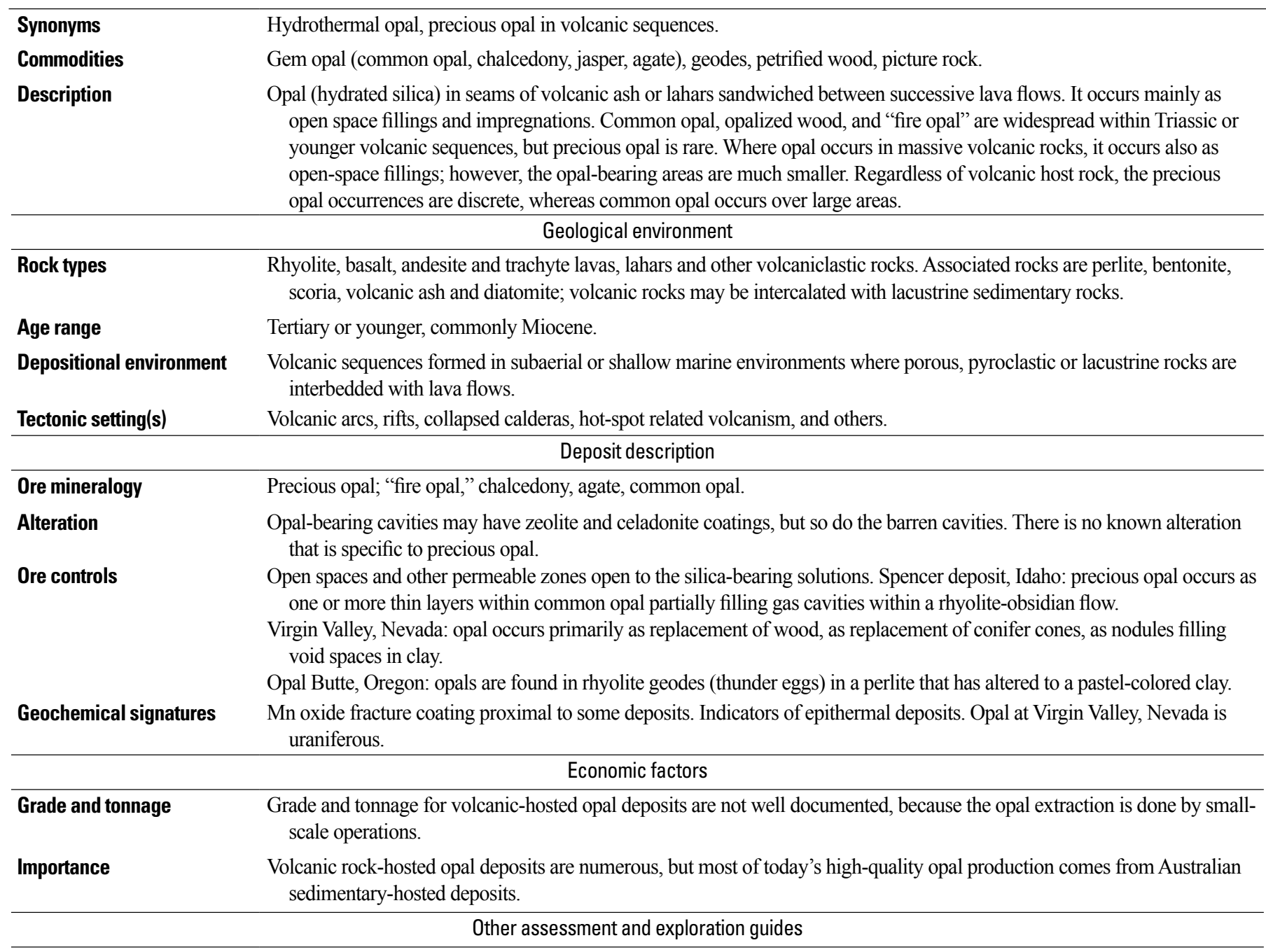

Boulder tracing is commonly used in opal exploration.

Unmetamorphosed or weakly metamorphosed (zeolite facies) terrains (gem opal deteriorates and becomes brittle if subject to moderate temperatures).

Tertiary or younger volcanic rocks.

Areas containing known occurrences of precious or common opal, opalized wood and possibly chalcedony.

Opal occurrences hosted by volcaniclastic rocks are commonly confined to the same lithologic unit over a large area.

Presence of warm springs in an appropriate setting.

\begin{tabular}{l}
$\begin{array}{l}\text { In/near focal areas } \\
\text { Elsewhere }\end{array}$ \\
\hline $\begin{array}{c}\text { Virgin Valley, Nevada. } \\
\text { Blue Fire Opal Mine, Idaho. }\end{array}$ \\
$\begin{array}{l}\text { Paradis, S., Simandl, G.J. and Sabina, A., 1999, Opal deposits in volcanic sequences, } \text { in Simandl, G.J., Hora, Z.D., and Lefebure, D.V., eds., Selected } \\
\text { British Columbia mineral deposit profiles, volume 3-Industrial Minerals: British Columbia Ministry of Energy and Mines, Open File 1999-10, } \\
\text { accessed April 26, 2016, at http://www.empr.gov.bc.ca/Mining/Geoscience/MineralDepositProfiles/Pages/default.aspx. }\end{array}$ \\
Staatz, M.H., and Bauer, H.L., Jr., 1961, Virgin Valley opal district, Humboldt County, Nevada: U.S. Geological Survey Circular 142, 7 p. [Also available \\
at http://pubs.usgs.gov/circ/0142/report.pdf.] \\
U.S. Bureau of Mines, 1995, An overview of production of specific U.S. gemstones: U.S. Bureau of Mines Special Publication 14-95, accessed February \\
4, 2016, at http://minerals.er.usgs.gov/minerals/pubs/commodity/gemstones/sp14-95/contents.html. \\
\hline
\end{tabular}




\section{Hectorite (Lithium-Rich Clay) and Specialty Clay}

[ppm, parts per million; wt.\%, weight percent; kt, thousand metric tons]

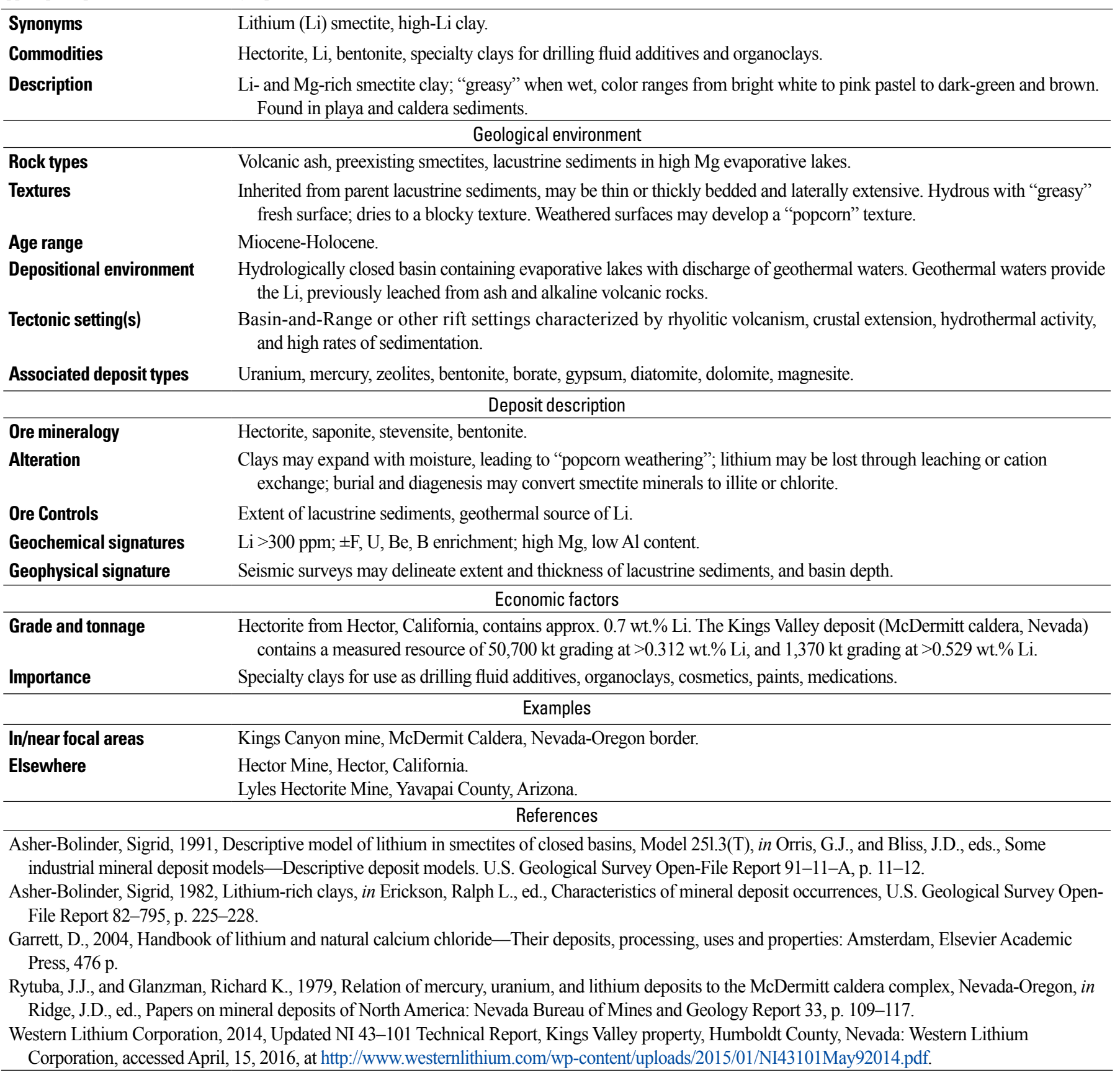




\section{Hydrothermal—Exhalative-Magmatic Processes System}

Deposit types in study area

Volcanogenic massive sulfide 


\section{Volcanogenic Massive Sulfide (Besshi-subtype VMS)}

[wt.\%, weight percent; km, kilometer; $\mathrm{t}$, metric ton; $\mathrm{g} / \mathrm{t}$, grams per metric ton; VMS, volcanogenic massive sulfide]

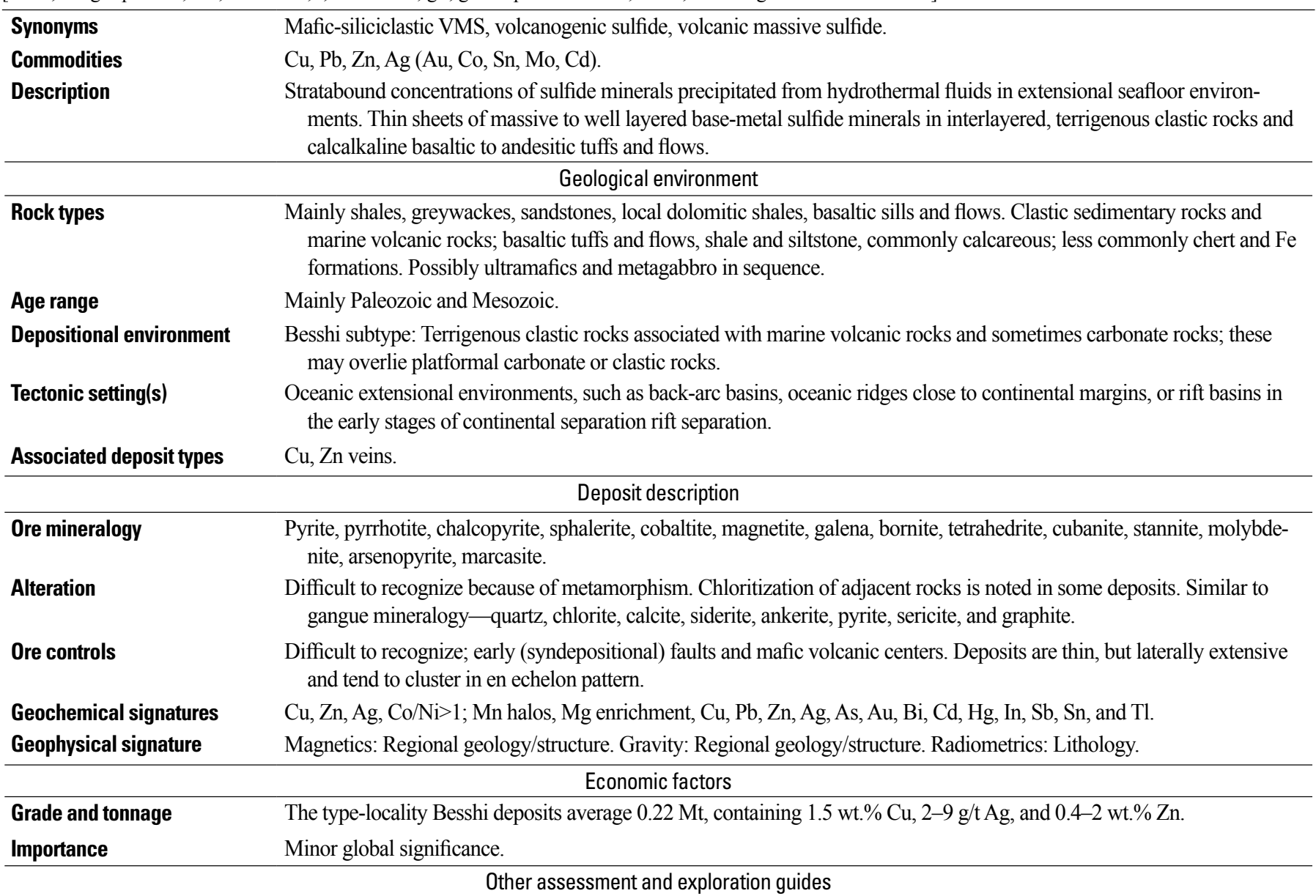

Mafic volcanic rocks (tholeiitic, less commonly alkalic) associated with clastic rocks.

Mn-rich garnets in metamorphosed exhalative horizons.

Presence of a submarine volcanosedimentary sequence having an age that falls within a time period containing numerous VMS deposits with large aggregate tonnages and base metal contents.

Evidence of an extensional geodynamic setting and synvolcanic faulting as reflected in distinctive compositions of volcanic and synvolcanic intrusive rocks.

Presence of coarse volcanic breccias or felsic domes indicating proximity to a volcanic center.

Occurrence of exhalites, especially those containing barite and (or) high concentrations of $\mathrm{Cu}, \mathrm{Zn}$, or $\mathrm{Pb}$.

Favorable marine volcanosedimentary units including felsic or mafic lavas or tuffs, coarse breccias, and rhyolite domes that host mineralization within the same belt.

VMS-type prospects or occurrences including stratabound sulfides and discordant veins.

Evidence of VMS-type alteration zones represented by abundant chlorite or white mica, or their metamorphosed equivalents; abundant tourmaline and (or) gahnite.

Synvolcanic structures such as growth faults, calderas, and fault intersections, which may have focused fluid flow and localized sulfide mineralization.

Local fine-grained, highly carbonaceous or graphitic sedimentary rocks that record breaks in volcanism and in most cases indicate coeval anoxic or sulfidic bottom waters that prevented seafloor weathering and oxidation of sulfides.

Large synvolcanic sills and (or) dikes, which typically occur in the stratigraphic footwall of the deposits, having served as sources of heat to drive the hydrothermal systems.

Abundant chlorite or white mica and their metamorphosed equivalents (including Al-rich minerals), as evidence of VMS-type alteration.

\section{Examples}

In/near focal areas

Rio Tinto, Nevada. 
Elsewhere Windy Craggy, British Columbia; Besshi, Japan.

References

Franklin, J.M., Lydon, J.W., and Sangster, D.M., 1981, Volcanic-associated massive sulfide deposits: Economic Geology, 75th Anniversary Volume, p. 485-627.

Hõy, Trygve, 1995, Besshi massive sulphide, in Selected British Columbia mineral deposit profiles, volume 1-Metallics and Coal, in Lefebure, D.V., and Ray, G.E., eds., British Columbia Ministry of Energy of Employment and Investment, Open File 1995-20, p. 49-50, accessed April 26, 2016, at http:// www.empr.gov.bc.ca/Mining/Geoscience/MineralDepositProfiles/Pages/default.aspx.

Shanks, W.C. Pat, III, and Thurston, Roland, eds., 2012, Volcanogenic massive sulfide occurrence model: U.S. Geological Survey Scientific Investigations Report 2010-5070-C, 345 p., accessed February 7, 2016, at http://pubs.usgs.gov/sir/2010/5070/c/. 


\title{
Hydrothermal—Exhalative-Sedimentary Processes System
}

\author{
Deposit types in the study area
}

SEDEX (sedimentary exhalative deposits) lead-zinc-silver

Bedded barite 


\section{Sedimentary-Exhalative (SEDEX) Lead-Zinc-Silver}

[wt.\%, weight percent; Mt, million metric tons; g/t, grams per metric ton; m, meter; km, kilometer; ${ }^{\circ} \mathrm{C}$, degree Celsius; SEDEX sedimentary exhalative; MVT, Mississippi-Valley-type]

\begin{tabular}{|c|c|}
\hline Synonyms & Shale-hosted Zn-Pb-Ag, sediment-hosted massive sulfide Zn-Pb-Ag, SEDEX Zn-Pb. \\
\hline Commodities & $\mathrm{Zn}, \mathrm{Pb}, \mathrm{Ag}$ (minor $\mathrm{Cu}$, barite). \\
\hline Synoptic statement & Hydrothermal deposit formed by the exhalation of metalliferous sedimentary brines into seawater. \\
\hline Description & $\begin{array}{l}\text { Beds and laminations of sphalerite, galena, pyrite, pyrrhotite and rare chalcopyrite, with or without barite, in euxinic } \\
\text { clastic marine sedimentary strata. Deposits are typically tabular to lensoidal in shape and range from centimeters to } \\
\text { tens of meters thick. Multiple horizons may occur over stratigraphic intervals of } 1,000 \mathrm{~m} \text { or more. }\end{array}$ \\
\hline \multicolumn{2}{|r|}{ Geological environment } \\
\hline Textures & $\begin{array}{l}\text { Sulfide and barite laminae are usually very finely crystalline where deformation is minor. In intensely folded deposits, } \\
\text { coarser grained, recrystallized zones are common. Sulfide laminae are typically monomineralic. }\end{array}$ \\
\hline Tectonic setting(s) & Intracratonic or epicratonic sedimentary basin. \\
\hline Associated deposit types & Mississippi-Valley type (MVT), bedded barite, iron formation, phosphate. \\
\hline \multicolumn{2}{|r|}{ Deposit description } \\
\hline Ore mineralogy & $\begin{array}{l}\text { Sphalerite, galena, pyrite, pyrrhotite } \pm \text { chalcopyrite. Barite may or may not be a major component of the ore zone. } \\
\text { Trace marcasite, arsenopyrite, bismuthinite, molybdenite, enargite, millerite, freibergite, cobaltite, cassiterite, } \\
\text { valleriite and melnikovite have been reported from these deposits. }\end{array}$ \\
\hline Alteration & $\begin{array}{l}\text { Alteration varies from well-developed to nonexistent. In some deposits a stockwork and disseminated feeder zone } \\
\text { lies beneath, or adjacent to, the stratiform mineralization. Alteration minerals, if present, include silica, tourmaline, } \\
\text { carbonate, albite, chlorite and dolomite. They formed in a relatively low temperature environment. Celsian, Ba- } \\
\text { muscovite and ammonium clay minerals have also been reported but are probably not common. }\end{array}$ \\
\hline Ore controls & Favorable sedimentary sequences, major structural breaks, basins. \\
\hline Geophysical signature & $\begin{array}{l}\text { Magnetics: Regional geology/structure. Basin geometry. Gravity: Regional geology/structure. Radiometrics: Lithology, } \\
\text { weak radioactivity in some deposits. Presence of graphite-rich zones in the host sedimentary rocks can complicate } \\
\text { the interpretation of electromagnetic conductors. }\end{array}$ \\
\hline \multicolumn{2}{|r|}{ Economic factors } \\
\hline Grade and tonnage & $\begin{array}{l}\text { SEDEX deposits range from } 0.01 \text { to } 746 \mathrm{Mt} \text {, with a median size of } 10 \mathrm{Mt} \text {. Median ore grades are: } 2.26 \mathrm{wt} . \% \mathrm{~Pb}, 5.55 \\
\text { wt. } \% \mathrm{Zn}, 0.6 \mathrm{wt} \% \mathrm{Cu} \text {, and } 45 \mathrm{~g} / \mathrm{t} \mathrm{Ag} \text {. }\end{array}$ \\
\hline
\end{tabular}


SEDEX deposits produce a significant proportion of the world's $\mathrm{Zn}$ and $\mathrm{Pb}$. Their large tonnage potential and associated $\mathrm{Ag}$ values make them an attractive exploration target.

Other assessment and exploration guides

All SEDEX deposits occur in intracratonic or epicratonic sedimentary basins.

Depth to crystalline basement greater than $3 \mathrm{~km}$ (to achieve required fluid temperatures $100^{\circ} \mathrm{C}$ ).

Organic-rich black shale or siltstone with greater than $1 \mathrm{wt} . \% \mathrm{C}_{\text {org }}$.

Brine salinity source: Saline brine ( $>17$ percent TDS) is necessary to form a SEDEX deposit. Basin-scale processes are required to produce the volume of brine necessary to form a deposit. Thus, direct geologic evidence for saline brine generation (such as evaporite minerals, breccias indicating salt dissolution or escape, or regional dolomitized platforms sequences) is required.

Basinwide organic-rich metalliferous black shales and $\mathrm{PO}_{4}, \mathrm{Fe}$, and $\mathrm{Mn}$ deposits may identify prospective sedimentary intervals in basins.

Areas within a few to tens of kilometers of large basin-bounding faults that control second-order features within sedimentary basins are highly favorable.

Synsedimentary faulting as indicated by abrupt and truncated facies boundaries in platform-to-slope transition, thick debris flows, intraformational breccias, changes in isopach thicknesses, and synsedimentary slump structures are highly useful indicators of favorable stratigraphic horizons for ore.

Extensive dolomitization of platform carbonate rocks and alkali-altered platform and rift-phase clastic sedimentary rocks are strong indicators of productive SEDEX basins.

On a local scale, faults that were fluid conduits may be identified by wallrock alteration with Fe- and Mn-rich carbonate rocks or silicification, and perhaps tourmalinization.

MVT-style mineralization and higher temperature dolomite along platform margins may be a strong indicator of the fluid-flow systems that form SEDEX deposits.

\begin{tabular}{|c|c|}
\hline \multicolumn{2}{|r|}{ Examples } \\
\hline In/near focal areas & Triumph, Idaho. \\
\hline Elsewhere & Red Dog, Alaska; Sullivan, British Columbia. \\
\hline \multicolumn{2}{|c|}{$\begin{array}{l}\text { Emsbo, Poul, 2009, Geologic criteria for the assessment of sedimentary exhalative (SEDEX) Zn-Pb-Ag deposits: U.S. Geological Survey Open-File } \\
\text { Report 2009-1209, } 21 \text { p., accessed February 1, 2016, at http://pubs.usgs.gov/of/2009/1209/. }\end{array}$} \\
\hline \multicolumn{2}{|c|}{$\begin{array}{l}\text { Leach, D.L., Sangster, D.F., Kelley, K.D., Large, R.R., Garven, G., Allen, C.B., Gutzmer, J., and Walters, S., 2005, Sediment-hosted lead-zinc } \\
\text { deposits-A global perspective, in Hedenquist, J.W., Thompson, J.F.H., Goldfarb, R.J., and Richards, J.P., eds., Economic Geology-One } \\
\text { hundredth anniversary volume 1905-2005: Littleton, Colorado, Society of Economic Geologists, Inc., p. 561-607. }\end{array}$} \\
\hline \multicolumn{2}{|c|}{$\begin{array}{l}\text { MacIntyre, Don, 1995, Sedimentary exhalative Zn-Pb-Ag, in Lefebure, D.V., and Ray, G.E., eds., Selected British Columbia mineral deposit profiles, } \\
\text { volume 1-Metallics and Coal: British Columbia Ministry of Energy of Employment and Investment, Open File 1995-20, p. 37-39, accessed April } \\
\text { 2, 2016, at http://www.empr.gov.bc.ca/Mining/Geoscience/MineralDepositProfiles/Pages/default.aspx. }\end{array}$} \\
\hline
\end{tabular}




\section{Bedded Barite}

[wt.\%, weight percent; Mt, million metric tons; SEDEX, sedimentary exhalative deposits; PGE, platinum-group elements; REE, rare earth elements]

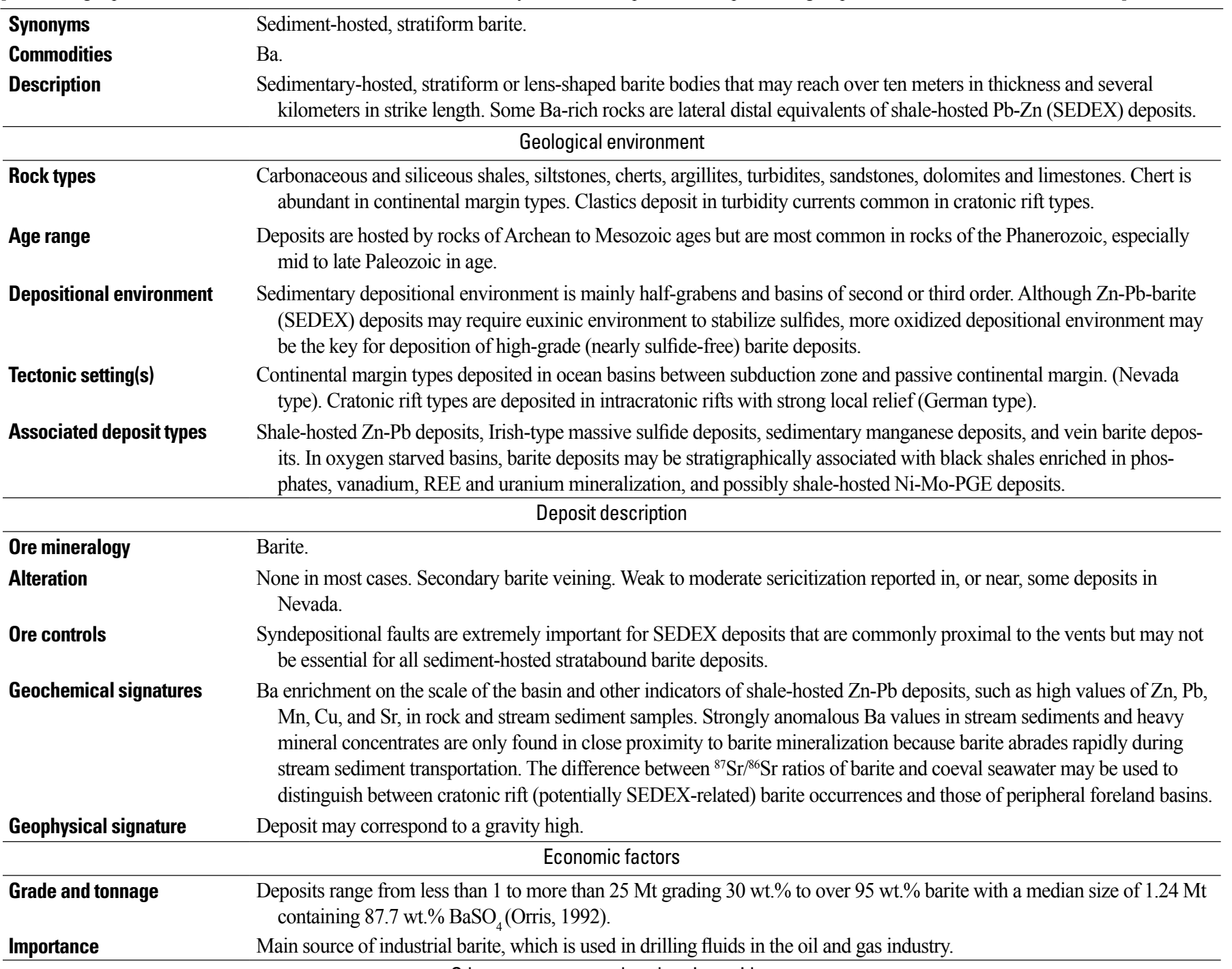
Other assessment and exploration guides

Appropriate tectonic and depositional setting.

Some barite deposits display breccias and slump structures.

In metamorphosed areas, barite may be remobilized forming veinlets and (or) recrystallized.

Proximity to known occurrences of barite, shale-hosted SEDEX, or Irish-type massive sulfide occurrences.

Exhalative chert, hematite-chert iron formations, and regional Mn marker beds.

Vegetation "kill zones" coincide with some barite occurrences.

\section{Examples}

In/near focal areas Snake Mountains, Nevada. 
Elsewhere Argenta, Rossi, Greystone, Big Ledge Mines, Nevada.

References

Maynard, J.B., and Okita, P.M., 1991, Bedded barite deposits in the United States, Canada, Germany, and China-Two major types based on tectonic setting: Economic Geology, v. 86, p. 364-376.

Orris, G.J., 1992, Grade and tonnage model of bedded barite, in Orris, G.J., and Bliss J.D., eds., Industrial minerals deposit models - Grade and tonnage models: U.S. Geological Survey Open-File Report 92-437, p. 40-42, accessed May 10, 2016, at https://pubs.usgs.gov/of/1992/0437/report.pdf.

Paradis, S., Simandl, G.J., MacIntyre, D., and Orris, G.J., 1998, Sedimentary-hosted, stratiform barite, in Geological Fieldwork 1997: British Columbia Ministry of Employment and Investment, Paper 1998-1, p. 24F-1 to 24F-4.

Shawe, D.R., Poole, F.G., and Brobst, D.A., 1967, Bedded barite in East Northumberland Canyon, Nye County, Nevada: U.S. Geological Survey Circular $555,8 \mathrm{p}$.

Torres, M.E., Bohrman, Gerhard, Dube, T.E., and Poole, F.G., 2003, Formation of modern and Paleozoic stratiform barite at cold methane seeps on continental margins: Geology, v. 31, p. 897-400. 


\section{Hydrothermal—Metamorphic Rock Associated System}

Deposit types in the study area

Orogenic low-sulfide gold-quartz veins 


\section{Orogenic Low Sulfide Gold-Quartz Veins}

[km, kilometer; $\mathrm{t}$, metric tons; $\mathrm{g} / \mathrm{t}$, grams per metric ton; ${ }^{\circ} \mathrm{C}$, degree Celsius $]$

\begin{tabular}{ll}
\hline Synonyms & $\begin{array}{c}\text { Turbidite-hosted gold, low-sulfide gold quartz veins, mesothermal gold, greenstone gold, Slate Belt gold, Mother Lode } \\
\text { type, Homestake type. } \\
\text { Commodities }\end{array}$ \\
$\begin{array}{l}\text { Au. } \\
\text { Description }\end{array}$ & $\begin{array}{l}\text { Structurally controlled lode gold in massive persistent quartz veins mainly in regionally metamorphosed volcanic rocks, } \\
\text { volcanic sedimentary rocks, and banded iron formation. }\end{array}$ \\
\hline & \multicolumn{1}{c}{ Geological environment } \\
\hline
\end{tabular}

Rock types

Age range

Depositional environment

Tectonic setting(s)

Ore mineralogy

Alteration

Ore controls

Geochemical signatures

Geophysical signature
A wide range of potential rock types within deformed and metamorphosed host terranes; greenstone belts; turbidites, banded iron formation. Mainly greenschist metamorphic grade rocks, less commonly amphibolite facies, rare granulite facies.

Archean to present.

Adjacent to major, regionally extensive, deep crustal fault zones with deposit locations controlled by secondary faults. Gold is deposited from near-neutral $\mathrm{pH}$, low-moderate salinity, and high $\mathrm{CO}_{2}$ hydrothermal fluids within, or in proximity to, zones of brittle and (or) ductile deformation; transported in solution along permeable large-scale fault zones; temperatures of deposition are $\pm 350^{\circ} \mathrm{C}$, at depths ranging from 4 to $12 \mathrm{~km}$.

Archaean granite-greenstone terrain.

Terrains of turbiditic metasedimentary rocks.

Continental margin accretionary (oceanic-continental) and collisional continent-continent) orogens.

Placer and paleoplacer gold deposits.

Gold, electrum, arsenopyrite, pyrite, pyrrhotite (minor chalcopyrite, sphalerite, galena, and telluride minerals). Au/Ag ratios $>1$. Mineralogy of deposits is limited, in descending order, to quartz, carbonates, alkali feldspar (usually albite), sericite, pyrite, and minor amounts of tourmaline, arsenopyrite, scheelite, molybdenite. No significant base metals.

Intense carbonate alteration is always present (ankerite, dolomite, calcite, magnesite). A progression from calcite to $\mathrm{Fe}-$ carbonate can often be observed toward the deposit.

Chlorite is an important alteration product when the wall rock is mafic.

Fe-sulfide (commonly as pyrite) is ubiquitous.

Silicification (an increase in modal quartz).

Alteration is most obvious when it occurs within low-grade rocks.

Commonly near major regional faults/shear zones but located in secondary faults and (or) near hinge zones of folds. Ore bodies typically strike parallel to subparallel to the host structures. Major regional structures often along terrane or block boundaries serve as fluid pathways.

Common pathfinder elements: $\mathrm{Ag}$, $\mathrm{As}, \mathrm{Au}, \mathrm{B}, \mathrm{Bi}, \mathrm{Hg}, \mathrm{Sb}$, Te, and W. Local, low-level enrichment of $\mathrm{Cu}, \mathrm{Pb}$, and $\mathrm{Zn}$ may occur in some deposits.

Faults indicated by linear magnetic anomalies.

Areas of alteration indicated by negative magnetic anomalies due to destruction of magnetite as a result of carbonate alteration.

Airborne and ground magnetic and gravity surveys to map bedrock geology including deformation zones.

Airborne and ground electromagnetic surveys to outline deformation zones, especially those that contain graphitic gouge and S-rich zones.

Linear resistivity survey lows may locate fault structures; resistivity highs may be associated with massive quartz veins. Radiometric surveys may aid in defining areas of potassium alteration.

Seismic-reflection surveys to locate linear fault zones.

\section{Economic factors}


Placer gold or elevated gold in stream sediment samples is an excellent regional and property-scale guide to gold-quartz veins.

Ore shoots can have many forms that are related to the wide variety of second and third-order structures that can develop in (or be used by) strike-slip fault systems.

Broad "deformation envelopes" adjacent to regional listric faults where associated with carbonate alteration.

Alteration and structural analysis can be used to delineate prospective ground. Economic gold concentration in a deformation zone is often located in places where increased extension has occurred, such as in pull-apart basins.

Mineralization is often contemporaneous with spatially associated granitic intrusions but not genetically related to them.

Within carbonate alteration zones, gold is typically only in areas containing quartz, with or without sulfides.

Serpentinite bodies, if present, can be used to delineate favorable regional structures. Largest concentrations of free gold are commonly at, or near, the intersection of quartz veins with serpentinized and carbonate-altered ultramafic rocks.

\begin{tabular}{ll}
\hline In/near focal areas & Examples \\
Elsewhere & Grass Valley, California; Timmins District, Ontario; Val d'Or District, Quebec; Homestake, South Dakota. \\
\hline
\end{tabular}

Ash, Chris, and Alldrick, Dani, 1996, Au-quartz veins, in Lefebure, D.V., and Hõy, T., eds., Selected British Columbia mineral deposit profiles, volume 2-Metallic deposits: British Columbia Ministry of Employment and Investment, Open File 1996-13, p. 53-56, accessed April 4, 2016 , at http://www. empr.gov.bc.ca/Mining/Geoscience/MineralDepositProfiles/Pages/default.aspx.

Bliss, J.D., 1992, Grade and tonnage model of Chugach-type low sulfide Au-quartz veins, in Bliss, J.D., ed., Developments in mineral deposit modeling: U.S. Geological Survey Bulletin 2004, p. 44 46, accessed May 20, 2016, at https://pubs.er.usgs.gov/publication/b2004.

Drew, L.J., 2003, Low-sulfide quartz gold deposit model: U.S. Geological Survey Open-File Report 03-077, 24 p., accessed February 7, 2016, at http:// pubs.usgs.gov/of/2003/of03-077/of03-077.pdf.

Goldfarb, R.J., Baker, T., Dubé, B., Groves, D.I., Hart, C.J.R., and Gosselin, P., 2005, Distribution, character, and genesis of gold deposits in metamorphic terranes, in Hedenquist, J.W., Thompson, J.F.H., Goldfarb, R.J., and Richards, J.P., eds., Economic Geology One Hundredth Anniversary Volume 1905-2005: Society of Economic Geologists, p. 407-450.

Goldfarb, R.J., Groves, D.I., and Gardoll, S., 2001, Orogenic gold and geologic time-A global synthesis: Ore Geology Reviews, v. 18 , p. 1-75.

Groves D.I., Goldfarb R.J., Gebre-Mariam M., Hagemann S.G., and Robert, F., 1998, Orogenic gold deposits-A proposed classification in the context of their crustal distribution and relationship to other gold deposits: Ore Geology Reviews, v. 13, p. 7-27. 


\title{
Sedimentary System (formed during or after the conversion from sediment to
} sedimentary rock)

Deposit types in the study area

\author{
Bentonite \\ Dolomite (high purity) \\ Sediment-hosted stratabound copper \\ Sandstone uranium (rollfront) in intermontane basins \\ Hydroallogenic volcanic-hosted uranium \\ Zeolites (closed system subtype) \\ Zeolites (open system subtype)
}




\section{Bentonite}

[Mt, million metric tons; $\mathrm{m}$, meter; km, kilometer]

\begin{tabular}{|c|c|}
\hline Synonyms & $\begin{array}{l}\text { Sodium }(\mathrm{Na}) \text { bentonite, calcium }(\mathrm{Ca}) \text { bentonite, swelling bentonite, nonswelling bentonite, hydrothermal bentonite, } \\
\text { Wyoming bentonite, southern bentonite, montmorillonite. }\end{array}$ \\
\hline Commodities & Na bentonite, Ca bentonite, hydrothermal bentonite. \\
\hline Description & Any material composed of smectite clay minerals, whose properties are dictated by the dominant smectite clay mineral. \\
\hline \multicolumn{2}{|r|}{ Geological environment } \\
\hline Rock types & Parent materials are felsic to intermediate volcanic rock, ash, and tuff. \\
\hline Textures & $\begin{array}{l}\text { Inherited from parent volcanic tuff or ash, clay deposits can be thinly bedded and laterally extensive, or they can be lens- } \\
\text { shaped and massively bedded bodies with thickness } 1-6 \mathrm{~m} \text {. }\end{array}$ \\
\hline Age range & Almost all commercial deposits are either Cretaceous or Tertiary \\
\hline Depositional environment & $\begin{array}{l}\text { Felsic to intermediate volcanism producing volcanic ash and (or) feldspar-rich rocks which are subsequently altered to clay } \\
\text { by reaction with alkaline, marine-, or hydrothermal waters. }\end{array}$ \\
\hline Tectonic setting(s) & Stable marine or fluvial-lacustrine basins. Hydrothermal bentonites form near conduits for thermal fluids. \\
\hline Associated deposit types & Diatomite, other clay minerals, limestone, dolomite, zeolites. \\
\hline \multicolumn{2}{|r|}{ Deposit description } \\
\hline Ore mineralogy & Na- and Ca-bentonite, montmorillonite, and other smectite clays. \\
\hline Alteration & $\begin{array}{l}\text { Leaching of } \mathrm{Mg} \text { and } \mathrm{Fe} \text { from bentonite may lead to formation of kaolinite, burial and diagenesis may convert smectite } \\
\text { minerals to illite or chlorite. Abundance decreases with depth of burial; smectites become rare when buried }>4 \mathrm{~km} \text {. }\end{array}$ \\
\hline Ore controls & $\begin{array}{l}\text { For sedimentary bentonites: proximity of volcanism to alkaline marine basin; for hydrothermal bentonites: faults and } \\
\text { fractures for fluid migration and reactive host rocks. }\end{array}$ \\
\hline Geochemical signatures & $\begin{array}{l}\text { Formed from alteration of volcanic ash and tuffs; often found containing feldspar, biotite, quartz, pyroxene, and zircon that } \\
\text { were phenocryts in the original volcanic material. Na bentonite contains exchangeable Na ions and may increase } 15-20 \\
\text { times in volume when wetted with water. Ca bentonite contains exchangeable Ca ions and may increase as much as five } \\
\text { times in volume in the presence of water. }\end{array}$ \\
\hline Geophysical signature & Seismic surveys may delineate extent and thickness of bentonite beds and basin depth. \\
\hline
\end{tabular}

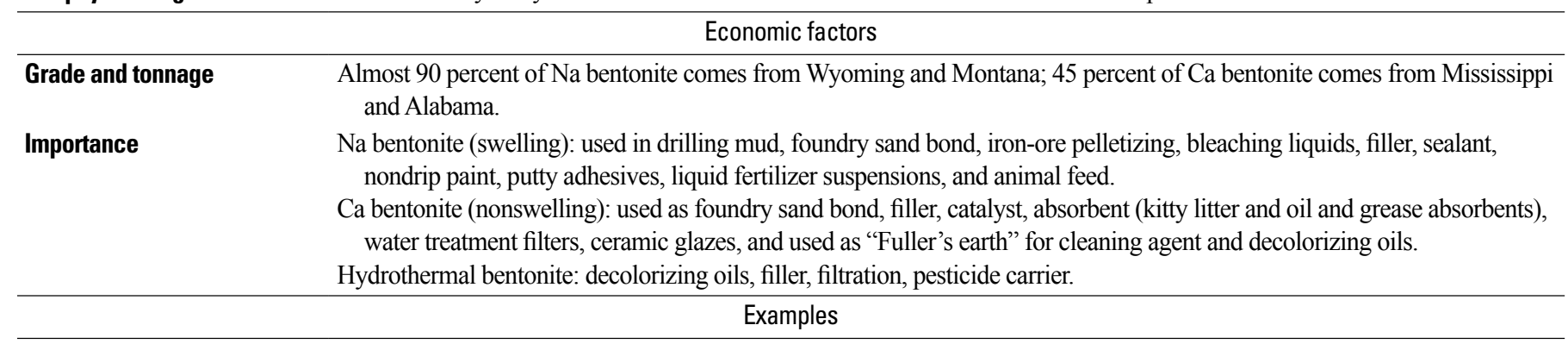

In/near focal areas

Ivanhoe Creek, Ca bentonite, Elko County, Nevada.

Glasgow and Malta areas, Na bentonite, Montana.

Ben-Jel bentonite mine, $22 \mathrm{~km}$ west of Grand View, Owyhee County, Idaho, $4.6 \mathrm{~m}$ thick bentonite bed overlying siliceous volcanic tuff.

Liddy Hot Springs bentonite occurrence, 3-m clay beds. 
Clay Spur Na Bentonite Bed, Cretaceous Mowry Shale near Black Hills in Wyoming and South Dakota. Sandy Ridge, a Ca bentonite at the base of the Late Cretaceous Ripley Formation, southeastern Lowndes County, Alabama.

References

Dean, L.S., 2008, Minerals in the economy of Alabama, 2007, Geological Survey of Alabama, Information Series 64R, 36 p.

Geitgey, Ronald P., 1989, Industrial Minerals in Oregon: Oregon Geology, v. 51, p. 123-129.

Hosterman, J.W., 1984, Ball clay and bentonite deposits of the central and western Gulf of Mexico coastal plain, United States: U.S. Geological Survey Bulletin 1558-C, $28 \mathrm{p}$.

Hosterman, J.W., and Orris, G.J., 1998, Preliminary descriptive model of sedimentary bentonite—Deposit subtype — Sodium bentonite, model 28e.2, in Orris, G.J., ed., Additional descriptive models of industrial mineral deposits: U.S. Geological Survey Open-File Report 98-505, p. 24-26.

Hosterman, J.W., and Orris, G.J., 1998, Preliminary descriptive model of sedimentary bentonite—Deposit subtype — Calcium bentonite, model 28e.1, in Orris, G.J., ed., Additional descriptive models of industrial mineral deposits: U.S. Geological Survey Open-File Report 98-505, p. $27-29$.

Hosterman, J.W., and Orris, G.H., 1995, Preliminary descriptive model of hydrothermal bentonite, model 251.1, in Orris, G.J., ed., Additional descriptive models of industrial mineral deposits: U.S. Geological Survey Open-File Report 98-505, p. 18-20.

Hosterman, J J.W., 1973, Clays, in Brobst, D.A., and Pratt, W.P., eds., United States Mineral Resources: U.S. Geological Survey Professional Paper 820, p. $123-131$.

Hosterman, J.W., and Peterson, Sam H., 1992, Bentonite and Fuller's earth resources of the United States: U.S. Geological Survey Professional Paper 1522, $50 \mathrm{p}$.

Rogers, M.C., 2011, Model B-9, bentonite, in Saskatchewan descriptive mineral deposit models: Saskatchewan Ministry of Energy and Resources, Open File Report 2014-2, p. B-9-1 to B-9-2. accessed July 15, 2016, at http://www.publications.gov.sk.ca/details.cfm?p=79909. 


\section{Dolomite (high-purity)}

[km, kilometer; $\mathrm{t}$, metric ton; wt.\%, weight percent]

\begin{tabular}{ll}
\hline $\begin{array}{l}\text { Synonyms } \\
\text { Commodities }\end{array}$ & $\begin{array}{l}\text { Dolostone, dolomitite, dolospar. } \\
\text { Dolomite (aggregate, filler). Sometimes dolomite may be a byproduct of quarrying limestone. }\end{array}$ \\
Description & A bedded or massive carbonate sedimentary rock that occurs as tabular bodies concordant with stratigraphy and beds \\
as much as tens of meters thick and zones controlled by faults and permeable zones. Dolomite contains more than \\
90 percent of the mineral dolomite and is usually a finely crystalline and slightly porous rock. Calcite is the most \\
common other mineral.
\end{tabular}

\begin{tabular}{lc}
\hline \multicolumn{1}{c}{ Geological environment } \\
\hline Rock types & Dolomites are often found within thicker sedimentary sequences with associated limestones, dolomitic limestones, \\
& argillites, sandstones, and evaporates. In island arcs, dolomites often have a volcanic component, such as tuffaceous \\
rocks, sills, submarine lavas, palagonite breccias, and sometimes cherty layers and interbeds. \\
Dolomite can be any age, but the ages of dolomitization for secondary deposits often are not well defined. Large- \\
scale regional dolomitization in western Canada has been linked to fluid circulation taking place during Devonian- \\
Mississippian and Late Cretaceous-Tertiary periods. Generally these deposits are believed to be concurrent with \\
large-scale tectonic activity. \\
Dolomite is most common as a secondary replacement of marine sedimentary rocks that were a slightly magnesian \\
calcium carbonate that was frequently aragonite originally and later recrystallized into calcite. Circulating ground \\
water (sea water, hypersaline brine, pore water) containing magnesium reacted with the calcium carbonate to \\
produce dolomitic limestones and dolomites. Dolomite may also form as a primary sediment, but this is not very \\
common.
\end{tabular}

Tectonic setting(s)

Dolomite is more common in Holocene and ancient continental shelf and subsiding marginal marine environments; however, economically attractive deposits also occur in island arc environments.

Associated deposit types

Mississippi Valley Type $\mathrm{Pb}, \mathrm{Zn}$, barite, fluorspar deposits, limestone, accumulations of oil and natural gas, and hydrogen sulfide.

\section{Deposit description}

Ore mineralogy
Alteration

Dolomite (may occur with quartz, brucite, calcite, chert, kaolinite, illite, sometimes bitumen).

Dolomite is typically an alteration product. It may be accompanied by a variety of sulfides (pyrite, sphalerite, galena), $\mathrm{Fe}-\mathrm{Mn}-\mathrm{Mg}$-Ca carbonates, chlorite, barite, gypsum or anhydrite, and fluorspar. High-temperature/low-pressure metamorphism may result in converting dolomite into a mixture of periclase $(\mathrm{MgO})$ and calcite. Periclase in nature easily alters into brucite $\mathrm{Mg}(\mathrm{OH})_{2}$.

Ore controls

Ore control reflects the mode and intensity of dolomitization. In some deposits a primary control is the chemical composition of the carbonate rock; in some others it is the upper and lower limits of the original limestone bed. For some deposits, the locations where fluid pathways along faults and permeable zones intersect reactive carbonate rocks are the control on the location of the replacement zones.

Geochemical signatures

Geophysical signature
High magnesium in carbonate rock.

Although karst features in dolomite are rather uncommon, resistivity and gravity could be used to outline karstaffected areas.

\section{Economic factors}

Grade and tonnage
Commercial dolomite must be very high-purity carbonate rock and almost stoichiometric in composition (30.4 wt.\% $\mathrm{CaO}$ and 21.9 wt.\% $\mathrm{MgO}$ ). Industry specifications are set for the calcined product - that is, a dolomitic lime. Depending on the end use, the limits for impurities are usually between 0.1 and 4.5 wt. $\% \mathrm{Fe}_{2} \mathrm{O}_{3}, \mathrm{SiO}_{2}$ between 0.5 and $1.0 \mathrm{wt} . \%$, and $\mathrm{Al}_{2} \mathrm{O}_{3}$ between 0.3 and $0.8 \mathrm{wt} . \%$. 
Importance

Very important as a source of magnesium to improve fluidity of molten product, such as in the production of mineral wool, float glass, and slag in metallurgical process. As agriculture soil conditioner; the magnesium content improves the neutralizing power and helps to retain the soil nutrients better than pure limestone. In many other end uses dolomite can be substituted by some other industrial minerals.

Other assessment and exploration guides

Sometimes yellow or brown color of outcrops; sandy talus.

Because of lower solubility of dolomite relative to calcite, dolomite does not fizz with diluted hydrochloric acid.

Ore control reflects the mode and intensity of dolomitization. In some deposits a primary control is the chemical composition of the carbonate rock, in some others it is the upper and lower limits of the original limestone bed. For some deposits, the locations where fluid pathways along faults and permeable zones intersect reactive carbonate rocks are the control on the location of the replacement zones.

Mining of high purity dolomite requires more exploration and quality control, and is more costly than mining dolomite for aggregate use.

\begin{tabular}{l}
\hline \multicolumn{1}{c}{ Examples } \\
$\begin{array}{l}\text { In/near focal areas } \\
\text { Elsewhere }\end{array}$ \\
\hline \multicolumn{1}{c}{ Mill Creek, Oklahoma; northeastern Illinois. } \\
\hline References \\
geology: London, Geological Society of London, p. 167-168. \\
Hora, Z.D., 1999, Dolomite (R10), in Simandl, G.J., Hora, Z.D., and Lefebure, D.V., eds., Selected British Columbia mineral deposit profiles, volume \\
3-Industrial Minerals: British Columbia Ministry of Energy and Mines, Open File 1999-10, accessed March 15, 2016, at http://www.empr.gov. \\
bc.ca/Mining/Geoscience/MineralDepositProfiles/Pages/default.aspx. \\
\hline
\end{tabular}




\section{Sediment-Hosted Stratabound Copper}

[Mt, million metric tons; wt.\%, weight percent; g/t, grams per metric ton; Ma, mega-annum or millions of years ago]

\begin{tabular}{ll}
\hline Synonyms & $\begin{array}{c}\text { Sediment-hosted stratiform } \mathrm{Cu}, \mathrm{Cu} \text { sandstone, sandstone } \mathrm{Cu} \text {; sandstone } \mathrm{Cu} \text { deposits are one of three subtypes: (1) reduced } \\
\text { facies-type, (2) sandstone } \mathrm{Cu} \text {-type, and (3) red bed-type. } \\
\text { Commodities }\end{array}$ \\
$\begin{array}{l}\mathrm{Cu}, \mathrm{Ag}, \text { or } \mathrm{Co} . \\
\text { Bescription }\end{array}$ \\
$\begin{array}{c}\text { Bodies of disseminated, cementing, and veinlet-hosted copper }(\mathrm{Cu}) \text { minerals that are peneconformable with their } \\
\text { sedimentary or metasedimentary host rocks. Deposits are characterized by strong zoning of the ore minerals laterally } \\
\text { along and across the bedding, from pyrite, to chalcopyrite, to bornite, to chalcocite, and to hematite. }\end{array}$
\end{tabular}

Geological environment

Rock types

Age range

Depositional environment

Tectonic setting(s)

Associated deposit types

Ore mineralogy

Ore controls

Geochemical signatures

Geophysical signature
Typically well-sorted feldspathic to arkosic sandstones. Where conglomeratic, they typically have only mud intraclasts and are not polymictic. These rocks were probably reservoir rocks for petroleum before copper minerals were deposited; petroleum was probably sour gas, for most cases.

Limited to sedimentary or metasedimentary formations younger than 2,300 Ma, when free oxygen first appeared in Earth's atmosphere and the earliest red beds formed.

Sandstone-type host rocks were deposited in subtidal nearshore, beach, eolian, and fluvial environments. Various depositional environments that are among deltaic topset beds. Host rocks at Spar Lake are the lower quartzite beds of the upper member of the Revett Formation of the Belt Supergroup, which were deposited in a prograding beach and bar nearshore environment, and middle quartzite host rocks were deposited by laterally shifting subtidal channels.

SSC deposits formed in sedimentary basins that now vary from virtually undeformed to intensely folded, thrust-faulted, and the host rocks metamorphosed. Host sedimentary-rock sequences were deposited within 20 to 30 degrees of the paleo-equator, associated with hot, dry climates that produced thick packages of red beds and commonly also produced evaporites.

Volcanic red bed $\mathrm{Cu}$, tabular sandstone-hosted $\mathrm{U}-\mathrm{V}$.
Alteration

Chalcocite and bornite zones are typically the ore zones. Mineral zonation both laterally and vertically from pyrite to chalcopyrite to bornite to chalcocite to hematite is characteristic. Less common ore minerals include digenite, djurleite, covellite, sulfur-rich bornite \pm carrollite, Co-rich pyrite, and native silver. Chalcocite, bornite, and digenite are commonly argentiferous.

Alteration gangue minerals are zonally arranged, with their zone boundaries parallel to the zonation of sulfide minerals. Authigenic hematite lining and filling pores is present in chalcocite zones of most deposits. Authigenic K-feldspar may occur as overgrowths on detrital K-feldspar grains and as cements and replacements. Authigenic chlorite. Fe- and Mn-rich calcite cement. Na-rich alteration accompanies mobilization and transport (sodium sulfate minerals, albite, or analcime, and at higher metamorphic grade, sodic amphibole riebeckite).

Traps to create gas reservoirs include anticlines, fault traps, and combination traps produced by pre-ore folding and faulting. Faults at high angles to host beds are common, and some fed cupriferous oxidizing ore fluids to the gas reservoirs.

$\mathrm{Cu}, \mathrm{Ag}$, and $\mathrm{Co} . \mathrm{Ag}$ is useful in the sandstone $\mathrm{Cu}$ mineralizing system of the Revett Formation, because anomalies with $\mathrm{Cu}$ and $\mathrm{Ag}$ are distinct from anomalies associated with other types of deposits. Other potential pathfinder elements include $\mathrm{Pb}, \mathrm{Zn}, \mathrm{As}, \mathrm{Hg}, \mathrm{Mn}$, and $\mathrm{Ba}$.

Gravity, magnetic, and electromagnetic surveys to map basement topography, bedrock geology, and basin and subbasin margins. Seismic reflection or refraction surveys can identify basin and subbasin margins, anticlines, stratigraphic traps, and combination. Radiometrics can be used to image lithology and alteration. Induced polarization (IP) may be effective in direct sensing of deposits. Remote sensing of colors using Landsat imagery or remote sensing of ferric oxides using Landsat imagery can be used to map pre-ore bleaching of red beds.

\section{Economic factors}

Grade and tonnage
Tonnages range from about 2 to $90 \mathrm{Mt}$, although the largest is $1,311 \mathrm{Mt}$; median size $10 \mathrm{Mt}$; Grades range from about 0.5 to $2.6 \mathrm{wt} . \% \mathrm{Cu}$, median $1.2 \mathrm{wt} . \% \mathrm{Cu}$; Ag grades 5 to $100 \mathrm{~g} / \mathrm{t}$. 
Importance

Sediment-hosted stratabound copper deposits account for approximately 20 percent of the world's past production and known resources of copper. Although such deposits are common throughout the world, economically significant deposits are rare.

Other assessment and exploration guides

Evidence of essential ore system components:

Source rocks for copper, typically oxidized (hematite-stable) siliciclastic sediment or mafic subaerial volcanic rocks.

Hematite-stable (oxidized) subsurface sedimentary brines capable of dissolving and transporting copper in solution.

Brines moving generally in the direction of dewatering of a sedimentary basin. Evidence of brine can include bedded evaporite or casts, molds of halite, gypsum, and other evaporite minerals nearby.

Rock seals confining beds, stratigraphic pinchouts, and (or) anticlinal traps (focus fluid flow of the copper-bearing brines to rocks that contain organic material that will cause sulfide mineral precipitation).

Organic-rich sedimentary rocks that serve as source rocks for natural gas, oil, and $\mathrm{H}_{2} \mathrm{~S}$, that cause the precipitation of copper from an oxidized subsurface sedimentary brine.

In terrains that have known sandstone $\mathrm{Cu}$ deposits, anticlines, areas with known stratigraphic traps, and those with known combination traps are more favorable than other parts of broadly permissive areas.

Areas of natural-gas production within basins that have known sandstone $\mathrm{Cu}$ deposits.

Host rocks overlie or are enclosed within thick (greater than 300 meters and commonly greater than 1 kilometer) sequences of red beds. The association with red beds is an important distinction from other $\mathrm{Cu}$ deposits found in sedimentary rocks.

\begin{tabular}{ll}
\hline & \multicolumn{1}{c}{ Examples } \\
\hline In/near focal areas & Griggs mine, Wyoming. \\
Elsewhere & Spar Lake, Belt-Purcell Basin, Montana; Udokan, Transbaikalian Russia; Chu Sarysu Basin, Kazakhstan; Chuxiong Basin, \\
& China.
\end{tabular}

\section{References}

Hayes, T.S., Cox, D.P., Piatak, N.M., and Seal, R.R., II, 2015, Sediment-hosted stratabound copper deposit model: U.S. Geological Survey Scientific Investigations Report 2010-5070-M, 147 p., accessed March 15, 2016, at http://dx.doi.org/10.3133/sir20105070M.

Zientek, M.L., Wintzer, N.E., Hayes, T.S., Parks, H.L., Briggs, D.A., Causey, J.D., Hatch, S.A., Jenkins, M.C., and Williams, D.J., 2015, Qualitative assessment of selected areas of the world for undiscovered sediment-hosted stratabound copper deposits: U.S. Geological Survey Scientific Investigations Report 2010-5090-Y, 143 p., and spatial data, accessed March 15, 2016, at http://dx.doi.org/10.3133/sir20105090Y. 


\section{Sandstone Uranium (Roll Front) in Intermontane Basins}

[wt.\%, weight percent; km, kilometer; $\mathrm{t}$, metric ton; g/t, grams per metric ton]

\begin{tabular}{ll}
\hline Synonyms & Roll front U. \\
Commodities & $\mathrm{U}$. \\
Description & $\begin{array}{l}\text { Microcrystalline uranium oxides and silicates deposited from groundwater in localized reduced environments within fine- to } \\
\text { medium-grained sandstone beds; some uranium oxides also deposited during redistribution by ground water at interface } \\
\text { between oxidized and reduced ground. }\end{array}$ \\
\hline
\end{tabular}

\begin{tabular}{|c|c|}
\hline \multicolumn{2}{|r|}{ Geological environment } \\
\hline Rock types & $\begin{array}{l}\text { Host rocks are feldspathic or tuffaceous sandstone. Pyroclastic material is felsic in composition. Mudstone or shale } \\
\text { commonly above and (or) below sandstones hosting diagenetic ores that have channeled and focused uraniferous } \\
\text { groundwater. }\end{array}$ \\
\hline Age range & $\begin{array}{l}\text { Jurassic to Oligocene sandstones in the Wyoming basin province, with most mineralization in the Paleocene Fort Union, } \\
\text { Oligocene Wasatch, Wind River, and Battle Spring Formations. }\end{array}$ \\
\hline Depositional environment & $\begin{array}{l}\text { Intracratonic basins, fluvial channels, braided stream deposits. Contemporaneous felsic volcanism or eroding felsic plutons } \\
\text { are sources of U. }\end{array}$ \\
\hline Tectonic setting(s) & Stable platform or foreland-interior basin; adjacent major uplifts provide favorable topographic conditions. \\
\hline Associated deposit types & Tabular remnant or "lag" deposits. \\
\hline \multicolumn{2}{|r|}{ Deposit description } \\
\hline Ore mineralogy & $\begin{array}{l}\text { At the roll-front, uraninite, coffinite, uranyl sulfate, uranium vanadates, arsenic with pyrite, ferroselite, marcasite, and } \\
\text { molybdenite }\end{array}$ \\
\hline Alteration & $\begin{array}{l}\text { The alteration zone on the oxidized side of the roll front is characterized by bleached sand containing limonite, hematite, } \\
\text { magnetite, and nontronite. Adjacent-to-ore siderite, ferroselite, and goethite with vanadium and arsenic enrichment. At } \\
\text { the roll-front interface, carbonate-cemented sand with iron oxides, siderite, ferroselite, and goethite. }\end{array}$ \\
\hline Ore controls & $\begin{array}{l}\text { Permeable sandstone sequences with low dips and adequate recharge to facilitate the movement of uranium rich groundwater } \\
\text { into the sequence; felsic plutons or felsic tuffaceous sediments adjacent to or above host rock are favorable source for U. } \\
\text { Groundwater flow as controlled by paleohighs (Casper arch southwest of Powder River Basin and the Granite Mountains } \\
\text { adjacent to the Shirley, Wind River, and Great Divide Basins in Wyoming) Regional redox interface marks locus of ore } \\
\text { deposition and has been attributed to amorphous organic material, petroleum, and natural gas within host sediments. } \\
\text { Coalified logs and other vegetal remains behind the oxidized roll fronts yield remnant or lag deposits of uranium. }\end{array}$ \\
\hline Geochemical signatures & $\begin{array}{l}\mathrm{U}, \mathrm{V}, \mathrm{Mo}, \mathrm{Se}, \text { locally } \mathrm{Cu} \text {, and } \mathrm{Ag} \text {. Anomalous radioactivity from daughter products of U. Typical zoning across a roll front is } \\
\mathrm{Se} / \mathrm{V}-\mathrm{U}-\mathrm{Mo} / \mathrm{As} \text {. }\end{array}$ \\
\hline Geophysical signature & $\begin{array}{l}\text { Magnetics: Regional geology/structure. Gravity: Regional geology/structure. Radiometrics: Lithology that may focus } \\
\text { grounwater flow (stream channels) }\end{array}$ \\
\hline \multicolumn{2}{|r|}{ Economic factors } \\
\hline Grade and tonnage & $\begin{array}{l}\text { Sandstone-hosted deposits of all types in the United States range in size from } 1 \text { to } 40 \text { million pounds of } \mathrm{U}_{3} \mathrm{O}_{8} \text { and grade from } \\
0.07 \text { to } 0.9 \mathrm{wt} . \% \mathrm{U}_{3} \mathrm{O}_{8} \text {. Roll-front deposits fall on the small size of this range and are characterized by their poddy nature } \\
\text { along extensive roll-front systems. Within the Great Divide Basin, Sheep Mountain contains } 16 \text { million pounds of } \mathrm{U}_{3} \mathrm{O}_{8} \\
\text { (average grade } 0.131 \mathrm{wt} . \% \mathrm{U}_{3} \mathrm{O}_{8} \text { ). }\end{array}$ \\
\hline Importance & $\begin{array}{l}\text { The majority of the } \sim 4-5 \text { million pounds of uranium currently being produced in the Untied States is from roll-front deposits in } \\
\text { Wyoming. The Sheep Mountain deposit has produced uranium and is under development by Energy Fuels Resources, Inc. }\end{array}$ \\
\hline \multicolumn{2}{|r|}{ Other assessment and exploration guides } \\
\hline \multicolumn{2}{|c|}{$\begin{array}{l}\text { Anomalous radon and helium over mineralization. } \\
\text { Areas where oxygenated waters migrating through an aquifer with traces of dissolved uranium encounter a reducing zone and precipitate uranium along with } \\
\text { other metals }\end{array}$} \\
\hline \multicolumn{2}{|r|}{ Examples } \\
\hline In/near focal areas & Great Divide Basin, Wyoming. \\
\hline Elsewhere & Gas Hills, Wyoming. \\
\hline
\end{tabular}

References

Boberg, W.W., 2010, The nature and development of the Wyoming uranium province: Society of Economic Geologists Special Publication 15, p. 653-674.

Mickle, D.G., and Mathews, G.W., 1978, Geologic characteristics of environments favorable for uranium deposits: U.S. Department of Energy Publication GJBS-67 (78), $250 \mathrm{p}$.

Turner-Peterson, C.E., and Hodges, C.A., 1986, Descriptive model of sandstone U, in Cox, D.P., and Singer, D.A., eds., Mineral deposit models: U.S. Geological Survey Bulletin 1693, p. 209-210. [Also available at http://pubs.usgs.gov/bul/b1693/.] 


\section{Hydroallogenic Volcanic-Hosted Uranium}

[wt.\%, weight percent; ft., feet; mi $^{2}$, square mile; lb, pound; NURE, National Uranium Resource Evaluation]

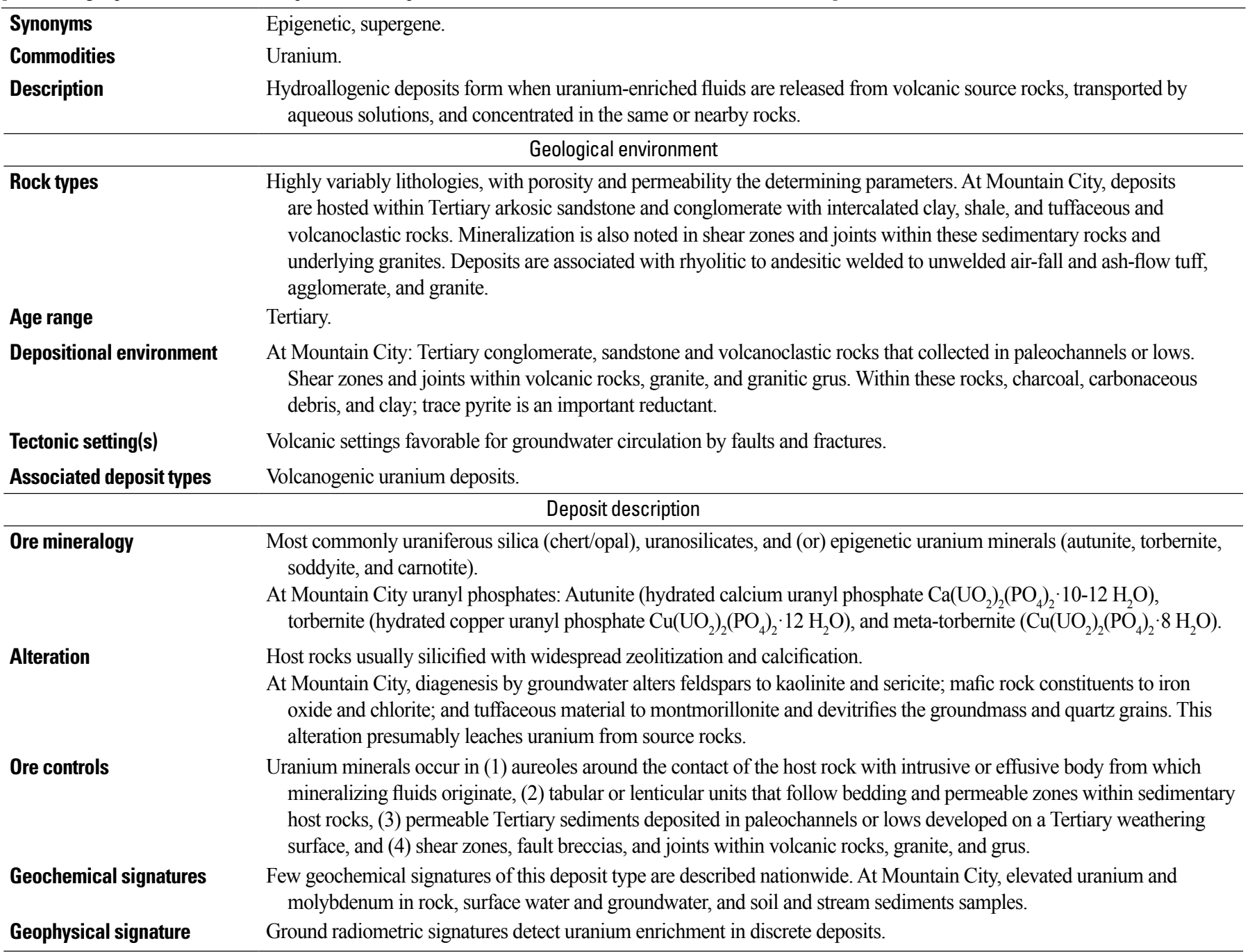

\begin{tabular}{|c|c|}
\hline & Economic factors \\
\hline Grade and tonnage & 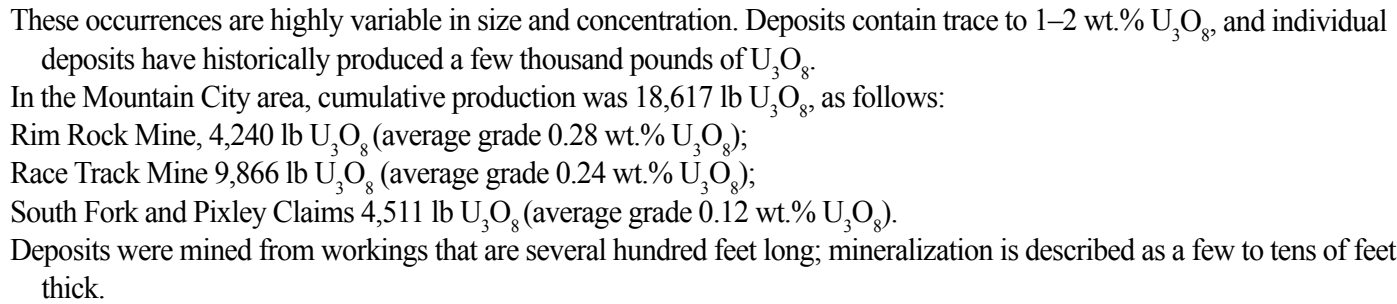 \\
\hline
\end{tabular}


Past production, relatively high uranium grades and widespread distribution of these deposits is noteworthy. For the hydroallogenic class of deposits, nationwide in all resource categories (probable, possible and speculative) NURE estimated 157 million pounds $\mathrm{U}_{3} \mathrm{O}_{8}$ in the $\$ 30 / 1 b \mathrm{U}_{3} \mathrm{O}_{8}$ cost category and 716 million $\mathrm{lb} \mathrm{U}_{3} \mathrm{O}_{8}$ in the $\$ 100 / \mathrm{lb}$ cost category (1980s prices). Most of this potential resource was identified in the Basin and Range resource region where, NURE estimated 148 million $\mathrm{lb}_{3} \mathrm{O}_{8}$ in the $\$ 30 / 1 b \mathrm{U}_{3} \mathrm{O}_{8}$ cost category and 653 million pounds $\mathrm{U}_{3} \mathrm{O}_{8}$ in the $\$ 100 / \mathrm{lb}$ cost category. Note that the higher cost category is cumulative.

Other assessment and exploration guides

Potential sources for leachable uranium including tuffaceous material and possibly granitic rocks.

Permeable sediments deposited on a paleo-topographic surface that allows transport of uranium-rich groundwater into host rocks.

Reductants within host rocks including charcoal, carbonaceous debris, clay, and pyrite.

Examples

In/near focal areas Nine deposits identified in the Mountain City region, Wells quadrangle, Nevada and Idaho.

Elsewhere Truckee Formation (Tertiary) in Nevada.

References

Mickle, D.G., and Matthews, G.W., eds., 1978, Geologic characteristics of environments favorable for uranium deposits: U.S. Department of Energy Report GJBX-67 (78), 250 p.

Proffitt, J.L., Mayerson, D.L., Parker, D.P., Wolverson, N., Antrim, D., Berg, J., and Witzel, F., 1982, National uranium resource evaluation, Wells quadrangle, Nevada, Idaho and Utah: U.S. Department of Energy publication PGJ/F-070 (82), 246 p. 


\section{Zeolites (Closed-Basin Subtype)}

[cm, centimeter; m, meter; wt.\%, percent]

\begin{tabular}{|c|c|}
\hline Synonyms & Closed-system zeolites. \\
\hline Commodities & $\begin{array}{l}\text { Analcime, chabazite, clinoptilolite, erionite, mordenite, phillipsite. } \\
\text { Byproducts: bentonite, fluorite, pumicite, potassium feldspar. }\end{array}$ \\
\hline Description & $\begin{array}{l}\text { Microcrystalline zeolite-bearing vitric tuff that consists chiefly of analcime, chabazite, clinoptilolite, mordenite, } \\
\text { phillipsite, and sometimes erionite. Deposit may consist of one or several stacked zeolite layers separated by } \\
\text { subeconomic or barren beds. }\end{array}$ \\
\hline \multicolumn{2}{|r|}{ Geological environment } \\
\hline Rock types & $\begin{array}{l}\text { Rhyolitic to dacitic, vitric tuff. Associated to rocks include bedded evaporites (trona, halite, borates), mudstone, diatomite, } \\
\text { oil shale. }\end{array}$ \\
\hline Age range & Late Paleozoic to Holocene, but most deposits are Cenozoic. \\
\hline Depositional environment & $\begin{array}{l}\text { Lacustrine basins that received silicic, vitric material either directly by airfall or by reworking. The saline lake water } \\
\text { commonly was of the sodium carbonate-bicarbonate variety and had a } \mathrm{pH} \text { of } 9 \text { or greater. These lakes are common in } \\
\text { arid and semi-arid regions where annual evaporation exceeds rainfall. }\end{array}$ \\
\hline Tectonic setting(s) & $\begin{array}{l}\text { Closed hydrographic basins in either block-faulted terrains (such as the Basin and Range Province) or trough valleys } \\
\text { associated with rifting. Lakes are commonly in block-faulted terranes or rift valleys. }\end{array}$ \\
\hline Associated deposit types & Continental-basin bedded evaporites; finely crystalline, disseminated fluorite in lacustrine rocks. \\
\hline \multicolumn{2}{|r|}{ Deposit description } \\
\hline Ore mineralogy & Analcime, chabazite, clinoptilolite, erionite, mordenite, phillipsite. \\
\hline Alteration & $\begin{array}{l}\text { In certain highly alkaline and saline lacustrine deposits, siliceous and alkali zeolites have been replaced during late } \\
\text { diagenesis by analcime or potassium feldspar in the central part of the basin. }\end{array}$ \\
\hline Ore controls & $\begin{array}{l}\text { Grain size and permeability of the host silicic, alkali-rich, vitric tuff. Salinity, } \mathrm{pH} \text {, and ratios of alkali and alkaline-earth ions } \\
\text { in the pore water are important. }\end{array}$ \\
\hline Geochemical signatures & $\begin{array}{l}\mathrm{B}, \mathrm{Li} \text { in lacustrine environment of sodium carbonate-bicarbonate type. } \\
\text { In most cases, zeolites can be detected and positively identified only by direct analytical techniques, such as x-ray } \\
\text { diffraction. Lithogeochemistry may be a useful tool. }\end{array}$ \\
\hline Geophysical signature & $\begin{array}{l}\text { Possible use of color-composite imagery from airborne multispectral scanner data to distinguish zeolitic tuffs. } \\
\text { Magnetics: Regional geology/structure. Gravity: Regional geology/structure. Radiometrics: Lithology. }\end{array}$ \\
\hline
\end{tabular}

Regional depositional environment of silicic, vitric tuffs in an alkaline, saline-lake deposit.

Alteration of tuff to zeolite require high alkalinity and lake brines rich the $\mathrm{HCO}_{3}$ ion.

Host rock of vitric tuff of rhyolitic or dacitic composition; lateral zonation of zeolites and associated silicate minerals.

Ashfalls of glassy tuffs into alkaline-saline playas or rift lakes are ideal settings for high-grade deposits.

Unmetamorphosed or very low metamorphic-grade environments.

Molds of saline minerals, chemical delta of calcite or aragonite, associated dolomitic mudstone, occurrence of bedded or nodular chert.

Zeolites are finely crystalline and resemble bedded diatomite, feldspar, or bentonite in outcrop. Combination of x-ray diffraction and ammonia cation exchange capacity (CEC) are essential in the early screening of zeolite prospects.

Concentric zonation and lateral gradation in a basinward direction of unaltered volcanic glass to alkali-rich, silicic zeolites to analcime and then to potassium feldspar in the central part of the depositional basin.

\begin{tabular}{lc} 
Economic factors \\
\hline Grade and tonnage & $\begin{array}{c}\text { Thickness of the zeolitic tuffs commonly ranges from } 10 \mathrm{~cm} \text { to } 10 \mathrm{~m} \text {. Areal extent is commonly tens to hundreds of square } \\
\text { kilometers. The cutoff grade varies greatly. For example, a } 10 \text { to } 20 \mathrm{~cm} \text { thick ore bed at Bowie contains } 60 \text { to } 80 \mathrm{wt} \% \\
\text { chabazite. Obviously, this zone would not have been economic if the main ore mineral was clinoptilolite. Most of the } \\
\text { commercial clinoptilolite deposits contain between } 50 \mathrm{wt} \% \text { and } 90 \mathrm{wt} \% \text { zeolite. } \\
\text { This deposit type contains the largest variety of zeolite species, accounts for most of the present zeolite production in the } \\
\text { United States, and is an important source for chabazite, erionite, and phillipsite in the United States. }\end{array}$ \\
Importance & Examples
\end{tabular}

In /near focal areas $\quad$ McDermitt caldera, Nevada; Bear River zeolite deposit, southeast Idaho. 


\begin{tabular}{l}
\hline References \\
\hline Eyde, T.H., and Holmes, D.A., 2006, Zeolites, in Kogel, J.E., Trivedi, N.C., Barker, J.M., and Krukowski, S.T., eds., Industrial minerals and rocks: \\
Littleton, Colo., Society for Mining, Metallurgy, and Exploration, Inc., p. 139-165. \\
Sheppard, R.A., 1991, Descriptive model of sedimentary zeolites, deposit subtype-Zeolites in tuffs of saline, alkaline-lake deposits in Orris, G.J., and \\
Bliss, J.D., eds., Some industrial mineral deposit models—-Descriptive models: U.S. Geological Survey Open-File Report 91-11-A, p. 19-21, accessed \\
February 1, 2016, at http://pubs.usgs.gov/of/1991/ofr-91-0011-a/ofr-91-0011a.pdf. \\
Sheppard, R.A., and Simandl, G.J., 1999, Closed-basin zeolites, in Simandl, G.J., Hora, Z. D., and Lefebure, D.V., eds., Selected British Columbia mineral \\
deposit profiles, volume 3-Industrial Minerals: British Columbia Ministry of Energy and Mines, Open File 1999-10, accessed February 1, 2016, at \\
http://www.unalmed.edu.co/ rrodriguez/MODELOS/columbia/Closed\%20Basin\%20Zeolites.htm. \\
\hline
\end{tabular}




\section{Zeolites (Open-Basin Subtype)}

[cm, centimeter; m, meter; wt. \%, percent]

\begin{tabular}{|c|c|}
\hline Synonyms & Open-system zeolites. \\
\hline Commodities & Chabazite, clinoptilolite, mordenite, phillipsite (bentonite, pumicite). \\
\hline Description & $\begin{array}{l}\text { Microcrystalline zeolites crystallized in relatively thick, generally nonmarine tephra sequences that commonly show a } \\
\text { more or less vertical zonation of zeolites and associated silicate minerals and that reflects the chemical modification of } \\
\text { meteoric water as it flowed through the vitric sequence. The zeolites crystallized in the postdepositional environment } \\
\text { over periods ranging from thousands to millions of years. }\end{array}$ \\
\hline \multicolumn{2}{|r|}{ Geological environment } \\
\hline Rock types & $\begin{array}{l}\text { Tuffs having a broad compositional range, including rhyolite to dacite, trachyte or phonolite, and basalt to basanite. The } \\
\text { silicic tuffs commonly were deposited as nonwelded ash flows. Associated with rhyolite to basalt flows; fluviatile } \\
\text { mudstone, sandstone, and conglomerate; diatomite. }\end{array}$ \\
\hline Age range & Mesozoic to Holocene, but most are Cenozoic. \\
\hline Depositional environment & Most deposits are nonmarine (fluviatile and lacustrine), but some are shallow marine. \\
\hline Tectonic setting(s) & $\begin{array}{l}\text { Variety of nonmarine and shallow marine basins in volcanic terrains. Some thick tuffaceous deposits were air-laid onto the } \\
\text { land surface and not into water. }\end{array}$ \\
\hline Associated deposit types & $\begin{array}{l}\text { The zonation of the open-system type of zeolite deposit is similar to the upper zones of burial diagenesis (burial } \\
\text { metamorphism) that affected thick sequences of silicic, vitric tuffs. Associated deposits include pumicite and bentonite. }\end{array}$ \\
\hline \multicolumn{2}{|r|}{ Deposit description } \\
\hline Ore mineralogy & Chabazite, clinoptilolite, mordenite, phillipsite. \\
\hline Alteration & $\begin{array}{l}\text { In silicic tuff sequences, the alkali-rich siliceous zeolites (clinoptilolite and mordenite) in the upper part of the deposit are } \\
\text { replaced at depth by analcime, potassium feldspar, and (or) albite. }\end{array}$ \\
\hline Ore controls & $\begin{array}{l}\text { Grain size and permeability of host tuff; flow of meteoric water downward in an open hydrologic system; hydrolysis } \\
\text { and solution of vitric material by the subsurface water in the upper part of the system raised the } \mathrm{pH} \text {, activity of } \mathrm{SiO}_{2} \text {, } \\
\text { and content of dissolved solids to values where zeolites crystallized; resulted in a vertical or near-vertical zonation } \\
\text { of zeolites and other authigenic minerals; composition of the vitric material may have dictated which zeolite species } \\
\text { precipitated; clinoptilolite and mordenite are common in silicic tuffs, but chabazite and phillipsite are common in mafic } \\
\text { or trachytic tuffs. }\end{array}$ \\
\hline Geochemical signatures & $\begin{array}{l}\text { None recognized. In most cases, zeolites can be detected and positively identified only by direct analytical techniques, } \\
\text { such as X-ray diffraction. Lithogeochemistry may be a useful tool. }\end{array}$ \\
\hline Geophysical signature & Possible use of color-composite imagery from airborne multispectral scanner data to distinguish zeolitic alteration. \\
\hline
\end{tabular}

Regional depositional environment containing thick sequence of vitric tuffs of Cenozoic age.

Very low grade or unmetamorphosed volcaniclastic sequences typically containing large proportions of ignimbrites.

Vertical zonation of zeolites and associated authigenic silicate minerals in thick (hundreds to thousands of meters) tuffaceous sequences, especially siliceous tuffs of Neogene age that were air-laid on land. The vertical zonation commonly is (from top to bottom) unaltered vitric material \pm smectite to clinoptilolite \pm mordenite \pm opal-(cristobilite-tridymite) to analcime \pm potassium feldspar \pm quartz and then to albite \pm quartz. This zonation may cut across bedding.

Thickness of the zeolitic tuffs commonly ranges from hundreds to thousands of meters. Areal extent is commonly hundreds to thousands of square kilometers.

Zeolitic tuffs commonly resist weathering and may be ledge formers.

\section{Economic factors}

Grade and tonnage

The value of zeolite deposits varies depending on the end product use and zeolite species present. Properties, such as cation exchange capacity for radionuclides, heavy metals or $\mathrm{NH}^{+4}$, are more meaningful than grade. This is because these properties are commonly different for the same zeolite species originating from two distinct deposits. The zeolite content of better deposits currently mined is estimated to have zeolite content above $60 \mathrm{wt} . \%$, but may reach over $80 \mathrm{wt} . \%$. Deposits supplying materials to control the odor to local farms may have zeolite content well below $50 \mathrm{wt} . \%$, but must be close to the market.

The Si/Al ratio and exchangeable cation ratios of the zeolites affect certain uses. Cation exchange capacity and adsorption capacity for various gases are important. Color (due to iron staining) and the abundance of nonzeolitic minerals may limit use. 
Important sources of natural clinoptilolite and mordenite. Bentonite, attapulgite, and other materials known for their high absorbency may be cost effective alternatives to zeolites for specific ion exchange applications.

\section{Examples}

In/near focal areas

Elsewhere
Miocene Paintbrush Group tuffs, tuffaceous beds of Calico Hills, and Crater Flat Group tuffs at Yucca Mountain, Nye County, Nevada (clinoptilolite and mordenite).

Oligocene-Miocene John Day Formation, Oregon (clinoptilolite).

Death Valley Junction, California (clinoptilolite).

\section{References}

Eyde, T.H., and Holmes, D.A., 2006, Zeolites, in Kogel, J.E., Trivedi, N.C., Barker, J.M., and Krukowski, S.T., eds., Industrial minerals and rocks: Littleton, Colo., Society for Mining, Metallurgy, and Exploration, Inc. (SME), p. 139-165.

Sheppard, R.A., 1991, Descriptive model of sedimentary zeolites, Deposit subtype-zeolite in tuffs of open hydrologic systems, in Orris, G.J., and Bliss, J.D., eds., Some industrial mineral deposit models—Descriptive models: U.S. Geological Survey Open-File Report 91-11-A, p. 16-18, accessed February 1, 2016, at http://pubs.usgs.gov/of/1991/ofr-91-0011-a/ofr-91-0011a.pdf.

Sheppard, R.A., and Simandl, G.J., 1999, Open-system zeolites D01, in Simandl, G.J., Hora, Z.D., and Lefebure, D.V., eds., Selected British Columbia mineral deposit profiles, volume 3-Industrial Minerals: British Columbia Ministry of Energy and Mines, Open File 1999-10, accessed February 1, 2016, at http://www.unalmed.edu.co/ rrodriguez/MODELOS/columbia/Closed\%20Basin\%20Zeolites.htm. 


\section{Sedimentary System (formed during deposition of the sediment)}

Deposit types in the study area

Banded iron (Algoma type)

Lacustrine diatomite 


\section{Banded Iron Formation (Algoma type)}

[wt.\%, weight percent; Mt, million metric tons; $\mathrm{nT}$, nanotesla; Ga, giga-annum or billions of years; REE, rare earth elements]

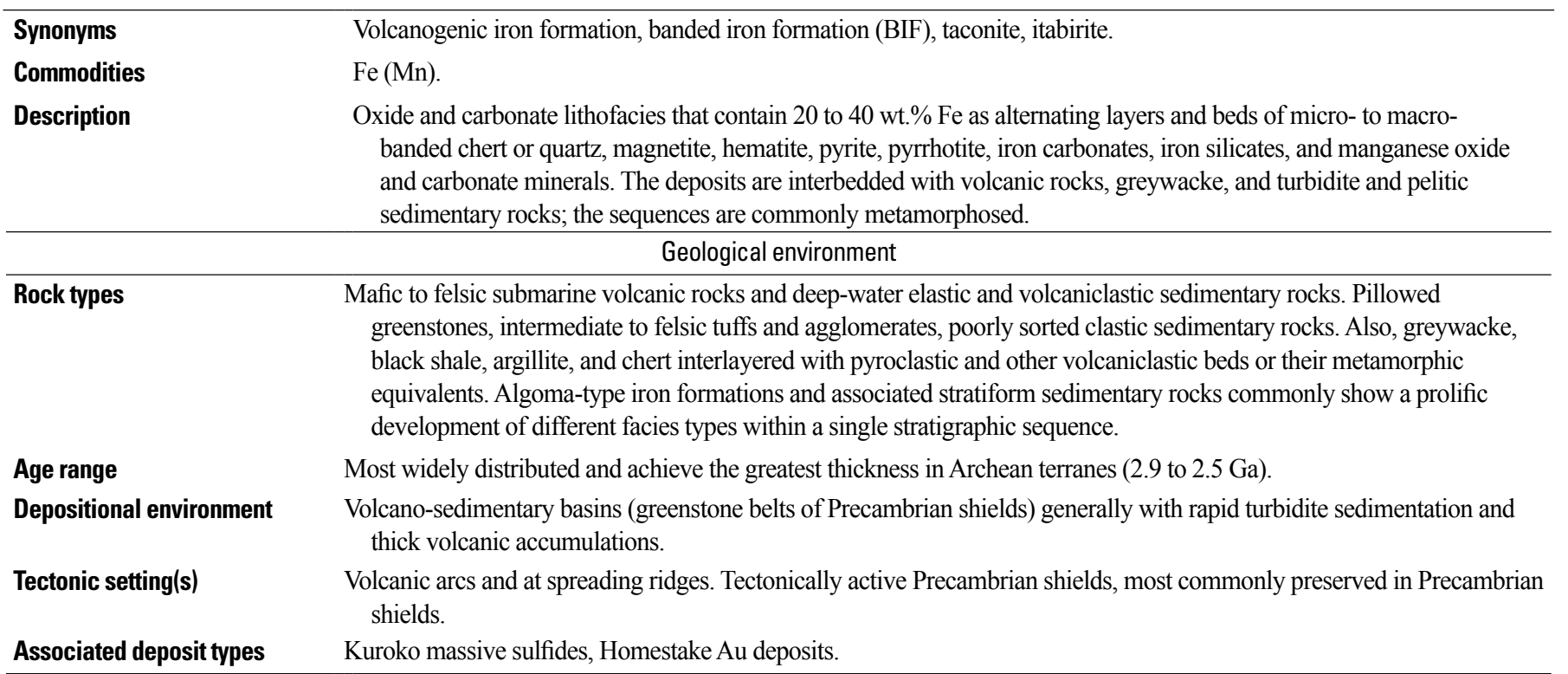
Deposit description

Ore mineralogy
Alteration
Ore controls

Geochemical signatures

Geophysical signature
Magnetite, hematite; some deposits consist of siderite interbedded with pyrite and pyrrhotite.

No syngenetic alteration, but commonly metamorphosed to varying degrees and weathered.

Iron-rich stratigraphic horizons with little clastic sedimentation, often near volcanic centers. Some Algoma-type ironformations contain ore deposits due to metamorphic enhancement of grain size or structural thickening of the mineralized horizon.

Elevated values for $\mathrm{Fe}$ and $\mathrm{Mn}$; at times elevated values for $\mathrm{Ni}, \mathrm{Au}, \mathrm{Ag}, \mathrm{Cu}, \mathrm{Zn} \mathrm{Pb}, \mathrm{Sn}, \mathrm{W}, \mathrm{REE}$, and other minor elements.

Gravity and magnetic methods can be used to delineate greenstone belts within granite-greenstone terranes at provincial to regional scales. Magnetic low and gravity high anomalies are usually associated with relatively nonmagnetic, dense greenstone terranes, whereas magnetic high and gravity low anomalies are usually associated with magnetic, lowdensity granitic. Gravity and magnetic methods can also be used for deposit-scale iron-formation studies. Most ironformation is associated with positive, high-amplitude gravity anomalies because it contains elevated abundances of high-density iron minerals, including magnetite and hematite. The magnetic signature of an iron formation is usually one to two orders of magnitude greater than that of its host rock.

Remote-sensing imaging spectroscopy can also be used in regional exploration because iron ore minerals and their alteration products have distinct spectral signatures.

The magnetic character of an iron formation is dependent on magnetic mineral content, alteration, structural attitude, and remanent magnetization. Iron formation with low magnetite content, or deposits in which magnetite has been oxidized to nonmagnetic hematite, produce low-amplitude anomalies of tens to hundreds of nT. Flat-lying deposits with normal magnetic polarization typically produce positive anomalies of about several thousand nT. Steeply dipping or folded iron-formation dominated by remanent magnetic polarization can produce anomalies with extremely high positive amplitudes of as much as tens of thousands of nT.

Electrical and electromagnetic methods are generally not applied to iron-formation exploration because the ore is resistive owing to high silica (chert) content. However, electrical techniques could be used to locate conductive sulfide facies or to delineate graphitic shale horizons associated with ore deposits.

\section{Economic factors}

Grade and tonnage

Ore bodies range in size from about 1,000 to less than $100 \mathrm{Mt}$ with grades ranging from 15 to $45 \mathrm{wt} . \% \mathrm{Fe}$, averaging 25 wt.\% Fe. Precambrian deposits usually contain less than 2 wt.\% Mn. 
Discrete, well-defined magnetite and hematite lithofacies of iron formation are preferred with a minimum of other lithofacies and clastic sediment interbedded in the crude ore.

Iron formations are usually large regional geological features that are relatively easy to define.

Detailed stratigraphic information is an essential part of the database required for defining grade, physical and chemical quality, and beneficiation and concentration characteristics of the ore.

Basin analysis and sedimentation modeling enable definition of factors that controlled the development, location and distribution of different iron formation lithofacies.

\begin{tabular}{ll}
\hline & \multicolumn{1}{c}{ Examples } \\
\hline In/near focal areas & Atlantic City-South Pass, Wyoming. \\
Elsewhere & Archean examples: Vermillion iron formation, Minnesota; Sherman Mine, Temagami, Ontario; Helen Mine, Wawa, \\
& Ontario; early Proterozoic example: Wadi Sawawin, Saudi Arabia. \\
\hline
\end{tabular}

\section{References}

Cannon, W.F., 1986, Descriptive model of Algoma Fe, in Cox, D.P., and Singer, D.A., eds., Mineral deposit models: U.S. Geological Survey Bulletin 1693, p. 198.

Cannon, W.F., Hadley, D.G., and Horton, R.J., 1995, Algoma Fe deposits, in du Bray, E.A., ed., Preliminary compilation of descriptive geoenvironmental mineral deposit models: U.S. Geological Survey Open-File Report 95-0831 p. 209-214. [Also available at http://pubs.usgs.gov/of/1995/ofr-95-0831/.]

Gross, G.A., 1996, Algoma-type iron-formation, in Lefebure, D.V. and Hõy, T., eds., Selected British Columbia mineral deposit profiles, volume 2Metallic deposits: British Columbia Ministry of Employment and Investment, Open File 1996-13, p. 25-28, accessed April 23, 2016, at http://www. empr.gov.bc.ca/Mining/Geoscience/MineralDepositProfiles/Pages/default.aspx. 


\section{Lacustrine Diatomite}

[wt.\%, weight percent; ft, feet; $\mathrm{mi}^{2}$, square mile; m.y., million years]

\begin{tabular}{ll}
\hline Synonyms & Diatomaceous earth, kieselguhr, bog deposits. \\
Commodities & Diatomaceous earth. \\
Description & A chalk-like, soft, earthy siliceous sedimentary rock composed of diatoms. Lacustrine diatomite deposits formed in \\
& fresh to brackish water, generally associated with volcanism, found worldwide both in paleosediments and in recent \\
& lake sediments. Large amount of silica necessary for thick accumulations of diatoms is from the weathering and \\
& decomposition of silica rich volcanic rocks where silica is transported to the lake through runoff, groundwater, and hot \\
& or cold springs.
\end{tabular}

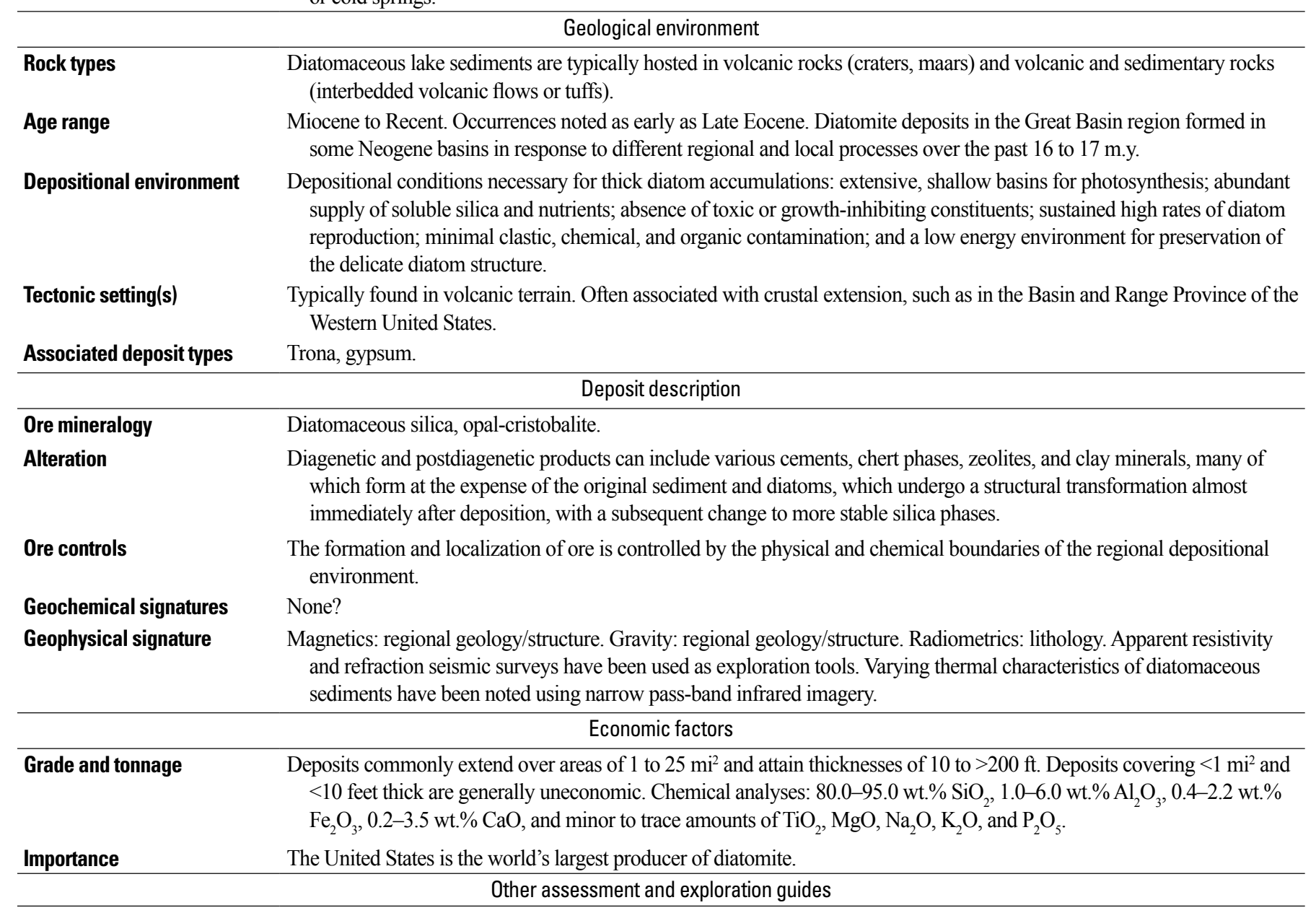

Tectonostratigraphic setting.

Basinal sediments.

Overburden typically $<5: 1$.

\begin{tabular}{ll}
\hline In/near focal areas & Examples \\
\hline
\end{tabular}


Elsewhere Juntura and Otis basins, Oregon.

References

Shenk, J.D., 1991, Lacustrine diatomite, in Orris, G.J., and Bliss, J.D., Some industrial mineral deposit models; descriptive deposit models: U.S. Geological Survey Open-File Report 91-11-A, p. 26-30.

Wallace, A.R., 2003, Regional geologic setting of Late Cenozoic lacustrine diatomite deposits, Great Basin and surrounding region-Overview and plans for investigation, in Bliss, J.D., Moyle, P.R., and Long, K.R., eds. Contributions to industrial-mineral research: U.S. Geological Survey Bulletin 2209-B, 16 p. [Also available at http://pubs.usgs.gov/bul/b2209/.]

Wallace, A.R., Frank, D.G., and Founie, Alan, 2006, Freshwater diatomite deposits in the Western United States: U.S. Geological Survey Fact Sheet 2006-3044, 2 p. [Also available at http://pubs.usgs.gov/fs/2006/3044/.] 


\title{
Surficial-Mechanical (Placer) Mineral System
}

\author{
Deposit types in the study area
}

Heavy mineral placer

Placer and paleoplacer gold 


\section{Heavy Mineral Placers}

[wt.\%, percent; Mt, million metric tons; REE, rare earth elements; PGE, platinum-group elements]

\begin{tabular}{ll}
\hline $\begin{array}{l}\text { Synonyms } \\
\text { Commodities } \\
\text { Description }\end{array}$ & $\begin{array}{l}\text { Placer deposits, placer heavy mineral deposits, black sand deposits, stream placers } \\
\text { Ti-minerals (ilmenite, rutile), zircon, monazite, } \pm \text { garnet, cassiterite, sillimanite, staurolite, xenotime, PGE } \\
\text { Concentrations of water-deposited minerals with high specific gravities; formed by the physical-mechanical concentration of } \\
\text { bedrock minerals freed by weathering, then deposited and reworked in fluvial environments. }\end{array}$ \\
\hline $\begin{array}{l}\text { Geological environment } \\
\text { Age range } \\
\text { Depositional environment }\end{array}$ & $\begin{array}{l}\text { Unconsolidated to weakly consolidated layers of fluvial sediments (alluvium). } \\
\text { Quaternary; principally modern, Holocene and Pleistocene alluvial sediments. }\end{array}$ \\
& $\begin{array}{l}\text { Ancient and modern alluvial valleys fed by streams and rivers that drain terranes where abundant high-grade metamorphic } \\
\text { processes. }\end{array}$ \\
Tectonic setting(s) & Various.
\end{tabular}

\begin{tabular}{ll}
\hline & Deposit description \\
\hline Ore mineralogy & Mainly gold, ilmenite, rutile, zircon, monazite; occasionally cassiterite, xenotime
\end{tabular}

Alteration None

Ore controls High-grade metamorphic or heavy mineral-rich igneous are source rocks. Fluvial processes in streams and rivers concentrate the heavy-minerals.

Geochemical signatures Ti, Hf, REE, Th, $\mathrm{U}, \mathrm{Nb}$, and $\mathrm{Ta}$ in stream sediments can be pathfinder elements for gold ( $\mathrm{Au}$ ), ilmenite (FeTiO $)_{3}$, rutile $\left(\mathrm{TiO}_{2}\right)$, zircon $\left((\mathrm{Zr}, \mathrm{Hf}, \mathrm{U}) \mathrm{SiO}_{4}\right)$, monazite $\left((\mathrm{Ce}, \mathrm{La}, \mathrm{Y}, \mathrm{Th}) \mathrm{PO}_{4}\right)$, xenotime $\left(\mathrm{YPO}_{4}\right)$, platinum-group minerals, and euxenite $\left((\mathrm{Y}, \mathrm{Ca}, \mathrm{Ce}, \mathrm{U}, \mathrm{Th})(\mathrm{Ti}, \mathrm{Nb}, \mathrm{Ta})_{2} \mathrm{O}_{6}\right)$.

Geophysical signature High-resolution magnetic, gravity, and seismic-reflection surveys can map paleotopography and outline paleochannels; electromagnetic surveys may be useful in detecting conductive material in paleochannels; ground-penetrating radar may be useful in delineating the geometry of shallow channels and deposits; and radiometric surveys can locate radioactive heavy-mineral concentrations.

\section{Economic factors}

Grade and tonnage

Grade and tonnage in fluvial placers can vary considerably (see Robertson and Storch, 1955; Anderson, 1958; Storch and Holt, 1963; Staatz and others, 1979, 1980). The average heavy-mineral content of Idaho placers sampled by the U.S. Bureau of Mines ranged from 0.10 to $1.06 \mathrm{wt} . \%$ of the sediments, with an average of $0.5 \mathrm{wt} \%$ (Staatz and others, 1980).

Importance

Heavy-minerals sands are a principal source of $\mathrm{Zr}$ and a primary source of $\mathrm{Ti}$ for the $\mathrm{TiO}_{2}$ pigments industry. However, currently these elements are almost entirely produced from heavy-mineral sands deposited in coastal environments. Heavy mineral placers are significant sources of Au in some areas of the United States, such as Alaska, and also in some countries elsewhere (Yeend and others, 1989).

$$
\text { Other assessment and exploration guides }
$$

Identify streams and rivers that drain terranes with outcropping (1) abundant high-grade metamorphic or igneous rocks or (2) ore bodies that host native gold, electrum, or platinum-group minerals

Restrict the assessment areas to unconsolidated or weakly consolidated Quaternary fluvial sediments as a first-level exploration and assessment guideline.

Detailed geologic mapping that distinguishes amongst Quaternary sedimentary units can benefit the search for deposits. For example, alluvium is the target host of heavy mineral sands, whereas landslide and colluvium generally lack the sorting necessary to form concentrations of heavy minerals.

Limited only to near-surface, unconsolidated or weakly consolidated alluvial sediments. Economic deposits of this type, regardless of their heavy-mineral content (grade), typically are exploited only if they lie at or within a few tens of meters of the surface.

\section{Examples}

In/near focal area Central Idaho valleys that are within or adjacent to the Idaho batholith (Staatz and others, 1980).


Anderson, A.L., 1958, Uranium, thorium, columbium, and rare earth deposits in the Salmon region, Lemhi County, Idaho: Idaho Bureau of Mines and Geology Pamphlet 115, 81 p.

Force, E.R., and Creely, Scott, 2000, Titanium mineral resources of the western U.S.-An update: U.S. Geological Survey Open-File Report 00-442, 37 p. Jones, J.V., III, Karl, S.M., Labay, K.A., Shew, N.B., Granitto, M., Hayes, T.S., Mauk, J.L., Schmidt, J.M., Todd, E., Wang, B., Werdon, M.B., and Yager, D.B., 2015, GIS-based identification of areas with mineral resource potential for six selected deposit groups, Bureau of Land Management Central Yukon Planning Area, Alaska: U.S. Geological Survey Open-File Report 2015-1021, 78 p., 5 appendixes, 12 pls., accessed May 1, 2016, at http://dx.doi. org/10.3133/ofr20151021.

Garnett, R.H.T., and Bassett, N.C., 2005, Placer deposits, in Hedenquist, J.W., Thompson, J.F.H., Goldfarb, R.J., Richards, J.P., eds., Economic Geology one hundredth anniversary volume 1905-2005: Society of Economic Geologists, p. 813-843.

Robertson, A.F., and Storch, R.H., 1955, Rock Creek radioactive mineral placer area, Blaine County, Idaho: U.S. Atomic Energy Commission RME-3129, $25 \mathrm{p}$.

Storch, R.H., and Holt, D.C., 1963, Titanium placer deposits of Idaho: U.S. Bureau of Mines Report of Investigations 6319, 69 p.

Staatz, M.H., Armbrustmacher, T.J., Olson, J.C., Brownfield, I.K., Brock, M.R., Lemons, J.F., Jr., Coppa, L.V., and Clingan, B.V., 1979, Principal thorium resources in the United States: U.S. Geological Survey Circular 805, 42 p.

Staatz, M.H., Hall, R.B., Macke, D.L., Armbrustmacher, T.J., and Brownfield, I.K., 1980, Thorium resources of selected regions in the United States: U.S. Geological Survey Circular 824, 32 p.

Yeend, W., and Shawe, D.R., 1989, Gold in placer deposits: U.S. Geological Survey Bulletin 1857-G, 19 p.

Youngson, J. H., and Craw, D., 1995, Evolution of placer gold deposits during regional uplift, central Otago, New Zealand: Economic Geology, v. 90, p. 731-745. 


\section{Placer and Paleoplacer Gold}

[g/t, grams per metric ton; Mt, million metric tons; PGE, platinum-group elements]

\begin{tabular}{ll}
\hline Synonyms & Holocene placer deposits; terrace placers; fluvial, alluvial, colluvial placers, buried-channel placers, paleoplacers. \\
Commodities & Au, platinum-group elements (PGEs), and Sn. \\
Description & Concentrations of valuable detrital (gold, PGE, cassiterite) formed by sedimentary processes where the high specific \\
gravity of the minerals results in their concentration at or near the surface, usually in Holocene fluvial deposits or in \\
buried valleys (typically with at least several meters of overlying barren material, usually till, clay or volcanic rocks), \\
mainly as channel-lag and gravel-bar deposits.
\end{tabular}

Geological environment

Rock types

Age range

Depositional environment

Tectonic setting(s)

Associated deposit types

Generally mature, well-sorted, fine to coarse-grained, quartz-rich sands and sandstones, and mature, well-rounded, clastsupported, quartz-rich gravels and conglomerates.

Mainly Tertiary and Quaternary. Older paleoplacers are rare due to poor long-term preservation of deposits in high-relief, subaerial environments.

Surficial fluvial placer: large, high-order, stream channels and along bedrock in high-energy, steep-gradient, low-sinuosity, single-channel streams.

Alluvial fan, fan-delta and delta deposit: relatively unconfined depositional settings dominated by massive or graded sands and gravel.

Colluvial placers: develop from residual deposits associated with primary lode sources by sorting associated with downslope migration of heavy minerals.

Paleoplacers: Incised paleochannels in mountainous areas such as high-gradient narrow bedrock-floored valleys (paleogulches); high-level, abandoned tributary valleys with intermediate gradients large, buried trunk valleys (on the order of 100 meters deep, a few hundred meters wide and $>1 \mathrm{~km}$ long) with low channel gradients; channels buried in modern alluvial valleys with gradients similar to the modern streams.

Stable intracratonic basin, platform, and intermontane plateau settings characterized by long periods of erosion and reworking of clastic sediments; accretionary orogenic belts, commonly in proximity to major faults that expose the bedrock sources to weathering and erosion.

The source mineral-deposit type will determine the type of placer deposit (lode gold deposit will erode to produce placer gold).

Deposit description

Ore controls

Geochemical signatures

Geophysical signature
Ore mineralogy
Alteration

Native gold, gold nuggets, flakes, and grains, electrum, PGE minerals, cassiterite (gems).

$\mathrm{Fe}$ and $\mathrm{Mn}$ oxide precipitates common; Ag-depleted rims of Au grains increase in thickness with age.

Fluvial settings: channel irregularities, bedrock depressions and below natural riffles created by fractures, joints, cleavage, faults, foliation or bedding planes that dip steeply and are oriented perpendicular or oblique to stream flow. Basal gravels over bedrock typically contain the highest placer concentrations. Fine-grained placer concentrations occur where channel gradients abruptly decrease or stream velocities lessen.

Gold in alluvial fan placers is found in debris- flow sediments and in interstratified gravel, sand and silt.

Colluvial placers are best developed on steeper slopes, generally over a weathered surface and near primary lode sources.

Anomalous concentrations of $\mathrm{Au}, \mathrm{Ag}, \mathrm{Hg}, \mathrm{As}, \mathrm{Cu}, \mathrm{Fe}, \mathrm{Mn}$, Ti, or $\mathrm{Cr}$ in stream sediments. Au fineness (relative $\mathrm{Ag}$ content) and trace element geochemistry $(\mathrm{Hg}, \mathrm{Cu})$ of $\mathrm{Au}$ particles can be used to relate placer and lode sources.

Magnetic, gravity, and seismic-reflection surveys to map paleotopography and outline paleochannels; inducedpolarization/resistivity surveys to locate conductive disseminated mineralization; electromagnetic surveys may be useful in detecting conductive material in paleochannels; ground-penetrating radar may be useful in delineating the geometry of shallow channels and deposits; and radiometric surveys to locate radioactive heavy-mineral concentrations.

\section{Economic factors}

Grade and tonnage

Deposits are typically high tonnage (0.1 to $100 \mathrm{Mt})$ but low grade (0.05-0.25 g/t Au, 50-200 g/t Sn). Placer concentrations are highly variable both within and between individual deposits. 
Historically, placer gold deposits accounted for more than two-thirds of the world's gold. Shallow alluvial placers also account for a large part of world tin (mainly from Southeast Asia and Brazil) and diamond (Africa) production.

Other assessment and exploration guides

Quartz pebble conglomerates near lode gold sources.

Recognition of paleochannels in stratigraphy.

Panning and other methods of gravity sorting are used to identify concentrations of gold and other heavy minerals. Many placer gold paystreaks overlie clay beds or dense tills and in some camps these "false bottom" paystreaks are important.

Examples

In/near focal areas

Elsewhere
Yankee Fork placers, Idaho; Homestake paleoplacer, Idaho.

Klondike Au district, Yukon.

\section{References}

Garnett, R.H.T., and Bassett, N.C., 2005, Placer deposits, in Hedenquist, J.W., Thompson, J.F.H., Goldfarb, R.J., and Richards, J.P., eds., Economic Geology one hundredth anniversary volume 1905-2005, Society of Economic Geologists, p. 813-843.

Levson, V.M., 1995, Surficial placers, in Lefebure, D.V., and Ray, G.E., eds., Selected British Columbia mineral deposit profiles: British Columbia Geological Survey, Open File 1995-20, p. 21-23.

Levson, V.M., and Giles, T.R., 1995, Buried-channel placers, in Lefebure, D.V., and Ray, G.E., eds., Selected British Columbia mineral deposit profiles: British Columbia Geological Survey, Open File 1995-20, p. 25-28.

Yeend, W.E., 1986, Descriptive model of placer Au-PGE, in Cox, D.P., and Singer, D.A., eds., Mineral deposit models: U.S. Geological Survey, Bulletin 1693 , p. 261. 


\section{Other (Non-Locatable) Deposit Types}

Deposit types in the study area

Dimension stone (sandstone and quartzite)

Sand and gravel

Volcanic ash (pumice and cinders)

Perlite 


\section{Dimension Stone (Sandstone and Quartzite)}

[m, meter; $\mathrm{t}$, metric ton; wt.\%, weight percent; SEDEX, sedimentary exhalative; VMS, volcanogenic massive sulfide]

\begin{tabular}{|c|c|}
\hline Synonyms & $\begin{array}{l}\text { High silica quartzite, quartz sandstone, silica rock silicastone. Bluestone, brownstone, freestone, arkose, greywacke, } \\
\text { quartzite. }\end{array}$ \\
\hline Commodities & Building stone. \\
\hline Description & $\begin{array}{l}\text { Uniform massive beds of sandstone with very few and well-spaced (more than } 1 \mathrm{~m} \text { ) fractures and bedding planes. } \\
\text { Sandstone must be suitable to be removed from a quarry face in square shaped blocks that are } 10 \mathrm{t} \text { or larger with } \\
\text { minimum waste. Metamorphic equivalent (quartzite) of uniform, massive beds of siliceous sediments, such as } \\
\text { sandstone. These beds are commonly formed in sedimentary sequences. They have high silica contents with very } \\
\text { limited impurities, usually less than } 1 \mathrm{wt} . \% \text {. }\end{array}$ \\
\hline Rock types & $\begin{array}{l}\text { Siliceous sediments are found with a variety of clastic and carbonate rocks; quartzites are the metamorphic } \\
\text { equivalents. }\end{array}$ \\
\hline Age range & Precambrian to Tertiary. \\
\hline Depositional environment & $\begin{array}{l}\text { Shallow continental shelf, inland sea or large continental lacustrine basins with low energy environment and a steady } \\
\text { supply of well sorted, detrital, sand size particles. The mineral composition is influenced by the regional climate } \\
\text { over the source area; speed, type and intensity of weathering and speed of transport into the sedimentary basin. }\end{array}$ \\
\hline \multicolumn{2}{|r|}{ Deposit description } \\
\hline Ore mineralogy & Quartz; chert can also have other forms of amorphous and microcrystalline silica. \\
\hline Alteration & Secondary Fe-Mn hydroxides and (or) calcium carbonate along fractures. \\
\hline Ore controls & $\begin{array}{l}\text { Source terrains that minimize impurities and depositional environments that includes long or repeated } \\
\text { transportation with intensive wear of particles which includes separation from other silicates like feldspars for } \\
\text { example. This may occur both by physical as well as chemical weathering. }\end{array}$ \\
\hline Geochemical signatures & $\begin{array}{l}\text { In general, more than } 98 \text { wt.\% silica with traces of other elements. High silica contents and low aluminosilicate and } \\
\text { carbonate contents. }\end{array}$ \\
\hline Geophysical signature & $\begin{array}{l}\text { Only applicable where there is significant contrast in physical rock properties of silica-rich rocks with surrounding } \\
\text { rocks. }\end{array}$ \\
\hline \multicolumn{2}{|r|}{ Economic factors } \\
\hline Importance & Used for building and construction and decorative stone. \\
\hline
\end{tabular}

$$
\text { Other assessment and exploration guides }
$$

Large smooth bedrock exposures in cuts, on valley slopes and along shorelines lacking fragmented rock are good indicators. An air photo study can identify large outcrop areas and boulder fields.

Look for resistant ridges and outcrops and absence of impurities in hand sample visible to the naked eye.

Usually weather resistant, resulting in morphological highs.

Massive beds of thickness more than $1 \mathrm{~m}$, may be layered or cross bedded, and uniform in appearance.

Deposits commonly extend over areas of at least several square kilometers. Usually the deposits are horizontal or tilted, and rarely folded. 


\begin{tabular}{|c|c|}
\hline \multicolumn{2}{|r|}{ Examples } \\
\hline In/near focal areas & Idaho. \\
\hline Elsewhere & Texas, Indiana, Wisconsin, Massachusetts, Georgia. \\
\hline \multicolumn{2}{|c|}{$\begin{array}{l}\text { Hora, Z.D., 1999, Silica-rich rocks, in Simandl, G.J., Hora, Z.D., and Lefebure, D.V., eds., Selected British Columbia mineral deposit profiles, } \\
\text { volume 3-Industrial Minerals, Model R07: British Columbia Ministry of Energy and Mines, Open File 1999-10, accessed February 15, 2016, at } \\
\text { http://www.empr.gov.bc.ca/Mining/Geoscience/MineralDepositProfiles/. }\end{array}$} \\
\hline \multicolumn{2}{|c|}{$\begin{array}{l}\text { Orris, G.J., 1992, Preliminary grade and tonnage model of sandstone/quartzite silica, in Orris, G.J., and Bliss, J.D. Industrial minerals deposit models- } \\
\text { Grade and tonnage models: U.S. Geological Survey Open-File Report 92-437, } 84 \text { p., accessed April 25, 2016, at http://pubs.usgs.gov/of/1992/ofr-92- } \\
\text { 0593/593in.pdf. }\end{array}$} \\
\hline
\end{tabular}




\section{Sand and Gravel}

[km, kilometer; t, metric ton; kt, thousand metric tons; g/t, grams per metric ton; ASTM, American Society for Testing and Materials; CSA, Canadian Standards Association]

\begin{tabular}{|c|c|}
\hline Synonyms & $\begin{array}{l}\text { Aggregate, granular deposits, fluvial and glaciofluvial sediments, ice-contact deposits, outwash, alluvial sand and gravel, } \\
\text { beach sand and gravel. }\end{array}$ \\
\hline Commodities & All-purpose construction aggregate, special fill, railroad ballast. \\
\hline Description & $\begin{array}{l}\text { Surficial sediment of sand and gravel deposited as a stream channel and terrace deposits, alluvial fans, and glacial or } \\
\text { marine deposits. }\end{array}$ \\
\hline \multicolumn{2}{|r|}{ Geological environment } \\
\hline Rock types & $\begin{array}{l}\text { Usually poorly to moderately well-sorted pebble, cobble and (or) boulder gravel with variable proportions of fine- to } \\
\text { coarse-grained sand; deltaic deposits locally interbedded with glaciomarine or glaciolacustrine silts and clays; ice-- } \\
\text { proximal glaciofluvial deposits commonly interbedded with till or glaciogenic debris flow deposits; fluvial sands and } \\
\text { gravels often overlain by floodplain silts and organic deposits. }\end{array}$ \\
\hline Age range & Mainly Holocene and Pleistocene in glaciated areas; Holocene to Tertiary in unglaciated regions. \\
\hline Depositional environment & Streams, alluvial fans, glaciated areas. \\
\hline Tectonic setting(s) & $\begin{array}{l}\text { Generally unimportant. Sand and gravel deposits occur in high energy stream sediments in all tectonic belts. In coastal } \\
\text { areas, isostatic or tectonic uplift produces raised landforms that are readily mined. }\end{array}$ \\
\hline
\end{tabular}
Deposit description

Ore mineralogy

Composition of aggregate particles depends on the source areas. Provenance is also a major factor in determining the quality of the resulting aggregate product. Bedded and schistose rocks usually provide lower quality products, whereas massive igneous rocks and metamorphic rocks, such as gneisses and quartzites, produce better quality aggregate. In sedimentary source areas, limestones and cemented sandstones are better than shales, siltstones, or weak sandstone.

Alteration

Soft and weak rocks are a deleterious component of every type of construction aggregate. Prolonged weathering may weaken some otherwise competent rock types. This is particularly true for older Pleistocene and Tertiary deposits in glaciated areas, and for all deposits in nonglaciated areas. Percolating groundwater may result in coating of gravel particles with calcium carbonate, clay, or iron hydroxides. Such coatings may negatively affect the strength and durability of bonding with cement in concrete structures.

Ore controls

The composition of the bedrock in the source area has a major impact on aggregate quality. A variety of factors influence the usability of granular sediment for individual products, which frequently have distinct quality requirements. Quality of construction aggregate for particular end uses is controlled by a number of physical and chemical parameters specified in ASTM and CSA Standards. The main factors influencing suitability for different end uses are the relative proportions of competent rock types, components reactive with cement like chert, other amorphous silica varieties, volcanic glass, sulfides, and organics like peat. Other important criteria include the absence of clay and silt; clean clast surfaces; isometric shapes and granulometric composition. Sometimes in the absence of a quality aggregate, some granular deposits can be improved by more sophisticated processing. Use of a different type or higher proportion of cement in a concrete mix may be another solution.

Geochemical signatures

Geophysical signature
None.

Ground-penetrating radar can delineate the geometry, structure, and thickness of granular deposits provided they are not overlain by clay or clay-rich till. Shallow seismic and resistivity surveys can help outline the thickness and homogeneity of a granular deposit, particularly the presence of clay layers or till, and depth of the groundwater level.

\section{Economic factors}

Grade and tonnage
Grade is determined by ASTM or CSA specifications and can be highly variable, depending on location and intended use. Tonnage also can vary widely. For example, even a small deposit of a few hundred thousand tons may be an important source for local use in populated areas. Such a deposit, however, must contain aggregate that does not require complicated processing. Similar examples are borrow pits used in road construction and maintenance. 
Importance

Sand and gravel are the main, basic construction materials for building cities and infrastructure. Building an average family home requires about $100 \mathrm{t}$ of aggregate; for a school it takes approximately 15,000 t; for $1 \mathrm{~km}$ of 4-lane highway, between 40 and $60 \mathrm{kt}$ of aggregate are needed.

Other assessment and exploration guides

Geologic maps serve as a primary source of information for beginning the search for new sources of aggregate.

\begin{tabular}{l}
\hline Examples \\
\hline In/near focal areas \\
\hline All focal areas have sand and gravel (salable minerals). \\
\hline Hora, Z.D., 1999, Sand and gravel, in Simandl, G.J., Hora, Z.D., and Lefebure, D.V., eds., Selected British Columbia mineral deposit profiles, \\
volume 3-Industrial Minerals: British Columbia Ministry of Energy and Mines, Open File 1999-10, accessed February 15, 2016, at http://www. \\
empr.gov.bc.ca/Mining/Geoscience/MineralDepositProfiles/. \\
Knepper, D.H., Jr., Langer, W.H., and Miller, S.H., 1994, Remote sending and airborne geophysics in the assessment of natural aggregate resources: U.S. \\
Geological Survey Open-File Report 94-158, 62 p, accessed April 25, 2016, at https://pubs.er.usgs.gov/publication/ofr94158. \\
Langer, W.H., 1988, Natural aggregates of the conterminous United States: U.S. Geological Survey Bulletin 1594, 33 p.
\end{tabular}




\section{Volcanic Ash (cinders and pumice)}

[km, kilometer; t, metric ton; Mt, million metric tons; ASTM, American Society for Testing and Materials]

\begin{tabular}{|c|c|}
\hline Synonyms & Volcanic scoria, volcanic ejecta, agglomerate, pyroclastics, lapilli, tuff. \\
\hline Commodities & $\begin{array}{l}\text { Lightweight aggregate, landscaping aggregate, anti-skid sand, stonewashing pumice, "lava (barbecue) rock," pozzolan, } \\
\text { abrasive powders, absorbents, insulation fill, filler, filtration media. }\end{array}$ \\
\hline Description & $\begin{array}{l}\text { Unconsolidated pumice, cinder and other pyroclastic deposits are usually found near a volcanic vent or edifice. It is } \\
\text { typically the vesicular pyroclastic material that is exploited because of its appearance or attractive strength to weight } \\
\text { ratio. Pumice occurs in felsic pyroclastic flows, air-fall blankets, and flow domes; cinder usually forms basaltic } \\
\text { pyroclastic tephra cones and blankets. }\end{array}$ \\
\hline Age range & Any age, although preserved deposits are commonly Tertiary to Holocene. \\
\hline Depositional environment & $\begin{array}{l}\text { Pumice in calderas, lava flow dome complexes and Plinian-type central eruptions. Blanket deposits are found in the vicin- } \\
\text { ity of stratovolcanoes. }\end{array}$ \\
\hline Tectonic setting(s) & Volcanic arcs and rift zone belts. \\
\hline
\end{tabular}

\section{Deposit description}

Ore

Alteration

Ore controls
Pumice, cinder, volcanic ash, bombs, blocks.

Clay minerals, alunite, zeolites, hematite, limonite.

Pumice, a product of highly viscous rhyolite magma, commonly forms an ashfall blanket surrounding the source vent. Its thickness depends on intensity and longevity of eruption. Large volumes of pumice and pumiceous rhyolite also accumulate in the upper parts of rhyolite and obsidian flow domes, as well in ash-flow tuffs in calderas. Volcanic cinder, because of low viscosity and higher density of the mafic magma, is more concentrated in proximity to the vent as coneshaped deposits.

For pumice, look for rhyolite compositions.

Ground-penetrating radar can delineate structure and thickness of a pyroclastic deposit. Shallow seismic surveys can help to outline the presence of lave flows or dikes in cinder cones, as well as the boundary between pumiceous rhyolite and nonporous rock facies.

\section{Economic factors}

\section{Grade and tonnage}

Importance
Deposits range in size from 10,000 t to $10 \mathrm{Mt}$, although occasionally, deposits may reach $400 \mathrm{Mt}$. The average production from a single deposit in Western United States is approximately 35,000 t per year for cinder and 10,000 t per year for pumice. Use of a lightweight aggregate has several ASTM specifications for particle sizing and unit weight, so do some specific end uses, like stone washing.

Regionally important as a specialty aggregate, but represents only a small part of the overall aggregate market in North America (0.1 percent in the year 2000).

Lightweight aggregate transportation costs ultimately determine the geographic extent of the market, as it can be substituted by expanded shales and similar products. Only specialty products, like "barbecue lava rock," stone-washing pumice, absorbents, landscaping cinder, and filter media can reach more distant markets. The demand for these specialty products is only a fraction of total production.

Other assessment and exploration guides

Proximity to volcanic vents, particularly on the downwind side.

Areas with remnant volcanic edifices.

Remote sensing and air photo interpretation are useful to map the limits of cinder and pumice blanket areas.

\begin{tabular}{l}
\hline \multicolumn{1}{c}{ Examples } \\
\hline In/near focal areas $\quad$ References focal areas except North-Central Montana. \\
\hline $\begin{array}{l}\text { Hora, Z.D., 1999, Volcanic ash. Cinders and Pumice, in Simandl, G.J., Hora, Z.D., and Lefebure, D.V., eds., Selected British Columbia mineral deposit } \\
\text { profiles, volume 3-Industrial Minerals: British Columbia Ministry of Energy and Mines, Open File 1999-10, accessed February 15, 2016, at http:// } \\
\text { www.empr.gov.bc.ca/Mining/Geoscience/MineralDepositProfiles/. }\end{array}$ \\
\hline
\end{tabular}




\section{Perlite}

[wt.\%, weight percent; km, kilometer; t, metric ton; g/t, grams per metric ton; kg, kilogram; Mt, million metric tons; ${ }^{\circ} \mathrm{C}$, degree Celsius; ASTM, American Society for Testing and Materials]

\begin{tabular}{|c|c|}
\hline Synonyms & Onion skin rhyolitic glass, pitchstone, obsidian. \\
\hline Commodities & Expanding perlite (pumice, foundry flux, synthetic zeolite feedstock). \\
\hline Description & $\begin{array}{l}\text { Hydrated volcanic glass, usually of rhyolite composition, formed through secondary alteration by the incorporation of } \\
\text { water into the glass/silica structure. It is often distinguished by vitreous, pearly luster and concentric (onion skin) } \\
\text { fractures. When heated, it will expand as much as } 10 \text { to } 40 \text { times its original volume. }\end{array}$ \\
\hline \multicolumn{2}{|r|}{ Geological environment } \\
\hline Rock types & $\begin{array}{l}\text { Perlite is hosted by flow domes and lava flows of rhyolite composition. Most obsidian contains less than } 1 \mathrm{wt} . \% \text { of total } \\
\text { water (water left after heating to } 105^{\circ} \mathrm{C} \text { ); the hydration of perlite increases the water content level to } 2 \text { to } 5 \mathrm{wt} \% \text { but } \\
\text { may reach as much as } 10 \mathrm{wt.} \% \text {. }\end{array}$ \\
\hline Age range & Normally Tertiary through middle Quaternary, occasionally older. \\
\hline Depositional environment & $\begin{array}{l}\text { Rapidly cooled volcanic rocks of rhyolite composition occurring as the glassy parts of domes and flows, vitric tephra, chill } \\
\text { margins of dikes and sills, and welded ash-flow tuffs. }\end{array}$ \\
\hline Tectonic setting(s) & Orogenic rift belts and volcanic arcs. \\
\hline Associated deposit types & Vitric tephra, ash-flow tuffs, pumiceous rhyolite and pumicite. \\
\hline
\end{tabular}
Deposit description

Ore Expandable hydrated siliceous volcanic glass. Most commercial perlites are "high silica rhyolites" with 75 to 77.5 wt.\% $\mathrm{SiO}_{2}$. In a few countries, obsidian and pitchstone are also expanded.

Alteration Because volcanic glass is unstable, devitrification changes Tertiary age or older volcanic glass into a microcrystalline equivalent (there may be some rare exceptions of older volcanic glass being preserved). Alteration can introduce clay minerals and (or) chalcedony and can produce deposits of halloysite.

Ore controls Perlite forms carapaces that partially or fully comprise extrusive domes and flows and tephra and tuff beds, where percolating meteoric water had access to hydrate the glassy volcanic material. Because felsic flows are viscous, most perlite deposits form close to the volcanic vent.

Geochemical signatures

Felsic volcanic rocks with more than $65 \mathrm{wt} . \%$ silica, preferably greater, as much as $75 \mathrm{wt} . \%$; water contents of 2 to $10 \mathrm{wt} . \%$. Geophysical signature

Hydrated glass can be distinguished from nonhydrated obsidian by electrical properties.

\section{Economic factors}

Grade and tonnage Average perlite has an expanded density between 20 and $40 \mathrm{~kg}$ per cubic meter. Some deposits can contain as much as 15 percent nonperlite material. The quality of perlite products is controlled by performance standards developed by the Perlite Institute, as well as ASTM specifications. Deposits range in size from less than $5 \mathrm{Mt}$ to more than $100 \mathrm{Mt}$. Annual production in North America is reported between 500,000 and 600,000 $\mathrm{t}$ annually. It comes from 10 production centers in the Western United States.

Importance Important for horticulture and for construction products. Expanded perlite has a very limited number of substitutes; therefore, it may be shipped considerable distances. For example, Greece has exported perlite to the eastern seaboard of North America, whereas New Mexico supplies Canada and numerous Eastern U.S. locations. Perlite is usually mined from open pits (the Caliente deposit in Nevada is underground) and processed in expanding plants located in market areas. Raw perlite is shipped by truck or by rail and boat to more distant processing plants. The average capacity of an expanding plant is about 10,000 t per year. As a relatively large volume product, perlite products are sensitive to transportation costs.

Other assessment and exploration guides

A small portable blowtorch is the most effective field test. A potential perlite either expands or decrepitates; nonexpanding rock just glows red.

Detailed mapping must delineate rock type, perlite textures, and the abundance of contaminants, such as clay, felsite, phenocrysts, and obsidian.

A great variability of textures and zonation require careful deposit modeling.

For drilling the potential deposit, the core diameter must be large enough to ensure high and representative core recovery.

\begin{tabular}{ll}
\hline \multicolumn{1}{l}{$\begin{array}{l}\text { In/near focal areas } \\
\text { Elsewhere }\end{array}$} & \multicolumn{1}{c}{ Caliente, Nevada. } \\
& Grants, Socorro, New Mexico; Malad City, Idaho. \\
\hline \multicolumn{1}{c}{ References } \\
\hline $\begin{array}{l}\text { Hora, Z.D., 1999, Perlite, in Simandl, G. J., Hora, Z.D., and Lefebure, D.V., eds., Selected British Columbia mineral deposit profiles, volume 3-Industrial } \\
\text { science/MineralDepositProfiles/. }\end{array}$
\end{tabular}




\section{Appendix 4. Strategic and Critical Materials}

There is no global consensus on a definition for "strategic and critical" commodities. In general, it has been accepted as those materials that are considered vital to support societal requirements and Government policy. The Defense Logistics Agency, Strategic Materials, in the U.S. Department of Defense, is the leading U.S. agency for the analysis, planning, procurement, and management of materials critical to national security. Among the agency's many functions, is the acquiring, upgrading, rotating, and disposing of materials needed to support national defense as authorized under the Strategic and Critical Material Act (50 U.S.C. 98 et seq.)(Defense Logistics Agency, 2016). The stocks held by the agency include mineral-based commodities (alloys, compounds, metals, and minerals) that are not found or produced in sufficient quantity in the United States to meet the Nation's requirements and results in a dependence on foreign sources.

Table 4-1 lists most of the elements of the non-fuel mineralbased commodities held as stock by Defense Logistics Agency (DLA), as of September 30, 2015 (U.S. Geological Survey, 2016).
Table 4-2 lists proposed additions of non-fuel mineral commodities in fiscal year 2016 (Defense Logistics Agency, 2016).

None of the locatable mineral commodities containing the elements listed in tables 1 and 2 are currently produced in significant amount and (or) as the primary source of revenue from mines operating within the assessment area; however, they may be produced as minor byproducts. Individual market demand profiles include a discussion related to a mineral commodity's strategic and critical importance.

\section{References Cited}

Defense Logistics Agency, 2016, Strategic materials: Defense Logistics Agency Web site, accessed on March 18, 2016, at http://www.dla.mil/HQ/Acquisition/StrategicMaterials.aspx.

U.S. Geological Survey, 2016, Mineral commodity summaries 2016: U.S. Geological Survey, 202 p., accessed on March 18, 2016, at http://dx.doi.org/10.3133/70140094.

Table 4-1. Elemental listing of materials stockpiled by the Defense Logistics Agency.

[Materials in the inventory may be in the form of mineral ores and concentrates but are more commonly held as advanced materials alloys, compounds, or metals (U.S. Geological Survey, 2016)]

\begin{tabular}{lll}
\hline & Stockpiled material & \\
\hline Beryllium & Manganese & Tantalum \\
Chromium & Mercury & Tin \\
Cobalt & Nickel & Titanium \\
Columbium & Platinum-group elements & Tungsten \\
Germanium & Silicon & Zinc \\
Lithium & Talc & \\
\hline
\end{tabular}

Table 4-2. Potential acquisitions of materials selected by the Defense Logistics Agency for fiscal year 2016.

[Materials may be in the form of alloys, metals, compounds, or advanced materials (Defense Logistics Agency, 2016)]

\begin{tabular}{lll} 
& \multicolumn{1}{c}{ Potential acquisitions } & \\
\hline Boron carbide & Germanium metal & Triamino-trinitrobenzene \\
Carbon fibers & Lithium cobalt oxide & Tungsten-rhenium alloy \\
Cadmium Zinc Tellurium & Lithium-nickel-cobalt-aluminum oxide & Yttrium oxide \\
Dysprosium metal & Mesocarbon microbeads & \\
Ferro-niobium & Tantalum & \\
\hline
\end{tabular}





\section{Appendix 5. Market-Demand Commodity Profiles}

The following market-demand profiles for the locatable mineral commodities relevant to the Sagebrush MineralResource Assessment (SaMiRA) project conducted by the U.S. Geological Survey (USGS) are listed in alphabetical order below by commodity:

\section{Antimony}

Alloys containing antimony are used in a variety of applications, including lead-acid storage batteries and solders for joining pipes that carry potable water. Antimony is converted to antimony trioxide, which is primarily used in the flame-retardant industry in applications such as children's clothing and aircraft seats (U.S. Geological Survey, 2013).

Publications of the USGS National Minerals Information Center reported that no marketable antimony was recovered from mines in the United States in 2014 and 2015. In 2013, one operation in Pershing County, Nevada, produced less than 1,000 metric tons ( $t$ ) of unprocessed ore that is not within the assessment area. Information regarding the ore's antimony content was not available. The company experienced financial challenges during 2014, and the mine was place on care-and-maintenance status in early 2015. Although no or only negligible quantities of antimony have been recovered from domestic mines since 2000, the United States produced an average of $326 \mathrm{t}$ per year of antimony contained in ore and concentrates from 1993 through 1999. Most of this antimony was recovered as a byproduct from silver-copper sulfide ore mined primarily in northern Idaho. There has also been some intermittent mining in central Idaho (Yellow Pine District) near Stibnite from 1925 to 1997. Midas Gold Corp. is considering the reactivation of the Yellow Pine property. Although, it is primarily a gold project, the deposit contains significant amounts of potentially recoverable antimony (Midas Gold Corp., 2016).

Primary antimony metal and oxides were produced from imported concentrates at a smelter in Montana. In 2014, approximately 4,230 t of secondary antimony was recovered, almost entirely as a component of lead alloys from recycled leadacid batteries at secondary lead smelters.

The United States relies on foreign sources of raw and processed antimony to meet its commercial and strategic requirements. In 2014, the United States imported approximately $24,200 \mathrm{t}$ of antimony contained in concentrates, raw metal, and other unwrought forms, and net import reliance, as a percentage of apparent consumption, was 84 percent. In 2014, China accounted for 76 percent of global antimony mine production and for 76 percent of antimony metal and oxide (metal content) imported to the United States. In 2014, world antimony mine production was estimated to be $158,000 \mathrm{t}$. Other major producers and their percentage share of world production in 2014 were Russia (approximately 6 percent); Australia (4 percent); and Bolivia, Tajikistan, and Turkey (3 percent each). From the year
2000 through 2014, the compound annual growth rate of world antimony production was 2 percent.

The U.S. Defense Logistics Agency does not hold a stockpile of antimony, although it is monitored for supply adequacy. Antimony sulfide is used by the U.S. Department of Defense (DOD) as a constituent in percussion primers for ammunition. Currently, there are few, if any, substitutes for antimony sulfide that meet DOD requirements, and sources of antimony sulfide are primarily limited to China. Antimony is not typically categorized as a critical metal (National Science and Technology Council, 2016).

The average annual antimony price since the year 2000 ranged from a low of about $\$ 1,430$ per metric ton $(\$ / t)$ in 2001 to a high of $\$ 14,300 / t$ in 2011. In 2015, the nominal average price of antimony had dropped to approximately $\$ 7,200 / t$ (Kelly and Matos, 2007; Llewellyn, 1993; Guberman, 2015, 2016).

\section{References Cited}

Guberman, D.E., 2015, Antimony [advanced release] in Metals and minerals: U.S. Geological Survey, Minerals Yearbook 2013, v.1, p. 6.1-6.8, accessed February 9, 2016, at http:// minerals.usgs.gov/minerals/pubs/commodity/antimony/ myb1-2013-antim.pdf.

Guberman, D.E., 2016, Antimony: U.S. Geological Survey Mineral Commodity Summaries 2016, p.24-25, accessed February 4, 2016, at http://minerals.usgs.gov/minerals/pubs/ commodity/antimony/mcs-2016-antim.pdf.

Kelly, T.D., and Matos, G.R., compilers, 2007, Historical statistics for mineral and material commodities in the United States: U.S. Geological Survey Data Series 140, ver. 2011, accessed February 4, 2016, at http://minerals.usgs. gov/minerals/pubs/historical-statistics/.

Llewellyn, T.O., 1993, Antimony: U.S. Bureau of Mines Mineral Commodity Summaries 1993, p. 22-23.

Midas Gold Corp., 2016, Midas Gold projects: Midas Gold Corp. Web page, accessed March 10, 2016, at http://www.midasgoldinc.com/s/goldenmeadows. asp?ReportID $=445651$.

National Science and Technology Council, 2016, Assessment of critical minerals - Screening methodology and initial application: National Science and Technology Council, Subcommittee on Critical and Strategic Mineral Supply Chains of the Committee on Environment, Natural Resources, and Sustainability, 47 p., accessed March 10, 2016, at https://www.whitehouse.gov/sites/default/files/ microsites/ostp/NSTC/csmsc_assessment_of_critical_ minerals_report_2016-03-16_final.pdf. 
U.S. Geological Survey, 2013, Metal prices in the United States through 2010: U.S. Geological Survey Scientific Investigations Report 2012-5188, p. 7-12, accessed February 10, 2016, at http://pubs.usgs.gov/sir/2012/5188/.

\section{Barite}

Barite is the mineralogical name for barium sulfate $\left(\mathrm{BaSO}_{4}\right)$, also known as barytes. In pure form, it has the highest specific gravity of any nonmetallic mineral, which makes it useful as a filler, extender, and weighting agent in a wide variety of applications including cement, paints, plastics, and rubber. However, its primary use is as a weighting agent in fluids used in the drilling of oil and natural gas wells. Globally, more than 80 percent of barite is used for this purpose (The Barytes Association, undated), and in the United States this use exceeds 97 percent.

For most applications, barite needs to be ground to a small uniform size before use. The American Petroleum Institute (API) sets specifications for barite used in drilling fluids. The most important characteristic of barite used in drilling mud is its specific gravity (SG), and until 2010, the API specification called for a minimum SG of 4.2. After concerns developed about dwindling reserves of 4.2-SG barite in the United States, the API issued a new edition of API Specification 13A, Specification for Drilling Fluids Materials, adding specifications for 4.1-SG barite (American Petroleum Institute, 2010). Since the adoption of the 4.1-SG specification, 4.1 and sub 4.1-SG barite gained widespread acceptance in the U.S. drilling industry. Barite's other advantageous properties include low abrasion, low oil absorption, chemical and physical inertness, nontoxicity, low solubility, and being relatively inexpensive in comparison to alternatives.

The United States was the world's fourth-ranked producer of barite, producing approximately 8 percent of total world production in 2014. The leading producers and their percentage share of world production were China (44 percent), India (19 percent), and Morocco (11 percent) (McRae, 2015a). The United States is the world's leading barite consumer, using an average of approximately 3 million metric tons (Mt) per year for the past 10 years. Nearly all U.S. production is used domestically. Domestic barite production peaked in the early 1980s, when more than $2 \mathrm{Mt}$ was produced annually. A large decrease in domestic consumption, coupled with the availability of low-priced foreign imports contributed to a sudden decrease in domestic barite production in the mid-1980s (Bleiwas and Miller, 2015; Kelly and Matos, 2014). During this same time period, China surpassed the United States as the world's leading barite producer, and U.S. imports surpassed domestic production. Since 2000, the United States net import reliance, as a percentage of apparent consumption, has averaged approximately 80 percent. Barite is not considered a critical or strategic mineral under any of the widely accepted definitions.

Although numerous States have historically produced barite, barite mine production in Nevada has long led all other domestic production, the bulk of which has been concentrated in Elko (located within or near the boundaries of the assessment area) and Lander Counties. The Big Ledge Mine in Elko is within the Public
Land Survey System (PLSS) and has historically produced barite as the need arises. It was restarted in 2007 by Spirit Minerals, LP, and operated currently by National Oilwell Varco, LP. Nevada is thought to contain the leading share of U.S. barite resources. Since 2007, USGS estimated that U.S. barite reserves were approximately $15 \mathrm{Mt}$, most of which is located in ore deposits in Nevada (Miller, 2007; McRae, 2015a). It should be noted that the latest revision to the reserve estimate was made when 4.2-SG barite was the industry standard and before the widespread usage of 4.1 and sub 4.1-SG barite.

After peaking in the early 1980s, consumption trended downward through 2003, and U.S. barite consumption began resurgence in 2005 owing to advances in the application of horizontal drilling techniques and hydraulic fracturing in onshore shale and other tight formations. Concern was growing, however, within the barite industry about an imminent shortage of 4.2 SG barite.

As a consequence, exploration and development projects have been very active in northeastern Nevada in the past decade. Three oil services companies have either opened or begun development of new mines, two in Lander County and one in Elko County. A fourth company completed an expansion project of its mine in Elko County and the Bureau of Land Management announced in late 2015 that it was preparing an environmental impact statement for another expansion that would extend mine life by an additional 8 years (Bureau of Land Management, 2015). These same companies have also invested in processing capacity. In 2005, Nevada's grinding mill capacity was estimated to be 650,000 metric tons per year (Roskill Information Services, Ltd., 2006, p. 152). In 2015, grinding capacity was an estimated $1.7 \mathrm{Mt}$ per year, more than double the amount of current annual mine production (Allen, 2015).

Numerous smaller projects have also received permits; primarily projects reprocessing tailings piles at abandoned mine operations. Because barite is often associated with gold deposits, gold exploration companies have been known to enter into agreements allowing other companies to explore for barite on their properties (McRae, 2015b). It is unknown if any of these projects have come to fruition.

Since 1990, the price of barite per metric ton $(\$ / t)$, expressed in constant 1998 U.S. dollars was lowest in 2003 at about $\$ 40 / t$ to high of about \$96/t in 2012 (Kelly and Matos, 2014). The price of crude barite had increased significantly from the mid-2000s through 2014 in response to increased demand for domestic drilling by the oil and gas industry. In 2014, the average 1998 U.S. dollar unit value for crude barite was $\$ 93 /$, free on board (f.o.b.), mine.

The number of operating drill rigs exploring for oil and gas traditionally has been a good barometer of barite consumption or industry stockpiling. The monthly average of drill rigs operating in December 2014 was 1,882, which by December 2015 had decreased to 714. Petroleum production in the United States is expected to decline through 2017, and many companies are expected to scale back investment in new projects (U.S. Energy Information Administration, 2016). The decrease in drilling 
activity is estimated to have reduced domestic barite consumption by approximately 25 percent to 30 percent in 2015 . Because of this decline, it is likely that many of the aforementioned barite exploration and development projects have been put on hold until oil prices stabilize. However, a return to growth in the U.S. onshore oil and gas industry will necessitate a return to development of barite resources.

\section{References Cited}

Allen, John, 2015, Barytes sourcing and marketing: IMFormed Oilfield Minerals and Markets Forum Houston 2015, Houston, Texas, May 27-29, Presentation.

American Petroleum Institute, 2010, API Specification 13A 18th Edition, August 2010: American Petroleum Institute, accessed March 11, 2016, at http://www.api.org/ /media/Files/Certification/ Monogram-APIQR/program-updates/13A-18th-Edition-PurchGuidlines-R1-2011-12-06.pdf.

Barytes Association, The, [undated], What is barytes? - Introduction: Derbyshire, United Kingdom, The Barytes Association, accessed March 10, 2016, at http://www.barytes.org/barytes.html.

Bleiwas, D.I., and Miller, M.M., 2015, Barite-A case study of import reliance on an essential material for oil and gas exploration and development drilling: U.S. Geological Survey Scientific Investigations Report 2014-5230, 6 p., accessed March 10, 2016, at http://dx.doi.org/10.3133/sir20145230.

Bureau of Land Management, 2015, BLM seeks input on proposed Rossi mine expansion: Bureau of Land Management news release, Sept. 15, accessed March 10, 2016, at http://www.blm.gov/nv/st/ en/info/newsroom/2015/september/blm_seeks_public_input.html.

Kelly, T.D., and Matos, G.R., comps., 2014, Historical statistics for mineral and material commodities in the United States: U.S. Geological Survey Data Series 140, accessed March 10, 2016, at http://minerals.usgs.gov/minerals/pubs/historical-statistics/.

McRae, M.E., 2015a, Barite: U.S. Geological Survey Mineral Commodity Summaries 2015, p. 24-25, accessed January 25, 2016, at http://minerals.usgs.gov/minerals/pubs/commodity/ barite/mcs-2015-barit.pdf.

McRae, M.E., 2015b, Barite in Metals and minerals: U.S. Geological Survey, Minerals Yearbook 2013, v.1, p. 9.1-9.8, accessed January 25,2016 , at http://minerals.usgs.gov/minerals/ pubs/commodity/barite/myb1-2013-barit.pdf.

Miller, M.M., 2007, Barite: U.S. Geological Survey Mineral Commodity Summaries 2007, p. 30-31, accessed January 25, 2016, at http://minerals.usgs.gov/minerals/pubs/commodity/ barite/mcs-2008-barit.pdf.

Roskill Information Services, Ltd., 2006, The economics of barytes: Roskill Information Services, Ltd., 2006, 254 p.
U.S. Energy Information Administration, 2015, Short-term energy outlook (STEO): U.S. Energy Information Administration, 12 p., accessed March 10, 2016, at http://www.eia.gov/forecasts/steo/pdf/ steo_full.pdf.

\section{Bentonite Clay}

Bentonite predominantly consists of smectite-group minerals (usually montmorillonite) with minor amounts of feldspar, biotite, and quartz. Bentonite is divided into two major types, nonswelling (calcium rich) and swelling (sodium rich). Nonswelling bentonite is used primarily as a binding agent for pelletization of iron ore and foundry sand, as well as for water treatment and filtering. The molecular structure of bentonite with sodium as the major exchangeable cation enables it to absorb several times its dry weight in fluid. The swelling behavior of the clay makes it useful as an important component in drilling muds required for drilling in oil and gas exploration and development, as an impermeable liner for isolating fluids from the environment, and for pet-waste absorbents (Flanagan, 2016; Industrial Minerals AssociationNorth America, 2016; Virta, 2015).

In 2014, the USGS National Minerals Information Center (NMIC) reported that the United States produced a combined total of 25.9 million metric tons (Mt) of six types of clays. At $4.8 \mathrm{Mt}$, bentonite clay represented about 19 percent of the total clay sold or used by domestic producers in 2014. Swelling clays represented about 95 percent of that amount (Flanagan, 2016; Virta, 2015).

In 2013, Alabama was the leading domestic producer of nonswelling bentonite, followed by Mississippi and California (Virta, 2015). These States are not included in the assessment area.

In 2013, Wyoming led all States in the production of swelling bentonite with a 97 percent share, followed, in descending order of tonnage, by Utah, Texas, California, Oregon, Nevada, Montana, and Colorado (Virta, 2015). The States, which include the assessment area, are briefly discussed in the following paragraphs in descending order of estimated production.

Much of Wyoming's bentonite production originated in Big Horn County, which is outside of the SaMiRA project assessment area. Since 2005, bentonite production has been reported in Crook, Hot Springs, Johnson, Natrona, Washakie, and Weston Counties. None of these counties are included in the assessment area (U.S. Geological Survey, 2008e, 2015e).

Utah has produced bentonite since 2005 in Sanpete and Sevier Counties. The two counties are not included in the assessment area (U.S. Geological Survey, 2008d, 2015d).

Bentonite production in Oregon has been reported since 2005 in Malheur County, which is included in the assessment area, and in Crook County, which is not included in the assessment area (U.S. Geological Survey 2008c, 2015c)

Bentonite production in Montana has been reported in Carter County, Montana, since 2005, which is outside of the assessment area. New operations in Valley County are within the assessment area (U.S. Geological Survey 2008a, 2015a).

Bentonite production has been reported since 2005 in the Nevada counties of Esmeralda, Humboldt (possibly hectorite and 
not bentonite), Nye, and Pershing. Humboldt County is in the assessment area, but the others are not (U.S. Geological Survey 2008b, 2015b).

It is possible that bentonite was mined within the assessment area and not identified for reasons which may include (1) clay production reported without identifying type(s), (2) incomplete and inconsistent reporting, and (3) intermittent low-tonnage production.

In 2014, the quantity of bentonite sold and used in the United States of 4.8 Mt was more than the $3.47 \mathrm{Mt}$ that was sold and used in 1990. From 1990 to 2014, the compound annual growth rate in production was approximately 1.4 percent. The trend of increasing domestic production of bentonite from the mid-1990s was driven by its increased use as pet-waste absorbent and in domestic drilling for oil and gas exploration and development. Domestic production of bentonite has leveled off somewhat in recent years as demand for conventional drilling has decreased in response to weaker petroleum prices, increased use of proppants made from kaolin for horizontal drilling, and increases in the amount of imported bentonite (Flanagan, 2016; Kelly and Matos, 2007; Virta, 1993, 1994, 1996, 2004, 2015).

In 2014, approximately 22,000 metric tons ( $t$ ) of bentonite was imported to the United States. This was a significant increase from 1990, when about 2,045 $t$ were imported, but still only represents less than one-half of one percent of domestic usage. The principal sources of bentonite imports in 2013 were Mexico (43 percent), China (23 percent), Egypt (13 percent), and the United Kingdom (12 percent) (Virta, 2015 Kelly and Matos, 2007).

In 2014, the United States exported about 901,000 t of bentonite, or about 19 percent of estimated domestic sales. Canada was the primary recipient of U.S. bentonite exports ( 49 percent), followed by Japan (11 percent) and China (6 percent). For the years 1990 through 2014, exports reached a high of $1.43 \mathrm{Mt}$, but declined shortly thereafter in response to the global recession (Flanagan, 2016; Virta, 2015).

The United States is a net exporter of bentonite. The U.S. bentonite industry is able to meet domestic demand with relatively low imports while at the same time continuing to export comparatively high tonnages of the clay (Flanagan, 2016).

Apparent consumption of bentonite in the United States was approximately $2.78 \mathrm{Mt}$ in 1990 and trended upward to about $3.48 \mathrm{Mt}$ in 2013. Apparent consumption increased during the 24-year period as a function of growing demand for use in drilling muds and absorbents, which was met by an increase in domestic production and imports relative to the amount of bentonite exported (Kelly and Matos, 2007).

The U.S. Defense Logistics Agency does not hold a stockpile of bentonite, and the commodity is not considered of strategic or critical importance. The United States has large reserves and significant production. The United States does not rely on imports to meet its commercial and strategic requirements for the commodity.

From 1990 to 2014, the total world bentonite mine production increased from $9.6 \mathrm{Mt}$ to an estimated $16.1 \mathrm{Mt}$, for an average compound annual growth rate of 2.2 percent. In 1990, the United States was the world leader in bentonite production with $3.47 \mathrm{Mt}$ that represented a 36 percent share of world production. In
2014, the United States maintained its position as the world leader in bentonite production with $4.8 \mathrm{Mt}$, albeit with a lower percentage share of 30 percent. Other major producers of bentonite in 2014 and estimates of their respective share of global production were China (22 percent) and Greece and India (about 7 percent each). The increase in world bentonite production was driven primarily by demand in the oil and gas energy sector and the broad uses of the clay as an absorbent and binder in iron ore pelletizing and foundry sand to meet the needs of a growing global population (Flanagan, 2016; Kelly and Matos, 2007; Virta, 1992).

The average annual unit value per metric ton $(\$ / t)$ of bentonite, expressed in constant 1998 U.S. dollars, ranged from a low of $\$ 17.10 / \mathrm{t}$ in 2008 during the global recession to a high of about $\$ 45.50 / t$ in 2014 . The increase in price over the past several years was primarily driven by higher demand for drilling mud. The price and level of demand for bentonite may be somewhat lessened over the next few years as if drilling for oil and gas continues to decrease (Flanagan, 2016; Kelly and Matos, 2007; Virta, 1992, 1993, 2004, 2015).

\section{References Cited}

Flanagan, D.M., 2016, Clays: U.S. Geological Survey Mineral Commodity Summaries 2016, p. 50-51, accessed February 22, 2016, at http://minerals.usgs.gov/minerals/pubs/commodity/clays/mcs2016-clays.pdf.

Industrial Minerals Association-North America, 2016, What is bentonite?: Washington, DC, Industrial Minerals AssociationNorth America, accessed March 3, 2016, at http://www.ima-na. org/?page=what_is_bentonite.

Kelly, T.D., and Matos, G.R., comps., 2007, Historical statistics for mineral and material commodities in the United States: U.S. Geological Survey Data Series 140, ver. 2011, accessed February 22, 2016, at http://minerals.usgs.gov/minerals/pubs/historicalstatistics/.

U.S. Geological Survey, 2008a, The mineral industry of Montana, in Area reports-Domestic: U.S. Geological Survey Minerals Yearbook, 2005, v. II, p. 28.1-28.7, accessed March 3, 2016, at http:// minerals.usgs.gov/minerals/pubs/state/2005/myb2-2005-mt.pdf.

U.S. Geological Survey, 2008b, The mineral industry of Nevada, in Area reports-Domestic: U.S. Geological Survey Minerals Yearbook, 2005, v. II, p. 30.1-30.12, accessed March 3, 2016, at http:// minerals.usgs.gov/minerals/pubs/state/2005/myb2-2005-nv.pdf.

U.S. Geological Survey, 2008c, The mineral industry of Oregon, in Area reports-Domestic: U.S. Geological Survey Minerals Yearbook, 2005, v. II, p. 39.1-39.4, accessed March 3, 2016, at http://minerals.usgs.gov/minerals/pubs/state/2005/myb22005-or.pdf.

U.S. Geological Survey, 2008d, The mineral industry of Utah, in Area reports-Domestic: U.S. Geological Survey Minerals Yearbook, 2005, v. II, p. 47.1-47.9, accessed March 3, 2016, at http:// minerals.usgs.gov/minerals/pubs/state/2008/myb2-2008-ut.pdf. 
U.S. Geological Survey, 2008e, The mineral industry of Wyoming, in Area reports-Domestic: U.S. Geological Survey Minerals Yearbook, 2005, v. II, p. 53.1-53.6, accessed March 3, 2016, at http://minerals.usgs.gov/minerals/pubs/state/2005/myb22005-wy.pdf.

U.S. Geological Survey, 2015a, The mineral industry of Montana, in Area reports-Domestic: U.S. Geological Survey Minerals Yearbook, 2010-2011, v. II, p. 28.1-28.12, accessed March 3, 2016, at http://minerals.usgs.gov/minerals/pubs/state/2010_11/ myb2-2010_11-mt.pdf.

U.S. Geological Survey, 2015b, The mineral industry of Nevada, in Area reports-Domestic: U.S. Geological Survey Minerals Yearbook, 2010-2011, v. II, p. 30.1-30.17, accessed March 3, 2016, at http://minerals.usgs.gov/minerals/pubs/state/2010_11/ myb2-2010_11-nv.pdf.

U.S. Geological Survey, 2015c, The mineral industry of Oregon, in Area reports-Domestic: U.S. Geological Survey Minerals Yearbook, 2010-2011, v. II, p. 39.1-39.9, accessed March 3, 2016, at http://minerals.usgs.gov/minerals/pubs/state/2010_11/ myb2-2010_11-or.pdf.

U.S. Geological Survey, 2015d, The mineral industry of Utah, in Area reports-Domestic: U.S. Geological Survey Minerals Yearbook, 2010-2011, v. II, p. 47.1-47.14, accessed March 3, 2016, at http://minerals.usgs.gov/minerals/pubs/state/2010_11/ myb2-2010_11-ut.pdf.

U.S. Geological Survey, 2015e, The mineral industry of Wyoming, in Area reports-Domestic: U.S. Geological Survey Minerals Yearbook, 2010-2011, v. II, p. 53.1-53.8, accessed March 3, 2016, at http://minerals.usgs.gov/minerals/pubs/state/2010_11/ myb2-2010_11-wy.pdf.

Virta, R.L., 1992, Clay, in Metals and minerals: U.S. Bureau of Mines, Minerals Yearbook 1992, v. 1, p. 379-412, accessed February 22, 2016, at http://minerals.usgs.gov/minerals/pubs/ commodity/clays/190494.pdf.

Virta, R.E., 1993, Clays: U.S. Bureau of Mines Mineral Commodity Summaries 1993, p. 48-49.

Virta, R.L., 1994, Clay, in Metals and minerals: U.S. Bureau of Mines, Minerals Yearbook 1994, v. 1, p. 1-23, accessed February 22, 2016, at http://minerals.usgs.gov/minerals/pubs/ commodity/clays/190494.pdf.

Virta, R.L., 1996, Clays: U.S. Geological Survey Mineral Commodity Summaries 1995, p. 44 45, accessed on February 22, 2016, at http://minerals.usgs.gov/minerals/pubs/commodity/ clays/claysmcs96.pdf.

Virta, R.L., 2004, Clay and shale, in Metals and minerals: U.S. Geological Survey, Minerals Yearbook 2004, v. 1, p. 18.118.28, accessed February 22, 2016, at http://minerals.usgs.gov/ minerals/pubs/commodity/clays/claysmyb04.pdf.
Virta, R.L., 2015, Clay and shale [advanced release], in Metals and minerals: U.S. Geological Survey, Minerals Yearbook 2013, v. 1, p. 18.1-18.22, accessed February 22, 2016, at http://minerals.usgs. gov/minerals/pubs/commodity/clays/myb1-2013-clays.pdf.

\section{Copper}

Copper finds its major use in electrical applications distributed throughout all sectors of the global economy through use in the generation and distribution of electricity, signal transfer, and the circuitry of electronic devices. Other uses include plumbing tube, heat exchangers, building hardware, and roofing, and coinage.

Publications of the USGS National Minerals Information Center (NMIC) reported that in 2014 the United States remained the world's fourth-ranked mine producer of copper, behind Chile, China, and Peru, and accounted for approximately 7 percent of global production. Although from 1990 through 2014 U.S. copper mine production decreased at a compound annual rate of 1 percent, from 1990 through 1997, copper mine production rose by 22 percent to a record-high 1.94 million metric tons (Mt) before trending downward to $1.11 \mathrm{Mt}$ in 2010. From 2011 through 2014, U.S. mine production trended upward, increasing by 22 percent from $1.11 \mathrm{Mt}$ through $1.36 \mathrm{Mt}$ (Brininstool, 2016).

Mine production during the next several years will likely remain close to the current level. The principal mining States for copper were, in descending order of production, Arizona, Utah, New Mexico, Nevada, and Montana, which altogether accounted for more than 99 percent of domestic production (Brininstool, 2016). No significant copper production has been reported within the assessment area since at least 1990. Nearly all of the copper in the United States is recovered from ore extracted from large openpit mines that used conventional flotation to produce concentrate for smelting and refining or leaching and solvent extractionelectrowinning methods to recover refined copper.

The United States exports a significant amount of copper concentrate for offshore smelting and refining. In 2014, it was estimated that U.S. copper ore reserves contained approximately $35 \mathrm{Mt}$ of copper. In addition to $1.05 \mathrm{Mt}$ of domestic primary refined copper production in 2014, an additional 796 thousand metric tons of copper was recovered from scrap. There are also large producer, merchant, and consumer stocks of copper maintained in the United States. The U.S. Defense Logistics Agency does not hold a stockpile of copper, having liquidated its inventories in 1993. Historically, copper has been considered a strategic and critical material, with various price controls, export controls, Government stockpiling, and production incentives through the World Wars and the Vietnam War. The United States currently produces a significant amount of copper relative to its reduced consumption levels, and domestically imported supplies of copper are varied and generally from the Western Hemisphere. Therefore, copper is no longer categorized as a strategic and critical commodity despite its importance to the U.S. economy. 
The United States relies on foreign sources of raw and processed copper to supplement its commercial and strategic requirements. In 2014, U.S. apparent consumption of refined copper was approximately 1.78 Mt. In 1990, net import reliance, as a percentage of apparent consumption, was 3 percent. By 2014, net import reliance had increased to 31 percent as a result of increased exports of concentrates for offshore treatment because of decreased domestic smelting and refining capacity (Brininstool, 2016).

From 1990 to 2014, the total world copper mine production more than doubled at an average compound annual growth rate of nearly 4 percent (Brininstool, 2016; Kelly and Matos, 2007). Since 2000, world refined copper production increased at average compound annual growth rate of approximately 2.6 percent, reaching about $21 \mathrm{Mt}$ in 2014 with about 18 percent from secondary sources. The general trend of increased copper production reflects the growing global demand for use in consumer products, such as appliances and automobiles, and for building and upgrading infrastructure in China, India, and other developing economies. China has emerged as the leading driver for global demand, accounting for more than 40 percent of global consumption since 2011 and about 48 percent in 2014 (International Copper Study Group, 2016, p. 19). Barring global economic recession, the trend of increasing consumption may continue for the balance of the decade.

The average annual domestic producer price per pound of copper in nominal dollars over the past decade ranged from a low of $\$ 1.73$ per pound in 2005 to a high of $\$ 4.06$ in 2011 (Kelly and Matos, 2007). The price of the metal declined throughout 2015. In 2015, the average producer price was $\$ 2.56$ per pound (M. Brininstool, USGS, written commun., January 21, 2016). In general, higher prices reflect periods of greater demand and a tightening of supply.

\section{References Cited}

Brininstool, M., 2016, Copper: U.S. Geological Survey Commodity Summaries 2015, p. 54-55, accessed on February 4, 2016, at http://minerals.usgs.gov/minerals/pubs/mcs/2016/mcs2016.pdf.

International Copper Study Group, 2016, December 2015 Copper Bulletin: Lisbon Portugal, International Copper Study Group, February 22, $53 \mathrm{p}$.

Kelly, T.D., and Matos, G.R., comps., 2007, Historical statistics for mineral and material commodities in the United States: U.S. Geological Survey Data Series 140, ver. 2011, accessed on February 4, 2016, at http://minerals.usgs.gov/minerals/pubs/ historical-statistics/.

\section{Diatomite}

Diatomite is a chalk-like, soft, friable, earthy, very finegrained, siliceous sedimentary rock comprised of fossilized diatom remains. Diatomite is used for filter aids ( 55 percent), as a cement additive (21 percent), as a filler (14 percent), as an absorbent ( 9 percent), and in other applications (Crangle, 2013, 2016).

The USGS National Minerals Information Center (NMIC) reported that about 901,000 metric tons $(\mathrm{t})$ of processed diatomite ore was sold and used by producers in the United States in 2014. The United States ranked first in global diatomite mine production. In 2014, diatomite was produced from mines in California, Nevada, Oregon, and Washington (Crangle, 2016). Diatomite production is ongoing or has occurred in the assessment area States since 2005 in the Nevada counties of Elko, Humboldt, and Washoe. Diatomite was previously mined in Lake County, Oregon, and a deposit was identified in Camas County, Idaho (Powers, 1947; Taylor, 1994).

In 2014, 901,000 $t$ of diatomite was sold and used by producers, significantly more than the 631,000 $\mathrm{t}$ in 1990 . The average annual growth rate was 1.5 percent over the period. In 2014, U.S. diatomite reserves were estimated to be 250 million metric tons $(\mathrm{Mt})$. The apparent consumption of diatomite in the United States increased from 488,000 $\mathrm{t}$ in 1990 to $823,000 \mathrm{t}$ in 2014 (Crangle, 2016; Kelly and Matos, 2007).

In 2014, the United States exported about 82,000 t of diatomite compared to 488,000 t exported in 1990. The decrease in exports reflects the increased domestic consumption, as well as increases in production among some competing foreign producers, such as China. Approximately 4,000 t of diatomite were imported for domestic consumption in 2014 compared to $1,000 \mathrm{t}$ in 1990. Imports have not been a significant component of domestic consumption (Crangle, 2016; Kelly and Matos, 2007). For 2011-14, three countries accounted for 80 percent of U.S. diatomite imports-Mexico (30 percent), Canada (26 percent), and France (24 percent) (Crangle, 2016).

The United States is a net exporter of diatomite making its net import reliance as a percentage of apparent consumption zero for 2014, which has been the case since at least 1990 (Crangle, 2016; Davis, 1992).

The U.S. Defense Logistics Agency does not hold a stockpile of diatomite. Diatomite is not considered a strategic or critical commodity because of substantial U.S. production and substantial reserves and stocks held by producers and consumers (Crangle, 2016; Davis, 1992). In addition, substitutes exist for diatomite in most applications.

From 1990 to 2014, total world diatomite production increased from $1.68 \mathrm{Mt}$ to $2.26 \mathrm{Mt}$ for an average annual growth rate of about 1.2 percent. In 2014, the United States was the world leader in diatomite production with 901,000 t, which represented a 40 percent share. Other major diatomite producers in 2014 and their respective share of global production were China (19 percent), Peru (6 percent), and Argentina (4 percent). In 1994, China represented about 11 percent of world production (Taylor, 1994). Production in China for the years 1990-93 was not available.

According to reported by U.S. diatomite producers, the average unit value per metric ton $(\$ / t)$ of diatomite ranged from a high of $\$ 283 / \mathrm{t}$ in 1993 to a low of about $\$ 170 / \mathrm{t}$ in 2009. In 2014 , the average unit value of diatomite in nominal dollars was approximately \$298/t (Kelly and Matos, 2007; Crangle, 2016). 


\section{References Cited}

Crangle, R.D., Jr., 2013, Diatomite [advanced release], in Metals and minerals: U.S. Geological Survey, Minerals Yearbook 2014, v. 1, p. 22.1-22.5, accessed February 9, 2016, at http://minerals. usgs.gov/minerals/pubs/commodity/lead/myb1-2010-lead.pdf.

Crangle, R.D., Jr., 2016, Diatomite: U.S. Geological Survey Mineral Commodity Summaries 2016, p. 58-59, accessed February 4, 2016, at http://minerals.usgs.gov/minerals/pubs/ mcs/2016/mcs2016.pdf.

Davis, L.L., 1992, Diatomite: U.S. Bureau of Mines Mineral Commodity Summaries 1992, p. 60-61.

Kelly, T.D., and Matos, G.R., comps., 2007, Historical statistics for mineral and material commodities in the United States: U.S. Geological Survey Data Series 140, ver. 2011, accessed on February 4, 2016, at http://minerals.usgs.gov/minerals/pubs/ historical-statistics/.

Powers, H.A., 1947, Diatomite deposits of southwestern Idaho, Idaho mineral resources report no. 4: Moscow, Idaho, School of Mines, University of Idaho and Idaho Bureau of Mines and Geology, 27 p., accessed February 11, 2016, at http://www. idahogeology.org/PDF/Mineral_Resource_Reports_(MR)/ MR-04.pdf.

Taylor, H.A., 1994, Diatomite, in Metals and minerals: U.S. Bureau of Mines Minerals Yearbook 1994, v. 1, accessed February 9, 2016, at http://minerals.usgs.gov/minerals/pubs/ commodity/diatomite/250494.pdf.

\section{Dimension Stone-Quartzite}

Dimension stone can be defined as a natural rock material quarried for the purpose of obtaining blocks or slabs that meet specifications as to size (width, length, and thickness) and shape. Color, grain texture and pattern, and surface finish of the stone are aesthetically desirable properties. Durability (essentially based on mineral composition, hardness, and past performance), strength, and the ability of the stone to take a polish are other important selection criteria. In addition to these desirable characteristics, a deposit will only have economic value if the rock is amenable to mining at a profit. Important criteria include the geometry of the deposit, orientation, and the site's access to infrastructure.

Although a variety of igneous, metamorphic, and sedimentary rocks are used as dimension stone, the principal rock types are granite, limestone, marble, sandstone (which includes quartzite), and slate. Other varieties of dimension stone that are normally considered to be special minor types include alabaster (massive gypsum), soapstone (massive talc), and various products fashioned from natural stone (Dolley, 2015).

The USGS National Minerals Information Center (NMIC) reported that approximately 2.47 million metric tons (Mt) of dimension stone valued at $\$ 470$ million was sold or used by U.S. producers in 2014. Dimension stone was produced by 216 companies operating 293 quarries in 34 States. Leading producer States were, in descending order by tonnage, Texas, Indiana, Wisconsin, Massachusetts, and Georgia. These five States accounted for about 66 percent of the production and contributed about 63 percent of the value of domestic production. Approximately 42 percent by tonnage of dimension stone sold or used was limestone, followed by granite (21 percent), sandstone (which includes quartzite; 17 percent), miscellaneous stone (16 percent), marble ( 2 percent), and slate (2 percent). By value, the leading sales or uses were for limestone ( 38 percent), followed by granite ( 25 percent), miscellaneous stone (18 percent), sandstone (which includes quartzite; 11 percent), marble (4 percent), and slate (4 percent) (Dolley, 2016).

Quartzite, a metamorphosed sandstone, has been identified as a dimension and dressed stone that has been quarried in or proximal to the assessment area in Idaho. As there is a wide variety among the types and uses of dimension stone, a full discussion of types other than quartzite is beyond the scope necessary for the assessment area. The USGS does not publish statistical information specific to quartzite dimension stone. Statistical data related to quartzite production is aggregated with sandstone statistics. Quartzite represents a relatively small percentage of the stone included in the category, and in some cases, quartzite may be reported to the USGS as sandstone. Detailed information on production from individual sites is often considered confidential by companies and is therefore not published.

Rough stone represented 59 percent of the tonnage and 49 percent of the value of all the dimension stone sold or used by domestic producers, including exports. The leading uses and distribution of rough stone, by tonnage, were in building and construction (58 percent) and in irregular-shaped stone (27 percent). Dressed stone (usually cut to shape and sometimes smoothed) was primarily sold for facades and partially squared pieces (44 percent), curbing ( 20 percent), and flagging (11 percent), by tonnage (Dolley, 2016).

In 2014, approximately 63,700 metric tons ( $\mathrm{t}$ ) of dimension stone, most of which was slate, was produced in Idaho. It had a nominal value of $\$ 8.64$ million. Quarries that have produced the majority of Idaho's quartzite decorative and dimension stone are located outside the cities of Clayton in Custer County and Oakley in Cassia County. Decorative quartzite and dimension-stone production from Idaho's famous "Oakley Stone," a micaceous quartzite quarried on Middle Mountain, was reported by the USGS in Cassia County, Idaho, in 2000-11. The Three Rivers Quarry near Clayton in Custer County reported production of 18,000 $\mathrm{t}$ of argillaceous quartzite, probably a fine-grained quartzite dimension stone used for flagstone, in 2002 (U.S. Geological Survey, 2004). Production was 23,000-27,000 t in 2006 and 32,000 $t$ in 2007. Production data for prior and subsequent years were withheld to avoid disclosing company proprietary data (Dolley, 2007; U.S. Geological Survey, 2002a, b, 2003, 2005, 2008, 2009, 2010, 2012, 2014, and 2015). 
Examples of the applications of quartzite produced by companies in Cassia County include flagstone, hearths and mantels, retaining walls, steps, table tops, tile, and veneer (Northern Stone Supply, Inc., 2016). It is likely that similar products are also produced by operations in Custer County.

On-site prices for the types of quartzite products vary significantly. Determining factors include the amount of finishing work, dimensions, and shape. It is likely that the bulk of sales of quartzite products shipped from Idaho are limited to regional markets because transportation is a major cost component.

The U.S. Defense Logistics Agency does not hold a stockpile of quartzite or any type of dimension stone. It is not considered a strategic or critical commodity because it is mostly for decorative purposes and numerous materials are readily available that can serve as a substitute for use in its applications.

\section{References Cited}

Dolley, T.P., 2007, Stone, dimension [advanced release], in Metals and minerals: U.S. Geological Survey, Minerals Yearbook 2005, v. 1, p. 72.1-72.13, accessed March 11, 2016, at http:// minerals.usgs.gov/minerals/pubs/commodity/stone_dimension/ dstonmyb05.pdf.

Dolley, T.P., 2015, Stone, dimension [advanced release], in Metals and minerals: U.S. Geological Survey, Minerals Yearbook 2013, v. 1, p. 72.1-72.14, accessed March 9, 2016, at http://minerals. usgs.gov/minerals/pubs/commodity/stone_dimension/myb12013-stond.pdf.

Dolley, T.P., 2016, Stone (dimension): U.S. Geological Survey Mineral Commodity Summaries 2016, p. 152-153, accessed March 9, 2016, at http://minerals.usgs.gov/minerals/pubs/ commodity/stone_dimension/mcs-2015-stond.pdf.

Northern Stone Supply, Inc., 2016, Products: Oakley, Idaho, Northern Stone Supply, Inc., accessed March 10, 2016, at http:// www.northernstonesupply.com/quarries/index.html.

U.S. Geological Survey, 2002a, The mineral industry of Idaho, in Area reports-Domestic: U.S. Geological Survey Minerals Yearbook 2000, v. II, p. 14.1-14.5, accessed March 9, 2016, at http://minerals.usgs.gov/minerals/pubs/commodity/stone_ dimension/800400.pdf.

U.S. Geological Survey, 2002b, The mineral industry of Idaho, in Area reports-Domestic: U.S. Geological Survey Minerals Yearbook 2004, v. II, p. 14.1-14.6, accessed March 11, 2016, at http://minerals.usgs.gov/minerals/pubs/commodity/stone_ dimension/dimsmyb02.pdf.

U.S. Geological Survey, 2003, The mineral industry of Idaho, in Area reports-Domestic: U.S. Geological Survey Minerals Yearbook 2001, v. II, p. 14.1-14.5, accessed March 11, 2016, at http://minerals.usgs.gov/minerals/pubs/commodity/stone dimension/dimsmyb01.pdf.
U.S. Geological Survey, 2002, The mineral industry of Idaho, in Area reports-Domestic: U.S. Geological Survey Minerals Yearbook, 2002, v. II, p. 14.1-14.5, accessed March 3, 2016, at http:// minerals.usgs.gov/minerals/pubs/state/2002/idstmyb02.pdf.

U.S. Geological Survey, 2005, The mineral industry of Idaho, in Area reports-Domestic: U.S. Geological Survey Minerals Yearbook 2003, v. II, p. 14.1-14.5, accessed March 11, 2016, at http://minerals.usgs.gov/minerals/pubs/state/2003/idstmyb03. pdf.

U.S. Geological Survey, 2008, The mineral industry of Idaho, in Area reports-Domestic: U.S. Geological Survey Minerals Yearbook 2005, v. II, p. 14.1-14.7, accessed March 9, 2016, at http://minerals.usgs.gov/minerals/pubs/state/2005/myb22005-id.pdf.

U.S. Geological Survey, 2009, The mineral industry of Idaho, in Area reports-Domestic: U.S. Geological Survey Minerals Yearbook 2006, v. II, p. 14.1-14.7, accessed March 9, 2016, at http://minerals.usgs.gov/minerals/pubs/state/2005/myb22005-id.pdf.

U.S. Geological Survey, 2010, The mineral industry of Idaho, in Area reports-Domestic: U.S. Geological Survey Minerals Yearbook 2007, v. II, p. 14.1-14.5, accessed March 9, 2016, at http://minerals.usgs.gov/minerals/pubs/commodity/stone dimension/myb1-2007-stond.pdf.

U.S. Geological Survey, 2012, The mineral industry of Idaho, in Area reports-Domestic: U.S. Geological Survey Minerals Yearbook 2008, v. II, p. 14.1-14.5, accessed March 9, 2016, at http://minerals.usgs.gov/minerals/pubs/state/2008/myb22008-id.pdf.

U.S. Geological Survey, 2014, The mineral industry of Idaho, in Area reports-Domestic: U.S. Geological Survey Minerals Yearbook 2009, v. II, p. 14.1-14.6, accessed March 9, 2016, at http://minerals.usgs.gov/minerals/pubs/state/2009/myb22009-id.pdf.

U.S. Geological Survey, 2015, The mineral industry of Idaho, in Area reports-Domestic: U.S. Geological Survey Minerals Yearbook 2010-2011, v. II, p. 14.1-14.11, accessed March 9, 2016, at http://minerals.usgs.gov/minerals/pubs/state/2010_11/ myb2-2010_11-id.pdf.

\section{Gallium}

Mined gallium is recovered globally as a byproduct of processing bauxite and zinc ores. Gallium is used in microelectronic components of a wide variety of products. The components include gallium arsenide (GaAs), gallium nitride (GaN), and copper-indium-gallium selenide (CIGS) direct band-gap semiconductors. GaAs and $\mathrm{GaN}$ are used in the manufacture of light-emitting diodes (LEDs), laser diodes, photo detectors, and solar cells. These devices are important for 
the aerospace and telecommunications industries. They are also used in the production of highly specialized integrated circuits, semiconductors, and transistors to help regulate the flow of electricity and amplify power. These components are necessary for high-performance computers and smartphones (cellular telephones that have advanced personal computer-like functionality). Power transistors made with GaN operate at higher voltages and with a higher power density than those made with GaAs. The types and numbers of products that use advanced $\mathrm{GaN}$ based transistors are expected to increase in the future. CIGS was developed to make lightweight and durable thin-film photovoltaics that have a high absorption coefficient and applications in the manufacture of solar cells (Foley and Jaskula, 2013).

GaAs applications accounted for about 80 percent of the worldwide gallium market, whereas GaN and CIGS applications accounted for about 7 percent and 5 percent, respectively. Various other applications accounted for the remaining 8 percent (Jaskula, 2015).

Domestically, GaAs and GaN wafers used in integrated circuits and optoelectronic devices accounted for approximately 75 percent of gallium consumption. Uses in the United States include integrated circuits for defense applications, highperformance computers, and telecommunications equipment. Optoelectronic devices, which include laser diodes, LEDs, photodetectors, and solar cells, accounted for nearly all of the remaining gallium consumption (Jaskula, 2016).

Publications of the USGS National Minerals Information Center (NMIC) reported that in 2014, the United States did not recover gallium metal from domestic mining and has not done so since 1987 . The Cordero primary gallium project, located within the assessment area, has been actively explored, but no production has been reported (Business Wire, 2005). The U.S. Geological Survey publishes detailed analyses and statistical data related to gallium derived from mining (gallium metal), GaAs wafers, and GaN wafers. GaAs and GaN wafers are manufactured products; the major focus of the following discussion is unwrought gallium metal, "waste," and "scrap," as it is more relevant to the methodology applied to the assessment area as it relates to mining (Jaskula, 2015, 2016).

Gallium is not recovered from old scrap in the United States; however, substantial quantities of domestic and imported new scrap generated in the manufacture of GaAs-based devices are reprocessed to recover high-purity gallium at one facility in Utah. The amounts and type of exported scrap are not available (Jaskula, 2016).

Approximately 53.9 metric tons $(\mathrm{t})$ of unwrought gallium waste and scrap were imported and consumed in the United States in 2014. Imports have increased significantly since 1990, when only $9.9 \mathrm{t}$ were imported. The rise reflects the increase in domestic waste-processing capacity and the Nation's demand for the production of electronic circuitry and other products that use the metal. The compound average annual growth rate in imports of nearly 7 percent over the time period reflects the increase in demand for technologically advanced products and growth in domestic manufacturing. For the years 2011-14, Germany was the leading import source with a 35 percent share. Other major import sources and their percentage shares were China (26 percent), United Kingdom ( 22 percent), and Ukraine ( 9 percent) (Jaskula, 2016; Kelly and Matos, 2007). The United States does not have a vertically integrated gallium mining and processing industry and therefore relies completely on foreign imports to meet the Nation's commercial and strategic requirements. Since 2000, the net import reliance of the United States, as a percentage of apparent consumption has been estimated at 99 or 100 percent (Jaskula, 2016; Kramer, 2001).

Gallium is considered a strategic and critical mineral material because of total or nearly total U.S. import reliance and gallium's use in advanced commercial and military applications. GaAs- and GaN-based integrated circuits are used in many defense-related applications because of their unique properties, and no effective substitutes exist in these applications. The U.S. Defense Logistics Agency, however, does not hold a stockpile of gallium (Jaskula, 2016). From 1990 to 2014, the total amount of byproduct lowgrade primary gallium recovered annually from global mines increased from approximately 37 to $438 \mathrm{t}$. The compound average annual increase of nearly 11 percent reflects the growth in global demand for use in a wide array of applications in advanced technologies. This rate of growth exceeds that of base metals and many other mineral commodities. In 2014, gallium recovered from mining was estimated to be $438 \mathrm{t}$, significantly below the estimated world capacity of $670 \mathrm{t}$, owing to large inventories of primary gallium. China is by far the leading primary gallium producer and possessed more than 80 percent of global production capacity. China's primary gallium production capacity expanded to approximately $550 \mathrm{t}$ per year in 2014 from $140 \mathrm{t}$ in 2010 on the expectations of increases in LED backlighting and general lighting demand. The other major primary gallium producing countries are Germany, Hungary, Japan, Kazakhstan, Republic of South Korea, Russia, and Ukraine (Jaskula, 2015, 2016; Kelly and Matos, 2007; Brian Jaskula, gallium commodity specialist, USGS, oral commun., March 15, 2016).

The average annual price per kilogram of gallium (\$/kg), expressed in constant 1998 U.S. dollars for the purpose of comparison for the years 1990-15, was at a low of $\$ 203 / \mathrm{kg}$ (\$295/kg in nominal dollars) in 2015 owing to China's continued overproduction and continued stock buildup of low-grade primary gallium. Prices attained a high of $\$ 626 / \mathrm{kg}$ in 1999, when gallium supply became tight because of high demand in the telecommunications industry (Jaskula, 2010, 2016; Kelly and Matos, 2007; Kramer, 2001).

\section{References Cited}

Business Wire, 2005, Gold Canyon reports greater than 90 percent recovery of gallium at Cordero: Business Wire, accessed on March 21, 2016, at http://www.businesswire.com/news/ home/20050726005839/en/Gold-Canyon-Reports-Greater-90Recovery-Gallium.

Foley, Nora, and Jaskula, Brian, 2013, Gallium-A smart metal: U.S. Geological Survey Fact Sheet 2013-3006, 2 p., accessed March 15, 2016, at http://pubs.usgs.gov/fs/2013/3006/. 
Jaskula, B.W., 2010, Gallium: U.S. Geological Survey Mineral Commodity Summaries 2010, p. 58-59, accessed on March 15, 2016, at http://minerals.usgs.gov/minerals/pubs/commodity/ gallium/mcs-2010-galli.pdf.

Jaskula, B.W., 2015, Gallium [advanced release], in Metals and minerals: U.S. Geological Survey, Minerals Yearbook 2013, v. 1, p. 27.1-27.8, accessed March 14, 2016, at http:// minerals.usgs.gov/minerals/pubs/commodity/gallium/myb12013-galli.pdf.

Jaskula, B.W., 2016, Gallium: U.S. Geological Survey Mineral Commodity Summaries 2016, p. 64-65, accessed on March 14, 2016, at http://minerals.usgs.gov/minerals/pubs/commodity/ gallium/mcs-2016-galli.pdf.

Kelly, T.D., and Matos, G.R., comps., 2007, Historical statistics for mineral and material commodities in the United States: U.S. Geological Survey Data Series 140, ver. 2011, accessed February 4, 2016, at http://minerals.usgs.gov/minerals/pubs/ historical-statistics/.

Kramer, B.W., 2001, Gallium: U.S. Geological Survey Mineral Commodity Summaries 2000, p. 60-61, accessed on March 14, 2016, at http://minerals.usgs.gov/minerals/pubs/commodity/ gallium/460301.pdf.

\section{Gemstones}

At least three gemstones are known to be produced in or proximal to the SaMiRA project assessment area - aventurine, precious opal, and sunstone.

Aventurine, also known as aventurine quartz, is a type of light- to dark-green quartz that exhibits a metallic iridescence or glittering (aventurescence), which is caused by light reflecting off of included fuchsite (green mica) flakes. Sometimes it occurs with red- or golden-brown color exhibiting metallic iridescence caused by included hematite flakes. It is cut into cabochons (unfaceted stones) and is carved into ornamental objects. Aventurine deposits are found in Austria, Brazil, India, Russia, Tanzania, and the United States (Schumann, 1998, p.122).

Opal is a mineraloid in the form of hydrated amorphous silicon dioxide and is generally classified as common opal or precious opal. It is valued as a precious opal for the intense rainbow of colors displayed as it diffracts and refracts light when it is shaped and polished to produce cabochons and, less commonly, cut and faceted. The value of precious opal can vary significantly and depends largely on the size of the gem, the intensity and range of colors it displays, and uniformity of the stone (Geology.org, 2016). A large part of the world's precious opal is mined in Australia, but it is also mined in significant quantities in Brazil, Ethiopia, Guatemala, Honduras, Indonesia, Japan, Mexico, Russia, and the United States. Common opal is usually milky in color, opaque, and may be used in jewelry and may have value to mineral collectors. It does not usually share the more-valued "rainbow" of colors and other characteristics of precious opal and is rarely considered a gemstone. Common opal has relatively low value and is mined in many countries (Schumann, 1998, p. 150-152).

Sunstone, also known as aventurine feldspar, is a type of clear, blue, green, orange-brown, red-brown, or yellow oligoclase feldspar that exhibits aventurescence caused by light reflecting off included copper, hematite, or goethite platelets or flakes. It typically is cut into cabochons and is sometimes faceted. Sunstone deposits are found in Canada, India, Madagascar, Norway, Russia, and the United States (Schumann, 1998, p. 166). Sunstone is the State gemstone of Oregon.

The USGS National Minerals Information Center (NMIC) reports on a wide range of statistical data related to the domestic and global production of gemstones with a focus on natural and synthetic gemstones, such as diamonds, emeralds, pearls, and rubies (Olson, 2014, 2016). The NMIC does not publish information on the carat weight of individual gemstone types produced by State, but does provide information on the estimated value of total gemstone production by State through a voluntary survey of mining companies. Statistics may underestimate actual production owing to the relatively low level of response to surveys and the amount of unreported production by individual collectors.

The total value of aventurine production in 2014 is withheld to avoid revealing company proprietary data. Commercial aventurine production and collection by hobbyists takes place in Utah. Production of aventurine in or proximal to the assessment area includes Northern Stone Supply's aventurine operation in Box Elder County, Utah.

The NMIC reported that in 2013 the total value of opal production in the United States was approximately $\$ 93,000$ and represented less than 1 percent of the total estimated value of domestic natural gemstone production. Preliminary estimates suggest that the value of opal production in 2014 was about 5 percent lower (Olson, 2016). Commercial opal production and collection by hobbyists takes place in Arizona, California, Idaho, Louisiana, Nevada, and Oregon. Production of precious and common opal in or proximal to the assessment area includes the Spencer Mine in Clark County, Idaho, and several mines in the Virgin Valley area and in the Calico Mountains in Humboldt County, Nevada (Austin, 1995; U.S. Geological Survey, 2015; Olson, 2016).

The total value of 2013 sunstone production in the United States was approximately $\$ 576,000$ and represented about 6 percent of the total estimated value of domestic natural gemstone production. Preliminary estimates suggest that the value of sunstone production was slightly less in 2014. Production of sunstone in or proximal to the assessment area includes several mines in Harney, Jackson, and Lake Counties, Oregon (Olson, 2016), including the Dust Devil Mining Company, which operates a fee digging sunstone mine near Plush, Oregon.

Aventurine, precious opal and sunstone are not considered to have strategic or critical importance to the United States. Their value is solely based on their actual or speculative desirability for personal adornment. 


\section{References Cited}

Austin, G.T., 1995 Opal, in Gemstones-An overview of production of specific U.S. gemstones: U.S. Bureau of Mines Special Report 14-95, accessed February 19, 2016, at http:// minerals.er.usgs.gov/minerals/pubs/commodity/gemstones/ sp14-95/opal.html.

Gemdata.org, 2016, Common opal: Gemdata.org Web page, accessed on February 19, 2016, at http://www.gemdat.org/gem5981.html.

Geology.com, 2016, Precious opal: Gemdata.org Web page, accessed on February 19, 2016, at http:/geology.com/ gemstones/opal/precious-opal.shtml.

Olson, D.W., 2014 Gemstones, in Metals and minerals: U.S. Geological Survey, Minerals Yearbook 2014, v. 1. p. 62-63, accessed May 23, 2016, at http://minerals.usgs.gov/minerals/ pubs/mcs/2014/mcs2014.pdf.

Olson, D.W., 2016, Gemstones, in Metals and minerals: U.S. Geological Survey, Minerals Yearbook 2013, v. 1, p. 29.129.25, accessed February 19, 2016, at http://minerals.usgs.gov/ minerals/pubs/commodity/gemstones/myb1-2013-gemst.pdf.

Schumann, Walter, 1998, Gemstones of the world: New York, Sterling Publishing Co., Inc., 273 p.

\section{Gold}

Publications of the USGS National Minerals Information Center (NMIC) reported that in 2014, U.S. mines produced about 210 metric tons $(\mathrm{t})$ of gold as a primary product and as coproduct or byproduct of other metals mining and processing; U.S. output ranked fourth in the world. Mines in Nevada and Alaska, the two leading producing States, accounted for about 72 percent and 15 percent, respectively, of domestic gold mine production in 2014. The remainder, in descending order of production, was from mines in Colorado, Utah, Washington, California, Montana, South Dakota, Arizona, and New Mexico, (George, 2016).

Within the assessment area, gold production was reported in Custer and Lemhi Counties, Idaho; in Fergus and Phillips Counties, Montana; and, most significantly, in Elko and Humboldt Counties, Nevada (Environmental Working Group, 2016; U.S. Geological Survey, 2015a, b). Gold production in these States is not within the specified proposed withdrawal areas, at the time of this analysis, but production in Elko and Humboldt Counties in Nevada, does fall within a 25-kilometer $(\mathrm{km})$ zone outside the study area. In 2014, approximately 30 percent of all gold production in Nevada came from mines within the $25-\mathrm{km}$ buffer zone in Elko and Humboldt Counties.

In 2014, the U.S. mine production of gold was about $210 \mathrm{t}$, significantly less than the estimated $294 \mathrm{t}$ that was produced in 1990. Although gold production declined by an average compound annual rate of about 1.4 percent from 1990 through 2014, production rose to a record-high level of $366 \mathrm{t}$ in 1998, owing to development of open-pit leach operations in the Carlin trend. The decline in domestic gold mine production since 1998 can be attributed to a combination of increasing costs, lower ore grades, decreased ore throughput at some mines, closure of some mines, and, reduced output from copper mines. During this period, an increased share of copper mine production was from leaching methods that preclude the recovery of gold. In 2014, it was estimated that U.S. gold ore reserves contained approximately 3,000 t of gold (George, 2016; Kelly and Matos, 2007).

In addition to domestically mined gold, an additional $140 \mathrm{t}$ of the metal was recovered from the recycling of scrap in 2014; a substantial increase from 1990 when $44 \mathrm{t}$ was recovered.

In 2014, the United States exported about 500 t of gold in refined bullion, doré, concentrates, and precipitates and imported approximately $308 \mathrm{t}$ for domestic consumption. Four countries supplied 81 percent of U.S. imports-Mexico (41 percent), Canada (19 percent), Colombia (13 percent), and Peru (8 percent (George, 2016).

For 2014, U.S. consumption of gold was estimated to be $150 \mathrm{t}$, significantly lower than in 1990 when it was estimated to be $215 \mathrm{t}$. The United States has long been a net exporter of gold; however, large unreported investor stock changes preclude calculation of meaningful net import reliance (George, 2016; Kelly and Matos, 2007).

The U.S. Defense Logistics Agency does not hold a stockpile of gold. Gold is not considered a strategic or critical commodity. The United States has substantial production and stocks of gold held by industry and investors, the U.S. Treasury Department, and commodity exchanges. The U.S. Department of Defense operates a Government-wide secondary precious-metals recovery program (George, 2016). From 1990 to 2014, total world mine production of gold increased from 2,180 to 2,990 t at an average compound annual growth rate of about 1.5 percent. In 2014, China led the world in mined gold production with $450 \mathrm{t}$. This was a significant increase from 1990 when China produced an estimated $100 \mathrm{t}$. Other major gold producers in 2014, and their respective shares of global production, were Australia (9 percent); Russia (8 percent); the United States ( 7 percent); Canada, Peru, and South Africa (5 percent each); and Mexico (4 percent). The increase in world gold output from 1990 to 2014 has been driven by an overall increase in the demand for the metal in electronics and jewelry and as an investment vehicle, especially among some Asian countries, notably India (George, 2016; Kelly and Matos, 2007).

The average annual gold price per troy ounce, expressed in constant 1998 U.S. dollars, since 1990, ranged from a low of about $\$ 250$ per troy ounce $(\$ 8,060,000 / \mathrm{t})$ in 2001 to a high of $\$ 1,673$ per troy ounce in $2012(\$ 38,200,000 / t)$. In 2015 , the average price of gold in nominal dollars was approximately $\$ 1,163$ per troy ounce $(\$ 32,262,000 / \mathrm{t})$ (Kelly and Matos, 2007; George, 2016). 


\section{References Cited}

Environmental Working Group, 2016, Who owns the West: Environmental Working Group Web page, accessed on February 16, 2016, at http://www.ewg.org/mining/plans/index. php?stab=ID\&fips.

George, M.W., 2016, Gold: U.S. Geological Survey Mineral Commodity Summaries 2016, p.72-73, accessed on February 4, 2016 at http://minerals.usgs.gov/minerals/pubs/mcs/2016/ mes2016.pdf.

Kelly, T.D., and Matos, G.R., comps., 2007, Historical statistics for mineral and material commodities in the United States: U.S. Geological Survey Data Series 140, ver. 2011, accessed February 4, 2016, at http://minerals.usgs.gov/minerals/pubs/ historical-statistics/.

U.S. Geological Survey, 2015a, The mineral industry of Utah, in Area reports-Domestic: U.S. Geological Survey Minerals Yearbook 2010-2011, v. II, p. 47.1-47.14, accessed February 4, 2016, at http://minerals.usgs.gov/minerals/pubs/state/2010_11/ myb2-2010_11-ut.pdf.

U.S. Geological Survey, 2015b, The mineral industry of Nevada, in Area reports-Domestic: U.S. Geological Survey Minerals Yearbook 2010-2011, v. II, p. 30.1-30.17, accessed February 4, 2016, at http://minerals.usgs.gov/minerals/pubs/state/2010_11/ myb2-2010_11-nv.pdf.

\section{Gypsum}

The USGS National Minerals Information Center (NMIC) reported that the United States produced gypsum from about 54 mines in 16 States in 2014. The United States was the world's third-ranked mine producer of crude gypsum with 11 million metric tons (Mt) accounting for nearly 5 percent of world production. Domestic reserves of crude gypsum were estimated to be $700 \mathrm{Mt}$. The United States and other countries also produce significant tonnages of synthetic gypsum, which is predominantly generated as a byproduct at coal-fired electrical power plants. In 2014, the United States sold approximately $15 \mathrm{Mt}$ of synthetic gypsum, most of which was produced from flue-gas desulfurization (FGD) systems at coal-fired electric power plants. Some gypsum scrap that was generated by wallboard manufacturing, wallboard installation, and building demolition in the United State was recycled. The recycled gypsum was used primarily for agricultural purposes and feedstock for the manufacture of new wallboard.

In 2015, the leading crude gypsum-producing States

were, in descending order of production, Oklahoma, Texas, Nevada, Kansas, Iowa, and Arkansas, which together accounted for 70 percent of total domestic output (Crangle, 2015a, b, 2016). Ongoing or previous gypsum mining activities in the States or counties within the assessment areas studied include Washoe County in northwestern Nevada, but these locations were not within the proposed withdrawal area (State of Nevada, 2015, p. 15-24; Weissenborn, 1963).

A significant driver for gypsum production is the demand for its use as a component of wallboard and portland cement in the construction industry. From 1990 to 2014, total annual world mined gypsum production more than doubled from approximately 104 to $244 \mathrm{Mt}$ for an average annual growth rate of about 3.5 percent. The effect of the global recession in 2008 was reflected by a decrease in world production in response to decreased demand for gypsum (Kelly and Matos, 2007). Increased use of wallboard in Asia, coupled with new gypsum-product manufacturing plants, spurred increased production and consumption in that region. As wallboard becomes more widely used in other regions, the trend of worldwide production of gypsum is expected to increase. In 2014, the United States apparent consumption of crude and synthetic gypsum was $25.7 \mathrm{Mt}$, about 15 percent higher than 1990. However, domestic production of crude gypsum decreased over the same period from $16 \mathrm{Mt}$ to $11 \mathrm{Mt}$ and synthetic gypsum production increased from 735,000 to $11 \mathrm{Mt}$. In 1990, 8.7 Mt of crude gypsum was imported and about 129,000 $t$ was exported, but in 2014, imports of crude gypsum had decreased to $3.7 \mathrm{Mt}$ and exports had decreased to 67,000 t. From 2011 through 2014, the leading import sources of crude gypsum and their percentage shares were Mexico (42 percent), Canada (35 percent), and Spain (22 percent) (Davis, 1992; Crangle, 2016). The U.S. net-import reliance as a percentage of apparent consumption was 14 percent in 2014.

The U.S. Defense Logistics Agency does not maintain an inventory of gypsum. Gypsum is not considered either of critical or strategic importance because of the numerous domestic sources, both crude and synthetic, and the significant number of foreign producers.

In 2014, approximately 80 countries produced mined gypsum for a total of about $244 \mathrm{Mt}$. China was the leading producer with an estimated $129 \mathrm{Mt}$ and accounted for an approximately 53 percent share of world crude gypsum production. China is likely to maintain its position for the foreseeable future. The other leading producers were Iran and Turkey, each representing a 6 percent share of world production, followed by the United States accounting for nearly 5 percent (Crangle, 2016).

The average annual price per metric ton $(\$ / t)$ of the total value of domestic sales of calcined and uncalcined gypsum in nominal dollars was about $\$ 12.00 / \mathrm{t}$ in 2014. Since 1990, average annual price per metric ton has ranged from a low of $\$ 9.70 / t$ in 1992 to a high of $\$ 15.90 / t$ in 2005 (Kelly and Matos, 2007). In 2014, the average nominal price for crude gypsum was approximately $\$ 9.00 / \mathrm{t}$, free on board at the mine (Crangle, 2016).

\section{References Cited}

Crangle, R.C., Jr., 2015a, Gypsum, in Metals and minerals: U.S. Geological Survey, Minerals Yearbook 2013, v. 1, p. 33.133.10, accessed February 3, 2016, at http://minerals.usgs.gov/ minerals/pubs/commodity/gypsum/myb1-2013-gypsu.pdf. 
Crangle, R.C., Jr., 2015b, Gypsum: U.S. Geological Survey Mineral Commodity Summaries 2014, p. 94-95, accessed February 4, 2016, at http://minerals.usgs.gov/minerals/pubs/ mcs/2015/mcs2015.pdf.

Crangle, R.C., Jr., 2016, Gypsum: U.S. Geological Survey Mineral Commodity Summaries 2015, p. 76-77, accessed February 4, 2016, at http://minerals.usgs.gov/minerals/pubs/mcs/2016/ mes2016.pdf.

Davis, L.L., 1992, Gypsum: U.S. Bureau of Mines Mineral Commodity Summaries 1992, p. 78-79.

Kelly, T.D., and Matos, G.R., comps., 2007, Historical statistics for mineral and material commodities in the United States: U.S. Geological Survey Data Series 140, ver. 2011, accessed February 4, 2016, at http://minerals.usgs.gov/minerals/pubs/ historical-statistics/.

State of Nevada, 2015, Directory of Nevada mine operations, January-December, 2014: Carson City, Nevada, State of Nevada, Department of Business and Industry, Division of Industrial Relations, Mine Safety and Training Section, August 19, 2015, 324 p., accessed February 4, 2016, at http:/dir. nv.gov/uploadedFiles/dir.nv.gov/content/MSATS/Features/ Complete\%20Mine\%20Directory.pdf.

Weissenborn, A.E., 1963, Mineral and water resources of Montana: Montana Bureau of Mines and Geology, Special Publication No. 28, accessed February 5, 2016, at http://www. mbmg.mtech.edu/sp28/contents.htm.

\section{Iron Ore}

The principal ore minerals of iron are hematite, magnetite, siderite, and goethite. An estimated 98 percent of the ore shipped in the world is consumed in the manufacture of iron and steel. The remaining 2 percent is used in the manufacture of cement, heavy-medium materials, pigments, ballast, agricultural products, or specialty chemicals, among other uses. As a result, demand for iron ore is tied directly to the production of raw steel, the availability and cost of high-quality ferrous scrap, and the percentage of steel produced using basic oxygen furnaces.

Publications of the USGS National Minerals Information Center (NMIC) reported that in 2014 the United States produced 55.9 million metric tons (Mt) of iron ore for use in steel production and ranked eighth in global iron-ore production. All of the ore is recovered from surface operations. Mines in Michigan and Minnesota shipped 98 percent of the usable iron ore in the United States (Tuck, 2016). Iron-ore production has not occurred in the assessment area within the past 10 years; however, production was reported in Utah County, Utah, in 1990 and in Fremont County, Wyoming, until about 1983 (Jeske and Gloyn, 1991; Starch and Glass, 1984).

In 2014, U.S. mine production of iron ore was slightly lower than the estimated 56.4 Mt that were produced in 1990. Except for a drop in production in the years surrounding the global recession, domestic iron-ore production has been relatively stable since 1990. In 2014, it was estimated that U.S. iron-ore reserves were approximately 11.5 billion metric tons of crude ore, which is equivalent to a $3.5 \mathrm{Bt}$ of iron (Tuck, 2016).

In 2014, the United States exported about 12.1 Mt of iron ore compared with 3.2 Mt in 1990. The increase in exports followed the increasing trade of iron and steel between Canada, Mexico, and the United States as domestic iron-ore producers expanded their iron and steel operations throughout North America. Approximately 5.1 Mt of iron ore were imported for domestic consumption in 2014 compared with $18.1 \mathrm{Mt}$ in 1990. The decrease in iron-ore imports was a result of decreased domestic steel production. The countries importing the most U.S. iron ore during 2011-14, and their respective shares, were Canada (56 percent), Brazil ( 35 percent), Sweden ( 3 percent), and Argentina (2 percent) (Tuck, 2016).

Apparent consumption of iron ore in the United States has declined by 36 percent to $45.9 \mathrm{Mt}$ in 2014 from 71.4 Mt in 1990 . This trend resulted from decreasing imports and increasing exports of iron ore and reduced domestic steel production. The United States was a net exporter of iron ore in 2014 in contrast to 1990, when net import reliance as a percentage of apparent consumption was 21 percent.

The U.S. Defense Logistics Agency does not hold a stockpile of iron ore (Tuck, 2014, 2016). Iron ore is not considered a strategic or critical commodity because of substantial U.S. production, well-established domestic steel manufacturing, steel recycling, reliable import sources, and abundant stocks held by producers and consumers. The greatest risk to the domestic ironore industry lies in rising levels of steel imports, which increased by nearly one-third from 2013 to 2014 . The sustained increase has directly affected the iron and steel industry causing iron-ore mines and iron-based steel production facilities to be idled, reducing the overall domestic capacity for raw steel production. Iron and steel is essential all aspects of the U.S. economy, because it is a critical component of all modern technology sectors, including agriculture, communications, defense, manufacturing, and transportation.

From 1990 to 2014, the total world iron-ore production increased from $982 \mathrm{Mt}$ to $3.4 \mathrm{Bt}$, for an average compound annual growth rate of about 8.9 percent. During this period of time, U.S. production varied only slightly, while production in some other countries increased significantly. Iron-ore production rose nearly sixfold in Australia, nearly threefold in Brazil, and nearly fourteenfold in China from 1990 through 2014. Much of the increased production was to supply increased demand by China's steel industry for domestic construction goods, manufacture of consumer goods, and export. In 2014, China was the world leader in iron-ore production with $1,510 \mathrm{Mt}$, which represented a 44 percent share; however, unlike most of the reported global iron-ore production, which has an iron content averaging 62.5 percent iron content, China reports ore production as crude ore, which has an estimated iron content of 20 percent to 30 percent. Other major iron-ore producers in 2014, and estimates of their respective share of global production, were Australia (23 percent), Brazil (12 percent), 
India (4 percent), and Russia ( 3 percent) (Kelly and Matos, 2007; Kuck, 1992; Tuck, 2016).

The average annual unit value of iron ore, expressed in constant 1998 U.S. dollars for the purpose of comparison, has varied since 1990 but reached a low of about \$22/t in 2001 to a high of $\$ 74 / t$ in 2010 . The increase in iron-ore unit value beginning around 2004 was driven to a large extent by high demand from China. Prices began to weaken in 2014 as demand began to wane. In 2014, the average price of iron ore in nominal dollars was approximately $\$ 92.78 / \mathrm{t}$ (Kelly and Matos, 2007; Tuck, 2016).

\section{References Cited}

Jeske, R.E., and Gloyn, R.W., 1991, The mineral industry of Utah, in Area reports-Domestic: U.S. Bureau of Mines Minerals Yearbook 1991, v. II, p. 515-528, accessed February 11, 2016, at http://digicoll.library.wisc.edu/cgi-bin/EcoNatRes/ EcoNatRes-idx?type=turn\&entity=EcoNatRes.MinYB1991v2. p0528\&id=EcoNatRes.MinYB1991v2\&isize=M.

Kelly, T.D., and Matos, G.R., comps., 2007, Historical statistics for mineral and material commodities in the United States: U.S. Geological Survey Data Series 140, ver. 2011, accessed February 4, 2016, at http://minerals.usgs.gov/minerals/pubs/historicalstatistics/.

Kuck, P.H., 1992, Iron ore, in Metals and minerals: U.S. Bureau of Mines, Minerals Yearbook 1990, v. 1, p. 559-606, accessed March 4, 2016, at http://digicoll.library.wisc.edu/cgi-bin/ EcoNatRes/EcoNatRes-idx?type=turn\&entity=EcoNatRes. MinYB1990v1.p0610\&id=EcoNatRes.MinYB1990v1\&isize=M.

Starch, K.E., and Glass, G.B., 1984, The mineral industry of Wyoming, in Area reports-Domestic: U.S. Bureau of Mines Minerals Yearbook 1982, v. II, p. 591-601, accessed February 11, 2016, at http://digicoll.library.wisc.edu/cgi-bin/EcoNatRes/ EcoNatRes-idx?type=turn\&entity=EcoNatRes.MinYB1991v2. p0528\&id=EcoNatRes.MinYB1991v2\&isize=M.

Tuck, C.A., 2014, Iron ore, in Metals and minerals: U.S. Geological Survey, Minerals Yearbook 2012, v.1, p. 39.1-39.18, accessed February 10, 2016, at http://minerals.usgs.gov/minerals/pubs/ commodity/iron_ore/myb1-2012-feore.pdf.

Tuck, C.A., 2016, Iron ore: U.S. Geological Survey Mineral Commodity Summaries 2016, p. 90-91, accessed February 10, 2016, at http://minerals.usgs.gov/minerals/pubs/mcs/2016/ mcs2016.pdf.

\section{Lead}

The major application for lead is in all types of lead-acid storage batteries. Other significant uses included ammunition, oxides in glass and ceramics, casting metal, and sheet lead. The remainder is consumed in solders, bearing metals, brass and bronze billets, covering for cable, caulking lead, and extruded products (Guberman, 2015, 2016).

Publications of the USGS National Minerals Information Center (NMIC) reported that in 2014 the United States produced about 379,000 metric tons (t) of lead in concentrates as a principal product, coproduct, or byproduct of mining. Lead is recovered from ore extracted from underground or open pit mines and concentrated using conventional flotation methods. In 2014, the United States ranked third in global mine production of lead. Mines in Alaska and Missouri accounted for most of the domestic mined lead production in 2014. The remaining production came from mines in Shoshone County, Idaho, and in Pend Oreille County, Washington (Gabby, 2007; Guberman, 2012, 2015). Lead production is ongoing or has occurred since 2005 in Jefferson County, Montana, and Shoshone County, Idaho (U.S. Geological Survey, 2015a, b, c). No mine production of lead was reported in the assessment areas or the 25-kilometer (km) buffers. In 2014, the U.S. mine production of lead in concentrates was about $379,000 \mathrm{t}$, significantly less than the 497,000 t produced in 1990. The compound annual growth rate has been about negative 1 percent in domestic lead mine production during the period, which can be attributed to a combination of shutdowns and curtailments at zinc and lead mines. Mine production of lead remained essentially unchanged from 2011 to 2013. In 2014, it was estimated that U.S. ore reserves contained approximately 5 million metric tons $(\mathrm{Mt})$ of lead (Guberman, 2016; Kelly and Matos, 2007).

In 1990, approximately 404,000 tof primary refined lead was produced from domestic and imported concentrates by domestic refiners. In 2014, as a result of plant closures, the United States did not produce any primary refined lead. All domestically produced lead concentrates were exported and essentially no concentrates were imported. It is unlikely that lead concentrates will be smelted and refined in the United States before the end of the decade or perhaps the foreseeable future.

In 2014, in addition to domestically mined lead, $1.13 \mathrm{Mt}$ of lead was recovered from the recycling of scrap, an increase from 1990 when about 922,000 $t$ was recovered. Spent lead-acid batteries are the primary source of lead recovered from recycling (Guberman, 2016; Woodbury, 1992).

In 2014, the United States exported about 356,000 $\mathrm{t}$ of lead in concentrates plus 60,000 t of refined-lead (wrought and unwrought). Approximately 596,000 t of refined lead (wrought and unwrought) was imported for consumption in 2014 compared with $97,000 \mathrm{t}$ in 1990. The increase reflects reduced domestic mine production and closures of U.S. primary lead smelters and refineries. For the years 2011-14, five countries accounted for 90 percent of refined-lead (wrought and unwrought) importsCanada (57 percent), Mexico (20 percent), Peru (5 percent), and Australia and Kazakhstan (4 percent each) (Guberman, 2016).

Apparent consumption of lead in the United States has increased from 1,300 Mt in 1990 to 1,670 Mt in 2014, primarily owing to increased consumption for use in lead-acid batteries (Guberman, 2015; Woodbury, 1992).

The United States became increasingly reliant on imports of refined lead from 1990 through 2014, primarily owing to 
the closures of all primary lead refineries. In 2014, net import reliance as a percentage of apparent consumption of refined lead was 32 percent, a substantial increase from 1990 when it was 3 percent (Guberman, 2015; Woodbury, 1992).

The U.S. Defense Logistics Agency does not hold a stockpile of lead. Lead is not considered a strategic or critical material because of substantial U.S. production of lead from recycling, reliable sources for imports, and sufficient stocks held by producers and consumers (Guberman, 2016). Although not held in the stockpile, the U.S. Department of Defense (DOD) has modeled for potential shortfalls of lead and looked into substitutes for specific applications that are vital to DOD. Refined lead is not considered to be difficult to obtain; however, there are some military applications, such as high-purity refined lead used in batteries for submarines, that use types of lead that have limited supply sources.

From 1990 through 2014, total world mine production of lead increased from 3.37 Mt to $4.87 \mathrm{Mt}$ for an average compound annual growth rate of about 1.6 percent. In 2014, China was the leading world producer of mined lead with $2.4 \mathrm{Mt}$, accounting for 49 percent of world lead production. This was a significant increase from 1990 when China produced an estimated 315,000 $t$ or about 9 percent of world mine production. Other major lead producers in 2014 were Australia (15 percent), United States ( 8 percent), Peru (6 percent), and Mexico (5 percent). The increase in world lead-mine production during that time period was driven primarily by increases in consumption in China and other developing nations (Guberman, 2015; Kelly and Matos, 2007; Woodbury, 1992).

The average annual lead price, expressed in constant 1998 U.S. dollars since the year 1990, ranged from a low of about $\$ 855$ per metric ton in 2003 to a high of $\$ 2,150$ per metric ton in 2007. The elevated price of the metal in 2007 was a result of increased global consumption, most notably in China, and a decline in global stocks. Prices decreased in subsequent years, partially owing to a global economic slowdown and more moderate increases in lead consumption in China. In 2014, the average annual price of lead expressed in constant 1998 U.S. dollars was approximately $\$ 1,610$ per metric ton (Kelly and Matos, 2007; Guberman, 2016).

\section{References Cited}

Gabby, P.N., 2007, Lead, in Metals and minerals: U.S. Geological Survey, Minerals Yearbook 2005, v. 1, p. 43.1-42.19, accessed February 9, 2016, at http://minerals.usgs.gov/minerals/pubs/ commodity/lead/leadmyb05.pdf.

Guberman, D.E., 2012, Lead [advanced release], in Metals and minerals: U.S. Geological Survey, Minerals Yearbook 2010, v. 1, p. 42.1-42.18, accessed February 9, 2016, at http://minerals.usgs. gov/minerals/pubs/commodity/lead/myb1-2010-lead.pdf.

Guberman, D.E., 2015, Lead [advanced release], in Metals and minerals: U.S. Geological Survey, Minerals Yearbook 2013, v. 1, p. 42.1-42.16, accessed February 9, 2016, at http://minerals.usgs. gov/minerals/pubs/commodity/lead/myb1-2013-lead.pdf.
Guberman, D.E., 2016, Lead: U.S. Geological Survey Mineral Commodity Summaries 2016, p.72-73, accessed February 4, 2016 at http://minerals.usgs.gov/minerals/pubs/mcs/2016/ mcs2016.pdf.

Kelly, T.D., and Matos, G.R., comps., 2007, Historical statistics for mineral and material commodities in the United States: U.S. Geological Survey Data Series 140, ver. 2011, accessed February 4, 2016, at http://minerals.usgs.gov/minerals/pubs/ historical-statistics/.

U.S. Geological Survey, 2015a, The mineral industry of Idaho, in Area reports-Domestic: U.S. Geological Survey Minerals Yearbook 2010-2011, v. II, p. 14.1-14.11, accessed February 4, 2016, at http://minerals.usgs.gov/minerals/pubs/state/2010_11/ myb2-2010_11-id.pdf.

U.S. Geological Survey, 2015b, The mineral industry of Montana, in Area reports-Domestic: U.S. Geological Survey Minerals Yearbook 2010-2011, v. II, p. 28.1-28.12, accessed February 4, 2016, at http://minerals.usgs.gov/minerals/pubs/state/2010_11/ myb2-2010_11-mt.pdf.

U.S. Geological Survey, 2015c, The mineral industry of Utah, in Area reports-Domestic: U.S. Geological Survey Minerals Yearbook 2010-2011, v. II, p. 47.1-47.14, accessed February 4, 2016, at http://minerals.usgs.gov/minerals/pubs/state/2010_11/ myb2-2010_11-ut.pdf.

Woodbury, W.D., 1992, Lead, in Metals and minerals: U.S. Bureau of Mines Minerals Yearbook 1992, v. 1, p. 709-733, accessed February 9, 2016, at http://digicoll.library.wisc.edu/cgi-bin/ EcoNatRes/EcoNatRes-idx?type=turn\&entity=EcoNatRes. MinYB1992v1.p0741\&id=EcoNatRes. MinYB1992v1\&isize=M.

\section{Lithium}

Although lithium markets vary by location, global end-use markets are estimated as follows: batteries, 35 percent; ceramics and glass, 32 percent; lubricating greases, 9 percent; air treatment and continuous-casting mold-flux powders, 5 percent each; polymer production, 4 percent; primary aluminum production, 1 percent; and other uses, 9 percent. Lithium consumption for batteries has increased significantly in recent years because rechargeable lithium batteries are used extensively in the growing market for portable electronic devices and increasingly are used in electric tools, electric vehicles, and grid-storage applications. Lithium minerals are used directly as ore concentrates in ceramics and glass applications worldwide (Jaskula, 2016).

The USGS National Minerals Information Center (NMIC) reported that in 2015 the United States continued to produce lithium from one lithium-brine operation located at Silver Peak in Esmeralda County, Nevada (Jaskula, 2016). In 2013, the mine produced approximately 870 metric tons $(\mathrm{t})$ of lithium and represented about 3 percent of world production. Historical production statistics for the Silver Peak operation are withheld 
to avoid disclosing company proprietary data in most years (Jaskula, 2015).

The United States was the world's leading producer until the late-1990s, when relatively low-cost lithium production recovered from subsurface lithium-rich brines in Chile underwent significant growth. In response to the lower market prices, hard-rock mining operations in North Carolina decreased production and eventually closed.

The recovery of lithium from scrap is an emerging industry, and only a relatively small quantity of lithium is recovered from the secondary sources such as batteries (Jaskula, 2015).

The estimated consumption of lithium in the Untied States from 1990 to 2014 ranged from a high of 2,800 metric tons $(t)$ for the years 1997-2000 (when the two largest lithium-consuming sectors were ceramics and glass and primary aluminum production) to $1,100 \mathrm{t}$ in 2002 (owing to the closure of several major aluminum smelters and a large cookware factory) and 2010 (owing to the economic downturn which began in 2008).

The United States relies on foreign sources of lithium carbonate, lithium hydroxide, and other lithium compounds to supplement its commercial and strategic requirements. In 2014, the United States imported approximately 2,120 $t$ and exported about $1,420 \mathrm{t}$ of lithium contained in a variety of different lithium compounds. In the 1990s until about 2001, the United States was a net exporter of lithium. With the closure of mines in the United States and increased imports for consumption, import reliance has increased. In 2014, net import reliance was estimated to be greater than 60 percent. From 2011 through 2014, the two leading import sources of lithium to the United States were Chile, with an average 58 percent share, and Argentina, with a 38 percent share of total imports. China supplied 3 percent of total U.S. imports over the same period (Jaskula, 2016).

The Defense Logistics Agency (DLA) Strategic Materials maintains the National Defense Stockpile (NDS) of strategic and critical materials to supply the military, industrial, and essential civilian needs of the United States for national defense. In an effort to modernize the NDS by acquiring new materials needed for defense applications, the DLA announced plans to acquire 150 kilograms $(\mathrm{kg})$ of lithium cobalt oxide and $540 \mathrm{~kg}$ of lithium nickel cobalt aluminum oxide during fiscal year 2015. The materials are to be used for cathodes in lithium-ion batteries. By the end of 2015, the NDS had acquired stocks of $241 \mathrm{~kg}$ of lithium cobalt oxide and $690 \mathrm{~kg}$ of lithium nickel cobalt aluminum oxide, with plans to make additional purchases in the subsequent years (Defense Logistics Agency Strategic Materials, 2014, 2015; Jaskula, 2016).

From 1990 to 2014, total annual world lithium production, excluding U.S. production, increased from approximately 5,400 to $31,700 \mathrm{t}$ for a compound average annual growth rate of more than 7.5 percent. The effect of the global recession is reflected by a short term, but significant decrease, in world production in 2009 (Kelly and Matos, 2007). A significant driver for increased world lithium production was the rise in demand for lithium compound use in rechargeable lithium-ion battery applications for electronic devices and electric and hybrid vehicles. Consumer demand in this sector is anticipated to continue to increase, barring technological breakthroughs using different materials, economic downturns, and other factors. In 2014, Australia led the world in mined lithium production with a nearly 42 percent share, all of which was contained in lithium minerals. Other countries with significant lithium production included Chile, Argentina, and China, with 36,10 , and 7 percent shares of world production, respectively. Lithium in Argentina and Chile is recovered from brine deposits, and lithium from China is recovered from a combination of brine and mineral deposits. In 2014, world lithium reserves were estimated at 14 million metric tons; with about 3 percent located in the United States.

The average annual unit value per metric ton $(\$ / t)$ of lithium content since 1990, expressed in constant 1998 U.S. dollars, has ranged from a low of $\$ 1,220 / t$ in 2005 to a high of $\$ 5,040$ in 1991 (Kelly and Matos, 2007). Prices are weighted toward lithium carbonate, because it is produced in the largest quantity and has the highest combined value among lithium compounds. The average unit value for lithium carbonate in 2014 was $\$ 3,110 / t$ (Jaskula, 2016). In general, higher prices reflect periods of greater demand and a tightening of supply.

\section{References Cited}

Defense Logistics Agency Strategic Materials, 2014, Annual materials plan for FY 2015 for possible acquisition of new NDS stocks: Defense Logistics Agency Strategic Materials, October 2, 1 p., accessed March 10, 2016, at http://www.dla.mil/ Portals/104/Documents/StrategicMaterials/3088\%20FY15\%20 AMP_ACQ.pdf.

Defense Logistics Agency Strategic Materials, 2015, Annual materials plan for FY 2015 for possible acquisition of new NDS stocks: Defense Logistics Agency Strategic Materials, October 1, 1 p., accessed March 10, 2016, at http://www.dla.mil/ Portals/104/Documents/StrategicMaterials/3088\%20FY15\%20 AMP_ACQ.pdf.

Jaskula, B.W., 2015, Lithium: U.S. Geological Survey Commodity Summaries 2014, p. 94-95, accessed February 4, 2016, at http:// minerals.usgs.gov/minerals/pubs/mcs/2015/mcs2015.pdf.

Jaskula, B.W., 2016, Lithium: U.S. Geological Survey Commodity Summaries 2015, p. 100-101, accessed February 4, 2016, at http://minerals.usgs.gov/minerals/pubs/mcs/2016/mcs2016.pdf.

Kelly, T.D., and Matos, G.R., comps., 2007, Historical statistics for mineral and material commodities in the United States: U.S. Geological Survey Data Series 140, ver. 2011, accessed February 4, 2016, at http://minerals.usgs.gov/minerals/pubs/ historical-statistics/.

\section{Mercury}

Publications of the USGS National Minerals Information Center (NMIC) reported that mercury has not been produced as a principal mineral commodity in the United States since 1992. 
From 1990 to 1992, the United States produced a total of $684 \mathrm{t}$. About 70 percent of the production originated from the McDermitt Mine located in Humboldt County, Nevada, which closed in late-1990 (Reese, 1989, 1990, 1991). The balance of the domestic mercury-mine production during that period was as a byproduct of the pyrometallurgical treatment of sulfidic refractory gold concentrates in the Nevada counties of Elko, Eureka, Humboldt, Mineral, Nye, Washoe, and White Pine; Napa County, California; and Tooele County, Utah. In 2015, mercury continued to be recovered as a product of processing gold-silver ore at several mines in Nevada; however, production data were not reported. Mercury is also recovered by recycling batteries, compact and traditional fluorescent lamps, dental amalgam, medical devices, and thermostats, as well as mercury-contaminated soils (George, 2016). Owing to mercury's toxicity and concerns for the environment and human health, overall world mercury consumption has declined. Most of the metal's current end use is in chlor-alkali plants for the production of chlorine and sodium hydroxide (only two plants using mercury remained operating in the United States in 2015) and for the recovery of gold by artisanal miners, mostly in developing countries. The trend of decreasing global consumption is reflected in global mercury mine production statistics for the years 1990 to 2014, which has contracted from 4,100 metric tons $(t)$ to $2,350 \mathrm{t}$ for an average compound annual rate of decline of just more than 2 percent. It is likely that this trend will continue for the balance of the decade. In 2014, China produced an estimated 1,600 $t$ of primary mercury and accounted for 68 percent of world production. Statistical data on mercury production in Mexico is incomplete, but based on the country's level of exports, it is likely they were the second leading producer with about a 21 percent share of world production (George, 2016). China is expected to continue to be the world's major producer for the foreseeable future.

At the end of 2014, an inventory of 4,436 t of mercury was held in storage at the Hawthorne Army Depot, Hawthorne, Nevada, and about 1,200 t of mercury was held by the U.S. Department of Energy, Oak Ridge, Tennessee. Sales of mercury from the National Defense Stockpile remained suspended. Beginning in January 1, 2013, the export of elemental mercury from the United States was banned, with some exceptions, under the Mercury Export Ban Act of 2008. Less than $1 \mathrm{t}$ of mercury was exported in 2013, and no exports have been recorded in subsequent years. Imports for consumption to the United States declined substantially from $249 \mathrm{t}$ in 2012 to $49 \mathrm{t}$ in 2014 (George, 2015, 2016). Mercury is not considered a strategic and critical material, mainly because of its (1) limited remaining applications as determined by legislation, (2) substitution by other materials through advances in technology, and (3) large inventories.

The average free-market price in nominal dollars for mercury has remained unchanged at about $\$ 53,700$ per metric ton $(\$ / t)(\$ 1,850$ per flask) since 2011. Expressed in constant 1998 U.S. dollars, for the purpose of comparison, the price of mercury has increased nearly four-fold since 1990, when the price of mercury was $\$ 9,020 / \mathrm{t}$. Two major factors contributed to the substantial increase in the price of mercury beginning in about 2009. Supply decreased from primary production, owing to the increase in regulation of the production and trade of mercury, and secondary production decreased, owing to reduced availability from recycling. Secondly, an increase in demand for mercury in the artisanal and small-scale mining industry resulted from a substantial increase in the price of gold.

\section{References Cited}

George, M.W., 2015, Mercury: U.S. Geological Survey Mineral Commodity Summaries 2014, p. 102-103, accessed on February 4, 2016, at http://minerals.usgs.gov/minerals/pubs/ mcs/2015/mcs2015.pdf.

George, M.W., 2016, Mercury: U.S. Geological Survey Mineral Commodity Summaries 2016, p. 108-109, accessed on February 4, 2016, at http://minerals.usgs.gov/minerals/pubs/ mcs/2016/mcs2016.pdf.

Reese, R.G., Jr., 1989, Mercury, in Minerals Yearbook 1989, Staff, Branch of Nonferrous Metals, p. 705-708 accessed on February 4, 2016, at http://digicoll.library.wisc.edu/cgi-bin/EcoNatRes/ EcoNatRes-idx?type=article\&did=EcoNatRes.MinYB1989v1. i0049\&id=EcoNatRes.MinYB1989v1\&isize=M.

Reese, R.G., Jr., 1990, Mercury, in Minerals Yearbook 1990, p. 743-747, v. 1, accessed March 15, 2016, at http:// digicoll.library.wisc.edu/cgi-bin/EcoNatRes/EcoNatResidx?type=article\&did=EcoNatRes.MinYB1990v1. RReese\&id=EcoNatRes.MinYB1990v1\&isize=M.

Reese, R.G., Jr., 1991, Mercury, in Minerals Yearbook 1991, p. 989-995, accessed March 15, 2016, at http:// digicoll.library.wisc.edu/cgi-bin/EcoNatRes/EcoNatResidx?type $=$ article $\& d i d=$ EcoNatRes.MinYB1991v1. RReese\&id=EcoNatRes.MinYB1991v1\&isize=M.

\section{Molybdenum}

Molybdenum is a refractory metallic element used principally as an alloying agent in cast iron, steel, and superalloys to enhance hardenability, strength, toughness, and wear-and corrosion resistance. Other uses for molybdenum are in catalysts, chemicals, lubricants, and pigments (Polyak, 2015a, b).

The USGS National Minerals Information Center (NMIC) reported that in 2014, the United States produced 68,200 metric tons $(t)$ of molybdenum in concentrates from 13 mines as either a primary product or byproduct of mining, ranking second in global mine production. In 2014, molybdenum was recovered from 5 mines in Arizona, 2 in Colorado, and 1 mine each in Montana, Nevada, and Utah. Molybdenum production is ongoing or has occurred within the States included in the assessment area since 2005 in Custer County, Idaho; Silver Bow County, Montana; White Pine County, Nevada; and Salt Lake County, Utah (Polyak, 2013, 2016). There are two molybdenum mines-Thompson Creek in Custer County and Ashdown Mine in Humboldt County, Nevada, that are within 25 kilometers $(\mathrm{km})$ of the assessment area. 
The Thompson Creek went on care and maintenance status in December 2014. There was no production in 2015. The Ashdown Mine has been closed since early 2012.

In 2014, U.S. mine production of molybdenum was about $68,200 \mathrm{t}$ contained in concentrate, about 11 percent more than the estimated 61,600 t of molybdenum contained in concentrates that was produced in 1990. The average compound annual rate of growth was less than half of a percent. In 2014, estimated U.S. molybdenum ore reserves contained approximately 2.7 million metric tons (Mt) of molybdenum (Polyak, 2016).

Molybdenum is recycled as a component of catalysts, ferrous scrap, and superalloy scrap. The recycling of steel, which contains molybdenum as an alloying agent (the major use of molybdenum), is the most significant source of recovered molybdenum from secondary sources. Molybdenum is not separated and remains as a component of the reused steel. Currently, no processes for the separate recovery and refining of secondary molybdenum from its alloys are used. Data regarding the amount of molybdenum contained in the recycled steel are not available.

Approximately 25,300 $\mathrm{t}$ of molybdenum contained in concentrates (mostly as molybdenum trioxide) and other molybdenum-containing materials, such as ferromolybdenum, were imported for consumption to the United States in 2014, compared with 2,560 $\mathrm{t}$ in 1990 . Total imported molybdenum ores and concentrates (roasted and unroasted) increased from about $433 \mathrm{t}$ of contained molybdenum in 1990 to $15,770 \mathrm{t}$ in 2014. For the years 2011-14, Mexico was the leading source of imported molybdenum ores and concentrates with a 31 percent share. Other major import sources during that time period and their share of imports were Canada (28 percent), Peru (23 percent), and Chile (17 percent) (Blossom, 1992, 1993; Polyak, 2015a, 2016).

The quantity of imported ferromolybdenum, also a component of molybdenum imports, increased from 1990 to 2014 from 871 to 5,110 t of contained molybdenum (Blossom, 1993; Polyak, 2015). The increases reflect higher production of specialty steels in the United States, mainly in full alloy steels for the construction and transport industry. For the years 2011-14, Chile was the leading source of ferromolybdenum with 83 percent, followed by Canada with 9 percent (Blossom, 1992, 1993; Polyak, 2015, 2016).

In 2014, the United States exported about 65,100 t of molybdenum contained in various products, most of which was contained in roasted concentrates (molybdenum trioxide), a significant increase from 1990 when the United States exported 43,400 t (Blossom, 1993; Polyak, 2016).

In the United States, molybdic oxide and ferromolybdenum are used principally in steels, with a significant volume of oxide being used in catalysts. Ammonium and sodium molybdate are used in pigments, catalysts, and other chemical uses. Molybdenum metal (mostly powder) products are used mainly in mill products and nonferrous alloys. Apparent consumption of molybdenum in the United States has increased from about 20,300 t in 1990 to an estimated 27,900 t in 2014 (Blossom, 1992, 1993; Polyak, 2016).

The U.S. Defense Logistics Agency does not hold a stockpile of molybdenum (Polyak, 2016). Molybdenum is not considered a strategic or critical commodity because of the Nation's substantial mine production and capacity of processing facilities and stocks held by consumers and producers. The United States has been a net exporter of molybdenum in various forms and compounds for several decades. For that reason, the United States is not reliant on imported molybdenum.

From 1990 to 2014, world production of molybdenum in concentrate increased from 112,000 to $281,000 \mathrm{t}$, for an average compound annual growth rate of about 4 percent. In 2014, China was the world leader in the production of molybdenum in concentrate with 103,000 t, which represented a 37 percent share. This was a significant increase from 1990, when the China produced an estimated 2,000 t of molybdenum in concentrate and represented a 2 percent share of world production. Other major producers of molybdenum in concentrate in 2014 were the United States (24 percent), Chile (17 percent), Peru (6 percent), and Mexico (5 percent) (Blossom, 1992, 1993; Polyak, 2016). Molybdenum consumption has continued to increase, owing to increases in China's industrial growth fueled by steel manufacturers producing higher-grade steel products for domestic consumption in China, as well as to increase steel exports. The principal areas of molybdenum growth are expected to be in the use of stainless and other steels containing molybdenum in aerospace and aircraft-engine components, chemical and petrochemical processing plants, motor-vehicle components, nuclear power plants, and in wind power generation components.

The average annual molybdenum price per metric ton (\$/t) of molybdenum contained in technical-grade molybdic oxide, expressed in constant 1998 U.S. dollars for the purpose of comparison since the year 1990, ranged from a low of about $\$ 4,780 / \mathrm{t}$ (\$2.16/per pound) in 2001 to a high of $\$ 58,500 / \mathrm{t}$ (26.53/per pound) in 2005. The sharp rise in the price of the metal in 2005 was a result of high demand by China and tight supply. Prices dropped in subsequent years in response to increased production followed by weakened demand for the metal in most major molybdenum-consuming nations during the global recession. In 2014, the average price of molybdenum contained in technical-grade molybdic oxide in nominal dollars was approximately $\$ 25,840 / \mathrm{t}$ ( $\$ 11.72 /$ per pound). Metal prices, in general, decreased during the 2014-15 period in response to decreasing demand and oversupply (Blossom, 1992, 1993; Kelly and Matos, 2007; Polyak, 2015a, 2016).

\section{References Cited}

Blossom, J.W., 1992, Molybdenum: U.S. Bureau of Mines Mineral Commodity Summaries 1992, p. 118-119.

Blossom, J.W., 1993, Molybdenum, in Metals and minerals: U.S. Bureau of Mines Minerals Yearbook 1993, v. 1, p. 669-683, accessed February 10, 2016, at http:// digicoll.library.wisc.edu/cgi-bin/EcoNatRes/EcoNatResidx?type=turn\&entity=EcoNatRes.MinYB1993v1. p0683\&id=EcoNatRes.MinYB1993v1\&isize $=$ M. 
Kelly, T.D., and Matos, G.R., comps., 2007, Historical statistics for mineral and material commodities in the United States: U.S. Geological Survey Data Series 140, ver. 2011, accessed on February 10, 2016, at http://minerals. usgs.gov/minerals/pubs/historical-statistics/.

Polyak, D.E., 2013, Molybdenum [advanced release], in Metals and minerals: U.S. Geological Survey, Minerals Yearbook 2013, v.1, p. 50.1-50.12, accessed February 10, 2016, at http://minerals.usgs.gov/minerals/pubs/commodity/ molybdenum/myb1-2013-molyb.pdf.

Polyak, D.E. 2015a, Molybdenum [advanced release], in Metals and minerals: U.S. Geological Survey, Minerals Yearbook 2014, v.1, p. 50.1-50.12, accessed February 10, 2016, at http://minerals.usgs.gov/minerals/pubs/commodity/ molybdenum/myb1-2014-molyb.pdf.

Polyak, D.E., 2015b, Molybdenum: U.S. Geological Survey Mineral Commodity Summaries 2015, p.106-107, accessed February 10, 2016, at http://minerals.usgs.gov/minerals/ pubs/commodity/molybdenum/mcs-2016-molyb.pdf.

Polyak, D.E., 2016, Molybdenum: U.S. Geological Survey Mineral Commodity Summaries 2016, p.112-113, accessed February 10, 2016, at http://minerals.usgs.gov/minerals/ pubs/commodity/molybdenum/mcs-2016-molyb.pdf.

\section{Rare Earth Elements}

The rare earth elements (REE) include the lanthanide elements with atomic numbers 57 through 71, plus scandium and yttrium. The lanthanides include, in order of atomic number, lanthanum, cerium, praseodymium, neodymium, promethium, samarium, europium, gadolinium, terbium, dysprosium, holmium, erbium, thulium, ytterbium, and lutetium (International Union of Pure and Applied Chemistry, 2005).

The principal ores from which REE are extracted are characterized by the minerals bastnäsite, loparite, monazite, lateritic ion-adsorption clays, and xenotime. Bastnäsite, the leading ore mineral source of REE in the world, is enriched with cerium, lanthanum, neodymium, praseodymium, and other REE. Bastnäsite, a fluorocarbonate mineral, is produced in China and formerly in the United States. Loparite, which is an oxide mineral, is produced at one mine in Russia near Revda, Murmansk Oblast, and further processed into REE compounds in Solikamsk, Perm Oblast. Monazite is a phosphate mineral that contains REE and the radioactive element thorium. Although monazite has been and could be produced as a byproduct of many heavy-mineral operations, limited demand for thorium, and in some cases, environmental concerns associated with radioactivity, had led most producers outside of China to stop recovering monazite; however, recent efforts in India and elsewhere may be reversing this trend. REE mineral concentrates containing mostly supergene (enriched) monazite low in thorium are produced in Australia and then exported to Malaysia to be further processed into REE compounds. Xenotime, a phosphate mineral rich in yttrium and certain other REE, has been produced from tin-bearing cassiterite deposits and is a potential byproduct from the production of heavy-mineral placer deposits. Like most REE minerals, xenotime may contain some level of thorium.

Lateritic deposits in southern China contain clays that have rare earth ions adsorbed into their mineral surfaces. These deposits make up the world's principal supply source of yttrium and the heavy REE (terbium, dysprosium, holmium, erbium, thulium, ytterbium, and lutetium).

Rare earth elements (individually and in combination with other REE) are used in a wide range of applications, including batteries, catalysts, ceramics, electronics, glass, lasers, medicine, permanent magnets, phosphors, polishes, and a host of metal alloys including aluminum-base, iron-base, magnesium-base, and super alloys. In 2014, the domestic consumption of rare earths by end use was as follows, in decreasing order: catalysts (60 percent), metallurgical applications and alloys (10 percent), ceramics and glass (10 percent), glass polishing (10 percent), and other (10 percent). The China Rare Earth Association reported that China's rare earth oxide equivalents (REOE) consumption in 2014 was 90,000 metric tons (t). The end use distribution in China was, in descending order, magnets (35 percent), polishing (18 percent), catalysts (15 percent), ferrosilicon ( 8 percent), hydrogen alloys ( 8 percent), aluminum alloys ( 6 percent), phosphors ( 2 percent), and magnesium alloys ( 0.2 percent). Rare earth demand in China was forecast to increase to $149,000 \mathrm{t}$ by 2020 .

In 2014, bastnäsite was mined by one company in the United States at Mountain Pass, California. The mine produced $5,400 \mathrm{t}$ of REOE contained in mineral concentrates that were processed into downstream rare earth compounds. In October 2015, the mine shut down after nearly 4 years of continuous operation. The Mountain Pass mine was first developed in the 1950s and was idle from 2002 through 2011. Although the operation continued to process previously mined ore, no domestic mine production of REE was reported during those years. Domestic production in 2014 was significantly less than the estimated 22,700 t of REOE produced in 1990. Domestic production ceased in the early 1990s from the processing of monazite as a byproduct from heavy-mineral sands in Florida and North Carolina. No production of REE have been reported within the assessment area, although they may have been contained in heavy-mineral placers and not recovered. In 2014, it was estimated that U.S. reserves contained approximately 1.8 million metric tons of REOE (Bleiwas and others, 2013; Gambogi, 2016a, b; Hedrick, 1992, 1993, 1994; Kelly and Matos, 2007).

In addition to domestically mined material, a limited amount of REE was recovered from the recycling of batteries, permanent magnets, and fluorescent lamps (Gambogi, 2016a).

In 2014, the United States exported about 6,180 t of REOE contained in various rare earth compounds and metals. During the period 1990 to 2014, U.S. exports have varied between 5,360 $\mathrm{t}$ and 13,000 $\mathrm{t}$, often fluctuating based on market conditions. Outside of China, the United States has been a 
leading consumer of rare earths. The characteristics (elemental composition, type of compound, purity, and other qualities) of rare earth exports have changed over time because of the loss of downstream processing capabilities (Gambogi, 2016a).

In 2014, an estimated 11,600 t of REOE contained in various rare earth compounds and metals were imported to the United States. Increases in imports since 2012 reflect lower prices for rare earth compounds and metals. The leading import sources and their respective percentage shares for rare earth compounds and metals for the years 2011-14 were China (71 percent), Estonia (7 percent), and France and Japan (6 percent each) (Gambogi, 2016a).

Domestic consumption in 2014 was estimated at 17,000 $\mathrm{t}$ of REOE, significantly less than in 1990 when it was an estimated $28,700 \mathrm{t}$. Much of the decrease reflects reduced consumption by intermediate processors of rare earth compounds (Gambogi, 2016a; Kelly and Matos, 2007).

Net import reliance, as a percentage of apparent consumption in 2014, was estimated at 68 percent, an increase from 1990 when it was estimated at 20 percent. The significant change in import reliance from 1990 to 2014 reflects the reductions in domestic mining and processing of REE compounds (Gambogi, 2016a, b; Kelly and Matos, 2007).

Rare earths are important to numerous defense applications such as such as aircraft, communications, drive motors, electronics, lasers, optics, precision-guided missiles, radar, and smart bombs. The Defense Logistics Agency, Strategic Materials Division (DLA-SM) has conducted numerous assessments in regard to availability of REE for defense applications, and the Department of Defense has recommended that Congress authorize the acquisition of specific materials to mitigate the potential shortfalls. In the fiscal year 2014 National Defense Authorization Act, Congress authorized the acquisition of dysprosium and yttrium (Gambogi, 2016a; Grasso, 2013; Ucore Rare Metals, Inc., 2015).

From 1990 to 2014, the total world REOE mine production increased to $123,000 \mathrm{t}$ from $52,900 \mathrm{t}$ for an average compound annual growth rate of nearly 4 percent. The upward trend reflects technological advances that increased demand for REE used in materials such as batteries, catalysts, and magnets. In 2014, China produced 105,000 $t$ of REOE and accounted for 85 percent of world production. This was a significant increase from 1990, when China produced an estimated 16,500 $t$ and accounted for about 30 percent of world production. Other producers of mined REE in 2014, and estimates of their respective share of global production were Australia (7 percent), the United States (4 percent), and Russia and Thailand (about 2 percent each) (Hedrick, 1992, 1993, 1994; Gambogi, 2016a, b; Kelly and Matos, 2007). In general, the price per unit of the heavy REE is considerably higher than for light REE (lanthanum, cerium, praseodymium, neodymium, samarium, europium, and gadolinium). This price differential is driven by scarcity and higher processing costs.

Because of their importance for advanced technologies, the upward trend in demand for REE is likely to continue. The price of REE and their compounds vary considerably and are often negotiated by contract. Examples of published prices at yearend 2014 ranged from a low of 4 to 5 U.S. dollars per kilogram $(\$ / \mathrm{kg})$ for cerium oxide (99.5 percent minimum) to a high of $\$ 680-730 / \mathrm{kg}$ for europium oxide ( 99.9 percent minimum). In general, the prices for REE dropped significantly from prices published during the past several years as the available supply has exceeded growth in demand (Gambogi, 2016a, b).

\section{References Cited}

Bleiwas, D.I., and Gambogi, Joseph, 2013, Preliminary estimates of the quantities of rare earth elements contained in selected products and in imports of semi manufactured products to the United States, 2010: U.S. Geological Survey Open-File Report 2013-1072, 14 p., accessed March 8, 2016, at http://pubs.usgs. gov/of/2013/1072/.

Gambogi, Joseph, 2016a, Rare earths: U.S. Geological Survey Mineral Commodity Summaries 2016, p. 134-135, accessed March 8, 2016, at 4, 2016, at http://minerals.usgs.gov/minerals/ pubs/commodity/rare_earths/mcs-2016-raree.pdf.

Gambogi, Joseph, 2016b, Rare earths [advanced release], in Metals and minerals: U.S. Geological Survey, Minerals Yearbook 2013, v. 1, p. 60.1-60.17, accessed March 8, 2016, at http://minerals.usgs.gov/minerals/pubs/commodity/rare_earths/ myb1-2013-raree.pdf.

Grasso, Valerie, 2013, Rare Earth Elements in National Defense-Background, Oversight Issues, and Options for Congress: Washington, D.C., Congressional Research Service, December 23.

Hedrick, J.B., 1992, Rare earth metals: U.S. Bureau of Mines Mineral Commodity Summaries 1992, p. 140-141.

Hedrick, J.B., 1993, Rare earth metals: U.S. Bureau of Mines Mineral Commodity Summaries 1993, p. 138-139.

Hedrick, J.B., 1994, Rare earths, in Metals and minerals: U.S. Geological Survey, Minerals Yearbook 1994, v. 1, p. 1-10, accessed March 8, 2015, at http://minerals.usgs.gov/minerals/ pubs/commodity/rare_earths/740494.pdf.

International Union of Pure and Applied Chemistry, 2005, Nomenclature of Inorganic Chemistry - IUPAC Recommendations 2005, accessed March 14, 2016, at http://www.iupac.org/fileadmin/user_upload/databases/ Red_Book_2005.pdf.

Kelly, T.D., and Matos, G.R., comps., 2007, Historical statistics for mineral and material commodities in the United States: U.S. Geological Survey Data Series 140, ver. 2011, accessed February 4, 2016, at http://minerals.usgs. gov/minerals/pubs/historical-statistics/.

Ucore Rare Metals, Inc., 2015, Rare earths: Ucore Rare Metals, Inc., Web site, accessed on March 14, 2016, at http://ucore.com. 


\section{Silver}

Traditional use categories for silver include coin and medal fabrication; industrial applications, including electrical and electronics components; jewelry and silverware; and photography (Virta, 2015).

Publications of the USGS National Minerals Information Center (NMIC) reported that in 2014 the United States mined about 1,180 metric tons $(\mathrm{t})$ of silver as the principal product, coproduct, or byproduct from mines in 11 States. Combined, these mines accounted for approximately 4 percent of global silver mine production. In 2013, the principal mining States for silver were, in descending order of production, Alaska, Nevada, Idaho, and Utah. In Nevada, silver production is ongoing or has recently occurred in the gold producing counties of Elko, Esmeralda, Eureka, Humboldt, Pershing, Lander, Mineral, Nye, and White Pine (U.S. Geological Survey, 2015a). One silver producing company is within 25-kilometer $(\mathrm{km})$ of the study area in Elko County, Nevada. In Idaho, silver production comes from two mines in Shoshone County. In Utah, silver is currently being produced in Salt Lake County, primarily from the Bingham Mine (U.S. Geological Survey, 2015b). In 2014, U.S. mine production of silver was about 1,180 t, which was significantly less than the $2,120 t$ that was produced in 1990 . The overall decrease in silver domestic production can be attributed to a combination of increasing costs, lower ore grades, mine closures, and a decrease in the proportion of copper recovered through conventional flotation and smelting. Copper ores processed through leaching and solvent extraction-electrowinning do not yield any silver. Although the price of silver increased significantly from 1990 to its record-high level in 2011, silver mine production in the United States generally trended downward through several cycles from its near peak level in 1990 by an average compound annual rate of decline of about 1 percent. In addition to domestically mined silver, an additional 1,400 $\mathrm{t}$ of the silver was recovered from new and old scrap in 2014, a decrease of about 16 percent from the $1,675 \mathrm{t}$ that was recovered in 1990. In 2014, it was estimated that U.S. ore reserves contained approximately $570,000 \mathrm{t}$ of silver (George, 2016; Hilliard, 2000; Reese, 1992).

In 2014, the United States exported about $383 \mathrm{t}$ of silver in concentrates and refined bullion and doré and imported approximately 4,960 t for domestic consumption. From 2011 through 2014, four countries accounted for 87 percent of U.S. imports. The country shares were Mexico (54 percent), Canada (26 percent), Poland ( 4 percent), and Peru (3 percent).

In 2014, the U.S. apparent consumption of silver was estimated to be $7,150 \mathrm{t}$, significantly higher than in 1990 when it was estimated at 4,355 t. A net decrease in consumption of silver in photographic applications was more than offset by increased consumption in other industrial uses, jewelry, and investment holdings. Net import reliance in 2014, as a percentage of apparent consumption, was estimated at 64 percent. Although the United States is a net importer of silver, changes in unreported investor stocks precluded calculations for reliable estimates of import reliance for the period 1990-97, but import reliance in 1998 was estimated at 14 percent.
The U.S. Defense Logistics Agency does not hold a stockpile of silver. Silver is not considered a strategic and critical commodity because of adequate supplies from substantial domestic production from primary and secondary sources; stocks held by industry, investors, traders, and the U.S. Treasury Department; and availability from multiple import sources (George, 2016; Hilliard, 2000; Reese, 1992).

In 2013 , about 29 percent of global silver mine production was from primary silver ores, 38 percent was from lead and zinc ores, 20 percent from copper ores, 13 percent from gold ores, and less than 1 percent was from other types of mining operations (Virta, 2015). From 1990 through 2014, total world mine production of silver increased from 16,600 to $26,800 \mathrm{t}$ for an average compound annual growth rate of nearly 2 percent. In 2014, Mexico was the leading mine producer of silver and accounted for 19 percent of global production. Other major silver producers were China (15 percent); Peru (14 percent); Australia and Chile (6 percent each); Bolivia, Poland, and Russia (5 percent each); and the United States (4 percent). China's silver production has increased more than thirtyfold from approximately $130 \mathrm{t}$ in 1990 to $4,060 \mathrm{t}$ in 2014. The increase in world silver production from 1990 to 2014 has been driven by an overall increase in consumption for electronics and jewelry and for demand as an investment vehicle.

Market sectors for silver consumption have changed since the early 1990s. For example, consumption in the photographic sector, which in 1990 used about 50 percent of total U.S. silver consumption, decreased to 8 percent in 2014 with the increase in use of digital photography (George, 2016; Reese, 1992).

The average annual silver price per troy ounce, ranged from a low of about $\$ 4.00$ per troy ounce $(\$ 1,300 / \mathrm{t})$ in 2001 to a high of nearly $\$ 36$ per troy ounce in $2011(\$ 1,130,000 / t)$. In 2014 , the average price of silver was approximately $\$ 13.00$ per troy ounce (Kelly and Matos, 2007; George, 2016).

\section{References Cited}

George, M.W., 2016, Silver: U.S. Geological Survey Mineral Commodity Summaries 2016, p.152-153, accessed on February 4, 2016, at http://minerals.usgs.gov/minerals/pubs/ commodity/silver/mcs-2016-silve.pdf.

Hilliard, H.E., 2000, Silver: U.S. Geological Survey Mineral Commodity Summaries 2000, p. 152-153, accessed on February 4, 2016, at http://minerals.usgs.gov/minerals/pubs/ commodity/silver/880300.pdf.

Kelly, T.D., and Matos, G.R., comps., 2007, Historical statistics for mineral and material commodities in the United States: U.S. Geological Survey Data Series 140, ver. 2011, accessed on February 4, 2016, at http://minerals.usgs. gov/minerals/pubs/historical-statistics/.

Reese, R.G., Jr., 1992, Silver: U.S. Geological Survey Mineral Commodity Summaries 1992, p. 160-161. 
U.S. Geological Survey, 2015a, The mineral industry of Nevada, in Area reports-Domestic: U.S. Geological Survey Minerals Yearbook 2010-2011, v. II, p. 30.1-30.17, accessed February 4, 2016, at http://minerals.usgs.gov/minerals/pubs/state/2010_11/ myb2-2010_11-nv.pdf.

U.S. Geological Survey, 2015b, The mineral industry of Utah, in Area reports-Domestic: U.S. Geological Survey Minerals Yearbook 2010-2011, v. II, p. 47.1-47.14, accessed February 4, 2016, at http://minerals.usgs.gov/minerals/pubs/state/2010_11/ myb2-2010_11-ut.pdf.

Virta, R.L., 2015, Silver: U.S. Geological Survey Minerals Yearbook 2013, p. 68.1-68.13, v. 1, accessed on February 8, 2016, at http://minerals.usgs.gov/minerals/pubs/commodity/ silver/myb1-2013-silve.pdf.

\section{Specialty Clay-Hectorite}

Hectorite is a bright white lithium-rich magnesium silicate mineral that belongs to the smectite clay group. Hectorite occurs in mineral deposits and can also be produced synthetically. The mineral's unique physical and chemical properties make it useful for applications such as increasing thermal stability and viscosity in ceramics and oil-based drilling mud and for adding color, spreadability, and viscosity in deodorants, facial cleansers, moisturizers, shampoos, and paints (Dell, 1996; Paint \& Coatings Industry, 2004; Schlumberger, Ltd., 2016; Western Lithium USA Corp., 2016). Statistics on the distribution of domestic and global end-use markets are not available; however, in recent years hectorite clay products have been increasingly used in drilling muds by the oil and gas industry for directional drilling in unconventional reservoirs and deep drilling in high pressure-high temperature environments, owing to the mineral's inherent high temperature thermal stability (Lithium Americas Corp., 2016a, b).

Natural hectorite production data are not published to avoid revealing company proprietary information, but the United States continues to be world's largest natural hectorite producer, with surface mines in Hector, California, (the origin of the mineral's name) and the Kings Valley deposit in Humboldt County, Nevada. Some intermittent hectorite production also has been reported from the Disaster Peak Mine in Humboldt County, Nevada (Nevada Bureau of Mines and Geology, 2008, 2013). The United States does not rely on foreign sources of hectorite to supplement its commercial requirements. The Hector Mine is currently the world's leading producer of natural hectorite. The Kings Valley Mine came on-line at the end of 2014 and is within the Nevada assessment area. The company that operates the Kings Valley Mine has indicated that it may also become a source of lithium as the company continues toward a feasibility study and permitting of possible lithium extraction (Western Lithium USA Corp., 2014, 2015).

The Defense Logistics Agency (DLA) maintains the National Defense Stockpile (NDS) of strategic and critical materials to supply the military, industrial, and essential civilian needs of the
United States for national defense. Hectorite is not considered a strategic or critical mineral.

The price of hectorite clay and hectorite-based products are not published in industry literature. Prices are usually negotiated between the seller and buyer. In 2015, Hectatone ${ }^{\circledR}$, a hectoritebased specialty product for use in high pressure-high temperature drilling applications, was reported to sell in the range of $\$ 2,000$ 4,500 per short ton, free on board (f.o.b.) (IMFORMED Industrial Mineral Forums \& Research, Ltd., 2015).

\section{References Cited}

Dell, Don, 1996, Hectorite as a critical element in manufacturing high-grade ceramic slips, bodies, and glazes, in A collection of papers presented at the 97th annual meeting and the 1995 Fall meetings of the Materials \& Equipment/Whitewares Divisions: Ceramic engineering and science proceedings, April 30-May 3, 1995, Cincinnati, Ohio and September 13-16, 1995, Virginia Beach, Virginia, v. 17, issue 1, p. 70-71, accessed on March 22, 2016, at http://samples.sainsburysebooks.co.uk/9780470316375_ sample_378778.pdf.

IMFORMED Industrial Mineral Forums \& Research, Ltd., 2015, World's second hectorite source on stream: IMFORMED Industrial Mineral Forums \& Research, Ltd., accessed March 24, 2016, at http://imformed.com/worldssecond-hectorite-source-on-stream/.

Lithium Americas Corp., 2016a, Applications: Vancouver, British Columbia, Canada, Lithium Americas Corp., accessed March 24, 2016, at http://www.hectatone.com/ drilling-additives-applications/.

Lithium Americas Corp., 2016b, Introducing Lithium Americas formerly Western Lithium: Vancouver, British Columbia, Canada, Lithium Americas Corp., accessed March 22, 2016, at http://www.westernlithium.com/about/ overview/.

Nevada Bureau of Mines and Geology, 2008, The Nevada mineral industry 2007: Carson City, Nevada, Nevada Bureau of Mines and Geology special publication MI-2007, $180 \mathrm{p}$.

Nevada Bureau of Mines and Geology, 2013, The Nevada mineral industry 2011: Carson City, Nevada, Nevada Bureau of Mines and Geology special publication MI-2011, $160 \mathrm{p}$.

Paint \& Coatings Industry, 2004, The innovation of hyperdispersible hectorite clays for automotive applications: Paint \& Coatings Industry, May 1, accessed March 24, 2016, at http:// www.pcimag.com/articles/84353-the-innovation-of-hyperdispersible-hectorite-clays-for-automotive-applications.

Schlumberger, Ltd., 2016, Oilfield glossary-Hectorite: Schlumberger, Ltd., accessed March 22, 2016, at http://www. glossary.oilfield.slb.com/Terms/h/hectorite.aspx. 
Western Lithium USA Corp., 2014, Updated NI 43-101 technical report, Kings Valley property, Humboldt County, Nevada: Western Lithium USA Corp., accessed on March 22, 2016, at http://www.westernlithium.com/wp-content/uploads/2015/01/ NI43101May92014.pdf.

Western Lithium USA Corp., 2015, Western Lithium announces investor conference call-Provides updates on projects in Argentina and Nevada: Toronto, Ontario, and Vancouver, British Columbia, Canada, Western Lithium USA Corp. press release, December 17, accessed March 25, 2016, at http://www. westernlithium.com/wp-content/uploads/2015/12/WLC_NR_ Dec172015.pdf.

\section{Titanium Mineral Concentrates}

Most titanium is not consumed in its metal form but is consumed as titanium dioxide $\left(\mathrm{TiO}_{2}\right)$, a white pigment used in paints, paper, and plastics because of its whiteness, brightness, and opacity. On a gross weight basis, 95 percent of domestic consumption of titanium mineral concentrates was used to produce $\mathrm{TiO}_{2}$ pigment in 2014. The remaining 5 percent was used to produce metal and other miscellaneous products, including fluxes and welding-rod coatings. Because of the high strength-to-weight ratio of its alloys and their resistance to corrosion, titanium metal is an important strategic and critical material and is used widely for high-performance military and civilian aircraft in both engines and airframes (Bedinger, 2016).

Titanium minerals of economic importance include ilmenite, leucoxene, and rutile. Mining of titanium minerals is usually performed by surface-mining operations using dredging and dry-surface mining techniques for the recovery of heavy minerals, which include titanium mineral concentrates. Separation by gravity is used to isolate the heavy-mineral components. Further processing and separation of the heavymineral suite is accomplished using magnetic and electrostatic circuits, with ilmenite and rutile being the two principal mineral concentrates for titanium. Ilmenite is the most abundant titanium mineral and has a stoichiometric $\mathrm{TiO}_{2}$ content of 53 percent, but intercalation and weathering causes the $\mathrm{TiO}_{2}$ content to vary significantly. Rutile, a naturally occurring $\mathrm{TiO}_{2}$ mineral with contained $\mathrm{TiO}_{2}$ of about 95 percent, is less abundant. Ilmenite is often processed to produce a titanium concentrate, either as synthetic rutile or titaniferous slag. Although numerous technologies are used to produce synthetic rutile, nearly all are based on either selective leaching or thermal reduction of iron and other impurities in ilmenite (Bedinger, 2015; Gambogi, 2001; Kelly and Matos, 2007).

Because of heavy-mineral placer occurrences in or near the assessment area, rutile and ilmenite production derived from domestic mining operations is the major focus of this discussion. A search of U.S. Bureau of Mines, USGS, and other publications has not indicated any commercial production of ilmenite or other titanium ore minerals as a principal commodity within the assessment area since at least 1990. There are some Idaho placer deposits and abandoned historical dredge waste piles that contain ilmenite (Anderson, 1958; Storch and Holt, 1963), but there is no evidence that it was ever recovered as a salable product.

In 2014, U.S. mine production ${ }^{1}$ of ore concentrates, from two mines in Virginia and one mine in Florida, was about 100,000 metric tons ( $\mathrm{t}$ ) of contained $\mathrm{TiO}_{2}$, significantly less than the $300,000 \mathrm{t}$ of contained $\mathrm{TiO}_{2}$ produced in $2000 .{ }^{2}$ For the years 2000-14, domestic mine production averaged about 200,000 t of contained $\mathrm{TiO}_{2}$ and has trended downward since 2007 , owing to a combination of shutdowns and production curtailments resulting from factors such as depletion of reserves and economic factors. In 2015, both mine operations in Virginia were scheduled to shut down, but there were also plans in place to mine heavy-mineral concentrates in Georgia and New Jersey. In 2014, it was estimated that U.S. reserves contained approximately 2 million metric tons $(\mathrm{Mt})$ of $\mathrm{TiO}_{2}$. No titanium concentrates were recycled in the United States, but titanium metal was recycled (Bedinger, 2016; Kelly and Matos, 2007).

Because domestic consumption has exceeded domestic production of titanium mineral concentrates, the United States has been import reliant for the entire period of consideration. In 2000, the United States was 79 percent net import reliant and in 2014 was 92 percent net import reliant. From 2011 to 2014, four countries represented 94 percent of U.S. imports of titanium mineral concentrates-South Africa (35 percent), Australia (31 percent), Canada (17 percent), and Mozambique (11 percent) (Gambogi, 2002; Bedinger, 2016).

From 2000 to 2014 the total world mine production of contained $\mathrm{TiO}_{2}$ in ilmenite concentrates increased by 29 percent from an estimated $4.70 \mathrm{Mt}$ to $6.04 \mathrm{Mt}$ of contained $\mathrm{TiO}_{2}$ concentrate for an average compound annual growth rate over the period of about 2 percent. The increase in production of concentrates was brought about to a large extent by increased demand by China (Gambogi, 2002; Kelly and Matos, 2007; Bedinger, 2016).

In 2014, China was the leading world mine producer of Ilmenite concentrates with 960,000 t of contained $\mathrm{TiO}_{2}, 16$ percent of global production. This was a significant increase from 2000 when China produced about 150,000 t of contained $\mathrm{TiO}_{2}$, less than 5 percent of global production. Australia was the world's leading producer in $2000-1.5 \mathrm{Mt}$ of contained $\mathrm{TiO}_{2}$, which was about 31 percent of world production. By 2014, Australia produced $910,000 \mathrm{t}$ of contained $\mathrm{TiO}_{2}, 15$ percent of global production (Bedinger, 2016; Gambogi, 2002).

Other major producers in 2014, and their respective share of global Ilmenite production, were South Africa (10 percent), Vietnam ( 9 percent), and Mozambique ( 8 percent). The market for titanium mineral concentrates is expected to continue to be driven by the production of $\mathrm{TiO}_{2}$ pigment (Bedinger, 2016).

\footnotetext{
${ }^{1}$ Domestic mine production was rounded to one significant digit to avoid disclosing company proprietary data.

${ }^{2}$ Domestic mine production for the years 1983-99 were not published to avoid the disclosure of company confidential data.
} 
World production of $\mathrm{TiO}_{2}$ contained in natural rutile concentrate increased from about $390,000 \mathrm{t}$ in 2000 to $470,000 \mathrm{t}$ in 2014, an average compound annual-growth rate over the period of about 1.3 percent. The increase in production of natural rutile concentrates resulted from the development of mines in Sierra Leone beginning in 2006. World production of $\mathrm{TiO}_{2}$ in natural rutile concentrates was subordinate to that of ilmenite concentrate over the entire period. In 2014, Australia was the world leader in mined natural rutile production - about 190,000 t of contained $\mathrm{TiO}_{2}$ with a 40 percent share. This was a decrease from 2000 when the country produced an estimated 195,000 t, 58 percent of world mine production. In 2014, Sierra Leone produced about $110,000 \mathrm{t}$ of contained $\mathrm{TiO}_{2}$, about 23 percent of $\mathrm{TiO}_{2}$ in natural rutile concentrates (Bedinger, 2016; Gambogi, 2002, 2003; Kelly and Matos, 2007).

Other major natural rutile producers in 2014, and their respective production percentage share of global $\mathrm{TiO}_{2}$ contained in rutile concentrates, were Ukraine (13 percent), South Africa (11 percent), and Kenya (5 percent) (Bedinger, 2016).

The price per metric ton $(\$ / t)$ of ilmenite concentrate (54 percent of contained $\mathrm{TiO}_{2}$ free on board (f.o.b.) Australian port), expressed in constant 2000 U.S. dollars for the purpose of comparison since the year 2000, ranged from a low of about \$59/t (\$73/t nominal) in 2009 to a high of \$225 in 2012 (\$300/t nominal). Prices were depressed in 2009 in response to weakened demand during the global recession but rebounded as world economic conditions improved and demand increased, with China's increased consumption being a major contributing factor. In 2014, the average price of ilmenite concentrate was approximately $\$ 113 / \mathrm{t}$ (\$155/t nominal) (Gambogi, 2011; Bedinger, 2016; Kelly and Matos, 2007).

The price per metric ton $(\$ / t)$ of natural rutile concentrate, 95 percent contained $\mathrm{TiO}_{2}$, f.o.b, Australian ports, expressed in constant 2000 U.S. dollars for the purpose of comparison since the year 2000, ranged from a low of about $\$ 402 / \mathrm{t}(\$ 430 / \mathrm{t}$ nominal) in 2003 to a high of $\$ 1,650$ in 2012 (\$2,200/t nominal). Prices increased significantly beginning in 2011 in response to increased demand.

China's consumption was a major contributing factor. In 2014 , the average price of rutile concentrate in dollars was approximately $\$ 691 / \mathrm{t}$ (\$950/t nominal) (Bedinger, 2016; Gambogi, 2005; Kelly and Matos, 2007).

\section{References Cited}

Anderson, A.L., 1958, Uranium, thorium, columbium, and rare earth deposits in the Salmon region, Lemhi County, Idaho: Idaho Bureau of Mines and Geology Pamphlet 115, 81 p.

Bedinger, G.M., 2015, Titanium [advanced release], in Metals and minerals: U.S. Geological Survey, Minerals Yearbook 2013, v. 1, p. 78.1-78.14, accessed February 12, 2016, at http://minerals.usgs.gov/minerals/pubs/commodity/titanium/ myb1-2013-titan.pdf.
Bedinger, G.M., 2016, Titanium mineral concentrates: U.S. Geological Survey Mineral Commodity Summaries 2016, p.178-179, accessed February 10, 2016, at http://minerals. usgs.gov/minerals/pubs/commodity/titanium/mcs-2016timin.pdf.

Gambogi, Joseph, 2001, Titanium, in Metals and minerals: U.S. Geological Survey, Minerals Yearbook 2001, v. 1, p. 79.1-79.16, accessed February 12, 2016, at http://minerals. usgs.gov/minerals/pubs/commodity/titanium/670400.pdf.

Gambogi, Joseph, 2002, Titanium mineral concentrates: U.S. Geological Survey Mineral Commodity Summaries 2002, p.176-177, accessed March 10, 2016, at http://minerals. usgs.gov/minerals/pubs/commodity/titanium/673302.pdf.

Gambogi, Joseph, 2003, Titanium in Metals and minerals: U.S. Geological Survey, Minerals Yearbook 2003, v. 1, p. 78.1-78.16, accessed March 9, 2016, at http://minerals.usgs. gov/minerals/pubs/commodity/titanium/titanmyb03.pdf.

Gambogi, Joseph, 2004, Titanium, in Metals and minerals: U.S. Geological Survey, Minerals Yearbook 2004, v. 1, p. 78.1-78.17, accessed March 9, 2016, at http://minerals.usgs. gov/minerals/pubs/commodity/titanium/titanmyb04.pdf.

Gambogi, Joseph, 2005, Titanium, in Metals and minerals: U.S. Geological Survey, Minerals Yearbook 2005, v. 1, p. 176-177, accessed March 9, 2016, at http://minerals.usgs. gov/minerals/pubs/commodity/titanium/titanmyb05.pdf.

Gambogi, Joseph, 2011, Titanium mineral concentrates: U.S. Geological Survey Mineral Commodity Summaries 2011, p.178-179, accessed March 10, 2016, at http://minerals. usgs.gov/minerals/pubs/commodity/titanium/mcs-2011timin.pdf.

Kelly, T.D., and Matos, G.R., comps., 2007, Historical statistics for mineral and material commodities in the United States: U.S. Geological Survey Data Series 140, ver. 2011, accessed February 4, 2016, at http://minerals.usgs. gov/minerals/pubs/historical-statistics/.

Storch, R.H., and Holt, D.C., 1963, Titanium placer deposits of Idaho: U.S. Bureau of Mines Report of Investigations 6319, $69 \mathrm{p}$.

\section{Tungsten}

The leading use of tungsten is in cemented carbides. Cemented carbides (also called hardmetals) are wearresistant materials used by the construction, metalworking, mining, and oil and gas drilling industries. Tungsten metal contacts, electrodes, filaments, wires, and other products are used in electrical, electronic, heating, lighting, and welding applications. Tungsten is also used to make corrosion- and wear-resistant alloy parts and coatings; specialty steels for 
pipes, tools, and valves; superalloys for turbine engine parts; and tungsten heavy alloys (also called "heavy-metal alloys") for armaments, heat sinks, and high-density applications, such as weights and counterweights. Tungsten, often in combination with less-dense materials, is used as a substitute for lead in ammunition, fishing weights, hunting shot, radiation shielding, wheel weights, and other high-density applications. Tungsten chemicals are used to make catalysts, corrosion-resistant coatings, dyes and pigments, fire-resistant compounds, lubricants, phosphors, and semiconductors (U.S. Geological Survey, 2013; Shedd, 2015a).

The USGS National Minerals Information Center (NMIC) reported that in 2014 the only tungsten concentrate production in the United States was from a mine north of Los Angeles, California. Historically, tungsten has been produced from, or was present at, numerous mines in the following counties that were within 25 kilometers $(\mathrm{km})$ of the assessment area-Blaine, Butte, Camas, Custer, Elmore, and Lemhi Counties in Idaho; Beaverhead County in Montana; Elko, Humboldt, and Washoe Counties in Nevada; Box Elder and Summit Counties in Utah; and Fremont County in Wyoming. Annual tungsten production statistics for domestic mines have not been published by USGS since 1987. U.S. tungsten concentrate production contracted significantly in the early 1980s, when mines and beneficiation plants, most of which were located in California and Nevada, shut down in response to reduced consumption owing to a worldwide recession, a significant increase in low-priced exports of tungsten concentrates and intermediate products from China, and a precipitous drop in the price of tungsten concentrate (U.S. Geological Survey, 2013). In 2014, it was estimated that U.S. tungsten reserves were approximately 140,000 metric tons $(\mathrm{t})$, most of which were located in California (Shedd, 2015b).

Apparent consumption of all forms of tungsten in the United States in 1990 was approximately 8,500 $t$ and increased to $15,000 \mathrm{t}$ by 2014 . The increase was due in large part to the increase in U.S. industrial activity during that period.

The United States relies on foreign sources of tungsten concentrate and other tungsten-bearing materials, such as ammonium paratungstate and ferrotungsten, to supplement its commercial and strategic requirements. Shipments of tungsten materials from the National Defense Stockpile (NDS), which is administered by the U.S. Defense Logistics Agency Strategic Materials, and consumption of tungsten-bearing scrap also contribute to U.S. supply.

In 2014, the United States imported 12,800 t of tungsten contained in concentrates and other forms and exported 6,660 t. For 2011-14, China was the leading supplier, with a 40 percent share. Bolivia and Canada each represented an 8 percent share and Germany a 6 percent share. The balance of 38 percent was imported from more than 50 other countries. In 1990, U.S. net import reliance, as a percentage of apparent consumption, was estimated to be 81 percent. By 2014, import reliance had dropped to 43 percent mainly as a result of increased scrap consumption (Shedd, 2016).
In 2014, NDS held 11,600 $t$ of tungsten in concentrate (Shedd, 2016). Government stockpiling is a means of reducing potential supply disruptions. Although the United States is a leading tungsten consumer, it has limited mine production and is highly reliant on imports for its tungsten needs. Tungsten's high concentration of world production in a single country (China) increases the risk of supply disruption. These factors, combined with tungsten's importance in a wide variety of commercial, industrial, and military uses and the limited options for substitution in most applications, are reasons why it has been identified as a strategic and (or) critical material by the U.S. Defense Logistics Agency Strategic Materials and other organizations.

From 1990 through 2014, world tungsten concentrate production expanded at a compound annual growth rate of approximately 2 percent, reaching $86,800 \mathrm{t}$ of contained tungsten in 2014. China produced about 71,000 $\mathrm{t}$ ( 82 percent of world tungsten concentrate production) in 2014, a significant increase from 1990 when the country produced an estimated 32,000 t (62 percent of world production). China's increase can be explained in part by the country's investment in its domestic industries to produce goods for internal consumption and export. Other leading tungsten concentrate producers in 2014 were Vietnam (5 percent) and Canada and Russia (3 percent each) (Shedd, 2016).

Tungsten materials are not traded on the London Metal Exchange, Ltd., but are traded on some Chinese exchanges. Most tungsten sales are negotiated between producers and consumers or between traders and consumers. Prices published by trade journals, such as Metal Bulletin, Platts Metals Week, and CRU Ryan's Notes, are derived from information collected from consumers, producers, and traders. The average annual U.S. spot market price of tungsten concentrate per metric ton unit (MTU) of tungsten trioxide $\left(\mathrm{WO}_{3}\right)$ in nominal dollars over the past 15 years ranged from a low of approximately $\$ 47 /$ MTU in 1999 to a high of about \$358/MTU in 2012. A metric ton unit is equivalent to 10 kilograms $(\mathrm{kg})$. For the purpose of comparison, the U.S. free-market price of ammonium paratungstate (the most important chemical precursor for most tungsten products), expressed in constant 1998 U.S. dollars per metric ton $(\$ / t)$ of tungsten, ranged from a low of $\$ 6,920 / \mathrm{t}$ in 1999 to a high in 2012 of $\$ 40,200 /$ t. During this period, China's economy grew, its tungsten consumption increased, and its control over tungsten production and exports was strengthened. Prices trended downward beginning in 2013 and into 2015, as world tungsten-concentrate production was in oversupply, owing to an economic slowdown in China and weak economic conditions elsewhere (U.S. Geological Survey, 2015; Shedd, 2013, 2015b, 2016).

\section{References Cited}

Shedd, K.B., 2015a, Tungsten, in Metals and minerals: U.S. Geological Survey, Minerals Yearbook 2013, v. 1, p. 79.1-79.20, accessed January 25, 2016, at http://minerals. usgs.gov/minerals/pubs/commodity/tungsten/myb1-2013tungs.pdf. 
Shedd, K.B., 2015b, Tungsten: U.S. Geological Survey Mineral Commodity Summaries 2015, p. 174-175, accessed January 25, 2016, at http://minerals.usgs.gov/minerals/pubs/ commodity/tungsten/mcs-2015-tungs.pdf.

Shedd, K.B., 2016, Tungsten: U.S. Geological Survey Mineral Commodity Summaries 2016, p. 180-181, accessed March 3, 2016, at http://minerals.usgs.gov/minerals/pubs/ commodity/tungsten/mcs-2016-tungs.pdf.

U.S. Geological Survey, 2013, Tungsten, in Metal prices in the United States through 2010: U.S. Geological Survey Investigations Report 2012-5188, p. 187-193, accessed February 10, 2016, at http://pubs.usgs.gov/sir/2012/5188/.

U.S. Geological Survey, 2015, Tungsten statistics, in Kelly, T.D., and Matos, G.R., comps., Historical statistics for mineral and material commodities in the United States: U.S. Geological Survey Data Series 140, accessed March 9, 2016, at http://minerals.usgs.gov/minerals/pubs/historicalstatistics/.

\section{Uranium $\left(\mathbf{U}_{3} \mathbf{O}_{8}\right)$}

The primary use for uranium is as a fuel for generating electricity in nuclear power plants. Globally there are 439 operating reactors, 99 of which are in the United States (International Atomic Energy Agency, 2016). Other uses for uranium include nuclear medicine, nuclear weapons, and propulsion. Depleted uranium is used as ballast, high-density projectiles in weaponry, and as a material for shielding from radiation.

Mining uranium has been accomplished by conventional mining techniques and through in-situ mining, where aqueous fluids are pumped through a porous ore deposit. Historically, a significant amount of U.S. uranium-mine production was located in the Western United States but outside of the assessment area. Carnotite ore produced on the Colorado Plateau of western Colorado and eastern Utah was a major source of domestic supply. Exploration for uranium has occurred within many parts in or proximal to the assessment area; production has occurred in Custer County, Idaho; Lake and Malheur Counties, Oregon; and Converse, Freemont, and Sweetwater Counties, Wyoming (Petersen, 1969; University of Wyoming, 2010; Van Gosen and others, 2005).

The United States produced an estimated 2,200 metric tons ( $\mathrm{t}$ ) of $\mathrm{U}_{3} \mathrm{O}_{8}$ equivalents ${ }^{3}$ in 2014, which represented about 4 percent of world production. Production has recently taken place from 2 underground mines in Mohave County, Arizona, and San Juan County, Utah; and 8 in-situ leach operations in Dawes County, Nebraska; Brooks, Duval, and Karnes Counties, Texas; and Campbell, Converse, Johnson, and Sweetwater Counties, Wyoming. Some byproduct uranium was recovered from

\footnotetext{
${ }^{3}$ Units of production are often expressed in the literature as uranium (U) and triuranium octoxide $\left(\mathrm{U}_{3} \mathrm{O}_{8}\right)$. All units expressed in source literature as $\mathrm{U}$ were adjusted to $\mathrm{U}_{3} \mathrm{O}_{8}$ equivalents by multiplying by 1.179 for the purpose of consistency.
}

phosphate mining in the Western United States (St. George News, 2013; U.S. Energy Information Administration, 2015; Uranium Producers of America, 2014).

In 1993, the United States produced approximately $952 \mathrm{t}$ of $\mathrm{U}_{3} \mathrm{O}_{8}$ equivalents from mills and in-situ mining, which was significantly less than the 2,200 $t$ of $\mathrm{U}_{3} \mathrm{O}_{8}$ equivalents produced in 2014. The average compound annual rate of growth in production of about 4 percent over the 22 -year time period can be attributed the development of relatively low-cost in-situ mining, the source for most of domestic uranium production. Many U.S. hard-rock mines have closed or suspended operation over the past two decades as a result of high costs, reserve depletion, and other factors. Uranium reserves in the United States are estimated at 163,000 t of $\mathrm{U}_{3} \mathrm{O}_{8}$ equivalents at prices of as much as $\$ 220,460$ per metric ton ( $\$ 100$ per pound) of $\mathrm{U}_{3} \mathrm{O}_{8}$ equivalents (U.S. Energy Information Administration, 2015).

In 2014, the United States imported approximately 23,000 t of $\mathrm{U}_{3} \mathrm{O}_{8}$ equivalents to meet its commercial-civilian requirements. In 1990, the United States imported approximately 12,000 t of $\mathrm{U}_{3} \mathrm{O}_{8}$ equivalents, but by 1992 , as some U.S. operations closed and few new mines were developed in response to decreasing prices, imports had increased to $21,000 \mathrm{t}$ of $\mathrm{U}_{3} \mathrm{O}_{8}$ equivalents. Domestic production rebounded with the development of relatively low-cost in-situ mining. In 2014, Kazakhstan was the leading import source with a 23 percent share. Other major importers and their percentage share were Australia (21 percent), Canada (20 percent), Russia (14 percent), and Namibia (9 percent) (U.S. Energy Information Administration, 1995; U.S. Energy Information Administration, 2015; Organization of Economic Cooperation and Development, 2000). Data regarding the amount of exports of uranium-containing compounds from the United States are not available.

Uranium compounds are not part of the National Defense Stockpile managed by the Defense Logistics Agency within the U.S. Department of Defense. The National Nuclear Security Administration within the U.S. Department of Energy (DOE) controls an inventory of excess uranium from military use. DOE's inventories of uranium come from various sources, including governmental weapons programs, from its own former enrichment activities, and from inventories of natural uranium of Russian origin. Inventories of uranium are also held by domestic producers and consumers. According to the U.S. Energy Information Administration, at the end of 2014, commercial inventories were estimated to include $61,100 \mathrm{t}$ of $\mathrm{U}_{3} \mathrm{O}_{8}$ equivalents. Data regarding U.S. supplier inventories of natural and enriched uranium hexafluoride $\left(\mathrm{UF}_{6}\right)$ were withheld (U.S. Energy Information Administration, 2015).

In 1990, approximately 56,000 t of $\mathrm{U}_{3} \mathrm{O}_{8}$ equivalents were produced from mines worldwide. Production continued to remain near this level through the 1990s into the early 2000s, as secondary-sourced materials were available from recycled nuclear warheads and other sources (Underhill and Müller-Kahle, 1993; World Nuclear Association, 2015). Total world mine production of $\mathrm{U}_{3} \mathrm{O}_{8}$ equivalents increased nearly every year since 2004 , when $47,400 \mathrm{t}$ of $\mathrm{U}_{3} \mathrm{O}_{8}$ equivalents were produced. In 2014, world production of $\mathrm{U}_{3} \mathrm{O}_{8}$ from mining was estimated at 66,300 t of $\mathrm{U}_{3} \mathrm{O}_{8}$ equivalents. The increase over the past 10 years has been driven 
by the decrease in secondary sources and demand for fueling nuclear power plants. In 2014, Kazakhstan was the world's leading in producer with $27,300 \mathrm{t}$ of $\mathrm{U}_{3} \mathrm{O}_{8}$ equivalents, which represented a 41 percent share. This was a significant increase from that of 2007 when Kazakhstan produced about 7,800 tof $\mathrm{U}_{3} \mathrm{O}_{8}$ equivalents. Other major producers in 2014 and their respective share of global production were Canada (16 percent), Australia (9 percent), Niger (7 percent), Namibia (6 percent), Russia ( 5 percent), Uzbekistan (4 percent), United States ( 4 percent), and China ( 3 percent) (World Nuclear Association, 2015).

Uranium is not traded on an open market like most other mineral commodities. Buyers and sellers generally negotiate contracts privately. The average annual spot price per metric ton $(\$ / t)$ of $\mathrm{U}_{3} \mathrm{O}_{8}$ equivalents, expressed in constant 1998 U.S. dollars since the year 1990, ranged from a low of about $\$ 855 / \mathrm{t}$ ( $\$ 7$ per pound, $\$ / 1 b)$ in 1991 to a high of $\$ 2,150 / t(\$ 107 / 1 b)$ in 2007 (Cameco, 2016). The elevated price of $\mathrm{U}_{3} \mathrm{O}_{8}$ equivalents in 2007 was a result of concerns related to potential interruptions of supply, anticipation of an increase in demand from China and India, and reduced availability of weapons-grade uranium for recycling. Prices dropped in subsequent years when the concerns did not materialize to the extent expected. In early 2016, the nominal price of $\mathrm{U}_{3} \mathrm{O}_{8}$ was approximately $\$ 75,000$ per $\mathrm{t}$ ( $\$ 34 / \mathrm{lb}$ ) (Johnson, 2010; UXC, 2016; U.S. Energy Information Administration, 2015).

\section{References Cited}

Cameco, 2016, Uranium price: Cameco Web page, accessed on February 16, 2016, at https://www.cameco.com/invest/markets/ uranium-price.

International Atomic Energy Agency, 2016, Operational \& longterm shutdown reactors: International Atomic Energy Agency Web page, accessed on March 10, 2016, at https://www.iaea. org/PRIS/WorldStatistics/OperationalReactorsByCountry.aspx.

Johnson, Toni, 2010, Global uranium supply and demand: Council on Foreign Relations, accessed on February 16, 2016, at http:// www.cfr.org/world/global-uranium-supply-demand/p14705.

Organization of Economic Cooperation and Development, 2000, Uranium 1999 - Resources, production and demand - A joint Report by the OECD Nuclear Energy Agency and the International Atomic Energy Agency: Organization of Economic Cooperation and Development accessed on February 16, 2016, at https://www.oecd-nea.org/ndd/pubs/2000/2369uranium-1999.pdf.

Petersen, N.V., 1969, Uranium, Mineral and water resources of Oregon: Oregon Department of Geology and Mineral Industries, Bulletin 64, p. 180-184.

St. George News, 2013, Operations resume at uranium mine in Mohave County: St. George News, accessed on March 16, 2016, at http://www.stgeorgeutah.com/news/ archive/2013/05/10/operations-resume-at-uranium-mine-inmohave-county/\#.Vumt301f2Ax.
Underhill, D.H., and Müller-Kahle, E., 1993, World uranium supply and demand-The changing market: International Atomic Energy Agency Bulletin, v. 3/1993, accessed on February 16, 2016, at https://www.iaea.org/sites/ default/files/publications/magazines/bulletin/bull353/35302680813.pdf.

U.S. Energy Information Administration, 1995, Uranium industry annual report: U.S. Department of Energy, accessed on March 10, 2016, at https://www.eia.gov/ uranium/marketing/archive/047894.pdf.

U.S. Energy Information Administration, 2015, 2014 domestic uranium production report: U.S. Department of Energy, accessed on February 16, 2016, at http://www.eia.gov/ uranium/production/annual/pdf/dupr.pdf.

University of Wyoming, 2010, An overview of uranium production of Wyoming: University of Wyoming, School of Energy Resources, accessed on February 17, 2016, at http://www.uwyo.edu/ser/_files/docs/conferences/2010/ uraniumforum/uraniumforumwhitepaper.pdf.

Uranium Producers of America, 2014, Uranium in America, accessed on February 16, 2016, at http:/www.theupa.org/ uranium_in_america/.

$\mathrm{UXC}, 2016, \mathrm{U}_{3} \mathrm{O}_{8}$ prices [publishing information]: UXC Web page, accessed on February 16, 2016, at http://www.uxc. com/p/prices/UxCPrices.aspx.

Van Gosen, B.S., Hammarstrom, J.M., Eppinger, R.G., Briggs, P.H., Crock, J.G., Meier A.L., Sutley, S.J., Theodorakos, P.M., and Hageman, P.L., 2005, A reconnaissance geochemical and mineralogical study of the Stanley Uranium District, Custer County, Central Idaho: U.S. Geological Survey Scientific Investigations Report 2005-5264, 54 p., accessed February 16, 2016, at http://pubs.usgs.gov/sir/2005/5264/.

World Nuclear Association, 2015, Uranium production figures, 2004-2014: World Nuclear Association, accessed on February 16, 2016, at http://www.world-nuclear.org/information-library/ facts-and-figures/uranium-production-figures.aspx.

\section{Vanadium}

Metallurgical use, primarily as an alloying agent for iron and steel, accounted for about 93 percent of domestic vanadium consumption in 2014. The vanadium industry is thus heavily dependent on the demand cycles from steel production. Other uses for vanadium are in chemical applications, specifically in catalysts. A growing use of vanadium is in rechargeable vanadium redox batteries, which may have significant potential for use in large power-grid applications and for electric vehicles (Polyak, 2016a, b).

The USGS National Minerals Information Center (NMIC) reported that in 2014 the United States did not produce any 
vanadium as a byproduct or coproduct of mining uranium. The United States is a significant producer of vanadium pentoxide, ferrovanadium, and other vanadium products, although their production is almost exclusively from secondary and imported materials. From 1990 through 2014, mined vanadium production peaked at 3,730 metric tons (t) in 1999, most of which was produced as a coproduct from the mining of uraniferous sandstones on the Colorado Plateau. No vanadium was produced as a coproduct from 2000 through 2007 as a consequence of poor market conditions in the primary uranium industry and the Western U.S. phosphate industry. The uranium industry revived somewhat in 2008, and vanadium was once again produced as a coproduct from carnotite ores on the Colorado Plateau until 2014. In 2013, $591 \mathrm{t}$ of vanadium was produced as a coproduct, but none was produced in 2014 or 2015 . This vanadium production was outside the assessment area.

In the 1980s, Idaho followed Colorado as the second ranked producer of vanadium from mining. The ore was mined from vanadiferous phosphate ores in the Phosphoria Formation, which extends into the assessment area, although essentially all of the vanadium was produced from phosphate ores mined from outside the boundaries. The vanadium was extracted from ferrophosphorous slag, which was generated during the processing of phosphate ore to produce elemental phosphorous. Some minor amounts of vanadium may have been recovered from ores shipped from mines within the assessment area, but no production of vanadium has occurred from phosphate ores in Idaho since about 2000 (Judd and others, 1986; Kelly and Matos, 2007; Minarik and Gilleman, 1991; Ohl and Davis, 1991; Polyak, 2016a, b; U.S. Geological Survey, 2012).

Vanadium, contained in black shales in Eureka County, Nevada, also outside of the assessment area, have been investigated and evaluated for potential development (Miningtechnology.com, 2016).

Statistical data on the amount of vanadium recovered from catalysts and specialty alloys in the United States through recycling are not available. Vanadium is recycled incidentally as a constituent of ferrous and nonferrous scrap (Goonan, 2011; Polyak, 2016a, b).

In 2014, the United States exported about 1,000 t of vanadium contained in various products, significantly less than that in 1990 when exports totaled 3,920 t, which were the highest for the period 1990 to 2014. The compound average rate of decline was estimated to be about 5.5 percent. A large part of the decrease can be attributed to the decline of domestic mine production (Kelly and Matos, 2007).

The United States does not import vanadium ores or concentrates produced directly from mining but does import significant tonnages of vanadium contained in ferrovanadium, vanadium pentoxide, and other materials, such as vanadiumbearing ash and slag, that require further processing. In 2014, the quantity of vanadium contained in imported materials was estimated to be 13,700 t, the highest for the period analyzed. The compound annual growth rate (CAGR) from 1990 to 2014 was estimated at 4.5 percent. The major sources for imported ferrovanadium for 2011-14 were Czech Republic (43 percent),
Canada (22 percent), Republic of Korea (18 percent), and Austria (14 percent). For vanadium pentoxide, the leading import sources were South Africa (40 percent), Russia ( 35 percent), and China (18 percent). For ash and other residues, the major import sources were Canada ( 80 percent) and Mexico (13 percent).

Apparent consumption of vanadium in the United States has increased from 4,080 $\mathrm{t}$ in 1990 to 12,400 $\mathrm{t}$ in 2014 for a CAGR of about 3.9 percent over the period (Kelly and Matos, 2007; Polyak, 2016a). U.S. import reliance for vanadium was estimated to be 100 percent in 2014, as a consequence of increased imports and no primary domestic production.

The U.S. Defense Logistics Agency did not maintain a stockpile of vanadium in 2015. In the early 1990s, approximately $651 \mathrm{t}$ of vanadium contained in various materials was held in the stockpile.

Vanadium has been considered a strategic and critical material for its essential use in defense, energy, and construction applications, as well as its limited substitutability. Sharp increases in prices that occurred between 2003 and 2008 caused some steelmakers, particularly in China, to switch from vanadium to niobium. However, replacement of vanadium requires significant technical adjustments to steel production to ensure that product specifications and quality are not compromised. Therefore, substitution is normally not considered for short-term changes in market conditions.

In 2014, approximately $82,700 \mathrm{t}$ of vanadium was mined globally. China was the world leader with a 54 percent share. In 2014, China's production was nearly 10 times than that of 1990 and reflected the country's accelerated industrialization over this time period. Other leading producers of mined vanadium in 2014, and their respective share of world production, were South Africa (25 percent) and Russia (18 percent).

The average annual price per metric ton $(\$ / t)$ of contained vanadium, expressed in constant 1998 U.S. dollars for the purpose of comparison since the year 1990, ranged from a low of about $\$ 4,780 / t$ in 2002 to a high of $\$ 53,500 / t$ in 2005 (Kelly and Matos, 2007). Industry analysts ascribed the low price in 2002 to an increase in global supply of material. The price rise in 2005 was primarily owing to strong demand in the steel and aerospace industries and the inability of producers to increase production of vanadium in a timely manner (Magyar, 2006). In 2015, the nominal price was $\$ 9,700 / t$ of contained vanadium. Prices have declined since 2009 in response to reduced global demand for steels, triggered to a large extent by a slowdown of the economy in China (Polyak, 2016a).

\section{References Cited}

Goonan, T.G., 2011, Vanadium recycling in the United States in 2004: U.S. Geological Survey Circular 1196-S, 23 p., accessed February 16, 2016, at http://pubs.usgs.gov/circ/circ1196-S/.

Judd, J.C., Sandberg, R.G., and Huiatt, J.L., 1986, Recovery of vanadium, uranium, and phosphate from Idaho phosphorite ores: U.S. Bureau of Mines Report of Investigation 9025, 15 p. 
Kelly, T.D., and Matos, G.R., comps., 2007, Historical statistics for mineral and material commodities in the United States: U.S. Geological Survey Data Series 140, ver. 2011, accessed February 4, 2016, at http://minerals.usgs.gov/minerals/pubs/ historical-statistics/.

Magyar, M.M., 2006, Vanadium: U.S. Geological Survey Mineral Commodity Summaries 2006, p.184-185, accessed February 14, 2016, at http://minerals.usgs.gov/minerals/pubs/mcs/2006/ mcs2006.pdf.

Minarik, R.J., and Gillerman, V.S., 1991, The mineral industry of Idaho, in Area reports-Domestic: U.S. Bureau of Mines Minerals Yearbook 1989, v. II, p. 157-166.

Mining-technology.com, 2016, Gibellini vanadium, project Nevada, United States of America: Mining-technology.com Web site, accessed February 16, 2016, at http://www.miningtechnology.com/projects/gibellini-vanadium-project/).

Ohl, J.P., and Davis, M.W., 1991, The mineral industry of Colorado, in Area reports-Domestic: U.S. Geological Survey Minerals Yearbook 1989, v. II, p. 103-114.

Polyak, D.E., 2016a, Vanadium: U.S. Geological Survey Mineral Commodity Summaries 2016, p.182-183, accessed February 16, 2016, at http://minerals.usgs.gov/minerals/pubs/commodity/ vanadium/mcs-2016-vanad.pdf.

Polyak, D.E., 2016b, Vanadium [advanced release], in Metals and minerals: U.S. Geological Survey, Minerals Yearbook 2014, v. 1, p. 80.1-80.10, accessed February 16, 2016, at http://minerals. usgs.gov/minerals/pubs/commodity/vanadium/myb1-2013vanad.pdf.

U.S. Geological Survey, 2012, The mineral industry of Idaho, in Area reports-Domestic: U.S. Geological Survey Minerals Yearbook 2008, v. II, p. 14.1-14.6.

\section{Zeolites}

Zeolites are hydrated aluminosilicate minerals with loosely bound alkali and alkaline-earth metals within the crystalline structure that can be exchanged by water or other cations. Zeolite deposits in the United States occur predominantly in Arizona, California, Idaho, Nevada, New Mexico, Oregon, Texas, and Wyoming. Zeolite minerals present within these deposits are chabazite, clinoptilolite, erionite, mordenite, and phillipsite (Eyde and Holmes, 2006).

In 2014, the USGS National Minerals Information Center (NMIC) reported that the United States produced about 64,100 metric tons ( $\mathrm{t}$ ) of natural zeolite. Chabazite was mined in Arizona, and clinoptilolite was mined in California, Idaho, New Mexico, Oregon, and Texas. New Mexico was the leading natural zeolite-producing State, followed by Texas, Idaho, California, Oregon, and Arizona (Virta and Flanagan, 2015). Areas within or proximal to the assessment area where natural zeolite production is ongoing or has occurred since 2005 include Franklin and Owyhee Counties, Idaho; Nye County, Nevada; Malheur County, Oregon; and Sweetwater County, Wyoming (Flanagan, 2016; Virta, 2002, 2006, 2010; Virta and Flanagan, 2015). Due to obligations to withhold company confidential data, no specific production amounts can be provided. Zeolite deposits in the United States are mined by surface methods.

Domestic uses for natural zeolites are, in decreasing order by tonnage, animal feed, odor control, water purification, other end uses, pet litter, wastewater treatment, gas absorbents (and air filtration), fertilizer carriers, oil absorbents, desiccants, catalysts, fungicide or pesticide carriers, aquaculture, and cement. Animal feed, odor control, water purification, pet litter, and wastewater treatment accounted for nearly 80 percent of the domestic sales tonnage (Virta and Flanagan, 2015). On a global basis, domestic mine production was about 2 percent of world production but sufficient for domestic consumption (Flanagan, 2016). Domestic reserves of zeolites are not quantified, but are considered adequate for the foreseeable future.

In 2014, approximately $64,100 \mathrm{t}$ of natural zeolite was produced in the United States, compared to 1990 when production was $15,600 \mathrm{t}$. The compound annual growth rate of about 6 percent over the period can be attributed to a significant extent on the increased domestic consumption of zeolite in animal feed. Sales for cement, odor control, wastewater treatment, and water purification applications also increased in the past 10 years, although expansion of these markets has not been as great as with animal feed (Flanagan, 2016; Virta, 1993, 2002, 2006, 2010; Virta and Flanagan, 2015).

Nearly all imports and exports of zeolites are synthetic zeolite products. Comprehensive statistics distinguishing between the quantities of natural or synthetic zeolite products are not available because zeolite trade data are included under a category for miscellaneous mineral substances. In 2014, the United States exported an estimated $175 \mathrm{t}$ of zeolites compared to an estimated 3,000 to $7,000 \mathrm{t}$ in 2005. Imports have not been a significant component of domestic consumption. Zeolite imports were estimated to be only $25 \mathrm{t}$ in 2014 and probably have not exceeded $500 \mathrm{t}$ in any of the past 10 years (Virta, 2002, 2006, 2010; Virta and Flanagan, 2015; Flanagan, 2016). The United States was a net exporter of natural zeolites in 2014 (Flanagan, 2016) and has been so for at least the past 20 years.

The U.S. Defense Logistics Agency does not hold a stockpile of zeolites. Zeolites are not considered a strategic or critical commodity because domestic production is adequate to meet demand and substantial reserves exist (Flanagan, 2016).

In 2014, total world zeolite production was approximately 2.75 million metric tons. U.S. production represented about 2 percent of this amount. China dominates the world production of natural zeolite, with an estimated 73 percent, followed by the Republic of Korea, the world's second ranked producer, with 8 percent.

In 2014, the price per metric ton $(\$ / t)$ of zeolite sold in bulk shipments typically ranged from $\$ 100 / \mathrm{t}$ to $\$ 230 / \mathrm{t}$ (Flanagan, 2016). 


\section{References Cited}

Eyde, T.H., and Holmes, D.A., 2006, Zeolites, in Kogel, J.E., Trivedi, N.C., Barker, J.M., and Krukowski, S.T., eds., Industrial minerals and rocks (7th ed.): Littleton, Colorado, Society for Mining, Metallurgy, and Exploration Inc., p. 1039-1064.

Flanagan, D.M., 2016, Zeolites (natural): U.S. Geological Survey Mineral Commodity Summaries 2016, p. 190-191, accessed March 7, 2016, at http://minerals.usgs.gov/minerals/pubs/ commodity/zeolites/mcs-2016-zeoli.pdf.

Virta, R.L., 1993, Zeolites in 1993: U.S. Bureau of Mines Mineral Industry Surveys, 6 p., accessed March 7, 2016, at http:// minerals.usgs.gov/minerals/pubs/commodity/zeolites/myb11993-zeoli.pdf.

Virta, R.L., 2002, Zeolites, in Metals and minerals: U.S. Geological Survey Minerals Yearbook 2002, v. 1, p. 84.1-84.3, accessed March 7, 2016, at http://minerals.usgs.gov/minerals/ pubs/commodity/zeolites/zeolmyb02.pdf.

Virta, R.L., 2006, Zeolites, in Metals and minerals: U.S. Geological Survey Minerals Yearbook 2005, v. 1, p. 84.1-84.3, accessed March 7, 2016, at http://minerals.usgs.gov/minerals/ pubs/commodity/zeolites/zeolimyb05.pdf.

Virta, R.L., 2010, Zeolites, in Metals and minerals: U.S. Geological Survey Minerals Yearbook 2008, v. 1, p. 83.1-83.3, accessed March 7, 2016, at http://minerals.usgs.gov/minerals/ pubs/commodity/zeolites/myb1-2008-zeoli.pdf.

Virta, R.L., and Flanagan, D.M., 2015, Zeolites, in Metals and minerals: U.S. Geological Survey Minerals Yearbook 2014, v. 1, p. 83.1-83.3, accessed March 7, 2016, at http://minerals.usgs. gov/minerals/pubs/commodity/zeolites/myb1-2014-zeoli.pdf.

\section{Zinc}

Zinc is used mostly for galvanizing steel, where it acts as a protective coating against corrosion. Zinc is also consumed for the production of zinc-based alloys for the die-casting industry, as a component of brass and bronze, and in chemical compounds, including zinc oxide used in tire manufacturing and zinc sulfate for fertilizers.

Publications of the USGS National Minerals Information Center (NMIC) reported that in 2014 the United States produced 832,000 metric tons $(t)$ of zinc in concentrate and was the world's fourth-ranked mine producer of zinc behind China, Australia, and Peru, accounting for approximately 6 percent of global production (Tolcin, 2016). U.S. zinc-mine production has increased at a compound annual growth rate of about 2 percent in the past 25 years, mostly owing to increased production in Alaska beginning in the mid-to-late 1990s.

In 2014, zinc was produced in five States; Alaska was the leading zinc-producing State, followed by Tennessee, Missouri,
Idaho, and Washington. No significant zinc production has been reported in or near the assessment area since at least 1990. Zinc was recovered from ore extracted from both open-pit and underground mines that used conventional flotation to produce concentrate for smelting and refining. In 2014, U.S. proven and probable ore reserves contained approximately 11 million metric tons (Mt) of zinc (Tolcin, 2016).

In 1990, approximately $263,000 \mathrm{t}$ of zinc metal was produced from domestic and imported concentrates by domestic smelters (Jasinski, 1993). By 2014, as a result of plant closures and suspensions for various reasons, zinc production at primary smelters more than halved to approximately 110,000 metric tons (t). It is unlikely that new production capacity for processing zinc concentrates will be constructed in the United States before the end of the decade or perhaps the foreseeable future. An additional $70,000 \mathrm{t}$ of zinc metal was recovered by secondary smelters from the recycling of scrap in 2014 (Tolcin, 2016).

The United States exports a significant amount of zinccontaining concentrates to foreign smelters and imported most of the zinc metal it consumed. In 2014, U.S. exports of zinc in concentrate were $644,000 \mathrm{t}$, whereas imports were less than $500 \mathrm{t}$, and imports of refined zinc were 805,000 t, whereas exports were 20,000 t. Zinc in concentrate was exported primarily to Canada (35 percent), the Republic of Korea (87 percent), and Spain (11 percent), and refined zinc was imported mostly from Canada (55 percent), Australia (14 percent), and Mexico (13 percent) (Jasinski, 1993; Jolly, 1993; Tolcin, 2016).

In 2014, U.S. apparent consumption of refined zinc was 965,000 t. From 1992 to 2008, annual apparent consumption exceeded $1 \mathrm{Mt}$, reaching a high of $1.43 \mathrm{Mt}$ in 1999. Consumption declined in 2008 after the global economic recession began in late 2007 and fell to less than $1 \mathrm{Mt}$ in 2009. Although the recession ended in 2009, consumption remained less than $1 \mathrm{Mt}$ from 2010 to 2014, owing mostly to increased imports of galvanized steel from China (Kelly and Matos, 2007; Tolcin, 2016).

The U.S. Defense Logistics Agency holds a stockpile of about 7,000 t of zinc (Tolcin, 2016). As such, zinc continues to be considered a strategic or critical commodity, although domestically imported supplies of zinc are varied with a substantial amount sourced from North American Free Trade Agreement partners.

In the past 25 years, global zinc-mine production increased by a compound annual growth rate of 2.6 percent, from 7.15 Mt in 1990 to $13.3 \mathrm{Mt}$ in 2014. During this period of time, China had the most substantial increase in zinc production and became the leading global producer-from producing 660,000 t of zinc in concentrate in 1990 (9 percent of the world's total) to producing $4.93 \mathrm{Mt}$ in 2014 (37 percent of the world's total). Other major producers of mined zinc in 2014, and their share of global production, were Australia (12 percent), Peru (10 percent), United States (6 percent), India (5 percent), and Mexico ( 5 percent). The increase in world zinc production has been driven primarily by an upsurge in demand in China for galvanized steel and other materials used 
in construction and consumer goods (Jasinski, 1993; Tolcin, 2015, 2016).

The average annual North American price for special high grade (SHG) zinc, expressed in constant 1998 U.S. dollars for the purpose of comparison since the year 1990, ranged from a low of about $\$ 772$ per metric ton $(\$ 0.35$ per pound in 2002$)$ to a high of $\$ 2,830$ per metric ton ( $\$ 1.28$ per pound) in 2006 . Prices dropped shortly thereafter in response to weakened demand for the metal in most major zinc-consuming nations during the global recession, with China being an exception. Prices recovered somewhat in 2011 and 2012 but softened thereafter as demand for the metal lessened. In 2014, the average price of zinc in nominal dollars was approximately $\$ 2,359$ per metric ton (\$1.07 per pound) (Kelly and Matos, 2007; Tolcin, 2016).

\section{References Cited}

Jasinski, S.M., 1993, Zinc, in U.S. Bureau of Mines Minerals Yearbook 1993, v. 1, p. 1279-1292, accessed February 9, 2016, at http:/digicoll.library.wisc.edu/cgi-bin/EcoNatRes/ EcoNatRes-idx?type $=$ article\&did=EcoNatRes.MinYB1993v1. SJasinski\&id=EcoNatRes.MinYB1993v1\&isize=M.

Jolly, J.H., 1993, Zinc: U.S. Bureau of Mines Mineral Commodity Summaries 1993, p.196-197.
Kelly, T.D., and Matos, G.R., comps., 2007, Historical statistics for mineral and material commodities in the United States: U.S. Geological Survey Data Series 140, ver. 2011, accessed February 4, 2016, at http://minerals.usgs.gov/minerals/pubs/historicalstatistics/.

Tolcin, A.C., 2015, Zinc [advanced release], in Metals and minerals: U.S. Geological Survey, Minerals Yearbook 2013, v. 1, p. 84.1-84.13, accessed February 9, 2016, at http://minerals.usgs. gov/minerals/pubs/commodity/zinc/myb1-2013-zinc.pdf.

Tolcin, A.C., 2016, Zinc: U.S. Geological Survey Mineral Commodity Summaries 2016, p.192-193, accessed February 4, 2016, at http://minerals.usgs.gov/minerals/pubs/mcs/2016/ mes2016.pdf.

\section{Acknowledgments}

Several people made valuable contributions to the information provided by the USGS National Mineral Information Science Center (NMIC). These include George M. Bedinger, Donald I. Bleiwas, Robert D. Crangle, Jr., Daniel M. Flanagan, Joseph Gambogi, Micheal W. George, David I. Guberman, Brian W. Jaskula, Michele E. McRae, Donald W. Olson, Désirée E. Polyak, Kim B. Shedd, Amy C. Tolcin, and Christopher A. Tuck. 

Menlo Park Publishing Service Center, California Manuscript approval date June 14, 2016

Edited by James W. Hendley II

Design and layout by Cory Hurd 
萑

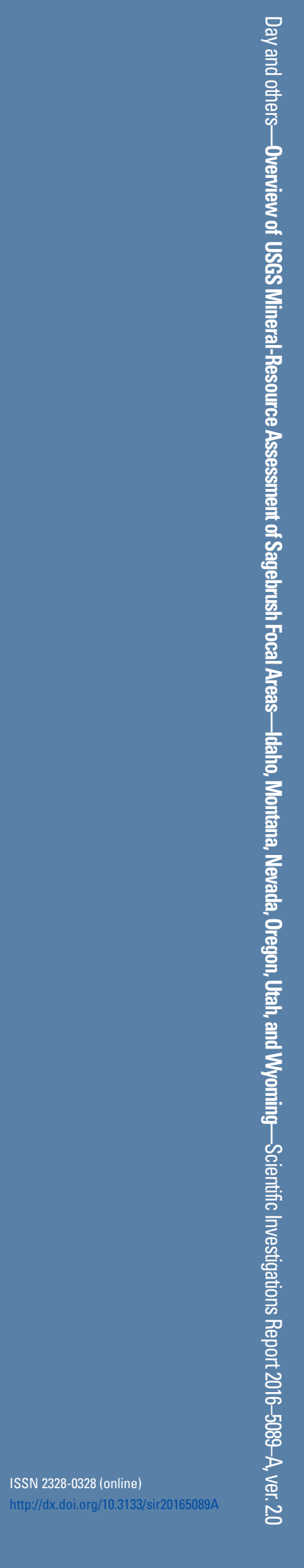

